\title{
La biotecnología y sus repercusiones \\ socioeconómicas y políticas
}

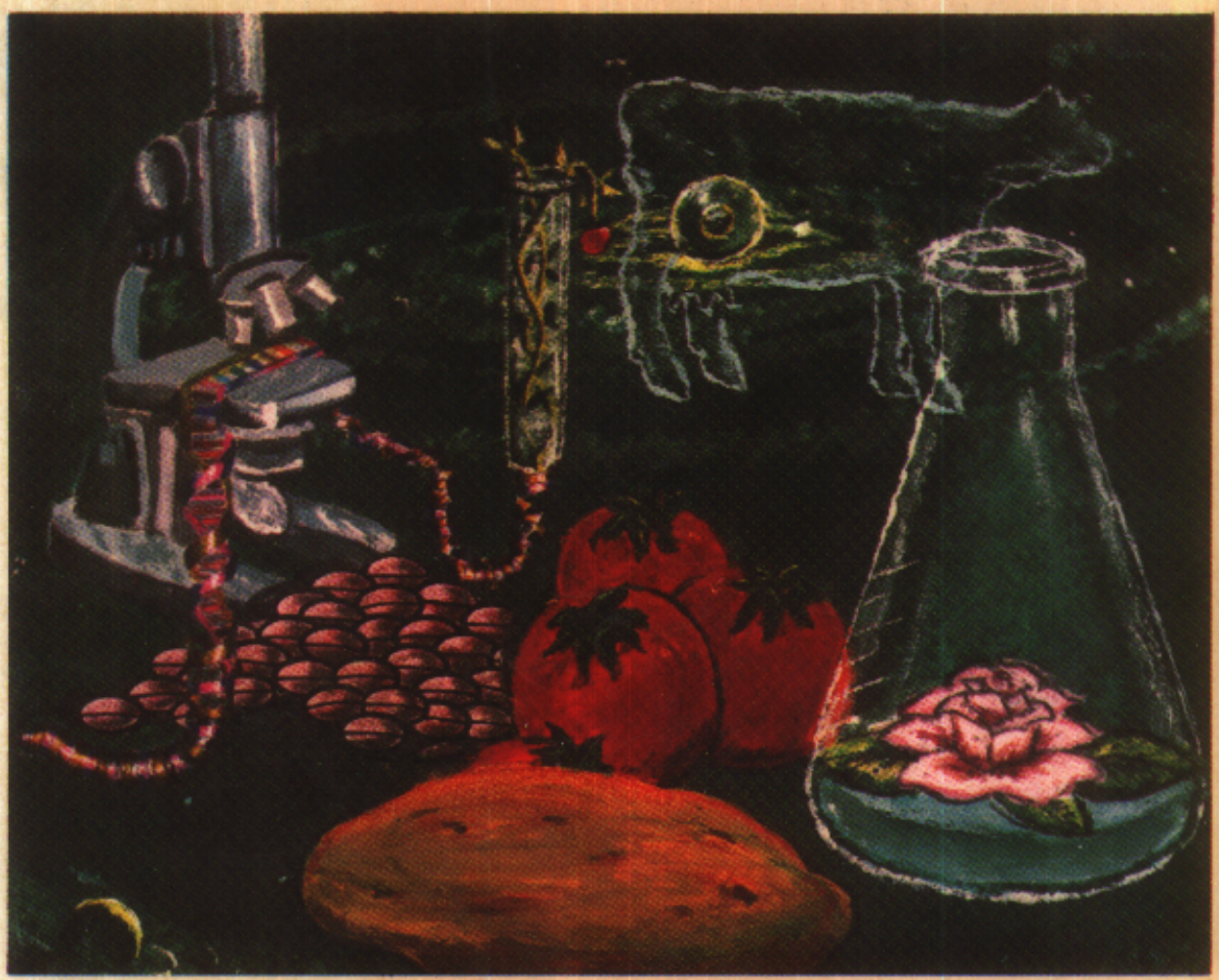

Coordinadoras:

Rosalba Casas Michelle Chauvet Dinah Rodríguez

U1. Instituto de Investigaciones Económicas. UNAM Casa abierta a tiempo Instituto de Investigaciones Sociales. UNAM 


\section{Aal}

UNIVERSIDAD AUTÓNOMA METROPOLITANA

Rector General

Dr. Gustavo Chapela Castañares

Secretario General

Dr. Enrique Fernández Fassnacht

Rectora de la Unidad Azcapotzalco

Dra. Sylvia Beatriz Ortega Salazar

Secretario de la Unidad

Ing. Enrique Tenorio Guillén

Director de la División de Ciencias Sociales y Humanidades

Lic. Jorge Fernández Souza

Jefe del Departamento de Sociología

Miro. José Othón Quiroz Trejo

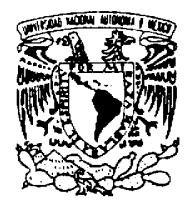

UNIVERSIDAD NACIONAL AUTÓNOMA DE MÉXICO

\section{Rector}

Dr. José Sarukhán Kermez

Secretario General

Dr. Salvador Malo Álvarez

Director General de Publicaciones

Mtro. Vicente Quirarte

\section{INSTITUTO DE INVESTIGACIONES ECONÓMICAS}

\section{Director}

Lic. Benito Rey Romay

Secretario Académico

Dr. José Rangel

Secretario Técnico

Lic. Víctor Manuel Bernal Sahagún

\section{INSTITUTO DE INVESTIGACIONES SOCIALES}

\section{Director}

Dr. Ricardo Pozas Horcasitas

Secretaria Académica

Dra. Rosalba Casas Guerrero

Jefa del Departamento de Publicaciones

Dra. Sara. Gordon Rapoport 


\section{La biofecnología y sus repercusiones socioeconómicas y políticas}




\section{La biotecnología y sus repercusiones socioeconómicas y políticas}

COORDINADORAS:

ROsalba casas
michele chauvet
DInaH RoDríguez
MICHLLE CHAUVE
DINAH RODRÍGUEZ

Instituto de Investigaciones Sociales. Unam

Departamento de Sociología. vam-Azc. Casa aberta al trempo Instituto de Investigaciones Económicas. unam

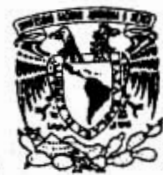


Copyrigth @ 1992

ISBN 968-36-2703-X

UAM-Azcapotzalco

Instituto de Investigaciones Económicas. UNAM

Instituto de Investigaciones Sociales. UNAM

Cuidado de la edición: Marcela Pineda Camacho

Diseño de la portada: Rosa Elvia Barajas Ochoa 


\title{
La biotecnologia y sus repercusiones socioeconómicas y políticas
}

\author{
Coordinadoras: \\ Rosalba Casas \\ Michelle Chauvet \\ Dinah Rodríguez.
}

\section{Autores:}

Gilberto Aboites Manrique Silvia Almanza

Gonzalo Arroyo

Rosa E. Barajas

Rosalba Casas

Yolanda Castañeda

Raúl Conde

Michelle Chauvet

Amarella Eastmond

Rosa Luz González

Luis Kato Maldonado

Martin Kenney
Jack Kloppenburg Jr.

Luis Lago Castro

Argelia Lorence

Yolanda Massieu Trigo

Gerardo Otero

Leonardo Héctor Rioja Peregrina Dinah Rodriguez Chaurnet José Luis Solleiro

Blanca Suárez

Idolina Velázquez S.

Juvencio Wing 



\section{Índice}

Presentación

Ricardo Pozas Horcasitas

Introducción . . . . . . . . . . . . . . . . . . . . . . . III

Rosalba Casas, Michelle Chauvet y Dinah Rodríguez

REPERCUSIONES POLITICAS: BIOSEGURIDAD Y PATENTAMIENTO . . . . I

La biotecnología en la restructuración productiva actual . . . . . . . . 3

Dinah Rodríguez Chaumet

Agricultura, biotecnología e integración norteamericana . . . . . . . . 19

Gerardo Otero

"iProhibido cazar!" Expoliación científica, los derechos de los

indígenas y la biodiversidad universal.

Jack Kloppenburg Jr.

Propiedad intelectual, biotecnología y desarrollo intemacional . . . . . . 51

Martin Kenney

Problemas que plantea la biotecnología en el marco legislativo

de la propiedad intelectual: el caso de México

Gilberto Aboites Manrique

La desregulación en la industria de las semillas: patentes

y biotecnología

Blanca Suárez

La bioseguridad en la dinámica actual de las relaciones internacionales

y sus repercusiones en México . . . . . . . . . . . . . . . 105

Leonardo Héctor Rioja Peregrina

COMENTARIOS . . . . . . . . . . . . . . . . 139

Repercusiones políticas de la biotecnología . . . . . . . . . . . . 141

Francisco Martínez Gómez

La propiedad intelectual y la biotecnología . . . . . . . . . . . . 147

Roberto Guadarrama Sistos

REPERCUSIONES SOCIOECONÓMICAS EN DIFERENTES SECTORES . 155

El patrón potencial de difusión de la biotecnología en el sector

petroquímico

Luis Kato Maldonado

La biotecnología aplicada a la producción ganadera en México .

Michelle Chauvet, Yolanda Massieu, Yolanda Castañeda

y Rosa Elvia Barajas 
El tratamiento biológico de aguas residuales: ¿́demanda social

o coyuntura política?

Rosalba Casas

Consideraciones sobre la aplicación de la biotecnología vegetal

en el sureste de México.

Amarella Eastmond

Efecto socioeconómico de la biotecnología en el cultivo de la papa:

el caso de Cuba

Luis Lago Castro

Aplicaciones de la biotecnología a la floricultura de México:

efectos en el empleo . . . . . . . . . . . . . . . . . . . . 253

Yolanda Massieu, Michelle Chauvet, Yolanda Castañeda

y Rosa Elvia Barajos

Avances y repercusiones de la biotecnología en la producción de café . . 281 Idolina Velózquez S.

Potencialidades de la biotecnología para la producción de tomate . . . 301 Argelia Lorence Quiñones

COMENTARIOS ............................. 319

Oportunidades para la aplicación de la biotecnología . . . . . . . 321 Alejandro Blanco

La biotecnología agńcola . . . . . . . . . . . . . . . . . 327 Héctor Lozoya Saldaña

POLÍTICA BIOTECNOLÓGICA: ELEMENTOS PARA SU DEFINICIÓN . . 337

La biotecnología en Chile y las experiencias de su aplicación . . . . . . 339 Gonzalo Arroyo

Las políticas de promoción de la ciencia y la tecnología:

el caso de la biotecnología . . . . . . . . . . . . . . . . . . 363

Raúl Conde, Rosa Luz González y Juvencio Wing

Importancia de la reflexión prospectiva en el desamollo biotecnológico . . 385 José Luis Solleiro, Rosa Luz González y Silvia Almanza

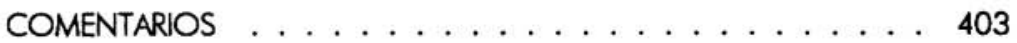

Puntos críticos en el establecimiento de políticas científicas:

el caso de la biotecnología . . . . . . . . . . . . . . . . . 405 Miguel Ángel Campos

Prospectiva y planeación para la biotecnología . . . . . . . . . 413 Leonel Corona

La impontancia socioeconómica de la biotecnología . . . . . . . . 419 Arturo Bonilla 


\title{
Presentación
}

\author{
RICARDO POZAS HORCASITAS
}

El presente libro es resultado del simposio nacional sobre "Efectos socioeconómicos de la biotecnología". Este acontecimiento académi$\mathrm{co}$, un hecho significativo en sí mismo, es también el fruto de más de una década de estudio y trabajo llevados a cabo por los científicos sociales en torno a la biotecnología.

La preocupación de las ciencias sociales mexicanas por la biotecnología expresa un viraje en los problemas centrales de estas disciplinas. Este cambio se orienta hacia la búsqueda de opciones sociales frente a los nuevos problemas planteados por los avances científicos y los desarrollos tecnológicos.

El desarrollo científico y tecnológico influye en la organización y reproducción sociales; pero también confirma las viejas formas de división en la sociedad global en las que ahora se acrecientan las diferencias en el manejo y disponibilidad de los recursos producidos por el conocimiento. Este ancestral problema reitera hoy los límites alcanzables de los beneficios sociales del capital científico y tecnológico.

Hoy, como hace mucho tiempo, el.problema de la justicia y la equidad ronda en torno a la utilización de los recursos científicos, considerados, por una parte, patrimonio de la humanidad y, por la otra, derecho particular a usufructo de quienes concentran el mayor capital intelectual y tecnológico en el mundo. Este debate, opacado por un clima intelectual y político que convierte el patrimonio público y social en derecho privado, no es soslayado por los científicos sociales que participan en los textos del presente libro, quienes mantienen viva la tradición humanista del científico y su preocupación por el beneficio racional de los hallazgos tecnológicos.

El texto nos vincula también a uno de los problemas capitales de la ciencia: la relación entre la organización social y la naturaleza. Este viejo problema se encuentra en el fundamento de todas las teorías sociales y, en este caso en particular -el estudio de los efectos sociales de la biotecnología-, no solamente se entabla un nuevo diálogo con lo esencial de las tradiciones del pensamiento social, sino que 
se emprende a partir de una nueva relación entre relaciones sociales y naturaleza.

La relación contemporánea entre naturaleza y sociedad ha roto con la vieja concepción de un medio natural indestructible y sin límites, planteada por las teorías sociales decimonónicas fundadas en el evolucionismo. En esas concepciones, la naturaleza fue un supuesto de las relaciones sociales y económicas; la clave de la relación social con ella estaba dada por las formas de apropiación. En el presente la naturaleza es un límite inaplazable y una determinante de la acción social. Antes el hombre se apropiaba de la naturaleza; hoy la consume y agota.

La visión contemporánea pone a la sociedad frente a limitaciones claras y nos muestra un largo y devastador camino de irracionalidades, no sólo privativo del llamado capitalismo en su doble acepción, occidental y oriental, sino como elemento constitutivo de los regímenes socialistas.

La traición a la utopía clásica comunista de crear una sociedad en "armonía con la naturaleza" aparece en la insensata devastación a los recursos del entorno como condición de desarrollo de los regímenes socialistas. En la actualidad, el posible derrumbe ecológico se presenta como un problema global y no condicionado a la resolución previa de los problemas de los diversos regímenes políticos.

Hoy sabemos que la relación con la naturaleza, y sobre todo su manejo, no es prioridad de los científicos, sino que entraña también una cultura en su acepción más amplia, con todas sus repercusiones valorativas, y que el manejo de la naturaleza no es una prerrogativa de los que la conocen sino un patrimonio de la sociedad. Esta cultura tiene como uno de sus ejes articuladores la desmitificación de la racionalidad científica y, sobre todo, de los científicos.

La cosmovisión sobre los riesgos y múltiples contenidos ideológicos y culturales en el manejo científico de la naturaleza ha dado origen en el siglo XX a un cúmulo importante de estudios sociales enfocados a analizar el desarrollo del conocimiento científico y tecnológico. En México, los estudios sobre el desarrollo del conocimiento científico y tecnológico parte de la década de los años setenta, período en el cual se inicia la formación de los grupos de trabajo y las corrientes de opinión en torno a la necesidad de hacer frente a ese vacío de conocimiento. En el campo de la biotecnología se ha cubierto ya esa necesaria etapa de las generalizaciones que siempre precede a los períodos de especialización de una nueva disciplina, de lo cual el presente libro es ya su prueba. 


\section{Introducción}

\section{ROSALBA CASAS, MICHELLE CHAUVET Y DINAH RODRÍGUEZ}

La restructuración de la economía mundial, hoy en día signada por profundas transformaciones políticas y sociales, ha desembocado en la creación y promoción de nuevas tecnologías que están produciendo cambios significativos en el orden económico internacional que se traducen, en primer lugar, en un vuelco trascendental en la división internacional del trabajo, principalmente en la interacción entre la productividad del capital, la dimensión de los mercados y un bajo nivel de salarios.

Así, el incremento sin precedentes en la productividad, la creación de nuevos productos y la disminución de los montos de energía en el proceso productivo desencadenan efectos económicos, sociales y políticos que afectan tanto la relocalización de recursos y el remplazo de insumos conio la alteración en los niveles de empleo y las normas laborales.

Las diferentes expresiones de las nuevas tecnologías y sus efectos en la producción constituyen el núcleo generador de cambios masivos fundamentales en el comportamiento de los agentes económicos. La robótica aplicada a la producción ha trastocado prácticas salariales y de empleo.' Es probable que en los próximos años los nuevos materiales, base de los superconductores, logren la creación de dispositivos para almacenamiento de energía de alto rendimiento. ${ }^{2}$ En lo referente a la biotecnología, las técnicas logradas durante las dos últimas décadas han permitido el desarrollo y aplicación de nuevas opciones para manipular la materia viva mediante la ingeniería genética.

El interés por el estudio de las determinaciones y repercusiones socieconómicas y políticas de las nuevas tecnologías ha adquirido gran importancia pues revolucionan las relaciones entre los hombres y la naturaleza. El análisis del desarrollo de las nuevas tecnologías se

${ }^{1}$ L. Mertens, Crisis económica y revolución tecnológica, Caracas, Venezuela: Ed. Nueva Sociedad, pp. 60-61, 1990.

2 G. Aguilar Sahagún, El hombre y los materiales, México: SEP/FCE/CONACY, cap. III., 1988. 
convierte en un tema más complejo que el de las tecnologías denominadas "convencionales" ya que son innovaciones que están transformando los recursos naturales, las etapas y las formas de producción, la secuencia tradicional de las cadenas productivas, el empleo y los patrones de consumo de la población. La reflexión social sobre este campo resulta necesaria por diversas razones: definir las condiciones y las limitaciones de la ciencia y la tecnología, determinar los efectos reales de su aplicación en la sociedad y finalmente definir las arientaciones de la política científica y tecnológica que tengan repercusiones sociales y económicas.

Cabe mencionar, como sostiene Pérez, ${ }^{3}$ que el mundo de lo técnicamente posible es mucho más amplio que el de lo económicamente rentable y mayor que el de lo socialmente aceptable; estos dos últimos tampoco coinciden. La rapidez con que se van dando los descubrimientos científicos rebasa la velocidad con que se reflexiona sobre sus efectos y repercusiones y quizás esta práctica nos impida enmendar errores.

La biotecnología surge como campo de investigación durante la década de los sesenta. Sus aplicaciones y efectos se relacionan con muy diversos sectores e industrias. La agricultura, la salud, el medio ambiente -entre otros- han sido considerados como los ámbitos en los que la biotecnología está dando importantes aportaciones.

Muchas y variadas son las acepciones de la biotecnología. Una de las más difundidas es la que se refiere a la manipulación de los seres vivos y su aplicación en el aparato productivo para elaborar bienes y servicios. Podemos distinguir tres generaciones en el desarrollo de la biotecnología: la primera se refiere a los procesos de fermentación para la produción de alimentos y bebidas, que datan de la Antigüedad; la de segunda generación se caracteriza por los avances de la microbiología, el uso exitoso de mutaciones y selección de cepas para mejorar los rendimientos, los refinamientos de los sistemas de fermentación y el desarrollo de procesos continuos; y la biotecnología de tercera generación, que se refiere al desarrollo de técnicas de inmovilización enzimática y avances de la ingeniería genética que están dando lugar a las combinaciones genéticas y a sus repercusiones en los sectores farmacéutico, agrícola y pecuario.

Al manejar las moléculas de la vida, el hombre da nueva forma al mundo en que vive y en este campo la biotecnología ofrece grandes potencialidades. Al modificar el microcosmos de la célula del ser humano, se enfrenta a un gran dilema: estas increíbles

${ }^{3}$ Carlota Pérez, "Las nuevas tecnologías: una visión de conjunto", en La tercera revolución industrial. Impactos internacionales del actual viraje, Buenos Aires: Rlal. Anvario, Grupo Editor Latinoamericano, 1986. 
herramientas pueden llevarto incluso a manipular nuestra propia herencia genética.

Dichas repercusiones resultan particularmente delicadas si cobramos conciencia de que atañen a la esfera de la ética. Frente a la posibilidad de modificar la información genética de los seres vivos, su control plantea un tremendo reto: el riesgo de alterar las formas de vida tal y como hasta ahora las conocemos.

Los estudios sociales enfocados al desarrollo del conocimiento científico y tecnológico surgen desde hace varias décadas en el plano internacional. En el caso de México, en la década de 1970 empiezan a gestarse grupos de científicos sociales interesados en el análisis de las tendencias del conocimiento científico y sus relaciones con la sociedad. En el ámbito de las ciencias sociales los trabajos que se han producido sobre el desarrollo de la biotecnología han aportado, en su mayor parte, generalizaciones sobre sus efectos potenciales, sus consecuencias en los países en desarrollo y la necesidad de generar desarrollos biotecnológicos endógenos. Sin embargo, hasta la fecha, tanto en el ámbito internacional como en el caso específico de México, se ha avanzado lentamente en el estudio de las repercusiones sociales de las biotecnologías. Es cierto que muchos de sus efectos aún no pueden ser apreciados; empero, resulta indispensable analizar las tendencias de este campo de investigación y prever sus posibles alcances sobre la sociedad.

Las potencialidades de la biotecnología se orientan a diversas áreas de aplicación; en las que se prevén mayores posibilidades son el sector alimentario, el sector farmacéutico y el medio ambiente. Por lo que se refiere a la producción de medicamentos, mediante las técnicas de ingeniería genética se ha logrado obtener y comercializar productos tales como la insulina y la hormona del crecimiento, a partir de bacterias a las cuales se ha introducido el gen codificador, en este caso de la insulina, para que actúe como una biofábrica. En relación con la agricultura, la biotecnología ha logrado la obtención de plantas diseñadas genéticamente para resistir condiciones adversas tales como salinidad, viento y plagas. En lo referente a alimentación, han aparecido nuevos productos que sustituyen a los naturales; tal es el caso de los jarabes fructuosados de maíz y el aspartame, que han desplazado a la caña de azúcar por variadas creaciones de laboratorio.

La biotecnología ha adquirido una gran importancia en las naciones industrializadas. En esencia se trata de un área que se apoya en la investigación básica; y de ahí que en sus inicios su desarrollo haya estado fuertemente vinculado a los centros universitarios y a los institutos de investigación. No obstante, ahora la tendencia es hacia la privatización del conocimiento. Los grandes consorcios industriales exigen cada 
vez mayor protección a sus descubrimientos biotecnológicos y no están dispuestos a compartir los hallazgos que les han llevado mucho tiempo y fuertes inversiones.

El carácter privado de la biotecnología en los países desarrollados se ha subrayado con respecto a sus aplicaciones en la agricultura, ${ }^{4}$ por lo que se ha llegado a legislar sobre el patentamiento de formas de vida genéticamente modificadas, con lo cual se ha incrementado el interés de las grandes empresas privadas por el mejoramiento genético, particularmente de plantas. Estas formas de propiedad intelectual tratan de ser extendidas en general al germoplasma, transformándolo de este modo de un bien público a un recurso privatizado.

La privatización acarrea consecuencias negativas, sobre todo para los países del Tercer Mundo, los cuales se localizan en la zona de mayor biodiversidad aunque, si bien cuentan con múltiples especies, carecen de los conocimientos y la inversión necesaria para su explotación biotecnológica. La tendencia seró hacia la comercialización de los productos e incluso de los procesos, por lo que el beneficio social que pudiera derivarse de las innovaciones biotecnológicas estara orientado solamente a ciertos sectores de la sociedad. El patentamiento está poniendo en riesgo el acceso de los países en desarrollo a sus propios recursos naturales y al conocimiento en general.

Los intereses comerciales de las corporaciones transnacionales están puestos no sólo en la venta de sus productos biotecnológicos y la sustitución de recursos naturales por otros de origen biosintético, sino además en la apropiación del germoplasma que servirá de base para sus ulteriores manipulaciones genéticas y, finalmente, para la venta de nuevas semillas o cultivos a los países de menor desarrollo.

La carrera competitiva por asegurar la exclusividad de los nuevos procesos se manifiesta de manera aguda entre los países desarrollados y sus empresas transnacionales, tal y como quedó evidenciado en la Conferencia de las Naciones Unidas sobre Medio Ambiente y Desarrollo, también conocida como "La Cumbre de la Tierra", realizada en junio de 1992 en Río de Janeiro, Brasil. En dicha reunión Estados Unidos fue la única nación que se negó a firmar el Convenio sobre Biodiversidad, que incluye el compromiso de aplicar normas de bioseguridad, además del respeto a los recursos naturales de las naciones. Más aún, los riesgos alcanzan también a la población de los países industrializados, ya que al carecer de normas de liberación al ambiente de organismos modificados genéticamente, pueden generarse graves problemas ambientales cuyos efectos hasta ahora se desconocen.

4 F. Buttel, M. Kenney y J. Kloppenburg, "The ARCs and the development and application of biotechnologies in developing countries", Biolechnology in International Agricultural Research, Manila: International Rice Research Institute, 1985, pp. 383-394. 
Las posibles repercusiones sobre el patentamiento de los recursos vegetales y animales, que afectarán la apropiación de variedades vegetales y de los productos industriales que se deriven de los procesos biotecnológicos, representan un reto para los países en vías de desarrollo que plantea dos tareas urgentes: identificar prioridades de desarrollo biotecnológico y evaluar aspectos jurídico-económicos relacionados con tales desarrollos.

Las potencialidades de la biotecnología pueden ser aprovechadas tanto por los países industrializados como por los países en vías de desarrollo. Sin embargo, las nuevas tecnologías, y la biotecnología no es una excepción, deben ser consideradas a la luz de las repercusiones inmediatas y de las estrategias tecnológicas que cada nación pueda presentar para hacerles frente. La biotecnología plantea un reto para los países en vías de desarrollo: aunque en muchos aspectos puede ser favorable, también puede resultar inconveniente para los países que no han logrado consolidar procesos de aprendizaje y generación de capacidades propias en ciencia y tecnología.

La importancia social de la biotecnología ha sido muy discutida al tratar de detectar las oportunidades que presenta para los países en desarrollo, y lo mismo ha sucedido con sus repercusiones socioeconómicas. Se ha planteado que la biotecnología es una tecnología muy apropiada para resolver las necesidades básicas de las poblaciones del Tercer Mundo, así como también para mantener y emplear la gran diversidad de cultivos existentes en esos países y adaptarlos a condiciones poco propicias para su producción. También se ha argumentado que una de las vías de solución para los problemas que aquejan a los países en desarrollo está en las nuevas técnicas biotecnológicas y en su adecuación a los diferentes problemas característicos de las regiones que conforman el mundo subdesarrollado. Los atractivos potenciales de la biotecnología hicieron que, al inicio de la década de 1980 , se le señalara como la solución a la crisis de los sectores agrícolas y a considerársele como una panacea para los países del Tercer Mundo.

Se ha sostenido que la biotecnología puede contribuir considerablemente al desarrollo del Tercer Mundo, sobre todo mediante la producción de alimentos para consumo humano y animal, la producción de insecticidas microbianos, la fijación biológica del nitrógeno, el tratamiento de desechos y el mejoramiento de cultivos. ${ }^{5}$ Asimismo, se ha argumentado que los países del Tercer Mundo deben explotar sus ventajas, tales como la biotecnología de plantas y otras técnicas como las de fermentación en medio líquido y sólido, el reciclaje de desechos,

5 P. A. Van Hement, H. L. M. Lilieveld y J. W. M. La Riviere, Biotechnology in Developing Countries, Holanda: Delft University Press, 1982. 
la producción de gas metano, la descomposición de biomasa lignocelulósica y la transformación de combustibles. ${ }^{6}$

Sin embargo, hacia mediados de la década pasada comenzaron a aparecer anólisis que advertían sobre los efectos socioeconómicos de carácter negativo que se producirían en los países en desarrollo debido a la aplicación de las biotecnologías. Algunos de dichos efectos se derivan de las tendencias que está siguiendo la biotecnología en el mundo desarrollado y que serán difíciles de revertir al incorporarse dichas tecnologías al mundo en desarrollo. ${ }^{7}$ Otros efectos se refieren a las repercusiones de la biotecnología sobre los sectores agrícolas del Tercer Mundo dadas las experiencias previas en la aplicación de tecnologías agrícolas, concretamente la experiencia derivada de la Revolución Verde. ${ }^{8}$ Otro conjunto de repercusiones se manifestarán en diversos aspectos como el empleo, los ingresos y la propiedad agrícola. 9,10 En el caso del empleo se afirma que el remplazo de cultivos tradicionales por nuevas variedades causará el desempleo de mano de obra agrícola, tal como ya ocurre en Costa Rica al sustituir el cultivo de banano por el de palma de aceite. Hobbelink y Ruivenkamp "l argumentan que, dadas las tendencias de la biotecnología, ésta no aporta una promesa al problema del hambre y la desnutrición en el Tercer Mundo, sino que ocasionará una concentración cada vez mayor del sector agroindustrial y un posterior debilitamiento del poder de sus gobiernos para negociar en el ámbito internacional.

En el marco de la problemática antes expuesta surge el interés por reflexionar sobre los efectos de la biotecnología. La preocupación por el análisis de la situación de la biotecnología en México se gestó primero entre los biotecnólogos, quienes se preguntaron por el estado del arte de esta área y plantearon la necesidad de contar con más recursos financieros y diseñar una política para formar recursos humanos. Desde el inicio de 1980 los especialistas en biotecnología han tratado de anticipar en la definición de una política biotecnológica nacional, la cual en diferentes momentos ha logrado algunas formulaciones pero permanece sin un planteamiento sólido y orientándose de

${ }^{6}$ A. Sasson, Quelles biotechnologies pour les pays en développement?, París: Biofutur/UNESCO, 1986.

7 D. Dembo, C. Días y W. Morehouse, "Social impacts in developing countries of the privatization of biotechnology", Social, Economic and Legal Aspects of Biotechnology in Brazil, Brasilia: en prensa, 1985.

${ }^{8}$ F. Buttel, M. Kenney y J. Kloppenburg, op. cit. pp. 383-394.

${ }^{9} \mathrm{H}$. Hobbelink, y G. Ruivenkamp, "Biotecnología y Tercer Mundo: desenmascaramiento de una nueva promesa", Revista de $\triangle D O B, D^{\prime}$ Affairs Internationals, Barcelona: Invierno, 1986, pp. 18.19.

${ }^{10}$ A. Sasson, op. cit.

11 H. Hobbelink, y G. Ruivenkamp, op. cit. pp. 18-19. 
manera casuística y circunstancial, mientras los desarrollos científicos, legislativos y políticos en el mundo hacen cada vez más difícil la definición de una estrategia nacional.

A fines de 1990, promovidos por la Universidad Autónoma Metropolitana y la Universidad Nacional Autónoma de México, se inician los trabajos del seminario que analiza y discute aspectos diversos de la problemática socioeconómica de la biotecnología. Este esfuerzo se constituyó así en el primer foro de índole interinstitucional y multidisciplinaria para el estudio de los efectos socioeconómicos de la biotecnología. El semingrie permanente que durante 1991 concluyó con la realización de un simposio nacional sobre el mismo tema, que tuvo como propósito fundamental avanzar en el análisis de campos específicos de aplicación de la biotecnología, así como en la discusión de la problemática sociopolítica que está determinando el desarrollo de este campo de investigación.

Este libro es el resultado de un esfuerzo por avanzar de manera organizada en el análisis socioeconómico y político de la biotecnología. Las discusiones sostenidas durante el simposio que precedió a la publicación de este libro resaltaron las repercusiones políticas de la biotecnología y sus relaciones con el posible tratado de libre comercio. Se abandonaron las generalizaciones imperantes en torno a los efectos socioeconómicos de esta disciplina y se abordó el estudio de caso de avances biotecnológicos y su influencia en diferentes ámbitos. Con esta perspectiva se discutieron los efectos potenciales y deseables de la biotecnología, los efectos reales ya presentes derivados de la comercialización de productos biotecnológicos y las repercusiones en el plano nacional de biotecnologías transferidas del exterior. Se analizaron las serias consideraciones éticas y económicas que entraña la investigación biotecnológica y sus aplicaciones. Finalmente se plantearon y sugirieron lineamientos para definir una política biotecnológica basada en un enfoque prospectivo.

A pesar de los avances logrados como resultado de este foro de discusión, quedan aún por superar retos para lograr un enfoque socioeconómico y político del desarrollo de la biotecnología. Cabe mencionar, entre otros, aspectos tales como la realización de investigaciones interdisciplinarias y análisis colectivos que combinen la competencia disciplinaria de sus integrantes y los intereses de los diferentes sectores que participan en este campo de investigación; el logro de mecanismos que aseguren una relación exitosa entre tecnología e industria; la definición de una estrategia biotecnológica que se base en un enfoque prospectivo y que parta de la consideración de estudios de caso en campos específicos de desarrollo biotecnológico. 
La obra se divide en tres secciones temáticas. En la primera se aborda la discusión y análisis de las repercusiones políticas de la biotecnología en aspectos centrales como propiedad intelectual, patentes, bioseguridad, biodiversidad, así como su influencia en el sector productivo. La segunda sección se compone de un conjunto de estudios de caso sobre las repercusiones socioeconómicas reales o potenciales de la biotecnología en diferentes sectores, entre los que se analizan la agricultura, la floricultura, la producción pecuaria, la petroquímica y la contaminación del agua. La última sección del libro incluye propuestas para la aplicación de la biotecnología, la definición de una política y la formulación de prioridades para su desarrollo.

El libro que se presenta es el resultado de una selección rigurosa de los trabajos discutidos en el Simposio, en su mayor parte inscritos en la óptica de las ciencias sociales. Dada esta situación, y puesto que el propósito del simposio estuvo orientado hacia un ejercicio interdisciplinario, se enriqueció la discusión invitando a destacados biotecnólogos y a otros especialistas en el tema a comentar los trabajos incluidos en cada sección. Al final de cada una de las secciones que conforman el libro se insertan sus opiniones, que acotan los análisis elaborados por los autores. El estudio de las repercusiones socioeconómicas y políticas de la biotecnología es un campo de gran complejidad, que requiere del trabajo interdisciplinario entre biotecnólogos, científicos sociales y filósofos. Con la publicación de estas investigaciones deseamos aportar nuevos elementos a este campo de análisis y a la vez estimular la realización de estudios interdisciplinarios sobre este tema de gran trascendencia para el futuro de México.

Finalmente, queremos expresar nuestro agradecimiento a todos los participantes en el Simposio; al doctor Rodolfo Quintero; a los tres dictaminadores quienes evaluaron los trabajos que integran esta obra; al doctor Arturo Montenegro, al doctor Roberto Varela y al licenciado Arturo Bonilla, los cuales cedieron amablemente su tiempo para moderar las sesiones. Asimismo, agradecemos el apoyo económico aportado por la Dirección General de Investigación Científica y Superación Académica de la SEP, cuyo interés en la temática de la biotecnología hizo posible publicar esta obra. 


\section{REPERCUSIONES POLÍTICAS: BIOSECURIDAD Y PATENTAMIENTO}





\title{
La biotecnología en la restructuración productiva actual
}

\author{
DINAH RODRÍGUEZ CHAURNET*
}

\section{CONTEXTO INTERNACIONAL Y CAMBIO TECNOLÓGICO}

Un rasgo característico del mundo actual es la recomposición productiva impulsada por los países desarrollados a partir de la innovación tecnológica; ésta se ha vuelto un centro de poder que introduce modificaciones profundas en el aparato productivo, las cuales a su vez se reflejan como cambios trascendentales en la División Intemacional del Trabajo (DIT).

Ésta, concebida en otros momentos como la interacción entre la productividad del capital, la dimensión de los mercados y el nivel de salarios, está siendo hoy en día rebasada por el efecto que en el aparato productivo tienen las nuevas tecnologías, por lo cual es redefinida con una nueva dimensión de sus variables en tanto que ni el tamaño del mercado, ni el nivel de los salarios habrán de ser ahora las variables importantes puesto que mayores niveles de productividad, al influir en el costo de producción, rompen con el equilibrio anterior, por lo cual se relativiza la importancia de dichas variables.

El incremento sin precedentes de la productividad, la creación de nuevos productos, y la disminución de los montos de energía en el proceso productivo desencadenan efectos de tipo económico y social que afectan tanto la relocalización de recursos como el remplazo de insumos, entre otros.

Asimismo, se vislumbra una restructuración por bloques de países; una reconversión productiva como pauta industrial apoyada en nuevos recursos tecnológicos, con "reciclaje" de las normas laborales y los niveles de empleo como elementos estratégicos y de competencia en

* Investigadora del Instituto de Investigaciones Económicas, adscrita al Área de Ciencia y Tecnologín para el Desarrollo. 
el plano internacional, que incluyen aspectos tales como marcas y patentes, expresión de la propiedad intelectual, desregulación del aparato estatal, ahorro y renegociación de la deuda y logro de una mayor productividad y competitividad.

\section{PROCESO DE GLOBALIZACIÓN}

En este panorama de cambios, en los últimos treinta años se producen descensos continuos en la demanda de los productos del mundo subdesarrollado, en tanto que las importaciones provenientes de los países desarrollados tienen un mayor contenido tecnológico. El fenómeno subyacente en este acontecer refleja una clara tendencia global: las nuevas tecnologías permiten un ahorro significativo de insumos energéticos y materias primas agrícolas y minerales, en las que se advierten las siguientes posibilidades (Mertens, 1990):

1. Producción de materias primas antes exportadas por los países en vías de desarrollo.

2. Sustitución de la importación de materias primas por la industrialización de recursos abundantes.

3. Sustitución de la importación de materias primas por la fabricación de nuevos productos de origen sintético.

Acaso el significado más profundo que encierra la producción de sustitutos y productos de síntesis con base en las nuevas tecnologías es la "autonomización" del abastecimiento de materias primas energéticas y fuerza laboral contenida en ellos, hechos que explican la reducción en la demanda mundial de materias primas agrícolas y no agrícolas.

Esto, a su vez, repercute en una sobreoferta, lo cual ocasiona la caída de los precios en los mercados mundiales, así como un deterioro casi permanente en los términos de intercambio para los países en vías de desarrollo, otrora importantes exportadores de materias primas y productos semielaborados.

Podríamos decir que la actual revolución tecnológica está "erosionando" las ventajas comparativas tradicionales hasta hoy existentes en los países en vías de desarrollo. Así, la robótica aplicada a la producción ha trastoca do tiempos, costos, prácticas salariales y de empleo, y roto formas laborales establecidas.

La fábrica tlexible permite hoy regular los montos de inventarios, las jornadas laborales, automatizar una serie de puestos relacionados entre sí, reducir plazos y movimientos en el conjunto de tiempos de operación, así como "flexibilizar" el contrato colectivo de trabajo. 
No menos importante es la privatización del conocimiento científico vía reglamentación de la propiedad intelectual aplicada a toda una gama de productos de importancia estratégica, conocidos en términos de las negociaciones del GATT como "nuevos servicios": circuitos integrados, semiconductores, o bien cepas genéticas e incluso organismos vivos, para citar dos casos de la biotecnología.

Es así que las diferentes expresiones de la revolución científico-técnica se constituyen hoy día en núcleo generador de cambios masivos fundamentales en el comportamiento de los agentes económicos (Ominami, 1988).

Todo ello ha hecho posible que en los momentos actuales los países desarrollados produzcan, por ejemplo, textiles a un costo inferior al que los producían países con mano de obra barata. Tal es el caso de India y México. En el mismo orden de cosas, México, pionero en la producción de "semillas mejoradas", ha visto suplantada su capacidad tecnológica por las transnacionales semilleras que ahora las producen por subcontratación en suelo mexicano. Se trata de las mismas compañías que abogan por la incorporación del sector agrícola en las negociaciones del Tratado de Libre Comercio para tener un mejor acceso a los recursos fitogenéticos del país.

Los países industrializados, destacados en la investigación y desarrollo de tecnología de punta, contrastan con los países en vías de desarrollo, ya que éstos son receptores de tecnología extranjera, pues carecen de un núcleo endógeno de investigación y desarrollo (I \& D). Mientras que en 1988 Japón, Suiza, Alemania y Estados Unidos gastaron en I \& D alrededor de $3 \%$ del producto interno bruto (PIB), México, Perú y Brasil le dedicaron menos del uno por ciento (cuadro 1), cifras muy inferiores a lo que recomiendan los organismos internacionales para los países de menor desarrollo, y todavía muy por debajo del promedio que destinan los países desarrollados (Blum, 1992) a sus investigaciones.

La enurme brecha tecnológica entre los países en vías de desarrollo y las potencias industriales, que se refleja en baja productividad o escaso y deficiente desarrollo industrial, es causa y consecuencia, a la vez, del fenómeno que nos ocupa.

La creciente ola de proteccionismo de los países industriales, la baja paridad frente al dólar (que reduce los ingresos por exportación de los países en vías de desarrollo) son hechos que sin lugar a dudas ponen freno a la importación de bienes necesarios en su proceso de industrialización y al no menos importante problema de la deuda externa.

Resulta evidente que la capacidad científica y tecnológica se concentra actualmente en los países industrializados, centros de poder que determinan el desarrollo tecnológico actual. Hoy en día 
CUADRO 1

Gasto nacional en investigación y desarrollo

\begin{tabular}{|lcc|}
\hline \multicolumn{1}{r}{ PAÍS } & AÑO & \% del PIB \\
\hline JAPÓN & 1988 & 2.91 \\
ALEMANIA & 1990 & 2.84 \\
ESTADOS UNIDOS & 1990 & 2.78 \\
SUECIA & 1989 & 2.84 \\
FRANCIA & 1990 & 2.38 \\
HOLANDA & 1988 & 2.26 \\
REINO UNIDO & 1988 & 2.20 \\
CANADÁ & 1990 & 1.33 \\
ARGENTINA & 1988 & 0.50 \\
CHILE & 1988 & 0.50 \\
BRASIL & 1985 & 0.40 \\
VENEZUELA & 1985 & 0.30 \\
MÉXICO & 1990 & 0.28 \\
PERÚ & 1984 & 0.20 \\
\hline
\end{tabular}

FUENTE: ONU Statistics Yearbook 1988; onv Monthly Bulletin of Statistics, dic. de 1990.

la apropiación del conocimiento científico tecnológico se vuelve un instrumento para afrontar la crisis que padece la economía mundial a partir de los años setenta, caracterizada por un desplome de la productividad industrial, tendencia descendente de la tasa de ganancia, agudización de la competencia entre potencias capitalistas, inestabilidad financiera internacional originada por la crisis del dólar, fuertes contratiempos petroleros, continuas fluctuaciones en el precio internacional de las materias primas, etcétera, situación que acusa un fuerte deterioro del modelo de acumulación vigente.

En este orden de cosas, como una opción para salir de la crisis, se recurre a la recomposición industrial con base en las nuevas tecnologías, transformaciones que tienden, sin embargo, a consolidar un proceso de mayor independencia de las economías industriales en su relación con las economías en vías de desarrollo.

A cargo de un elevado costo social, las llamadas políticas de ajuste estructural de corte neoliberal emanadas del Fondo Monetario Internacional (FMI) y del Banco Mundial (BM) apoyan las estrategias instrumentadas por los países desarrollados y éstos se están imponiendo a nivel global en su aspiración por conquistar y conservar para sí el mercado mundial (Bonilla, 1991). En este orden de cosas, la estrategia más viable es el recurso de los bloques comerciales, v. gr., CAME, CEE, Cuenca del Pacífico y el TLC, actualmente 
en proceso de negociación entre México, Estados Unidos y Canadá. La regla del juego en esta estrategia consiste en ser neoliberal hacia adentro y proteccionista hacia afuera, de tal manera que los países industrializados puedan intervenir en la economía, particularmente en el desarrollo de nuevas tecnologías, y que apliquen políticas proteccionistas contra los bienes importados (Rodríguez, 1992).

\section{LAS NUEVAS TECNOLOGÍAS BÁSICAS}

Los logros más espectaculares de la revolución científico-técnica se han producido a partir de la informática apoyada por la microelectrónica, cuyo impresionante grado de penetración en la economía (que ha alterado los costos de producción) está imponiendo modalidades en la escala de producción y un mayor control sobre el proceso de trabajo, los nuevos materiales y la biotecnología.

Indudablemente, el elemento que caracteriza la actual revolución científico-técnica es la velocidad de la información, que viene a representar una verdadera mutación técnica, científica e industrial comparable en importancia solamente -en opinión de algunos autores-al paso del nomadismo al sedentarismo, que origino el nacimiento de la civilización y la vida urbana (Garaudy, 1972).

Asimismo, nuevos materiales y biotecnología están operando importantes cambios en el proceso de producción debido a su alto grado de penetración en la economía, por las ventajas que ofrecen no sólo en la reducción de costos de mano de obra directa y costo de materiales, sino por su flexibilidad en la escala de producción y el mayor control que permiten sobre el proceso de trabajo.

Los nuevos materiales, representados por los llamados "biomateriales" y "productos para la vida"; los materiales fabricados en el espacio exterior - los nuevos materiales compuestos, tales como las aleaciones de aıuminio-litio; de aluminio-hierro-molibdeno-zirconio, que pueden mantener sus cualidades a temperaturas por arriba de los $1000^{\circ} \mathrm{C}$; ios nuevos productos cerámicos; el láser, los nuevos plásticos y los superconductores, capaces de "conducir" intensas corrientes eléctricas a temperaturas "elevadas", que se espera en los próximos años podrán crear dispositivos para almacenamiento de energía de alto rendimiento (Aguilar Sahagún, 1988).

La biotecnología, "información codificada genéticamente inducida", es considerada por algunos autores como la revolución tecnológica del mañana, ya que mediante la manipulación de los códigos genéticos de los seres vivos está por identificar todos 
los genes humanos y determinar la secuencia de los tres mil millones de moléculas que constituyen el ADN humano (sustancia química de la cual están compuestos los genes).

Sus logros espectaculares en el área farmacéutica, de alimentos y de ingeniería ambiental tienen profundas repercusiones en el aparato productivo y por tanto en el entorno social, político y cultural que se reflejan en notables cambios en la vida cotidiana.

A modo de ejemplo, citaremos los llamados "vegetales máquina", diseñados genéticamente para resistir condiciones adversas, tales como salinidad, viento, plagas, etcétera; la obtención de plantas que generan su propio insecticida; el mejoramiento de las cualidades organolépticas de algunas plantas alimenticias; el incremento de los rendimientos por hectárea que permiten ampliar la frontera agrícola aun en tierras antes no aptas para la agricultura (Quintero, 1986). Donde más logros ha obtenido es en el campo farmacéutico en lo referente a vacunas, hormona del crecimiento, insulina humana, etcétera.

No cabe duda que una de las características de las nuevas tecnologías es su interdependencia. Por ejemplo, un biorreactor requiere del uso de una computadora. De no contar con ella para determinar la secuencia de los tres mil millones de moléculas del ADN, la ingeniería genética tendría ante sí una labor casi insuperable. Asimismo, el biochip es la expresión de esta dependencia entre biotecnología y microelectrónica, "usando la capacidad de las células para guardar y procesar grandes cantidades de información como si fueran códigos genéticos" (Mertens, ibid.).

Es indudable que la promoción de estas tecnologías "confiere" ventajas económicas antes inexistentes a los países y compañías que participan en su desarrollo al hacer posible la creación de nuevos productos con menos energía, monto de insumos y de mano de obra incorporados en el proceso final, "relativizando" así la importancia de los insumos.

Pese a que los países en vías de desarrollo (PVD) desempeñan un papel marginal en este proceso de desarrollo tecnológico, son los que habrán de resentir en los tiempos por venir un amplio rango de efectos de tipo productivo (y consecuentemente económico y social) que comprenden la relocalización de los recursos, el remplazo de materias primas, los niveles de empleo, la alteración "de la cadena agroalimentaria, el patentamiento de especies vegetales y animales, etcétera, y que requieren, ahora más que nunca, de la promoción en I \& $D$, de la interdisciplinariedad y de la cooperación regional para desarrollar políticas alternativas.

De ahí que juzgáramos importante bosquejar, así sea someramente, algunas de las repercusiones que ya se manifiestan en los momentos actuales. 


\section{DESMATERIALIZACIÓN DE LA PRODUCCIÓN}

Como ya se mencionó en líneas anteriores, en la sociedad industrial tienden a disminuir los insumos materiales y energéticos: la industria moderna procura operar con mayor eficiencia al generar nuevos materiales y energías provenientes de fuentes baratas y fácilmente accesibles, por ejemplo la generación de energía solar sin recurrir al energético fósil. En pocas palabras: remplazo de materias primas escasas y caras por otras, provenientes de fuentes baratas y fácilmente accesibles.

A este proceso se le ha llamado "desmaterialización" de la producción y se le define generalmente como la reducción en la intensidad y uso de energía y materiales en la composición de la demanda de países industrializados. "En otras palabras, expresa la tendencia a producir el mismo valor de uso con un continuo y decreciente uso de insumos" (Junne, 1988). Asimismo, se presenta como tendencia complementaria de este proceso la desmaterialización del trabajo: las grandes empresas de los emporios tecnológicos se orientan cada vez más al sector servicios, a la vez que se deshacen de gran parte de la producción material. El fenómeno cada vez más importante de la subcontratación vendría a poner de manifiesto que la actual restructuración capitalista no es exclusivamente industrial (Pérez, 1986).

Aunque el proceso de la desmaterialización se ha hecho patente aún antes de los avances de la "nueva" biotecnología, pues ya en la década de los años cuarenta aparecen en el mercado de las fibras sintéticas hules y plásticos de origen petroquímico, es evidente que hoy día su papel resulta más importante.

Algunos ejemplos, los más conocidos quizá, serían los jarabes fructosados de maíz, que se hicieron realidad a partir de la reducción de costos en las enzimas y el ahorro energético. Otro caso que se ha hecho célebre es el Aspartame, edulcorante de base química sintética.

Otros productos pueden ser desplazados en la medida que las técnicas del cultivo de tejidos resulten suficientemente baratas para que la sustitución de productos naturales por creaciones de laboratorio sea una realidad; se trata de tinturas, saborizantes, fragancias, etcétera, sin periuicio de que algunos de ellos ya hayan sido desplazados como el añil de la India y Bangladesh y los esteroides de México (Chesnais, 1990).

\section{COMERCIO INTERNACIONAL Y CAMBIO TECNOLÓGICO}

Es generalmente aceptado por la escuela de economía neoclásica que las llamadas "ventajas comparativas" resumen en símismas los factores que definen el comercio internacional. . 
El paradigma de "producir barato y vender caro", expresado por la ventaja comparativa, estaría reflejando situaciones favorables en cuanto a la localización, condiciones climáticas, mano de obra abundante, determinadas materias primas, etcétera, o la combinación de varias de ellas.

Ahora bien, bajo el efecto de la innovación y el cambio tecnológico, la ventaja comparativa se "relativiza", es decir, sufre perturbaciones y diferenciaciones que se expresan ya sea en el cambio, alteración o desaparición de los flujos comerciales debido a la aparición de sucedáneos. De ahí que al presentarse los cambios tecnológicos se debiliten las ventajas comparativas de los países exportadores de materias primas.

El debilitamiento actual de las ventajas comparativas de los países exportadores de materias primas frente a la microelectrónica y la ingeniería genética colocan en un segundo plano el aceno y diversidad de recursos naturales; la disponibilidad de mano de obra; el nivel de salarios y, por tanto, la "especialización productiva".

Aquí nuevamente habremos de referirnos al azúcar. En 1975, 90\% de la exportación de este producto provenía de los países en vías de desarrollo, en tanto que $70 \%$ era importado por países desarrollados. Para 1981 la sustitución del producto natural por los "nuevos edulcorantes" cambia radicalmente la situación: sólo $67 \%$ de la exportación azucarera provino de países en vías de desarrollo, y $57 \%$ fue importado por países desarrollados.

La caída del precio internacional del azúcar cruda ocurre a principios de los años ochenta, cuando pasa de 62.3. centavos de dólar $/ \mathrm{kg}$ a 12 centavos de dólar/ $\mathrm{kg}$ en 1985. Adicionalmente, un reporte (OCDE, 1989) nos indica que podrían darse posteriores repercusiones con el desarrollo de la fructosa cristalizada, que según se piensa puede generar posteriores olas de sustitución; y aunque en el futuro próximo el incremento en el consumo de nuevos edulcorantes puede ser lento, ya que tanto en EU como en Japón el nivel de sustitución esté cercano al punto de saturación, es indudable que la avalancha de sustitutos que se avecina habrá de afectar profundamente la exportación de productos, con la virtual "desaparición" de las ventajas comparativas de que disfrutaban algunos países en gracia a condiciones específicas de clima, lugar, producción, mano de obra, etcétera.

\section{EMPLEO}

Por lo que hace a este factor, se considera que el acervo de mano de obra barata ha sido hasta la fecha una ventaja que se refleja en los 
bajos costos de producción. Sin embargo, con la innovación y el cambio tecnológico, el monto de participación de la mano de obra en la producción necesariamente habrá de reducir su importancia, ya que las nuevas tecnologías son ahorradoras de este factor, lo que constituye un aspecto más de la "desmaterialización productiva".

Algunos ejemplos resultan convenientemente ilustrativos: la intensidad de mano de obra en textiles, vestuario y ensamblaje electrónico está siendo sustituida por intensidad de capital.

Consecuentemente, la llamada fábrica flexible tendrá requerimientos de fuerza laboral versátil (de especialización múltiple), aunque más reducida que la actual; una de sus características distintivas es la producción en pequeños lotes requeridos sobre pedido ajustado a las preferencias del consumidor, lo que da paso a la reducción de inventarios de productos terminados así como de insumos. De esta manera, la estrategia empresarial de contratación por horas y a destajo puede prescindir del escalafón, lo cual restringe la capacidad negociadora sindical (Bonilla, ibid.).

Por lo que respecta a la biotecnología agrícola, se observan las mismas tendencias del factor empleo que en la industria. Es pertinente recordar aquí que uno de los objetivos de esta ciencia es aplicar los resultados de la investigación a una escala que permita utilizarla en muchos sectores de la actividad industrial. Así, de lograrse sustitutos de carácter industrial que compiten con los de origen natural, el efecto, así fuera por poco tiempo, sería profundamente negativo, como una vainilla de laboratorio que dejara sin trabajo a 70 mil pequeños agricultores malgaches, o bien nuevos edulcorantes industriales que sacaran del mercado a muchos trabajadores en los países azucareros.

En esos dos casos, lo que podemos apreciar es que, en las condiciones apuntadas, la tasa de salarios tiene un papel poco importante, o bien neutro, para explicar la localización de una actividad económica que tradicionalmente estuvo determinada tanto por factores climáticos como por el nivel de la tasa salarial.

En la nueva situación tecnológica originada por la creación de productos de laboratorio que sustituyen a los naturales, la relocalización se explicaría por un crecimiento de la demanda de los nuevos productos, variable que desempeña un papel clave en la explicación del volumen de empleo en la nueva coyuntura tecnológica en la que lo verdaderamente trascendental es el peso del salario en el costo total unitario, así como la relación entre éste y el precio.

Ahora bien, las innovaciones tecnológicas suelen producir efectos complejos y dispares. En tanto que las revoluciones tecnológicas nunca han sido uniformes en el tiempo, en sus logros o en los efectos que 
producen, puede suceder que el volumen de empleo en cierta unidad productiva aumente, al tiempo que se produce en ella una disminución de mano de obra por unidad de producto si el caso fuera que tanto el producto como la mano de obra hubieran crecido, pero que el primero lo haya hecho más rápidamente que la segunda. Previsiblemente, el comportamiento de otras unidades productivas podría ser diferente (Wing Shum, 1991).

Es de esperarse, sin embargo, que los adelantos tecnológicos se dirijan principalmente a los cultivos ligados a consumos masivos de amplia circulación tanto en los mercados internos como en los internacionales, o los vinculados a consumos restringidos, con altas tasas de ganancia. Y de ser cierta la disparidad en el desenvolvimiento tecnológico, los puestos de trabajo productivo perdidos por el surgimiento de la nueva tecnología podrían compensarse con la creación de nuevos puestos de trabajo en tareas complementarias o de nuevos puestos de un trabajo productivo de nuevo tipo (empleo directo y empleo complementario).

Ahora bien, si antes la empresa transnacional consideraba el mundo como una "fábrica mundial" y se asentaba en los países con acervo de mano de obra barata, hoy en día el incentivo de ubicarse en ellos se ve minimizado y relativizado, ya que son otros los factores del costo total de producción los que guían la relocalización del capital.

Sin embargo, dicha relocalización incluye movimientos de capital en ambos sentidos, de tal manera que en los momentos actuales se ve restringida por las tendencias globalizadoras que habró de imponer la negociación por bloques.

En la biotecnología se podrá observar asimismo la tendencia al desempleo en labores productivas. No obstante, se podrá ver incrementada en labores secundarias no necesariamente productivas; estas dos tendencias encontradas podrán arrojar un saldo ya sea de incremento o de decremento del empleo, según la influencia en la cadena productiva de la innovación tecnológica de que se trate.

\section{RESTRUCTURACIÓN DE LA CADENA AGROINDUSTRIAL}

Con la obtención de nuevos productos biotecnológicos alimenticios alternativos a partir de insumos alimentarios, así como a la inversa: utilización de materias primas alimenticias que se convierten en insumos para obtener productos químicos, se "rompe", por así decir, el eslabonamiento tradicional de la cadena agroalimentaria. Es decir, no sólo se sustituyen unos productos por otros debido a su nueva calidad de 
intercambiabilidad; más aún, el significado cualitativo más profundo que tiene el rompimiento de la cadena agroalimentaria de producción es la aparición de nuevos sistemas productivos que virtualmente se habrán de imponer "desde fuera" a los países de la periferia, y que por fuerza habrán de alterar y modificar la DIT agroalimentaria, en la cual los alimentos serán cada vez menos productos agrícolas procesados para convertirse en combinación de varios productos básicos representados por un paquete cuyo resultado final será una combinación apropiada de sabor, color, olor, proteína y grasa (Ruivenkamp, 1986).

La cadena agroindustrial, aun cuando es una unidad dinámica, se puede desagregar, para fines de análisis, en cinco eslabones. Los tres primeros están insertos en los procesos productivos; quedan los eslabones cuarto y quinto fuera de este ámbito (Arroyo y cols., 1985).

PRIMER ESLABÓN: conocido como de la producción hacia arriba, compuesto por los insumos agropecuarios industriales utilizados por las actividades agropecuarias.

SEGUNDO ESLABÓN: procesamiento de productos agropecuarios de primera y segunda transformación.

TERCER ESLABÓN: distribución de los productos agropecuarios procesados hasta el consumo final.

Ahora bien, en este nuevo proceso de restructuración productiva que se aproxima, en el primer eslabón las tendencias consisten en separar la producción agrícola de su medio natural: la tierra. Tal sería el caso representado por la obtención de los llamados vegetales transgénicos, verdaderos productos diseñados o programados, según conveniencia, en el laboratorio. Aquí entra toda la gama de plantas y alimentos que mantendrán las apariencias de los naturales y que a veces no provienen siquiera de materias primas agrícolas; y de este modo, "por primera vez desde el Neolítico, la alimentación humana podrá autonomizarse del cultivo de la tierra", y su característica distintiva será el componente científico incorporado en el producto (Arroyo, 1989).

En el segundo eslabón de la cadena se separa la producción alimentaria de la producción agrícola. Toda la producción de metabolitos secundarios: colores, sabores, aromas, etcétera, así como la de aceites, edulcorantes, proteínas y vitaminas, puede obtenerse en laboratorios industriales, de tal manera que cada vez serán menos la resultante del procesamiento de productos agrícolas. La producción del sabor de la vainilla en laboratorio; el colorante para 
alimentos que hasta hace poco se extraía de la flor de cempazúchil; el aroma del café, etcétera, son un buen ejemplo de ello.

Por lo que hace al tercer eslabón de la cadena, se produciría la separación de la producción agrícola de sus cualidades intrínsecas. Esta separación es posible gracias a la "nueva" cualidad de intercambiabilidad que permite un uso adicional antes no explotado de los productos agrícolas. Tal sería el caso del gasohol, energético obtenido a partir de la caña de azúcar en Brasil, los jarabes fructosados de maíz (JFM), etcétera.

En los eslabones cuarto y quinto, como ya se señaló anteriormente, quedan fuera de los procesos productivos. Sus transformaciones, sin embargo, se irán moldeando en consonancia con el sistema de la cadena. No obstante, habrán de esperarse cambios en los métodos de comercialización en cuanto a envases, empaques, presentación y sobre todo en almacenamiento, ya que acentuarán la tendencia hacia el consumo de materiales de origen industrial, entre ellos los conseguidos mediante alta tecnología.

\section{PRIVATIZACIÓN DEL CONOCIMIENTO}

Es bien conocido el hecho de que la privatización del conocimiento puede generar una posición monopólica, convenientemente protegido por medio de la patente. Así, las empresas de los PD, altamente innovadoras, de tiempo atrás desarrollan acciones coordinadas a favor de este recurso legal, tanto en el marco del Acuerdo General sobre Aranceles y Comercio (GATT) como de la Organización Mundial para la Protección Intelectual (OMPI).

Por ser fuente de multiplicidad de aplicaciones, incluida el área militar ly por lo mismo considerada por mucho países como área estratégica), la biotecnología no podía sustraerse a este movimiento, privilegiado en los momentos actuales por las economías desarrolladas y sus empresas transnacionales.

El patentamiento viene a reforzar la posición monopólica en el mercado; es decir, dada su condición económica, está en aptitud de imponer el más alto precio posible, a la vez que resulta un medio eficaz para controlar la difusión de la innovación. De ahí que la estrategia de la ET sea patentar en un determinado país, no con el objetivo de transferir tecnología, sino de exportarla desde el país de origen, lo cual le permite fijar el precio arbitrariamente (Solleiro y Arriaga, 1990).

Además, el patentamiento se vuelve un recurso idóneo para imponer medidas de control político, en tanto que para los PVD puede significar, por 
ejemplo, una limitación para obtener alimentos frente al acaparamiento y manejo de las semillas (Martínez y Aboites, 1990).

Uno de los principales argumentos en los que centran los PD su campaña a favor de las patentes, es "el efecto positivo que éstas tendrían sobre el flujo de inversiones y tecnología extraniera hacia los países en desarrollo" (Correa, 1991); aunque, en opinión del mencionado autor, no hay

hasta el momento evidencias concluyentes ni en favor de la tesis que sostiene una relación positiva ni de las que afirman una relación neutra - aun negativa, porque, en algunos casos, la falta de protección puede ser un estímulo mayor a la inversión extranjera que su existencia (Correa, ibid.).

Tal parece, más bien, que la aplicación de criterios generales es riesgosa y hasta contradictoria y que, por ser un tema tan complejo, lo pertinente es tomar decisiones específicas, según la posición relativa de cada país en relación con la privatización de determinada rama productiva o recurso.

Los recursos genéticos, en particular, son motivo de un intenso debate entre los PD y los PVD; estos últimos cuentan con una gran biodiversidad. El riesgo que éstos enfrentan es que sus materiales genéticos, "protegidos y mejorados durante generaciones, pudieran convertirse en propiedad de las empresas de los países desarrollados sobre la base de una alteración inducida por métodos biotecnológicos" (Correa, ibid.).

Un indicador de los alcances que tiene este debate en el plano mundial lo refleja la posición estadunidense en las negociaciones actuales del TLC en el sentido de que se adopten e impongan estrictamente las leyes sobre patentes, derechos de autor y marcas registradas con la orientación con que han sido promulgadas en Estados Unidos, lo cual refleja la preocupación de sus grupos empresariales tales como la Pharmaceutical Manufacturers Association y el Intellectual Property, coalición de 13 compañías importantes, grupo que sostiene estrecha relación con el US Trade Representative y el Departamento de Comercio, hecho que ha resultado determinante para que el IPC influya en el curso y actitudes por debatirse en la negociación (Rodríguez, 1992).

A modo de síntesis, podríamos decir que el desarrollo y la aplicación de las técnicas biotecnológicas habrá de repercutir en múltiples aspectos ya mencionados a lo largo de este trabajo, los cuales se manifiestan en:

-Desmaterialización productiva.

-Alteraciones y aun dislocaciones en el mercado-intemacional de materias primas, frente al desarrollo de nuevos productos sustitutivos o "intercambiables". 
-Deslocalización productiva que permite el retorno de la industria a los países industrializados.

-Relativización de las ventajas comparativas.

-Dislocaciones o rompimientos en el eslabonamieno de la cadena agroindustrial.

-Privatización de los recursos biotecnológicos, con graves repercusiones para difundir la innovación tecnológica y la fijación de precios.

De todas las repercusiones anteriores se deducen efectos tanto positivos como negativos para los países en vías de desarrollo. Entre estos últimos podríamos mencionar la pérdida de mercados de exportación, la competencia de productos agrícolas baratos en los propios mercados locales; un creciente control agroindustrial de las grandes empresas transnacionales mediante la privatización de insumos tales como las "nuevas semillas", que encierran en sí procesos tecnológicos complejos; tendencia creciente a la concentración de la tierra y las oportunidades, lo mismo que aconteció con la revolución verde.

Entre los efectos positivos, podríamos citar la ampliación de la frontera agrícola al utilizar tierras hasta ahora no aptas para el cultivo; aumentos en el rendimiento de la productividad agrícola con variedades de mayor eficiencia biológica; obtención de productos agrícolas altamente "diferenciados", lo que permitiró incrementos en el precio, mejoramiento en los ecosistemas como consecuencia del uso de biofertilizantes, y plantas portadoras de su propio bioinserticida, etcétera.

Finalmente debemos considerar que los rompimientos de la cadena agroalimentaria incluyen la posibilidad de estrategias alimentarias alternativas, ya que tanto el productor como el consumidor local habrán de estar separados o ya lo están, en el caso de algunos productos, mediante los mecanismos del mercado mundial. Asimismo, se excluyen las posibilidades de "nacionalización" en cualquiera de las fases de la cadena agroindustrial.

De ahí que se refuerce nuestra convicción de que estos cambios, que llegarán junto con el siglo XXI (algunos de los cuales como ya señalamos son una realidad), están orientados a producir nuevos sistemas de interrelaciones productivas, cuya hegemonía estará determinada por el control de la tecnología en los medios de producción. Así, los productos "programados" y convenientemente "privatizados" habrán de adquirir un contenido político que se convierten en los momentos actuales en un reto a enfrentar y superar por parte de los países en vías de desarrollo. 


\section{REFERENCIAS}

Aguilar Sahagún. 1988. El hombre y los materiales. México: SEP, CONACYT, FCE.

Arroyo, Gonzalo y cols. 1985. Agricultura y alimentos en América Latina. México: ICI.UNAM, pp. 49-50.

Arroyo, Gonzalo, coord. 1989. La biotecnología y el problema alimentario en México. México: UAM-X, Plaza y Valdés.

Blum, Elsa. 1992. "La política de ciencia y tecnología y sus repercusiones para la universidad". Miguel Ángel Campos, Política científica e innovación tecnológica en México. México: IMAS. UNAM.

Bonilla, Arturo. 1991. "Hacia la inestabilidad mundial: un reto para Estados Unidos". Problemas del Desarrollo, vol. xxll, núm. 85, Instituto de Investigaciones Económicas, UNAM.

Correa, Carlos Ma. 1991."Patentes y biotecnología: opciones para América Latina". Políticas de propiedad industrial de inventos biotecnológicos y uso de germoplasma en América Latina y el Caribe. Costa Rica: ICA-PNUD/UNESCO/ONUDI.

Chesnais, François. 1988. "Biotechnology and the agricultural exports of developing countries-review of the trends and their implications". París: GREIDT.

Garaudy, Roger. 1972. La alternativa. Buenos Aires: Ed. Tiempo Nuevo. Junne, Gerd. 1988. "Incidence of biotechnology advances on developing countries". Biotechnology revolution and the third world research and information system for the non-aligned and other developing countries. Nueva Dehli.

Martínez, Francisco, y Aboites, Gilberto. 1991. "Estado, protección legal y diversidad fitogenética". Sociológica, Universidad Autónoma Metropolitana-Azcapotzalco. Núm. 13, mayo-agosto.

Mertens, Leonard. 1990. Crisis económica y revolución tecnológica. Organización Interamericana de Trabajadores (ORIT). Caracas: Editorial Nueva Sociedad, cap. II.

Ominami, Carlos. 1986. "Tercera revolución industrial y opciones de desarrollo". La tercera revolución industrial, impactos internacionales del actual viraje tecnológico. Buenos Aires: Grupo Editor Latinoamericano.

Organización de Cooperación y Desarrollo Económico (OCDE). 1989. Biotechnology, Economic and Wider Impacts. París.

Pérez, Carlota. 1986. "Potencialidades y límites de las nuevas tecnologías". La tercera revolución industrial, impactos internacionales del actual viraje tecnológico. Buenos Aires: Grupo Editor Latinoamericano. 
Quintero, Rodolfo. 1986. "Agricultura y cambio tecnológico: desarrollo y dependencia". Ponencia presentada en el "Sexto Seminario sobre Economía Agrícola del Tercer Mundo". Instituto de Investigaciones Económicas, UNAM.

Rodríguez, Dinah. 1992. "La brecha biotecnológica entre México, Estados Unidos y Canadá". La agricultura mexicana frente al Tratado de Libre Comercio. México: Ed. CIESTAMM-UACH, Juan Pablos.

Ruivenkamp, Guido. 1986. Biotechnology, the production of new relations within the agroindustrial chain of production. Amsterdam: Universidad de Amsterdam, mimeo.

Solleiro, José Luis, y Arriaga, Elena. 1990. "Patentes en biotecnología: oportunidades, amenazas y opciones para América Latina". Revista de Derecho Industrial, añoXII, núm. 34, Buenos Aires: Ed. Depalma.

Wing Shum, Juvencio. 1991. Seminario Permanente Interinstifucional "Efectos Socioeconómicos de la Biotecnología". UAM-UNAM, 29/1/91, Sesión de Discusión. 


\title{
Agricultura, biotecnología \\ e integrución norteamericana
}

\author{
GERARDO OTERO'
}

El propósito del presente trabajo es examinar algunas de las principales repercusiones que tiene el surgimiento de la biotecnología ante la inminente formalización de un tratado de libre comercio entre Canadá, Estados Unidos y México (TLC). Si bien las economías de Canadá y Estados Unidos, por una parte, y las de México y Estados Unidos, por otra, se encuentran ya bastante integradas, el TLC no sólo formalizará tal integración, sino que promoverá profundos cambios adicionales, sobre todo en la economía menos desarrollada de las tres: la de México.

El trabajo enfoca los efectos de la integración estadunidense sobre la agricultura de México. Sin embargo, parte de la gran influencia tecnológica que el modelo de la agricultura de Estados Unidos ha tenido en México durante las últimas décadas pues la agricultura estadunidense ha venido a representar el "paradigma tecnológico" de la "agricultura moderna", es decir, capitalista. Además, en vista de que se gesta también una "revolución biotecnciógica, en su mayor parte en Estados Unidos, es preciso observar las principales tendencias de su desarrollo desde el país de origen.

En este trabajo se entiende por "biotecnología" un conjunto de técnicas nuevas desarrolladas durante los años setenta y ochenta, que han hecho posible que los biólogos manipulen los propios cimientos de construcción de la vida. Algunas de estas técnicas son el cultivo celular y de tejidos, la hibridización somática o fusión de protoplastos, y la ingeniería genética. Las primeras dos técnicas han sido identificadas con lo que serían las "biotecnologías de segunda generación". Por contraste, las biotecnologías tradicionales incluyen viejos procesos tales

1 Departamento de Español y Estudios Latinoamericanos, Simon Fraser University, Burnaby, Columbia Británica, Canadá. 
como los utilizados en la producción de cerveza, queso y vino, pero ellas no forman parte del objetivo del presente estudio.

Ahora bien, como la biotecnología no está surgiendo en el vacío, sino que en cierta medida es una continuación de la anterior revolución agrícola que encarnó en la "agricultura moderna", es necesario observar los parámetros de esta última para tratar de estimar la trayectoria que muestra la biotecnología, pues una de sus posibilidades técnicas y teóricas es servir de base para acceder a un nuevo tipo de agricultura que no dependa tanto de los insumos petroquímicos, como sucede con el actual modelo.

En la primera sección se plantea la pregunta de si el paradigma tecnológico de la agricultura moderna puede ser trascendido a partir de los productos de la biotecnología. Luego se presenta un esbozo de las principales repercusiones que tiene la biotecnología en el empleo y la ecología. El auge y la proliferación de patentes y las tendencias hacia la monopolización del material fitogenético se abordan en la tercera sección. La cuarta plantea los dilemas de la agricultura mexicana ante la biotecnología y la integración estadunidense a partir de sus perfiles estructurales. Finalmente, en las conclusiones se proponen algunos interrogantes para investigación futura.

\section{AGRICULTURA MODERNA: ¿CÓMO TRASCENDER ESTE PARADIGMA TECNOLÓGICO?}

¿Por qué resulta necesario preguntarse si el paradigma tecnológico de la agricultura moderna puede trascenderse? ¿̇No ha sido tan exitoso en aumentar espectacularmente la producción y la productividad? Sí, la agricultura moderna ha contribuido muchísimo a aumentar la producción y la productividad de los alimentos en todo el mundo; pero también ha acarreado una serie de problemas que a últimas fechas ha cobrado graves proporciones, a saber: 1) gran dependencia de los recursos no renovables; 2) problemas ecológicos, tales como la erosión del suelo y su degradación y desforestación; 3 ) erosión de la diversidad fitogenética, dado el hincapié que se ha hecho en homogeneizar las nuevas variedades vegetales; 4) aumento en la vulnerabilidad de los cultivos debido a su uniformidad genética; 5) contaminación de aguas subterráneas y superficiales por los insumos petroquímicos; y 6) polarización regional y social de la estructura agraria, lo cual favorece a las zonas irrigadas y a los productores mejor dotados de recursos.

En Estados Unidos ha aparecido un movimiento minoritario que propone una agricultura alternativa, la cual sería sostenible y regeneradora de los ecosistemas que hacen posible la propia agricultura: 
Los sistemas alternativos integran y aprovechan las interacciones benéficas que ocurren naturalmente, en contraste con la agricultura tradicional. Dichos sistemas dan mayor importancia a la organización; las relaciones biológicas, tales como las que existen entre las plagas y sus predadores; $y$ los procesos naturales, tales como la fijación del nitrógeno en lugar de los métodos químicos intensivos. El objetivo es sostener y promover en vez de reducir y simplificar las interacciones biológicas sobre las cuales depende la producción agrícola ... (National Research Council, 1989a).

Un objetivo adicional que puede plantearse a la agricultura alternativa es que tendría que estar conformada por tecnologías neutras a la escala de las unidades productivas, de tal modo que agricultores con cualquier tamaño de operación puedan aprovecharlas.

Surge pues la pregunta: ¿́puede lograrse ese tipo de agricultura alternativa a partir de los productos que promete la biotecnología? Ahora bien, żcómo podemos estudiar las consecuencias de un conjunto de nuevas tecnologías cuyos resultados permanecen, en su mayor parte, dentro de un laboratorio? Una primera aproximación consiste en analizar el efecto que tienen las tecnologías actuales sobre la estructura social y la ecología. Otra en estudiar los pocos pero importantes productos de la biotecnología que ya comienzan a llegar al mercado. En esta sección se intenta la primera aproximación, y se deja la segunda para la que sigue.

\section{AGRICULTURA MODERNA Y REVOLUCIÓN VERDE}

Al hablar de "agricultura moderna" en este trabajo nos referimos a un "paquete tecnológico", el cual está compuesto por las semillas híbridas y mejoradas, los fertilizantes petroquímicos, los plaguicidas, la mecanización y la irrigación. Ahora bien, la Revolución Verde está compuesta básicamente por ese paquete, pero se trata del nombre que adoptó al ser exportado de Estados Unidos a los países del Tercer Mundo durante los años sesenta y setenta. Sin embargo, su origen y desarrollo está ubicado en la agricultura de Estados Unidos, y data de los años treinta. Dicho paquete se ha convertido en un "paradigma tecnológico" (Dosi, 1984) para la agricultura "moderna". 2 Los cultivos más afectados por

2 Giovanni Dose ha definido "paradigma tecnológico" por analogía con el concepto kuhniano de "paradigma científico". Lo define "como un 'modelo' o 'patrón' de solución de problemas tecnológicos selectos, con base en principios selectos derivados de las ciencias naturales y tecnologías materiales selectas". Los paradigmas tecnológicos se mueven a lo largo de "trayectorias tecnológicas" o del "patrón de la actividad "normal" en la solución de problemas ..." Ademós, los paradigmas tecnológicos tienen un poderoso efecto de exclusión: los esfuerzos y la imaginación fecnológica de los ingenieros y sus organizaciones 
este modelo, en lo que se refiere a semillas híbridas y mejoradas, han sido el maíz, el arroz y el trigo; pero el resto del paquete tecnológico se ha extendido a una gran cantidad de cultivos, los cuales han sido objeto de aplicaciones masivas de químicos basados en hidrocarburos.

Sin embargo, la Revolución Verde no ha sido aplicada por entero en todos los países en desarrollo. Como paquete completo se adoptó principalmente en las zonas irrigadas de América Latina, del Cercano Oriente y el Norte de Africa, mientras que en Asia se ha dado una adopción selectiva, mucho menos intensiva en el uso de maquinaria. En contraste con lo anterior, muy pocas regiones de Africa al sur del Sahara han adoptado las tecnologías de la Revolución Verde (OIT, 1988). Este patrón de adopción está claramente relacionado con los de tenencia de la tierra y las relaciones sociales de producción en las distintas regiones agrícolas del mundo.

Una de las consecuencias de tal adopción diferencial de la innovación tecnológica es que vastas regiones del mundo han quedado marginadas de la economía mundial. Si se toma la "superficie irrigada" como indicador de la proporción de tierra agrícola sometida a la agricultura moderna, resulta que en 1985 tal proporción era de sólo $20 \%$ en los países en desarrollo. Aunque parte de las mejores áreas de temporal también ha sido adecuada para las tecnologías modernas, la mayor proporción de la superficie cultivada en esos países ha quedado sin ellas (Paarlberg, 1988).

Hay una interpretación optimista posible para tal situación: si esas áreas "marginadas" de la agricultura se orientaran hacia otro tipo de agricultura moderna tendrían la posibilidad de ir más allá de la "era petroquímica" de la agricultura, hacia otro tipo de agricultura que eleve al máximo las sinergias biológicas de los ecosistemas con el fin de aumentar la producción y también las oportunidades de empleo. Es decir, ya que se conocen los problemas económicos y ambientales de la agricultura moderna, trataría de pasarse directamente de una agricultura tradicional hacia otra que podríamos llamar "postmoderna".

Infortunadamente, las tendencias económicas e institucionales actuales plantean un panorama más bien pesimista. De hecho este trabajo sostiene que la biotecnología tal vez reforzará y profundizará los cambios estructurales que trajo la Revolución Verde y que, dado el muy distinto contexto institucional donde surge la biotecnología, es probable que ésta tenga efectos sociales y regionales aún más polarizadores que los atribuidos a la Revolución Verde (Hewitt de Alcántara, 1978). Además, se plantea la hipótesis de que el mayor obstáculo para orientarse hacia una agricultura opcional o "postmoderna" es la actual se enfocan en direcciones muy precisas, mientras que se 'ciegan' con respecto a otras posibilidades tecnológicas (1984:15, cursivas del autor). 
estructura de mercado en la industria de insumos agrícolas en el complejo agroalimentario, compuesto por empresas transnacionales oligopólicas que dirigen la trayectoria de la investigación biotecnológica por la vía equivocada: en vez de crear productos que hagan a los agricultores menos dependientes del uso de agroquímicos, muchos de ellos tóxicos y carcinogénicos, su investigación tiende a instalar y extender la era química y plaguicida de la agricultura (Golburg y cols., 1990).

Puesto que Estados Unidos sigue estando a la cabeza en innovación tecnológica agrícola, es probable que los nuevos adelantos que surian en ese país afecten directa $\circ$ indirectamente la agricultura mundial. De ahí que el análisis de los efectos de la biotecnología tenga que plantearse en una perspectiva mundial, observando lo que sucede en Estados Unidos y cuáles pueden ser las opciones para países como México, si es que existe alguna. Antes de abordar las repercusiones de la biotecnología, sería útil ver cuáles han sido las consecuencias más destacadas de la agricultura moderna en Estados Unidos. De esta manera estaremos preparados para efectuar la segunda aproximación al estudio de la influencia de la biotecnología, mediante el estudio directo del perfil de sus pocos pero significativos productos nuevos.

\section{EFECTOS DE LA AGRICULTURA MODERNA EN EU}

El principal problema que debía enfrentar la agricultura en los años treinta era la relativa escasez de alimentos en el contexto de un gran crecimiento en la población. Dado el problema, se podría concluir que los avances en la agricultura moderna fueron espectaculares pues se lograron aumentos de producción y productividad sin precedentes: de una situación en que cada granjero estadunidense producía lo suficiente para alimentar a cuatro personas en el cambio de siglo, para 1988 un granjero producía lo suficiente para alimentar a 75; empero, otros efectos no fueron tan positivos. Con respecto a la composición de insumos, se dio una notable sustitución de fuerza de trabajo por capital. Asimismo, la nueva estructura de mercado contenía un profundo cambio en la estructura agraria. El nuevo complejo agroindustrial estaría constituido por dos sectores que escoltarían a la actividad agrícola propiamente dicha: la industria de la producción de insumos, fuertemente oligopólica, en la cual los productores tienen un control considerable sobre los precios de venta de sus productos; y el sector procesador y distribuidor de alimentos, que presenta una estructura oligopsónica, es decir, con pocos compradores de productos agrícolas, quienes pueden controlar sus precios de compra. Los propios agricul- 
tores, aun cuando son cada vez menos y con superficies mayores, siguen constituyendo un sector competitivo en el sentido de que ningún productor individual o pequeño grupo de productores puede controlar ni los precios de compra ni los de venta.

El desplazamiento de fuerza de trabajo agrícola en Estados Unidos tuvo como contrapartida un proceso de migración rural-urbana sin precedentes en ese país; pero la mayoría de los trabajadores y granjeros desplazados de la agricultura pudieron ser absorbidos productivamente por el robusto proceso de industrialización que se daba en EU durante y después de los años treinta, de modo que actualmente solo $2 \%$ de la fuerza laboral estadunidense trabaja en la agricultura. No obstante, la presente polarización de la estructura agraria de EU se expresa claramente en las siguientes cifras: aunque la población total se ha multiplicado, el número total de unidades productivas o granjas ha declinado de más de seis millones en 1930 a sólo dos millones en 1983. La mayor parte de las granjas, que representa $49.3 \%$ del total, son "muy pequeñas" y controlan 13\% de la superficie agrícola y apenas $3.6 \%$ de las ventas agrícolas totales. En contraste, $4.3 \%$ de las unidades agrícolas - las que están en la categoría de granjas "grandes" - controlan $22 \%$ de la superficie agrícola y $47.5 \%$ de las ventas agrícolas totales. El resto de las proporciones corresponde a las granias "pequeñas" y de "tamaño medio", las cuales contienen a las más típicas "granias de trabajo familiar". Las granjas "muy pequeñas", casi la mitad de los dos millones del total en EU, son prácticamente intrascendentes para la producción agrícola; de hecho se ven en la necesidad de subsidiar su operación con ingresos no agrícolas (GAO, 1985).

Esta última categoría de unidades pequeñas representa a los granjeros que han sido convertidos en "ineficientes" por el paradigma tecnológico de la agricultura moderna, la cual cortiene un sesgo inequívoco en favor de la gran escala productiva. Por lo tanto, sólo aquellos que adoptan temprano las innovaciones tecnológicas, quienes están bien dotados financiera y organizativamente, pueden mantenerse a flote en la agricultura estadunidense (Cochrane, 1979).

Hoy en día, la agricultura moderna de Estados Unidos enfrenta cuatro problemas principales. Primero, ha dejado de ser rentable para la mayoría de los productores, debido a una buena parte a la nueva estructura del complejo agroindustrial: puesto que los agricultores siguen siendo muchos, no pueden controlar los precios de sus insumos y tampoco los de sus cultivos. Los subsectores más importantes en la producción de insumos agrícolas y el procesamiento de alimentos muestran "índices de concentración" tan altos que 50\% de las ventas o las compras, respectivamente, es controlado por sólo cuatro o menos compañías gigantes. Un ejemplo extremo de este fenómeno es Camp- 
bell's, que controla $90 \%$ del mercado de sopas enlatadas en EU. Por tanto, los productores directos enfrentan costos de producción crecientes, al tiempo que sus vínculos "hacia adelante" con una estructura oligopsónica les dificulta enormemente retener los beneficios de su mayor productividad, resultado de adoptar nuevas tecnologías. Si bien algunos de estos beneficios se transfieren a los consumidores vía precios más bajos, la mayor parte es acaparada por las grandes compañías procesadoras de alimentos.

Un segundo gran cambio, derivado del anterior, es el surgimiento del agronegocio como productor, promotor y propagador de las tecnologías para el campo. En el principio de la revolución agrícola de los años treinta, los creadores y diseminadores de tecnologías para la labranza eran las universidades agrícolas de Estados Unidos y sus servicios de extensión: las llamadas Land Grant Colleges que existen en todos los estados de la Unión Americana.

En el caso de los países en vías de desarrollo, los principales difusores de la Revolución Verde han sido los Centros Internacionales para la Investigación Agrícola (CIIA), sobre todo durante y después de los años setenta (Kloppenburg y Kenney, 1984). Ambas instituciones, universidades y centros internacionales, tienen carácter público o semipúblico. En contraste con esto, los nuevos productores de tecnología, sobre todo en el caso de la biotecnología, son las grandes empresas transnacionales (ETNs), ayyas metas no buscan contribuir al mejoramiento de los agricultores pequeños o medianos (lo cual formaba parte del mandato de las instituciones públicas y semipúblicas) sino simple y llanamente maximizar ganancias, sin importar si ello ocasiona la polarización de la estructura agraria.

Tercero, y estratégicamente más importante, la agricultura moderna ha causado graves problemas ecológicos que ahora ponen en duda la continuación de su desarrollo. Por una parte, los fitomejoradores han producido nuevas variedades, pero cada vez son genéticamente más homogéneas. Con esto se han creado dos complicaciones adicionales que se refuerzan mutuamente: ha declinado mucho la diversidad fitogenética a medida que las variedades criollas son abandonadas en favor de las mejoradas, y la homogeneidad así aumentada de las plantas las hace más vulnerables a las plagas (Kloppenburg, 1988; Fowler y Mooney, 1990). Por otra parte, el uso intensivo de petroquímicos ha ocasionado problemas sombríos de degradación y erosión del suelo, contaminación de mantos acuíferos, y presencia de residuos químicos en los alimentos, lo cual está vinculado con la aparición de cánceres y enfermedades genéticas en seres humanos (National Research Council, 1989a).

Las consecuencias de la agricultura moderna en lo referente a erosión de los recursos fitogenéticos es en verdad alarmante. Cuando 
los agricultores adoptan variedades nuevas, mejoradas, abandonan las variedades tradicionales locales. Puesto que éstas habían sido antes domesticadas, una vez que los agricultores las abandonan simplemente desaparecen de la faz de la Tierra.

Al parecer nadie se daba cuenta de que, tras innumerables generaciones, las variedades tradicionales habían sido domesticados. A diferencia de las hierbas o las especies silvestres, aquéllas se habían vuelto dependientes de la gente para su existencia. Su remplazo era simplemente otra palabra para su extinción. Las variedades tradicionales que desaparecieron lo hicieron para siempre (Fowler y Mooney, 1990:63).

La gravedad de este problema en Estados Unidos se evaluó recientemente para el caso de 75 cultivos. Se calcula que desde 1900 se ha perdido hasta $97 \%$ de las variedades criollas (Fowler y Mooney, 1990:63).

¿Por qué es importante la diversidad fitogenética? Porque es la materia prima donde los fitomejoradores encuentran las características para producir nuevas variedades vegetales. En otras palabras: la materia prima para mejorar las variedades vegetales está desapareciendo.

El cuarto problema que se ha determinado recientemente en Estados Unidos tiene que ver con el patrón de consumo alimentario que se ha promovido, el cual está muy inclinado hacia la producción de proteína animal. Esto ha exigido dedicar cantidades enormes de granos para alimentar el ganado. Una indicación de la irracionalidad de esta manera de producir proteínas está dada por las siguientes cifras. En 1986, el total de granos dedicado a la ganadería en los países industriales avanzados ascendió a 400 millones de toneladas. Una cantidad similar fue la que representó el consumo humano de granos en los países en vías de desarrollo, donde se concentra $77 \%$ de la población mundial (Goodman y Redclift, 1989).

Aparte de la inequidad e ineficiencia de tal manera de producir proteínas, hace poco sonaron las alarmas por sus efectos en la salud de los seres humanos. En Estados Unidos, recientemente se ha vinculado la dieta basada en carne y productos lácteos con los dos problemas de salud más frecuentes en ese país: las enfermedades cardiacas y el cáncer, los cuales dan cuenta del $70 \%$ de los fallecimientos anuales en ese país. En efecto, la National Academy of Science ha determinado, según los resultc.dos de un nutrido equipo interdisciplinario de investigadores, que la dieta promovida durante los años cuarenta, con grandes contenidos de carnes y lácteos, no es sana tanto por lo que contiene como por lo que le falta: es muy abundante en grasas saturadas y colesterol y muy baja en su contenido de fibra. Mientras el 
exceso de grasas y colesterol está vinculado causalmente con enfermedades del corazón, una dieta con mayor contenido de fibra ayudaría a reducir los riesgos de contraer varios tipos de cáncer (National Research Council, 1989b). En los últimos años han aparecido varios informes de agencias públicas estadunidenses que ofrecen conclusiones similares. De manera lenta pero segura, los consumidores de Estados Unidos están exigiendo alimentos con mayor contenido de fibra y menos grasas saturadas y colesterol. Paradbjicamente, la tendencia en América Latina parece ser la opuesta, pues su consumo alimentario sigue avanzando en dirección de una dieta basada en trigo, carne y leche, en detrimento de granos y cereales locales.

\section{BIOTECNOLOGÍA, EMPLEO Y ECOLOGÍA}

Las dos aportaciones principales de la biotecnología se orientan al empleo y el medio ambiente. Mientras que la agricultura moderna ha sido claramente intensiva en el uso de capital y desplazadora de mano de obra, la biotecnología contiene el potencial teórico y técnico de producir innovaciones neutras en la escala de producción. Esto permitiría su utilización por pequeños y medianos agricultores, los cuales pueden ser más benévolos con la ecología. Sin embargo, el análisis precedente muestra que será difícil realizar tal potencial debido a las fuerzas sociales y económicas que moldean las formas específicas que toman los productos de la biotecnología.

A casi dos décadas del inicio de la "industria" biotecnológica, pueden observarse dos tendencias decisivas en el desarrollo de la biotecnología. Primero, lo que pudo llegar a ser una industria propiamente dicha ha desaparecido en los últimos años. Esto se debe a que muchas pequeñas empresas intensivas en la investigación biotecnológica se han visto en problemas financieros que las han llevado a establecer alianzas con otras empresas. Por lo general han sido absorbidas por grandes transnacionales de las industrias química y farmacéutica. Así pues, la biotecnología ha perdido su independencia como industria (Otero, 1991a).

En segundo lugar, y relacionado con lo anterior, es posible que la biotecnología haya perdido también su potencial de llegar a trascender el paradigma tecnológico actual pues las empresas que han absorbido a las de biotecnología han hecho exactamente lo mismo con la mayor parte de las empresas semilleras, que están bien asentadas en el sector que produce otros insumos agroquímicos para la agricultura (Otero, 1991b). Se trata de las mismas empresas que durante décadas han estado beneficiándose del paquete tecnológico 
de la agricultura moderna. Por eso la biotecnología está siendo utilizada ya dentro de ese paradigma tecnológico, lo cual agudiza todos los problemas relacionados con él. En el caso de las biotecnologías agrícolas, hay una cantidad relativamente pequeña de grandes empresas transnacionales que controla los programas de investigación en un camino que lleva al entronamiento de la agricultura basada en los petroquímicos.

\section{SUSTITUCIÓN Y EMPLEO}

Parecería que la principal amenaza a corto y mediano plazos que plantea la biotecnología es su tendencia a la sustitución (Goodman, Sori y Wilkins, 1987). El caso más conocido hasta hoy es el de los edulcorantes logrados mediante nuevas técnicas enzimáticas que se producen a partir del maíz. El "jarabe de maíz de alta fructosa" ha ocasionado ya graves estragos en países exportadores de azúcar (Ahmed, 1988; Junne, 1991; Otero, 1989a). Sin embargo, una posibilidad de más largo plazo es crear productos totalmente nuevos, hoy impensables.

\section{BIOTECNOLOGÍA Y ECOLOGÍA}

En la década de los ochenta surgieron más claramente en Estados Unidos las preocupaciones por los problemas ecológicos causados por la agricultura moderna en Estados Unidos. Y no es casual que haya sido en ese país donde tales preocupaciones surgieran primero, pues es ahí donde las tecnologías modernas se han aplicado en la mayor escala.

El surgimiento de la biotecnología y su potencial teórico de promover los procesos naturales en el sentido de otro tipo de agricultura fueron causa de optimismo para los ecologistas; pero con los primeros productos que han comenzado a aparecer en los últimos años la desilusión ha aparecido en algunos grupos: se piensa que en vez de acabar con la dependencia de los químicos tóxicos en la agricultura, profundizarán y extenderán la era de los plaguicidas (Golburg y cols., 1990:5).

En efecto, hay compañías que han creado nuevas variedades vegetales con tolerancia a los herbicidas que ellas mismas producen. En vez de liberar a la agricultura y a la humanidad de la dependencia de la petroquímica, las variedades con tolerancia a los herbicidas prometen expandir el paquete tecnológico de la agricultura moderna. 
La industria de los plaguicidas se encuentra tan concentrada que sólo ocho compañías controlan cerca del $70 \%$ de todos los plaguicidas con protección industrial en el mundo. Son estas mismas compañías las que financian la investigación sobre tolerancia vegetal a los plaguicidas.

\title{
LAS PATENTES Y LA MONOPOLIZACIÓN DE LOS RECURSOS FITOGENÉTICOS
}

\author{
En tecnología de punta, las patentes son \\ símbolos de virilidad. El número de ellas \\ solicitado por una compañía es signo de \\ su inventiva y de su futura prosperidad \\ ("The Pitfalls of Patents", The Economist, 9 \\ de mayo de 1987, p. 82).
}

Una de las características que ha marcado el surgimiento de la biotecnología es el frenesí por las patentes, las cuales representan una de las maneras jurídicas de proteger la propiedad industrial. En Estados Unidos una patente otorga el monopolio sobre el uso de las invenciones protegidas - que pueden ser productos o procesos industrialesdurante 17 años. El titular de una patente puede a su vez conceder una licencia a quienes estén dispuestos a pagar regalías, aunque en algunos casos también se pueden otorgar sin pago. Esto último es práctica frecuente en muchas universidades estadunidenses que no tienen suficiente experiencia en la mercantilización de su ciencia y tecnología (Peach, 1986).

En Estados Unidos, la administración de Ronald Reagan (19801988) se planté promover la mercantilización de la ciencia mediante la Ley Pública 96-517, aprobada en 1981. Esta ley otorga a las pequeñas empresas e instituciones que no persiguen fines de lucro (entre ellas las universidades) el derecho de retener el título de las patentes resultantes de investigaciones financiadas por el gobierno federal.

La conocida economista británica Joan Robinson define las patentes de la siguiente manera:

Una patente es un instrumento que evita la difusión de nuevos métodos antes de que el inventor original haya recuperodo una ganoncia adecuada que estimule la inversión que se requirió. La justificación del sistema de patentes es que, al frenar la difusión del progreso técnico, se asegura que habró más progreso técnico que difundir... Puesto que estó enraizado en una contradicción, no puede haber algo que semeje un sistema de patentes idealmente benéfico, y es posible que produzco resultados negativos en instancias particulares, lo cual impide innecesariamente el progreso aun 
cuando sus efectos generales tengan un saldo favorable (citada por Nelkin, 1984:15)

Una opinión contrastante sobre las patentes ha sido expresada recientemente por David C. Mowery y Nathan Rosenberg (1989), quienes critican por dos razones básicas el "marco de apropiabilidad" que subyace al sistema de patentes. Primero, hay suficiente tiempo entre invención y copiado para que los inventores obtengan una renta o superganancia. Segundo, los autores argumentan que lo importante es comercializar la tecnología para el crecimiento económico, lo cual se podría lograr mediante presiones del mercado, más que a través de la protección que ofrecen las patentes.

Uno de los múltiples problemas planteados por la proliferación de patentes es la tremenda desigualdad de condiciones que hay entre los Estados-nación para producir invenciones. Así, los países con sólidos sistemas de ciencia y tecnología tendrán las mayores ventajas en monopolizar el uso comercial del conocimiento. Esta situación produce un mecanismo adicional de polarización económica y diferenciación entre los países, pues los más desarrollados se preparan para proteger internacionalmente su propiedad industrial mediante la promoción de legislaciones homogéneas en todo el mundo (Otero, 1989a).

Ahora bien, en el caso particular de la biotecnología, el surgimiento de las patentes resulta verdaderamente frenético; tanto es así que la Oficina de Patentes y Marcas (PTO) de Estados Unidos tiene un tremendo retraso en su procesamiento:

Aunque el número de acciones finales sobre solicitudes pendientes aumentó a $2472,21 \%$ en 1987, ahora las compañías tienen que esperar aproximadamente 2.5 años antes que un examinador vea una solicitud. Luego se llevan 25.3 meses en promedio para llegar a una decisión final. En contraste, las solicitudes de patentes para farmacéuticos basados en compuestos orgánicos por lo regular reciben una resolución final dentro de dos años después de presentarlas.

... El total del retraso en solicitudes pendientes, entre ellas apelaciones y enmiendas, ascendió a 6907 para el 31 de diciembre [de 1987] comparado con 5837 un año antes; pero esto resulta más significativo que el aumento de nuevas solicitudes que esperaban ser revisadas al final de 1986 [debe ser 1987] pues totalizaban 4051 , un salto del $22 \%$ en 12 meses (Crawford, 1988).

En suma, la creciente privatización del conocimiento, junto con la concentración cada vez mayor de la industria de la biotecnología y el complejo agroindustrial en general, prometen grandes dificultades para que el "progreso técnico" que producen se aplique a bajos costos. Más bien al contrario; la evidencia indica que los patrones 
de difusión de productos biotecnológicos aumentarán la presencia de las ETNs en los países en vías de desarrollo, lo que resultará en un aumento en el deterioro de la diversidad fitogenética y la polarización social. ¿Cuáles son las repercusiones para México?

\section{PERFILES DE LA ESTRUCTURA AGRARIA MEXICANA}

Se ha visto cómo la agricultura moderna en Estados Unidos ha ocasionado la eliminación de la mayoría de los agricultores. En el fondo de este proceso están varios factores: la tendencia de la agricultura moderna hacia la gran escala, el requerimiento para un uso intensivo de insumos comprados, y las estructuras de mercado en la producción de insumos agrícolas y en el procesamiento y distribución de alimentos. Esto se ha reflejado en el hecho de que sólo el $2 \%$ de la fuerza laboral estadunidense se dedica a la agricultura, cuando esa cifra ascendía a más del $30 \%$ en los años treinta.

Canadá tiene un perfil estructural agrario similar al de Estados Unidos; pero en el caso de México alrededor de $25 \%$ de su fuerza laboral aún depende directamente de la agricultura. Esto no significa que la estructura agraria mexicana no esté polarizada; por el contrario, puede estar más polarizada aún que en Estados Unidos: en 1970, más del $53 \%$ de las unidades productivas eran de "infrasubsistencia" (CEPAL, 1982). Si las tendencias de décadas anteriores continuaron en los años setenta y ochenta, y no hay razones para dudarlo, entonces esa cifra es tal vez mucho mayor ahora. Sin embargo, hay todavía muchos campesinos que han logrado aferrarse a sus cultivos tradicionales, aunque haya sido a falta de mejores opciones.

Es de preverse que la integración económica norteamericana tenderá a homogeneizar las estructuras agrarias de los tres países. Es decir, en el caso mexicano habrá una aceleración profunda del desarrollo capitalista en el campo, con la adopción del paradigma tecnológico propio de la agricultura moderna. Ejemplos como el caso de Vaquerías dan fe de ello.

En vista de lo anterior habrá que enfrentar dos problemas centrales: uno es cómo preservar la diversidad fitogenética, y otro tiene que ver con las grandes masas de población rural que serán desplazadas por la modernización de la agricultura.

La erosión de la diversidad fitogenética se identificó como un problema importante desde los años setenta. La principal solución que se ha aplicado desde entonces ha sido construir "bancos de germoplasma", la mayor parte de los cuales está ubicada en los países avanzados del Norte. Estados Unidos tiene la mayor cantidad de 
muestras de plantas y semillas. Sin embargo, se ha descubierto recientemente que los bancos de germoplasma también tienen problemas: hay una tendencia a perder plantas cuando éstas son almacenadas si no se regeneran de cuando en cuando. Desde luego, este es un proceso muy costoso y no se está practicando como es necesario.

Otra posibilidad hacia la conservación fitogenética es formar reservas de la biosfera. Si bien esto ofrece una serie de ventajas, los seres humanos quedan fuera del proceso: las reservas de la biosfera deben ser medios sin ninguna perturbación por parte del hombre. Las variedades criollas fueron domesticadas por los seres humanos cuando éstos tenían una relación más armónica con la naturaleza. Entonces, si las sacamos de la escena, la ecología deja de ser natural y las variedades tradicionales se pierden. Esto plantea la necesidad de un tercer enfoque en el que los cultivadores humanos tengan una parte que vaya más allá del que tienen en el enfoque de los bancos.

Considerando que México es uno de los centros de diversidad genética más importantes del mundo (Kloppenburg, 1988; Fowler y Mooney, 1990), el tercer enfoque podría tener algún futuro combinando los esfuerzos de universidades y otras instituciones de investigación con los de los agricultores campesinos. Huelga decir que mientras no se generen tecnologías neutras respecto a la escala de producción como para iniciar una agricultura "posmoderna", estos campesinos tendrán que obtener algún tipo de subsidio a cambio de preservar la diversidad fitogenética, pues de lo contrario no podrán sobrevivir a los efectos de la modernización.

Por lo que se refiere al problema de desempleo rural, el resto de la economía tendría que ofrecer muchas y nuevas oportunidades de empleo remunerador para absorber a los campesinos desplazados de sus tierras y su actividad agrícola. De lo contrario, la actual situación de miseria y desempleo en la mayor parte de las zonas rurales de México proliferara, junto con la tendencia a migrar hacia el Norte. De hecho uno de los efectos de una mayor modernización desigual de la agricultura moderna mexicana será el abandono cada vez más marcado de tierras marginales, donde residen y subsisten los campesinos pobres. Éstos resistirán cada vez menos la competencia de cultivos producidos de manera capitalista, y las presiones para vender sus tierras que por décadas fueron "inalienables".

Después de tres décadas de una tendencia antiagrícola en las políticas de desarrollo industrial, a finales de los años sesenta la agricultura mexicana entró en una aguda crisis de la cual aún no se recupera (Bartra y Otero, 1988; Otero, 1989b). En la administración 
de José López Portillo (1976-1982) el gobierno introdujo una nueva legislación agraria orientada a facilitar la penetración de las inversiones de capital en el ejido a partir de la asociación entre capitalistas y ejidatarios.

Desde el principio de la administración de Carlos Salinas de Gortari (1988-1994) se mostró que el sistema ejidal de tenencia de la tierra sería profundamente modificado con el propósito de reconcentrar las tierras y sentar las condiciones para un desarrollo capitalista vigoroso. Durante los primeros tres años de su administración parecía que se le daba la vuelta a la cuestión jurídica del ejido y que se promoverían formas más bien veladas para estimular el capitalismo agrícola. Se renovaron los intentos por aplicar la muy discutida Ley de Fomento Agropecuario de fines del período de López Portillo. En este sentido se impulsó una alianza entre el conjunto de empresarios integrado en el Grupo Gamesa, de Monterrey, para establecer lo que sería conocido como el Proyecto de Vaquerías, en el cual 2000 hectáreas ejidales han sido sometidas a una profunda modernización y se les han introducido las tecnologías más avanzadas de Estados Unidos, entre ellas sistemas de riego y maquinaria pesada. En sólo seis meses se rompieron todos los récords nacionales en rendimientos de frijol por hectárea (Santos de Hoyos, 1991). Desde luego, tal experiencia ha sido utilizada como "caballito de batalla" para promover la asociación entre empresarios y ejidatarios. Los últimos, claro está, de hecho pierden su condición campesina y se convienten en obreros disfrazados de rentistas.

Esos esfuerzos iniciales por impulsar la asociación entre campesinos y capitalistas eran un modo de prolongar la preservación del ejido como forma de tenencia de la tierra; pero las iniciativas jurídicas que el Poder Ejecutivo envió al Congreso el 7 de noviembre de 1991 están encaminadas directamente a hacer posible la privatización de la tierra ejidal. Aunque quizás haya una agitada discusión concerniente a las modalidades y restricciones sobre la venta de los ejidos, está claro que con una mayoría prí́sta en el congreso se dará una profunda transformación de esa institución legada de la revolución de 1910-1917.

Para empezar, es probable que los principales inversionistas en tierras hoy ejidales serán los propios ejidatarios más capitalizados y otros agricultores capitalista nacionales. En el mediano plazo, sin embargo, estos inversionistas podrán ser acompañados por empresas canadienses y estadunidenses del "agronegocio". En cualquier caso, un resultado obvio de la expansión de la agricultura capitalista en México es que se difundirá proporcionalmente al paradigma tecnológico basado en los hidrocarburos, la irrigación, la mecanización, las variedades mejoradas, etcétera. $Y$ todo esto sucede en el amanecer de la revolu- 
ción biotecnológica que se gesta ya (Otero, 1991a, 1991b). ¿Cuáles serían las consecuencias para la estructura social y la ecología de tales procesos?

\section{CONCLUSIONES: HACIA UN PROGRAMA DE INVESTIGACIÓN}

Comparada con otros bloques económicos que surgen actualmente en la economía mundial, la región norteamericana está dotada de recursos humanos, naturales, científicos y tecnológicos envidiables. Si el Tratado de Libre Comercio plantea problemas, ciertamente no es por falta de cualquiera de esos recursos. En el caso de la agricultura, el problema reside más bien en quién controla los recursos y la dirección de las trayectorias tecnológicas para la agricultura, pues con los agentes económicos determinantes de hoy las repercusiones en lo referente a polarización social y desastre ecológico son bastante claras.

En este trabajo se ha argumentado que, dada la estructura del complejo agroindustrial y del paradigma tecnológico predominante en la agricultura moderna, la biotecnología agudizará los problemas que han surgido con la Revolución Verde. Además, la integración economica norteamericana sólo hará más patente el imperativo tecnológico de orientarse hacia la gran escala productiva en el desarrollo economico, en la medida que sólo las unidades que se dirijan hacia los grandes mercados serán viables y competitivas en la economía mundial. Tal imperativo está en clara contradicción con la preservación del balance ecológico y la diversidad fitogenética, y con un desarrollo social equitativo.

Se trata de una de las grandes paradojas del triunfo de las "fuerzas del mercado": mientras que dicha ideología se ha consolidado junto con una tendencia hacia la democratización política en todo el mundo, surge en un momento en que el control de las decisiones económicas descansa en las manos de cada vez menos agentes: las grandes empresas transnacionales y las instituciones internacionales que representan al capital financiero internacional, tales como el Fondo Monetario Internacional y el Banco Mundial. Esta contradicción que surge entre la democratización de la política al tiempo que la economía se muestra cada vez más concentrada y antidemocrática no se sostendrá durante mucho tiempo.

Por lo tanto, una de la preguntas decisivas de investigación es la siguiente: en una época en que los Estados-nación estón perdiendo influencia sobre los procesos económicos en sus territorios (McMichael y Myhre, 1990), y en que la economía adopta un carb́cter mundial con las empresas transnacionales como los principales agentes económi- 
cos, źqué mecanismos pueden diseñarse para dirigir el desarrollo en una dirección social y ecológicamente deseable? ¿Podrán las ETNs guiarnos en tal dirección mediante su búsqueda de las máximas ganancias sobre la base del "libre cambio"? ¿Qué mecanismos democráticos y con influencia internacional pueden impulsarse para evitar los aspectos más negativos del desarrollo económico y tecnológico? ¿Cómo pueden introducirse cambios en los programas científicos de investigación, de manera que se trate de trascender el actual paradigma tecnológico?

\section{BIBLIOGRAFIA}

Bartra, Roger, y Gerardo Otero. 1988. "Crisis agraria y diferenciación social en México". Revista mexicana de sociología, año L, núm. 1. Cochrane, Willard W. 1979. The Development of American Agriculture: A Historical Analysis. Minneapolis, Mn.: University of Minnesota Press.

Comisión Económica para América Latina (CEPAL), Alejandro Schejtman. 1982. Economía campesina y agricultura empresarial: tipología de productores del agro mexicano. México: Siglo XXl Editores.

Crawford, Mark.1988. "Patent Claim Buildup Haunts Biotechnology". Science. Vol. 239, 12 de febrero, p. 723.

Dosi, Giovanni. 1984. Technical Change and Industrial Transformation. Londres: Macmillan.

Fowler, Cary, y Mooney, Pat. 1990. Shattering: Food, Politics and the Erosion of Genetic Diversity. Tucson: University of Arizona Press.

General Accounting Office (GAO), USA Congress. 1985. Agriculture Overview: U.S. Food/Agriculture in a Volatile World Economy (Briefing Report to the Congress). Washington, GAO/RCED-86-3BR, noviembre.

Golburg, Rebecca; Rissler, Jane; Shand, Hope; y Hassebrook, Chuck. 1990. Biotechnology's Bitter Hanest: Herbicide-Tolerant Crops and the Threat to Sustainable Agriculture, A Report of the Biotechnology Working Group (USA).

Goodman, David; Sori, B.; y Wilkins, J. From Farming to Biotechnology. Londres: Macmillan.

Goodman, David, y Redclift, Michael. 1989. The International Farm Crisis. Londres: Macmillan.

Hewitt de Alcántara, Cynthia. La modernización de la agricultura mexicana: 1940-1970. México: Siglo XX1 Editores.

Junne, Gerd. 1991. "The Impact of Biotechnology on International Trade". Biotechnologies in Perspective: Socio-Economic Implica- 
tions for Developing Countries, compilado por Albert Sasson y Vivien Costarini, París: UNESCO.

Kenney, Martin, y Kloppenburg Jr., Jack. 1983. "The American Agricultural Research System: An Obsolete Structure?" Agricultural Administration, 14:1-10.

Kloppenburg Jr., Jack R. 1988. First The Seed: The Political Economy of Plant Biotechnology, 1492-2000. Nueva York: Cambridge University Press.

McMichael, Philip, y Myhre, David. 1990. "Global Regulation vs. the Nation-State: Agro-Food Systems and the New Politics of Capital". Capital and Class/Review of Radical Political Economics, núm. especial conjunto, "Beyond the Nation-State".

Mowery, David C., y Rosenberg, Nathan. 1989. Technology and the Pursuit of Economic Growth. Nueva York: Cambridge University Press.

National Research Council. 1989a. Altemative Agriculture: Committee on the Role of Altemative Farming Methods in Modern Production Agriculture. Washington, D. C.: National Academy Press.

1989b. Diet and Health: Implications for Reducing Chronic Disease Risk. Washington, D. C.: National Academy Press.

Nelkin, Dorothy. 1984. Science as Intellectual Property: Who Controls Research. Nueva York: Macmillan Publishing Company.

Organización Internacional del Trabajo (OIT). 1988. Rural Employment Promotion, International Labour Conference, 75th Session, Report vii, Ginebra: OIT.

Otero, Gerardo. 1991 a. "The Coming Revolution of Biotechnology: A Critique of Buttel". Sociological Forum, 6 (2): 551-565.

. 1991b. "Biotechnology and Economic Restructuring: Toward a New Technological Paradigm in Agriculture?" Biotechnologies in Perspective: Socio-Economic Implications for Developing Countries, compilado por Albert Sasson y Vivien Costarini. París: UNESCO.

1989a. "Industry-University Relations and Biotechnology in the Sugar and Dairy Industries: Contrasts Between Mexico and The United States". World Employment Programme research working paper. Ginebra: Organización Internacional del Trabajo.

. 1989b. "Agrarian Reform in Mexico: Capitalism and the State". William Thiesenhusen, Searching for Agrarian Reform in Latin America, Boston: Unwin Hyman.

Paarlberg, Robert L. 1988. "U.S. Agriculture and the Developing World: Opportunities for Joint Gains". Growth, Exports \& Jobs in a Changing World Economy: Agenda 1988. John W. Sewell, Stuart K. Tuker y cols. New Brunswick: Transaction Books. 
Santos de Hoyos, Alberto (GAMESA). 1991. "Partnership in Production: And Option for Modernizing the Agricultural Sector". The Devolopment of Agricuture in Mexico: Current Prospects and Policies, Texas Papers on Mexico, Pre-publication working papers of the Mexican Center. Institute of Latin American Studies, University of Texas at Austin, Conference Publication Series núm. 90-92.

"The Piffalls of Patents". The Economist, 9 de mayo de 1987, p. 82. 
. 


\title{
"iProhibide cazar!" \\ Expoliación científica, los derechos de los indígenas y la biodiversidad universal*
}

\author{
JACK KLOPPENBURG JR.**
}

En un artículo reciente, Carlos Fuentes denunció la invasión de Panamá y citó una declaración de Bush en la que afirma que piensa cazar en América Latina a quienquiera, a lo que sea, y cuando lo desee. Advirtió Fuentes: "Si no fijamos carteles que adviertan 'iProhibido Cazar!', se va a cazar furtivamente en nuestras tierras. Debemos fijar rápidamente nuestros carteles y estar listos a imponerlos con prudencia y fuerza de voluntad" (Fuentes 1990:203).

Cierto, hace muchos años que Estados Unidos estó al acecho de la presa política en América Latina; pero el drama intenso de la persecución de Manuel Noriega y los sandinistas indica que ademós de presas políticas hay presas económicas. El hecho de que Estados Unidos destituya directa e indirectamente a los líderes y gobiernos del Tercer Mundo muchas veces le han facilitado extraer materias primas -especialmente productos agrícolas- según las condiciones favorables a sus intereses comerciales (Cadwell, 1977).

En años recientes ha aumentado la caza de las materias primas en América Latina y en otras partes del Tercer Mundo. La tierra, el aire y el agua son considerados como los tres recursos naturales básicos del mundo; pero el germoplasma - la sustancia hereditaria contenida en cada célula- debe considerarse el cuarto recurso en orden de importancia. La enorme utilidad de este recurso genético ha sido magnificada por el desarrollo de la biotecnología (Kloppenburg, 1988). Hoy en día vivimos el comienzo de una nueva era de la producción en que la información genética será utilizada como materia prima fundamental.

* Quiero dar las gracias a Elia Armacanqui, quien me ayudó a escribir en español.

* Departamento de Sociología Rural, Universidad de Wisconsin. 
Puesto que ahora es un instrumento de producción del ingeniero genético, el inventario entero de los recursos genéticos se ha vuelto pertinente en un sentido económico. Según Winston Brill, dirigente de la empresa biotecnológica Agracetus, "entramos actualmente en un siglo en que la riqueza genética, en particular en las regiones tropicales como las selvas, que constituyeran hasta ahora un fondo inaccesible, está convirtiéndose en una moneda corriente con un valor alto e inmediato" (citado en Myers, 1983:218).

Los mercaderes de genes atribuyen un gran valor a los recursos genéticos del Tercer Mundo, lo cual pocas veces sucede en las naciones donde se "cazan" esas materias genéticas, consideradas "la herencia común de la humanidad"; por ello los biólogos de las universidades y de las empresas de los países desarrollados los obtienen de manera gratuita (Fuentes diría que son "cazados furtivamente").

Según el World Resources Institute (Instituto de los Recursos Mundiales, en Washington, D. C., Estados Unidos), el germoplasma puede ser el petróleo de la Era de la Información (Elkington, 1986:23). $Y$, al igual que el petróleo, la distribución mundial del germoplasma no es homogénea. De hecho los recursos genéticos están más concentrados en los países del Tercer Mundo (Kloppenburg y Kleinman, 1987). Las selvas tropicales, por ejemplo, cubren no más del $7 \%$ de la superficie del mundo, pero contienen más de la mitad de las especies del planeta. Sólo en México se han identificado más de 30 mil especies de plantas vasculares. En contraste, la flora de Estados Unidos -un país mucho más grande- incluye $18 \mathrm{mil}$ y en toda Europa hay solamente 12 mil (Toledo, 1988:17). Si, como afirma el agrónomo Hugh Popenoe (citado en Stevens, 1989:19), con la biotecnología "resulta provechoso sacar de lo que la naturaleza tiene en la despensa", resultará mucho más provechoso sacarlo de Chiapas que de Minnesota.

Tales consideraciones ayudan a explicar el "reverdecimiento" del Banco Mundial y el gran interés que muestran las instituciones de desarrollo y las organizaciones conservadoras del norte en los trueques de "deuda por naturaleza". Además de estas iniciativas que son, por supuesto, diseñadas para conservar los recursos biológicos del Tercer Mundo in situ (es decir, en su sitio natural), se encuentra también el apoyo a programas que son de verdad extractivos. Los científicos de los gobiernos, las universidades y las empresas de los países desarrollados del Norte se ocupan actualmente de recolectar organismos trupiales de todo tipo -plantas, animales, insectos, hongos, seres del mar, microorganismos, etcétera- para apreciar sus características bioquímicas útiles en aplicaciones agricolas, industriales o medicinales. 


\section{LA EDAD DE ORO DE LA RECOLECCIÓN DE PLANTAS}

Este tipo de "caza económica" tiene una historia tan larga como su contraparte políica. Los países desarrollados ya han obtenido beneficios enormes de los recursos genéticos del Tercer Mundo, lo cual tal vez se vea más claramente en el caso de las plantas agrícolas. Aunque hoy en día Estados Unidos se ha constituido en un gran poder agrícola, pocos de los cultivos cosechados en este país son nativos del lugar. De hecho los cultivos de las economías agrícolas de los países desarrollados: maíz, trigo, soya, papa, alfalfa, cebada, sorgo, tomate, algodón, tabaco, etcétera, han sido introducidos al Norte desde sus zonas de origen: el Tercer Mundo (Wilkes, 1983). El desarrollo agrícola que ha sostenido la industrialización del Norte (rico en dinero, pero pobre en genes), se ha basado en la obtención de recursos fitógenéticos del Sur (pobre en dinero, pero rico en genes).

En Estados Unidos la necesidad de obtener germoplasma fue particularmente aguda dada la relativa pobreza genética del país. En 1819 el Secretario del Tesoro dirigí una misiva a todos los consulados y oficiales navales para coleccionar semillas y plantas que pudieran ser útiles a la agricultura de su país. Y de hecho los militares desempeñarían un papel importante en la "acumulación primitiva" de recursos genéticos. El famoso almirante Perry no sólo abrió los puertos del Japón al comercio norteamericano con sus lanchas cañoneras, sino que también regresó con semillas de soya. Tal como lo dijo un botánico yanqui del siglo XIX: "Cuanto más tiempo estén allí nuestras tropas la ciencia se beneficiara" (Bruce, 1987). La responsabilidad militar por la recolección de las plantas poco a poco fue transferida al Departamento de Agricultura, y al institucionalizarse la Oficina de Introducción de Plantas en 1898 se hizo oficial la recolección globial del germoplasma vegetal. Con ello se dio inicio a lo que ha sido denominado por los historiadores "La Edad de Oro de la recolección de plantas", que se llevaría a cabo durante el primer tercio del siglo XX (Klose, 1950).

No obstante, hoy en día continúa este incesante saqueo de los recursos genéticos del Tercer Mundo por parte de los países industrializados, en tanto el germoplasma obtenido constituye una mínima porción de la variabilidad genética en sus materiales, debido a la uniformidad genética que muestran. Debemos recordar que las poblaciones biológicas son entidades dinámicas y maleables. Las variedades de los cultivos siempre están sometidas a la presión de nuevas pestes y enfermedades a medida que los patógenos o las condiciones ambientales cambian. Las variedades con estrecha base genética son consideradas de uso limitado para responder a tales retos. De modo que los científicos de plantas todavía deben dirigirse a las reservas de la 
biodiversidad en el Tercer Mundo para encontrar los genes que les permitirán codificar nuevas resistencias en variedades de alto rendimiento en la agricultura moderna de alta tecnología (Wilkes, 1983).

Por lo anterior, científicos del Norte continúan regresando al Tercer Mundo para recolectar semillas y plantas, que generalmente son obtenidas de los campesinos y los pueblos indígenas. Es muy importante comprender que estas materias no son simplemente productos de la naturaleza, sino productos del ingenio y la aplicación del trabajo humano. Los agricultores tradicionales han logrado grandes avances en la productividad de los cultivos. El botánico Jack Harlan ha reconocido la "magnífica" intervención de los indígenas de América por sus mejoramientos en maíz, papa, mandioca, camote, cacahuate y frijol. Norman Simmonds, famoso criador de plantas, ha señalado que "probablemente el cambio total genético alcanzado por agricultores a lo largo de milenios fue mucho más grande que lo realizado en el último siglo por los esfuerzos sistemáticos de la ciencia" (Simmonds, 1979:11). Además, este trabajo productivo continúa dondequiera que los pueblos indígenas han conservado sus vínculos con la tierra. En sus actividades, los campesinos y los pueblos indígenas del mundo constantemente producen y reproducen la diversidad genética que es la materia prima del criador científico de plantas.

El acceso a esta biodiversidad ya ha contribuido con miles de millones de dólares a las economías de los países desarrollados. Daré dos ejemplos de entre muchos. Los genes introducidos de tomates recolectados en el Perú permitieron incrementar el contenido de los sólidos solubles en los frutos de las variedades cosechadas en Estados Unidos (lltis, 1981:2); hace un año, en la Universidad de Wisconsin, un fitomejorador (genetista de plantas) logro crear variedades de frijol que podían suministrarse hasta $60 \%$ del nitrógeno necesario para su propio cultivo (Seedsmen's Digest, 1987). Las semillas que permitieron este avance fueron enviadas a Wisconsin por el Centro Intemacional de Agricultura Tropical, localizado en Colombia, que las había obtenido de campesinos de Centro y Sudamérica; empero, los que se benefician de este avance no son los campesinos, sino los agricultores estadunidenses que podrán reducir las aplicaciones de fertilizantes sintéticos.

La utilidad de los recursos genéticos del Tercer Mundo está aumentando con el surgimiento de la biotecnología. La estructura química de la clave genética es la misma en todas las especies y, por lo mismo, Raymond Valentine, dirigente en la empresa biotecnológica Calgene, ha sugerido que el lema de los ingenieros genéticos sea "cualquier gen fuera de cualquier organismo, dentro de las plantas" (California Agricultural Lands Project, 1982:13). Mientras que criadores de plantas y genetistas moleculares aprenden a utilizar sus nuevos 
instrumentos y técnicas de investigación más efectivamente, la demanda por la materia prima de su trabajo está aumentando. Por consiguiente, el Departamento de Agricultura de Estados Unidos ha acondicionado una base de datos computarizada para que aporte información sobre los recursos fitogenéticos en cualquier poís. Además, con el propósito de aumentar el flujo constante de materias de plantas, la Oficina de Exploración de Plantas mandará este año 30 expediciones de recolección a 17 países diferentes. De hecho la Edad de Oro de la recolección de plantas nunca ha terminado.

\section{EL BOTIQUÍN BOTÁNICO}

Como lo muestra claramente el comercio internacional de heroína, cocaína y mariguana, las características agronómicas no son los únicos elementos de interés en las plantas del Tercer Mundo; además de sus usos mós conocidos, estas drogas también tienen usos importantes en la medicina. De hecho mós de una cuarta parte de las sustancias farmacéuticas contiene ingredientes activos extraídos de esas plantas, y de entre los fármacos utilizados contra el cáncer, el cálculo se eleva al 40 por ciento. En 1985, el mercado mundial de medicamentos que contuvieron ingredientes activos extraídos de plantas era más o menos de 43 millones de dólares (Principe, 1989:9).

Y como es el caso en las especies agrónomas, la mayor parte de las plantas con usos medicinales tiene su origen en el Tercer Mundo. Por ejemplo, en cirugía resulta muy importante un relajador de músculos que fue aislado de una liana del Amazonas. El esteroide diosgenin, ingrediente principal en las pastillas anticonceptivas, es extraído de un ñame silvestre nativo de México y Guatemala. De la periwinkle rosa, flor de Madagascar, se obtiene la vincristina y la vinblastina, usadas contra la enfermedad de Hodgkin y la leucemia juvenil; de las ventas de estos fórmacos se obtienen 160 millones de dólares cada año. Asimismo, la planta asiática llamada rauwolfia, fuente del tranquilizante conocido como reserpina, rinde 260 millones de dólares de ganancias anualmente como sustancia medicinal.

Los 121 fármacos derivados de plantas fueron descubiertos después de examinar casi 35 mil especies, de las cuales cinco mil fueron cuidadosamente analizadas. Se estima que hay de 300 a 750 mil especies de plantas en el mundo; es claro, pues, que hay muchísimas más sustancias de uso medicinal en las plantas esperando ser descubiertas, y seguramente la mayor parte de tales descubrimientos va a ser con plantas nativas del Tercer Mundo. Por ello, el Instituto Nacional del Cáncer de Estados Unidos ( $\mathrm{NCl}$ ) ha iniciado un programa de millones 
de dólares para recolectar miles de plantas de las selvas tropicales durante los próximos cinco años (Booth, 1987).

$\mathrm{El} \mathrm{NCl}$ se interesa no sólo en las plantas; los ingredientes activos en el $15 \%$ de los fármacos son derivados de microorganismos o de animales vertebrados. El antibiótico cloromicetín, por ejemplo, fue aislado de un microorganismo encontrado en la tierra de Venezuela. $\mathrm{El} \mathrm{NCl}$ piensa gastar varios millones de dólares en recolectar no sólo plantas sino también seres del mar como hongos, algas, microbios, etcétera, y analizarlos en un nuevo laboratorio que puede probar cada año 10 mil sustancias por actividad biológica en 100 células de cáncer distintas y en las del virus del SIDA (Booth, 1987).

¿Cómo se realiza esta "búsqueda química" — descrita así por el entomólogo de la Universidad de Cornell, Thomas Eisner (citado en Holden, 1989:754) — de una manera eficiente? Dentro de la inmensa variedad de los organismos existentes, źcómo se puede decidir cuáles son los que merecen recolección y análisis? Uno de los métodos es concentrarse en los organismos ya utilizados por grupos humanos. Los pueblos de la cordillera andina, por ejemplo, cosechan más de 35 especies de cultivos alimenticios; un campo particular puede contener 40 variedades diferentes de papa, cada una reconocida en la taxonomía tradicional por sus características agronómicas distintas. En el sureste de Asia los curanderos utilizan unas 6500 especies de plantas. En todo el mundo los pueblos indígenas usan más de tres mil especies de plantas para controlar la fertilidad de las mujeres (Caulfield, 1985:223). Así pues, en los campesinos y pueblos tradicionales hay un acervo enorme de información cultural que puede proporcionar una guía de los elementos de la naturaleza que merecen recolección y análisis.

La utilidad de ese acervo ya se conoce. Tres cuartas partes de las plantas que aportan ingredientes activos para elaborar fármacos llamaron la atención de los científicos a causa de sus usos en la medicina tradicional. Por consiguiente, la estrategia de recolección del $\mathrm{NCl}$ presta particular atención a la sabiduría de los curanderos. Asimismo, la políica del USDA para adquirir germoplasma tiene como prioridad obtener las semillas características de regiones específicas.

EI NCl y el USDA son agencias públicas, pero el sector privado también muestra un interés cada vez mayor en la búsqueda química y genética. Una empresa llamada MYCOsearch ("Buscadora de Hongos") fue establecida para comercializar la recolección de los hongos, y una empresa llamada SeaPharm ("Farmacéutica del Mar") tiene como objetivo hacer lo mismo en los seres del mar. La empresa biotecnológica Native Plants, Inc., ya ha empezado a recolectar semillas de quinoa, planta de los Andes. Y Monsanto, empresa transnacional, ha comen- 
zado a hacer pruebas de laboratorio con uruchnumi a fin de formular un medicamento vendible; si lo logra, Monsanto va a reforzar sus derechos privados sobre ese fármaco con el objeto de obtener una patente de invención. Durante los quince años pasados, las empresas de los países industrializados han trabajado arduamente para imponer leyes que garanticen que las materias genéticas forganismos completos, cultivo de tejidos, células, secuencias de ADN, etcétera) pasen a ser de su propiedad.

\section{UNA ASIMETRÍA FUNDAMENTAL}

Hay aquí una asimetría fundamental: los recursos genéticos y culturales son extraídos del Tercer Mundo por procesamiento en los laboratorios de los países desarrollados. El objeto de este procesamiento es explícitamente producir nuevas mercancías de propiedad privada con objeto de que las compañías obtengan ganancias para sí; empero, cuando estos recursos son recolectados por los campesinos de los Andes o por los indígenas del Amazonas, los científicos los consideran como "la herencia común de la humanidad". Como afirma Garrison Wilkes, biólogo de la Universidad de Massachusetts, "los principales cultivos alimentarios no son posesión de una sola persona ya que son parte de nuestra herencia humana del pasado" (Wilkes, 1983:156).

Resulta paradbjico que durante tanto tiempo los países desarrollados hayan extraído del Tercer Mundo gran cantidad de recursos (de los que han obtenido enormes beneficios y de los que aún dependen en gran medida) sin pagar nada por ellos. En efecto, los países del Sur han emprendido un programa de ayuda enorme para beneficio de los países del Norte. La información genética y cultural ha sido producida y reproducida durante milenios por los campesinos y los pueblos antiguos; pero, como sucede con el trabajo gratuito de las mujeres, los frutos de sus esfuerzos no están valorados pese a su utilidad obvia. Por otro lado, cuando tal información es transformada en los laboratorios de los países desarrollados, la comprensión de su valor es impuesta por mandatos jurídicos y políticos.

Es así como puedo leer un artículo en el periódico académico La botánica económica, que trata de los usos tradicionales de un árbol de Asia ("El potencial del árbol neem para alejar a los insectos y para el desarrollo rural"), y un año más tarde leer un artículo en el Capital Times (periódico popular de Madison, Wisconsin, Estados Unidos), titulado "Pesticida de un hombre de Wisconsin en camino a la fama" (Capital Times, 1987:31). Este segundo artículo describe cómo "Tony Larson, hombre de negocios, ha impresionado a los comerciantes y 
oficiales del gobierno con su campaña de suministrar a los agricultores del mundo un pesticida hecho de semillas de un árbol de Asia". De alguna manera, al pesticida descubierto por los campesinos de Asia se le ha llamado "pesticida de un hombre de Wisconsin". Y esto no es simplemente retórica, pues desde que Larson recibió una patente por su formulación del extracto de neem, llamado "Margosan-O", éste ha sido aprobado por la EPA (Agencia para la Protección del Medio Ambiente), se puede comprar, y Larson ha autorizado que la trasnacional W. R. Grace se encargue de su desarrollo comercial e investigaciones adicionales. Si Monsanto produce un medicamento rentable de la planta uruchnumi no hay razón para suponer que se recompense a los jíbaros o al Perú por su contribución en este avance (aunque se haya recompensado a los pobladores de Madagascar por la vinblastina o la vincristina).

Quiero ser clarísimo en esto: no es posible negar que, mediante sus manipulaciones los científicos públicos y los de las empresas añaden valor a la información genética y cultural que adquieren del Tercer Mundo; pero también hemos de reconocer que las materias recolectadas tienen un valor en sí. En un mundo en el que los jíbaros tienen poco que vender excepto su fuerza de trabajo, Zresulta ético no darles alguna recompensa por su contribución de materias genéticas e información que son claramente útiles y tal vez muy valiosas? Si el acceso a estas materias primas produce beneficios a las empresa o a los consumidores, żno hay una obligación ética que asegure un beneficio para los jibaros?

\section{"iPROHIBIDO CAZAR SIN PERMISO!"}

Si la conducta ética fuera universal, Fuentes no habría tenido que escribir sobre la invasión a Panamá; pero, dadas las circunstancias, tiene razón al observar que si no se fijan carteles de "iProhibido Cazar!", va a continuar la caza furtiva en las tierras del Tercer Mundo, cuyas naciones y pueblos tienen derecho a insistir en poner término a la extracción de la información genética y cultural no recompensada y a requerir que se controle la búsqueda genética y química según reglas bien definidas que aseguren que los donadores de tales recursos reciban beneficios recíprocos.

Un primer paso necesario hacia esta meta consiste en que los pueblos, las organizaciones activistas, los científicos y los gobiernos del Tercer Mundo reconozcan la importancia de este asunto. A fin y al cabo son esos grupos los que van a tener la responsabilidad de decidir si se fijan o no los carteles de "iProhibido cazar!", cuáles serón sus 
leyendas y cómo imponerlas a los países expoliadores de sus recursos naturales. En los países del Tercer Mundo hay un acuerdo cada vez mayor respecto al punto de vista recientemente expresado por Miguel Altieri, agroecologista chileno:

Los países en curso de desarrollo deben tener sus propias razones para la preservación de los recursos fitogenéticos. Estos recursos son la propiedad nacional de esos países, y tienen el derecho a definir estrategias de conservación autónoma y de insistir en la recompensa por parte del Norte para la utilización de sus recursos genéticos. La conservación de los recursos fitogenéticos a nivel nacional es crucial para el desarrollo de una agnicultura sostenible que disminuya la dependencia de cosas importadas para la agricultura y que depende mucho de los recursos locales que satisfacen las necesidades de los pobres rurales y urbanos (Altieri, 1989:77-78).

Sin embargo, źcómo se construye una armazón institucional para la recompensa? Los acuerdos bilaterales generarán la tendencia a producir un mercado para la información genética, y, cierto, será posible para las naciones o las comunidades fijar precios de exploración a los buscadores genéticos, o determinar un precio para las materias recolectadas. No obstante, puesto que los genes útiles son una proporción muy pequeña e indeterminable de la variabilidad genética total, los precios que atraerán a los buscadores depreciarón los recursos genéticos. Ademós, un mercado para estos recursos quizá aislaría a los países del Tercer Mundo y los pondría en sus papeles tradicionales como competidores en el suministro de materias primas al Norte (Kopplenburg y Kleinman, 1987). Convendría mós una estrategia basada en el reconocimiento de que la utilización de los recursos genéticos es un elemento de conflicto entre el Norte y el Sur.

Los contornos de tal estrategia ya pueden observarse en las actividades recientes de la Organización de las Naciones Unidas para la Alimentación y la Agricultura (FAO). Hace diez años, los países subdesarrollados comenzaron a ver una contradicción en el estatuto de sus recursos genéticos como recursos gratuitos y el estatuto de las compañías comerciales como propiedad privada. La frustración cada vez mayor del Tercer Mundo encontró su expresión en la conferencia bienal de la FAO en 1983; en esa ocasión se aprobó una Resolución Internacional sobre los Recursos Fitogenéticos, la cual afirmo el principio de que "los recursos fitogenéticos son la herencia de la humanidad y consecuentemente deben estar disponibles sin restricción alguna" (FAO, 1983:5). Sin embargo, a continuación especifica que bajo este rubro deben incluirse también "los inventarios genéticos especiales (entre ellos las líneas élites y de criadores contemporáneos)". Es decir, la Resolución declara que las variedades comerciales y las creadas por 
los campesinos del Tercer Mundo son "herencia común" y, por tanto, propiedad compartida de la humanidad.

Tal disposición era claramente inaceptable para las naciones industrializadas, las cuales consideraron a la Resolución nada menos que como un asalto al principio de la propiedad privada. Por su parte, los representantes del Tercer Mundo declararon que si no había libre acceso a todos los recursos fitogenéticos, entonces no debería haberlo a ninguno. En lo que The Wall Street Joumal ha llamado "La guerra de las semillas" (Paul, 1984:1), se habla de un "OPEP de genes" y, sin haber acuerdo global, algunas naciones cerraron sus fronteras a la exportación de recursos genéticos. El prospecto de prohibiciones sistemáticas sobre recursos tan fundamentales parecía escalofriante, sobre todo para criadores de plantas de las universidades y de las empresas del Norte. En términos generales, reconocer el valor del germoplasma del Tercer Mundo tal vez sea una opción preferible a sortear conflictos continuos sobre dicha materia prima estratégica.

Al parecer actualmente hay una tendencia a la "guerra de las semillas". A margen de la última conferencia de la FAO, en noviembre de 1989, surgió una "interpretación acordada" de la Resolución de 1983 (FAO, 1989), la cual reconoce los derechos de los agricultores. Así como los criadores merecen recompensa por su trabajo en la creación de variedades comerciales, también la merecen los agricultores por producir y reproducir recursos fitogenéticos. Con el propósito de aportar un mecanismo que se encargue de impartir esa recompensa, la FAO estableció un Fondo Internacional para Recursos Fitogenéticos.

La disposición acordada en la FAO es un avance importante, ya que representa un reconocimiento oficial al valor de las múltiples formas de producción del conocimiento que se ubican fuera de las instituciones formales de su producción, como son las universidades y las empresas. De esta iniciativa de la FAO puede nacer un mecanismo para impartir la recompensa por concepto de actividades de innovación, vastas pero mal reconocidas, de los campesinos y los pueblos indígenas.

Todavía hay mucho por hacer para garantizar que el Fondo de la FAO alcance no un reconocimiento retórico de "derechos" abstractos, sino una verdadera redistribución del flujo de los beneficios entre el Norte y el Sur. Claro, es necesario que las contribuciones al fondo sean obligatorias. Los científicos no aceptan recompensas voluntarias por sus trabajos genéticos, y tampoco deberían hacerlo los campesinos y los pueblos indígenas. Si el Fondo recibe apoyo financiero, resulta indispensable que distribuya cuidadosamente la moneda, pues los burbcratas de los gobiernos del Tercer Mundo van a sufrir la gran tentación de apropiarse de los fondos según sus intenciones personales e improductivas; un método para disminuir tal tentación es especificar los usos 
apropiados del dinero. En ese sentido hay dos puntos que merecen mucha atención.

Primero, debe haber un mecanismo para asegurar que los campesinos y los pueblos indígenas se beneficien directamente de los fondos recolectados bajo el rubro de "derechos de los agricultores"; no sólo se trata de un deber ético, sino también de un imperativo práctico. No vamos a conservar los recursos genéticos a largo plazo sin la ayuda y participación de las personas que mejor los conocen, los mantienen, los producen, los reproducen y los emplean cada día. Cierto, debe haber disposiciones para canalizar el dinero a grupos y organizaciones populares extragubernamentales que estén comprometidos con las iniciativas del desarrollo sostenible.

Segundo, para poder controlar la información genética resulta preciso conocerla y saber cómo se emplea. En zonas donde los países del Tercer Mundo padecen una gran deficiencia, el Fondo de la FAO debe apoyar el aumento de las capacidades científicas de los países subdesarrollados, especialmente la construcción de bancos de genes y la capacitación a criadores de plantas y otros biólogos.

Quizá se den pasos adicionales y concretos hacia un Nuevo Orden Genético Internacional bajo los auspicios del Programa del Medio Ambiente de las Naciones Unidas (UNEP). En cooperación con el Instituto de los Recursos Mundiales (WRI) y la Institución para la Conservación de la Naturaleza (IUCN), la UNEP está preparando un borrador para una convención internacional sobre la Diversidad Biológica. El reconocimiento de los derechos legítimos de los campesinos y los pueblos tradicionales debe ser parte importante y fundamental de tal convención. Crear un mecanismo para recompensar por la apropiación pasada y presente de la información genética y cultural remediaría una desigualdad importante entre los pueblos tradicionales y el mundo desarrollado, que por largo tiempo se ha beneficiado del conocimiento profundo que tienen de la naturaleza.

\section{BIBLIOGRAFÍA}

Altieri, Miguel. 1989. "Rethink Crop Genetic Resource Conservation: A View from the South". Conservation Biology, 3:1, marzo:77-81. Booth, William. 1987. "Combing the Earth for Cures to Cancer, AIDS". Science, 237, 28 agosto: 969-970.

Bruce, Robert V. 1987. The Launching of Modern American Science 1848-1876. Nueva York: Alfred A. Knopf.

Caldwell, Malcolm. 1987. The Wealth of Some Nations. Londres: Zed Press. 
Caulfield, Katherne. 1985. In the Rainforest. Chicago, II.: The University of Chicago Press.

Elkington, John. 1986. "Double Dividens. U. S. Biotechnology and Third World Development". WRI Paper, núm. 2, noviembre, Washington, D. C., World Resources institute.

Fuentes, Carlos. 1990. "Time for our Sinatra Doctrine". The Nation, 12 de febrero, pp. 198-203.

Holden, Constance. 1989. "Entomologist Wane as Insects Wax". Science, 246, 10 de noviembre, pp. 754-756.

lltis, Hugh. 1981-1982. "Discovery of No. 832: An Essay in Defense of the National Science Foundation". Desert Plants, 2:4, pp. 175-192.

Kloppenburg Jr., Jack. 1988. First the Seed: The Political Economy of Plant Biotechnology, 1492-2000. Nueva York: Cambridge University Press.

Kloppenburg Jr., Jack, y Kleinman, Daniel Lee. 1987. "Seed Wars:

Common Heritage, Private Property, and Political Strategy". Socialist Review, núm. 95, septiembre-octubre, pp. 7-41.

Klose, Norman. 1950. America's Crop Heritage: The History of Foreign

Plant Introduction by the Federal Govemment, Ames, la.: lowa State University Press.

Myers, Norman. 1983. A Wealth of Wild Species. Boulder, Co.: Westview Press.

Organización para la Alimentación y la Agricultura (FAO). 1983. "International Undertaking on Plant Genetic Resources", Resolución 8/83, C 83/REP/8, 22 de noviembre, Roma: FAO.

1989. Report of the Conference of FAO, 25th Session, 11-1, 29 de noviembre, C/89/Rep. Roma: FAO.

Principe, Peter, J. 1989. "The Economic Significance of Plants and Their Constituents as Drugs". Economic \& Medicinal Plant Research, 3:9. . 1987. "New Bean Strains Fix More Nitrogen". Seedsmen's Digest, 38:2, 28 de febrero.

Simmonds, Norman. 1979. Principles of Crop Improvement. Nueva York: Longman.

"State man's pesticide on road to fame". Capital Times, 27 de noviembre, p. 31.

Stevens, William K. 1989. "Rediscovering the Lost Crops of the Incas". The New York Times, 31 de octubre, pp. 17-19.

Toledo, Víctor. 1988. "La diversidad biológica de México". Ciencia y Desarrollo, 81, julio-agosto, pp. 77-30.

Van Dam, Laura. 1986. "Old Lore, New Cure". Technology Review, 8 de octubre, pp. 8-10.

Wilkes, Garrison. 1983. "Current Status of Crop Germoplasm". Critical Reviews in Plant Sciences, 1, pp. 133-181. 


\title{
Propiedad intelectual, bioteenología y desarrollo internacional
}

\author{
MARTIN KENNEY*
}

En los últimos diez años la economía mundial ha experimentado una transformación total; después del derrumbe de la URSS Europa marcha hacia la unificación, Japón ha comenzado a sustituir a Estados Unidos como la economía más dinámica del sistema capitalista, y la importancia de los PMD (países menos desarrollados) como mercados y productores de bienes industriales ha aumentado. Estos cambios son simultáneos a transformaciones fundamentales en las tecnologías que subyacen a la acumulación de capital. La clave para comprender las repercusiones de estas tecnologías es entender que, cada vez con mayor frecuencia, el valor se genera a partir de la labor intelectual. Con estos cambios en la tecnología y la coyuntura mundial de las fuerzas económicas, las empresas capitalistas (especialmente las de Estados Unidos) tratan de cambiar los regímenes de la propiedad intelectual en todo el mundo.

En este contexto es donde deben entenderse los problemas actuales en torno a los regímenes de propiedad intelectual de los organismos vivientes. La biotecnología, como se practica en la actualidad, es una tecnología básicamente de información pues gran parte de su valor agregado proviene de la investigación; además, el modelo que subyace al descubrimiento de la manera como se "codificaron" las proteínas y se transmitio su "mensaje" a través del ADN se predijo en el modelo cibernético de procesamiento de la información de Norbert Weiner (para una mayor discusión del tema véase Yoxen). Al igual que con otras tecnologías de la información, la copia es más fácil que el descubrimiento inicial. Por ejemplo, una

* Departamenio de Ciencias Aplicadas y del Comportamiento, Universidad de California, Davis. 
vez que un gen ha sido secuenciado, cualquiera que tenga ciertos conocimientos en este campo y reciba la secuencia, puede reproducir el gen de manera poco costosa. En términos económicos esto significa que, si no se cuenta con nuevos tipos de derechos a la propiedad, la capacidad de apropiación de este invento resulta comparativamente baja.

\section{LA BIOTECNOLOGÍA COMO INDUSTRIA}

Es difícil señalar el momento en que los investigadores se percataron de la posibilidad de que las nuevas técnicas de ingeniería genética y biología molecular crearan valores económicos. Para la nueva biotecnología el acontecimiento más importante fue sin duda el nacimiento en 1976 de Genetech, empresa que abriría brecha en esta ciencia. Los fundadores de Genetech fueron Robert Swanson, inversionista, y el profesor Herbert Boyer, biólogo molecular del Centro Médico de San Francisco en la Universidad de California y ganador del premio Nobel. Ambos consiguieron una inversión inicial de 100 mil dólares del ex patrón de Swanson, la empresa de capital de inversión "Kleiner Perkins", y comenzaron la investigación corporativa en el laboratorio de fondos estatales de Boyer en la Universidad de California. En 1980, cuando Genetech se fundó oficialmente, la participación tanto de Swanson como de Boyer en la empresa ya valía decenas de millones de dólares (Kenney, 1986).

La experiencia de Genetech mostró claramente que la investigación básica en biología molecular realizada en la universidad podía generar inventos que aportaban ganancias financieras impresionantes al científico. A fines de la década de 1970, y aún más en la de 1980, los biólogos moleculares universitarios lograron obtener fondos de capital financiero y crear sus propias compañías. Durante este período, muchos profesores universitarios e inversionistas crearon al menos 200 pequeñas empresas en Estados Unidos aprovechando la investigación universitaria. En gran medida fue un fenómeno estadunidense (y en mucho menor grado, británico); aunque algunas empresas en sus inicios intentaron reclutar profesores europeos y una compañía (Biogen) llegó al extremo de abrir un laboratorio en Ginebra (ya cerrado).

Los profesores que participaron estrechamente en los inicios recibieron salarios de asesoría, fondos para la investigación y, lo más importante, acciones de la empresa. Por supuesto, con tales beneficios de capital, el resto de los profesores se sintió enormemente presionado a utilizar sus conocimientos para obtener ganancias personales (Kenney, 1986). La revolución ocurrida en la biología ha seguido aportando 
nuevas posibilidades comerciales y, por consiguiente, han seguido creándose empresas empeñadas en explotar la investigación académica. Hoy en día es habitual que todo biólogo molecular estadunidense de primera línea tenga relaciones con alguna empresa en ciernes.

La ventaja de este tipo de sistema de comercialización es que traslada con rapidez los nuevos descubrimientos al sector comercial. Por otra parte, el enorme valor que pueden llegar a tener los intereses de los profesores en las empresas ha creado conflictos potenciales de interés entre sus responsabilidades académicas y su situación financiera personal. Como ejemplo de lo anterior, la relación estudiante-profesor puede violarse cuando un profesor utiliza una idea del primero en su empresa sin compensación alguna. A menudo los profesores se concentran tanto en su compañía que abandonan la enseñanza y las responsabilidades del servicio universitario; o bien un profesor puede dirigir a los estudiantes hacia la investigación en temas útiles para su empresa. Ello representa un problema considerable porque las ideas y la información son fuentes de valor y resulta mucho más difícil establecer derechos de propiedad claros.

En los PMD hay mucha menos actividad empresarial de alta tecnología que en los países desarrollados, por diversas razones: primera, hay muy poco capital de inversión disponible, y en muchos países, aunque no en todos, las corporaciones nacionales no son dadas a correr riesgos. En contraste con lo que ocurre en los países desarrollados, una de las quejas comunes de los científicos en los PMD es que la industria parece poco interesada en sus ideas de nuevos productos, y prefiere adquirir un proceso o tecnología completamente desarrollados por empresas en los países industrializados. Esta tendencia significa que la poca demanda para innovar evita que haya nuevos descubrimientos. El capital local a menudo sufre de cierta "pereza" y falta de disposición a invertir en proyectos riesgosos, lo cual ha llevado a situaciones en las cuales las empresas del país desarrollado proporcionan fondos a investigadores de instituciones gubernamentales en los países en desarrollo a cambio del acceso a los productos y conocimientos generados por esta investigación. Estos descubrimientos son entonces patentados por la empresa extranjera no sólo en los países desarrollados, sino también en los PMD.

Por ejemplo, el director de un centro latinoamericano de biotecnología tiene relaciones cercanas con una empresa estadunidense; ello le proporciona acceso a reactivos costosos, a información pertinente y a excelentes científicos. Por otra parte, la información obtenida en el centro latinoamericano también se proporciona a la empresa. En otro caso, una compañía estadunidense aporta fondos para investigación a otro instituto latinoamericano. Los científicos de los PMD a menudo 
visitan las instalaciones de la empresa estadunidense y viceversa. Finalmente, un problema relacionado con el anterior es que continúa la "fuga de cerebros" puesto que los investigadores científicos de los PMD emigran en busca de empleos más lucrativos en el mundo desarrollado.

Recientemente han aparecido ciertas señales que indican que los investigadores de universidades e institutos estón comenzando a formar pequeñas empresas para comercializar sus conocimientos y descubrimientos. En México, por ejemplo, un empresario, con la ayuda de profesores universitarios, ha formado una pequeña empresa que se especializa en el cultivo de tejidos de flores. De manera similar, en Brasil algunas pequeñas compañías se han desarrollado a partir de institutos universitarios de investigación para comercializar nuevas técnicas. La supervivencia de estas pequeñas empresas y su crecimiento hasta dimensiones que les permitan obtener beneficios económicos es discutible. Si la experiencia de Estados Unidos puede servir de guía, una cantidad cada vez mayor de estas empresas pequeñas será adquirida por compañías más grandes que buscan la experiencia y las patentes de las primeras (Florida y Kenney, 1990).

El acelerado desarrollo de la biotecnología fue una sorpresa para las multinacionales químicas y farmacéuticas. Para fines de los años setenta ya era claro que muchas industrias podrían ser afectadas por productos elaborados mediante los recursos de la genética molecular. Estas grandes corporaciones se basaban en la química sintética y tenían muy poca o ninguna experiencia propia en el campo de la genética molecular. Así pues, cuando surgieron las posibilidades de la biotecnología, las multinacionales no pudieron asimilar con rapidez los potenciales comerciales abiertos por estos avances científicos. Para obtener el acceso a los conocimientos y las habilidades en este terreno, fue necesario acceder al mismo grupo de profesores que los inversionistas estaban reclutando para ayudar en las nuevas empresas.

El mecanismo formulado por las multinacionales fue firmar contratos con investigadores universitarios. Estos contratos preveían que, a cambio de fondos para la investigación, la empresa tendría derechos sobre cualquier producto resultante. Para la unidad universitaria, la ventaja era que se dispondría de fondos para la investigación sin necesidad de preparar solicitudes largas y complicadas para obtener subvenciones y la consecuente inseguridad en lo referente a los fondos. Para los administradores universitarios había la posibilidad de cobrar todo tipo de gastos y así garantizar beneficios financieros. De 1980 a 1983 más de 140 millones de dolares fueron aportados mediante contratos a largo plazo por parte de compañías en todo el mundo (Kenney, 1986).

Esta comercialización ha tenido ciertos efectos sutiles en la manera como se lleva a cabo la biología molecular en los países desarrollados. 
Antes de su comercialización, los materiales y la información se intercambiaban libremente. Por ejemplo, el intercambio antes informal de materiales, actualmente sólo se realiza después de la firma de elaboradas formas de renuncia de derechos que prometen que los descubrimientos a los que se llegue con los nuevos materiales no serán patentados y los materiales no serán compartidos con los de otros investigadores. De este modo, el intercambio de información, tan decisivo para el avance académico, ha sido truncado y debilitado por la inyección de motivos comerciales en intereses académicos tradicionales.

La importancia atribuida por las universidades a la patente de descubrimientos ha aumentado constantemente debido a la preocupación entre los patrocinadores corporativos respecto a la capacidad de apropiarse los beneficios de la investigación que recibió fondos y la posibilidad de que la universidad obtenga ingresos de tales descubrimientos. Este aumento en el número de patentes inyecta nuevos elementos importantes al proceso de investigación. Primero, se requiere de gran secreto para proteger las patentes. Se pone mucho mayor cuidado para establecer quién debe participar en la investigación, y se excluye a quienes "no son esenciales". Tercero, los artículos de los expertos deben escribirse de tal manera que resulten útiles para el proceso de patentar el producto. Nuevamente, la inclusión de estos motivos ulteriores produce efectos tanto en el medio ambiente como en el ethos de la universidad y en el centro mismo de la empresa académica.

Las consecuencias más graves son las referentes a las relaciones entre los miembros de la institución. Se han dado casos en que dos profesores se han negado a participar en comités de tesis de posgrado debido a su lealtad a diferentes compañías. Pueden verse problemas similares en la falta de disposición de miembros del profesorado para discutir sus resultados más recientes en reuniones departamentales debido al temor de que sus competidores puedan hallar valor comercial en sus avances. En una atmósfera como ésta, la desconfianza y el secreto sustituyen el diáloǵo académico característico, tan necesario para la vida universitaria (Kenney, 1986). En algunos casos, los laboratorios de investigación en las universidades han adoptado algunos de los atributos de las corporaciones lucrativas.

\section{LA PROPIEDAD INTELECTUAL Y LOS PMD}

Las economías capitalistas otorgan diversos privilegios a los atributos no físicos de la creación humana, a saber: patentes, marcas registradas, 
copyrights, derechos al cultivo de plantas, derechos para proteger semiconductores y secretos de profesión. En el presente artículo sólo nos referiremos a los derechos y patentes del cultivo de plantas; sin embargo, de manera más general, todos estos derechos actualmente están cambiando de modos que despiertan gran interés para los estrategas de los PMD. Además, los países desarrollados no son monolíticos ni están de acuerdo con la índole ni con el alcance de ninguna de estas formas de protección. En la mayor parte de los casos, Estados Unidos ha presionado para obtener una proteccion mós estricta, mientras que Japón y Europa han tendido a favorecer protección y consideraciones del bien social como un aspecto de las decisiones menos estrictas.

La patente es un Derecho de Propiedad Intelectual (DPI) otorgada a una(s) persona(s) que formulan una invención. El propietario de la patente tiene derecho de excluir a otros de utilizar su invención durante un tiempo determinado. El término usual de una patente es de entre 17 y 20 años, según el país. Existen tres criterios para que una invención sea sujeta a patente: primero, debe ser novedosa; segundo, debe ser útil $y$, finalmente, no debe ser natural. La patente también debe proporcionar la información indispensable para que cualquiera con suficientes habilidades en el terreno pueda utilizar la invención cubierta por la patente (Nelson y Merges, 1990:9). Por supuesto, esta definición resulta excesivamente amplia y un gran número de creaciones útiles puede incluirse en los estatutos de las patentes. En consecuencia, lo que es patentable resulta, nuevamente, una decisión de política social. Así, por ejemplo, en Europa las variedades de plantas y animales, y fundamentalmente los procesos biológicos para producir plantas y animales, quedan excluidas de la posibilidad de patente (Dickson, 1989:1003).

Los Derechos del Cultivo de Plantas (DCP) son otro tipo de DPI que resulta importante para la biotecnología. Los DCP son el otorgamiento de protección para una variedad específica. Sin embargo, esta variedad puede reproducirse libremente con otra, y los resultados pueden entonces también protegerse como una nueva variedad. Por otra parte, los DCP también protegen a los agricultores contra la reproducción y nueva siembra en las granjas (Van Wiik, 1990:6). Sin embargo, en las discusiones recientes en la Comunidad Europea las grandes multinacionales han aplicado presiones para modificar el sistema y eliminar el derecho de los agricultores a volver a utilizar las semillas en temporadas sucesivas. Dicho de otra manera, la práctica tradicional de los agricultores desde el principio de la historia (es decir, guardar las semillas para volver a plantarlas) quedaría prohibida por los nuevos reglamentos de semillas (Seedling, 1990:13). Es poco probable que una medida tan 
radical se adopte próximamente; sin embargo, resulta un claro indicio de la meta final de la industria.

\section{PATENTES, BIOTECNOLOGÍA Y LOS PMD}

Tradicionalmente, los propios organismos vivientes no han sido patentables. Sin embargo, los cultivadores de plantas han logrado garantizar su protección mediante la legislación de la Protección a las Variedades de Plantas (PVP). ${ }^{1}$ Un breve análisis de la PVP nos da un excelente ejemplo de cómo los derechos a la propiedad intelectual son siempre un derecho político y no un derecho "natural". El hecho de que la PVP pudiera calificarse como una modalidad "débil" de protección se debe a tres factores: primero, los agricultores han tenido el suficiente poder político para evitar que los gobiernos den a la industria una manera estricta de propiedad intelectual; segundo, gran parte del cultivo de plantas se realizo en el sector público, y las empresas de semillas del sector privado simplemente comercializaban los productos de la investigación; tercero, técnicamente resultaba difícil establecer el sujeto real de la patente así como definir rigurosamente los mecanismos para su patente. De esta manera, era política y técnicamente difícil exigir y justificar un régimen de protección estricto.

Las nuevas herramientas extremadamente poderosas de biología molecular cambiaron esta situación de dos maneras: primero, ahora los genes mismos que producían ciertas características podían definirse rigurosamente. Segundo, la inversión masiva en esta nueva tecnología atrajo a actores mucho más importantes hacia la rama de semillas de la industria de los insumos agrícolas. Estas compañías, en gran medida de la industria agroquímica, estaban más acostumbradas al régimen de propiedad intelectual particular de la industria química, y especialmente la farmacéutica, en la cual las patentes son más importantes que en industrias como la de maquinaria (Beier y cols., 1985; Nelson, 1990). Y, por supuesto, políticamente eran mucho más poderosas.

El primer otorgamiento de una "verdadera" protección de patente para organismos vivientes fue la decisión de 1980 "Diamond vs. Charkrabarty" por parte de la Suprema Corte de Estados Unidos. Esta decisión proporcionaba protección de patente a un microorganismo creado mediante ingeniería genética (pero no recombinante), bacteria que supuestamente podía descomponer el petróleo cuando se presentaban derrames (OTA, 1989:52). Esta decisión de 1980 mostró a todos los actores en este terreno que las patentes en productos biológicos se

1 Para una brillante discusión de la PVP, véase Kloppenburg, 1988. 
tomarían en consideración, y con ello comenzó una especie de fiebre por patentar materiales biológicos de todo tipo. La mós importante de éstas fue la patente Cohen-Boyer para insertar material genético externo en un plásmido, el cual sería entonces inyectado en otro microorganismo. Esta patente, fundamental para todo el ADN recombinante, es propiedad de la Universidad de Stanford y la Universidad de California.

La siguiente reglamentación importante sobre patentes fue ex parte Hibberd, el primer caso de una planta patentada. La ley de patentes ofrece una protección mucho mayor que la vieja Patente para los Derechos de los Cultivos (PDC). Sin embargo, las patentes no dan al agricultor una cláusula de exención; además, la variedad patentada no puede utilizarse para cultivar y vender una nueva variedad sin que el propietario de la patente reciba compensación. En efecto, la nueva variedad queda cerrada y fuera de la jurisdicción de otros para que la mejoren (OTA, 1989: 77). Esta protección resulta mucho más amplia que la (PDC) y da al propietario el monopolio del germoplasma de la semilla patentada (para un análisis de los posibles problemas que comprende la patente de formas vivientes véase Barton, 1989).

La ampliación final de la ley referente a la propiedad intelectual fue la decisión que tomó la Oficina de Patentes de Estados Unidos en 1988 y que permitiría a la Universidad de Harvard patentar un ratón creado mediante ingeniería genética que tiene particular propensión a contraer cáncer (oncomouse). Esto pone a todo el reino animal a disposición de la privatización. Por supuesto, los animales cuya aparición es natural no pueden patentarse. Sin embargo, si un científico creara un nuevo tipo de perro, este animal podría patentarse. Ahora bien, cualquier animal que sea único, útil y no natural puede considerarse una máquina o un producto químico y ser patentado (OTA, 1989:110).

Con el objeto de ayudar a imponer leyes mucho más estrictas sobre todo tipo de propiedad intelectual, Estados Unidos ha creado un nuevo Circuito de Cortes de Apelación únicamente para juzgar casos de patentes muy pro DPI, y ahora está apoyando el $70 \%$ de las infracciones a las patentes llevadas ante la corte (Mody, 1990:215). Así pues, es probable que las patentes de organismos vivientes y de partes de éstos se vuelvan mucho más estrictas y que una porción mucho más considerable del mundo biológico natural pase a manos del sector privado.

Esta sección se ha centrado en Estados Unidos porque las cortes y la oficina de patentes de este país han pugnado por promover los derechos de propiedad de los organismos vivientes. En Europa, en cambio, esta tendencia no se ha dado tan marcadamente. Asl, por ejemplo, en 1991, Europa y el comité agrícola del Parlamento europeo 
rechazaron una propuesta para "ampliar las patentes no sólo a organismos vivientes, sino también a partes de éstos como los genes". Especialmente importante para el comité era el posible "efecto sobre las bases económicas, sociales, ecológicas y éticas de la sociedad" (Science, 1991:19). En el caso de las plantas seguirán con los DPC, y los animales simplemente no serón patentados. La posición japonesa aún no es clara, sobre todo en el área de plantas creadas mediante biotecnología (Saba, 1987:4). ${ }^{2}$ Así pues, resulta poco probable que Europa acepte la posición de Estados Unidos respecto a la patente de plantas y animales (Dickson, 1989:1003).

\section{CONCLUSIONES}

Hay consenso en el sentido de que las patentes son necesarias para alentar la innovación en el capitalismo, lo cual no ha resultado concluyente en el campo de la biotecnología. Por ejemplo, la patente Cohen-Boyer ciertamente se practicarla con o sin haber sido autorizada. De manera similar, el invento Kohler-Milstein de anticuerpos monoclonales no fue patentado y en la actualidad se utiliza ampliamente (para un análisis al respecto véase Kenney, 1986; Nelson y Merges, 1990, pp. 69-70).

Contrariamente a lo que afirman los economistas en el sentido de que las empresas invierten en investigación con el propósito de elevar sus ganancias al máximo, la verdad es que la inversión se hace para garantizar la supervivencia (la posición de los economistas puede consultarse en Rozek, 1990:37). Por ejemplo, Evenson (1990:354-355) argumenta que para los PMD más débiles sería una buena política "fortalecer los derechos nacionales de la protección intelectual y adoptar una posición negociadora respecto a DPI mós estrictos para extranjeros". La industria de semiconductores no tuvo patentes durante años, y de cualquier manera la inversión en este campo seguía siendo enorme. Es decir, las patentes y la innovación están daramente correlacionadas.

Al igual que las tierras antes de que llegaran los occidentales al Nuevo Mundo, los DPI no son un derecho divino ni natural, sino que de hecho son dados socialmente. Como Noble (1977) ha demostrado con claridad, los DPI se han cambiado constantemente para adecuarse a las necesidades de quienes detentan el poder. De hecho la reflexión sobre el capitalismo nos lleva a concluir que los derechos a la propiedad intelectual han sido formulados en beneficio de los capitalistas. Por lo que respecta al desarrollo internacional, es interesante señalar que los

2 También puede suponerse que Japón todavía no está listo para tomar una posición frente a la patente de animales producidos mediante ingeniería genética. 
países que reciben las mayores presiones para imponer los DPI son los que han tenido el mayor éxito en el desarrollo de sus economías: Corea, Taiwán, Hong Kong, Singapur y, más recientemente, Tailandia, y que han sido señalados por Estados Unidos para recibir las mayores presiones (Schumann, 1990).

Por supuesto, la ventaja es que estos países dependen de Estados Unidos como mercado y, por consiguiente, los sectores de exportación de la economía pueden movilizarse o ser amenazados para poder cumplir con las exigencias de Estados Unidos. Como lo señala Mody (1990:225), Estados Unidos está presionando a otros países para que adopten leyes de protección a la propiedad intelectual idénticas a las estadunidenses, aunque éstas no sean ni las más convenientes ni las más lógicas. Además, muchos de estos nuevos tipos de DPI son simplemente aquellos que Estados Unidos considera que serán los que mejor protegerán sus industrias debilitadas. ${ }^{3}$ La mayor ironía de esto es que el país que probablemente se beneficiará no será Estados Unidos, sino Japón, el cual se está volviendo cada vez más el líder tecnológico (véase, por ejemplo, Florida y Kenney, 1990).

Es interesante señalar cómo son tratados los países tercermundistas en trabajos supuestamente académicos en torno a las patentes. Por ejemplo, un país que no reconozca los DPI estadunidense $u$ occidental, practica la "piratería". 4 Sin embargo, sacar el material genético, los conocimientos médicos indígenas, los estilos musicales o los patrones artísticos o artesanales únicos de los PMD no se califica de piratería (para un estudio en este sentido, véase Brush, 1993). Frischtak (1990:61) concluye que "ciertas desventajas jurídicas y administrativas clave en cuanto a la protección de los derechos a la propiedad intelectual no parecen tener un efecto significativamente adverso sobre las actuales actividades tecnológicas de la mayor parte de las compañías brasileñas". La legislación sobre la propiedad intelectual nu necesariamente resulta un beneficio claro para los PMD; por tanto, antes de adoptar reglamentos parecidos a los de los países desarrollados es preciso un profundo análisis de sus repercusiones.

3 De hecho, Karkala (1990: 284) argumenta que el enfoque de Japón a la protección de software en computación se acerca mucho más que el estadunidense a lo que sería socialmente óptimo para alentar la innovación. La tendencia de Estados Unidos parece mucho más dirigida a conseguir ganancias monopólicas para el inventor que a optimizar la innovación. La ley de patentes no se justificó originalmente para proporcionar ganancias monopólicas, sino para alentar la innovación. La mayor debilidad del modelo de innovación estadunidense que se centra en los descubrimientos más que en la producción y en la innovación gradual se discute con mayor profundidad en Florida y Kenney (1990).

${ }^{4}$ Gran parte de este lenguaje tan cargado de interpretaciones se viliza entre los supuestos economistas de "libre valor". Como ejemplo, véase un número de los artículos en Rushing y Brown, 1990 o Ayres, 1986. 


\section{BIBLIOGRAFÍA}

Ayres, Robert. 1986. "Technological Protection and Piracy: Some Implications for Policy". Technological Forecasting and Social Change, 30, pp. 5-18.

Barton, John. 1989. "Patenting Life Forms: The Central Issues". Inédito, Universidad de Stanford.

Beier, F.K., Crespi, R.S. y Straus, J. 1985. Biotechnology and Patent Protection. París: Organización de Cooperación Económica y Desarrollo.

Brush, Stephen. 1993. "Farmer's Rights and Genetic Conservation in Traditional Farming Systems". World Development, enero.

Dickson, David. 1989. "No Patent for Harvard's Mouse?" Science 243, febrero 24, p. 1003.

Evenson, Robert. 1990. "Intellectual Propenty Rights, R\&D, Inventions, Technology Purchase, and Piracy in Economic Development: An International Comparative Study". Science and Technology: Lessons for Development Policy. Compilado por R. Evenson y G. Ranis. Boulder, Co.: Westview Press.

Florida, Richard, y Kenney, Martin. 1990. The Breakthrough Illusion. Nueva York: Basic Books.

Frischtak, Claudio. 1990. "The Protection of Intellectual Property Rights and Industrial Technology Development in Brazil". Intellectual Property Rights in Science. Technology, and Economic Performance. Compilado por F. Rushing y C. Brown. Boulder, Co.: Westview Press, pp. 66-98.

Kenney, Martin. 1986. Biotechnology: The University Industrial Complex. New Haven: Yale University Press.

Kloppenburg, Jack. 1988. First the Seed: The Political Economy of Plant Biotechnology. Cambridge: Cambridge University Press.

Merges, Robert, y Nelson, Richard. 1990. "On the Complex Economic of Patent Scope". Columbia Law Review, 90 (4), pp. 839 916.

Mody, Ashoka. 1990. "New International Environment for Intellectual Property Rights". Intellectual Property Rights in Science, Technology, and Economic Performance. Compilado por F. Rushing y C. Brown. Boulder, Co.: Westview Press, pp. 203-240.

Nelson, Richard, y Merges, Robert. 1990. "Market Structure and Technical Advance: The Role of Patent Scope Decisions". Consortium on Competitiveness and Cooperation. University of California, Berkeley, Documento de trabajo núm. 90-10.

Noble, David. 1977. American by Design. Oxford: Oxford University Press. 
Office of Technology Assessment (OTA). 1989. New Developments in Biotechnology: Patenting Life. Washington, D. C.: US Government Printing Office.

Rozek, Richard. 1989. "Protection of Intellectual Property Rights: Research and Development, Decisions and Economic Growth". Intellectual Property Rights in Science, Technology, and Economic Performance. Compilado por F. Rushing y C. Brown. Boulder, Co.: Westview Press, pp. 31-48.

Rushing, Francis, y Brown, Carole. 1990. Intellectual Property Rights in Science, Technology, and Economic Performance. Boulder, Co.: Westview Press.

Saba, Shoichi. 1987. "Protecting Intellectual Properties: Toward Establishment of New International Rules". Keidanren Review 107, octubre, pp. 2-4.

Schumann, Gunda. 1990. "Economic Development and Intellectual Property in Southeast Asia". Intellectual Property Rights in Science, Technology, and Economic Performance. Compilado por F. Rushing y C. Brown. Boulder, Co.: Westview Press, pp. 157-202.

Science. 1991. "Europe's Bio-Patent Dispute", núm. 254, 4 de octubre, p. 19.

Seedling. 1990. "EC Breeder's Rights Law Tabled", octubre, pp. 13-15. Van Wijk, J. 1990. "Intellectual Property Protection for Plants". Biotechnology and Development Monitor, 4, septiembre, pp. 3, 7. Yoxen, Edward. 1984. The Gene Business. Londres: Pan Books. 


\title{
Problemas que plantea la biotecnología en el mareo legislativo de la propiedad intelectual: el caso de México
}

\author{
GILBERTO ABOITES MANRIQUE'
}

\section{INTRODUCCIÓN}

En el contexto de la conformación de una nueva división internacional del trabajo manifiesta en las reconversiones industriales, la ocupación o desarrollo de nuevos mercados depende de los avances tecnológicos, a los que se pretende proteger de manera más eficaz confiriendo particular importancia a los mecanismos de apropiación de los resultados generados por las costosas investigaciones. De ahí la trascendencia que adquieren los medios jurídicos de protección a la propiedad intelectual referidos prioritariamente al otorgamiento de patentes de bioproductos y bioprocesos.

La paulatina pero evidente pérdida de competitividad de la economía estadunidense en sectores de mediana, e incluso de alta, tecnología impulsan a modificar las reglas del juego que rigen la protección intelectual; el propósito es hacer valer su innegable superioridad en biotecnología, basada en un sistema científico-tecnológico más desarrollado y consolidado que el de sus competidores, lo cual ahonda la profunda asimetría en el sistema económico internacional entre norte y sur respecto a las capacidades de producción tecnológica, y propicia la consolidación de una división internacional del trabajo entre los países que concentran la innovación y los que accederán a los resultados principalmente por vía del comercio internacional.

El que esta disputa tenga lugar en el contexto de la Ronda de Uruguay (GATT) y para el caso de México también en las negociaciones Narro".

1 Profesor del Depto. de Sociología de la Universidad Autónoma Agraria "Antonio 
del Tratado de Libre Comercio (TLC) y no en organismos internacionales, hasta hace poco considerados como propios, v. gr. la Organización Mundial de la Propiedad Intelectual (OMPI), responde a una propuesta globalizadora de las relaciones económicas donde se negocia conjuntamente comercio, tecnología y finanzas.

La ausencia de mecanismos que garanticen internacionalmente el respeto a la propiedad intelectual bajo ningún sistema de protección internacional: Convenio de París o El Convenio para la Protección de Obtenciones Vegetales, explican el porqué del interés estadunidense en que sea en el GATT o en el TLC donde se negocien los cambios en el sistema de propiedad intelectual, ya que en ambos se contemplan mecanismos que obligan al cumplimiento de las reglas. Por ello México vive las presiones para adecuar sus leyes de propiedad intelectual conforme a la visión del "deber ser" norteamericano, de la globalidad y la modernidad, de manera más intensa, dada su manifiesta premura por concretar el TLC.

Tanto es así que en menos de dos años el Gobierno Federal ha impulsado y logrado una radical transformación del marco jurídico que rige esta cuestión.

No obstante lo anterior, es importante señalar que el tema de la propiedad intelectual y la biotecnología recién comienza, y sus perfiles en el plano internacional se están definiendo; de ahí que incluso México - con todo y la aprobación de una nueva normatividad- no represente sino un engranaje más del aparato que en ciernes se levanta y cuyos actores principales son los países desarrollados, más precisamente sus empresas trasnacionales y las instituciones internacionales vinculadas a la administración de instrumentos jurídicos como OMPI.

El presente ensayo muestra - de manera general y sucinta- un panorama del estado que guarda, a nivel internacional, la normatividad de la protección industrial biotecnológica que sirve de referencia para encuadrar la nueva legislación mexicana en la materia. Señala también los puntos conflictivos, y finalmente hace algunos comentarios que llevan la discusión al ámbito del qué hacer en las universidades mexicanas respecto a los problemas de la protección biotecnológica.

La necesidad de comprender los efectos socioeconómicos que estos cambios en la legislación pueden ocasionar en el sector agropecuario mexicano, punto de referencia y del conocimiento al que nos circunscribe la pertenencia a una institución como la Universidad Autónoma Agraria "Antonio Narro", me hicieron concentrar la atención no sólo en la biotecnología sino también en lo referente a la biotecnología de vegetales, de donde proviene mi interés en el tema de las variedades vegetales. 
El trabajo comienza con una descripción de la manera como se ha conformado la relación derecho-biotecnología; después se exponen las características de la nueva legislación mexicana relativas a la biotecnología y concluye con una serie de propuestas para que las instituciones de investigación modifiquen sus patrones de comportamiento en virtud de lo que se identifica como nuevas realidades.

\section{EL DERECHO Y LA PROPIEDAD INTELECTUAL}

Aunque las denominaciones "propiedad intelectual" y "propiedad industrial" se emplean indistintamente lo cierto es que difieren. La primera incluye a la segunda. De igual manera llega a confundirse propiedad intelectual con derechos de autor, pese a que, nuevamente, la primera incluye a la segunda (véase cuadro 1). Ambas confusiones derivan de que el desarrollo industrial vivido durante el siglo $X X$, resguardado por la protección industrial, fue tan dominante que en el lenguaje común englobó bajo su nombre a los demós instrumentos jurídicos de protección.

En general la propiedad industrial consiste en todas las creaciones - tales como un producto técnicamente nuevo, una mejora a una máquina o aparato, un diseño original para hacer más útil o más atractivo un producto, un proceso de fabricación novedoso, una indicación distintiva del fabricante o distribuidor particular, una denominación identificadora de un establecimiento, un aviso publicitario, una aclaración sobre el origen geográfico que distingue y hace especial al producto, etcétera- que día con día se presentan y se utilizan en las actividades de producción y comercialización de bienes y servicios, las cuales, se supone, redundan tanto en un beneficio económico para sus creadores como en mayor bienestar para los consumidores o usuarios (SECOFIN, 1991:2).

\section{CUADRO 1}

\begin{tabular}{|c|c|c|}
\hline $\begin{array}{l}\text { Sistema de protección } \\
\text { a la propiedad } \\
\text { intelectual }\end{array}$ & $\begin{array}{l}\text { Sistemas de } \\
\text { patentes o } \\
\text { Propiedad } \\
\text { Industrial }\end{array}$ & $\begin{array}{l}\text { Patentes. } \\
\text { Modelos y dibujos } \\
\text { industriales. } \\
\text { Certificados de } \\
\text { invención. } \\
\text { Tecnoinnovaciones. } \\
\text { Tronsferencia de } \\
\text { tecnología. } \\
\text { Secreto comercial. } \\
\text { Marcas. }\end{array}$ \\
\hline
\end{tabular}

Sistemas de derechos de autor 


\section{El derecho y la propiedad sobre la vida}

Como señala Edelman (1989), mientras el conocimiento del hombre permitió únicamente contemplar al ser vivo como totalidad no apropiable, no hubo problema en la relación entre el derecho, la ciencia y la tecnología.

En el derecho se podía establecer la relación técnica que el hombre mantenía con la naturaleza: si éste la explotaba con sus facultades intrínsecas, se tenía una relación entre fuerzas naturales; pero si creaba artefactos, inexistentes a la fecha, entonces se trataba de algo construido para transformar la naturaleza: un invento. Así pues, se creb una jurisprudencia para proteger el objeto y para reconocer a su creador un derecho propio mediante la obtención de una patente.

Por ende, el derecho de las patentes no es más que la protección jurídica de un invento - siempre que sea nuevo y útil a la industria-, que se resuelve en un monopolio de explotación. Concebida para dominar la naturaleza física, la patente reproducía en su mismo objeto (el invento) no sólo el estado científico, sino también una distinción fundamental: cosa/persona. ${ }^{2}$ Hasta aquí nos desenvolvíamos en un modelo epistemológico donde lo vivo, lo "animado", se diferenciaba claramente de lo inanimado y esta dicotomía se trasladaba al derecho bajo la forma de cosa vs. persona. El hombre posee la naturaleza pero no se la apropia; solamente una "cosa" puede ser objeto del derecho de propiedad. El hombre no se confundía con las cosas, sino que su destino técnico era dominarlas, o sea transformarlas, por el derecho, en "bienes".

Concebido en el respeto a "las leyes de la naturaleza", el invento patentable debía reproducirlas en su estructura misma y, al igual que la naturaleza, tenía que utilizar fuerzas o fenómenos para producir un resultado determinado, repetible e inevitable. La relación de causalidad que se observa en las leyes de la naturaleza se ha de hallar también en el invento y, dado que convenía circunscribir el campo del invento a la actividad propia del hombre, se excluían de la protección los "descubrimientos" por las mismas razones que las leyes naturales.

En 1930, con la aprobación por parte del Congreso de Estados Unidos de Norteamérica de la Ley de Plantas, se da paso a un nuevo paradigma e irrumpe lo vivo en el campo de la patente. En esa ocasión se señaló que "la distinción pertinente no ha de hacerse entre las cosas vivas y las inanimadas, sino entre los productos de la naturaleza - vivos - no- y los inventos del hombre" (Edelman, 1989). Un segundo momento en la evolución del derecho de lo vivo corresponde a la

2 Para el desarrollo de este párrafo se utiliza el artículo de Bernard Edelman, "EI derecho y el ser vivo", Mundo Cientffico, 1989, núm. 95, pp. 1012-1022. 
solución que en el derecho se encuentra en lo referente a las variedades vegetales donde, recurriendo a un modelo "mecánico" de lo vivo, se califica como "máquina" a la variedad vegetal.

El planteamiento del "derecho de obtención vegetal" propio de Europa clarifica el punto. Primeramente, dado que en la naturaleza se ejerce la facultad de reproducir lo idéntico en la mutación, el productor de variedades alcanzará la protección de éstas sólo cuando sean distinguibles, uniformes y estables entre generaciones, es decir, cuando "inmovilizan" la evolución natural; por ejemplo cuando la variedad vegetal sea idéntica a ella misma en el tiempo. ${ }^{3}$ Es decir, la intervención del hombre consiste en romper la evolución para hacer perdurable una variedad original. De ahí que la organización jurídica de tal estabilidad, con el fin de proteger una variedad, debe estar lo bastante distante de las variedades más próximas, ser homogénea, ser estable (en el sentido en que las poblaciones, de generación en generación, serán idénticas). En segundo lugar, esta ley toma en cuenta el hecho de que no sólo la variedad creada es un producto directo de la naturaleza, sino también que las plantas son necesarias para la vida humana; de donde surge la idea de que el productor disfrute de un monopolio restringido.

Así pues, aunque el mismo productor puede oponerse a que alguien se apodere de su variedad con el propósito de comercializarla, no puede impedir, en cambio, que un usuario consuma los productos logrados, y menos aún que otro se sirva de su material para crear una nueva variedad. Puede decirse que dicha formulación correspondía al "modelo europeo de la naturaleza". El monopolio parcial es suficiente para asegurar la rentabilidad de inversiones a largo plazo; pero no lo bastante cerrado para bloquear una variación perpetua que, dentro de la repetición idéntica por la que se reproduce la naturaleza, constituye la propiedad misma de la vida.

En un derecho unitario se reagrupan dos elementos contradictorios: al aspecto creación del hombre corresponde el monopolio; al aspecto poco independiente de la naturaleza, el límite del monopolio. El equilibrio entre monopolio y no monopolio, relacionado con un paradigma epistemológico que establece ya no la separación entre el hombre y la naturaleza (animada e inanimada), sino entre inventos del hombre y productos de la naturaleza, salta en pedazos con el desarrollo científico y la irrupción de las nuevas biotecnologías, y da lugar a una nueva diferenciación: vida natural (no patentable) y vida artificial

${ }^{3}$ Convenio para la Protección de Obtenciones Vegetales (UPOV), Art. 6 (condiciones requeridas para beneficiarse de la protección) ... condiciones que debe cumplir la variedad para que pueda gozar de protección. Las condiciones se refieren a la novedad, la distinción, la homogeneidad y la estabilidad de la variedad objeto de la protección. Sin embargo, en ninguna legislación hay una definición precisa referente a lo que es una variedad vegetal. 
(patentable). Ahora la posibilidad de trabajar con ADN recombinante cuestiona una vez más las bases del derecho de lo vivo.

Mientras fue posible patentar el gen agregado - digamos a una semilla - su resultado era una contradicción: una nueva variedad, lo estipulado previamente con el derecho de obtentor, lo cual nos remite a un monopolio parcial. La contradicción se presenta porque: en una semilla genéticamente modificada, el gen incorporado puede ser protegido por una patente, mientras que la variedad de "acceso" o variedad original es "libre", o sea no patentable. En cambio, si se hiciera prevalecer el gen sobre la variedad, es decir, la patente sobre el derecho de obtención vegetal, se llegaría al resultado siguiente: los seleccionadores no tendrían acceso a este gen, pero el inventor sí en todas las variedades existentes; podría insertar en ellas su gen y, por consiguiente, obtener una protección para dichas variedades (véase cuadro 2).

Semejante paradoja se encuentra al revisar la evolución del derecho en relación con los microorganismos. En la patentabilidad de los usos industriales de los microorganismos no se había planteado ningún problema grave pues las patentes se referían a "procesos microbiologicos" que intervenían en la fabricación de muchos productos, en la cual la patente no pretendía proteger al microorganismo, sino sus efectos.

CUADRO 2

ALCANCE DE PROTECCION

Patente de A porque la célula contiene nueva información genética
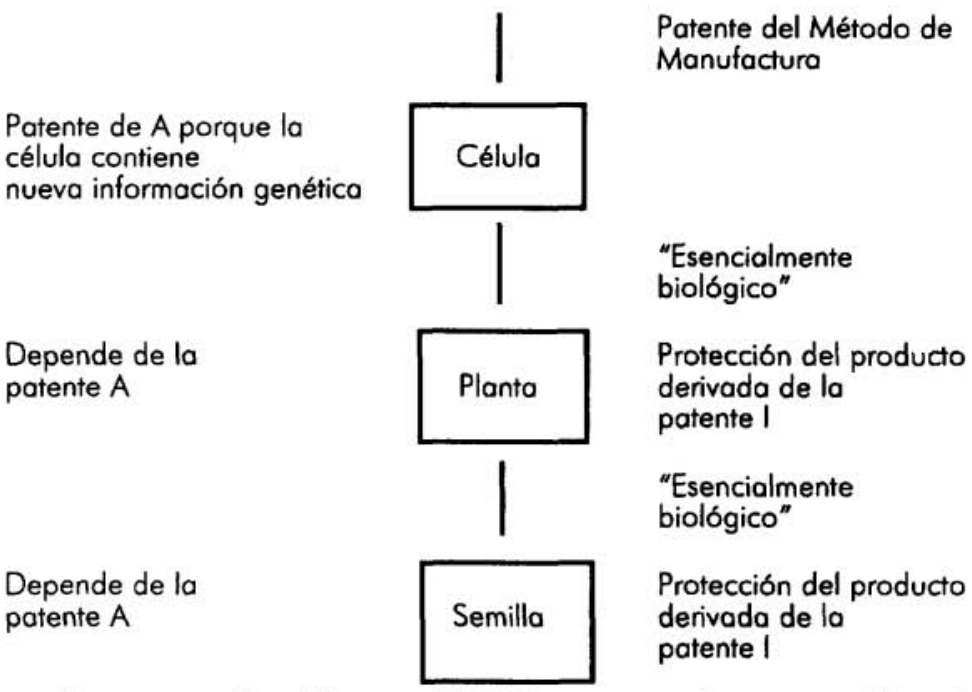

FUENTE: WIPO y Cornell University, 1987, Symposium on the profection of biotechnological inventions, junio 4-5, Ithaca, Nueva York, p. 170. 
En observancia a esa pauta, la Convención de Estrasburgo de 1963 sobre la unificación de ciertos "elementos" del derecho de las patentes de invenciones previo, en su artículo $2 b$, aplicar la patentabilidad "a los procesos microbiológicos y a los productos obtenidos mediante estos procesos". El artículo 53 de la Convención de Munich sobre la concesión de las patentes europeas recogí esta proposición. ${ }^{4}$ Tampoco planteó ningún problema la no patentabilidad de "microorganismos aislados de fuentes naturales", puesto que se trataba de "descubrimientos" y no de inventos. La duda surge cuando los microorganismos son objeto de un cultivo "puro" obtenido por selección de células y formado por una cepa genética con todos sus caracteres específicos de la célula madre. ${ }^{5}$

A medida que la naturaleza vegetal y animal va descomponiéndose en objetos "fabricados", entra en la categoría de objeto de mercado; para el derecho se convierte en "cosa" y, por lo tanto, es patentable.

\section{EL DERECHO Y LA BIOTECNOLOGIA}

De aceptarse la solicitud de ampliar la protección conferida a un procedimiento respecto de los productos obtenidos por él (protección del producto por el proceso), puede significar un dilatado monopolio para el que logre patentar primero algún proceso, pues en ello irá la patente al producto. Como señala Bercel (1990), diversas legislaciones excluyen del patentamiento a los procedimientos esencialmente biologicos, donde la influencia técnica carece de significación.

Al reiterar el criterio amplio sobre patentamiento de seres vivos, la OMPI sostiene

que es necesario interpretar restrictivamente las disposiciones sobre exclusión de la protección por patente, porque un procedimiento en varias etapas en el que por lo menos una etapa inventiva no es esencialmente biológica (no técnica), debería considerarse que no es esencialmente biológica (no técnica). Por la misma razón -continúa-, un procedimiento en el que la intervención humana consiste en más que seleccionar un material biológico determina-

4 El problema de la patentabilidad de procesos y productos biotecnológicos constituye uno de los temas principales de la "armonización de las legislaciones de patentes" discutidas en la OMP. Sobre este y otros temas importantes en la problemática de la propiedad intelectual, véase Carlos María Correa, 1989, "Propiedad intelectual, innovación tecnológica y comercio internacional", Comercio Exterior, México, vol. 39, núm. 12, diciembre, p. 1072.

5 Huni y Buss, "La protection par brevets dans le domaine du génie génétique", citado por Bernard Edelman, "El derecho y el ser vivo", Mundo Científico, 1989, núm. 95. 
do y permitir que éste cumpla una función biológica inherente en condiciones naturales no debería considerarse esencialmente biológico (no técnico).

Obviamente que el centro de la cuestión en debate estriba en determinar el significado de "proceso biológico". La industria de la biotecnología define rotundamente sus actividades como esencialmente técnicas y por ello patentables (OMPI, 1989b). La discusión resulta fundamental, sobre todo en la industria química, en las producciones basadas en fermentaciones que emplean microorganismos resultado de una selección y clonación; y, mós recientemente, cuando refieren a organismos transgénicos, pues se esgrime que en el proceso biológico intervienen elementos determinantes no "naturales".

El problema resulta sobremanera preocupante para nuestros países, que tienen la fortuna de ser "Centros de diversidad genética", llamados "Centros Vavitov", pues en las discusiones llevadas a cabo en OMPI, las secretarías de ésta (fuertemente influidas por los países industrializados) pretenden llevar a límites inadmisibles la protección de las innovaciones en materia de especies vegetales. Veamos la manera como se plasma la modalidad amplia de protección que preconiza la OMPI en relación con la extensión del procedimiento a los productos obtenidos por él, por réplica (clonación) o evolución (de una planta a partir de una célula), reseñado por Bercel (1990). Señala la OMPI que

si el objeto de una patente es un procedimiento para la producción de materia viva $u$ otra materia que contenga información genética que permita su multiplicación en forma idéntica o evolucionada, toda protección conferida por la patente de procedimiento al producto obtenido por éste debería extenderse no sólo al producto inicialmente obtenido por el procedimiento patentado, sino también a los productos idénticos o evolucionados de las generaciones ulteriores obtenidas a partir de él, consideróndose ese producto como obtenido directamente por el procedimiento patentado (OMP1, 1989b).

El centro del debate radica en lo siguiente: si el procedimiento da lugar a la reproducción de materia viviente que contenga información genética, hay que discernir si la patente abarca el producto obtenido del proceso o si, además, comprende las siguientes generaciones del producto. De aceptarse el criterio sustentado por la OMPI, la patente podría entrañar un derecho de propiedad sobre el germoplasma, en la medida en que el procedimiento incluya manipulación genética. 
En efecto, si por un procedimiento de ingeniería genética se llegare a modificar o agregar una cualidad al germoplasma, el producto obtenido daría al titular de la patente la posibilidad de controlar la totalidad de variedades a la que se incorpore el gen. Lo cual nos hace interrogarnos sobre la validez de apropiarnos el germoplasma.

En materia jurídica, el problema para nuestros países atañe a la cobertura de la patente, pues en la protección del proceso se protege también el producto final, y un mismo proceso puede generar productos variados. Por otra parte, en este como en todos los puntos de conflicto referentes a la protección de algo vivo, la disputa se centra en la diferencia entre "invento" y "descubrimiento". Sólo se patenta lo que no existe en la naturaleza, aquello que el hombre construye para apropiórselo mediante el proceso de producción, lo cual, dado el período histórico en que nos encontramos, nos refiere a la industria. De ahí que la invención patentable requiere que tenga aplicación industrial o utilidad industrial; en este rubro se considera a la artesanía, la agricultura, la minería, la pesca, los servicios (OMPI, 1989a).

El planteamiento llevado a sus extremos entraña que, en virtud del desarrollo de la ciencia y la tecnología, se han creado las condiciones materiales para que incluso el descubrimiento deba ser objeto de patente cuando esté mediado por algún invento, es decir cuando el descubrimiento sea resultado, más que del hombre, del desarrollo científico técnico.

La magnitud del peligro que enfrentarian los países subdesarrollados se manifiesta al denominar los adelantos científico-técnicos, celosamente concentrados en países industrializados, como "el microscopio de barrido de túnel" (STM) (Scanning Tunneling Microscopy). Este instrumento puede ver los átomos que facilitan la producción de descubrimientos económicamente valiosos, por ejemplo detectar estructuras moleculares productoras de nuevas proteínas, que para conseguirse en nuestros centros de investigación exigen de un esfuerzo en tiempo más que proporcional. En el Instituto de Ingeniería de Proteínas en Osaka, Japón, mediante la utilización del STM y de la mejor computadora de ese país, la estructura molecular de una proteína se conoció en media hora, lo que en el CINVESTAV-Irapuato exigió tres meses de intensos trabajos (Guadarrama, 1991). Hay, pues, una tendencia a reproducir y acentuar los desequilibrios económicos vía el desarrollo de una tecnología exclusiva y excluyente.

Más grave que la protección de los procesos biotecnológicos y por ende de los bioproductos es lo que Herrera (1991) llama la "patente de conceptos", la cual se refiere a la protección de ideas, es decir patentar una "característica", dada por un gen o genes, cuyo ámbito de acción no está acotado sino por el concepto mismo. Veamos un 
ejemplo que muestra la importancia del punto. La Compañía Calgene elaborb una patente para proteger los resultados que sus investigadores lograron en torno a que la enzima "poligalacturonasa" retrasaba el ablandamiento de los frutos. La compañía trabajo sobre plantas de tomate, pero la patente era sobre el uso de la estrategia de ARN-antisentido contra enzimas hidrolíticas para obtener variedades vegetales cuyos frutos tienen un proceso de ablandamiento mós lento. La patente cubre cualquier enzima hidrolítica y cualquier especie vegetal. El interrogante es si, jurídicamente, la patente sólo debiera cubrir el uso de ARN-antisentido contra la "poligalacturonasa" en tomate, o si debería extenderse a cualquier especie vegetal y a cualquier enzima hidrolítica relacionada en este proceso, para lo cual todavía se tendría que aislar el gen o los genes correspondientes, desarrollar la metodología de transformación genética y demostrar que la estrategia es útil en esa especie en particular (Herrera, 1990). El punto se encuentra en espera de una decisión que siente jurisprudencia en Estados Unidos; de aprobarse, se trataría de la facultad de patentar el futuro y lo desconocido. Nuevamente, para nuestros países esto se presenta como un peligro por la generalidad de la patente; es decir, no hay una clara definición de lo que en derecho se denomina "el espacio para el producto" que cubre la patente.

Otro gran problema se refiere a la protección de variedades vegetales, pues ninguna legislación cuenta con una definición precisa del concepto; en su lugar está la exigencia de cumplir algunos criterios operativos para obtener el privilegio de la protección. En el Convenio para la Protección de Obtenciones Vegetales (UPOV), en el artículo 6, se establecen las condiciones que debe cumplir la variedad para poder disfrutar de protección. Se trata de la novedad, la distinción, la homogeneidad y la estabilidad de la variedad objeto de la protección.

Como señala Schmid (1989), lo nuevo, lo no natural, se refiere a la distinción entre el estado anterior de la técnica y el estado actual; lo nuevo supone decidir cuáles son sus características sobresalientes y su margen de variación.

En el caso de patentes, la novedad y la distinción se encuentran vinculadas con el concepto jurídico de "espacio para el producto", el cual determina la proximidad y disponibilidad de bienes sustitutivos, es decir precisa el espacio jurídico que permita proteger un producto definiendo el espacio donde quedan los productos naturales y el que deberán cubrir las nuevas patentes. Así pues, hay una definición en negativo de lo que puede ser protegido mediante patentes: todo lo que no sea natural (véase cuadro 3). El espacio para el producto determina los sustitutivos del estado anterior de la técnica y limita con lo no natural y con los equivalentes. Lo anterior entraña el concepto de "invenciones 
sustitutivas" y nos conduce a la "doctrina de los equivalentes" que por un lado refiere a la idea de inadmisibilidad de alteraciones menores y por otro a la de que, dentro de cierto margen, los productos nominalmente diferentes son en realidad equivalentes.

\section{CUADRO 3}

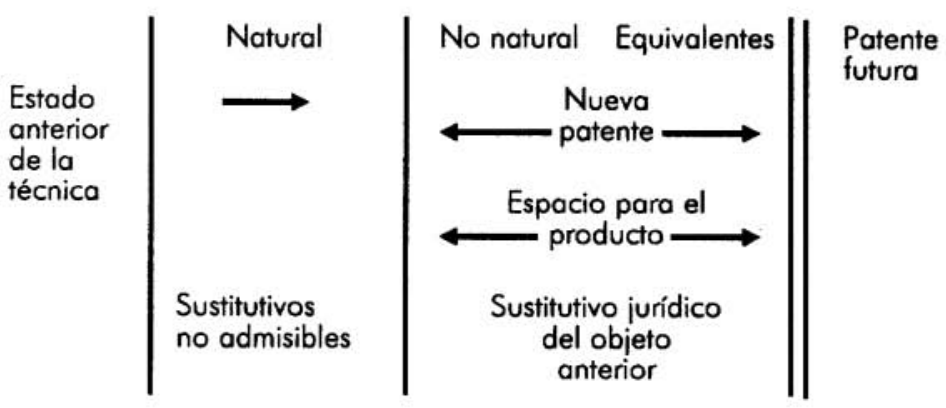

FUENTE: A. Allan Schmid, 1989, "Protección legal de variedades vegetales, biotecnología y derechos cambiantes de propiedad en agricultura", Revista Agricultura y Sociedad, núm. 53, octubre-diciembre, Madrid.

El problema surge cuando hay que indicar hasta qué punto es diferente lo diferente, lo cual, por lo demás, constituye una pregunta válida para todo lo que es vida.

En lo referente a patentes un elemento de juicio importante para reconocer la novedad del invento es su descripción, que sirve además para difundirlo e impulsar la generación de bienes sustitutivos que, sin ser copia, partan de él, pues ello beneficia a la sociedad en la medida que restringe el tiempo del monopolio característico de la patente. Sin embargo, en variedades vegetales el desconocimiento de las plantas condujo a una solución pragmática: existen nuevas variedades vegetales cuando una variedad se puede distinguir por su hábito, inmunidad a las enfermedades, condición del suelo, color de la flor, de la hoja, del fruto o del tallo, aroma, productividad, perfume, forma y facilidad de reproducción asexual. Esta solución adoptada en Estados Unidos con la Ley de Patentes sobre Vegetales de 1930, permitía evadir el escollo de la descripción señalada en el artículo 112 del Título 162 de la Ley 35 USC (Schmid, 1989), y es el parámetro que rige en otras legislaciones sobre el punto.

Tal vez por eso, cuando en 1970 se aprueba en Estados Unidos la Ley de Protecciones de Variedades Vegetales, adaptación de la legislación del Convenio para la Protección de Obtenciones Vegetales 
(UPOV), se olvidó la doctrina de los equivalentes y se favorecieron las condiciones para que imperara un considerable gasto de recursos económicos en trabajos de selección "cosmética". Como señala Schmid (1989), las variedades lanzadas por las estaciones públicas de experimentación son retrocruzadas por seleccionadores privados que cambian uno o mós de sus descriptores, como el color de la cascarilla en el trigo, y después patentan y comercializan el producto como una variedad nueva. Por supuesto, se reduce el tiempo del monopolio en la comercialización de variedades; pero también deja de aplicar incentivos pues significa una reducción del espacio para el producto, lo cual entraña otorgar derechos de corto alcance.

En la próctica los criterios de novedad y distinción en variedades vegetales se traducen en un conjunto de descriptores que refieren a características morfológicas; con ellos se intenta diferenciar una variedad de otra, por ejemplo los pelos de las hojas y tallos y el ancho de la hendidura de las semillas. Sin embargo, conforme surgen nuevas variedades, la diferenciación taxonómica y la evaluación en campo de los cultivos resulta —además de costosa-insuficiente, lo cual propicia la creación de métodos más precisos para identificar variedades, por ejemplo el análisis de electrofóresis, cromatográficos, serológicos, citologicos y ultraestructurales (McDonald, 1979).

No menos problemáticos son los términos de homogeneidad y estabilidad, ya que lograrlos resulta antieconómico o contraproducente para la agronomía.

$\mathrm{Si}$ el fin de generar nuevas variedades vegetales es dotar a los productores de mejores semillas (sea por su rendimiento, resistencia a factores adversos o adecuación a condiciones climóticas), la obtención de homogeneidad es un criterio que contraviene la velocidad de su generación pues depende de un proceso reproductivo que entraña una mayor homogeneidad (homocigosis). Así pues, cuanto mayor sea la generación de la variedad lanzada, mayor su homogeneidad y mayor el costo de la investigación; sobre todo cuando se trata de variedades de especies alógamas, pues son menos uniformes que las autógamas. Por ello, en todos los países los fitomejoradores lanzan variedades que, aunque no sean puras, demuestran en las pruebas de campo y laboratorio ser progenies superiores, lo que significa definir un margen de plantas atípicas en la variedad lanzada (Quiñones, 1991).

Por otra parte la variación genética supone una mayor capacidad de adaptabilidad ante condiciones adversas $y$, bajo determinadas circunstancias, este criterio agronomico se impone al de la uniformidad y estabilidad. En síntesis, para el Estado resulta caro y difícil proteger las variedades vegetales. 


\section{SITUACIÓN DE LA LEGISLACIÓN BIOTECNOLOGGICA EN MÉXICO}

Los que alguna vez sugerimos la importancia estratégica de que México avanzara por el intrincado camino de la protección intelectual, aprovechando marcos jurídicos y políticos distintos del de patentamiento -que pudieran ser complementarios y no necesariamente antagónicos-, como por ejemplo la normatividad de UPOV en materia de variedades vegetales, o lo acordado en el Compromiso Internacional de los Recursos Fitogenéticos (FAO), ${ }^{6}$ hoy no podemos sino concentrarnos en detectar los resquicios que deja la política de modernización, impulsada por el Gobierno Federal, que prefiere transferir tecnología del exterior a desarrollarla en el país, lo cual acentúa la dependencia biotecnologica.

En enero de 1990 el Congreso de la Unión autorizó un nuevo reglamento de la Ley sobre el Control y Registro de Transferencia de Tecnología y el Uso y Explotación de Patentes y Marcas, cuyo objetivo fue agilizar los trámites administrativos para la transferencia tecnológica y poner a tono con la modernidad nuestro marco jurídico correspondiente. Es decir, aporta mecanismos jurídicos que en lo reglamentario ołorguen operatividad y seguridad en su aplicación, toda vez que la interconexión cada vez mayor de los mercados mundiales, a juicio de SECOFIN,

subraya la necesidad de fortalecer el aceno tecnológico del aparato productivo mundial, para sustentar su posición competitiva ... y que el dinamismo de la tecnología mundial plantea a las unidades de producción en el país la necesidad de agilizar la selección, la adquisición, la adaptación y el desarrollo de las tecnologías que utilizan ... (SECOFIN, 1990:3).

Era de hecho una salida que el gobierno de México daba para flexibilizar las condiciones reglamentarias de la inversión, cuestión relacionada con el ámbito del desarrollo tecnológico en lo que respecta a la inversión en la industria y ésta a la transferencia tecnológica. En perspectiva, podemos ver que se trataba de ceder sin abrirnos de capa: guardar la legislación sobre propiedad intelectual según avanzaran las negociaciones del Tratado de Libre Comercio. Y también ahora sabemos que no fue mucha la capacidad de negociación, ya que en junio del siguiente año (1991) se autorizó una nueva legislación referente a la propiedad industrial y no sólo a temas tangenciales. Un mes después, en julio de 1991, se aprobó la nueva legislación sobre semillas y, asi,

${ }^{6}$ Véase al respecto F. Martínez y G. Aboites, Estado, protección legal y diversidad fitogenética, 1991. 
en dos años de gobierno, se modificó radicalmente la situación jurídica de la propiedad industrial que -entre otros puntos - incluye la protección de productos y procesos biotecnológicos. Muy probablemente a finales de este año contaremos también con una nueva Ley de Sanidad Fitopecuaria.

Por lo anterior tenemos que el marco normativo de la biotecnología remite en materia de propiedad industrial a la Ley de Fomento y Protección a la Propiedad Industrial (LFPPI) de 1991. En cuanto a producción y comercialización de semillas, complementan al instrumento señalado la Ley Sobre Producción, Certificación y Comercio de Semillas (LPCCS) de 1991, y en materia de sanidad y control ambiental se cuenta con la Ley de Sanidad Fitopecuaria de Estados Unidos Mexicanos (LSF) de 1974; la Ley Federal para Prevenir y Controlar la Contaminación Ambiental (LFPCCA) de 1971; el Reglamento para la Prevención y Control de la Contaminación de Aguas (RPCCA) de 1973 y finalmente el Código Sanitario de Estados Unidos Mexicanos (CS) de 1974.

\section{PROTECCIÓN DE PRODUCTOS Y PROCESOS BIOTECNOLOGICOS}

Al comparar la nueva LFPPI y el instrumento anterior, la Ley de Invenciones y Marcas (LIM), ${ }^{7}$ resalta el mayor peso otorgado a la reglamentación de las invenciones, modelos de utilidad y diseños industriales, cuyo articulado representa el $31.27 \%$ de la Ley, mientras que, en la LIM, lo que sería su correlato sumaba el 26.1 por ciento.

Asimismo, resalta la incorporación de una nueva figura jurídica: "los modelos de utilidad", instrumento que permite proteger modificaciones pequeñas a invenciones patentadas, e incorporar como título de los "secretos industriales", aspecto fundamental en las estrategias de protección de empresas biotecnológicas. Y, finalmente, la incorporación como capítulo "de los delitos", con un capítulo para las infracciones, lo que resalta la intención punitiva de esta ley.

Lo anterior es producto de una nueva disposición por la cual el derecho de propiedad intelectual deja de ser un instrumento de polfica (sujeto a las necesidades del crecimiento industrial, cientffico, tecnológico y cultural del país que concede) para convertirse en instrumento de aplicación universal (P. Roffe, 1987; 1070), como se pretende que sea el esquema de la globalidad económica al que sólo se accede en un mercado cuando se garantiza eficazmente la aplicación irrestricta y plena de

\footnotetext{
7 Sobre esa ley y su aplicación en biotecnología puede consultarse Gilberto Aboites, "Biotecnología y propiedad industrial", ponencia presentada on el ॥ Congreso latinoamericano de biotecnología, La Habana, Cuba, 7 al 11 de agosto de 1990.
} 
protecaion intelectual, es decir, cuando se establecen disposiciones jurídicas que sancionan. La legislación mexicana es muy clara al respecto, pues mientras que en la LIM la sanción por violar el secreto industrial era de cinco a cincuenta pesos de multa o de dos meses a un año de cárcel, ${ }^{8}$ la LFPPI establece una sanción de dos a seis años de prisión y multa por el importe de cien a diez mil días de salario mínimo vigente en el Distrito Federal.

Más que el reconocimiento social a una aportación o invención, que motiva a la sociedad a premiar a su creador con un monopolio sobre su invento, se destaca el factor defensivo contra las copias o imitaciones de invenciones como argumento de peso para imponer una legalidad internacional que en realidad busca asegurar la reproducción de una determinada división del trabajo internacional de la cual los países subdesarrollados sólo podrán participar como compradores de tecnología y no como generadores. 9

Ahora bien, en lo tocante a biotecnología la nueva ley establece en su artículo 20 que "Las invenciones que se refieran a materia viva", sin perjuicio de lo que se disponga en otros ordenamientos legales, se regirán por lo que se sigue:

Serán patentables:

a) Las variedades vegetales.

b) Las invenciones relacionadas con microorganismos, como las que se realicen usándolos, las que se apliquen a ellos o las que resulten en los mismos. Quedan incluidos en esta disposición todos los tipos de microorganismos, tales como las bacterias, los hongos, las algas, los virus, los microplasmas, los protozoarios y, en general, las células que no se reproduzcan sexualmente.

c) Los procesos biotecnológicos de obtención de farmacoquímicos, medicamentos en general, bebidas y alimentos para consumo animal y humano, fertilizantes, plaguicidas, herbicidas, fungicidas o productos con actividad biológica.

No serán patentables:

a) Los procesos esencialmente biológicos para la obtención o reproducción de plantas, animales o sus variedades, incluyendo los procesos genéticos o relativos a material capaz de conducir su propia

${ }^{8}$ El artículo 210 marca una pena de 5 a 50 pesos o de dos meses a un año. EI artículo 211, la marca de 50 a 500 pesos y de uno a cinco años de córcel. Código Penal para el Distrito Federal, 4a. edición; México: Colección Porrúa, 1990.

${ }^{9}$ Sobre este punto resulta interesante revisar el libro de D. Goldstein, Biotecnología, universidad y política, México: Siglo xxl Editores, 1989. 
duplicación, por símisma o por cualquier otra manera indirecta, cuando consistan simplemente en seleccionar o aislar material biologico disponible y dejarlo que actúe en condiciones naturales.

b) Las especies vegetales...

c) El material biologico tal como se encuentra en la naturaleza.

d) El material genético.

e) Las invenciones referentes a la materia viva que compone el "cuerpo humano" (Gobierno Federal, 1991).

De lo anterior se desprende que prácticamente todo to rentable puede patentarse, y lo que no corresponda a este rubro sólo requiere de tiempo y de dinero, es decir de investigación, para que la alteración previa de su estado "natural" pueda protegerse. De este modo, nuestra riqueza genética queda expuesta a la apropiación privada, mediada por un proceso de transformación que, independientemente de lo costoso, arduo o difícil que haya sido, requirió de la base genética que natura da y que nuestras comunidades campesinas han preservado. Así pues, dado un artilugio jurídico, la biotecnología puede ser el camino para limitar a nuestros pueblos y valorizar su riqueza genética si, como es de suponer, no consolidamos un aparato cientifico capaz de inventar e innovar, aprovechando la biotecnología en beneficio de procesos productivos que beneficien a nuestro país y no sólo reproduzcan su subdesarrollo y dependencia.

Por lo anterior se desprende que están dadas las condiciones para que los centros de investigación que ganen la carrera del conocimiento de la estrucutura genotípica de las plantas puedan apropiarse de nuestro material y riqueza genética previa modificación - por transferencia de genes- de su estructura genética. La patente prevalece sobre la variedad vegetal, es decir sobre el derecho de obtentor de variedades vegetales.

Es interesante señalar al respecto cómo nuestra legislación referente a las variedades vegetales incorpora una mezcla de principios propios de marcos jurídicos diferentes, donde por un lado se acepta la patente y en consecuencia el monopolio, y por otro se limita el monopolio al introducir salvedades en la violación a los derechos de patentes cuando se trate de variedades vegetales. En esta tesitura podemos señalar que, afortunadamente, la LFPPI incorpora tres salvaguardas socialmente importantes puesto que integran el aparato científico tecnológico nacional y el estrato social más numeroso de México: los campesinos.

La primera se refiere al artículo 19, que descarta los descubrimientos como invento, por lo cual no resultan patentables.

La segunda nos remite al artículo 22 en su fracción V, donde estipula que el derecho que confiere una patente no producirá efecto 
alguno contra un tercero que, en el caso de patentes relacionadas con materia viva, utilice el producto patentado como fuente inicial de variación o propagación para obtener otros productos, salvo que dicha utilización se realice de manera reiterada. Esto confiere libertad al genetista para continuar en sus trabajos de investigación y generación de nuevas variedades sin cortapisas, es decir, sin tener que gestionar autorizaciones para trabajar con material patentado o pagar regalías.

Permanece en el aire el problema de la reglamentación en tomo al intercambio de germoplasma y de su propiedad cuando éste se encuentre resguardado en los bancos de germoplasma, pues los antecedentes muestran cómo los países estigmatizados como "enemigos" de Estados Unidos de Norteamérica no tienen acceso a ese material, pese a que es su fuente de origen, como le sucedió a Cuba, Nicaragua y Afganistán con material solicitado al Banco de Fort Collins. ${ }^{10}$

La tercera salvedad señala que el productor agrícola podrá seguir utilizando su semilla sin pagar regalías siempre que su producción sea como grano o producto terminal y no como semillas; o sea que no puede producir y utilizar materia viva para multiplicación o propagación con fines comerciales. Ahora bien, la Ley Sobre Producción, Certificación y Comercio de Semillas (1991) introduce tres cambios de importancia respecto a su antecesora.

En primer lugar, ahora se dispone de libertad total para realizar investigaciones orientadas a producir semillas, cuestion un tanto restringida por la Ley sobre Producción, Certificación y Comercio de Semillas del 14 de abril de 1961 y sus modificaciones de 1983, que incluso daban pábulo a la discrecionalidad de la SARH —-como instancia administrativa- para decidir si autorizaba o no la investigación realizada por parte de compañías privadas y no solamente de INIFAP. Por ello es de esperarse una tendencia más marcada, evidente en México hacia mediados de los años ochenta, a concentrar la investigación de semillas en compañías trasnacionales, con la capacidad económica e institucional para penetrar en ese campo.

En segundo lugar destaca el que ahora se considere como compromiso que la SARH "... tendrá a su cargo el Banco Oficial de Germoplasma, en el que se conservarán las reservas mínimas de semillas originales de variedades mejoradas o formadas por la propia dependencia o por otras personas, de acuerdo con lo dispuesto por el reglamento de esta ley" (artículo 40). A la fecha no se ha

10 Hermenegildo Castro, "Imponen medidas de control político. Saquean transnacionales los recursos genéticos de Al", en La Jornada, 10 de abril de 1987, cita el documento base de la Reunión de Expertos Gubernamentales de Alto Nivel en Materia de Germoplasma Vegetal, que reunió a representantes de 21 naciones latinoamericanas. 
publicado el citado reglamento, pero cabe destacar que empiecen a aparecer regulaciones para proteger la diversidad fitogenética en el país, pues es la base para cualquier progreso en el desarrollo de nuevas y mejores variedades de plantas que satisfagan los requerimientos sociales de la población, sobre todo dada la heterogeneidad de la legislación sobre el empleo de los recursos genéticos almacenados en bancos. 11

\section{CUADRO 4}

EMPRESAS TRASNACIONALES AUTORIZADAS PARA REALIZAR INVESTIGACIONES

Master de México

Northrup King

Semillas híbridas (Deklab)

Ciba-Geigy (Funk's)

Asgrow mexicana
Sorgo

Sorgo y maíz

Maíz

Sorgo y maíz

Sorgo y maíz

FUENTE: Jesús Fernández B., 1991, "Situación actual de la industria semillera nacional", Memorias del III curso de actualización de semillas, septiembre de 1984, Saltillo, Coah., UAAAN, 1987.

CUADRO 5

COMPAÑIAS QUE HAN SOLICITADO SU REGISTRO PARA HACER INVESTIGACION AGRICOLA

Selecciones genéticas

Comercial semillera

Semillas y fertilizantes de Sinaloa

Mexagro Internacional

Desarrollo Agropecuario Dixa

Investigaciones Agrícolas, S.A.
Sorgo

Maíz

Hortalizas

Maíz y sorgo

FUENTE: Jesús Fernández B., 1991. "Situación actual de la industria semillera nacional", Memorias del III curso de actualización de semillas, septiembre de 1984, Saltillo, COah., UAAAN, 1987.

$Y$ finalmente destaca una regulación sobre el manejo de materiales transgénicos: "Los interesados en llevar a acabo una investigación de materiales transgénicos de alto riesgo requerirán de permiso previo y estarán sujetos a la supervisión de los trabajos por parte de la Secretaría."

11 Sobre el particular véase $\mathrm{FAO}$, Situación jurídica de las colecciones base y activas de recursos fitogenéticos. Roma: FAO, CPGR/87/5, enero, 1987. 
La Secretaría determinará (mediante dictamen técnico debidamente fundado en consideraciones científicas o previo análisis de laboratorio) cuáles serán considerados "materiales transgénicos de alto riesgo" (artículo 5); a quienes lleven a cabo investigación con materiales transgénicos de alto riesgo sin la autorización a que se refiere el artículo 5, la Secretaría les impondrá multa por el equivalente de mil a diez mil días de salario (artículo 16). Esto resulta importante porque es común enterarnos de que los investigadores prueban sustancias y materiales que en Estados Unidos están prohibidos, pues en México nuestra legislación no prohíbe utilizarlas.

Tal es el marco referencial de la disputa que recientemente se presentó entre la compañía Monsanto y el gobierno de México porque quería probar en nuestro país una planta transgénica de tomate (Romero, 1991).

Conforme avanza la ingeniería genética y surgen nuevos bioproductos, las sociedades de los países desarrollados generan al mismo tiempo una conciencia social que antepone el temor, y a veces la ignorancia, a la opción de contar con mejores satisfactores. $Y$ es en esta dinámica que los países subdesarrollados, ávidos de inversión, se convierten en el laboratorio de pruebas de nuevos materiales; sobre todo cuando las empresas biotecnológicas están urgidas de probar sus productos en el campo. A este respecto tan sólo en Estados Unidos el número de permisos solicitados para pruebas de material genético en campo ha crecido de manera exponencial: entre 1987 y 1990 fueron 7, en 1990 subieron a 67 y en 1991 hubo una demanda de 236 (Obvando, 1991).

Oponerse a dicha lógica requerirá, fundamentalmente, de una conciencia social que aprecie nuestra naturaleza (y por ende la posibilidad de alterar un equilibrio ecológico que perjudicańa nuestra diversidad genética) aś́ como de leyes más precisas, para lo cual seró indispensable fortalecer un sistema científico tecnológico que pueda evaluar y sugerir con fundamento medidas preventivas. Tal debería ser el criterio rector de la futura ley sobre sanidad fitopecuaria. Veremos qué sucede.

\section{CONCLUSIONES: LOS RETOS DE LAS INSTITUCIONES DE INVESTIGACIÓN ANTE UNA NUEVA REALIDAD Y UNA NUEVA LEGISLACIÓN}

Hay varios supuestos que, en mi opinión, justifican el pugnar por fortalecer el aparato científico-tecnológico nacional y, por ende, las universidades públicas, como única posibilidad viable de desarrollo biotecnológico en el país ante el impulso que da la nueva legislación a la protección de productos y procesos biotecnológicos y a la investigación misma. 
Primero, que la legislación tiende a consolidar un esquema de desarrollo en materia de biotecnología donde la empresa trasnacional es quien gana, pues está en mejores condiciones materiales -capacidad económica e infraestructura- para crear nuevos bioproductos o bioprocesos, sobre todo ahora que están presionados por la urgencia de patentar resultados antes que los competidores. En este sentido la legislación está formalizando lo que la economía inició hace ya una "década.

Difícil resulta imaginar que empresas nacionales de carácter privado incursionen de manera sustancial aportando recursos para investigación, ya sea por su escala económica o porque les resulta costeable importarla; sobre todo que se centren en trabajos que insumen biotecnologías que no son de punta, por ejemplo el cultivo de tejidos. A respecto, en una encuesta realizada en América Latina, en 153 laboratorios que emplean biotecnología ( $61 \%$ del total) se detecto una participación privada del $27 \%$, la cual cuatro años antes sólo alcanzaba el 11 por ciento. Se descubrió también que las áreas de trabajo en cultivo de tejidos y células (especialmente en micropropagación de ápices o micropropagación masiva comercial) representan el $63 \%$ de todos los proyectos realizados en las instituciones encuestadas; y un incipiente pero importante interés en ingeniería genética y biología molecular, que representa el $8.6 \%$ del total de proyectos (Izquierdo, 1989).

No hay en México nada que indique que en el corto o mediano plazo habrá de revertirse la tradición de acceder a la tecnología vía su transferencia del exterior; no hay interés en el factor determinante de la investigación: el ser humano. Al respecto señalan López Ortega y Musalem L6pez (1990): en México las empresas que han ocupado recursos de los programas de financiamiento para la reconversión industrial y adquirir bienes de capital de Nacional Financiera han destinado sólo entre $0.03 \%$ y $0.04 \%$ para capacitar o contratar recursos humanos especializados, esto es, İsolamente una empresa de las 307 participantes en el Programa de Reconversión Industrial!, principal mecanismo financiero de apoyo a la reconversión nacional industrial.

Si se consideran estas cifras como representativas del conjunto de empresas, se estaría ante una concepción de la modemización industrial basada fundamentalmente en la adquisición de activos físicos y una gran despreocupación por el ingrediente tecnológico que corresponde a los recursos humanos (López y Musalem, 1990:11).

Dado lo anterior podemos señalar un segundo elemento: si la iniciativa privada no va a aportar recursos considerables para investigación (y tampoco es probable que lo haga el Estado dada la astrin- 
gencia económica actual, en la cual, por ejemplo, la relación entre el Producto Interno Bruto Agrícola y lo destinado a investigación agrícola ha pasado de $0.08 \%$ en $1965,0.18 \%$ en $1970,0.44 \%$ en 1975 , $0.75 \%$ en 1980 y $0.51 \%$ en 1984 ), es claro entonces que el aparato científico tecnológico mexicano, compuesto por INIFAP y los centros de investigación vinculados con instituciones de educación superior, tendrá que replantear sus objetivos y procedimientos al tenor de los siguientes elementos:

1) Es urgente e indispensable establecer prioridades nacionales sobre qué investigar.

2) Establecer criterios uniformes para la aceptación de proyectos de investigación.

3) Establecer mecanismos de comunicación y concertación que posibiliten una ágil consulta sobre lo que se investiga y solicita, a fin de evitar duplicidades.

4) En virtud de que se cuenta con infraestructura y capacidades diferenciadas entre las diversas instituciones de investigación, es preciso impulsar proyectos de investigación con carácter interinstitucional a fin de potencializar los recursos y fortalezas que se tienen.

5) Es imperativa una restructuración de la mecánica utilizada en la investigación universitaria, que delegue la administración de los recursos económicos en los investigadores y no en instancias burocráticas.

6) Es urgente contar en cada universidad estatal o regional con personal cuya tarea sea fomentar la articulación entre aparato productivo y centros de investigación y que considere el nuevo esquema legislativo a fin de poder proteger todo conocimiento e invención. Para esto debe aprovecharse la experiencia del Centro de Innovación Tecnológica de la UNAM.

7) Es necesario impulsar la investigación biotecnológica en las áreas que a nuestras condiciones socioeconómicas le resultan necesarias con el objeto de evitar que la investigación llevada a cabo en nuestras universidades se concentre en la repetición de pruebas ya realizadas en otras latitudes; pero fundamentalmente con el propósito de que el potencial que se le reconoce a la biotecnología (en cuanto a adaptabilidad a cualquier nicho ecológico) se concrete en una multiplicidad de biotécnicas que incluyan la solución al problema campesino y el acceso a su mundo.

8) Es imprescindible establecer un sistema de comunicación que permita el monitoreo intemacional de los avances en biotecnología, a fin de hacer ajustes en los programas nacionales de investigación.

9) Ante la perspectiva de patentar nuestro material genético previa transformación, se debe impulsar un programa especial que tienda al conocimien- 
to del genoma de las especies vegetales que resulten de importancia particular para nuestro pueblo, con el propósito de ganar la carrera para patentarlas.

10) Además del sistema de protección industrial, deberíamos pugnar por consolidar los marcos normativos internacionales que buscan garantizar el acceso irrestricto del fitogermoplasma y enaltecer a las comunidades rurales que han logrado conservar la diversidad genética actual, por ejemplo el compromiso internacional de los recursos fitogenéticos (FAO). ${ }^{12}$

11) Es imperiosa una profunda transformación del sistema educativo a fin de adecuarlo a los niveles de excelencia que se requiere para hacer en la actualidad ciencia de frontera y para que en el mediano plazo le resulte atractivo a la planta productiva su articulación con nuestro aparato científico tecnológico.

12) Debemos aprovechar el TLC para establecer convenios entre instituciones de investigación estadunidenses a fin de garantizar el intercambio de conocimientos, que las patentes tienden a restringir; pero para ello requerimos de investigación de excelencia pues sólo así habrá algo que podamos ofrecer en reciprocidad.

13) Es menester concretar la oferta de la LFPPI en el sentido de divulgar las patentes, ya que esto es parte fundamental del sistema que desafortunadamente se olvida en los países subdesarrollados. Ello debe orientar la investigación y favorecer las estrategias de venta de nuestra tecnología.

Termino el ensayo reproduciendo la opinión de un destacado biotecnólogo latinoamericano:

Sólo se podrá poner coto al robo de información genética cuando los países del Sur puedan: $a$ ) reconocer su importancia; $b$ ) identificar sustancias con acciones farmacológicas, agrícolas, pecuarios o agroindustriales interesantes; c) aislarlas y caracterizarlas química y funcionalmente; d) aislar los receptores sobre los que actúan; e) identificar las moléculas naturales que actúan sobre esos receptores; f) determinar sus sendas biosintéticas y degradativas; $g$ ) aislar los genes que codifican las enzimas biosintéticas y degradativas; $h$ ) encontrar sustancias naturales que modifiquen la acción de las moléculas activas; i) imaginar y explorar la factibilidad de su uso; i) modificar las estructuras de las moléculas activas para hacerlas compatibles con el uso deseado; $k$ ) patentar todos los pasos y los conocimientos patentables; I) patentar los genes útiles adecuadamente marcados; $\mathrm{m}$ ) patentar las aplicaciones posibles de esos genes.

12 Consúltese Francisco Martínez G. y Gilberto Aboites M., "Estado, protección legal y diversidad fitogenética", ponencia presentada en el Segundo Congreso Nacional de Teoría y Práctica del Estado Contemporáneo, México, D. F., marzo de 1991, UNAM. 
Para combatir el robo del germoplasma hay que ganar la carrera por su identificación y su patente (D. Goldstein, 1989:223).

\section{BIBLIOGRAFÍA}

Aboites, Gilberto. 1990. "Biotecnología y propiedad industrial". Ponencia presentada en el II Congreso Latinoamericano de Biotecnología. La Habana, Cuba: 7 al 11 de agosto.

Bercel, Salvador Darío. 1990. "Los países subdesarrollados ante el actual debate sobre patentamiento de las especies vegetales". Revista del Derecho Industrial, núm. 39, Buenos Aires.

Correa, Carlos María. 1989. "Propiedad intelectual, innovación tecnológica y comercio intemacional". Comercio Exterior, vol. 39, núm. 12. Edelman, Bernard. 1989. "El derecho y el ser vivo". Mundo Científico. Núm. 95.

Fernández, B. Jesús. 1991. "Situación actual de la industria semillera nacional". Memorias del ill curso de actualización de semillas, septiembre de 1984, UAAAN, Saltillo, Coah.

Gobierno Federal. 1990. Código Penal para el Distrito Federal. 4a edición. México: Colección Porrúa.

. 1991. Ley de Fomento y Protección a la Propiedad Industrial, publicada en el Diario Oficial de la Federación, 27 de agosto, México.

Goldstein, D. 1989. Biotecnología, universidad y política. México: Siglo XXI Editores.

Guadarrama, Roberto. 1991. "Impactos socioeconómicos de la biotecnología". Conferencia. UAAAN, Saltillo, Coah., septiembre.

Herrera E., Luis. 1990. "¿Patente de organismos?" ICrT Informa. Vol. 12, núm. 166/167, julio-agosto, México.

1991. Participación en el Primer Simposio Nacional de Biología Molecular en la Investigación Agrícola, junio, Celaya, Gto. zzquierdo, Juan. 1990. "Situación actual de los laboratorios de biotecnología vegetal de América Latina y el Caribe". Catálogo regional de laboratorios de biotecnología vegetal. Encuesta regional 1989. 90. FAO. Oficina Regional para América Latina y el Caribe. Santiago de Chile.

López Ortega, Eugenio, y Musalem López, Omar. 1990. “Desarrollo tecnológico-industrial y empresas de base tecnológica". Simposio nacional sobre ciencia y tecnología. Prospectiva social y revolución científico-tecnológica. UNAM-UAM, Cd. de México, del 1 al 3 de octubre. 
Martínez, F. y Aboites, G. 1991. "Estado, protección legal y diversidad fitogenética". Sociológica. UAM-A, núm 16, México.

Martínez G., Francisco, y Aboites M., Gilberto. 1991. Estado, protección legal y diversidad fitogenética. Ponencia presentada en el Segundo Congreso Nacional de Teoría y Próctica del Estado Contemporáneo, marzo de 1991, UNAM, México, D. F.

McDonald, M. B., Jr. 1979. "Rapid Laboratory Techniques for Varietal Identification". Ohio Seed Improvement Research Foundation Annual Report, 5.

Obvando Rodríguez, Raúl. 1991. Conferencista en el "Primer Seminario sobre Biología Molecular". CIFAP. 24 de junio, Celaya Gto.

Organización Mundial de la Propiedad Intelectual (OMPI). Herrera E., Luis. 1989a. Disposiciones legales sobre profección de las invenciones e innovaciones biotecnológicas en paises industrializados seleccionados. Ginebra, wo/30-II.

.1989b. Documento BIOT/CE/IV/2.

Organización para la Alimentación y la Agricultura (FAO). 1987. Situación juŕdica de las colecciones base y activas de recursos fitogenéticos. FAO, CPGR/87/5, Roma.

Quiñones, Marco A. 1991. "Problemática de la producción de semilla de trigo". Memorias del III curso de actualización de semillas. Septiembre de 1984. Saltillo, Coah.: UAAAN.

Roffe, P. 1987. "Evolución e importancia del sistema de propiedad industrial". Comercio Exterior. Vol. 37. Núm. 12.

Romero Chavez, Jesús. 1991. Intervención en la inauguración del "Primer Seminario sobre Biología Molecular". CIFAP. 24 de junio, Celaya, Gto.

Schmid, A. Allan. 1989. "Protección legal de variedades vegetales, biotecnología y derechos cambiantes de propiedad en agricultura". Revista Agricultura y Sociedod. Núm. 53, octubre-diiciembre, Madrid.

Secretaría de Comercio y Fomento Industrial (SECOFIN). 1990. "Reglamento de la Ley sobre el control y registro de transferencia de tecnología y el uso y explotación de patentes y marcas". Diario Oficial de la Federación (martes 9 de enero), reproducido en Excélsior, Sección Financiera, lunes 15 de enero, México.

1991. Información bósica sobre la ley de fomento y protección de la propiedad industrial. México: SECOFIN.

Solleiro, José L., y Arriaga, Elena. 1990. "Patentes de biotecnología: amenazas y opciones para América Latina". Comercio Exterior, vol. 40, núm. 12, México.

WIPO y Cornell University. 1987. "Symposium on the protection of biotechnological inventions". Junio 4 y 5, Ithaca, Nueva York. 


\title{
La desregulación en Ia industria de las semillas: patentes y biotecnología
}

\author{
BLANCA SUÁREZ*
}

\section{LOS RECURSOS FITOGENÉTICOS Y LA INDUSTRIA}

Los recursos genéticos y los materiales mejorados han transformado la agricultura al convertirse en insumos estratégicos que apoyan tanto al abastecimiento de alimentos básicos como a los productos de exportación. Es decir, constituyen un elemento fundamental para la economía nacional y por ello deberían ser mejor consideradas las actividades relacionadas con la prospección, evaluación, conservación, mantenimiento y utilización de los recursos fitogenéticos disponibles. Su importancia radica no sólo en preservar la diversidad genética del país, o en detener la erosión genética; también resultan vitales por una razón mucho más próctica: la diversidad genética tiene repercusiones directas en la capacidad de asegurar el futuro alimentario del país.

Hoy en día estos aspectos son aún más importantes que en el pasado debido a los cambios que generan en la organización aplicada para investigar y producir recursos fitogenéticos. La integración de las empresas semilleras con las productoras de agroquímicos y su inversión cada vez mayor en biotecnología entraña centralizar el control del mercado internacional de recursos fitogenéticos. Estas mismas empresas, con algunas nuevas que se han creado para explotar los avances de la biotecnología, ahora no sólo dominan el mercado internacional de semillas sino que también determinan las pautas en la investigación y sus aplicaciones en el campo de los recursos fitogenéticos. El control aumenta dada la enorme influencia que tienen estas empresas en conformar las estrategias de investigación de los centros universitarios y aun de los organismos públicos responsables de instrumentar los programas nacionales de investigación y elaboración de nuevas variedades.

* Centro de Ecodesarrollo, noviembre, 1991. 
A los especialistas en genética les interesa conservar el pool de variedades, mientras al fitomejorador le preocupa la particularidad de alguna variedad. Los dos aspectos sin duda son muy importantes, pero existe un tercero que trasciende el ámbito técnico: el interés económico y social que constituye el cómo y el para qué, a quién benefician los esfuerzos que se realizan en los dos campos mencionados.

La sustitución de variedades trajo consigo cambios en los hábitos alimentarios, a veces adecuados $y$, en otros casos, negativos para el conjunto de la sociedad. Sexenio tras sexenio, las autoridades gubernamentales han contribuido al proceso de erosión genética pues las instituciones encargadas de impulsar la investigación y la producción de otras variedades sustituyen los cultivos nativos, en lugar de destinar recursos para conservarlos. De esta manera, el futuro de los alimentos para las próximas generaciones se encuentra amenazado.

La certeza de proveer alimentos es un problema prioritorio. No sólo porque la producción agropecuaria no es suficiente para cubrir las necesidades de la población, sino porque el mercado de alimentos se encuentra bajo el control de unos cuantos grupos de decisión mundial que pueden utilizarlos (de hecho lo hacen) para ejercer presión sobre los países que requieren importar maíz, frijol, oleaginosas, sorgo. Esos mismos intereses redoblan ahora esfuerzos en su intento por apoderarse también de los recursos genéticos, fruto de un largo proceso de selección natural por parte de los grupos campesinos.

El mosaico de ecosistemas con que cuenta México ha permitido condiciones excepcionales para el florecimiento de una diversidad de plantas y semillas; no conservarlas traerá resultados desastrosos en los procesos que permiten a millones de campesinos realizar sus cultivos y producir lo que consumen las mayorías del país. Las dificultades de producción y abastecimiento han puesto de relieve los requerimientos alimenticios de la población; por lo tanto, cobra mayor importancia el uso y la conservación de los recursos fitogenéticos, pues su manejo y utilización seró un factor que permitirá definir el control que el país tendrá sobre sus recursos alimentarios.

En el avance de la biotecnología agrícola la disponibilidad de recursos fitogenéticos tiene un papel fundamental; se trata del material básico requerido para que los investigadores puedan experimentar y crear, mediante las técnicas que brinda la biotecnología, las semillas o plantas mejoradas o nuevas. Sin duda estas últimas son el vínculo determinante que utilizan las empresas para incorporar la biotecnología al campo. Por ello resulta de vital importancia profundizar acerca de los cambios que la industria presenta o que pueden preverse en relación con la biotecnología. 


\section{LA INDUSTRIA DE SEMILLAS Y LA DESREGULACIÓN}

La industria de semillas en México se organiza como actividad productiva durante los años sesenta; en este período empiezan a establecerse las primeras empresas orientadas hacia la producción de semillas. En un principio se limitan a la importación y distribución, y luego se crean las primeras plantas beneficiadoras de semillas. Entre las filiales de empresas norteamericanas más importantes de aquel entonces estaban Asgrow, Northrup King y Dekalb, las más destacadas en el mercado estadunidense.

La naciente industria se organizaba también mediante el Instituto Nacional de Investigaciones Agrícolas (actualmente INIFAP), Pronase, y tres dependencias oficiales (Comité Calificador de Variedades de Plantas, Registro Nacional de Variedades de Plantas y Servicio Nacional de Inspección y Certificación de Semillas). Estas instancias gubernamentales se encargarían de ampliar la producción de semillas de alto rendimiento utilizando los materiales que se generaran en el proceso de investigación. En 1961 se aprobó la ley que regularía a nivel nacional la investigación, producción, certificación y comercio de semillas; con ello se establecía el marco institucional bajo el cual se desarrollarían las actividades de la industria semillera.

Actualmente esta industria en México consta de treinta y un empresas privadas, agrupadas en la Asociación Mexicana de Semilleros, A. C. (AMSAC) y la Productora Nacional de Semillas (PRONASE). ' Asimismo, participan asociaciones de productores que ocupan una posición hasta cierto punto marginal en el panorama global, aunque su influencia en lo que se refiere a especies particulares es importante, por ejemplo en la semilla de trigo (que se encuentra bajo el control de algunas asociaciones del estado de Sonora); en el mercado de dicha semilla participa también PRONASE (véase cuadro 1).

Pese al notable aumento de empresas en la industria, la importación de semillas sigue siendo práctica habitual en casi toda la industria (véase gráfica). Se calcula que en 1990 México estaba entre los cuatro primeros importadores de semillas en el mundo. Los tipos varían; lo mismo se adquiere semilla básica y registrada para experimentar y obtener las variedades comerciales que para traer las certificadas o mejoradas.

${ }^{1}$ Esta empresa se creó en 1961, como instancia gubernamental para atender la producción y multiplicación de semillas certificadas que demandara la agricultura nacional. Dicho actividad estaría relacionada con el material que el Instituto Nacional de Investigaciones Agrícolas (INIA) proporcionara para tales fines. Inicialmente trabajó con los cultivos básicos; más tarde el INIA estuvo en condiciones de surtir semillas de nuevos cultivos y variedades en cantidades suficientes para poder poner en marcha programas de multiplicación, lo cual diversificaba considerablemente la oferta de semillas certificadas al mercado. En la década de los ochenta multiplicaba cerca de 25 semillas de cultivos. 
La importancia de las semillas básicas se circunscribe a las grandes compañías transnacionales, que generalmente cuentan con divisiones dedicadas a investigación y experimentación que se especializan en las líneas de híbridos de sorgo y de maíz; algunas otras empresas nacionales y transnacionales orientan sus esfuerzos a importar material de hortalizas y oleaginosas. Se da también el caso de empresas nacionales que compran únicamente semilla certificada o mejorada para distribuirlas en el mercado intemo. ${ }^{2}$ La mayor parte de las empresas productoras de semillas de propiedad nacional se dedica a las actividades semilleras vía la importación de semilla registrada. El mercado más importante para la compra de semillas es el estadunidense.

En 1987 las 31 empresas semilleras agrupadas en la Asociación Mexicana de Semilleros aportaron más de 140 mil toneladas de semillas; según sus estimaciones, su participación en el mercado nacional es la siguiente:

\begin{tabular}{|c|c|c|c|}
\hline Cultivo & $\%$ & Cultivo & $\%$ \\
\hline Hortalizas & 100 & Algodón & 20 \\
\hline Sorgo & 97 & Trigo & 50 \\
\hline Sorgo Forrajero & 100 & Maíz & 30 \\
\hline Leguminosas Forraj. & 87 & Arroz & $5 C$ \\
\hline Alfalfa & 100 & Cebada & 95 \\
\hline Cártamo & 10 & Soya & 33 \\
\hline Pasto & 87 & & 00 \\
\hline
\end{tabular}

FUENTE: Asociación Mexicana de Semilleros, 1988.

Además del grupo de empresas integradas en AMSAC, en el ramo de semillas y plantas hay pequeñas empresas de muy reciente creación (cinco años) que se han dado a la tarea de trabajar en la línea de cultivo de tejidos, principalmente ornamentales, algunos frutales y hortalizas. Esta técnica de multiplicación vegetativa se obtiene por cultivo de células o de meristemos (conjunto de células situado en el extremo del retoño de la planta) que se trasplantan in vitro. Cada uno de los retoños,

${ }^{2}$ Conforme a la ley, las semillas son:

-originales: producto de los trabajos de investigación, formación y mejoramiento de variedades que permanezcan bajo control de su formador, y que constituirán la fuente inicial para la producción.

-básicas: resultantes de la reproducción de las semillas originales que conserven el más alto grado de identidad gent́tica y pureza varietal.

-registradas: que descienden de las semillas básicas o de las mismas registradas que conservan satisfactoriamente su identidad genética y pureza de variedad.

-certificadas: que descienden de las semillas básicas, o las registradas cuyo proceso de certificación esté realizado de acuerdo con las normas estipuladas por la SARH. 
aislado y trasplantado en un medio nuevo, después de algunas semanas da una nueva planta que puede, a su vez, dividirse indefinidamente; aunque el número de operaciones estaŕ limitado por el fenómeno de la degeneración. ${ }^{3}$ En México la empresa INVERNAMEX trabaja con esta técnica en los tres grupos de productos señalados y cuenta con 33 especies; entre las más importantes se encuentran la fresa y la papa, aunque hasta ahora las ornamentales aportan los mejores resultados en el laboratorio y ofrecen muy buenas posibilidades en el mercado, sobre todo en el de exportación. A pesar de los avances logrados en estos cinco años y de una producción suficiente para entrar en el mercado exterior, uno de los problemas graves que enfrentan es que los agricultores acepten su producto. En ornamentales tienen ya cierto reconocimiento; pero en lo referente a la fresa, por ejemplo, han entrado en contacto con las asociaciones respectivas sin conseguir hasta ahora una respuesta favorable. Las limitantes pueden atribuirse a que las uniones regionales son las encargadas de adquirir la planta en el mercado exterior, la cual se importa como vivero para su reproducción en México. Así pues, se restringen los usos de las plantas a los determinados por la unión, y si un productor busca alternativas fuera de las decisiones de ella queda excluido o simplemente no se adquiere su producción; en otras palabras, mediante las importaciones la unión mantiene controlado el mercado de plantas de fresa. ${ }^{4}$

Hasta julio de 1991 PRONASE tuvo una influencia relativa en el mercado nacional $i$ de semillas pues participó en la producción de aproximadamente 20 cultivos distintos; sin embargo, a partir de esta fecha y como parte de la política de modernización agrícola en el país (que entraña urr paquete de desregulación en el sector) se ha decidido restringir su participación a cuatro cultivos: maíz, frijol, arroz y trigo, así como ayudar a los campesinos de regiones marginadas en las que la iniciativa privada no tenga interés en participar. Ello supone una mayor presencia de los grupos privados en las actividades de la industria y, por tanto, un menor control del Estado en los asuntos relativos a tan estratégico insumo.

Junto con el llamado "adelgazamiento" de PRONASE, dos meses después se expide la nueva ley sobre producción, certificación y comercio de semillas. En esta legislación se prevé que la Secretaría de Agricultura y Recursos Hidráulicos tendrá a su cargo la investigación oficial en semillas, administrará un banco oficial de germoplasma y

3 Para una consulta más amplia véase Pierre Douzou, Las biotecnologías, México: Fondo de Cultura Económica, 1986.

${ }^{4}$ Datos proporcionados por la Unión Regional de Productores de Fresa en el municipio de Zamora, Michoacán. Esta actividad representa sin duda un ingreso adicional para los directivos de las organizaciones. 
aplicarb́ las sanciones correspondientes. En el texto de la ley únicamente la SARH aparece como organismo rector; respecto a las instancias oficiales que conforman el sistema de producción como PRONASE e INIFAP no hay referencia alguna. Tal parece que serón excluidas como parte de la nueva organización de la industria, en la cual es evidente que la toma de decisiones correrá cada vez más por cuenta del sector semillero privado.

Con los cambios en la legislación, según AMSAC, se pretende alcanzar una internacionalización de los productos mexicanos, liberando muchas restricciones que no permitían acelerar la producción. La ley marca dos modificaciones sustanciales: la primera, referida a la investigación, que faculta al sector privado a realizarla y permite que lleve directamente los productos al mercado; la segunda elimina el proceso de calificación que antes efectuaba el Comité Calificador de Variedades de Plantas 5 y que ahora realizarán las empresas privadas, las cuales harán el estudio correspondiente y se encargarán de determinar cuáles serán las variedades para cada región del país. Para tal caso, la ley señala un nuevo concepto: el de semillas verificadas, a las que define como provenientes de las semillas básicas y registradas cuyo proceso de verificación será también realizado por las empresas bajo la supervisión de la SARH. En cuanto a la certificación, podrá efectuarla la empresa que así lo solicite y que cuente con el equipo necesario. Bajo estas nuevas premisas, los semilleros afirmaron que tendrán grandes posibilidades de crecer, tanto en número de empresas como en volúmenes manejados por la industria en su conjunto.

En cuanto a INIFAP, si bien continúa en sus actividades de investigación agrícola, se limitará a la investigación de sólo 35 cultivos, por lo cual se reduce su infraestructura en número de centros y en campos experimentales. En lo referente a los beneficios de la investigación generada, ahora se amplían, pues cualquier empresa privada nacional, transnacional o grupo de productores, tendrá acceso a los materiales. Por su parte, en lo que respecta a operación, PRONASE seró para INIFAP una empresa más que deberá cubrir los mismos requisitos que cualquier otra en relación con la demanda de materiales para multiplicación, lo cual incluye el precio. De este modo, la ley señala como única función de la autoridad agropecuaria el control fitosanitario de tránsito, entrada y salida del país de las semillas en cualquiera de sus categorías.

5 La nueva legislación lo denomina "Comité Consultivo de Variedades de Plantas" y está integrado por diez miembros designados por la SARH; tres servidores públicos de la Secretaría, uno de los cuales preside el Comitt; tres representantes de las principales organizaciones de semilleros; tres de organizaciones de agricultores consumidores de semillas y un representante de instituciones técnicas y cientfícas. Sus funciones serán básicamente de supervisión. 
Un aspecto que debe relacionarse con este nuevo marco jurídico es el de los esfuerzos previos (enero del 1991) de AMSAC por organizar al grupo de investigadores que forman parte de las distintas empresas semilleras y que integrarán un Consejo de Investigadores cuyos objetivos, entre otros, serán servir como cuerpo de arbitraje ante las diferentes autoridades en lo relativo al comportamiento de campo de híbridos y variedades de las empresas afiliadas a la Asociación, según se requiera, así como participar en las investigaciones de carácter científico que determinen los asociados, que sean de interés común, o que alguna empresa en particular solicite. Aun cuando los trabajos de organización del citado Consejo siguen en proceso, es previsible que los pasos que en este sentido se den signifiquen una reorganización que afecta al conjunto de la industria en las líneas de investigación, funcionamiento y probables mercados.

Un aspecto muy novedoso en la ley, estrechamente vinculado con los avances biotecnológicos en la agricultura, es la incorporación en el texto de una referencia a los materiales transgénicos de alto riesgo a los que define como aquellos con capacidad de transferir a otro organismo una molécula o gen recombinatorio con un potencial de alto riesgo por efectos inesperados debido a sus características de supervivencia, multiplicación y dispersión (Art. 2, párrafo VII). Esto sin duda establece las primeras bases para que las empresas (semilleras o no, nacionales o no) impulsen algunos trabajos en esas áreas o bien se legalice una actividad que muchos investigadores saben que ya realizan empresas como Campbell's de México con jitomate en el estado de Sinaloa, por encargo de Monsanto. No huelga insistir en el hecho de que las actividades de campo con variedades transgénicas están muy restringidas en Estados Unidos y prácticamente sólo se efectúan en laboratorio.

\section{EL AVANCE DE LA BIOTECNOLOGÍA Y LAS PATENTES}

Los adelantos que ha logrado la investigación biotecnológica en los distintos sectores (químico, alimentario, farmacéutico) a partir de los últimos veinte años han conformado una nueva industria integrada por gran cantidad de empresas que aumenta considerablemente ante la posibilidad de aprovechar los procedimientos biológicos que genera dicha investigación. Así pues, importantes grupos norteamericanos, europeos y japoneses han hecho cuantiosas inversiones en el área biotecnológica, aprovechando en cierta medida su propia infraestructura de investigación, o bien adquiriendo empresas pequeñas con experiencia en ese campo. 
Las empresas que han surgido en los últimos años se localizan tanto en el rubro de fármacos y alimentos como en el de mejoramiento de plantas, semillas e ingeniería genética (véase cuadro 2). ${ }^{6}$

El sistema de patentes tiene hoy en día importancia estratégica en la medida que da exclusividad en el uso de un proceso o producto y en su explotación comercial, al mismo tiempo que otorga una posición en el mercado a quienes tengan esta patente o derecho.

La canalización de grandes capitales hacia la biotecnología en el terreno de la agricultura, por ejemplo, contribuyó en buena medida a preparar una serie de dispositivos jurídicos a fin de proteger los resultados de las investigaciones. Los antecedentes al respecto se encuentran en el Convenio Internacional para la Protección de las Obtenciones Vegetales (UPOV), que legisla desde 1961 y el cual fue revisado en 1972 y 1978 . Actualmente (1990) son 19 países los miembros de la UPOV.7 El convenio señala en relación con los derechos de quienes obtienen las plantas que no sólo se protegerían las innovaciones desarrolladas sino también se haría explícito reconocimiento al trabajo realizado. Posteriormente, en el transcurso de los años setenta se revisó una serie de puntos relativos a la legislación de los "obtentores" vegetales de nuevas variedades (o especies) de plantas mediante títulos de protección particular o de una patente; sin embargo, el convenio también señala que cualquier país miembro de la Unión cuya legislación admita la protección en ambas modalidades tendró que aplicar sólo una de ellas a un mismo género o a una misma especie botánica. ${ }^{8}$ Bajo este criterio el obtentor será el único que decidirá sobre el uso de su material: para producción o comercialización.

Durante los años ochenta, la UPOV aprobó una nueva revisión centrada en la que se denominó "Propuesta Básica" con tres aspectos específicos: a) fortalecer el derecho del obtentor vegetal; b) ampliar el ámbito de aplicación del sistema de protección de las obtenciones vegetales; $y, c)$ redefinir las condiciones para la protección. ${ }^{9}$

${ }^{6}$ Es importante señalar que la nueva biotecnología, llamada "de cuarta generación", incluye técnicas "pioneras" como la del ADN recombinante que permite trasplantar genes de una célula a otra; la fusión de protoplastos, donde se obtienen híbridos de plantas fusionando sus células y la de los himbrodomas, que produce anticuerpos monoclonales. En conjunto estas técnicas se conocen con el nombre de ingeniería genética. Véase OMPI, Cuestiones relativas al patentamiento de las invenciones biotecnológicas, Documento preparado por la Oficina Internacional de la OMPI, Ginebra, 1990.

7 Países miembros: Alemania, Australia, Bélgica, Dinamarca, España, Estados Unidos, Francia, Hungría, Irlanda, Israel, Italia, Japón, Nueva Zelanda, Países Bajos, Polonia, Reino Unido, Sudáfrica, Suecia y Suiza.

${ }^{8}$ Convenio Internacional para la Protección de las Obtenciones Vegetales, 1978, Artículo 2.

${ }^{9}$ Véase OMPI, Guestiones relativas al patentamiento de las invenciones biofecnológicas, Documento preparado por la Oficina Internacional de la OMPI, Ginebra, 1990. 
Así pues, uno de los aspectos centrales de esta nueva revision haría obligatorio aplicar sus disposiciones a todos los géneros y especies botánicas; es decir, a todas las variedades del reino vegetal. En relación con los derechos del obtentor, se prevé una lista de actos de explotación de la variedad protegida que necesitan la autorización del titular; por ejemplo, con respecto al material de reproducción o de multiplicación de la variedad protegida, el titular podrá impedir que terceras personas produzcan o reproduzcan el material, lo acondicionen para fines de multiplicación, o bien se comercialicen los productos de cosecha o los productos fabricados directamente como resultado del uso no autorizado de la variedad protegida.

Ademós de las regulaciones y señalamientos que hace UPOV en lo referente a la protección de los obtentores, se cuenta con diversos foros internacionales donde se vienen discutiendo los distintos efectos de las patentes. En un estudio reciente acerca de la ley de patentes en 101 países, la Organización Mundial de la Propiedad Intelectual (OMPI) señala que en 51 países las leyes o tratados no consideran patentables las variedades o razas animales; 50 excluyen variedades vegetales y 46 no reconocen procedimientos fundamentalmente biológicos para producir variedades animales o vegetales. Según el documento, los motivos que justifican la exclusión se atribuyen a: 1) la imposibilidad de describir la invención por escrito y cumplir con los requisitos necesarios para su descripción; 2) razones de índole moral y de carácter público; y 3) la existencia de un sistema de protección alterno. ${ }^{10}$

A principios de los años ochenta algunos países, entre ellos Estados Unidos, establecen nuevas regulaciones sobre los derechos de los obtentores de plantas y de este modo se permite el patentamiento de nuevos organismos vivos que sean útiles para el hombre. En 1986 las nuevas reglas señalan no sólo el producto dentro del sistema de patentes, sino que también restringen su proceso.

Más que significar estímulos a los investigadores y promover sus actividades, esta nueva legislación en materia de patentes de productos y procesos se convierte en un recurso estratégico que propicia el control de unos cuantos grupos transnacionales sobre una importante línea de productos y mercados.

Hasta principios de 1991 en México no existía una legislación que otorgara derechos de patente a los obtentores de variedades de plantas. La antigua Ley de Inversiones y Marcas señalaba que no se otorgaban patentes a las variedades vegetales, las razas animales ni los procedimienros biológicos para obtenerlas; sólo la Ley sobre Producción, Certificación y Comercio de Semillas destacaba que los

10 Véose OMPI, Cuestiones relativas al patentamiento de las invenciones biotecno. Iógicas, Documento preparado por la Oficina Internacional de la OMPI, Ginebra, 1990. 
fitomejoradores privados que desarrollaran alguna variedad tendrían hasta 25 años de exclusividad para su aprovechamiento comercial y, cuando se tratara de recursos fitogenéticos de utilidad pública desarrollados por alguna instancia oficial, el Gobierno Federal sería el depositario. En cuanto a la circulación comercial por parte de particulares, tendría que tramitarse por intermedio de la Secretaría de Agricultura y Recursos Hidráulicos.

En junio de 1991 el Congreso de la Unión revisó la iniciativa de reformas a la ley de patentes, después de lo cual se modificó sustancialmente. Ahora pueden patentarse las variedades vegetales, las invenciones relacionadas con microorganismos tales como las bacterias, hongos, algas $(. .$.$) , y en general las células que no se reproduzcan$ sexualmente; además, los procesos biotecnológicos de obtención de farmacoquímicos, medicamentos en general, alimentos y bebidas para consumo animal y humano, agroquímicos o productos con actividad biológica (Art. 20, párrafo 1).

El debate sobre propiedad que se lleva a cabo entre países industrializados y países en vías de desarrollo se ha incluido también en la mesa de negociaciones del GATT bajo el tema de "servicios"; ello constituye un punto clave para los países desarrollados que tienen un control casi total sobre el sistema mundial de patentes. Respecto a las negociaciones del Tratado de Libre Comercio, en México se discutió el tema $y$, aunque poco se conoce respecto a dichas negociaciones, es evidente que la ley de patentes ha sido modificada, aun cuando se había previsto que las revisiones no se realizarían hasta 1997.

La imposibilidad de sustituir artificialmente los recursos fitogenéticos como materia prima para mejorar variedades y para los propios procesos biotecnológicos en la agricultura; la tendencia al deterioro y erosión de los centros de diversidad genética; la mayor vulnerabilidad ante enfermedades y plagas que presentan las nuevas variedades utilizadas por su homogeneidad genética; y principalmente el control cada vez mayor de un grupo sobre los recursos fitogenéticos que constituyen la base de la producción agroalimentaria, son elementos que determinan la urgencia de profundizar en los efectos al parecer ya inminentes en los diferentes sectores de la agricultura nacional.

Los cambios que en materia de legislación se han realizado en menos de un año señalan, sin duda, nuevos caminos para el futuro de la industria de semillas. Como en muchos otros sectores de la economía, prevalece la tendencia a la globalización; la venta de empresas, el adelgazamiento de otras (que muy probablemente llevará a la liquidación definitiva de PRONASE O BANRURAL) significa, en suma, la privatización de toda actividad económica vía un sustento jurídico que crea nuevas bases para negociar, sobre todo en el contexto 
externo. Así pues, los recursos fitogenéticos, "patrimonio de la humanidad", insumo vital para la producción de semillas, ahora deja de ser patrimonio para convertirse, mediante las patentes, en un recurso restringido a unas cuantas empresas que ya de por sí controlan una gran parte de los alimentos en el plano mundial.

\section{COMENTARIOS FINALES}

A manera de conclusión conviene insistir en que tanto la homologación de legislaciones nacionales sobre patentes a nivel mundial, que en buena medida ha sido promovida en el seno del GATT como premisa de intercambio e inversión, así como los recientes avances científicotecnológicos en materia agropecuaria, se relacionan estrechamente con una tendencia económica de expansión de las empresas que resultan más capaces para producir con mayor proporción y eficiencia. Fundamentalmente en los procesos relacionados con lo alimentario, es cada vez mayor la presencia de conglomerados productivos y de servicios que tienen una rama dedicada a la producción agropecuaria.

Las empresas semilleras tienden a ser absorbidas por grupos de empresas mayores que participan al mismo tiempo en diversos sectores, además del propiamente alimentario. Ello las ha provisto de gran capacidad de operación, así como de altas cuotas de inversión en investigación científica, lo cual ha cerrado los términos de competencia entre unas cuantas industrias de aprovisionamiento agrícola. Cabe destacar su estrecha vinculación con los centros de investigación, con universidades y grupos de profesionales, lo cual promueve el aumento de nuevos proyectos, especialmente en tecnología de punta, es decir, en biotecnología.

La manera de actuar de estas empresas contrasta notablemente con la indiferencia que la industria nacional ha mostrado con respecto a universidades y centros de investigación, casi siempre negando de antemano toda capacidad de generar resultados prócticos. Las semilleras del país se han condenado a sí mismas a convertirse en multiplicadoras y distribuidoras de variedades extranjeras, las más de las veces creadas a partir de variedades criollas de familias provenientes de regiones de América Latina, Africa o Asia.

Asimismo, mientras investigadores científicos y administradores de universidades europeas o norteamericanas diseñan mecanismos de inversión y amparo jurídico idóneos para proveerse de mayores insumos y capital para la investigación, en México resulta casi imposible allegarse recursos de las escasas industrias nacionales interesadas. 
Así, sólo el Grupo Ceres del estado de Sinaloa, mediante la filial Mexagro, antigua demandante de semillas básicas de la empresa Ferry-Morse (ahora retirada del mercado en México), ha procurado vinaularse con el CINVESTAV-Irapuato del IPN a fin de obtener participación en los resultados de las investigaciones que el Centro realiza en materia de hortalizas.

En cuanto al enfoque sobre reserva biótica, semillas y agricultura, convendría insistir en establecer un banco de germoplasma vegetal, tal como fue manifestado en el año de 1987 por las autoridades mexicanas en reuniones con organismos internacionales, en su caso FAO y SELA. Sin embargo, no sólo se restringió la consecución del proyecto, sino que la agencia del sector agricultura que debía encargarse de esa tarea, INIFAP, no tiene entre sus objetivos crear el mencionado banco.

En suma, la explicitada liberación comercial y normativa favoreceró una mayor capacidad de operación y de mercado de empresas semilleras extranjeras en el mercado del TLC, lo cual tenderá a disminuir los escasos márgenes de producción original de las semilleras nacionales, francamente desvinculadas del sector de investigación en el país. Este último, a su vez, carece de mecanismos operativos, tecnológicos y de interfase que permitiesen una relación más estrecha con el sector empresarial. A ello se suma la nueva protección jurídica que se da tanto a productos como a procedimientos. De ahí que, independientemente del carácter comercial y de integración horizontal de la empresa transnacional, será decisivo para investigadores y empresarios en el país tener una visión objetiva e informada de las nuevas vías que se seguirán en el corto plazo.

CUADRO 1

PRINCIPALES EMPRESAS SEMILLERAS EN.MEXICO, 1991

\begin{tabular}{|c|c|c|c|}
\hline $\begin{array}{l}\text { Nombre de la empresa } \\
\text { ciudades con oficinas }\end{array}$ & Entidad & Localización & Otras \\
\hline Semillas del Río Colorado & Baja Calformia Norte & Mexicali & \\
\hline Proveedora Agrícola Lagunera & Coahuila & Torreón & \\
\hline Semillas TACSA, S. A. de C. V. & Chiapas & Tapachula & \\
\hline $\begin{array}{l}\text { Semillas Hibridas de } \\
\text { Importación (American Hybrids) }\end{array}$ & Chihuahua & Cd. Cuauhtémoc & \\
\hline $\begin{array}{l}\text { Comercial Semillera de } \\
\text { Chihuahua, S. A. de C. V. }\end{array}$ & Chihuahua & $\begin{array}{l}\text { Nuevo Casas } \\
\text { Grandes }\end{array}$ & \\
\hline $\begin{array}{l}\text { Delta Pine de México, } \\
\text { S. A. de C. V. }\end{array}$ & Chihuahua & Ciudad Obregón & $\begin{array}{l}\text { México, } \\
\text { D. F. }\end{array}$ \\
\hline \multirow[t]{2}{*}{ MEXAGRO Internacional } & D.F. & Sinaloa & $\begin{array}{l}\text { Culiacón, } \\
\text { Sinaloa }\end{array}$ \\
\hline & & Jalisco & $\begin{array}{l}\text { El Fuerte, } \\
\text { Sinaloa }\end{array}$ \\
\hline
\end{tabular}




\begin{tabular}{|c|c|c|c|}
\hline $\begin{array}{c}\text { Nombre de la empresa } \\
\text { ciudades con oficinas }\end{array}$ & Entidad & Localización & Otras \\
\hline \multirow[t]{5}{*}{ MEXAGRO Internacional } & & Puebla & $\begin{array}{l}\text { Guamúchil, } \\
\text { Sinaloa }\end{array}$ \\
\hline & $\therefore$ & & $\begin{array}{l}\text { Guasave, } \\
\text { Sinaloa }\end{array}$ \\
\hline & & & $\begin{array}{l}\text { Los Mochis, } \\
\text { Sinaloa }\end{array}$ \\
\hline & & & $\begin{array}{l}\text { Guadalajora, } \\
\text { Jalisco }\end{array}$ \\
\hline & & & $\begin{array}{l}\text { Puebla, } \\
\text { Puebla }\end{array}$ \\
\hline $\begin{array}{l}\text { Semillas Berentsen, S. A. } \\
\text { (Compañía Beneficiadora del } \\
\text { Bajío, S. A. de C. V.) }\end{array}$ & D. F. & Guanajucto & Celaya \\
\hline Agrícola Gómez Moro & D. F. & México & \\
\hline $\begin{array}{l}\text { Harris Moran de México, } \\
\text { S.de R. L. de C. V. }\end{array}$ & D. F. & México & \\
\hline Semillas Sakata & Guanajuato & Celaya & \\
\hline Agrosurte S. A. de C.V. & Guanajuato & Celaya & \\
\hline $\begin{array}{l}\text { CIBA Geigy Mexicana, } \\
\text { S. A. de C. V. }\end{array}$ & Jalisco & Guadalajara & \\
\hline Pioneer de México, S. A de C. V. & Jalisco & Guadalajara & \\
\hline Industrias de la Garza y Garza & Jalisco & Guadalajara & \\
\hline $\begin{array}{l}\text { Northrup King y Cía., } \\
\text { S. A. de C. V. }\end{array}$ & Jalisco & Guadalajara & \\
\hline $\begin{array}{l}\text { Peto Seed Mexicana, } \\
\text { S. de R. L. de C. V. }\end{array}$ & Jalisco & Guadalajara & Tamaulipas \\
\hline Corgill de México, S. A de C. V. & Jalisco & Guadalajara & $\begin{array}{l}\text { México, } \\
\text { D. F. }\end{array}$ \\
\hline $\begin{array}{l}\text { Semillas Conlee Mexicana, } \\
\text { S. A. de C. V. }\end{array}$ & Jalisco & Guadalajara & \\
\hline Semillas Híbridas, S. A. de C. V. & Jalisco & Guadalajara & \\
\hline Semillas Century & San Luis Potosí & San Luis Potosí & \\
\hline SEMCA del Pacfífico, S. A de C. V. & Sinaloa & Los Mochis & \\
\hline \multirow{3}{*}{$\begin{array}{l}\text { Insecticidas del Pacífico, } \\
\text { S. A. de C. V. }\end{array}$} & Sinaloa & Los Mochis & \\
\hline & Sonora & Cd. Obregón & $\begin{array}{l}\text { Mexicali, } \\
\text { Baja } \\
\text { California } \\
\text { Norte }\end{array}$ \\
\hline & & & $\begin{array}{l}\text { Los } \\
\text { Mochis, } \\
\text { Sinaloa }\end{array}$ \\
\hline
\end{tabular}




\begin{tabular}{|c|c|c|c|}
\hline $\begin{array}{c}\text { Nombre de la empresa } \\
\text { ciudades con oficinas }\end{array}$ & Entidad & Localización & Otras \\
\hline \multirow[t]{2}{*}{$\begin{array}{l}\text { Insecticidas del Pacífico, } \\
\text { S. A. de C. V. }\end{array}$} & & & $\begin{array}{l}\text { Hermosillo, } \\
\text { Sonora }\end{array}$ \\
\hline & & & $\begin{array}{l}\text { Navojoa, } \\
\text { Sonora }\end{array}$ \\
\hline \multirow[t]{4}{*}{ Asgrow Mexicana, S. A de C. V. } & Tamaulipas & Matamoros & $\begin{array}{l}\text { Celaya, } \\
\text { Guanajuato }\end{array}$ \\
\hline & & & $\begin{array}{l}\text { Guadalajora, } \\
\text { Jalisco }\end{array}$ \\
\hline & & & $\begin{array}{l}\text { Puebla, } \\
\text { Puebla }\end{array}$ \\
\hline & & & $\begin{array}{l}\text { Los Mochis, } \\
\text { Sinaloa }\end{array}$ \\
\hline Empresas Longoria, S. A. & Tamaulipas & Matamoros & Méx., D.F.' \\
\hline INAGRO, S. A. de C. V. & Tamaulipas & Matamoros & Méx., D.F. \\
\hline (Semillas Garrizon) & & & $\begin{array}{l}\text { Irapuato, } \\
\text { Guanajuato }\end{array}$ \\
\hline \multirow[t]{4}{*}{ (Semillas Columbia de México) } & & & $\begin{array}{l}\text { Guadalajora, } \\
\text { Jalisco }\end{array}$ \\
\hline & & & $\begin{array}{l}\text { Cuautla, } \\
\text { Morelos }\end{array}$ \\
\hline & & & $\begin{array}{l}\text { Culiacón, } \\
\text { Sinaloa }\end{array}$ \\
\hline & & & $\begin{array}{l}\text { Veracruz, } \\
\text { Veracruz }\end{array}$ \\
\hline $\begin{array}{l}\text { Productora Agroindustrial } \\
\text { Matamoros, S. A. de C. V. }\end{array}$ & Tamaulipas & Matamoros & \\
\hline Semillas Agrícolas Mexicanas & Tamaulipas & Matamoros & \\
\hline $\begin{array}{l}\text { Semillas Master de México, } \\
\text { S. A de C. V. }\end{array}$ & Tamaulipas & Matamoros & $\begin{array}{l}\text { México, } \\
\text { D.F. }\end{array}$ \\
\hline (Procesadora de Semillas) & & & $\begin{array}{l}\text { Salamanca, } \\
\text { Guanajuato }\end{array}$ \\
\hline \multirow[t]{2}{*}{ (Semillas Carna) } & & & $\begin{array}{l}\text { Guadalajara, } \\
\text { Jalisco }\end{array}$ \\
\hline & & & $\begin{array}{l}\text { Río Bravo, } \\
\text { Tamaulipas }\end{array}$ \\
\hline Semillas del Golfo, S. A de C. V. & Tamaulipas & Matamoros & \\
\hline Semillas Toro, S. A. de C. V. & Tamaulipas & Matamoros & \\
\hline $\begin{array}{l}\text { Tratadora y Procesadora de } \\
\text { Semillas, S. A. de C. V. }\end{array}$ & Tamaulipas & Matamoros & \\
\hline $\begin{array}{l}\text { Semilla MAC Warner Oro y } \\
\text { Delta de México, S. A. de C. V. }\end{array}$ & Tamaulipas & Matamoros & \\
\hline $\begin{array}{l}\text { Productora Nacional de } \\
\text { Semillas }\end{array}$ & uántas & pajar. & \\
\hline
\end{tabular}


CUADRO 2.

PRINCIPALES EMPRESAS BIOTECNOIOGICAS CREADAS A PARTIR DE 1970

Y CONGIOMERADOS QUE HAN INVERTIDO EN ESTE CAMPO

Empresa País $\begin{aligned} & \text { Empleados } \\ & \text { (Núm. de } \\ & \text { lmestigadores } \\ & \text { deobonivel) }\end{aligned} \quad$ Actividades

Principales empresas creadas a partir de 1

Cotus (Berkeley, California)

Genetech (San Francisco,

California)

Genex (Dockville, Maryland)

Biogen (Cambridge, Zurich, Ginebra)

Bethesda Research Lab.

(Gaithersburg, Maryland)

Agrigenetics (Denver, Colorado)

International Plant Research

Institute (San Carlos, California)

Native Plants (Salt Lake City,

Utah)

Collagen Corporation (Palo

Alto, California)

Centecor (Filadelfia,

Pensilvania)

Hybritech (La Jolla, California)

Celltech (Berkshire) Inglaterra

Biologicals (Toronto)

Allelix (Toronto)

Canadó

Estados Unidos (se han creado más de 200 empresas)
370 (40) Creada en 1971,

Ingeniería genttica

orientada hacia la

producción de masa

300 (75) Creada en 1976, ingeniería genética

100 (26) Creada en 1977. ingeniería genética orientada hacio la química

70 (25) Creada en 1978, ingeniería genética orientada hacia los medicamentos

650 (28) Mejoramiento de las plantas

120 (45) Mejoramiento de las plantas

85 (25) Agronomía, microorganismos

89 (10) Colágena para usos médicos y de laboratorio

35 (12) Investigaciones sobre híbridos

50 (10) Investigaciones sobre híbridos

40 Investigaciones sobre hibridomas y vacunas

56 (22) Instrumentación e investigaciones sobre fermentaciones

Biotecnología orientada hacia la agricultura, empresas forestales, química, energía y control de la contaminación. 
Transgene (Estrasburgo)

Genetica (Paris)

63 (Paris)

Inmunotech (Marsella)
50 (22) Ingeniería genética

Francia

Ingeniería genética

Ingeniería genética

Inmunología y anticuerpos monoclónicos

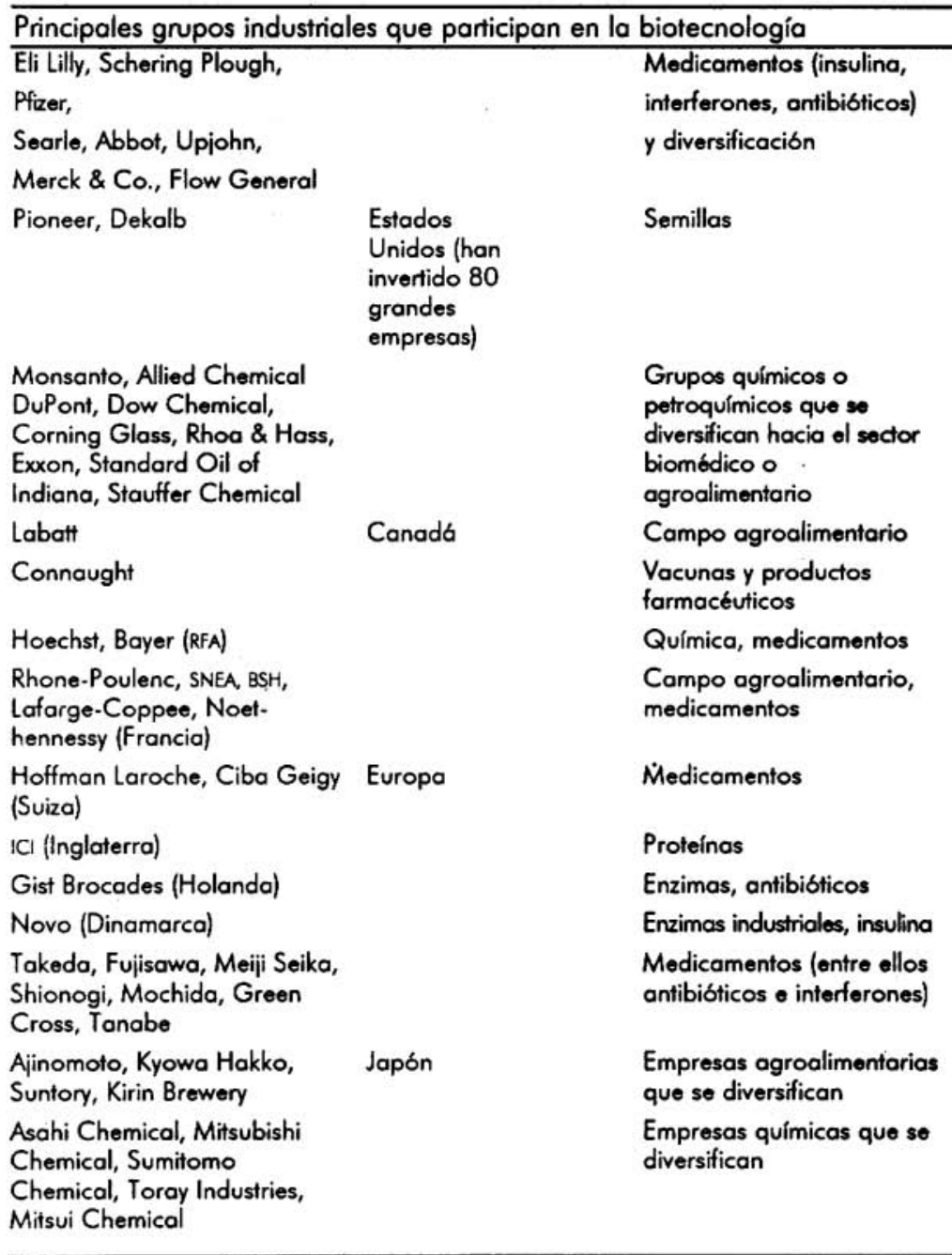

Fuente: Pierre Douzou, Las biotecnologías, México: Fondo de Cultura Económica, 1986. 


\section{IMPORTACIÓN DE SEMILLAS \\ 1976-1988}

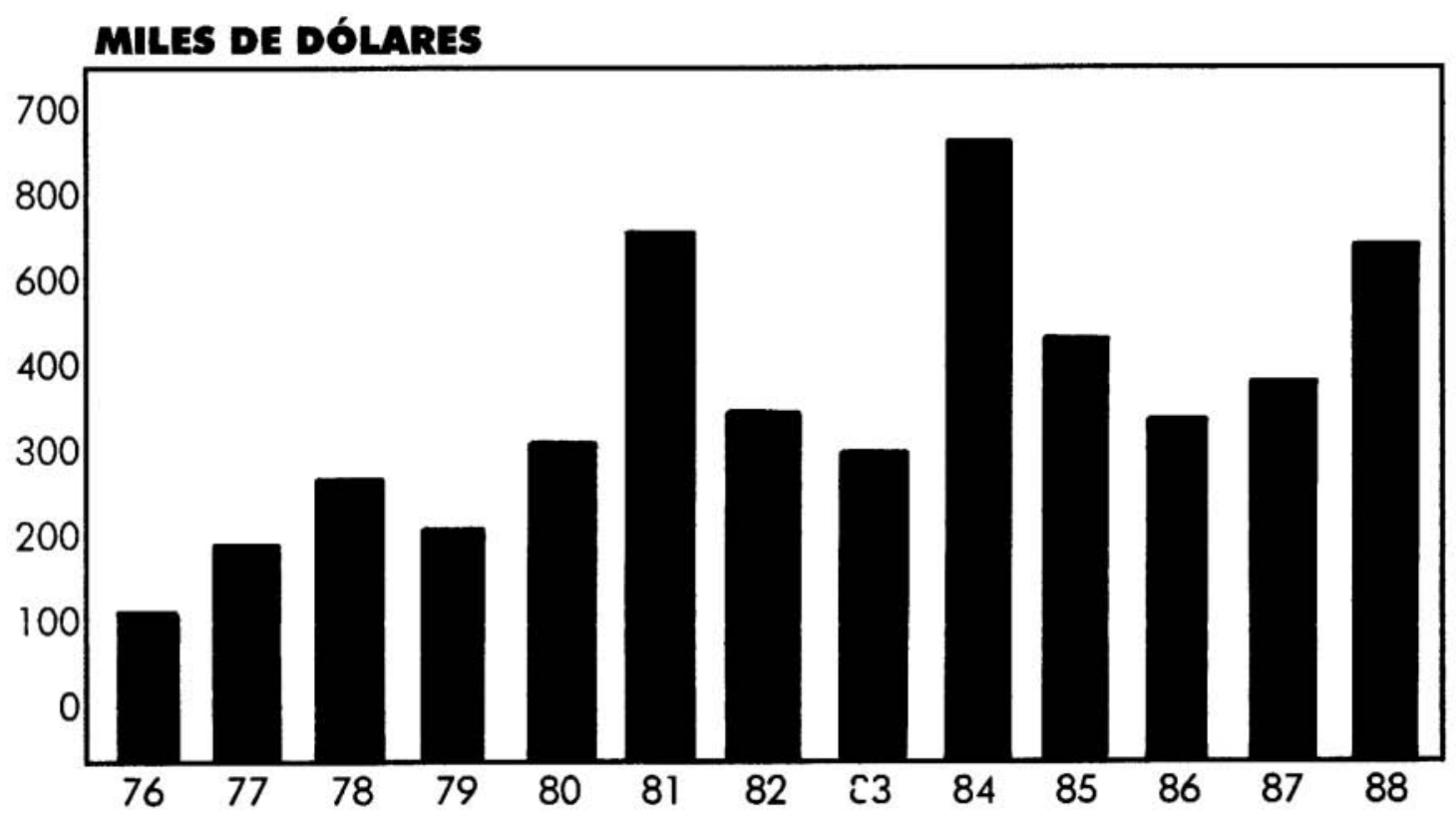

Ma. de los Ángeles Rodríguez, "Análisis de la balanza de comercio exterior agropecuario en México", México: Centro de Ecodesarrollo, 1992, mimeografiado. 



\title{
La bioseguridad en la dinámica actual de las relaciones internacionales y sus repercusiones en México
}

\author{
LEONARDO HÉCTOR RIOJA PEREGRINA*
}

\section{INTRODUCCIÓN}

La bioseguridad es un elemento que conforma un nuevo perfil de las relaciones internacionales; por lo tanto, se le considera dentro de los esquemas de seguridad e interés nacional de los países que conforman el sistema internacional $y$, en esa misma medida, se establece como extensión de dichos conceptos. Pese a su importancia, sin embargo, la mayor parte de los países subdesarrollados aún no tienen una visión y concepción clara de sus consecuencias.

Lo anterior pone a países como México en una posición desventajosa frente a las naciones desarrolladas, las cuales a través de sus gobiernos v organizaciones supranacionales están articulando estratégicamente sus políticas de desarrollo biotecnológico y prestan particular atención a lo que respecta a la bioseguridad. La política exterior de las grandes potencias pretende, conjuntamente con sus empresas, tener mayores ventajas para obtener el control tecnológico, económico, político y militar y mantenerlo y acrecentarlo en foros subregionales, regionales, continentales y transcontinentales bajo nuevas estructuras y relaciones económicas y de poder.

Así pues, la bioseguridad se está convirtiendo en un elemento económico, político y militar de los países del capitalismo post-industrial ya que con la información biotecnológica disponible se están estableciendo los criterios para evitar o promover, respectivamente, los efectos negativos o benéficos tanto para los seres humanos como para el

* Faculiad de Ciencias Políticas y Sociales, UNAM; Instituto para la Planeación del Desarrollo, Sociedad Civil. 
ambiente. Del mismo modo, la bioseguridad contribuye a determinar el desarrollo de la capacidad para disponer de los recursos bióticos existentes a lo largo y ancho del planeta; por ello se vincula directamente con las cuestiones ecológicas.

Es muy importante destacar la trascendencia que tiene el estudio de la bioseguridad, tanto desde la perspectiva cientifico-tecnológica como desde las diferentes apreciaciones políticas y sociales que de ella se hagan. Este trabajo pretende abordar algunas de las cuestiones políticas, económicas, sociales, militares y ambientales que giran en torno del problema que plantea la conceptualización de la bioseguridad y su vinculación con la realidad. Este ensayo pretende articular algunas consideraciones al respecto ante la inminencia de la firma del Tratado de Libre Comercio entre México, Estados Unidos y Canadá, pues supone que dichos países adoptarón diferentes criterios y concepciones en lo concerniente a seguridad, soberanía e interés nacional.

Para Estados Unidos y Canadá el concepto "seguridad nacional" se adecua a las circunstancias internas y externas en donde se pretende mantener una posición hegemónica que no vulnere sus intereses nacionales, los cuales pueden ser comerciales, ecológicos, políticos, económicos, financieros o militares, sustentados en el ejercicio de una política exterior próctica. Estos fundamentos pueden ser aplicados para garantizar su bioseguridad en los momentos que consideren pertinentes, dentro o fuera de sus fronteras.

Así, la bioseguridad se traduce en diversos factores dentro de las negociaciones del TLC, lo cual, a su vez, entraña efectos directos de gran trascendencia en el proceso de transformación social, económica, políica y jurídica de nuestro país.

\section{LA DINÁMICA DE LAS RELACIONES INTERNACIONALES Y LA BIOSEGURIDAD}

La bioseguridad como nuevo factor condicionante de las relaciones internacionales

En los últimos años, la biotecnología se ha convertido en un factor cada vez más influyente en el esquema del desenvolvimiento de las relaciones internacionales, tanto en sus aspectos políticos y económicos como en los jurídicos y militares. Por otra parte, las diferentes estructuras económicas plantean serias contradicciones políiticas, sociales y ecológicas dentro de los países que poseen menores capacidades científico-tecnológicas, lo cual se debe a que han sido, históricamente, receptores pasivos de tecnologías anticuadas, generadoras de patrones sociales ajenos a las culturas locales y destructoras del entorno natural. 
Independientemente de las consecuencias que pueda tener el avance de la nueva biotecnología, ésta se traduce en nuevos esquemas de control y dominación internacionales. El papel que la ingeniería genética desempeña en la Nueva División Internacional del Trabajo lo revela. En cuanto a sus efectos socioeconómicos, las compañías de los países desarrollados están pugnando por proteger el conocimiento generado de los procesos biotecnológicos dado que pueden ser explotados económicamente.

En esta nueva dinámica, las empresas biotecnológicas de los países avanzados son las que imponen el ritmo de la innovación y el crecimiento económico en áreas como agricultura, ganadería, forestal, acuícola, minería, farmacéutica, energía, química y medio ambiente. En apariencia, la biotecnología plantea soluciones a problemas en las áreas antes referidas. No obstante, los posibles efectos del uso de productos biotecnológicos a grandes escalas de producción y consumo aún se desconocen, aunque se cuenta con algunos sistemas de análisis de los efectos de la biotecnología en algunas de sus áreas de aplicación.

Es evidente que no se puede detener el avance cientifico, ni el desenvolvimiento económico en la actual restructuración económica mundial. Los vectores de la tecnología deben apuntar hacia la instrumentación de políticas biotecnológicas que pretendan cubrir las demandas sociales. Se deben reconocer, a su vez, los grandes beneficios que la biotecnología ha aportado en la búsqueda de soluciones para preservar la salud del hombre, pues se ha logrado erradicar gran cantidad de enfermedades mediante la aplicación próctica de diferentes biotecnologías, tanto tradicionales como nuevas.

El conocimiento científico-tecnológico ha creado a nivel internacional su propia dinámica de protección en la cual las naciones altamente industrializadas desempeñon el papel central. Es decir, mientras los países y empresas internacionales generan y explotan el conocimiento biotecnológico, se establecen al mismo tiempo reglas de protección y seguridad en relación con el usufructo de sus resultados; pero el resto de los países no tiene acces a este nuevo conocimiento y, por ende, al aprovechamiento de los beneficios generados. El conocimiento biotecnológico, por lo tanto, se guarda y asegura para que no pueda ser divulgado y no encuentre su punto de retorno en las sociedades de donde surgió originalmente.

A nivel general, el concepto de bioseguridad entraña cuestiones que van más allá de los planteamientos actuales. Se ha puesto particular atención en algunos problemas que surgen de la ingeniería genética, sobre todo a los Organismos Modificados Genéticamente (OMG) y a sus diferentes grados de peligrosidad (este aspecto se aborda detalladamente más adelante). Aunque esto no significa que la bioseguridad 
quede excluida de los problemas ambientales: escapes y accidentes radiactivos, derrames petroleros, extinción de especies animales y vegetales, salud del hombre y amenazas de guerras bacteriológicas. Por el contrario, cuanto mayor sea el grado de integración de los elementos tratados y abordados a través de un enfoque integral, mayor será la profundidad en el análisis de las repercusiones de la bioseguridad. Por ello se requieren esfuerzos adicionales en el estudio de cada uno de dichos elementos para profundizar, ampliar y reforzar la seguridad biológica.

En la actualidad se conforma un Código Internacional de Bioseguridad que tiene como objetivo central dictar las reglas que eviten la propagación de los efectos negativos que puedan ser generados por los Organismos Modificados Genéticamente (OMG). En una reunión de carácter no gubernamental celebrada el año pasado, asistieron representantes de 36 países industrializados y 6 semi-industrializados, entre los cuales se encuentra México. Es importante destacar que la participación de nuestro país fue fundamental, ya que frente a la oposición abierta y el descontento de Estados Unidos, en dicho encuentro se aprobó el establecimiento de este Código, el cual en principio fijará algunos de los lineamientos generales para buscar y preservar la bioseguridad. No obstante, son pocos los resultados prócticos que se puedan obtener con este conjunto de normas ya que la bioseguridad no quedará garantizada nunca por decreto. Por otra parte, no existe ninguna organización internacional para que haga efectivas las normas del Código de Conducta, ni país alguno obligado a cumplirlas. Sin embargo, a la luz de una opinión pública internacional, las conductas violatorias de los principios del Código pueden ser reprobadas, y esto, en principio, resultará un gran avance.

Hay una tendencia a desplazar las funciones y facultades de las instituciones internacionales encargadas de resolver, plantear y estudiar problemas en los diversos países que conforman el sistema internacional. Por ejemplo, las tareas de la bioseguridad relacionadas con las nuevas tecnologías del Acido Desoxirribonucleico recombinante (ADNr) deberían correr a cargo exclusivamente de la Organización Mundial de la Salud (OMS), la Organización Mundial para la Alimentación y la Agricultura (FAO) y la Organización de las Naciones Unidas para el Desarrollo Industrial (ONUDI). Por ello, son los países interesados quienes de manera independiente también están estableciendo una normatividad al parecer paralela en lo concerniente a cuestiones concretas de la bioseguridad.

Cabe señalar que la FAO realiza considerables esfuerzos encaminados a formular un Código de Conducta para la Biotecnología por medio de la Comisión de Recursos Fitogenéticos. A la fecha las 
reuniones realizadas han culminado con el establecimiento de un Sistema Mundial para la Conservación y Utilización de Recursos Fitogenéticos, en el cual se ha abordado el tema de la bioseguridad y sus repercusiones jurídicas y de reglamentación. Sin embargo, no se ha llegado a conclusiones determinantes en virtud de las características de las tareas por realizar.

La Comisión, en su cuarta reunión (abril de 1991) convino en términos generales en que en el Código podrían abordarse, entre otros temas, asuntos relativos al fomento del uso duradero de la biotecnología en la conservación y utilización de los recursos fitogenéticos; el fomento del acceso a los recursos fitogenéticos; la promoción de la bioseguridad, a fin de reducir al mínimo los peligros para el medio ambiente en todo el mundo ...?

Ante esta realidad, subsiste la necesidad de cambios profundos en la actual estructura de la Organización de las Naciones Unidas (ONU), así como una profundización en los estudios de los trabajos que habrían de realizarse, ya que dicho organismo internacional ha mostrado su incapacidad para mantener la paz y seguridad mundiales: es el Consejo de Seguridad el que toma las decisiones en momentos críticos, dejando de lado a la Asamblea General, instancia donde se encuentra representada la mayor parte de los países del planeta.

En los recientes reacomodos del poder mundial se observa el rompimiento del esquema bipolar mantenido a todo lo largo de la Guerra Fría. Tal ruptura da como resultado el surgimiento de un nuevo arreglo unipolar donde Estados Unidos se constituye, gracias a su gran poderío militar, en el país hegemónico del escenario mundial.

Ante este panorama, se observa que los países desarrollados han puesto mucha atención en la defensa de sus intereses nacionales mediante sistemas de bioseguridad, los cuales no están exclusivamente ligados al desarrollo de la nueva biotecnología pero en la actualidad están cobrando mucha importancia en este último sentido. Es decir, la bioseguridad es la extensión de su concepto de seguridad nacional, con el fin de garantizar su interés nacional, independientemente de las formas o prácticas que garanticen el bienestar de sus sociedades y sus recursos naturales.

En el caso de la relaciones entre México y Estados Unidos encontramos, en principio, diferentes actitudes y posturas frente a la defensa del interés y la seguridad nacionales. Por un lado, históricamente Estados Unidos ha sostenido su política exterior mediante actitudes

1 Conferencia, Organización de las Naciones Unidas para la Agricultura y la Alimentoción, Documento para el $26^{\circ}$ período de sesiones, Roma, 9.28 de noviembre, octubre, 1991, p. 5. 
pragmáticas que responden a circunstancias determinadas, sin principios fundamentales de conducta o respeto hacia el resto de los países. Por otro lado, cabe señalar que el interés y la seguridad nacionales estadunidenses se encuentran en todo el mundo y se ubican en los planos económico, geopolítico, y militar, particularmente en la bioseguridad. En este contexto, no sería extraño - pese a la conclusión de las negociaciones del Tratado de Libre Comercio (TLC) entre México, Estados Unidos y Canadá- que se puedan aducir cuestiones de bioseguridad (por ejemplo reglamentos fitosanitarios, pretextos ecologicos o cualquier otro tipo de argumentos) para intervenir en los asuntos internos de nuestro país y no cumplir con determinados puntos acordados en dicho tratado.

Por su parte, México hasta hace poco ha mantenido una política exterior primordialmente defensiva, pero sustentada en tres principios teóricos.

Los tres principios pueden reducirse a lo siguiente: en primer lugar, soberanía e independencio de los Estados, lo cual trae como consecuencia mantener el principio de igualdad, el de no intervención, el de autodeterminación, etcétera; en segundo lugar, cooperación, es decir que el principio de autodeterminación de los pueblos México no lo entiende como un principio que deba llevar al aislamiento de los diversos países, sino que la perfecta interpretación de autodeterminación de los pueblos lleva implícita la cooperación entre ellos; y el tercero es el relativo al mantenimiento de la paz y la seguridad internacionales. ${ }^{2}$

Estos principios se han nulificado debido a la evolución de los acontecimientos $y$ a las presiones internacionales.

Las presentes tendencias económicas de la mayor parte de los países latinoamericanos han sido forzadas por situaciones externas. Se ha vuelto indispensable llevar a cabo una "modernización" de sus economías mediante la aplicación de estrategias "globalizadoras". ${ }^{3}$ La actual política económica emprendida por el gobierno mexicano se debe en particular a las condiciones impuestas por el Fondo Monetario 89.

${ }^{2}$ Modesto Seara Vázquez, Politica exterior de México, México: Ed. Harla, 1985, p.

${ }^{3}$ Hay que entender que la globalización de la economía de cualquier país no significa única y exclusivamente abrir sus fronteras a la penetración de mercancías, servicios, capital, tecnología, etcétera, y fomentar sus exportociones. La globalización económica entraña una posición a nivel internacional sumamente dinámica sustentada en la estructura económica tan competitiva de los países industrializados, la cual sólo puede llegar a concretarse mediante la presencia y competencia cada vez más amplia de sus compañías transnacionales. 
Internacional (FMI). De no ser así, nuestro país dejaría de ser sujeto de crédito de las diversas instituciones financieras internacionales: Banco Mundial, FMl y la banca privada internacional. La instrumentación de la vigente política económica se muestra en las cartas de intención firmadas por nuestro país con el FMI. Hay que señalar que detrós de los principales bancos acreedores de México se encuentran grandes empresas transnacionales, las cuales por lo regular controlan los procesos productivos y comerciales petroleros, pero a su vez se perfilan y expanden hacia nuevos campos de producción que prometen ser muy rentables. Entre las compañías más importantes están Monsanto de Neumurs y DuPont, con estrategias de expansión encaminadas al control de procesos biotecnológicos mediante una fuerte inversión en Investigación y Desarrollo (I \& D). Con esto han logrado significativas innovaciones en ese renglón, lo cual las ubica a la vanguardia en determinados campos de la bioindustria a nivel internacional. Dicha orientación se traduce en intereses especiales en nuestro país.

Hay también solicitudes expresas por parte de diversas compañías extranieras, la mayor parte de ellas vinculadas de alguna manera con los bancos acreedores de México, ${ }^{4}$ para realizar investigaciones en territorio nacional sobre los compos de experimentación y explotación agroindustrial de organismos (entre los que se encuentran plantas, microorganismos y productos biológicos veterinarios). Estas empresas no han recibido respuesta hasta el momento, pero ya dicha solicitud se halla en una serie de evaluaciones que las autoridades se encargarán de estudiar para emitir los permisos correspondientes. Cabe señalar que, en la medida que aumenten las presiones de Estados Unidos hacia nuestro país y se hagan modificaciones a la legislación mexicana, se irán concediendo los respectivos permisos de liberación de organismos transgénicos con fines agroindustriales en mayores proporciones de superficies cultivables.

Esta situación supone que nuestro país pueda ser convertido en un campo de experimentación biotecnológica, sin una respuesta y una posición política oportuna del Comité Nacional de Bioseguridad (CNB). Al parecer, la significación y trascendencia de esta posibilidad no han sido debidamente definidas y analizadas en el plano nacional durante el proceso de negociación del TLC, lo cual resulta paradójico pues a nivel internacional, en el seno de la FAO, la bioseguridad internacional ha cobrado gran importancio.

En algunos estados de la Unión Americana y Canadá las extensiones para la explotación agroindustrial de organismos modificados por

${ }^{4}$ Esta información podrá conocerse con más detalle cuando se haga pública. Por ser de caracter confidencial no se hacen mayores precisiones. 
la ingeniería genética han aumentado considerablemente; es decir, el proceso de liberación al medio ambiente de dichos organismos con fines comerciales comienza a mostrar sus bondades en lo que respecta a su viabilidad económica. No obstante, debe recalcarse que hay muchas reservas al respecto, pues las consecuencias y los riesgos aún no han podido ser evaluados en su totalidad.

La biotecnología del ADN recombinante acarrea riesgos que podrían ser evitados si se aplicaran medidas de bioseguridad. En teoría, la información genética transmitida que se altera mediante biotecnologías respeta la estructura genética del organismo modificado; o sea que no representa ningún riesgo. Esto es lo que argumentan los biotecnólogos en pos del avance de la ciencia.

En la medida en que los criterios de rentabilidad económica y eficiencia productiva se vinculen con la aplicación del concepto de bioseguridad, se dará mayor importancia a los efectos negativos que la biotecnología pueda tener sobre los procesos productivos, en particular en la utilización de organismos modificados genéticamente. Por ello, las medidas de evaluación y regulación de los procesos biotecnológicos tienen que ser más rigurosas.

Es evidente que la mayor parte de la sociedad mexicana no ha participado en la toma de decisiones sobre las líneas de producción, comercialización, investigación y desarrollo de productos elaborados mediante biotecnologías. En los países desarrollados se está creando una conciencia social gracias a una amplia difusión de los posibles efectos que pueden tener las biotecnologías sobre la salud humana y el entorno natural. Este hecho se manifiesta con el surgimiento de asociaciones civiles organizadas que pugnan por la investigación profunda sobre las consecuencias que acarrea la aplicación de ciertas biotecnologías, particularmente las relacionadas con el ADN recombinante.

Las repercusiones de estas nuevas tecnologías no pueden calcularse pues los sistemas de evaluación se encuentran en un estado embrionario de desarrollo. Por lo tanto, los efectos que pudiera tener la aplicación a grandes escalas de procesos biotecnológicos sobre la sociedad mexicana están estudiándose de manera muy incipiente en las diferentes direcciones de los sectores económicos y estratos sociales.

En el actual esquema de desmantelamiento del aparato productivo nacional, ${ }^{5}$ las pocas industrias biotecnológicas mexicanas que logren adecuarse a la dinámica de los cambios impuestos tendrán notables desventajas con respecto a las que vengan del exterior pues éstas

${ }^{5}$ Véase John Saxe Fernández, "Deuda externa y desnacionalización integral", en Revista de estudios políticos y sociales, Facultad de Ciencias Politicas y Sociales-Universidad Nacional Autónoma de México, núm. 134, 1989, pp. 71.91. 
cuentan con bastantes elementos científico-tecnológicos y suficiente capital para cumplir con las "exigencias jurídicas" 6 de bioseguridad y las condiciones del mercado.

Sin embargo, lo anterior no significa que las compañías extranjeras de biotecnología garanticen niveles aceptables de bioseguridad. Aunque existieran medidas jurídicas al respecto, los sistemas de verificación de las autoridades pueden no adecuarse a la realidad, amén de la falta de personal altamente calificado y las prócticas de corrupción. La importancia económica puede ser tal que dichas medidas no se apliquen, lo cual ocasionaría factores de inseguridad biológica, tanto en sus procesos como en sus diseños y productos finales.

Para garantizar la bioseguridad se requieren grandes inversiones de capital en laboratorios y personal calificado, así como la participación activa y organizada de la sociedad. Mediante sus organizaciones políticas, ecológicas, sociales, etcétera, la sociedad civil puede presionar para que se establezcan criterios y sistemas de evaluación estrictc concernientes a los posibles efectos negativos de la biotecnología , otras tecnologías.

La conquista de la bioseguridad puede hacer inviables muchos proyectos biotecnológicos económicamente viables. Las consecuencias económicas de la bioseguridad tienen como elemento principal la viabilidad económica de los proyectos productivos fundamentados en el uso intensivo y en escalas industriales de la biotecnología. Es decir, la relación que se establece entre la importancia económica y la bioseguridad por lo regular no puede ser compatible.

Ante el TLC, los intereses atienden fundamentalmente cuestiones económicas y comerciales en las cuales los aspectos de bioseguridad no se tratan de manera particular. Así pues, una cierta variedad de productos elaborados por medios biotecnológicos pueden recibir permisos de las autoridades sanitarias y comerciales de nuestro país sin que se evalúe con anterioridad sus efectos potencialmente negativos.

La crisis económica que enfrenta Estados Unidos tiene características de depresión. Por ello es de esperarse que la puesta en marcha de lo acordado en cada uno de los puntos del TLC corra el riesgo de no llevarse a cabo, ya que una decisión unilateral de Estados Unidos, tomada, por ejemplo, so pretexto de su interés y seguridad nacionales, puede endurecer la política exterior en algunos puntos fundamentales que hagan inoperante dicho Tratado.

${ }^{6}$ Las exigencias jurídicas de bioseguridad no garantizan por sí mismas la bioseguridad. El contenido de las exigencias jurídicas concernientes a la bioseguridad en nuestro país son muy limitadas pues no se cuenta con una amplia participación de la comunidad científica que las sancione técnica ni cientificamente. Es decir, dichas reglas se han establecido, por un lado, para llenar el vocío jurídico que supone la incorporación de la biotecnología y, por el otro, para legitimar el uso intensivo de la biotecnología. 
Las constantes presiones de Estados Unidos en lo referente a modificar nuestras leyes ha dado resultado. La aplicación de los cambios requeridos para favorecer su interés nacional se refleja en el interés económico de sus empresas y en el aumento de la cantidad de éstas. Nuestro país presenta muchos atractivos a las compañías que se dedican a la biotecnología, y si las nuevas condiciones favorecen sus intereses, no tardarán en tomar posiciones ventajosas en el esquema de competencia por los mercados. Porque si se lesiona la seguridad nacional -en su conjunto- frente a este tipo de circunstancias, es de esperarse que la bioseguridad sufra paralelamente efectos adversos.

Las nuevas formas de producción biotecnológica llevan consigo el desarrollo de nuevos patrones de consumo, lo cual mantiene la tendencia a la concentración de la riqueza, producto del excedente económico. La sociedad mexicana, en general, se ve al margen en la distribución de esta generación de riqueza; sólo algunos sectores pueden tener acceso a los beneficios de la biotecnología, dados los costos de los productos que ésta genera.

Los aspectos de la bioseguridad están íntimamente ligados al desarrollo económico, mas no al crecimiento económico. En términos precisos, la bioseguridad refleja niveles de calidad de vida más altos para los seres humanos y su entorno natural; pero su expresión social aún no encuentra sus manifestaciones concretas. No hay sociedad en el mundo que se haya beneficiado ampliamente por las bondades de la biotecnología.

Mediante mapeos genotípicos ${ }^{7}$ técnicamente conocidos como Restriction Fragment Length Polimorfisms (RFLPs), la biotecnología puede permitir la aceleración de resultados productivos potencialmente viables y con fines económicos, sin llegar, por ahora, a la obtención de organismos transgénicos. Esta técnica generada por la ingeniería genética permite que el mejoramiento genético de las especies animales y vegetales destinadas para el consumo humano sea llevado a cabo por medio de las técnicas tradicionales de mejoramiento genético.

La viabilidad económica en lo referente a búsqueda de información genética mediante RFLPs en nuestro país permite ventajas en el mejoramiento productivo de algunas especies vegetales de importancia económica como el maíz, el frijol y el café. Las dos primeras, por constituir la base cultural de la alimentación de casi toda la sociedad mexicana, y la tercera por su importancia económica en lo relativo a divisas para

7 Genotipo: conjunto de características contenidos en los genes de todos los seres vivos; no todas se expresan fenotípicamente pero se transmiten de una generación a otra y son de una gran variabilidad en cuanto a la expresión de los rasgos particulares de la información genética retenida y transmitida. Fenotipo: conjunto de características externas que se han materializado en los seres vivos y que hace distinguibles a los individuos de una misma especie, dentro de sí misma y con respecto a las otras. 
el país. Estas consideraciones deben tomarse en cuenta cuando se plantean nuevas estrategias de desarrollo agrícola en beneficio de los grupos más necesitados de nuestro país y medidas para evitar mayores alteraciones al ambiente. En este sentido, la seguridod alimentaria se complementa con la bioseguridad en la búsqueda de la seguridad nacional.

\section{LA BIOSEGURIDAD: ELEMENTO QUE PERMEA LAS POLITICAS DE DESARROLLO Y AFECTA EL ENTORNO NATURAL}

En realidad la biodiversidad, la protección de la propiedad intelectual, la ecología, el sistema de patentes y la bioseguridad son elementos que están relacionados estrechamente. Sin embargo, para efectos de este trabajo, dichos elementos girarán en torno a uno de ellos debido a su importancia: la bioseguridad.

Esta ponencia pretende plantear un enfoque integral del concepto de bioseguridad sin restringirlo exclusivamente al terreno de la nueva biotecnología y sus potenciales efectos negativos. Hay niveles y diferencias cualitativas entre las biotecnologías que se están desarrollando. En el caso de México, la bioseguridad no entendida como concepto sino como realidad ha variado mucho. Por ejemplo, los elementos de bioseguridad que imperaron durante la "Revolución Verde" ${ }^{8}$ eran muy diferentes de los que ahora se plantean. Esto significa que, para poder llevar a cabo una expansión agroindustrial de gran envergadura, se adoptaron modelos productivos que no garantizaron la integridad de la seguridad biológica, sino que devastaron amplias zonas de cultivo y las dejaron inservibles. Igualmente, se generaron enfermedades en la población consumidora debido a los residuos tóxicos en los alimentos. La erosión causada por los agroquímicos, la falta de adecuación de las semillas a las condiciones particulares de las zonas y otros factores dieron como resultado un fracaso en la búsqueda de la autosuficiencia alimentaria.

La bioseguridad no tratada de manera integral puede transformarse en un concepto cada vez más restringido; ya en el presente se hace hincapié en el desarrollo de la biotecnología y, sobre todo, en relación con ciertos efectos generados por la ingeniería genética. Este concepto se circunscribe a las consecuencias negativas que puede tener la

${ }^{8}$ Este concepto se puede resumir como la búsqueda del aumento de las capacidades productivas en la agricultura mediante el uso intensivo de fertilizantes químicos, pesticidas, plaguicidas, fungicidas, maquinaria y equipo agrícola, así como el desarrollo de grandes infraestructuras de riego. Esta "revolución" surgió después de la Segunda Guerra Mundial, como modelo de desarrollo agrícola de los países altamente industrializados, mientras que los países subdesarrollados trataron de imitarla. 
liberación al medio natural de organismos que han sido modificados genéticamente, su aplicación en productos para la salud de los seres humanos, en la agricultura y la posible solución de problemas ambientales; pero no se abunda en los efectos que pueden causar los residuos que de estas actividades se generan. En realidad el concepto de bioseguridad tiene planos de aplicación más allá de este ámbito. Es decir, dentro de esta problemática también se incluye a todos los seres vivientes que existen sobre la Tierra.

La bioseguridad también debe entenderse como estrategias que permiten un desarrollo sostenido adecuando las tecnologías que logren alcanzar este objetivo. Por lo tanto, la bioseguridad se convierte en una prioridad estratégica integral en cualquier proyecto que se pretenda ubicar en la modernización económica, política y social de cualquier país. En este sentido, la bioseguridad no puede estar garantizada exclusivamente por una serie de reglamentaciones y leyes, ya que éstas no son respetadas por la corrupción de quienes, en determinado momento, no las aplican por las inercias burocráticas, la falta de adecuación de lo normafivo a la realidad, los intereses políticos de los grupos para la apropiación de los presupuestos, etcétera.

En el norte del país, por ejemplo, la gran franja fronteriza hace muy vulnerable a nuestro país en lo referente a la bioseguridad. Su extensión y la falta de puestos de vigilancia realmente efectivos no permiten un estricto control sobre el tráfico ilegal de especies vivas y organismos modificados genéticamente con fines de experimentación o explotación comercial. De igual manera, resulta difícil hacer una evaluación sobre las cantidades de desechos tóxicos, orgánicos, químicos o radiactivos de Estados Unidos que vienen a parar dentro de nuestra frontera o muy cerca de ella. Hace apenas unos meses se iniciaron trabajos por parte de las autoridades ecológicas mexicanas con el objeto de establecer cuáles son los puntos críticos en la frontera norte en relación con la contaminación que se ha generado.

Por otro lado, en los últimos años se ha llegado a saber que muchas de las especies animales y vegetales propias de México están en peligro de extinción gracias al tráfico ilegal que se hace con ellas hacia Estados Unidos y hacia otros países. Es muy difícil, por tanto, poder cuantificar los estragos que la biodiversidad nacional ha sufrido por este tipo de prácticas.

El control de migraciones naturales o transmisión de agentes patógenos (virus, plagas, etcétera) resulta muy difícil, pues no existen los medios para detener este tipo de propagaciones. En este sentido, la naturaleza no conoce fronteras políticas o diferencias socioeconómicas, aunque muchas enfermedades son propias del estado de pobreza en numerosos sectores de las sociedades de países como México. 
Por ello, se plantea una nueva posibilidad para evaluar los efectos que las tecnologías tienen sobre el medio ambiente y la salud de los seres humanos.

Con la amplia difusión de efectos negativos no previstos de las tecnologías, iniciada con la publicación en la década de los sesenta del libro Silent Springs, de Rachel Carsons, que documenta el efecto devastador de los agroquímicos sobre el medio ambiente, se reconoce la necesidad de evaluar las tecnologías para evitar sus efectos indeseables. ${ }^{9}$

Este tipo de prácticas se ha difundido particularmente en los países desarrollados. Y los tipos de evaluaciones que se realizan sobre los efectos de las tecnologías (en este caso las biotecnologías) responden más que nada a cuestiones políticas y económicas en las que poderosos intereses actúan al margen del beneficio general de la sociedad.

Cuando se pretende hacer este tipo de evaluaciones es necesario plantear tareas de diagnóstico, las cuales requieren de tiempo y disponibilidad de recursos materiales y humanos.

La experiencia acumulada llevó a revisar esa concepción de la evaluación tecnológica; hoy se la interpreta más como un proceso de negociación política entre los diversos actores que participan en el desarrollo tecnológico (científicos y tecnólogos, gobiernos, consumidores, industria, etcétera) sobre la orientación y características de este proceso. Ello refleja la concepción de la tecnología como una creación humana y social que como tal puede y debe ser producto de un consenso social y político básico. ${ }^{10}$

Sin embargo, esta lucha por el control de los procesos biotecnológicos se establece en un ambiente de competencia interempresarial donde el criterio predominante es colocar sus productos en los mercados nacionales e internacionales, y donde se aplican sistemas de evaluación y control de calidad "aceptable", según los criterios de la empresa en particular sobre su línea de producción.

La efectividad en las evaluaciones de los efectos de la biotecnología aún es poca; empero, se han establecido metodologías para tratar de evaluarlos. Las discusiones generadas a este respecto obedecen a diferentes posiciones y matices en tomo a los diversos efectos que la aplicación de la biotecnología puede tener en el ámbito productivo, comercial y militar.

${ }^{9}$ Walter R. Jaffer, comp., Análisis del impacto de las biotecnologías en la agricultura: aspectos conceptuales y metodológicos, San José, Costa Rica: Organización de Estados Americanos-Instituto de Investigaciones de Costa Rica, 1991, p. 9.

10 Op. cit., p. 10. 
Para comprender todo lo que significa el concepto de bioseguridad es necesario interrelacionar los factores que influyen en él y que lo condicionan. Este ejercicio hace posible analizar el problema desde distintos enfoques, los cuales permiten establecer criterios más amplios sobre las dimensiones del problema, asi como las limitaciones en la aplicación práctica de dicho concepto. Por ello resulta primordial vincular las cuestiones ecológicas con los problemas de bioseguridad.

Antes que la ciencia como tal, ya había una noción y una próctica cotidiana de la ecología.

Los conocimientos ecológicos, son, sin embargo, antiquísimos; los pueblos primitivos, en contacto íntimo con la naturaleza y en un ambiente muy poco modificado, poseían infinidad de datos empíricos acerca de la vida, hábitos, costumbres, épocas de reproducción, cría, emigraciones, floración, crecimiento, etcétera, de muchas especies útiles o de otras relacionadas con ellas de modo directo 0 indirecto. Estos conocimientos perduran actualmente, y con igual empirismo ... entre gentes que ... viven vinculadas a medios naturales diversos como pastores, cazadores, agricultores, pescadores, etcétera."

Sin embargo, en la actualidad es notable la progresiva y acelerada extinción de estas condiciones mínimas de equilibrio. El desarrollo industrial, sustentado en los avances científico-tecnológicos de los últimos doscientos años se ha caracterizado por su gran capacidad para destruir los recursos bióticos disponibles en la naturaleza. En este sentido, hay una fractura entre el desarrollo cientifico-tecnológico, el equilibrio ecológico y la bioseguridad, ya que el desarrollo económico de las sociedades contemporáneas se encuentra en una relación de permanente contradicción. "De todos es conocido la significación y el valor económico que tiene un fenómeno de tipo ecológico, el antagonismo de las especies biologicas cuando una de ellas es perjudicial para los cultivos o para alguna utilidad económica inmediata." 12 Mientras el crecimiento de la actividad económica siga basado en esquemas científico-tecnológicos anticuados e ineficientes, mayores serán los daños causados a la naturaleza; lo anterior sin tomar en cuenta las asimetrías en los niveles de estructuras científico-tecnológicas entre las diferentes formaciones económicas políticas y sociales del sistema internacional. Esta contradicción nos ha conducido a una profunda crisis ecológica que pone en riesgo la existencia no sólo de los seres humanos sino de todos los seres vivientes.

"Enrique Rioja, Algunos conceptos ecológicos para el sociólogo y el economista, $2^{\circ}$ ed.; México: Coordinación de Humanidades-UNAM, 1987, p. C7-115.

12 Op. cit., p. C.119. 
El problema de la sobrepoblación mundial ha modificado inmensamente las condiciones ecológicas y la biodiversidad ha sido muy periudicada. "Ante este estado de cosas, cada vez más agudo, surge el desasosiego y la alarma; esto conduce a los biólogos modernos a buscar y sugerir medidas conservacionistas de los recursos naturales." 13 Esto se traduce en bioseguridad, ya que es necesario establecer una serie de medidas políticas, económicas y jurídicas que deben aplicarse para alcanzar cierto equilibrio en el largo plazo.

La ecología al estudiar las comunidades biológicas las analiza desde los más diversos puntos de vista: genético, morfológico, funcional, evolutivo, etcétera. Una resultante de este análisis es la determinación de la capacidad productiva de aquellas agrupaciones, la cual está en íntima relación con el destino futuro de la colectividad analizada, próspero o adverso. ${ }^{14}$

Resulta vital para los seres humanos dar respuestas inmediatas a los problemas ecológicos generados por el desarrollo industrial; $y$ esto puede lograrse mediante su organización social y la aplicación de tecnologías novedosas que aporten soluciones apropiadas a los daños causados por las tecnologías que atentan contra la naturaleza y el hombre.

El ritmo de explotación de los recursos bióticos, la liberación al medio natural de sustancias tóxicas para cualquier tipo de vida, se han convertido en una constante dentro del proceso de industrialización y de la modernidad:

... casi la mitad de los bosques tropicales del mundo ha desaparecido ... la Tierra pierde entre 16 y 20 mil hectáreas boscosas por año y ... cada hora una especie se extingue ... para el año 2000 tres cuartas partes de los bosques de América Latina habrón sido arrosados y ... probablemente perderemos el $50 \%$ de sus especies. ${ }^{15}$

Los efectos de la degradación del medio ambiente se extienden a muchas otras áreas, como a la Zona Económica Exclusiva (ZEE), parte del mar territorial, lo que se traduce en un problema de seguridad e interés nacional y por ende en una cuestión de bioseguridad para México pues hay recursos biológicos en esa porción del país. Asimismo, los científicos han localizado graves problemas ecológicos en los mares:

${ }^{13}$ Op. cit., p. C7-121.

14 Op. cit., p. C7-116.

15 Grupo de los Cien, "Propuesta para la cumbre de paises iberoamericanos", La Jornada, 20 de julio de 1991, p. 10. 
... lo trágico es que los recursos vivos de las ZEE, en términos de productividad y biodiversidad costera y marina, se están perdiendo a rapidez vertiginosa. Hay cada vez más indicios de que la destrucción de los hábitats y ecosistemas costeros, en particular en países en desarrollo tropicales y subtropicales ha cobrado proporciones alarmantes ... En realidad ... puede afectar muy directamente a los pueblos más pobres del planeta, aquellos que viven en los países subdesarrollados tropicales y subtropicales. ${ }^{16}$

En este sentido, los biotecnólogos tendrán la tarea de conformar bancos de germoplasma de las especies en extinción para así poder garantizar mínimamente la supervivencia de algunas especies.

\section{LAS REPERCUSIONES MILITARES DE LA BIOTECNOLOGÍA}

En la historia de la humanidad los agentes biológicos se han utilizado como armas con fines militares. El envenenamiento de las aguas de los ríos o lagos fue práctica usual de guerra en determinadas culturas durante los últimos veinte siglos, y se ha seguido conservando con el fin de dominar económica, política, social y militarmente a grupos y sectores de determinadas sociedades, así como a países y regiones del actual sistema internacional.

Para asegurar su existencia, los Estados nacionales han recurrido a la fuerza militar y policial con el objeto de controlar sus sociedades, independientemente del régimen político que los sustente. Esto ha garantizado su evolución hacia Estados-nación de diversas características políicas y organización socioeconómica.

Uno de los fundamentos políticos y militares de los Estados nacionales contemporáneos es la seguridad nacional, que puede concebirse como la capacidad política, económica y militar que en el plano internacional tienen dichos Estados, dentro y fuera de las organizaciones internacionales, según la influencia específica que tengan dentro de la balanza internacional de poder. Militarmente, la seguridad nacional se expresa como la facultad para asegurar el espacio vital frente a las posibles agresiones externas, según la concepción que cada Estado tenga del interés y la seguridad nacionales, aspectos que a su vez varín de acuerdo con las cuestiones políiticas, económicas y sociales imperantes, tanto nacionales como internacionales.

En términos geográficos, el espacio vital de los países subdesarrollados es alterado ... por las constantes amenazas provenientes de

16 Olof Lidén, "Las consecuencias de las actividades humanas sobre los sistemas costeros tropicales", en La naturaleza y sus recursos, Parthenon Publishing Group, UNESCO, vol. 26, núm. 4, 1990, p. 3. 
las grandes potencias, en una guerra comercial, tecnológica y militar. Las relaciones de dependencia y subordinación, históricamente establecidas, de los países subdesarrollados respecto a los desarrollados muestran que los medios militares son fundamentales para mantener su posición hegemónica. De hecho la importancia que las grandes potencias atribuyen a los gastos militares se puede observar en la gran cantidad de recursos que siguen invirtiendo para la investigación en armamentos, a pesar de las "reducciones" que a últimas fechas se han aplicado.

Como consecuencia, la biotecnología en su expresión general (es decir, tanto las técnicas biológicas tradicionales como la nueva biotecnología) irrumpe en un escenario de utilización militar de los agentes biológicos que pueden ocasionar daños a los seres humanos y al ambiente. Este tipo de agentes causan un amplio espectro de síntomas y repercusiones negativas en todos los aspectos, ${ }^{17}$ lo cual ha hecho que se realice una serie de esfuerzos para detener el avance de este tipo de armamentos.

Los agentes de la guerra biológica se definen como aquellos ... organismos vivos de cualquier naturalezo, o material infeccioso derivado de ellos, destinados a causar enfermedades o la muerte de los seres humanos, animales o plantas y cuya efectividad depende de su capacidad de multiplicarse en la persona, animal, o la planta atacados. Los organismos vivos (por ejemplo, rickttsiae, virus, hongos, y bacterias) pueden usarse como armas comúnmente denominadas "bacteriológicas".

En el contexto internacional el desarrollo científico-tecnológico se constituye en uno de los ejes alrededor del cual giran las relaciones internacionales, ya que los países que históricamente han tenido la capacidad de llevar a cabo adelantos e innovaciones en este campo son los que se encuentran en una posición hegemónica sobre los demás, sobre todo en el plano militar. La base productiva de las sociedades se sustenta en el grado de desarrollo de sus fuerzas productivas. La base del poder se encuentra en la capacidad de desarrollar los factores de control y dominio mediante una capacidad destructiva que radica fundamentalmente en la tecnología militar. Dado que aquí interviene la aplicación de los medios de destrucción (y no de extracción, producción y consumo, etcétera), se trata de un tipo "discíclico económico", es decir un ciclo que produce fundamentalmente desperdicios. Las armas se fabrican como cualquier

17 Véase Organización Mundial de la Salud, Health Aspects of Chemical and Biological Weapons, 1982.

${ }^{18}$ Organización de Naciones Unidas, Desarme, Boletín de campaña mundial de desarme, vol. 9, núm. 3, junio de 1991, p. 6. 
otro producto, pero los "consumidores se destruyen y no devuelven a la naturalezo". 19

Por otro lado, hay que resaltar la importancia que han tenido los primeros intentos por detener la utilización de armas biológicos, aunque no hayan tenido hasta la fecha efectividad en sus principios fundamentales debido a las características que impone la lucha por el poder internacional. El primer hecho que formalmente propone no utilizar agentes biológicos con fines militares

... se remonta a la Declaración de Bruselas de 1874 y a las Convenciones de La Haya de 1899 y 1907, que prohibieron el empleo bélico de venenos y balos envenenadas, y uná declaración separada de la Convención de La Haya de 1899 que condenaba el empleo de proyectiles con la única finalidad de diseminar gases asfixiantes o nocivos. No obstante, durante la primera Guerra Mundial la utilización generalizada de agentes químicos causó alrededor de 1300000 víctimas, de las cuales 100000 fueron mortales ... -hasta- el Protocolo de Ginebra del 17 de junio de 1925. El Protocolo prohíbe el uso en la guerra de gases asfixiantes, tóxicos o similares y de líquidos, materiales o dispositivos anólogos, así como de métodos bacteriológicos de guerra. ${ }^{20}$

Los agentes biológicos que se utilizan con fines militares y la participación de científicos vinculados con la biotecnología militar se traducen en técnicas biológicas que permiten la investigación, fabricación, utilización, almacenamiento, transporte y activación de este tipo de armamento. La norma jurídica internacional señala al respecto que el '... Protocolo declara ilegal el 'uso', no prohíbe su desarrollo, producción y almacenamiento, deficiencia que llevó rápidamente a reconocer la necesidad de una prohibición mós completo". ${ }^{21}$

La carrera de armamentos que emprendieron las dos potencias ganadoras en la Segunda Guerra Mundial hizo surgir un esquema bipolar con el cual, además de repartirse el mundo, entraron en un acelerado proceso de rearme y fabricación de nuevos y más poderosos instrumentos de destrucción masiva, entre los cuales se encuentran las armas biológicas.

Con la caída del muro de Berlín y el desmoronamiento de la Unión Soviética, Estados Unidos se coloca a la cabeza del poderío militar mundial, mientras que la crisis del modelo socialista de la otrora URSS se caracteriza por la lucha por lograr el control del poderío militar.

${ }^{19}$ Véase Paul A. Baran y Paul M. Sweezy, "La absorción de excedentes: militorismo e imperialismo", El capital monopolista, $18^{\circ}$ ed.; México: Siglo xul Editores, 1986, pp. 143.173.

20 ONU, Anuario de las Naciones Unidas sobre desarme, 1989, p. 295. 
Aún hoy se mantiene el desequilibrio global entre el Norte y el Sur respecto a la capacidad militar. En 1987, los países desarrollados incurrieron en el $83 \%$ de los gastos militares. Aunque el valor total de las armas ha permanecido aproximadamente constante en los oños ochenta, la proporción respectiva de las principales alianzas ha cambiado en comparación con los países no alineados ...22

Durante el período en que se desarrolló la Guerra Fŕa, el proceso de investigación dirigido a mejorar los sistemas de destrucción se aceleró espectacularmente, a grado tal que los recursos económicos dedicados a esta carrera internacional oscilan en 900 mil millones de dólares al año. ${ }^{23}$

Sin embargo, el proceso para establecer la política de desarme formal en el seno de la Asamblea General de Naciones Unidas no ha dado los resultados propuestos. Sólo se contemplan intentos parciales por parte de las dos superpotencias. En particular, únicamente se ha llegado a acuerdos sobre desarme, no más allá de formulas bilaterales entre las superpotencias, y en ocasiones con la participación marginal de algún otro país.

Uno de los dilemas que enfrentan las grandes potencias actualmente es seguir conservando su hegemonía militar o buscar mayores niveles de competitividad dentro de una guerra comercial. Por eso están estableciéndose criterios que atentan contra la seguridad nacional militar y que dan prioridad a la competencia comercial. La contradicción fundamental se manifiesta entre las actividades civiles y las militares, ya que se ha observado y experimentado un cambio en el esquema de industrialización en que se sustenta la economía mundial:

La economía mundial ha entrado en una nueva era de competencia industrial. Toda nación industrial avanzada importante (y una cantidad cada vez mayor de naciones en vías de desarrollo) está en competencia por alcanzar las mismas tecnologías estratégicas. Un "Plan sobre Tecnologías Decisivas" publicado por el Departamento de Defensa identificó 22 tecnologías bosicas para la seguridad militar del futuro, aunque las tecnologías también son indicadoras de poder comercial. ${ }^{24}$

Una de las prioridades de seguridad nacional de Estados Unidos es crear tecnología de "defensa". En la actualidad los avances científi-

22 Anthony lan, "El comercio internacional de armas", en Desarme: Revista Periódica de las Naciones Unidas, 1990, p. 282.

23 lbid.

${ }^{24}$ Robert Kuttner, "How 'National Security' Hurts National Competitiveness", en Harvard Business Review, enero-febrero de 1991, p. 140. 
co-tecnológicos, unidos a los criterios de seguridad nacional, permiten reforzar los sistemas de defensa y ataque, lo cual fortalece relativamente su esquema de seguridad nacional.

Al mismo tiempo se ha llevado a cabo un proceso de desarme auspiciado por Naciones Unidas y mediante la Comisión de Desarme. En tanto los esfuerzos políticos por la paz mundial no han acabado con los conflictos internacionales, los métodos militares se han refinado, debido al avance de la ciencia y la tecnología. Mientras tanto, la carrera de armamentos sigue a diferentes ritmos su marcha y por diversos caminos.

Como resultado de esta expansión del saber y de su relieve en el conjunto socioeconómico y militar, las actividades científicas y tecnológicas toman un poderoso impulso. Se industrializan y militarizan con el apoyo directo e indirecto de gobiemos y empresarios. Ya no se trata de un quehacer accidental, oculto en los centros académicos y supeditado a fluctuaciones caprichosas del financiamiento público, sino que los científicos trabajan para las industrias - civiles y militares-y éstas se inclinan a levantar laboratorios propios cuando materializan uno apreciable escalo de producción e integración económica. ${ }^{25}$

En el caso de fabricación de armas bacteriológicas, se observa que los países subdesarrollados pueden utilizar y crear tecnologías propias, sin que ello signifique una total independencia de los países desarrollados en este aspecto, lo cual se debe a que los requerimientos en investigación son mínimos y están, técnica y científicamente, a su alcance. El principal peligro para muchas sociedades de los países que tienen menores capacidades tecnológicas es el amplio potencial para fabricar dichas armas mediante biotecnologías tradicionales, intermedias y en algunos casos de ingeniería genética.

Puesto que las cuestiones militares entrañan inevitablemente cuestiones de seguridad nacional, éstas no escapan a la bioseguridad. Es más, para países como Estados Unidos la bioseguridad se considera una cuestión de interés y seguridad nacional, que establecen, entre otras instancias, el Departamento de Defensa, el Departamento de Agricultura, el Departamento de Salud y la Agencia de Protección Ambiental; en la actualidad el Departamento de Defensa ha logrado generar un poder politico de gran magnitud, debido a su reciente participación en la guerra del Golfo Pérsico.

La fabricación de armas bacteriológicas es un punto que poco se ha abordado en los estudios realizados por las ciencias sociales, donde

25 Joseph Hodara, "Políticas para la ciencia y la tecnología", Grandes tendencias contemporáneas, UNAM, núm. 23,1986, p. 8. 
la biotecnología tiene un papel fundamental. La modificación de un organismo mediante técnicas de ADN recombinante no tiene efectos similares a las modificaciones que se efectúan mediante las técnicas genéticas clásicas. Las potencialidades destructivas pueden aumentar si se cuenta con conocimientos acerca de la biología molecular y la aplicación de la ingeniería genética.

En este sentido es necesario aclarar que, pese a la escasa información y a su carácter confidencial, es utilizada ampliamente dentro de los círculos militares en los más altos niveles en los países desarrollados. Surge, por lo tanto, un espectro que no permite vislumbrar claramente cuáles son los diversos proyectos que se están desarrollando en el campo de las armas biológicas.

Suele decirse que ni la exactitud ni la honestidad son virtudes habitualmente anexas a la información sobre los negocios del armamentismo, que junto con el de los combustibles, los medicamentos y el narcotráfico, figuran como las estrellas más fulgurantes del firmamento de los negocios. ${ }^{26}$

En la guerra del Golfo Pérsico se dieron a conocer algunas cifras, efectos posibles y probables de las consecuencias sobre la utilización del armamento químico y bacteriológico que lraq y algunos otros países aún poseen. Continúa la investigación y la producción de armas bacteriológicas por parte de los países que las aplicaron originalmente, entre los cuales se encuentran Estados Unidos, Francia e Inglaterra. Parte del arsenal químico y bacteriológico ha sido utilizado en la guerra contra Irán y en contra de la población civil por parte del ejército iraquí, durante las rebeliones kurdas en contra del gobierno de Bagdad.

La biotecnología es también un arma de destrucción masiva que ya ha sido utilizada, aunque se desconocen los efectos potenciales que pudiera tener su ulterior aplicación.

La construcción deliberada de agentes biológicos dañinos ha sido reconocida generalmente como el más extremo daño biológico asociado con la tecnología de la recombinación del ADN. La posibilidad de su uso con propósitos militares ha constituido siempre el fondo y controversia que rodea su desarrollo y aplicación. ${ }^{27}$

${ }^{26}$ Gregorio Selser, "Gasto militar de dos mil millones de dólores por minuto", EI Financiero, miércoles 12 de junio de 1991, p. 39.

27 Susan Wright y Robert L. Sinsheimer, "La tecnología del DNA y la guerra biológica", Contextos, Secretaría de Programación y Presupuesto, núm. 18, México, 30 de diciembre, 1983, p. 53. En: The Bulletin of Atomic Scientist, XI, 83, pp. 20-26. 
Si la capacidad productiva de los organismos modificados genéticamente es mejorada, en esa misma medida se amplía la capacidad destructiva de dichos organismos con fines militares. Según los diferentes usos que puede tener la biotecnología militar, es decir, ataque y defensa, se abren nuevas modalidades para enfrentar eventualidades militares que exijan recurrir a los agentes biológicos.

Dentro de las negociaciones de limitación de armas estratégicas recientemente llevadas a cabo entre la URSS y Estados Unidos, una vez más se omite y se condiciona el desarme, sin que por ello se ponga en riesgo su seguridad nacional. $Y$ se deja de lado otro tipo de armas "menos peligrosas". En este sentido quedan en segundo plano las negociaciones sobre armas biológicas, pues se supone que todos aquellos países que de alguna manera tengan que ver en esto deben aplicar ciertos principios surgidos de la Convención de Armas Biológicas de 1972. A pesar de dicha Convención, en donde se prohíbe producir y almacenar agentes biológicos, esta práctica no ha sido erradicada. En aquel entonces aprobaron la resolución de la Convención Estados Unidos y la Unión Soviética, al igual que casi el $50 \%$ de los países miembros de la ONU. Uno de los inconvenientes de la Convención es que no prohíbe de ninguna manera la investigación en esta materia. Estos problemas fueron discutidos en septiembre de 1991, en la Tercera Conferencia de Revisión de la Convención sobre Armas Biológicas, por lo que se espera la publicación de los resultados.

Dentro de los informes que deben ser tomados en cuenta para tratar este tema se encuentra el del Departomento de Defensa de Estados Unidos al Congreso. En éste se señaló que con la

... aparición de la tecnología de recombinación del ADN se reconoció que se podían usar nuevas técnicas para una variedad de propósitos militares, tales como el desarrollo de vacunas, producción masiva de sustancias que el Departamento de Defensa tuviera interés especial en su estudio .... ${ }^{28}$

Es decir, que cuando el Departamento de Defensa de Estados Unidos no cuenta con el equipo ni los recursos humanos para llevar a cabo determinada investigación, simplemente contrata o solicita a la Academia Nacional de Ciencias que realice determinado tipo de proyectos con fines militares.

México no participa de manera importante en la fabricación de agentes biológicos con fines militares ya que su capacidad bélica se enfoca a cuestiones defensivas, y depende de los suministros que le proveen las grandes potencias militares, por lo que se sitúa como un

${ }^{28}$ Op. cit., p. 55. 
cliente más en el comercio internacional de armas no atómicas. Aunque deben de existir planes de contingencia ante eventualidades que atañen a la bioseguridad, en las cuales las fuerzas armadas pueden participar activamente mediante la vacunación de sus elementos $u$ otras medidas de bioseguridad que eviten problemas de propagación de agentes patógenos producto de bioescapes o ataques con armas biológicas.

Respecto a México, se desconocen las actividades que pueden tener las fuerzas armadas mexicanas en lo que respecta a la investigación en biotecnología. En este sentido es necesario abundar al respecto para establecer claramente cuál es la situación actual y la participación de las fuerzas armadas en este campo de estudio, independientemente de los grados de avance o instrumentación o de si los motivos de estas actividades son pacíficas o bélicas.

Por lo anteriormente señalado se observa que dichas cuestiones atañen a los asuntos de seguridad nacional de nuestro país y por ende a la bioseguridad. Se puede adelantar, a manera de hipótesis, la participación activa de los sectores militares que estón vinculados particularmente con las cuestiones médicas y de sanidad, en donde se realizan algunos trabajos que utilizan las nuevas biotecnologías.

\section{LA BIOSEGURIDAD COMO ELEMENTO DE SEGURIDAD NACIONAL PARA MÉXICO}

\section{A. El Estado y la bioseguridad en México}

La relación entre seguridad nacional y proceso de cambio y desarrollo tecnológico se establece a partir de la función que la tecnología en general, y la biotecnología en particular, desempeñan en las actuales circunstancias: la de instrumento de poder tanto en las relaciones entre países en el contexto internacional como entre agentes económicos en el proceso económico, social y político.

Declarar que la tecnología tiene una dimensión mayor que el aumento cuantitativo de las posibilidades de producción y consumo de un país significa considerar que no es un insumo neutro que reportará automáticamente, y en todo momento, mejoras económicas para todos. La tecnología constituye un elemento que viene a reforzar los núcleos de control y de poder que mantiene una empresa o corporación en el sistema en que actúa. Engloba los objetivos e intereses de uno u otro protagonista económico y tiene, además, la posibilidad de excluir o incluso de cercenar los intereses de otros. En ese sentido el comportamiento de determinados grupos de poder o de interés nacionales o extranjeros no puede ser abordado sin considerar el aspecto tecnológico, mucho menos las relaciones que se establecen entre países en la esfera económica y política. 
Saber lo que está sucediendo en la frontera tecnológica mundial significa identificar la dinámica que adoptan las corrientes tecnológicas internacionales $y$, de esta manera, dilucidar el interés de entidades económicas y políticas nacionales y transnacionales para concertar arreglos de cooperación mutua entre países ya sea de manera bilateral - multilateral; pero sobre todo los costos y riesgos que entraña introducir ciertas tecnologías en los procesos productivos en lo que respecta a clases sociales, sectores relacionados, conflicto político-social; en suma: a estabilidad política regional y nacional.

El generar conocimiento para tomar decisiones sobre la correlación que guardan los aspectos de seguridad nacional y la biotecnología en la coyuntura económico-política actual cobra mayor importancia si se considera que toda estrategia de modernización, cuyo eje dinamizador lo constituye el sector externo de la economía, entraña necesariamente un tipo o método particular de adquisición o producción de tecnología que habrá de permear los centros de decisión del primer círculo de poder en la medida que çomprende aspectos vinculados con sociedades transnacionales, pues éstas son las principales difusoras de las innovaciones que se generan en sus centros de investigación.

En países como México, por lo tanto, la bioseguridad es una extensión de la seguridad nacional y una expresión política para preservar sus recursos bióticos así como proteger a la sociedad ante los potenciales efectos negativos que algunas biotecnologías pudieran tener. Para México y para los mexicanos,

... la seguridad nacional debe de entenderse como el conjunto de elementos económicos, políticos, sociales, diplomóticos y militares para definir y defender los espacios vitales de la soberanía e independencia nacionales y su proyecto nacional de desarrollo frente al expansionismo de las grandes potencias y a los reacomodos del poder mundial. ${ }^{29}$

Para entrar en materia, “ "... no existen en América Latina y el Caribe mecanismos ni experiencias de evaluación y regulación de liberaciones de organismos genéticamente modificados en el medio ambiente, con la sola excepción de un caso correspondiente a México". ${ }^{30}$ Este caso, el del jitomate transgénico, ocasionó un problema de seguridad nacional y bioseguridad con la compañía estadunidense Monsanto. Mientras en ese país las pruebas de campo tienen un límite determinado en

${ }^{29}$ Carlos Ramírez, "Indicador político", El Financiero, 18 de junio de 1991, p. 29.

30 Organización de Estados Americanos, Instituto Interamericano de Cooperación para la Agricultura, Guías para la liberación en el medio ambiente de organismos modificados genéticamente, San José, Costa Rica: ॥CA, 1991, p. 10. 
cuanto a la extensión de la superficie para liberar organismos transgénicos, en nuestro país las pruebas hechas en el estado de Sinaloa abarcaron extensiones superiores a lo permitido en Estados Unidos. Finalmente la compañía en cuestión se retiró del campo mexicano y abandonó sus intentos de experimentación con dicho jitomate de origen estadunidense.

La protección que el Estado da a las marcas y patentes no significa que automáticamente se garantice la bioseguridad. Más aún, la inseguridad biológica se puede asegurar mediante los instrumentos jurídicos de protección de descubrimientos, innovaciones o invenciones biotecnológicas aunque éstas hayan sido ya "evaluadas". Esto dependerá de los intereses económicos, comerciales o financieros y de las condiciones políticas y jurídicas imperantes en el momento de autorizar tal o cual patente. Ahora bien, en cuanto a tiempos, ciertas biotecnologías, particularmente las no relacionadas con criterios ecológicos, a corto y a mediano plazo pueden no mostrar signos negativos en su instrumentación. Sin embargo, a largo plazo podrían resultar adversas. Las presiones de los países industrializados hacia los semi-industrializados en lo referente a las reglas generales de protección a la propiedad intelectual se realiza mediante el establecimiento de normas en las que los primeros tienen mayores ventajas sobre los segundos.

Mientras existan lazos de dependencia tecnológica con respecto a los países altamente desarrollados, en particular a Estados Unidos, la bioseguridad no está garantizada. Es difícil hablar de ésta cuando "... la dependencia de la comunidad científica del Tercer Mundo respecto de una industria proveedora en el campo de la biotecnología es en sí misma cada vez mós transnacionalizada". ${ }^{31}$ Sin embargo, esta tendencia general por borrar todas las fronteras nacionales en términos comerciales no está encaminada a eliminar las diferencias sociales hacia uno y otro lado de dichas fronteras entre los países centrales y periféricos.

La creciente desnacionalización de la economía mexicana pone al Estado mexicano en un punto de contradicción: garantizar la seguridad e intereses nacionales en torno a la bioseguridad.

La economía nacional deja de ser autónoma y unidad del anólisis económico y la política económica. La economía mundial se vuelve central y determinante de la primera. La tecnología torna rápidamente obsoleta la noción básica de soberanía nacional y las políticas restringidamente nacionales: monetarias, cambiarias, fiscales, comerciales, industriales. ${ }^{32}$

${ }^{31}$ José Luis Solleiro y Elena Arriaga, "Patentes biotecnológicas: amenazas y opciones para América Latina", Comercio Exterior, vol. 40, núm. 12, diciembre de 1990, p. 1162.

32 Marcos Kaplan, "El desafío de la mutación tecnológica", en Omnia, México: Coordinación General de Estudios de Posgrado, UNAM, junio, 1989, p. 5. 
Es en este plano donde se ven afectados los intereses de la gran mayoría de la sociedad mexicana; las opciones de competencia en lo que respecta a productividad, eficiencia y calidad con dos economías que son más poderosas que la nuestra quedan reducidas sólo a visiones optimistas. Las diferencias en las estructuras económicas se expresan a su vez en diferencias histórico-culturales que no pueden ser soslayadas ni eliminadas con la firma de un tratado comercial.

México se ve obligado al pago puntual de la deuda externa y a cumplir al pie de la letra las políticas económicas dictadas por el FMI y demás organismos internacionales de crédito. Nuestro país vive en una crisis estructural sin precedentes, pese a las visiones optimistas que hablan de un crecimiento de la economía del $4 \%$ en los últimos meses.

La deuda extema de México seguirá pesando de manera importante sobre su economía, si no por el monto del principal, sí por el de los intereses que deben de pagarse. Aun si el primero creciese con una muy moderada tasa de ahorro al año 2010 (por ejemplo $2 \%$ anual) seguirá siendo mayor que la tercera parte del PIB del país y con ello la influencia de los acreedores (principalmente Estados Unidos, al que se debe una tercera parte del total; a Japón una sexta; y a los organismos internacionales una décima parte) podría seguir pesando de manera importante en las decisiones económicas. ${ }^{33}$

No obstante la renegociación de la deuda externa llevada a cabo por los funcionarios mexicanos de la Secretaría de Hacienda y Crédito Público (SHCP) y del Banco de México (BM), su monto no sufrió modificaciones cuantitativas que le permitan a nuestro país disponer de recursos suficientes para aplicar estrategias científico-tecnológicas que nos pongan a salvo de las fuertes corrientes de desnacionalización del quehacer científico-tecnológico. Esta situación de pérdida de capacidad política en el exterior, en particular ante Estados Unidos, tiene repercusiones directas y afecta también la capacidad de la negociación de la bioseguridad nacional.

El Estado es el garante de la Seguridad Nacional y, por ende, de la bioseguridad. Sin embargo, aunque muchos mecanismos político-jurídicos e institucionales apuntan en ese sentido, se convierten en los principales obstáculos para alcanzar dicho fin. En lo referente a las medidas políticas de bioseguridad, nos encontramos con el Comité Nacional de Bioseguridad, CNB, integrado por

${ }^{33}$ Antonio A. Concheiro, "Capacidad tecnológica y porvenir de México", Comercio Exterior, vol. 37, núm. 12, diciembre de 1987, p. 1055. 
... científicos de reconocido prestigio en el campo de la biotecnología, convocados por el CONACYT; especialistas técnicos en la octividad agnícola por el INIFAP, representantes del CONACYT; por parte de la SARH, se convocó a la D. G. de Sanidad Vegetal, de la D. G. de Política Agrícola y el Sistema Nacional de Certificación de Semillas. ${ }^{34}$

Sin embargo aún no se cuenta con una legislación nacional sobre bioseguridad; es un terreno que apenas se está estudiando, particularmente en lo que respecta a instrumentos metodológicos que permitan establecer las posibles repercusiones de la biotecnología en los seres humanos y el medio ambiente.

Hay que señalar que la legislación existente contiene casos específicos referentes a la bioseguridad, como la Ley Federal de Sanidad Fitopecuaria (con su respectivo Reglamento); el Reglamento para el Control de Productos Químicos, Farmacéuticos y Alimentos para Animales; el Reglamento para Campañas de Sanidad Animal, que le da sustento a la Secretaría de Agricultura y Recursos Hidráulicos. La Secretaria de Salud cuenta con instrumentos jurídicos, como la Ley General de Salud -con su respectivo Reglamento-, y el Acuerdo que crea la Comisión Interinstitucional de Investigación en Salud. Por su parte, la Secretaría de Desarrollo Urbano y Ecología encuentra su marco jurídico en la Ley General del Equilibrio Ecológico y la Protección al Ambiente.

Asimismo, otra institución vinculada a los aspectos jurídicos de la bioseguridad nacional es la Secretaría de Comercio y Fomento Industrial, pues determina cuáles formas de vida son patentables y cuáles no.

Así, no son patentables las plantas que ya existen en estado natural, aunque anteriormente fueran desconocidas para el hombre, los procedimientos de reproducción de organismos tal y como viven en la naturaleza, pues en estos casos no se satisfacen las condiciones mencionadas. Sin embargo, sí son patentables los nuevos microorganismos y los procedimientos de fipo industrial que los utilicen; las nuevas variedades vegetales; etcétera. ${ }^{35}$

En este sentido se advierte una contradicción fundamental dado que los "nuevos microorganismos" no surgieron por generación espontánea; tienen su origen en la naturaleza y se localizan en determinados

${ }^{34}$ Consejo Nacional de Ciencia y Tecnología, Programa de las Naciones Unidas para el Desarrollo, Secretaría de Relaciones Exteriores, Preparación del Programa Nacional de Cooperación en Biotecnología, México, 1991, p. 575.

35 Secretaría de Comercio y Fomento Industrial, "Información básica sobre la Ley de Fomento y Protección de la Propiedad Industrial", en Serie de Desarrollo Tecnológico, 2a. ed., 1991, pp. 32-33. 
ecosistemas, los cuales, a su vez, se encuentran en espacios geopoliticos establecidos y constituyen el espacio vital de nuestro país. Independientemente de las modificaciones que mediante la nueva biotecnología puedan incorporarse a ciertos organismos, tienen un hábitat natural determinado. ¿Cuál es la retribución que recibe el lugar de origen - sociedad o ecosistema- por las formas de vida que son extraídas de su medio natural para ser modificadas?

De igual manera, con las nuevas normas sobre las pruebas transgénicas se dejan de lado asuntos importantes como los experimentos realizados en los laboratorios particulares, los cuales no están sujetos a registro. Unicamente los Centros de Educación Superior tienen la obligación de registrar todos aquellos proyectos biotecnológicos en los que participe la ingeniería genética. Esta particularidad resulta incoherente, pues quienes deben estar sujetos a dicho control son todos aquellos laboratorios e institutos tanto públicos como privados que realicen investigación y explotación comercial generada de los procesos biotecnológicos. Resulta indispensable integrar cuadros altamente calificados para aprovechar los talentos con que cuenta nuestro país y resolver los problemas sociales y del ambiente que nos aquejan; así pues, todo lo anterior se traduce en un problema de seguridad nacional.

El riesgo que corre la bioseguridad nacional mexicana al adoptar modelos jurídicos impuestos por presiones políticas externas, y que éstos se institucionalicen mediante la expedición de leyes y reglamentos que no corresponden a las condiciones particulares del desarrollo biotecnológico y a la biodiversidad de nuestro país, es muy grande; sería un atentado que rebasaría los límites de la misma bioseguridad.

Es decir que, dada la delicadeza del asunto, es fundamental replantear la conducta que se ha tenido históricamente en la adopción de tecnologías que han resultado seriamente dañinas para México, y repensar el posible y probable futuro al desarrollar nuevas tecnologías ... ${ }^{36}$

Una de las propuestas es la reglamentación para "La Importación, Movilización Interestatal y Liberación en el Medio Ambiente de Organismos Modificados Genéticamente o Producidos a Través de Ingeniería Genética", 37 traducción casi literal (salvo algunas interpretaciones no muy lejanas) de la versión original emitida por el Departamento de Agricultura de Estados Unidos que lleva por título "Introduction of Organisms and Products Altered or Produced Through Genetic Engi-

${ }^{36}$ CONACYT, PNUD, SRE, op. cit., p. 574.

37 Sin referencia alguna, salvo el título y el contenido, esta propuesta circuló en algunos medios oficiales, científicos y tecnológicos, tales como el CONACrT. 
neering Which Are Plant Pests or Which There is Reason To Believe Are Plant Pests". ${ }^{38}$ Este es un asunto muy delicado si se considera que las disposiciones jurídicas recientes resultan muy similares, y si se toma en cuenta que no hubo discusiones amplias entre grupos interdisciplinarios de científicos de prestigio nacional e internacional reconocido que estuvieran especializados en biotecnología, ecología, agronomía, medicina (particularmente en virus, hongos, insectos, suelos, etcétera), amén de que se discutieron y aprobaron más por cuestiones políticas que por razones de bioseguridad.

En este sentido, el CNB debe: ser reforzado y ampliado en sus facultades para que garantice la bioseguridad nacional; coordinarse con el resto de las instituciones que se contemplan en sus ordenamientos jurídicos; ser asistido por un grupo interdisciplinario que pueda opinar sobre el contenido de la normatividad y que pueda a su vez dictaminar y evaluar (con todos los elementos científico-tecnológicos, económicos, jurídicos, políticos y sociales) los efectos negativos o positivos que puedan tener esas disposiciones. Asimismo, el Comité deberá tener la facultad de elaborar propuestas de reglamentación y planes de contingencia o campañas de divulgación ante eventuales problemas de bioseguridad en los campos que se presenten.

\section{B. Propiedad intelectual y bioseguridad}

El desarrollo de la biotecnología en México se ve afectado de manera indirecta por las condiciones prevalecientes en la actualidad, las cuales niegan la socialización del conocimiento científico-tecnológico, por la limitación de la tendencia que hay hacia su privatización. Esto ocasiona que los beneficios de los descubrimientos, innovaciones e invenciones lleguen a la sociedad como productos finales con un alto valor agregado para satisfacer las necesidades del capital y del mercado. Por eso es importante considerar la cuestión de las patentes; aunque éste no es el tema central, resulta necesario vincularlo con la bioseguridad.

La articulación del Estado mexicano en su política de apertura hacia el exterior se ha reflejado al adoptar modelos políticos, económicos y jurídicos que dejan de lado cuestiones importantes de seguridad nacional en lo referente a sus principios nacionales. Por ejemplo, la aprobación de la iniciativa de la Ley de Fomento y Protección de la Propiedad Industrial enviada por el ejecutivo a la Cámara de Senadores el 6 de noviembre de 1990 muestra cómo el Estado favorece los intereses externos so pretexto de una "globalización económica". Para la Secretaría de Comercio y Fomento Industrial,

${ }^{38}$ Este título quedó asentado el 16 de junio de 1987 en el Registro Federal del Departamento de Agricultura de Estados Unidos. 
... la iniciativa busca que la legislación mexicana se adecue a los estándares internacionales, de modo que se aliente el desarrollo industrial y comercial con base en los avances locales de la tecnología y de la calidad, complementados con los recursos y las técnicas novedosas que se atraigan desde el extranjero. ${ }^{39}$

Así pues, adoptar estos cánones no resulta algo tan internacional como aparentemente se muestra. Estas consideraciones y principios que rigen las nuevas disposiciones son copia casi exacta de las legislaciones de Estados Unidos y no preceptos que se establezcan en un código de conducta aprobado por los países correspondientes.

Un elemento que garantiza la bioseguridad de Estados Unidos y Canadá en lo que respecta a seguridad nacional es la efectividad de sus instrumentos jurídicos de patentes; en dichos países conseguir una licencia de explotación comercial depende de una serie de requisitos, previa evaluación de los efectos que pudiera tener el producto en cuestión.

Ante este panorama México queda en desventaja: los que imponen las reglas de cómo, qué y para qué patentar son los países desarrollados, en especial Estados Unidos y Canadá; por tanto las patentes de organismos, microorganismos y procesos llaman la atención por ser un punto fundamental en lo referente a su bioseguridad. En el caso de nuestro país, la biodiversidad nacional, es decir, su gran gama de manifestaciones de vida (únicas en el mundo 40 por la estructura e información genética de los seres vivos que se encuentran en los diferentes ecosistemas dentro del nuestro territorio) no puede ser propiedad de nadie en lo particular.

Sin embargo, hay procedimientos y productos que sí pueden ser patentables.

En México ... hasta la fecha no son susceptibles de patentamiento las variedades vegetales ni animales, ni los procedimientos esencialmente biológicos para obtenerlos. Cabe hacer notar que, conforme a la legislación mexicana, los procesos biotecnológicos para obtener productos farmacoquímicos y agroquímicos, los procedimientos genéticos para obtener especies vegetales y animales, y los productos farmacéuticos y agroquímicos, serón patentables a partir de enero de $1997 .{ }^{41}$

39 Excélsior, 8 de diciembre de 1990, p. 2.

${ }^{40}$ México está considerado el cuarto país en diversidad biológica de este planeta, según la clasificación hecha por Vaviiov y por investigaciones recientes.

${ }^{41}$ José Luis Solleiro y Elena Arriaga, "Patentes de biotecnología ...", p. 1164. 
Aunque los tiempos se han adelantado de manera vertiginosa con la nueva Ley de Fomento y Protección de la Propiedad Industrial, publicada en el Diario Oficial de la Federación el 27 de junio de 1991, surge la pregunta ¿quiénes van a controlar la mayor parte de los patentamientos en nuestro país?

Patentar o no hacerlo entraña profundas cuestiones de seguridad nacional; bajo la actual dinámica internacional que se ha generado en torno a la biotecnología,

... el sistema de patentes sobre el material biológico puede dar propiedad sobre las riquezas naturales de un país a una sola persona o empresa, la cual, con base en la estadística, muy probablemente no sea originaria de ese país. ${ }^{42}$

Lo cual se traduce, en términos de la firma y puesta en marcha del TLC, en una gran desventaja y pérdida gradual de la seguridad y soberanía nacionales para nuestro país.

Es un hecho que la información genética de los vegetales o germoplasma se halla concentrada en diversas regiones geográficas del mundo a las que el biólogo ruso Vavilov denominó Centros de Diversidad Genética y que éstos se concentran, preponderantemente, en los temitorios de países subdesarrollados, por lo que una situación fortuita se convierte en política. ${ }^{43}$

Cuando la diversidad genética sea parcial o totalmente negociable, no habrá ninguna garantía de bioseguridad gracias a la estructura del poder económico y político de los países industrializados y los países subdesarrollados; los primeros podrán apropiarse del germoplasma que les parezca conveniente para sus intereses económicos, mientras que los segundos los dotarán del material genético que les sea requerido en una relación de intercambio desigual.

La importancia del ritmo de otorgamiento de patentes biotecnologicas (tanto en producto como en diseño y proceso) es considerable si se toma en cuenta que "... de mayo de 1988 a diciembre de 1989 la lista de solicitud de registros de patentes biotecnológicas creció de 5977 a $8424 \ldots$..,44 lo cual no significa que ese total haya sido

42 Op. cit., p. 1166.

${ }^{43}$ Francisco Martínez y Gilberto Aboites, "Estado, protección legal y diversidad fitogénica", en Sociología, Departamento de Sociología, División de Ciencias Sociales y Humanidades, Uam Azcapotzalco, año 6, núm. 16, mayo-agosto, México, 1991, p. 104.

${ }^{44}$ Steven Burrill y Lee Kenneth B. Jr., Biotech 91: A Changing Environment, San Francisco, Cal.: Ernst \& Young, 1990, p. 61. 
concedido. Esto permite, en lo referente al mercado, mayores ventajas competitivas para Estados Unidos, ya que los tiempos entre solicitud de registro, revisión y aprobación de las patentes son cada vez menores:

las empresas deben esperar ahora cerca de 2.5 años antes de que un examinador revise su solicitud. Luego lleva 25.3 meses en promedio llegar a una decisión final. En contraste, las solicitudes de patentes para farmacéuticos basados en compuestos orgánicos habitualmente pueden recibir una resolución final dos años después de la solicitud. ${ }^{15}$

Lo anterior obedece más a la conveniencia económica que a la de bioseguridad. Los grandes intereses de las nuevas compañías biotecnológicas están tomando gran fuerza en la nueva dinámica económica y en el mercado de nuevos productos, por lo que resulta difícil pronosticar si la lógica de acumulación y reproducción del capital tomará en cuenta la importancia de la bioseguridad.

\section{BIBLIOGRAFÍA}

Baran, Paul A., y Sweezy, M. Paul. 1986. El capital Monopolista. $18^{\circ}$ ed. México: Siglo XXI Editores, $311 \mathrm{pp}$.

Burrill, Steven, y Lee, Kenneth B. Jr., 1990. Biotech 91: A Changing Environment. Sn Fco., Cal.: Ernst \& Young, 189 pp.

Chemical Marketing Reporter. (25 de febrero de 1991) Pesticide Registrations Cancelled en Masse by EPA, Nueva York.

Chesnais, François. "La biotecnología y la exportación de productos agrícolas de los países en desarrollo". Comercio Exterior. Vol. 40. Núm. 3, marzo de 1990, pp. 256-266.

Concheiro, Antonio A. "Capacidad tecnológica y porvenir de México".

Comercio Exterior. Vol. 37. Núm. 12, diciembre de 1987.

Consejo Nacional de Ciencia y Tecnología, PNUD, SRE. 1991. Preparación del Programa Nacional de Cooperación en Biotecnología, México, $655 \mathrm{pp}$.

Giglio, Nicolo. 1990. "Los factores críticos de la sustentabilidad ambiental del desarrollo agrícola". Comercio Exterior. Vol. 4. Núm. 12, diciembre, pp. 1135-1142.

Goldstein J., Daniel. 1989. "Biotecnología, universidad y política". México: Siglo XXI Editores, 264 pp.

${ }^{45}$ R. Walter Jaffe (comp.), Análisis de impacto de las biotecnologías en la agricultura: aspectos conceptuales y metodológicos, San José, Costa Rica: Organización de Estados Americanos-Instituto Interamericano de Cooperación para la Agricultura, mayo de 1991. 
Grupo de los Cien. 1991. "Propuesta para la Cumbre de Países Iberoamericanos". La Jomada, México, 20 de julio, p. 10.

Guadarrama Sistos, Roberto. 1991. "La nueva revolución científico-tecnológica de la humanidad", documento inédito, mayo, 9 pp.

Hodara, Joseph. 1986. "Políticas para la ciencia y la tecnología". Grandes tendencias contemporóneas. Núm. 23. México: Universidad Nacional Autónoma de México, 28 pp.

Jaffe, R. Walter. 1991. Análisis de impacto de las biotecnologías en la agricultura: aspectos conceptuales y metodológicos. San José, Costa Rica: Organización de Estados Americanos-Instituto Interamericano de Cooperación para la Agricultura, mayo, 186 pp.

Kaplan, Marcos. 1989. "El desafío de la mutación tecnológica". Omnia. México: Coordinación General de Estudios de Posgrado, Universidad Nacional Autónoma de México, junio, pp. 5-9.

Kuttner, Robert. 1991. "How 'National Security' Hurts National Competitiveness". Harvard Business Review, enero-febrero, pp. 140. 150.

Lidén, Olof. 1990. "Las consecuencias de las actividades humanas sobre los sistemas costeros tropicales". La Naturaleza y sus Recursos. Vol. 26. Núm.4. Ed. Parthenon Publishing Group. UNESCO. E. U. A., pp. 3-11.

Nolasco, Margarita. 1985. Café y sociedad en México. México: Ed. Centro de Ecodesarrollo.

Organización de Estados Americanos, IICA. 1991. Guías para la liberación en el medio ambiente de organismos modificados genéticamente. San José, Costa Rica: mayo. 145 pp.

Organización de las Naciones Unidas. 1991. Desarme, Boletín de la Campaña Mundial de Desarme. Vol. 9. Núm. 3, junio, p. 6.

Organización de las Naciones Unidas. 1989. Anuario de Las Naciones

Unidas sobre Desarme. Ed. Naciones Unidas, E. U. A., p. 295.

Organización Mundial de la Salud. 1982. Health Aspects of Chemical and Biologica/ Weapons. Nueva York: ONU, 280 pp.

Organización para la Alimentación y la Agricultura. 1991. Documento para el 26o. Período de Sesiones. Roma: Comisión de Recursos Fitogenéticos, octubre.

Ramírez, Carlos. 1991. "Indicador Político". El Financiero, 18 de junio. Ray, G. C. 1988. "Ecological diversity in coastal zones and oceans". Biodiversity. Compilado por E. O. Wilson y F. M. Peter. Washington, D. C.: National Academy Press, pp. 36-50.

Rioja, Enrique. 1987. Algunos conceptos ecológicos para el sociólogo y el economista. $2^{a}$ ed. México: Coordinación de Humanidades, UNAM, pp. C7-115-C7-150. 
Sagasti, Francisco, y Araoz, Alberto. 1988. La planificación científica y tecnologica en los paises en desarrollo. México: Fondo de Cultura Económica, $330 \mathrm{pp}$.

Saxe Fernández, John. 1989. “Deuda externa y desnacionalización integral". Revista Mexicana de Ciencias Políticas y Sociales. F. C. P. y S. UNAM. Núm. 134, pp. $71-91$.

Seara Vózquez, Modesto. 1985. Política exterior de México. México: Ed. Harla, pp. 414.

Secretaría de Comercio y Fomento Industrial. 1991. "Información básica sobre la Ley de Fomento y Protección de la Propiedad Industrial". Serie de Desarrollo Tecnológico. 2a. ed., julio.

Selser, Gregorio. "Gasto militar de dos mil millones de dólares por minuto". El Financiero, miércoles 12 de junio, 1991, p. 39.

Solleiro, José Luis, y Arriaga, Elena. "Patentes de biotecnología: amenazas y opciones para América Latina". Comercio Exterior. Vol. 40. Núm. 12, diciembre de 1990, pp. 1160-1170.

Toffler, Alvin. 1989. La tercera ola. México: Ed. Edivisión, 494 pp.

Trujillo Arriaga, Javier. "Desarrollo de una agricultura sustentable en México. El paradigma agroecológico". Comercio Exterior. Vol. 40. Núm.10, octubre, 1990.

Universidad Autónoma Metropolitana. "Biotecnología, transformación productiva y repercusiones sociales". Sociológica. Departamento de Sociología, División de Ciencias Sociales y Humanidades, UAM-Azcapotzalco. Año 6. Núm. 16, mayo-agosto, 1991, $395 \mathrm{pp}$.

Vega E., Fernando. "Biotecnología agrícola, espejo de la Revolución Verde". Comercio Exterior. Vol. 37. Núm. 11, nov. de 1989, pp. 947-952.

Wright, Susan, y Sinsheimer, Robert L. "La tecnología del DNA y la guerra biológica". Contextos, Secretaría de Programación y Presupuesto. Núm. 18, 30 de diciembre de 1983, pp. 53-59; The Bulletin of Atomic Scientist, Xl, 83, pp. 20-26. 
COMENTARIOS 



\title{
Repercusiones políticas de la biotecnología
}

\author{
FRANCISCO MARTÍNEZ GOMEZ*
}

El trabajo "'iProhibido Cazar!' Expoliación científica, los derechos de los indígenas y la biodiversidad universal", elaborado por Jack Kloppenburg Jr., con que se abordó el tema de las repercusiones políticas de la biotecnología, destaca como punto medular la importancia estratégica que tiene la biodiversidad en los desarrollos presentes y futuros de la agricultura, lo que ha generado un interés por parte de las empresas y los gobiernos sobre el control y apropiación prácticamente gratuita de los recursos genéticos indispensables para obtener plantas de mayor potencial productivo. El trabajo hace hincapié en cómo las viejas presiones por controlar el aprovisionamiento de las materias primas estratégicas continúan formando parte de los grandes propósitos políticos y militares de los gobiernos y las grandes empresas. Si acaso, cambian y se intensifican las maneras como las presiones se manifiestan ante el aumento de la competitividad, en este caso de los bienes de origen biológico en los mercados internacionales.

Por otra parte, el trabajo de Kloppenburg señala algo que no se ha reconocido plenamente: la importancia estratégica de los recursos genéticos. Las nuevas tecnologías demandan más bien las actividades relativas a conservar la biodiversidad, la cual incrementa las oportunidades de encontrar nuevos productos comerciales mediante tecnologías modernas como la biotecnología y la ingeniería genética. Incluso la biodiversidad es aún más buscada si además de los recursos genéticos se cuenta con los conocimientos ancestrales que tienen los campesinos sobre las propiedades de las plantas, los animales y los microorganismos que han utilizado en la alimentación, la medicina y en otros usos industriales. El valor del germoplasma no es sólo producto de la naturaleza, sino también del trabajo e ingenio de las sociedades rurales que durante muchas generaciones lo han cuidado y mejorado. Se señalan en este sentido distintos ejemplos de cómo la

* Coordinación de Ciencias Socioeconómicas de la UAAAN. Saltillo, Coahuila. 
riqueza generada de la diversidad genética es usufructuada por grandes compañías, sin que se beneficien en nada las sociedades rurales que aportaron los conocimientos fundamentales para su explotación.

No nos parece temeraria la cita que hace del World Resources Institute en el sentido de que el "germoplasma puede ser el petróleo de la era de la información". Sí en cambio nos resulta preocupante la poca importancia que los países centros de origen de especies de importancia económica dan a las actividades relativas al control, conservación y uso de estos estratégicos recursos.

En relación con el trabajo sobre la bioseguridad, de Leonardo $\mathrm{H}$. Rioja Peregrina, su definición del concepto de "bioseguridad" es interesante porque hay distintas maneras de definirla que de algún modo reflejan los distintos enfoques al respecto. Por una parte, la definición mós común en los países desarrollados es la referente a los daños que pueden causar a la salud pública los experimentos que emplean tecnologías modernas como la ingeniería genética, que pueden desencadenar procesos dañinos para la sociedad. Esta definición puede resultar estrecha pues excluye consideraciones importantes que tienen relación con el concepto de seguridad, entendido como el conjunto de factores que tiene que controlar un país o región para evitar ser excluidos en la determinación de actividades estratégicas que afecten su desarrollo y pongan en riesgo su soberanía. Hay analogías entre el concepto de bioseguridad y el de seguridad alimentaria mundial; éste se refiere al compromiso de la comunidad internacional por procurar que todos los habitantes del planeta tengan acceso seguro a una adecuada dieta alimenticia. Para que ello sea posible se hace necesario, entre otras acciones, distribuir mejor la producción de alimentos entre los países, así como equilibrar más y mejor el nivel de apoyo a la producción agrícola por parte de los gobiernos de los países. También es necesario un cambio en el orden internacional que genere las condiciones que lo permitan. El concepto de bioseguridad no debe limitarse tan sólo a los riesgos contra la salud que las nuevas biotecnologías pueden generar, tal y como lo consideran funcionarios públicos y privados de los países desarrollados e induso de los países en desarrollo. La creciente erosión genética y el fuerte deterioro social de los campesinos son situaciones reales en nuestro país que demandan soluciones, las cuales no pueden darse a partir de una percepción limitada. Los procesos de internacionalización de la economía y el carácter estratégico de la biodiversidad en la producción futura de alimentos y otros productos comerciales de origen biológico pueden vulnerar la seguridad de los países, particularmente de los más pobres, si no se establecen normas intemacionales y nacionales que regulen sobre bases de mayor equidad la generación y el uso de las nuevas tecnologías y de la biodiversidad. 
El trabajo de Dinah Rodríguez Chaurnet sobre la biotecnología en los nuevos modelos productivos destaca cómo los cambios del mundo actual están impulsados por los países desarrollados a partir de las innovaciones tecnológicas. Estos avances están produciendo profundos cambios en el aparato productivo y en las relaciones comerciales internacionales. Se observan problemas por la caída de la demanda de algunos productos además de la sobreoferta que ocasiona caídas de precios y deterioro de los términos de intercambio. También destaca la hegemonía de las grandes empresas por el control y la privatización del conocimiento científico aplicada a productos estratégicos, así como la erosión de las ventajas comparativas de los ecosistemas naturales de los países en desarrollo a causa de los nuevos adelantos tecnológicos. incluso se prevé cómo en muchos casos las ventajas del costo de la mano de obra tienden a ser más relativas.

Las tendencias del comportamiento de la economía mundial que señala Dinah Rodríguez en relación con los avances tecnológicos y sus consecuencias en los procesos productivos y en las relaciones comerciales internacionales nos parecen correctas. También nos parecen acertadas las propuestas hacia un desarrollo alternativo de la biotecnología sustentado en una mayor colaboración sur-sur en proyectos específicos que incluyan la formación y desarrollo de personal científico y el desarrollo de la biotecnología de bajo costo para las zonas rurales. Asimismo, son valiosos sus comentarios referentes al rescate de productos tradicionales de alto valor nutritivo y a la protección de la biodiversidad.

En su trabajo "Agricultura, biotecnología e integración norteamericana", Gerardo Otero examina algunas de las principales repercusiones de la biotecnología y del hecho inminente de la firma del Tratado de Libre Comercio entre Canadá, Estados Unidos y México.

La primera parte analiza la pregunta de si el paradigma tecnológico de la agricultura moderna puede ser trascendido. Posteriormente analiza los principales efectos de la biotecnología en el empleo y la ecología, así como la monopolización del material fitogenético. También presenta los sistemas de agricultura mexicana ante la biotecnología y la integración norteamericana. A manera de conclusiones se plantean algunas preguntas para investigación futura.

Nos parece que el trabajo plantea categorías de análisis significativas que permiten delimitar el perfil que la estructura agraria de México puede tener ante los nuevos adelantos tecnológicos y las fuerzas dominantes que los dirigen e impulsan.

Las conclusiones de los análisis del trabajo de Gerardo Otero plantean un panorama pesimista en relación con las perspectivas de la economía campesina. Sostiene que la biotecnología probablemente 
reforzará y profundizará los cambios estructurales que trajo la Revolución Verde. Señala que las tendencias económicas e institucionales favorecen el modelo de una agricultura fuertemente concentrada. Los nuevos adelantos científicos son generados según los requerimientos de los mercados, los cuales se encuentran condicionados por las grandes empresas transnacionales oligopólicas. La apropiación de los avances tecnológicos mediante mecanismos jurídicos como las patentes ha facilitado y permitido que la producción de insumos agrícolas se concentre cada vez más. Por otra parte, en este estudio de Otero se analizan las perspectivas de una agricultura alternativa que eleve al máximo las sinergias biológicas de los ecosistemas para aumentar la producción y también las oportunidades de empleo.

Son evidentes las asimetrías en los dos modelos: el de la agricultura moderna (cada vez más grande en tamaño de sus unidades de producción y menor en cuanto al número de unidades) y el de la agricultura alternativa (restringida de recursos y donde se ubica la mayoría de los productores).

En vísperas de la firma del Tratado de Libre Comercio de los países de América del Norte, la discusión y análisis de las perspectivas agrarias de México resultan de gran trascendencia ante las repercusiones sociales que la apertura comercial puede tener en la economía de muchos productores agrícolas, sobre todo por las diferencias tan fuertes de los apoyos a la producción agrícola por parte de los gobiernos. México, por ejemplo, es el país de América Latina que menos recursos destina a la investigación agrícola en función del volumen de la producción, de acuerdo con un estudio de Alain Du Janvry.

Es muy posible que el modelo dominante se continúe e incluso que se intensifiquen sus efectos de deterioro social y ecológico. Sin embargo, también es probable que la sociedad rural continúe generando mecanismos de defensa y sobrevivencia. Actualmente una proporción considerable de los productores nacionales viven bajo sistemas de producción que aprovechan al máximo las ventajas de que disponen y que difícilmente pueden ser aprovechadas para las grandes empresas.

En los cuatro trabajos se hace alusión a la biodiversidad; se reconoce su importancia en los desarrollos futuros del mejoramiento del ambiente y en la producción agrícola; se acepta explícita o implícitamente que los países centros de origen de especies de importancia social y económica como México no han apoyado lo suficiente las actividades relacionadas con su conservación y utilización. Se proponen distintas acciones al respecto, a las que me permito agregar otras propias sobre este aspecto tan decisivo para las actuales y futuras políticas agrícolas, ecológicas y sociales. 
Que los recursos genéticos sean considerados bienes públicos y propiedad de la Nación. Esta puede conceder la utilización para propósitos comerciales de los recursos que le sean solicitados para tales fines de acuerdo con las normas establecidas. Sin embargo, el Estado se puede reservar el derecho de cambiar o establecer otras disposiciones jurídicas cuando por el interés público así lo considere.

La Nación se reserva el control y la supervisión sobre todas las actividades relativas a la recolección, clasificación, conservación e intercambio de los recursos genéticos por considerarlas estratégicas para su desarrollo.

Para estos propósitos se recomienda el establecimiento de Comisiones Nacionales de Recursos Fitogenéticos que tengan los siguientes objetivos:

- Promover el establecimiento de una red de colecciones base y activas de recursos genéticos in situ y ex situ en los lugares apropiados dentro del territorio.

- Promover el establecimiento de un Fondo Nacional para la Conservación y Utilización de los Recursos Genéticos. Definir las prioridades y necesidades económicas en materia de conservación; determinar cuotas de recuperación y las asignaciones de su gasto.

- Establecer convenios con instituciones de investigación y centros de educación agrícola superior para elaborar proyectos relativos a la conservación e investigación de recursos genéticos.

- Promover la consecución de recursos para realizar estudios de posgrado y cursos de capacitación en actividades relativas a la consenación e investigación de recursos genéticos.

- Analizar las maneras de conservar y utilizar los recursos fitogenéticos que tienen las organizaciones agrarias e impulsar los modos de aprovechar los recursos genéticos acordes a las necesidades de las organizaciones y al contexto socio-económico actual.

- Promover el establecimiento de proyectos de conservación y utilización de recursos genéticos con las organizaciones agrarias.

- Promover campañas de difusión sobre la importancia de conservar los recursos genéticos y el medio ambiente en la sociedad rural y urbana.

- Promover, con la participación de entidades públicas, centros de educación superior y organizaciones de productores agrícolas, el establecimiento de parques nacionales, monumentos naturales, reservas ecológicas y reservas de la biosfera donde se proteja el germoplasma y los ecosistemas. 
Las Comisiones Nacionales de Recursos Genéticos pueden estar constituidas por representantes de las instituciones públicas relacionadas y también por personas reconocidas por sus trabajos orientados a mejorar las condiciones económicas de la sociedad rural y por preservar el medio ambiente. Se recomienda que participe la sociedad civil, particularmente los representantes de las organizaciones agrícolas. 


\title{
La propiedad intelectual y la biotecnología
}

\author{
ROBERTO GUADARRAMA SISTOS*
}

Quiero agradecer a las coordinadoras de esta obra la amable invitación que me hicieron para comentar las ponencias de Blanca Suárez, Martin Kenney, Gilberto Aboites y Gonzalo Arroyo. El primer aspecto que quisiera destacar es el referente al proceso histórico.

En la evolución de la propiedad intelectual y en particular de la industrial, la década de los ochenta representa una ruptura de su tendencia histórica que podemos relacionar con la gestación de un nuevo paradigma científico-tecnológico, el cual se expresa en el campo de la biotecnología en su evolución desde las fermentaciones, pasando por cultivo de tejidos, ya sean éstas de fusión protoplástica, variación somaclonal o embriogénesis somática. Cualquiera de las técnicas relacionadas con fermentaciones o cultivo de tejidos constituye una etapa de la biotecnología bastante bien caracterizada, con logros tecnológicos significativos y un concepto de propiedad industrial.

Sin embargo, un nuevo paradigma científico-tecnológico se gesta por la capacidad de modificar el ADN, factor esencial de la vida. Ya no se apuesta a la probabilidad de si se pueden o no fijar o estabilizar ciertas características en el fenotipo sino que ahora se controlan los procesos con una conciencia clara de lo que se quiere, una vez que se han modificado las estructuras de los genes y del genoma. Ahora se puede hacer ingeniería genética, y esto resulta cualitativamente distinto de todo lo hecho antes. Por eso creo que con la evolución de la ingeniería genética estamos entrando en un nuevo paradigma que requiere de un ajuste en lo referente a la propiedad intelectual que nos ha regido hasta el momento. Este es el primer punto que quisiera destacar y que los cuatro estudios anteriores presentan en común, aunque con distintas modalidades.

Un segundo aspecto que quisiera comentar es la necesidad de entender con claridad la diferencia entre consumidor de biotecnologías

* Instituto para la Planeación del Desarrollo, A. C. 
y generador de biotecnologías. Me parece que la legislación mexicana se engaña al suponer que mediante la concesión del derecho de monopolio que se logra con invenciones biotecnológicas es posible fomentar la capacidad creadora y la inventiva en nuestro país. Creo que debe destacarse la necesidad de contar con condiciones objetivas, muy claramente definidas, para inventar $y$, finalmente, poder patentar.

No creo que la libertad jurídica de tener derecho al monopolio sea suficiente; se requieren condiciones de laboratorio, germoplasma y recursos intelectuales para poder generar una invención patentable, condiciones objetivas de las que ahora en buena medida carecemos.

Hace tres años en el Instituto para la Planeación del Desarrollo iniciamos un trabajo sobre el registro de patentes en México durante la década de los ochenta y lo elaboramos con base en el Registro Nacional de Transferencia de Tecnología. El 94\% de las patentes registradas en México estaban en manos de extranjeros y tan sólo $6 \%$ correspondía a los nacionales, por cierto en casos bastantes intrascendentes. No es que nos falte capacidad inventiva; no es que no tengamos ganas de beneficiarnos económicamente con un monopolio sobre nuestra invención. Lo que sucede es que no tenemos las instalaciones ni el recurso humano suficiente para hacer el tipo de ciencia que se convierte en alta tecnología, es decir las condiciones objetivas de trabajo.

Desde esa óptica resulta muy importante entender que si el $94 \%$ de las patentes son extranjeras y nosotros somos fundamentalmente consumidores de tecnología, el proceso en el que Gilberto Aboites hace hincapié en su ponencia es que de hecho estamos legitimando un proceso en el cual nosotros somos compradores de tecnología. Hay un párrafo en su trabajo que me parece muy ilustrador y que se refiere a la nueva ley:

Más que el reconocimiento social a una aportación o subvención, que motiva a la sociedad a premiar a su creador con un monopolio sobre su invento, se destaca el factor defensivo contra las copias o imitaciones de invenciones como argumento de peso para imponer una legalidad internacional que en realidad busca asegurar la reproducción de una determinada división de trabajo internacional de la cual los países subdesarrollados sólo podrán participar como compradores de tecnología y no como generadores.

Esto es el esquema institucional, el marco jurídico que tiende, dicen algunos, a estimular una mayor capacidad inventiva a partir del espejismo de tener monopolios. Sin embargo, las condiciones objetivas 
de trabajo requeridas para poder inventar, nos lo dijo claramente Gonzalo Arroyo con los ejemplos de Brasil, Cuba y ahora Chile, son del orden de docenas de millones de dólares. El Centro Limonta de ingeniería genética y biotecnología en Cuba costo 60 millones de dólares; nos señala que la Fundación Chile maneja 50 millones de dólares y que la empresa que realiza ingeniería genética para cítricos en Campiñas, Brasil, costó 60 millones de dólares. En México contamos con dos o tres Centros que reúnen dichas condiciones. Este es el orden de magnitud del esfuerzo que hay que realizar para ser competitivos y las condiciones mínimas de trabajo para poder inventar.

El tercer punto que quisiera destacar es que debe comprenderse en qué consiste esta ruptura del paradigma científico-tecnológico. Cabe mencionar que dicha concepción no es compartida en la mayor parte de los foros; sin embargo, el nuevo paradigma científico-tecnológico puede denominarse como el "paradigma de los genotipos". El nuevo paradigma nos permite trascender de la apariencia fenotípica o fenomenológica de la materia viva (la que podemos ver, sobre la cual hemos hecho taxonomía desde Darwin, en la cual hemos formado y deformado a nuestros biólogos, midiendo el tamaño de las hojas, su color y tamaño como los aspectos que deben conocerse). Ese ipo de conocimientos taxonómicos del fenotipo está siendo superado.

Lo que está sucediendo es que algunos científicos básicos han trascendido la apariencia del fenotipo para construir el genotipo. Este plano de abstracción se centra en las estructuras y en sus procesos para poder trascender del fenotipo al genotipo, sin verlo. Hasta muy recientemente hemos podido verlo y fotografiarlo. Se ha debido ser muy cuidadoso en conceder el derecho de monopolio al que diseña el proceso con el cual otros científicos se aproximan al genotipo y por eso, efectivamente, las solicitudes de patentes en la mayor parte de los países industrializados tienen que ver en el proceso.

Toda la discusión a la que Gilberto nos invita cuando nos habla de cómo, en tres etapas, vamos llegando a la semilla, en la medida en que la semilla de maíz tiene un genotipo que ahora se puede conocer, estamos en la posibilidad de manejarnos en planos de abstracción de algo que no se ve: puedo ver, oler el fenotipo; tiene esas características organolépticas claramente especificadas. No sucede lo mismo con el gen; la estructura de los genes en el ADN no huelen. Por eso la necesidad de canalizar esfuerzos hacia el conocimiento de los procesos, hacia una identificación de que el resultado del proceso aplicado para llegar al genoma era, finalmente, la posibilidad de entender los procesos esencialmente biológicos. Estamos entendiendo a la naturaleza en su manera de operar, entendiendo cuáles son los procesos esencialmente biológicos; es preciso comprender el proceso fisiológico y sus 
reacciones bioquímicas para entender cómo, a partir de los genes, se da toda esta reacción bioquímica que nos permite finalmente conocer las características y las funciones de los genes en el genotipo.

Por esta razón, los productos, y posteriormente los procesos, están siendo objeto de patentamiento; pero, lo decía Gilberto, el concepto mismo también está siendo patentado, no sólo los procesos y los productos; por "productos" quiero decir plantas, microorganismos o animales superiores transgénicos y también el proceso que se sigue para lograr la transformación del producto. Ahora se está intentando patentar la manera como se conceptualiza el problema y su solución, el modo de concebir el problema y de enfocarlo. Una de las ventajas competitivas de los laboratorios que están patentando más aceleradamente es tratar de tener un monopolio sobre el enfoque, sobre dicho concepto.

Hace algunos años, en 1983, nos tocó en suerte participar con Francisco Martínez en la FAO. En representación de México declaramos proteger los recursos fitogenéticos no en aras de una utopía del patrimonio de la humanidad, como algunos nos lo criticaron, sino de entender que tanto la erosión del germoplasma como su flujo resultan algo grave que permite que grandes negocios se desarrollen sin que los pobladores de las zonas de diversidad genética se hayan visto mínimamente beneficiados. Concebir el germoplasma como elemento insustituible para la elaboración posterior de fármacos, químicos o semillas y que, como dijera Jack Kloppenburg, la naturaleza no es la única que ha creado las decenas de generaciones de pobladores; los centros Vavilov también han hecho su aportación a la diversidad genética actual.

Por eso constituyó una ardua batalla desde el punto de vista diplomático; el asunto era hasta dónde definir el germoplasma y cómo se formularía la definición, hasta dónde podíamos entrar a tratar de negociar las especies silvestres, las variedades locales, las variedades comerciales o las líneas de mejora. Blanca Sánchez sugiere este aspecto en su trabajo cuando destaca que el sector privado va a poder experimentar sobre variedades comerciales; ya Kloppenburg está señalando que se puede. La Ley de Patentes sobre semillas también indica que puede hacerse investigación sobre materiales patentados, fundamentalmente en lo referente a variedades comerciales; ahí es donde considero que se encuentran nuestras oportunidades.

Si el germoplasma es esencialmente diverso, ¿̇cuál es el que vamos a crear los países del Sur y cuántos tipos que nos permitan no sólo conservarlo sino aprovecharlo para nuestro desarrollo? Ciertamente los países del Norte lo han entendido con claridad; desde Darwin, lo han aprovechado en su beneficio y han patentado el germoplasma en 
la forma de variedades mejoradas híbridas que puedan seguir vendiendo anualmente.

Las nuevas posibilidades de entender el genotipo hacen que la frontera entre descubrimiento e invención se corra y se haga menos clara. El descubrimiento no se patenta; la invención sí, pero algunos laboratorios están haciendo descubrimientos de las funciones del genoma y los estón aprovechando económicamente. La Universidad de Tokio tiene al $50 \%$ de sus científicos en biología molecular haciendo taxonomía genotípica; obtienen organismos del fondo del mar e investigan cómo funcionan. Una vez que se conoce el mecanismo de funcionamiento, sencillamente lo utilizan para producir determinadas mercancías. Hay una barrera entre lo esencialmente biológico no patentable, porque es un descubrimiento, y la invención, pero ésta es muy sutil, poco precisa; de hecho algunos creemos que se están trascendiendo las barreras y que se está patentando lo biológico.

Todo lo anterior se da en el marco del nuevo paradigma; es precisamente lo que se está discutiendo en Ginebra en el GATT, en Viena en ONUDI: hasta dónde es invención o descubrimiento. La posición dominante es que los descubrimientos mediados por invenciones están siendo interpretados como invención patentable. Si una invención como el microscopio de barrido de túnel o criogénico, permite descubrir las estructuras moleculares y a partir de ellas conocer su funcionamiento y aprovecharlo, resulta patentable entre los japoneses. Este tipo de discusión no es ajena a nosotros, porque podríamos dedicarnos a hacer mapeos genotípicos y patentar nuestro germoplasma; es una opción altamente rentable.

Para realizar mapeos genotípicos la comunidad internacional está proporcionando recursos importantes, más allá de lo que podemos movilizar internamente para estos propósitos. El IICA recibirá cinco millones de dólares este año para hacer investigación y conservación de germoplasma in situ y ex situ de importancia económica para los países centroamericanos y sus mercados, por lo que debería dedicarse a caracterizar genotípicamente ese germoplasma.

Descubrimiento o invención, están influyendo en los acelerados ritmos de innovación biotecnológica en el mundo. En los últimos 10 años, el ritmo de invención e innovación del aparato productivo se ha reducido considerablemente. Entre una invención y su incorporación al aparato productivo como innovación lo tradicional era que pasaran 15 años; en la última década el proceso se ha reducido hasta tres años y en algunos casos a dos.

Precisamente lo que plantea Martin Kenney es que las inversiones en dólares han generado innovación porque ésta aporta nuevos valores a la capacidad competitiva de las empresas farmacéuticas, químicas y 
de semillas, las cuales están invirtiendo cantidades no imaginadas en el mundo hasta la década de los ochenta. Lo que vemos es que hay nuevas formas de hacer productos de muy alto valor agregado. Al final, el juego consiste en invertir en ciencia que genere descubrimientos patentables que a su vez permitan generar las ventajas tecnológicas de algunas empresas con el objeto de fortalecer su posición en los mercados, o desplazar a viejos competidores.

Martin Kenney hace señalamientos que yo comparto plenamente: la concepción de la comunidad científica como en movimiento, por así decir metamorfoseándose hacia un agente productivo. El que fuera considerado científicamente como generador de conocimientos es ahora, desde mi perspectiva, el factor productivo estratégico para las economías desarrolladas.

De hecho la nueva tecnología tiene un componente científico con el que no contaba antes. Los ingenieros no son ya quienes están haciendo tecnología, sino los científicos en la frontera del conocimiento: no sólo los biólogos moleculares, sino también los físicos del estado sólido que buscan lograr nuevas aleaciones o nuevas cerámicas; es decir, lo que antes hacía un ingeniero metalurgista ahora lo realiza un físico del estado sólido al estudiar cuál es la estructura molecular en los metales y cómo puede haber aleación entre metales que en condiciones "normales" no es posible integrar o alear en la presión atmosférica de la superficie de la Tierra.

Por esta razón la comunidad científica está recibiendo una importante inyección de capital: porque es el factor productivo estratégico en las economías desarrolladas. Esto nos lleva a la concepción de la estructura del sector económico. Ya Galbraith señalaba en algún momento la época de las tecnocracias y de las economías postindustriales. Creo, sin embargo, que se quedó un poco corto: no sólo se trata de la revolución de la informática, sino fundamentalmente de la de los genotipos, y con ella surge un nuevo sector económico, el cuaternario. Dicho sector valoriza el trabajo científico al generar servicios inteligentes; lo convierte en mercancía por su capacidad de transformar a las fuentes generadoras y distribuidoras de valor en los sectores productivos convencionales. Asimismo, porque también está transformando al sector terciario del cual nació.

Estados Unidos, Japón y Alemania empiezan a diferenciarse de los otros países desarrollados porque están creando el sector cuaternario, un sector de servicios intensivos en neuronas. La insistencia se debe a que los servicios intensivos en neuronas son los que permiten transformar las formas de generación, circulación y apropiación de excedente económico en la agricultura, en la industria y en los servicios tradicionales. 
Blanca Suárez aborda un aspecto medular: la oposición de los productores organizados y con criterio empresarial (como los productores de hortalizas) a la semilla. Con el objeto de atender las necesidades productivas del sector agropecuario, el CINVESTAV-I se instala en el Bajío. La primera sorpresa es que los freseros de Irapuato no pueden comprarle la semilla que desarrolla porque la exportación depende del intermediario norteamericano, que introduce la fresa en Estados Unidos y además les impone el paquete tecnológico, que incluye la semilla. Se trata de un mecanismo bien estudiado que indica que nuestros productos agrícolas dependen tecnológicamente del comercializador, tendencia que aumenta cada vez más.

Las plantas transgénicas, de las cuales hay en este momento 236 experimentos en marcha solicitados en Estados Unidos, incluyen productos de exportación tradicionales de México. Estamos hablando del jitomate, el pepino, de productos clásicos de la exportación mexicana que, y como ya se señalo, se pretende dotarlos de características que no tienen naturalmente; esto crea un nuevo tipo de proteccionismo hacia los mercados más dinámicos del orbe: un neoproteccionismo de carácter tecnológico.

Si la agricultura orgánica, minoritaria aún en Estados Unidos, está produciendo hábitos de consumo más naturales con sobreprecios o respondiendo a ellos, los materiales transgénicos van a ser el pretexto para establecer barreras que impidan que los productos no protegidos con ADN recombinado penetren en los mercados norteamericanos con el argumento de que el consumidor estadunidense no va a demandarlos porque tienen residuos de agroquímico. Esta es la gran lucha que habrá de librarse en el comercio y nadie la ha planteado; nos estamos limitando a la discusión de barreras económicas, de cualquier tipo, y no de las nuevas que impondrán las plantas transgénicas.

Finalmente, y pese a todo lo anterior, creo que tenemos algunas oportunidades como región y como sociedad; en principio afirmo que debe comprenderse que el germoplasma sigue siendo una de nuestras cartas fuertes en la negociación. Sin ambages, después de regresar de alguna universidad estadunidense, europea o japonesa, nuestros investigadores envían germoplasma como parte del compromiso de investigación con su profesor; así se ha ido la mayor parte del germoplasma de nuestro país. Repito, no por malevolencia ni perversidad; sencillamente por el proyecto de hacer una investigación, y para ella se requiere germoplasma y diversidad genética.

Se trata de recursos genéticos y de algo que señaló Gonzalo Arroyo: recursos humanos. La paradoja de nuestro subdesarrollo nos hace muy difícil entender que, pese a todo, tenemos algunos (muy pocos) centros de investigación de excelencia mundial. En el caso de 
México, la visión de algunos cientificos que dirigieron la ciencia y la tecnología en décadas pasadas permitio formar cuadros, como el del CINVESTAV-I, o el Instituto de biotecnología de la UNAM en Cuernavaca, el CICY en Yucatán, o el CINVESTAV-DF. Son unos cuantos centros de punta y siguen estando en la frontera del conocimiento; pero el doctor Alejandro Blanco advierte que todos los días perdemos terreno; por eso tenemos que retener a los Luis Estrella, Paco Bolívar, Mayra de la Torre, Manuel Robert, Eduardo Bórcena, Federico Sánchez, Miguel Lara y otros talentos científicos mexicanos.

Parte de mi optimismo radica en que la biodiversidad tiene que ver con nosotros. Si observamos una sociedad como la japonesa, descubrimos la estrecha base genética de su población. En el caso de México, nuestro mestizaje, nuestra juventud, e incluso nuestro desarrollo, es parte de nuestro capital. Como lo demostraron algunos en su momento, tenemos la capacidad de abordar los problemas de manera menos formal, más original y menos castrante. Creo que hay oportunidad; hay que formar buenos equipos, definir prioridades, apostar a los ganadores, sumar esfuerzos, porque evidentemente no podremos hacer lo anterior sin el concurso de los esfuerzos latinoamericanos en conjunto. 


\section{REPERCUSIONES SOCIOECONÓMICAS EN DIFERENTES SECTORES}





\title{
El patrón potencial de difusión de la biotecnología en el sector petroquímico
}

\author{
LUIS KATO MALDONADO*
}

\section{INTRODUCCIÓN}

Al contrario de lo que sucede con tecnologías de vanguardia como la microelectrónica o la tecnología aeroespacial, la biotecnología no ha encontrado, después de 13 años de haber sido redescubierta, mercados propios claramente definidos. Las empresas especializadas en biotecnología de punta (ingeniería genética) estimaban que el desarrollo y la aplicación comercial de la técnica de recombinación del ADN les permitiría impulsar nuevos mercados y productos y que sería posible producir una nueva generación de entidades químicas que pudieran satisfacer las necesidades cada vez mayores de compuestos orgánicos.

Para lograr ese fin, orientaron gran parte de sus trabajos a la investigación y desarrollo de productos farmacéuticos nuevos tales como hormonas, anticuerpos monoclonales, vacunas, antibióticos, etcétera. En este sentido, los trabajos realizados mostraron un avance impresionante en lo referente al descubrimiento de los mecanismos biológicos, bioquímicos y moleculares que permiten codificar y reproducir características genéticas. Sin embargo, la amplia comercialización de dichos avances científicos no se logró plenamente sino hasta cuando las empresas especializadas en biotecnología se asociaron con grandes empresas farmacéuticas.

Los altos costos de la investigación y comercialización que requiere promover nuevos productos biotecnológicos ahogaron financieramente a las empresas especializadas en biotecnología.' Este fenómeno se

* Departamento de Economía de la Universidad Autónoma Metropolitana - Unidad Azcapotzalco.

1 Se estima que el costo de desarrollar en laboratorio un anticuerpo monoclonal es de alrededor de 10 mil dólares, en tanto que los costos de su comercialización llegarían a los 10 millones de dólares. Véase Francesca Lunzer, "Cash Crisis Creates Biotech Alliances", High Technology, abril de 1988. 
manifestó claramente en 1987, cuando el valor de los activos de las empresas biotecnológicas (hasta ese momento independientes) cayo $44 \%$ en el mercado accionario de Wall Street y no fue sino hasta febrero de 1988 que recupero $23 \%$ de su valor. Este dato era síntoma inequívoco de que la euforia de los años ochenta por la biotecnología, como tecnología capaz de abrir un mercado propio, había terminado. ${ }^{2}$

Ante este panorama, las opciones que se presentaban a las empresas especializadas en biotecnología eran claras: tenían que asociarse con las grandes empresas farmacéuticas y químicas, y, por ende, con los grandes consorcios petroleros, empresas que eran las competidoras reales de las nuevas compañías biotecnológicas.

La manera de asociarse podía ofrecer dos posibilidades: la primera consistía en obtener contratos con las grandes empresas y así realizar proyectos de investigación, con la consecuente perdida de autonomía para delinear sus propias estrategias de investigación; la segunda consistía en concesionar la venta de los productos a cambio de un porcentaje sobre el monto total de ventas. Al parecer esta es la vía que se ha impuesto.

Actualmente el número de productos biotecnológicos comercializado de manera conjunta por las empresas especializadas en biotecnología y por las grandes empresas farmacéuticas llega a nueve. ${ }^{3}$ En 1988 estos productos farmacéuticos alcanzaron un volumen de ventas de mil millones de dólares, con io cual obtuvieron el $1 \%$ de las ventas mundiales de la industria farmacéutica.

El potencial comercial de la biotecnología es innegable. La posibilidad de fabricar y perfeccionar entidades químicas mediante procesos basados en la síntesis biológica a partir de la modificación genética de organismos vivos puede alterar radicalmente la estructura de articulación de la industria moderna. Esta posibilidad es bien conocida por los grandes conglomerados de la industria petroquímica y química-farmacéutica, por lo que, dado el control que ejercen sobre el mercado de productos orgánicos y a causa de la crisis financiera de las empresas especializadas en biotecnología, han subordinado a éstas y logrado con ello que las innovaciones biotecnológicas se lleven a cabo conforme a sus intereses. Lo anterior, lejos de limitar la aplicación de la biotecnología en el plano mundial, puede favorecer una expansión acelerada de las innovaciones biotecnológicas pues las grandes em-

${ }^{2}$ Para dar una idea del significado de lo anterior baste citar que, desde 1976 hasta agosto de 1987, las inversiones de Estados Unidos en biotecnología habían sido de 1.5 mil millones de dólares, op. cit.

3 Insulina humana, hormona de crecimiento, interferones (alfa, beta y gama), activador tisular de plasminógeno, eritropoyetina, vacuna de hepatitis 8 y anticuerpo monoclonal ork3. Véase François Laveque, "Los productos biotecnológicos en la prueba del mercado", Mundo Científico, vol. 10, núm. 100. 
presas multinacionales de las óreas petroquímica, farmacéutica y química son las que pueden comercializar de manera más eficiente los nuevos procesos y productos biotecnológicos y, así, sostener los altos montos de inversión necesarios para promover y hacer avanzar la biotecnología.

Esto se fundamentaría debido a los altos niveles de especialización alcanzados por estas empresas en el desarrollo e introducción al mercado de nuevas entidades químicas. Además, puesto que muestran una marcada tendencia a integrarse, dichas empresas podrían crear y consolidar mercados y líneas de comercialización para los nuevos productos logrados mediante procesos biotecnológicos; incluso podrían utilizar las innovaciones biotecnológicas para modernizar y actualizar sus procesos de producción.

En el presente artículo se plantean las principales problemáticas que presenta el sector petroquímico y por qué tiene interés en absorber empresas biotecnológicas. También se proponen algunas hipótesis que tratan de explicar la manera como incorporar la biotecnología, en sus procesos de producción y comercialización, en el plano mundial.

\section{EL PATRÓN DE COMPETENCIA DEL MERCADO MUNDIAL DE PETROQUÍMICOS Y SU PROBLEMÁTICA TECNOLÓGICA}

Como consecuencia del incremento en los precios del petróleo, ocurrido en 1973, las naciones altamente industrializadas se vieron en la necesidad de reducir la participación de los costos de los energéticos en los costos totales, por unidad de producto final. Se pretendía que, en el largo plazo, el consumo de energía no aumentara al mismo ritmo que el crecimiento del producto. Por otra parte, la búsqueda de la eficiencia energética significaba instrumentar estrategias que permitieran modificar, de manera radical, la organización de su estructura productiva.

Las perspectivas para lograr tal objetivo indicaban dos direcciones: la primera consistía en la implantación acelerada de innovaciones tecnológicas que permitieran producir y consumir con un menor costo energético. Dichas innovaciones se orientarían principalmente a perfeccionar los procesos productivos, obtener productos mediante un menor costo energético y lograr una planeación más precisa de los mecanismos de comercialización.

Una vez que se consiguiera racionar el empleo de energía, se impulsaría la segunda estrategia, orientada a obtener cambios estructurales en los encadenamientos productivos vigentes, tomando en cuenta las siguientes dimensiones: a) propiciar que las actividades 
económicas caracterizadas por un uso intensivo de energía (siderurgia, química, cemento) tengan menor peso dentro del producto total manufacturero; b) impulsar un patrón de especialización industrial tendiente a estructurar un sector manufacturero que pueda producir mercancías con mayor valor agregado por unidad de recursos; y c) crear una industria de alta tecnología, así como vender sus productos en los mercados internacionales.

La primera estrategia se sustentó en la revolución microelectrónica y su aplicación hizo posible instrumentar procesos automatizados en los productos que habrían de elaborarse, orientados a ejercer un mayor control en aquellas etapas de los procesos de producción en los cuales el consumo de energía era excesivo. ${ }^{4}$

La segunda crisis petrolera -ocurrida en el año de 1979 — tuvo menores consecuencias para los países desarrollados. Los procesos de automatización utilizados a lo largo de los años setenta en industrias que durante más de tres décadas se habían constituido en el motor de crecimiento de las economías industrializadas (siderurgia, petroquímica, química, maquinaria y equipo e industria automotriz), posibilitó ya no sólo un mayor control sobre los procesos de transformación de las materias primas, sino también la oportunidad de flexibilizar las escalas de producción, con lo cual se logró acelerar la rotación del capital fijo y reducir la participación de los costos de los energéticos por unidad de producto.

En esta segunda crisis petrolera las economías altamente industrializadas tenían ya la experiencia suficiente para impulsar un patrón de industrialización que pudiera adaptarse a un mercado petrolero al alza. Aunado a lo anterior, los precios más altos del petroleo hicieron que nuevos productores entraran en el mercado y, paulatinamente, durante los años ochenta fueron participando cada vez más en el mercado total de hidrocarburos. De esta manera, el mercado mundial de energéticos se había modificado radicalmente debido - entre otros factores- a la entrada de nuevos productores al mercado de hidrocarburos; al perfeccionamiento de los procesos productivos en ramas generadoras de insumos intermedios y de bienes de consumo final; y a la posibilidad de difundir, en todo el sector manufacturero, los logros tecnológicos orientados a buscar un mayor grado de flexibilización en las escalas de producción. Este último aspecto constituye el eje alrededor del cual se está diseñando el nuevo patrón de especialización en el sector industrial de los países desarrollados.

${ }^{4}$ El ejemplo más significativo del éxito alcanzado lo constituye la industria japonesa. Considerando el año de 1973 como base, la intensidad de energía específica, por unidad de producción industrial, se redujo en promedio a s6blo 50\% en 1984. Kasuya Fujime y Hisao Kibune, "Cambios de la estructura económica y la demanda de energía en Japón, 1973-1984", Comercio Exterior, vol. 37, núm. 10, octubre de 1987, pág. 869. 
La combinación de incremento de la productividad, control de calidad, flexibilización de las escalas de producción y control del mercado de hidrocarburos, entre otros factores derivados de la puesta en marcha de los procesos de automatización, permitió a las industrias de los países desarrollados consolidar sus ventajas competitivas en los mercados internacionales y, a partir del perfeccionamiento de los procesos productivos en industrias vitales, estimular innovaciones tecnológicas en el producto. Con ello se logró influir significativamente en la apertura de nuevos mercados $y$, en consecuencia, ejercer un mayor control en el crecimiento global de su empleo y de su producto nacional. Así, por ejemplo, los principales países consumidores de equipo microelectrónico se constituyeron en grandes productores de dicho equipo, lo que les permitió marcar la pauta en materia de tecnología de proceso, sin riesgo de perder su capacidad competitiva en los sectores tradicionales.

Este último aspecto hizo posible formular la segunda estrategia de restructuración al comenzar a transferir, desde los países desarrollados hacia los países de industrialización media, actividades económicas caracterizadas por un uso intensivo de energía. Por otra parte, el control que ejercen los países desarrollados sobre la tecnología de proceso les posibilita estructurar un comercio internacional en donde los flujos de intercambio tienden a organizarse con el propósito de lograr que los insumos y bienes intermedios que importan, en las etapas finales de transformación, incorporen los últimos adelantos de la tecnología de producto. En suma, puede hablarse de una tendencia a generar un mercado internacional a partir de cadenas tecnológicas en el cual los países desarrollados controlen el mercado de mercancías de mayor valor agregado y estimulen el desarrollo del mercado de tecnología de punta.

Esta estructura de competencia tiende a modificar radicalmente los requerimientos de productos petroquímicos intermedios a escala mundial. Las nuevas necesidades del mercado mundial apuntan hacia un incremento significativo de la demanda de productos orgánicos de gran especificidad, los que podrían producirse sin que necesariamente se relacionen a las cadenas petroquímicas. Así, por ejemplo, "en 1979 los automóviles se construían usando un promedio de $4.5 \%$ de materiales plásticos, o sea, alrededor de 80 kilogramos/automóvil. En 1980 , este porcentaje subio hasta $10 \%$ del peso total, o sea, 125-150 kilogramos/automóvil". 5 Este aumento en el consumo de plásticos en la industria automotriz tenía por objetivo reducir el peso de los vehículos,

${ }^{5}$ Pangtay Chow, Petroquímica y sociedad, México: Fondo de Cultura EconómicaSecretaría de Educación Pública-Consejo Nacional de Ciencia y Tecnología, 1987. pág. 103. 
lo que vendría a repercutir en un menor uso de combustible. Por otro lado, se sustituían productos propios de la siderurgia por productos plásticos relacionados con la producción de petróleo mediante subproductos con mayor grado de elaboración.

Para la industria de plásticos este incremento en la demanda supuso perfeccionar el método de producción de termoplásticos -en particular del polipropileno-y, por ende, aumentar sus requerimientos de productos petroquímicos secundarios, en particular el consumo de olefeaminas (véase la gráfica 1).

En la actualidad, la producción de petroquímicos secundarios se ha caracterizado por una relativa inflexibilidad tecnológica debido a la existencia de economías de escala indisolublemente vinculadas con la extracción, refinación, distribución y consumo de petróleo y sus derivados, primarios y secundarios. El $90 \%$ de la demanda mundial de compuestos orgánicos es satisfecha por los siete principales derivados primarios del petróleo (etileno, propileno, buteno, benceno, tolveno, xileno y metano). En la actualidad estos petroquímicos básicos se obtienen de manera altamenfe eficiente gracias al perfeccionamiento alcanzado en el desarrollo de la síntesis química, la cual ha permitido desagregar y utilizar prácticamente todos los compuestos orgánicos que componen el petroleo y el gas natural.

La tecnología de la síntesis química se ha constituido en el determinante fundamental del tamaño de planta en la industria petroguímica, lo cual permite, mediante el perfeccionamiento de los equipos y plantas utilizadas, especializar los procesos de producción. Dicha especialización está relacionada con el control de la oferta de los productos petroquímicos básicos; el desarrollo de patentes; los conocimientos acumulados de los procesos tecnológicos y la estructura del mercado en la que operan las diferentes empresas. En este sentido el abastecimiento abundante y barato de petróleo y gas natural se ha convertido en el elemento determinante que explica la estructuración de cadenas productivas relativamente independientes que pueden presentar una dinámica propia tanto en el logro de nuevos productos como en la apertura de nuevos mercados.

En el plano industrial la síntesis química se aplicó con base en los procesos de producción en flujo mediante los cuales fue posible controlar y vigilar, de manera precisa, las diferentes reacciones químicas que se van presentando en las diversas etapas de producción y que dan origen a los derivados de hidrocarburos. Al mismo tiempo, el perfeccionamiento logrado en la construcción de materiales y componentes de las plantas petroquímicas (compresoras, válvulas, recipientes de presión, sistemas de monitorización y de simulación computarizados, etcétera), ha permitido un alto nivel de calidad y uniformidad del 


\section{Gráfica 1: Productos petroquímicos. Consumo mundial}

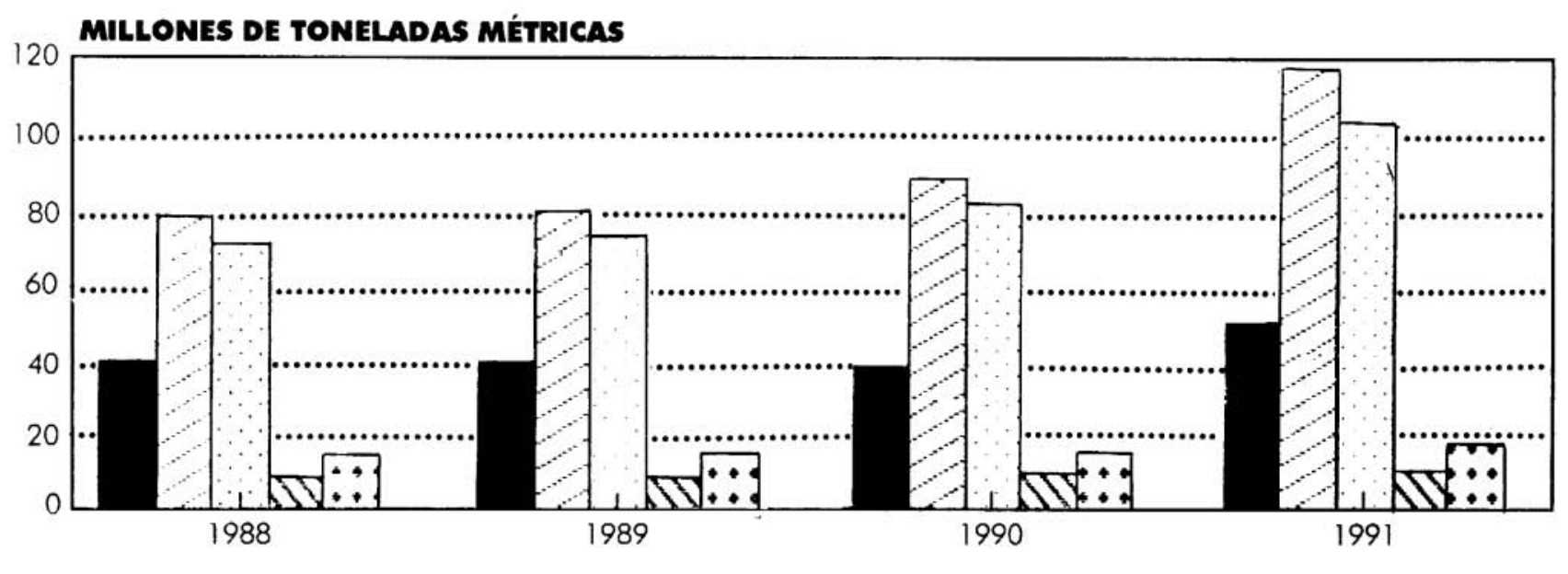

AÑos

$\square$ Series 1

DS Series 4
C Series 2

Series 5

\section{:: Series 3}


producto. Esto posibilita que la industria petroquímica tenga los más altos niveles de eficiencia y productividad en el mundo.

En términos económicos, los procesos de producción en flujo han permitido estructurar grandes economías de escala ${ }^{6}$ en la construcción de plantas y equipos y en los costos laborales por tipo de producto desarrollado. La reducción de costos vía la generación de economías de escala en la industria petroquímica permitió producir varios productos en una planta. De esta manera se fueron estructurando las cadenas petroquímicas sustentadas en rutas tecnologicas que dependen de la calidad y precio de los hidrocarburos. ${ }^{7}$

Esta estructura de producción se explica a partir del grado de concentración geográfica, en lo relativo al consumo de petroquímicos, por parte de Estados Unidos, Canadá, Europa Occidental y los países del sureste asiático (Japón, Corea del Norte, etcétera). Entre 1985 y 1990 estos países consumieron, en promedio, $82 \%$ de la producción mundial de petroquímicos intermedios (véase la gráfica 2) debido a los niveles de integración que tienen entre sí la petroquímica y la industria química-farmacétutica y a la diversidad de calidad y precio de los hidrocarburos.

Esa situación orilló a las empresas petroquímicas multinacionales a construir plantas en todo el mundo a fin de aprovechar las diferentes calidades de crudo. Esto entraña, en otras palabras, que pueden obtenerse productos idénticos a partir de cualquier tipo de crudo. Sin embargo, las rutas tecnológicas que se derivan varían significativamente, tanto en lo referente a costos como al rendimiento vulenido de productos secundarios.

La síntesis química y la producción de las plantas petroquímicas ha llegado a tal nivel de perfeccionamiento, que resulta cada vez más difícil y costoso introducir innovaciones tecnológicas radicales. En suma, la utilización plena de los derivados petroquímicos supone la existencia de grandes mercados de modo que hagan rentable los altos montos de inversión necesarios para estructurar cadenas petroquímicas. Es decir, en el sector petroquímico la escala de producción y, por tanto, el patrón de innovación tecnológica, depende del tamaño del mercado.

Lo anterior parece paradójico al considerar que la petroquímica fue uno de los sectores más afectados por la revolución microelectró-

6 Por economía de escala entendemos una reducción de costos causada por el incremento en la escala de producción.

${ }^{7}$ Según el Programa de Fomento de la Industria Petroquímica, hay cinco cadenas principales de las cuales derivan los principales productos de la industria química y farmacéutica. Estas cadenas son derivados: a) del gas natural; b) del etileno; c) del propileno; d) del butadieno; y e) productos aromáticos. Secretaría de Energía, Minas e Industria Paraestatal (SEMIP), "Programa Integral de Fomento a la Industria Petroquímica", México, 1986, p. 87. 


\section{Gráfica 2: Consumo de petroquímicos. Demanda geográfica}

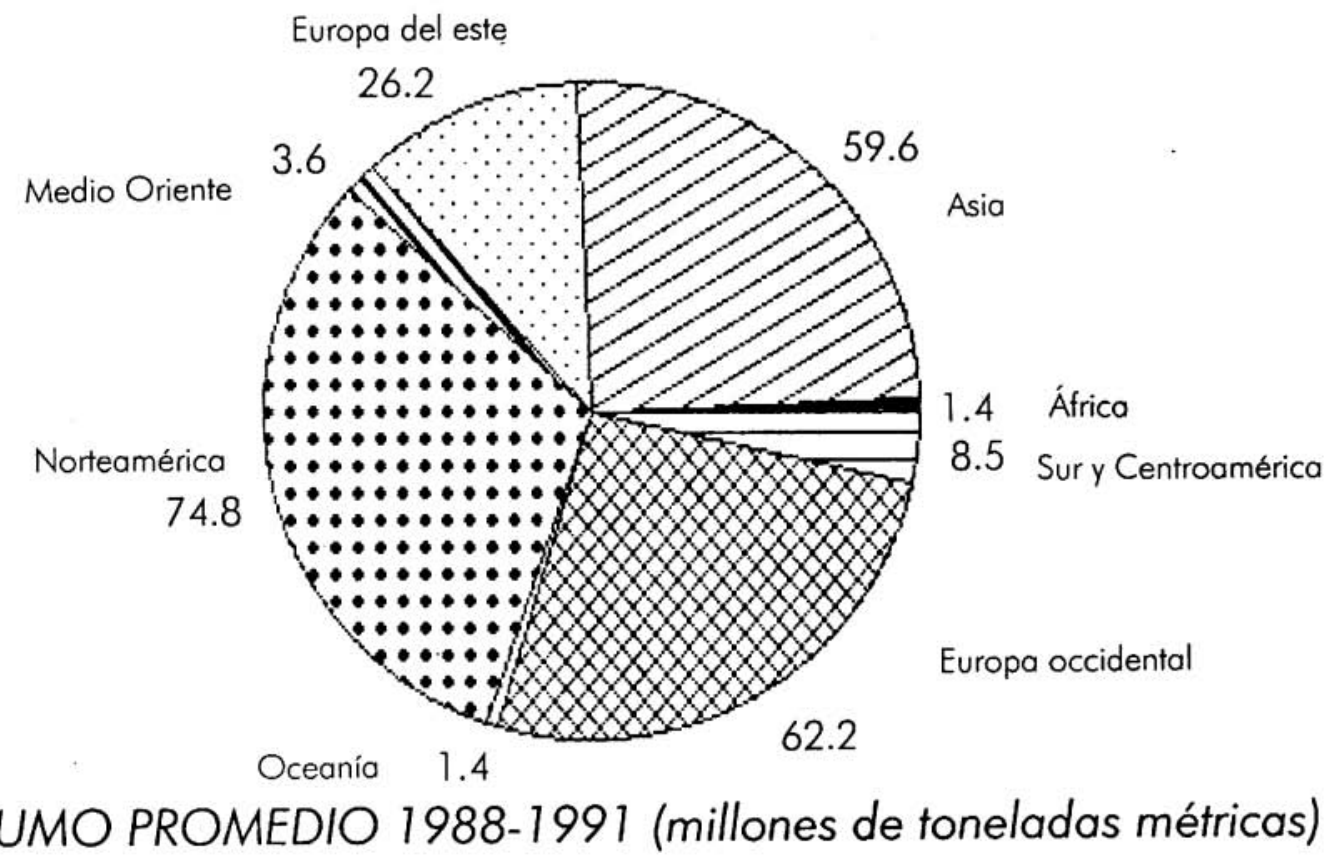


nica. La razón de ello reside en que los procesos de síntesis -el otro pilar de su dinámica innovadora-han evolucionado en sentido inverso a la búsqueda por lograr un mayor grado de flexibilidad en las escalas de producción. Esto último se refleja directamente en la incapacidad relativa de producir derivados de hidrocarburos y sustancias químicas en el plano comercial, con costos de producción inferiores a los que se obtienen mediante los encadenamientos petroquímicos.

Puesto que las estrategias de desarrollo tecnológico de las industrias con un crecimiento más dinámico o de las que tienen una fuerte participación en el mundo (automotriz, textiles, electrónica, resinas plásticas y sintéticas, electrónica y componentes, aeroespacial, maquinaria de oficina y computación, etcétera) tienden a redefinir sus eslabonamientos productivos con el propósito de generar un mercado intemacional acorde con la compatibilidad tecnológica, ${ }^{8}$ se estima que el sector petroquímico se encuentra en clara desventaja, ya que depende del desarrollo de nuevos procesos y de nuevos materiales, y del conocimiento y control que se realice sobre las transformaciones químicas; de la creación de nuevas fuentes de energía; del mantenimiento de la competitividad en los mercados internacionales de los países que controlan la tecnología de punta; y del cuidado que se tenga para lograr el equilibrio ecológico.

Las tendencias innovadoras, en especial la producción de nuevos materiales, dan prioridad a cadenas petroquímicas que presentan una fuerte posición competitiva debido al rendimiento obtenido en la producción de derivados, en particular los que muestran un alto rendimiento en la producción de material polimérico. A largo plazo este tipo de crudos presentará una propensión a incrementar sus precios debido a las nuevas necesidades generadas por la demanda mundial.

El sector petroquímico ha podido adaptarse a los requerimientos de nuevos materiales gracias a que hay un proceso de segmentación del mercado de petroquímicos que se expresa tanto en un sector que consume muchos productos petroquímicos con precios muy sensibles a las variaciones de precios de los diferentes tipos de hidrocarburos, como en otro sector que consume pocos petroquímicos y cuyos precios son poco sensitles a las variaciones de precio de los hidrocarburos. ${ }^{9}$

${ }^{8}$ En este sentido la tendencia se observa en tres direcciones: 1) articulaciones tecnológico-productivas, dirigidas a modificar las características físicas de las materias primas, a fin de cambiar la proporción en la cual los insumos son combinados y modificar la participación de los diferentes insumos utilizados en los costos de producción; 2) articulaciones tecnolbgico-productivas tendientes a modificar las características físicas del producto final con el objetivo de lograr una mayor diferenciación de productos; y 3) articulaciones tecnológico-productivas, tendientes a propiciar cambios en los procesos de producción en flujo para lograr mayor flexibilidad en las escalas de producción.

${ }^{9}$ La mayor o menor sensibilidad del precio de estos productos petroquímicos intermedios se explica por la afinidad que tienen sus procesos productivos con respecto a los procesos productivos de los petroquímicos básicos. 
Dentro del primer mercado encontramos los productos petroquimicos que presentan niveles de transformación primarios y que son producidos en procesos de producción en flujo a gran escala, por ejemplo amoniaco, anhídrido carbónico, metanol, cumeno, etileno, xileno, etcétera. A su vez, dentro del segundo mercado están los productos petroquímicos que han sufrido transformaciones de síntesis muy complejas y que son generados en procesos de producción en flujo a pequeña escala. Por lo general estos productos petroquímicos se derivan de la síntesis de varios productos petroquímicos básicos. Algunos de estos compuestos son los siguientes: herbicidas fenoxiácidos, copolímeros de acetato, etcétera.

En este segundo mercado es donde se obtiene un mayor margen de ganancia que frecuentemente se relaciona con una menor participación en los costos totales del capital fijo y al control del mercado ejercido por las diferentes empresas, derivado de la especialización obtenida en la producción de ciertos compuestos orgánicos. Y aunque se integran a partir de las materias primas que utilizan, las dinámicas innovadoras de estos dos mercados presentan una relativa independencia, aspecto que delimita la estructuración de mercados también relativamente independientes (química, farmacéutica, fibras y resinas sintéticas, productos plásticos, colorantes y pigmentos, fertilizantes y plaguicidas, aditivos alimentarios y jabones y detergentes).

En estos mercados la dinámica innovadora de la tecnología de producto es el factor fundamental de crecimiento. Para lograr un mayor grado de flexibilidad, un menor costo energético y mayores niveles de calidad en los productos finales, los avances tecnológicos han podido responder a los nuevos requerimientos de la industria. Sin embargo, su dinámica innovadora se encuentra condicionada por los generalmente elevados montos de inversión requeridos para producir petroquímicos básicos.

En el siguiente cuadro puede observarse el alto grado de capacidad utilizada en algunos de los principales productos petroquímicos intermedios. Los datos muestran, por un lado, las necesidades cada vez mayores del mercado mundial en lo referente a compuestos orgánicos de alta especificidad; por el otro lado, vemos la imperiosa urgencia de encontrar una tecnología distinta que haga posible producir estos compuestos orgánicos no a partir de la tecnología tradicional de la industria petroquímica. Cabe mencionar que varios de estos productos pueden ser producidos mediante técnicas biotecnológicas. 
CUADRO 1

INDICE DE CAPACIDAD UTILIZADA PARA DIFERENTES PRODUCTOS PETROQUIMICOS

(PROMEDIO 1985.1990)

\begin{tabular}{|lc|}
\hline ETILENO & $\begin{array}{c}\text { Capacidad utilizada } \\
\text { (porcentaje) } \\
\text { POLIETILENO }\end{array}$ \\
RESINAS & 81.6 \\
POLIESTIRENO & 87.1 \\
FIBRAS DE POLIESTER & 89.5 \\
FLLMES DE POLIESTER & 82.1 \\
ACETONA & 84.7 \\
ÁCIDO ACÉTICO & 86.9 \\
POLIPROPILENO & 86.8 \\
\hline
\end{tabular}

FUENTE: World Petrochemical SRI International, enero/1991.

\section{EL PATRÓN DE DIFUSIÓN TECNOLOGICA DE LA BIOTECNOLOGÍA EN EL SECTOR PETROQUIMICO}

En la industria, aplicar la tecnología de la síntesis química y el abastecimiento continuo y a bajos precios del petróleo y el gas natural (metano) ha hecho factible integrar y expandir los mercados para los compuestos orgánicos. La estructura de oferta de los productos petroquímicos puede describirse como altamente oligopólica y segmentada; es decir, en cada mercado hay una amplia gama de productos que va desde los que tienen un costo unitario reducido hasta los que presentan precios elevados a causa de su mayor nivel de transformación y diferenciación.

Ante la creciente competencia internacional, las grandes empresas transnacionales del sector tienden a buscar un mayor grado de especialización en sus mercados tradicionales, a fin de consolidarlos y evitar la entrada de nuevos productores. Esto explicaría el interés que tienen los grandes grupos transnacionales del sector petroquímico en absorber y fusionar a las empresas especializadas en biotecnología. Asimismo, la demanda mundial de compuestos orgánicos de alta especificidad es cada vez mayor.

La actual estructura de los encadenamientos productivos derivados de la petroquímica bósica es demasiado rígida para los nuevos requerimientos del mercado mundial. La necesidad de reducir y flexibilizar las escalas de producción con el objeto de promover el desarrollo de 
productos con mayor valor agregado por unidad de recursos -aparte de la necesidad de encontrar una nueva base de materias primas a partir de recursos renovables exigida por la demanda cada vez mayor de nuevos productos orgánicos-, le otorgan a la biotecnología un papel central dentro de esta tendencia del mercado mundial.

Si consideramos, por un lado, los procesos biotecnológicos que han podido ser impulsados en el sector petroquímico y, por otro, los avances logrados en procesos biotecnológicos (tanto los que se circunscriben a la denominada biotecnología tradicional como los que corresponden a la nueva biotecnología), y dadas las tendencias a integrarse que muestran las empresas biotecnológicas y las petroquímicas y químico-farmacéuticas, se han podido precisar tres grandes patrones potenciales de difusión tecnológica que convergen con las necesidades e intereses de las grandes empresas petroleras, químicas y farmacéuticas. Estos patrones son los siguientes:

A) Los productos biotecnológicos serán creados a partir de un producto existente en el mercado. El modelo de innovación de producto se impulsará debido al desarrollo tecnológico de la ingeniería genética y a la necesidad de impulsar una tecnología distinta que sustituya al petróleo, más que al impulso generado por las necesidades de la demanda.

Este patrón de difusión surge fundamentalmente tanto por el perfeccionamiento alcanzado en la tecnología de fermentación de la biomasa como por los avances logrados en el diseño y producción de enzimas y por el mejoramiento en la técnica de cultivo de tejidos. La utilización conjugada de estas tecnologías hará, finalmente, que los procesos de transformación de la biomasa puedan competir con los procesos de producción de la petroquímica básica y los de la industria química dentro de la perspectiva de sustituir parcialmente al petróleo, al carbón y al gas natural como bases de las materias primas del sector químico.

Se prevé que la utilización intensiva de la biomasa se impulse en dos direcciones. Abordaremos en seguida la primera línea de desarrollo: la producción de aquellos derivados primarios de hidrocarburos (etileno, benceno, etanol, butanol, acetaldehído, metano, acetona, ácido acético, diésel) tendientes a abastecer los mercados y que presentan una demanda sostenida para estos productos, en particular los mercados de fibras y resinas sintéticas, electrónica, solventes, farmacéutica y hules.

Se estima que la producción de tales derivados actúe, mediante la utilización intensiva de la biomasa, como un factor de estabilización del precio de los derivados primarios de hidrocarburos. En este sentido se considera que al emplear la biosfera y la geósfera de manera combi- 
nada se favorecerá una transición ordenada de utilización de recursos no renovables a renovables. Asimismo, esto permitirá una planeación más precisa del monto de las inversiones que se destinen al perfeccionamiento y reequipamiento de los grandes complejos petroquímicos, además de generar una estrategia de aceleración en lo que se refiere a la rotación del capital fijo de estos mismos complejos.

El control que las grandes empresas del sector petroquímico ejercen sobre la biotecnología de punta permite que dichas empresas utilicen otro tipo de materias primas y recursos con capitales fijos de igual valor para producir compuestos orgánicos sin riesgo de que competidores potenciales entren en sus mercados tradicionales. Utilizar petróleo y biomasa para producir derivados primarios permitirá un reparto de la demanda de éstos en función de la elasticidad en los precios de los insumos, lo cual propiciará nuevas relaciones insumoproducto entre el sector agrícola y el sector químico. En un primer momento, la disponibilidad de madera, desperdicios forestales, basura orgánica y algas marinas será la base de las materias primas fundamentales para transformar la biomasa.

Posteriormente, conforme avance la técnica de cultivo de tejidos, será posible ampliar la base de materias primas que habrán de utilizarse en la producción de compuestos orgánicos. Cabe resaltar que esta tendencia se acelerará si se utiliza el paquete tecnológico vigente en la agricultura, el cual se basa en la utilización, conjugada e intensiva, de fertilizantes e insecticidas químicos. En el corto plazo se impulsará la utilización de la biomasa para producir derivados petroquímicos intermedios a fin de incrementar el grado de independencia del sector químico respecto al sector petroquímico; o también se impulsará donde la escasez de recursos petrolíferos haga rentable utilizar esta tecnología.

El logro más significativo al respecto es la producción de etanol. Ya en 1982, cerca del $60 \%$ del consumo anual de Estados Unidos se obtenía mediante procesos fermentivos. Su producción, mediante esta tecnología, ha permitido formular otros procesos fermentivos que tienen como materia prima fundamental al etanol, por ejemplo los empleados para producir acetaldehído, butadieno, ácido acético y etileno. La obtención de estos productos - en particular la producción de etilenoa través de procesos fermentivos se ha difundido mucho porque la demanda mundial es significativa y cada vez mayor. En 1982 la demanda de este producto fue de 43 millones de toneladas métricas y para 1990 de 58152.5 millones de toneladas métricas al año (véase la gráfica 3).

El etileno se usa principalmente como producto intermedio de la industria química, y sus principales usos se remiten a la producción de polietileno, PVC, ésteres plásticos y etileno-glicol-óxido. La industria 


\section{Gráfica 3: Etileno \\ Capacidad de producción, oferta y demandas mundiales}

\section{MILLONES DE TONELADAS MÉTRICAS}

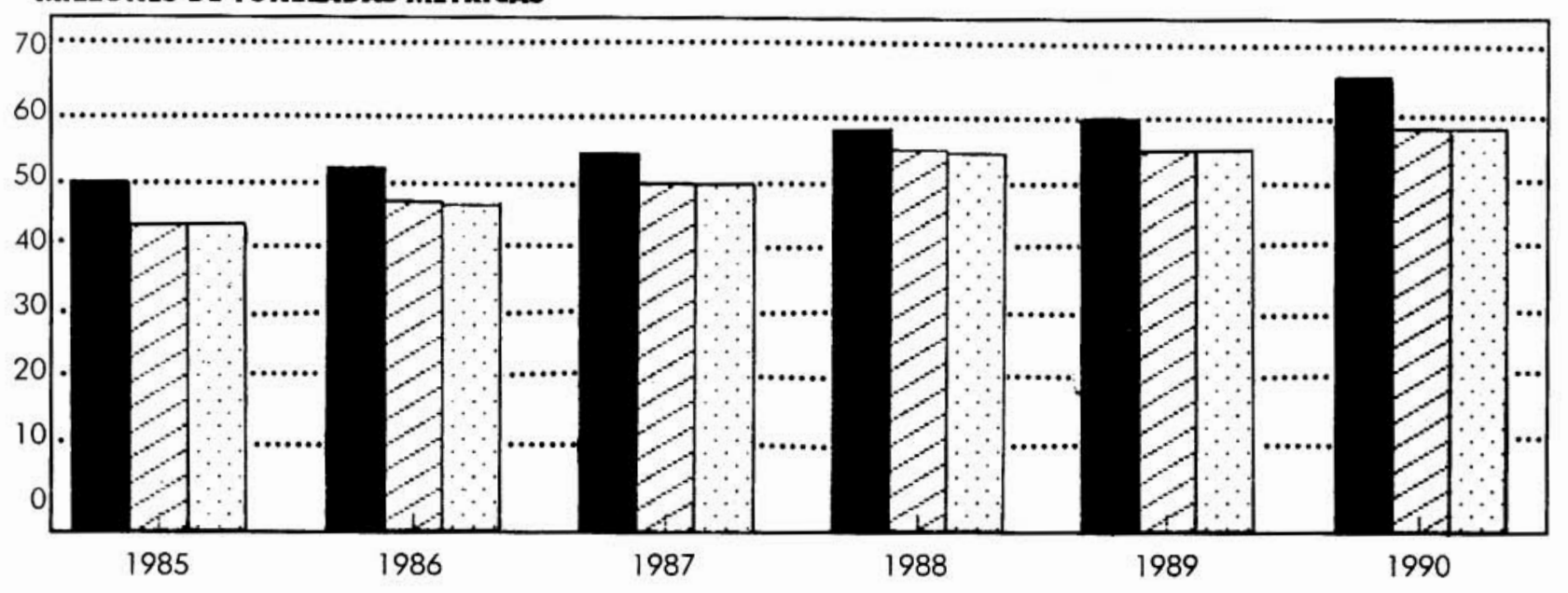

\section{AÑos}

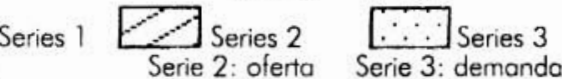

FUENTE: World Petrochemical, SRI INT. 
química produce los anteriores productos a través de las naftas, derivado del etileno, las cuales han subido de precio en el mercado mundial, por lo que en algunos países (Brasil y Alemania, por ejemplo) la producción de etileno, vía la fermentación de la biomasa, es tanto o más competitiva que la industria petroquímica tradicional.

La segunda línea, desarrollada para producir productos intermedios de hidrocarburos vía la transformación de la biomasa, se basa en la utilización de semillas ricas en aceites triglicéridos para producir diésel. Desde la primera crisis petrolera, en Estados Unidos se había planteado la posibilidad de producir diésel a partir de aceites triglicéridos con el objetivo de satisfacer su demanda en regiones agrícolas que presentaran altos rendimientos en producción de plantas ricas en aceites triglicéridos. Esta propuesta buscaba, en el largo plazo, liberar cerca de tres mil millones de galones anuales de diésel, lo que representa $13 \%$ de la demanda interna de ese combustible.

La propuesta fue acompañada de estudios de factibilidad económica y del desarrollo de procesos tecnológicos viables. Sin embargo, al bajar el precio del petróleo en los mercados internacionales la producción de este combustible a partir de semillas ricas en aceites triglicéridos resultó no competitiva en relación con la de los procesos tradicionales.

Pese a estos logros, la técnica de fermentación de la biomasa para producir productos intermedios petroquímicos de alto consumo mundial está lejos de poder competir con la industria petroquímica internacional. El problema fundamental es el bajo rendimiento de transformación de los microorganismos. La utilización de enzimas inmovilizadas es una opción tecnológica para crear reactores en continuo, lo que potencialmente puede ayudar a incrementar el nivel de transformación de la biomasa con una eficiencia energética óptima, pues gran parte de las reacciones enzimáticas pueden realizarse, en teoría, a temperatura ambiente.

$\mathrm{Si}$, como se estima, en el mediano plazo el precio de los hidrocarburos permanece estable - dada la sobreoferta que se manifiesta en el mercado-, será necesario aplicar las técnicas de mejoramiento genético en plantas con alto contenido de biomasa a fin de incrementar dicho contenido y reducir los requerimientos de fertilizantes e insecticidas. Esto podría disminuir el contenido de energía necesario para su crecimiento, con lo cual se lograría hacer competitivo el precio de estos insumos en relación con el petróleo.

Por último, los procesos de fermentación continua son una opción tecnológica que permite estructurar cadenas de procesos de fermentación y orientarlas hacia la producción de diversos productos petroquímicos intermedios. Estos procesos podrían permitir la utilización 
indistinta de materias primas diversas a fin de poder adecuar los procesos de producción para atender tanto los cambios imprevistos que puedan ocurrir en el abastecimiento de insumos como las modificaciones radicales que pueda sufrir la demanda.

El segundo patrón potencial de difusión de la biotecnología en el sector petroquímico se desplegará según la siguiente perspectiva:

B) Los nuevos productos se obtendrán a partir de la sustitución, con iguales características, de un producto ya existente en el mercado por un producto biotecnológico, el cual se elaborará mediante una tecnología de proceso que podría impulsar una nueva generación de innovaciones tecnológicas en el producto. El modelo de innovación del producto biotecnológico atenderá, en primer lugar, los requerimientos de la demanda y, en segundo, el impulso generado por la ingeniería genética; sin embargo, obedecerá fundamentalmente a la necesidad de impulsar la creación de nuevos productos mediante una tecnología alternativa que pueda independizar al sector químico del sector petroquímico.

Este segundo patrón de difusión se orientará a producir especialidades químicas con bajo volumen de consumo de productos petroquímicos intermedios que tienen un alto valor en los mercados internacionales. Los mercados considerados son: plásticos, textiles, lubricantes, detergentes, fibras y resinas sintéticas, cuya demanda ha aumentado considerablemente en el mundo en los últimos cinco años.

En conjunto, estos mercados consumen cerca de $10 \%$ del petróleo crudo producido anualmente en el mundo. Así, por ejemplo, en la industria de plásticos el mercado de espumas es ampliamente dominado por el poliestireno y los poliuretanos. En la actualidad, su dinámica innovadora se centra en crear poliamidas materiales, más resistentes a altas temperaturas e incluso no inflamables.

En este campo la biotecnología se aplica para poder extender y perfeccionar las técnicas de fermentación y, paralelamente, estructurar una matriz que utilice el poder catalítico de las enzimas y que permita generar especialidades químicas a partir de una utilización intensiva de materias primas ricas en compuestos orgánicos, como semillas ricas en aceites triglicéridos, madera y plantas ricas en fructuosa.

En la actualidad la programación genética permite diseñar enzimas. Estas proteínas pueden sintetizar una gran variedad de reacciones químicas con un alto grado de precisión, incluso mayor a la que se obtiene con los catalizadores utilizados para lograr la síntesis química. Sin embargo, a pesar de que las enzimas han sido ya utilizadas - de manera relativamente amplia-en actividades industriales (producción de alimentos, bebidas, medicamentos), presentan una gran desventaja en relación con los catalizadores utilizados en la síntesis química: su 
intolerancia a condiciones físicas extremas, tales como presión y temperatura altas, tensión mecánica, etcétera, y a la acción de solventes orgánicos y detergentes. Lo anterior, sumado a la baja participación de los costos de los catalizadores tradicionales en los costos totales de los productos petroquímicos, ha hecho que las enzimas no se utilicen ampliamente en los procesos industriales de la petroquímica.

Aún así, el alto grado de especificidad de la síntesis enzimática hace deseable que se aplique en procesos productivos que no requieren condiciones extremas para realizar su reacción. La posibilidad de formular procesos de fijación de enzimas para la hidrólisis de aceites triglicéridos ha sido explotada ya desde 1980 por empresas japonesas, las cuales lograron resultados altamente satisfactorios en cuanto al consumo de energía para realizar la reacción.

Las ventajas de ese proceso tecnológico radican en que se reducen tanto los costos de inversión de capital como las economías de escala vinculadas con la producción de compuestos químicos. Puede afirmarse que la tecnología enzimática tiene un vasto campo de desarrollo a partir de su utilización en los procesos hidrolíticos de aceites triglicéridos.

Actualmente, en Estados Unidos se han estudiado entre siete y ocho mil plantas ricas en aceites triglicéridos a fin de determinar su composición de ácidos grasos, el tipo de aceites que producen y algunas de sus características químicas y físicas más sobresalientes. Varias plantas estudiadas tienen un potencial comercial sumamente grande, ya que su estructura molecular permite la producción de polímeros nuevos, que cuentan con un amplio mercado.

En 1980 en Estados Unidos la producción de ácidos grasos vía la hidrólisis de semillas ricas en aceites triglicéridosos llegó casi a mil millones de libras. Los aceites triglicéridos presentan una amplia gama de usos industriales. El cuadro siguiente ilustra algunas de sus aplicaciones más importantes.

Estas plantas pueden ser producidas en ecosistemas muy variados, lo que les confiere una gran flexibilidad en cuanto a los requerimientos de capital necesarios para su producción intensiva. Los avances logrados en la técnica de cultivo de tejidos abren la posibilidad de aumentar el contenido de aceite de las semillas en estas plantas, con lo đúal mejoraría el rendimiento de productos químicos por hectárea cosechada. Por otra parte, estudiar la capacidad de síntesis de las enzimas será una herramienta de fundamental importancia para la modificación molecular de sus ácidos grasos, lo que permitiría obtener una nueva generación de polímeros.

El tercer patrón de difusión de la biotecnología en el sector petroquímico es el siguiente: 
CUADRO 2

USOS INDUSTRIALES DE IOS ACEITES TRIGLICÉRIDOS

\begin{tabular}{|c|c|c|}
\hline Productos & & Mercados \\
\hline Primarios Secundarios & Finoles & \\
\hline \multirow[t]{7}{*}{ 1. Ácidos grasos derivados } & Recubrimientos & \\
\hline & Nitrogenodos plásticos & \\
\hline & Ésteres Cosméticos & \\
\hline & Sales & Emulsificadores \\
\hline & Metálicas industriales & \\
\hline & & Química de textiles \\
\hline & & Aditivos alimentarios \\
\hline \multirow[t]{3}{*}{ 2. Glicerol } & & Farmacbutica \\
\hline & & Celofanes \\
\hline & & Explosivos \\
\hline \multirow[t]{6}{*}{ 3. Ácido azeloico } & Modificador & \\
\hline & & De politster \\
\hline & & Adhesivos \\
\hline & & Plastificantes \\
\hline & & Lubricantes \\
\hline & & Sintéticos \\
\hline \multirow[t]{3}{*}{ 4. Ácido pergamb́lico } & Cosméticos & \\
\hline & & Plastificante \\
\hline & & Aderezos \\
\hline 5. Furfuret & Fibras & sintéticas \\
\hline \multirow[t]{2}{*}{ 6. Alcoholes de furfural } & Solventes & \\
\hline & & Plastificantes de nilón \\
\hline
\end{tabular}

FUENTE: Elaboración propia a partir de "Biomass Process Handbook". 
C) Los nuevos productos se introducirán con el objetivo de abrir un mercado nuevo, en donde el proceso de innovación tecnológica se haya desarrollado a partir de una entidad química original.

La creación de nuevas entidades químicas ha sido impulsada fundamentalmente por la industria farmacéutica, la cual presenta un mayor nivel de independencia respecto a la industria petroquímica. Sin embargo, productos de amplio consumo mundial -como vitaminas y antibióticos- requieren utilizar productos petroquímicos intermedios, tales como isobuteno, formaldehído, acetona, acetileno, ácido acético.

La excesiva competencia entre las empresas y el control que ejercen sobre sus respectivos mercados ha impedido una mayor penetración de los productos biotecnológicos en el mercado farmacéutico. Resulta importante considerar lo anterior con el fin de evaluar las posibilidades reales de difusión de la biotecnología en el sector petroquímico.

\section{EVALUACIÓN Y CONCLUSIONES}

El análisis anterior pretende señalar que lograr la síntesis biológica a partir de la modificación genética de organismos vivos puede perfeccionar la tecnología de fermentación y la tecnología enzimática con el objeto de producir compuestos orgánicos generados con menor costo energético, escalas de producción inferiores a las existentes en el sector petroquímico tradicional y una base de materias primas renovables, lo que posibilitará un uso ordenado tanto de la geósfera como de la biosfera. Esto, por un lado, permitiría una mayor independencia de la industria química y farmacéutica con respecto a la industria petroquímica y, por otro, estructurar cadenas productivas con un mayor grado de flexibilización en las escalas de producción, así como reducir la participación de los costos de los energéticos por unidad de producto final.

Las nuevas necesidades del mercado mundial apuntan hacia un incremento significativo de la demanda de productos orgánicos de gran especificidad. Los avances logrados en la tecnología de recombinación del ADN, en especial el diseño de enzimas, hacen posible crear nuevos productos a partir de una tecnología alternativa, los cuales pueden obtenerse sin que se relacionen con las cadenas petroquímicas.

Por otra parte, al analizar los procesos de introducción de nuevos productos biotecnológicos en el sector farmacéutico se observan las grandes dificultades que tienen las empresas innovadoras para poder penetrar en mercados que les son relativamente ajenos, lo que se explicaría mediante la natural reacción de defensa con que actúan las empresas afectadas cuando buscan introducir en el mercado mercan- 
cías similares, producidas con técnicas alternativas o análogas. Una situación equivalente puede presentarse en el sector petroquímico, cuando se impulsen de manera profunda los procesos y productos biotecnológicos.

Así pues, para prever el éxito comercial de cualquier innovación tecnológica que se realice en el campo de la biotecnología (de producto o de proceso) tendrán que considerarse las posibles repercusiones en los encadenamientos productivos relacionados con la actividad en la cual se incorporó la innovación tecnológica.

Esto significard evaluar, al menos:

- la estructura del mercado en la que se interviene;

- los sistemas de control de la producción que tendrán que formularse cuando el proceso o producto se impulse a gran escala;

- las opciones posibles para sustituir los insumos ante cambios en los niveles de producción y cuando se generen productos mixtos;

- los requerimientos de mantenimiento del equipo que habrá de incorporarse;

- los gastos de investigación destinados a impulsar las innovaciones incrementales;

- los gastos relacionados con los controles de seguridad del proceso de trabajo y cuidado del medio ambiente; y

- por último, se estima imprescindible evaluar los efectos que pueda sufrir la estructura de consumo final.

\section{GLOSARIO}

1. Aromáticos. Compuestos químicos que contienen un aivillo de benceno.

2. Aceites triglicéridos. Estos aceites se forman por la mezcla de ésteres de glicerol y ácidos grasos. Se encuentran en gran cantidad en semillas de plantas tales como soya, girasol y algodón.

3. Anticuerpo monoclonal. Anticuerpo producido por una población de células genéticamente idénticas. Dichos anticuerpos sólo reconocen a un determinado tipo de antígeno.

4. Biomasa. Toda sustancia orgánica que resulta de la conversión fotosintética de la energía solar.

5. Cultivo de tejidos. Crecimiento de células en un medio artificial. 
6. Enzimas. Proteínas complejas producidas por células vivas que catalizan reacciones bioquímicas específicas.

7. Enzimas inmovilizadas. Fijación de enzimas en un soporte insoluble a fin de facilitar reacciones en continuo durante largos períodos sin necesidad de retirar el catalizador.

8. Fermentación. Transformación enzimática de sustratos orgánicos, generalmente acompañada de producción de gas; contraparte fisiológica de la oxidación, que permite a ciertos organismos vivir y crecer en ausencia de aire.

9. Hidrolisis. Reacción química que agrega agua en un enlace con el objeto de romperlo.

10. Hormona. Sustancia química que se halla en organismos vivos superiores y cuya función es transmitir mensajes que regulan el comportamiento celular.

11. Polímero. Molécula lineal, ramificada en subunidades repetidas.

12. Síntesis biológica. Producción de un compuesto químico mediante síntesis o degradación causada por un organismo vivo.

13. Sintesis química. Producción de un compuesto químico mediante síntesis o degradación causada por un compuesto químico.

\section{BIBLIOGRAFÍA}

Fuentes, Sergio, y Díaz, G. 1988. Catalizadores, żla piedra filosofal del siglo Xx? México: Consejo Nacional de Ciencia y Tecnología.

Kasuya, Fujime, y Hisao, Kibune. 1987. "Cambios en la estructura económica y la demanda de energía en Japón, 1973-1984". Comercio Exterior. Vol. 37. Núm. 10, octubre, pp. 865-873.

Kato Maldonado, Luis. 1989. "La nueva bioindustria". Análisis Economico. Universidad Autónoma Metropolitana, Azcapotzalco.

Laveque, François. 1989. "Los productos biotecnológicos en la prueba del mercado". Mundo Científico. Vol. 10. Núm. 100, pp. 276-285.

Lunzer, Francesca. 1988. "Cash Crisis Creates Biotech Alliances". High Technology. Abril, pp. 18-23.

Pangtay, Chow. 1987. Petroquímica y sociedad. México: Fondo de Cultura Económica-Secretaría de Educación Pública-Consejo Nacional de Ciencia y Tecnología.

Pratten, C.F. 1971. Economies of Scale in Manufacturing Industry. Cambridge: Cambridge University Press.

Pretis, S. 1987. Biotecnología. Barcelona: Salvat. 
Secretaría de Energía, Minas e Industria Paraestatal. 1966. Programa Integral de Fomento a la Industria Petroquímica. México.

Shultz, Eugene Jr., y cols. Fuel and Chemicals from Oilseed. Washington D.C.: Westvi Empress.

Technical Insight. 1983. "Biomass Process Handbook". Nueva Jersey (mimeografiado).

Teece, D. 1976. The Multinational Corporation and The Resource Cost Of International Technology Transfer. Cambridge, Mass.: Ballinger.

Tucker, B. 1985. "Protein to order". High Technology. Diciembre, pp. 26-34.

White, Howard L. 1986. Introduction to Industrial Chemistry. Nueva York: Wiley Interscience. 


\title{
La biotecnología aplicada a la producción ganadera en México
}

\author{
MICHELLE CHAUVET, YOLANDA MASSIEU, \\ YOLANDA CASTAÑNEDA Y ROSA ELVIA BARAJAS*
}

A mediados de los años ochenta, cuando muchos de los resultados de las investigaciones en biotecnología aún no se comercializaban, se hicieron afirmaciones a menudo generalizadoras en torno a su aplicación y consecuencias. Por ello, ahora que han pasado algunos años y que podemos encontrar diversos productos biotecnológicos en el mercado, el estudio por producto y región permite llegar a conclusiones más precisas sobre los efectos socioeconómicos de la biotecnología en México. Presentamos en seguida un avance del estudio sobre sus aplicaciones en la producción pecuaria, en concreto la que se emplea para producir leche y carne de ave en Aguascalientes.

\section{LA BIOTECNOLOGIAA APLICADA EN LA GANADERIA: PROMESAS Y REALIDADES}

Desde hace más de una década, las posibilidades que ofrece la biotecnología han sido múltiples y los resultados en laboratorio o en los experimentos resultan muy alentadores. Sin embargo, al momento de sus aplicaciones productivas se presenta una serie de obstáculos que rebasa los niveles técnicos y les restan potencialidades.

Es ampliamente conocido que a raíz de las promesas de la biotecnología, las acciones de las compañías dedicadas a esta materia subieron espectacularmente en la Bolsa de Valores de Estados Unidos. Sin embargo, al "retrasarse" los beneficios anunciados surgió el desencanto por ese tipo de acciones (Savitz y Wyatt: 1989). Un estudio

- Profesoras investigadoras del Departamento de Sociología, UAM-Azcapotzalco. Queremos manifestar nuestro agradecimiento al doctor Carlos Boy, quien nos prestó su valiosa colaboración para poder realizar el trabajo de campo. 
prospectivo del Congreso de ese país afirmaba, a mediados de los ochenta, que los cambios más promisorios se esperaban en el sector ganadero, más que en el agrícola (Arroyo y cols., 1989), lo cual es de alguna manera cierto; pero la realidad socioeconómica ha impuesto su sello a dicho avance. Algunos productos comerciales derivados de la investigación biotecnológica se han topado con reticencias tanto de productores como de consumidores, como por ejemplo las hormonas del crecimiento para bovinos de leche y carne.

En otras palabras, al inicio de los años noventa todo indica que la biotecnología no se perfila como el gran negocio del siglo, según pensaron algunos, y que no basta vencer los obstáculos técnicos y de prueba en campo para su aplicación rutinaria.

Los avances tecnológicos no se han incorporado del todo en la estructura productiva en esta etapa de reactivación de la economía capitalista, después de la grave crisis de los ochenta.

Aun cuando las nuevas tecnologías se han desarrollado e incluso aplicado en el terreno productivo, no constituyen todavía la base técnica predominante en el mundo capitalista. Es decir, se impulsa ya, pero todavía de manera localizada, sin alcanzar su generalización cabal. Una serie de barreras y dificultades se han opuesto al uso masivo de la tecnología. La propia crisis genera la base técnica para el nuevo proceso de trabajo, pero origina también los obstóculos para su proliferación (Rubio: 1991, 40).

Este fenómeno se presenta, por ejemplo, en la hormona del crecimiento para la producción lechera, que la Monsanto comercializa como lactotropina.

En relación con la seguridad sanitaria del consumidor de leche de vacas tratadas con HCB (hormona de crecimiento bovino), es conveniente señalar que esta hormona no es biológicamente activa en el humano y que, debido a su naturaleza proteica, es susceptible de ser digerida en el canal gastrointestinal y servir, en todo caso, como una fuente, aunque pequeña, de aminoácidos (Trujillo y cols., 1990:18).

Este producto recibió la aprobación de la Administración de Alimentos y Medicamentos (FDA) de Estados Unidos por considerarlo inocuo para el organismo humano. Más tarde, sin embargo, fue prohibido por el Congreso estadunidense por la presión de los productores de leche, en especial los de Wisconsin. La Comunidad Europea tampoco ha permitido su uso (Kleese, 1988). 
el sector de productores en el que las instituciones concentran sus servicios de asesoría (estratos con más de 161 cabezas) manifiestan su desinterés en recibirla, por contar quizás con otras opciones, o por cierta reticencia a innovar (Manrubio y cols., 1989:35).

En los ranchos dedicados a la producción de becerros para la exportación, el nivel tecnológico también es bajo y subsiste el carácter extensivo-extractivo.

Por el lado de la estructura productiva, las mencionadas son las bases tecnológicas de las cuales hay que partir para la modernización ganadera. En este marco se explica que los productos biotecnológicos en México se apliquen en las explotaciones de ganadería intensiva y aún no penetren en la extensiva.

\section{LA AVICULTURA}

La ganadería menor —avicultura y porcicultura - se caracteriza por la alta concentración de sus productores, con presencia de capital extranjero mediante empresas transnacionales, y porque se desarrolla con una tecnología intensiva; de ahí que se le denomine ganadería "industrial".

La avicultura "industrial" es anterior a la porcicultura, pero acusa una mayor dependencia del exterior en materia de insumos. Aunque la producción nacional es eficiente - sólo en pocas ocasiones es deficitaria-, el Estado ha otorgado permisos por ciertas temporadas para importar came de pollo fresca y congelada, así como aves de corral. Esta medida antiinflacionaria ha abierto las puertas a esos productos estadunidenses.

Si bien se ha logrado regular el abasto y el precio internos, el beneficio mayor es para el exportador: el Departamento de Agricultura de Estados Unidos prohíbe refrigerar las aves más de 40 días y el mercado mexicano es una salida para sus excedentes. Otra ventaja radica en la preferencia del consumo norteamericano por la carne blanca, es decir la pechuga, cuyas ventas pagan los costos de producción del pollo. Así que el sobrante se transforma en "desperdicio" que se puede colocar del otro lado de la frontera, obteniendo así un ingreso extra (Chauvet, 1990).

\section{LA SALIDA DE LA CRISIS}

No es casualidad que la biotecnología se esté introduciendo en los inicios de los noventa, cuando se perfila la salida de la crisis de ciertos sectores productivos, entre ellos el ganadero. Por la información que 
nosotros. ${ }^{2}$ Hasta el momento la aplicación de algunos productos resultado de la biotecnología se está llevando a cabo en el país en las explotaciones intensivas. Aunque el caso que nos ocupa es la producción lechera y avícola en la zona aledaña a la ciudad de Aguascalientes, consideramos pertinente introducir una breve caracterización de dichas ganaderías en el país.

\section{LAS CONDICIONES PRODUCTIVAS DE LA GANADERÍA}

La modernización ganadera se inscribe en la forma que ha tomado el desarrollo ganadero del país, el cual ha tenido dos modalidades: la intensiva, representada por la porcicultura, la avicultura y la producción lechera, y la extensiva, que es la ganadería bovina de came (Chauvet, 1989).

La ganadería intensiva es la que tiene control sobre todas las variables productivas: la alimentación del ganado es balanceada y uniforme durante todo el año, se previenen las enfermedades del hato y la reproducción no se deja a la espontaneidad sino que, mediante la inseminación artificial, se mantiene o mejora la calidad genética. La producción lechera estabulada, la de engorda en corrales y la avicultura y porcicultura comerciales se inscriben en esta clasificación y su nivel tecnológico es semejante al de los países industrializados, cuyos respectivos modelos productivos se han importado en paquete.

La ganadería bovina extensiva, ya sea de carne, de leche o de doble proposito, está sujeta a los designios de la naturaleza, y los controles genético y sanitario son mínimos o inexistentes. El problema fundamental es la alimentación, que depende de los pastos naturales y ellos, a su vez, del régimen de lluvias. Esta situación es común a la ganadería tanto del norte árido y semírido como a la del trópico.

Lós rasgos más sobresalientes del nivel tecnológico de la ganadería bovina del trópico son:

i) los predios ganaderos tienen un bajo nivel de adopción tecnológica;

ii) la estrategia de asistencia técnica se ha dirigido de manera fundamental a los aspectos sanitarios;

iii) $86.2 \%$ de los ganaderos que reciben asesoría técnica llevan a lo sumo seis años o menos de recibirla, y

iv) $51 \%$ de los productores no recibe ningún tipo de sevicios de asesoría, aunque la mayoría de ellos, concentrada en los estratos chicos y medios, manifiestan su interés en contar con asistencia técnica. Paradójicamente,

${ }^{2}$ Idem. 
el sector de productores en el que las instituciones concentran sus servicios de asesoría (estratos con más de 161 cabezas) manifiestan su desinterés en recibirla, por contar quizás con otras opciones, o por cierta reticencia a innovar (Manrubio y cols., 1989:35).

En los ranchos dedicados a la producción de becerros para la exportación, el nivel tecnológico también es bajo y subsiste el carácter extensivo-extractivo.

Por el lado de la estructura productiva, las mencionadas son las bases tecnológicas de las cuales hay que partir para la modernización ganadera. En este marco se explica que los productos biotecnológicos en México se apliquen en las explotaciones de ganadería intensiva y aún no penetren en la extensiva.

\section{LA AVICULTURA}

La ganadería menor - avicultura y porcicultura - se caracteriza por la alta concentración de sus productores, con presencia de capital extranjero mediante empresas transnacionales, y porque se desarrolla con una tecnología intensiva; de ahí que se le denomine ganadería "industrial".

La avicultura "industrial" es anterior a la porcicultura, pero acusa una mayor dependencia del exterior en materia de insumos. Aunque la producción nacional es eficiente - sólo en pocas ocasiones es deficitaria-, el Estado ha otorgado permisos por ciertas temporadas para importar came de pollo fresca y congelada, así como aves de corral. Esta medida antiinflacionaria ha abierto las puertas a esos productos estadunidenses.

$\mathrm{Si}$ bien se ha logrado regular el abasto y el precio internos, el beneficio mayor es para el exportador: el Departamento de Agricultura de Estados Unidos prohíbe refrigerar las aves más de 40 días y el mercado mexicano es una salida para sus excedentes. Otra ventaja radica en la preferencia del consumo norteamericano por la carne blanca, es decir la pechuga, cuyas ventas pagan los costos de producción del pollo. Así que el sobrante se transforma en "desperdicio" que se puede colocar del otro lado de la frontera, obteniendo así un ingreso extra (Chauvet, 1990).

\section{LA SALIDA DE LA CRISIS}

No es casualidad que la biotecnología se esté introduciendo en los inicios de los noventa, cuando se perfila la salida de la crisis de ciertos sectores productivos, entre ellos el ganadero. Por la información que 
presentamos en seguida, se puede afirmar que a mediados de los ochenta observamos una crisis ganadera que se reflejó en las disminuciones de la producción y del hato ganadero (véanse los cuadros 1 y 2).

La pérdida de rentabilidad de la actividad pecuaria tuvo causas externas, como la baja del ingreso de amplias capas de la población que las obligó a disminuir o eliminar el consumo de alimentos de origen pecuario; pero también tuvo causas internas, como el encarecimiento de los créditos que llevó a muchos productores a abandonar sus actividades.

El resultado de esta etapa fue la concentración de la actividad en los productores cuyos montos de inversión les permitieron sortear los problemas financieros apoyados en el volumen de su producción. Quizás el rasgo más sobresaliente sea que dichos productores son los que están integrados; el haberse agrupado para obtener sus insumos y buscar mercados, sin intermediación, los ha sostenido en la actividad. Los últimos seis años pueden considerarse como una "depuración" de productores: permanecieron quienes tienen mejores condiciones de producción.

Para el caso de la producción lechera podemos citar a los ganaderos de La Laguna, a los Ganaderos Productores de Leche Pura (ALPURA) y, de menores dimensiones, al Grupo Industrial Ganadero de Aguascalientes (GILSA).

\section{APLICACIÓN DE LA BIOTECNOLOGÍA EN LA GANADERÍA DE AGUASCALIENTES ${ }^{3}$}

Uno de los rasgos que han caracterizado a la ganadería nacional, aun a la intensiva, es la resistencia de los ganaderos a las innovaciones. Sin embargo, en las visitas que realizamos a diversos establos en Aguascalientes los entrevistados coincidieron en que hace 10 o 15 años era raro que los ganaderos tuvieran un médico veterinario de planta o aceptaran introducir modificaciones. Ahora las cosas han cambiado, en buena medida porque quienes están al frente de los ranchos son los hijos de los ganaderos, que son médicos veterinarios o ingenieros agrónomos, o que en todo caso tienen una mentalidad más abierta que sus padres.

Las condiciones productivas de los establos guardan un nivel tecnológico medio porque a pesar de contar con ordeñadoras meḉnicas y asesoría técnica permanente, varias de sus instalaciones son rústicas, como los corrales con piso de tierra que en tiempo de lluvias hacen que el lodo llegue hasta las ubres de las vacas.

${ }^{3}$ La información que se presenta en este apartado fue recabada durante la visita que realizamos en agosto de 1991 a varios productores de la cuenca lechera de Aguascalientes. 
En la región es frecuente la integración de la agricultura y la ganadería. Si las explotaciones lo permiten, el ganadero produce parte del alimento del ganado, que almacena en silos, y cada vez es más generalizado el registro de producción de cada vaca mediante un programa de computadora.

\section{LA INTRODUCCIÓN DE PRODUCTOS BIOTECNOLOGGICOS}

Entre las empresas dedicadas a fabricar productos biotecnológicos, la ALLTECH, Inc. y la Monsanto, en México a través de distribuidores como APLIGEN, ${ }^{4}$ comienzan a crear un mercado sólido que no sólo ofrece los productos sino también la asesoría necesaria para su uso en zonas específicas.

Uno de estos polos de atracción para las empresas transnacionales es el estado de Aguascalientes que sobresale por su producción lechera y su organización empresarial en los sectores ganadero y avícola.

APLIGEN es una distribuidora orientada a la nutrición animal que proporciona opciones "no antibióticas", como enzimas, levaduras y bacterias vivas, así como los metabolitos de dichos microorganismos. Estos productos se denominan probióticos ${ }^{5} y$, si se utilizan adecuadamente, ofrecen al productor pecuario un gran potencial para mejorar sus programas alimenticios (APLIGEN, 1991:1).

APLIGEN cuenta con una serie de productos para el ganado lechero que ya se utilizan en las zonas ganaderas. Cabe destacar los siguientes:

-Acid-Pak beneficia al rumiante porque mantiene normales y constantes la población de su flora bacteriana y las enzimas digestivas. Además, mejora la conversión alimenticia y reduce los diarreas en los lactantes. En general es una buena ayuda en la transición de la cría lactante a rumiante.

-YEA-SACC optimiza los procesos de digestión de la vaca por ser un producto con base en cultivos de levadura: aumenta la producción y el contenido de grasa y proteína de la leche, mejora las condiciones corporales del animal y disminuye sus trastornos digestivos; además, se obtienen mayores ganancias de peso en la engorda.

- SIl.All va a representar un gran ahorro en pérdidas de silos, por lo que conviene dejar claro qué es un silo y cuáles son los beneficios que APLIGEN atribuye a este probiótico.

${ }^{4}$ APIIGEN es en México el distribuidor exclusivo de AIITECH, y juntas han desarrollado y aplicado los productos a base de microorganismos vivos en México desde 1986.

5 "El concepto de probiótico se fundamenta en la teoría de que mediante la ingestión de microorganismos benéficos es posible controlar los microorganismos patógenos, lo que es conocido como el principio de exclusión competitivo" (APLIGEN, 1991: 2). 
El término "ensilado" en alimentación animal sirve para describir un producto que es resultado de la conservación mediante fermentación de un material de tipo forrajero (maíz, alfalfa, avena, cebada, rye grass, por mencionar los más utilizados). El principal objetivo de ensilar el forraje es conservarlo mediante un proceso rentable que permita:

—evitar la pérdida de sus nutrientes;

- conservar su calidad, y

—aprovechar sus temporadas de alta producción.

El proceso de ensilaje es una fermentación de tipo anaeróbica. Hay muchos factores que afectan la eficiencia de este proceso. La descomposición del forraje es por naturaleza, casi inmediata, por lo que retrasarla es primordial para conservar sus nutrientes. Además, el aire, el calor y la lluvia causan pérdidas y propician la aparición de bacterias y hongos que aceleran la descomposición.

Los actuales aditivos como los probióticos ayudan a la naturaleza a realizar una fermentación rápida y eficiente del forraje. A diferencia de los aditivos químicos que sólo ayudan a conservar el silo y en ocasiones alteran el sabor del ensilaje, el SIL-ALL es un inoculante de ensilados (productor de ácido láctico) que:

- Satisface todos los requerimientos de un inoculante biológico y seguro.

- Controla y dirige la fermentación de ensilado.

- Disminuye la pérdida de azúcar y de proteína, lo cual mejora la calidad del ensilado.

- Aumenta la eficiencia alimenticia de los animales, lo que se traduce en mayores utilidades.

- Su aplicación es fácil y no requiere de personal especializado.

Los siguientes probióticos aún no se comercializan en la región de Aguascalientes.

- All-LAC: primer probiótico a base de lactobacilos y estreptococos en altas concentraciones, recomendado para animales recién nacidos.

- All-LYTE: paquete de electrólitos balanceados biológicamente. Contiene electrolitos, bacterias benéficas, enzimas, fuente de energía y absorbentes 
de toxinas. Se utiliza en casos de deshidratación y como ayuda contra las diarreas. Se recomienda en temporadas calurosas.

- MEGALAC, del laboratorio Arm \& Hammer: grasas protegidas que complementan los requerimientos energéticos del rumiante y grasas vegetales cubiertas con sales de calcio que incrementan la energía con menos volumen. ${ }^{6}$

\section{GRUPO INDUSTRIAL DE LA LECHE}

El Grupo Industrial de la Leche (GILSA), organización ganadera establecida hace 18 años en Aguascalientes, ha permitido a APLIGEN llegar a los productores por las siguientes razones:

GILSA cuenta con una planta forrajera, una unión de crédito, tres plantas pasteurizadoras, una farmacia veterinaria y cinco empresas de servicios para los ganaderos. Además, ha incursionado en derivados lácteos como el queso, la mantequilla, la crema. El paso siguiente será ampliar la capacidad de la planta forrajera para no limitarse a dar servicio a los socios, sino también comercializar sus concentrados.

Sus avances en organización le permiten absorber $70 \%$ de la producción de leche en la zona, con un pago por litro de 1050 pesos. Ello representa un beneficio para los productores que logran costos de 750 pesos por litro cuando las explotaciones ganaderas invierten en productos innovadores como los biotecnológicos. A pesar de este margen de beneficio, los ganaderos están inconformes por la persistencia del control de precios en sus productos. En cambio, quienes no pertenecen a GILSA, como los ejidatarios, dependen de la recolección que realiza la NESTLÉ, que compra el litro a 850-870 pesos.

En julio de 1989, la planta forrajera de GILSA comenzó a incluir en algunos de sus concentrados ${ }^{7}$ el producto biotecnológico MEGALAC. En la actualidud, $60 \%$ de los ganaderos de la zona consume el concentrado, pues dicho complemento permite mantener el nivel de producción de la leche en la época de lluvias, cuando los silos tienden a ser insuficientes. Los productores más eficientes usan de modo cotidiano este tipo de productos.

${ }^{6}$ La información de los distintos productos que distribuye APIIGEN fue obtenida de los folletos informativos para ganaderos.

7 Los concentrados de GIISA contienen alrededor de 50\% de granos, 35\% de oleaginosas y pastas, $7.5 \%$ de melaza y $2.5 \%$ de minerales. La tecnología para la preparación del concentrado es bastante simple. La materia prima absorbe $88 \%$ del precio del producto, con un margen de utilidad mínimo de 4 ० 5 por ciento. Los demás costos se encuentran en la administración y fabricación. Ello obedece a que no es una empresa comercial sino una unión ganadera que beneficia a sus socios; si los costos suben, no se reflejan en el precio del concentrado. 
Asimismo, la farmacia veterinaria guarda una estrecha relación con el promotor de APLIGEN, que presta asesoría para el mejor uso de los probióticos sólo a los productores de la zona que compran el producto en la farmacia de GILSA.

La relación entre el promotor de APLIGEN y GILSA agiliza el trabajo con los productores, ya que permite romper paulatinamente los prejuicios ante estos nuevos productos, pues en la unión ganadera se realizan pruebas para demostrar su conveniencia. Sin embargo, no es sólo el uso de un producto biotecnológico lo que logrará aumentar la productividad en las explotaciones ganaderas, sino el cambio global en la alimentación del rumiante, la sanidad, el manejo del ganado, la infraestructura, etcétera. Dicho sea de paso, en Aguascalientes no se ha introducido biotecnología en materia de sanidad y vacunas.

Para los empresarios ganaderos de esa entidad federativa, el uso de probióticos es una experiencia nueva que se está generalizando. El MEGALAC se utiliza de manera directa durante seis meses cuando tienen sus propios granos; los otros seis viene incluido en el concentrado (Rancho "El Gigante", 1991).

También tiende a aumentar el uso del YEA-SACC y el ACID PAK, sobre todo entre las becerras recién nacidas, cuyo desarrollo resulta mejor que el de los rumiantes que se alimentan con concentrados comerciales.

Sin embargo, persiste la resistencia al cambio. Sólo $50 \%$ de los ganaderos de Aguascalientes acepta de buen grado los probióticos; los demás se quejan de que los productos son caros y no analizan las ventajas que una mayor inversión proporciona tanto en productividad como en ganancia.

Asimismo, la falta de experiencia de los trabajadores y el manejo tradicional del ganado obstaculizan la aplicación correcta de los probióticos, cuyo uso no es complicado y sólo requiere de constancia y limpieza.

Otro producto biotecnológico que ha despertado polémica es la lactotropina o somatotropina bovina, hormona cuya función es desarrollar el tejido mamario, lo que da a la ubre mayor capacidad de producción de leche. Hay tres opiniones frente a su empleo:

1. La de ciertas organizaciones de consumidores que temen sus efectos tanto en el ser humano que bebe la leche de vacas tratadas con ella como en el hato mismo.

2. En México la de grupos como ALPURA, que sin dar una explicación clara restringe su introducción.

3. La de quienes argumentan que el aumento en la producción lechera reduciría la importación de leche en polvo, con lo cual se 
afectaría a los sectores sociales pobres que se benefician con el lácteo subsidiado, como es el caso de LICONSA.

La lactotropina no se puede aplicar de manera indiscriminada; hay una serie de condiciones que se deben cumplir para que sea recomendable aplicarles la hormona:

- La vaca debe tener cierta condición corporal.

- No debe ser tratada después de los seis meses de estar preñada, ya que no resulta redituable para la producción de leche. Se recomienda proseguir con el tratamiento 99 dias posteriores al parto.

- Para que el programa de lactotropina sea rentable, hay que elegir a las altas productoras. Obviamente su alimentación debe corresponder a su incremento productivo.

- Se recomienda que $30 \%$ de las vacas de un establo participen en el programa durante todo el año, según indicaciones de los fabricantes.

La lactotropina es elaborada por los laboratorios Monsanto y ELANCO. En Aguascalientes, la Monsanto ha comenzado a distribuirla: $20 \%$ de los ganaderos la ha probado, pero sólo $8 \%$ la utiliza con constancia. El aumento diario en la producción de leche por vaca oscila entre 3.5 y 6 litros, siempre y cuando se trate de explotaciones ganaderas con buenas condiciones de sanidad, alimentación y manejo.

Es probable que un sector de los ganaderos no aplique la lactotropina por desconocer cómo se usa y cuáles son sus beneficios. Sin embargo, hay otro que aún no la introduce porque mediante métodos convencionales ha logrado promedios de producción hasta $20 \%$ mayores que hace diez años, por lo que no ve la necesidad de emplearla. Además, señala que las vacas bajo tratamiento requieren de mayor alimento, lo cual reduce los beneficios, o que se "acaban" más pronto. Esto no resulta del todo incorrecto, pues la alimentación requiere de ciertos ajustes para que el animal produzca más en función de un suministro mayor de energía y no a costa de gastar su energía de mantenimiento.

Aún persiste entre ciertos ganaderos la idea de que los hatos grandes son los que garantizan una mayor producción. Ello les genera reticencias a la innovación, por el temor de que sus vacas se "gasten" más rápido.

Un caso específico del uso de la lactotropina lo encontramos en Aguascalientes, en el rancho "El Gigante", donde se ha llegado a aplicar en 45 vacas con resultados positivos. Para su selección imperaron dos criterios: a) que fueran altas productoras; aun en períodos 
de lactancia (de 18 a 22 It. por día), y b) que, después de parir, hubiesen reducido su producción (14-12 It. por día). Una vez elegidas se las programa para ser inyectadas cada 14 días.

El responsable del rancho "El Gigante" considera que $30 \%$ del total de las vacas de un establo es un porcentaje demasiado elevado; él recomienda incluir en el programa un promedio de 50-60 de un establo de 300, según la época del año. En general se han logrado incrementos de leche de 3.5 a 5 litros por vaca, con buenos márgenes de utilidades a pesar del precio de la lactotropina.

GILSA señala que el uso generalizado de tal hormona en Aguascalientes ayudaría a disminuir la deficiencia en la producción lechera y que no se enfrentarían problemas de sobreproducción, ya que se cuenta con un mercado y una distribución eficiente.

Los ganaderos de la zona alegan que no emplean la hormona debido al costo que ocasiona; sin embargo, al realizarse la relación de cuánto representa el producto en el costo se determinó que con dos litros de leche diarios se paga la dosis de hormona.

Otra biotecnología que está revolucionando la línea genética del hato es el trasplante de embriones, que a principios de los años ochenta representó una mala experiencia para Aguascalientes. Promovida por organismos estatales y realizada con técnicas quirúrgicas, los resultados obtenidos por el uso de dicha técnica fue un aumento de $10 \%$ de fertilidad; cabe señalar que se trataba de animales en malas condiciones en materia de alimentación, sanidad, etcétera.

En cambio en 1987 la Secretaría de Agricultura y Recursos Hidráulicos llevó a cabo un programa de trasplante de embriones con técnicas más modernas y los ganaderos que participaron obtuvieron mejores resultados.

En uno de los casos, de diez trasplantes, siete llegaron a buen término. Fueron animales que tuvieron un trato normal, pero eran vacas superiores a sus contemporáneas que se procrearon de la manera tradicional (Rancho "El Gigante", 1991). En el caso del Rancho "La Estrella", de diez becerros que se lograron del transplante sólo uno sobrevivio.

En la actualidad la mayoría de los ganaderos de la zona utiliza la técnica de inseminación artificial con el objeto de mejorar la calidad genética del hato, según la importación del semen de los toros de Estados Unidos. Sólo algunos empresarios contratan los servicios de laboratorios de ese país para el trasplante de embriones con un costo aproximado de 400 mil pesos; obtienen un animal superior, pero requiere de mejor alimentación y un manejo más delicado.

Como un caso aislado, el Rancho "El Durazno" planea levantar la infraestructura necesaria para los trasplantes de embriones y contar con 
el personal especializado. Al principio esto representará una fuerte inversión, pero a largo plazo conseguirá no sólo su independencia en la técnica sino también reducciones de costos y mejoras en su hato. Los ganaderos que se dediquen a todo el proceso de trasplantes de embriones tendrán ahorros aproximados de 75 a 80 por ciento.

GILSA considera que en México no se cuenta con estudios de genética serios ni los ganaderos realizan esfuerzos para determinar qué tipo de toro trabajar y con qué objetivos, a fin de superar las explotaciones ganaderas.

Un aspecto que favorece al empresario ganadero de la zona es la posibilidad de sembrar parte de la alimentación del ganado y lograr una mejor conservación de su silo al aplicarle SIL-ALL. En Aguascalientes se comenzó a usar hace apenas un año. GILSA ha realizado observaciones de campo de las cuales se desprende que hay una marcada diferencia entre los silos tratados con SIL-ALL y los que no emplean este producto: los alimentos de los primeros tienen un porcentaje más alto de proteína, y en términos generales mayor calidad. El costo de su aplicación es relativamente bajo, pues se traduce en una mayor producción lechera y menores pérdidas en los silos. La respuesta de los ganaderos a este nuevo producto es todavía bajo: sólo 15\% lo utiliza.

Otro elemento que fortalece la zona ganadera es el uso de promotores del crecimiento en pasto y alfalfa para complementar el alimento del ganado. Asimismo, algunos ganaderos buscan diversificar sus ranchos, ya sea incursionando en la avicultura o bien, como en el caso del rancho "Ojo Zarco", sembrando ajos también mediante promotores del crecimiento ${ }^{8}$ de manera constante.

\section{USO DE LA BIOTECNOLOGÍA EN AVES}

Otra rama productiva que se ha favorecido por los cambios tecnológicos es la avícola en materia de vacunas, genética, alimentación y probióticos. En Aguascalientes la avicultura experimenta transformaciones radicales. Ya no son los simples ranchos familiares de autoconsumo o de mercado interno, sino que tienden a ser empresas tecnificadas donde los empresarios hacen uso de los avances de la biotecnología. Se han integrado varias grarijas que abarcan distintas fases del proceso. Por ejemplo, NUTRYAVES se dedica a la engorda, y "Pollitos de Aguascalientes" es la incubadora que le proporciona los pollitos; en ambas se utilizan probióticos.

8 Promotores del crecimiento significa: "controlar el crecimiento y desarrollo de plantas en el tiempo deseado, o alterar la composición de los productos agrícolas", López y Quintero, "Perspectivas internacionales de la biotecnología agrícola", en ¿Biotecnología para el progreso de Méxicoź, p. 52. 
En cuanto a genética las empresas avícolas de la zona dependen de la tecnología proveniente de Alemania, Holanda, Francia, Inglaterra y Estados Unidos. Esta dependencia es constante e irremediable mientras no se tengan líneas genéticas propias. Las progenitoras son aves que han tenido transformaciones genéticas y que han heredado a las aves reproductoras una serie de beneficios para el empresario avícola (por ejemplo, el pollo obtiene un crecimiento precoz con mayor volumen de carne). Sin embargo, los cambios en los genes propician problemas de salud en el animal.

A la séptima semana el pollo logra un peso de $2.300 \mathrm{~kg}$, mientras que antes lo obtenía en la décima. Sin embargo, su mayor peso en cantidad de carne no corresponde a sus órganos internos ni a su esqueleto, por lo que sufre problemas cardiovasculares propios de la enfermedad conocida como ascitis.

Los productores de Aguascalientes informan que esa enfermedad se ha presentado desde hace cerca de diez años; la altitud llega a ser un problema para el desarrollo de las aves. ${ }^{9}$ En el caso de NUTRYAVES, la granja cuenta con un millón de aves reproductoras ${ }^{10}$ y vende al mes un millón de pollos; $40 \%$ de sus ventas las coloca en los mercados de Aguascalientes y la ciudad de México.

\section{EL USO DE PROBIÓTICOS EN AVES}

La empresa avícola en Aguascalientes está altamente tecnificada y concentra una gran cantidad de aves. Ello propicia la constante innovación en el manejo y la alimentación de los animales.

Antes del nacimiento de las aves, su conducto gastrointestinal está libre de patógenos. Al momento de nacer es inevitable que las rodee todo tipo de microorganismos, los cuales determinan el estado de salud en las primeras etapas de vida del animal. Lo más conveniente es que se establezcan bacterias benéficas que permitan un balance microbiano óptimo. Como esto no es posible en la realidad, se busca la manera de encontrar, mediante probióticos, un equilibrio que:

- Disminuya la mortalidad.

- Reduzca las mermas causadas por la E. Colli.

- Baje los costos relacionados con los medicamentos y la cama.

${ }^{9} \mathrm{El}$ ambiente ideal para el crecimiento de estas aves modificadas genéticamente es al nivel del mar.

${ }^{10}$ Estos animales reproductores proporcionan pollo para engorda y huevo. 
- Mejore la conversión alimenticia y la ganancia de peso.

- Eleve la calidad del cascarón.

- Disminuya la incidencia de enfermedades.

- Aumente la producción del huevo.

- Incremente el porcentaje de huevo fértil.

Entre los probióticos más empleados por los productores se encuentran los siguientes:

- All-LAC: probiótico que se recomienda para animales recién nacidos; en las incubadoras se aplica por aspersión o se agrega al agua.

- LACTO-SACC: lactobacilos, estreptococos, enzimas y levaduras microencapsuladas para una conservación óptima de la actividad biológica, con lo cual se obtiene un huevo menos contaminado y para pollos de engorda.

- ACID.PAK 4 WAY: ideal para un control natural de microorganismos patógenos; se utiliza principalmente en pollos de engorda.

- DE-ODORASE: producto a base de microorganismos, enzimas y sarsaponinas que disminuye la producción de amoniaco por excretas animales; se recomienda en condiciones de confinamiento.

Los productores señalan que en términos generales el uso de los probióticos se traduce en una disminución de enfermedades y un aumento de peso de entre 6.15 y 10.9 por ciento. ${ }^{11}$

\section{CONCLUSIONES}

En diversos trabajos se ha afirmado que la modalidad extensivaextractiva de la producción ganadera ya no puede continuar y que por tanto es inminente el paso a modalidades intensivas. El trabajo de campo que apoya nuestra investigación nos permitió corroborar que, en efecto, la ganadería mexicana transita hacia formas intensivas de producción. Tanto en Aguascalientes como en Tabasco es cada vez más frecuente que los productores consideren inconveniente mantener

11 El porcentaje de mayor peso fue proporcionado por APLIGEN en evaluaciones realizadas en pollos de engorda alimentados con LACTO.SACC y ACID.PAK en Villahermosa, Tabasco, 1989. 
en el hato a animales que ya han dado su potencial productivo, y en consecuencia optan por sacrificarlos. Antes, sin embargo, la tradición señalaba que a más ganado, más producción.

Este proceso modernizador de la actividad pecuaria obedece a una necesidad del capital en su conjunto, al margen de los intereses individuales de los ganaderos. En la década de los años noventa, quienes se dedican a la producción bovina no podrán crecer como propietarios sino como inversionistas. La rentabilidad del capital vía la renta del suelo se ha agotado (Chauvet, 1990).

Los cambios se están operando en los productores asociados a alguna empresa ganadera. No nos referimos a la pertenencia a asociaciones ganaderas locales, que siempre han existido, sino a las formadas por socios de cierta región y que operan de manera cooperativa. Este tipo de agrupaciones llevan varios años funcionando y son las que han permitido a muchos ganaderos continuar en la actividad. La pertenencia a dichas empresas les ofrece una baja en los costos de los insumos, los mantiene más informados sobre aspectos productivos y comerciales, y -lo más importante- les asegura un mercado para sus productos. A fin de ser eficientes, estas empresas de servicio deben manejarse con toda la lógica de un negocio capitalista y ello ha influido sobre la manera de producir de sus asociados. Conforme crece el espíritu empresarial, gana importancia la productividad y, en consecuencia, se justifica la introducción de nuevas tecnologías.

Estas empresas integradas desempeñan un papel de difusores de biotecnología sin ser ése estrictamente su objetivo. GILSA, por ejemplo, al incrementar las ventas del concentrado con MEGALAC, fomenta el uso de probióticos.

En ese sentido, concluimos que dicho tipo de productores está introduciendo la biotecnología en la producción animal. Los laboratorios penetran mediante un distribuidor en el país, que a su vez asigna zonas a otros distribuidores; la estrategia de venta se basa en ofrecer servicio al ganadero por medio de un promotor. Las compañías distribuidoras cuentan con promotores que realizan visitas perib́dicas rancho por rancho para conocer la manera como se están aplicando los productos y brindar todo tipo de asesoría en cuanto al manejo del hato.

Otra conclusión es que los pequeños productores, como los ejidatarios, podrían beneficiarse de los probióticos. Sin embargo, además de que los desconocen, los laboratorios carecen de interés en promover sus productos en ese sector por su reducido volumen de compra.

Cabe recalcar que el uso de la biotecnología por sí mismo no va a modificar las condiciones de atraso en que se realiza la ganadería; 
se requieren transformaciones en materia de alimentación, sanidad y manejo de los animales.

Señalamos más arriba que la salida de la crisis ganadera se logró mediante la integración de los productores. Sin embargo, falta librar otra batalla: el enfrentamiento con los competidores externos. Ante un Tratado de Libre Comercio, la actividad ganadera nacional enfrenta serios retos, fundamentalmente porque el sector agropecuario de Estados Unidos goza de una serie de subsidios que hacen profundamente vulnerables a los productores nacionales.

De frenarse las importaciones de leche y pollo, estas aplicaciones de la biotecnología podrán lograr un fortalecimiento de la producción interna que permita estar en mejores condiciones frente a un TLC.

Por último, queremos señalar que hay sectores de la ganadería con una fuerte presencia transnacional, como la industrialización de la leche, la avicultura y la porcicultura.

Su permonencia actual dependerá de la relación costo-beneficio que lleve al capital externo a continuar produciendo aquí o surtir los bienes finales al consumidor, para dar salida a los excedentes de sus propias naciones (Chauvet, 1990).

En este marco es donde se empieza a aplicar la biotecnología en la producción animal de México. Aún quedan muchas preguntas por responder; pero consideramos pertinente dar a conocer estos avances.

\section{ANEXO ESTADÍSTICO}

CUADRO 1

EVOLUCIÓN DE LA PRODUCCIÓN PECUARIA (1960-1991)

(miles de toneladas)

\begin{tabular}{lrrrrrrrrrr}
\hline Product & 1960 & 1970 & 1980 & \multicolumn{1}{c}{1985} & 1986 & 1987 & 1988 & 1989 & 1990 & 1991 \\
\hline CARNES & 980 & 1617 & 2696 & 2862 & 2880 & 2860 & 2732 & 2499 & 2621 & 2859 \\
res & 557 & 818 & 1016 & 980 & 1248 & 1273 & 1217 & 1162 & 1114 & 1189 \\
cerdo & 292 & 541 & 1251 & 1293 & 959 & 915 & 861 & 726 & 757 & 812 \\
aves & 131 & 250 & 429 & 589 & 673 & 672 & 654 & 611 & 750 & 858 \\
LECHE $^{\circ}$ & 2106 & 4857 & 7021 & 7474 & 6539 & 6350 & 6281 & 5704 & 6266 & 6848 \\
HUEVO $^{2}$ & 202 & 383 & 644 & 826 & 998 & 975 & 1090 & 1047 & 1010 & 1141 \\
\hline
\end{tabular}

${ }^{\circ}$ Miles de litros

FUENTE: Dirección General de Estudios, Información y Estadística Sectorial de la SARH. 
CUADRO 2

EVOLUCIÓN DE LAS EXISTENCIAS PECUARLAS (1970-1991)

(miles de cabezas)

\begin{tabular}{lcccccccccc}
\hline PROD. & 1970 & 1980 & \multicolumn{1}{c}{1982} & \multicolumn{1}{c}{1984} & \multicolumn{1}{c}{1986} & \multicolumn{1}{c}{1987} & \multicolumn{1}{c}{1988} & 1989 & $1990^{\mathrm{P}}$ & $1991^{\top}$ \\
\hline OVINOS & 25499 & 34590 & 37191 & 30374 & 35237 & 34565 & 33756 & 33068 & 32054 & 3182 \\
SRCINOS $^{10541}$ & 16890 & 18096 & 19393 & 18397 & 18722 & 15884 & 16157 & 15203 & 1590 \\
VES $^{\circ}$ & 117160 & 178135 & 190259 & 202955 & 114760 & 223915 & 234069 & 238309 & 234055 & 23341 \\
\hline
\end{tabular}

- ilncluye productoras de huevo y carne.

' Cifras programadas.

${ }^{p}$ Cifras preliminares.

FUENTE: SARH. Tercer Informe de Gobierno, Lic. Carlos Salinas de Gortari, 1991, anexo estadístico.

\section{BIBLIOGRAFÍA}

Arroyo, G., Casas, R., Chambille, K., Escudero, G. 1989. La biotecnología y el problema alimentario. México: Ed. UAM/Plaza y Valdés.

Chauvet, M. 1989. "La modernización ganadera", ponencia presentada en el Noveno Seminario de Economía Agrícola del Tercer Mundo. IIEc, UNAM. Noviembre.

. 1990. "¿́a ganadería nacional en vías de extinción?" Comercio Exterior, septiembre.

. 1991. "Biotecnología y rentas tecnológicas". Sociológica.

Núm. 16, mayo-agosto, UAM-A.

Junne, Gerd, y Roobeek, Annemieke. 1989. "Social and economic impact of biotechnology". Biofutur. Noviembre, pp. 48-50.

Klesse, R. 1989. "El impacto de la biotecnología en la productividad agrícola". Sociológica. Núm. 16, UAM-A.

López, A., y Quintero, R. 1990. "Perspectivas internacionales de la biotecnología agrícola". ¿̇Biotecnología para el progreso de México? Coordinado por Blanca Suárez. México: Centro de Ecodesarrollo, pp. 47-77.

Manrubio, $M$. "El proceso de transferencia de tecnología en la ganadería bovina del trópico húmedo mexicano". Ponencia ganadora del VIII Seminario de Economía Agrícola del Tercer Mundo, IIEc, UNAM.

Rubio, B. 1991. "Desarrollo del capital en la agricultura mexicana y biotecnología: ¿́hacia un nuevo patrón de acumulación?" Sociológica. Núm. 16, mayo-agosto, UAM-A. 
Savitz, E., y Wyatt, E. 1989. "Fulfilling their promise. Wondrous products and even profits are in sight for Biotech Firms". Barron's, 25 de septiembre.

Trujillo, R., Martínez, F., Aboites, G. 1990. "La biotecnología animal en México". Ponencia presentada en el "I Congreso Latinoamericano de Biotecnología, La Habana, Cuba. 


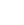

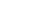

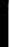

.

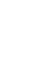

. 


\title{
El tratamiento biológico de aguas residuales: ¿demanda social • coyunfura polífica?'
}

\author{
ROSALBA CASAS*
}

\section{INTRODUCCIÓN}

El tema de los efectos socioeconómicos de la biotecnología ha estado presente desde hace varios años en la discusión académica en México. La polémica se ha centrado en las repercusiones que tienen las nuevas biotecnologías, entendidas como sinónimo de ingeniería genética, y las que tendrán en el futuro. Al respecto se han elaborado diversos análisis que identifican las tendencias de este campo en el plano internacional y que señalan las orientaciones para los países en desarrollo, entre otros para México.

Uno de los aspectos que ha estado presente en la discusión desde la década pasada y que aún sigue vigente gira alrededor del tipo de biotecnología que México requiere. Este asunto resulta complejo ya que la biotecnología es un campo muy amplio y sus orientaciones producirán muy diferentes repercusiones en la esfera socioeconómica. A diferencia de otras tecnologías (entre las que podrían citarse las generadas por la Revolución Verde y más recientemente las producidas por la microelectrónica), la biotecnología se relaciona con muy diversos sectores, por lo que no es previsible que sus efectos puedan generalizarse y agruparse en un modelo tecnológico perfectamente delimitado.

La biotecnología es un amplio campo de desarrollo tecnológico constituido por diferentes disciplinas; lo integran muy distintos niveles

${ }^{1}$ Es conveniente resaltar que ol presente trabajo constituye un primer acercamiento al análisis de las perspectivas biotecnológicas orientadas a resolver los problemas de contaminación del agua. Por ello, los planteamientos que se deriven de este material deben ser considerados como hipótesis de trabajo que servirán para orientar la investigación futura sobre esta temática.

* Instituto de Investigaciones Sociales, UNAM. 
tecnológicos y está relacionado con muchos sectores socioeconómicos. Cabe recordar que la biotecnología está constituida por tres generaciones de desarrollo tecnológico: la primera se refiere a los procesos de fermentación aplicados en la antigüedad para producir alimentos y bebidas; la biotecnología de segunda generación se caracteriza por los avances microbiológicos, el éxito en el uso de mutaciones en la selección de cepas para mejorar los rendimientos, en la refinación de los sistemas de fermentación y en el desarrollo de los procesos continuos; y la de tercera generación se gesta con el desarrollo de las técnicas de inmovilización enzimática y de ingeniería genética que están dando lugar a las combinaciones genéticas con sus consecuentes efectos sobre los sectores agrícola, farmacéutico y pecuario. Esta amplia gama de niveles biotecnológicos hace difícil prever todas las repercusiones que la biotecnología tendrá sobre la estructura socioeconómica; pero, al mismo tiempo, hace posible definir una estrategia para su impulso que se oriente a la aplicación de un patrón tecnológico cuyos efectos socioeconómicos vayan acordes con las necesidades imperantes y con un modelo de desarrollo para satisfacerlas.

Hasta ahora la discusión y la búsqueda de opciones ha recalcado los aspectos de la biotecnología que se relacionan con la agricultura y en cierta manera con la salud. En el caso de México este sector afronta una grave crisis que podría atenuarse mediante el logro de tecnologías más apropiadas a las condiciones de la agricultura nacional.

Puesto que los análisis se concentran en las potencialidades de las nuevas biotecnologías (es decir, en la biología molecular y las técnicas de ingeniería genética) y en su importancia para el desarrollo agrícola, han dejado de considerar otros campos de aplicación de estas tecnologías, así como otros niveles tecnológicos no incluidos en la nueva biotecnología. Tal es el caso de la biotecnología ambiental, campo de investigación desarrollado desde hace muchos años en México y que en los últimos meses ha comenzado a resurgir como resultado de las polticas ecológicas que el Estado ha venido instrumentado desde principios de 1990.

El desarrollo de la biotecnología ambiental se ha venido enfocando, desde hace varias décadas, tanto en el plano nacional como en el internacional, a controlar la contaminación. Este campo de investigación tiene amplias potencialidades para contribuir a aminorar los problemas de contaminación en agua, residuos sólidos y aire. ${ }^{2}$ Las

2 En trabajos previos se ha analizado la importancia de la biotecnología para afrontar los problemas ambientales. Al respecto consúltese: R. Cosas, "La biotecnología y su incidencia en los problemas ambientales", Revista Mexicana de Sociología, 1991, año LIII, núm. 2, abril/junio, IsS-UNAM. 
características de los procesos biotecnológicos orientados hacia este objetivo presentan particularidades propias y se enmarcan en contextos sociopolíticos distintos; puesto que resulta bastante complejo tratar de abordarlos conjuntamente, se hará referencia a la problemática actual que presentan para el tratamiento de aguas residuales, tanto en sus aspectos sociopolíticos como en sus características técnicas. El presente trabajo los aborda en tres apartados: 1) problemática sociopolítica actual del tratamiento de aguas residuales; 2) características de las tecnologías imperantes para el tratamiento y opciones que ofrece la biotecnología, y 3) perspectivas para un desarrollo biotecnológico endógeno que atienda a esta problemática.

\section{PROBLEMÁTICA SOCIOPOLÍTICA DEL TRATAMIENTO DE AGUAS RESIDUALES}

El problema de las aguas residuales y de sus efectos en la ecología y la salud ha sido un tema ampliamente tratado por diversos especialistas y para el que se han propuesto estrategias que aminoren sus efectos. En los últimos dos años este tema ha resurgido a raíz, en primer lugar, de la publicación del Programa Nacional para la Protección del Medio Ambiente 1990-1994 y, en segundo lugar, debido a las medidas y acciones que se han venido aplicando para asegurar que las aguas usadas que vierten las industrias y las que se generan como resultado de los usos domésticos sean tratadas para reducir la contaminación que han ocasionado desde hace muchas décadas.

La SEDUE y la SARH son las dos dependencias gubernamentales que participan en el monitoreo de la calidad del agua mediante estaciones manejadas por la primera dependencia y otras administradas por la segunda. Hacia 1990 México contaba con 256 plantas municipales de tratamiento de aguas residuales con capacidad para 14 mil litros por segundo y 150 plantas de tratamiento de aguas residuales de origen industrial con capacidad para 12 mil litros por segundo (Zúñiga, 1990).

Tal como lo han establecido algunos autores (López Mercado, 1985; Perló Cohen, 1989), la reutilización del agua entraña muy diversos problemas: a) el jurídico; b) el técnico-económico, y c) los sociopolíticos y culturales presentes tanto en el tratamiento como en el empleo que se da a las aguas residuales una vez que han sido tratadas. A continuación abordaremos brevemente cada uno de los aspectos de la problemática del tema que nos ocupa y que resulta de importancia para situar en su justa dimensión el desarrollo biotecnológico, aspecto central de este trabajo. 
a) El problema jurídico está motivado por el reto que significa definir una legislación adecuada, así como su aplicación estricta. Es importante destacar que en los últimos años ha habido avances importantes que están determinando que un gran número de empresas instalen equipos para tratar las aguas antes de descargarlas. El Programa Nacional para la Protección del Medio Ambiente 1990-1994, publicado en 1990, plantea como uno de sus objetivos centrales "detener y revertir la contaminación del agua, preservar su calidad y propiciar su aprovechamiento óptimo" (SEDUE, 1990). Como parte de las estrategias para lograr dicho objetivo se establece que "adquirirán prioridad de atención las 31 cuencas hidrológicas que se encuentran severamente deterioradas. Cinco de ellas, la del Lerma-Santiago, Pánuco, San Juan, Balsas y Blanco, requieren de atención urgente, tanto por sus niveles de contaminación, como por el hecho de que se encuentran localizadas entre grandes polos de desarrollo". Para esas cuencas se propone el control de descargas residuales, la construcción y operación de plantas de tratamiento y la restauración ecológica de las áreas aledañas.

Como parte de este marco jurídico, la Comisión Nacional del Agua (CNA), instituida en febrero de 1989, acaba de establecer reglamentaciones para las descargas de aguas residuales, entre las que destaca el pago del derecho por descargas; pago que tendrá que ser cubierto por las industrias que no instalen equipos para tratar sus aguas residuales. Asimismo, se ha establecido un programa mediante el cual las empresas en vías de instalar equipos para tratar sus aguas residuales quedan exentas de la obligación de pagar el derecho mencionado por un plazo de 12 meses a partir de octubre de 1991 (La Jornada, 1991). Para los organismos públicos el beneficio se prolongará hasta diciembre de 1992, fecha en la que todas las empresas que han registrado su proyecto constructivo o la ejecución de sus obras para instalar plantas tratadoras de aguas residuales habrán terminado su instalación y las plantas deberán estar en operación.

Las estrategias de la CNA para 1990-1994 plantean que el tratamiento de aguas residuales servirá para favorecer el riego agrícola, para usos industriales y municipales, así como para intercambio de aguas claras.

En comparación con los estatutos de mediados de la década pasada, la legislación vigente parece más atractiva y establece medidas concretas para evitar el aumento en la contaminación del agua y promover su reutilización. Sin embargo, un aspecto que queda aún incierto es el de la aplicación estricta de la legislación. Al respecto surgen algunas dudas sobre la exención en el pago de derechos por descargas 
de aguas residuales, que podría convertirse en un mecanismo permanente, sin que las industrias resuelvan efectivamente el tratamiento de sus aguas. Otro de los aspectos que aún no queda claro, y al que ya se refería Perlo (1989), es el de las atribuciones de las diferentes dependencias gubernamentales que intervienen en este proceso. Hasta 1989 sólo participaban la SARH y el DDF, pero actualmente también intervienen la SEDUE y la CNA, sin que haya quedado claramente establecido cuál es el ámbito de competencia de cada una y de qué manera se integran todas esas dependencias en una política coherente para el aprovechamiento de las aguas residuales en México.

b) El problema técnico y económico está relacionado con la aplicación de métodos adecuados para separar los compuestos de interés y lograr la rentabilidad económica de los procesos que tratan aguas residuales. En ese sentido, López Mercado (1985) hace hincapié en que deben desarrollarse métodos adecuados para separar los diferentes compuestos contenidos en las aguas residuales. A esto va ligado otro problema de tipo técnico que consiste en la manera de hacer más económicos los procesos de tratamiento de aguas residuales. Tal como se manifiesta en muchas otras tecnologías, el problema de la rentabilidad económica es un elemento decisivo en la industrialización de procesos tecnológicos orientados, en este caso, al tratamiento de las aguas residuales y muy frecuentemente se convierte en un difícil obstáculo para la aplicación de tecnologías con características importantes para el país, pero que no demuestran ser lo bastante rentables para generar un interés económico en su aplicación.

c) Los problemas sociopolíticos y culturales están íntimamente relacionados con el modelo de desarrollo urbano seguido hasta la fecha en el país, que no ha considerado en general los recursos hidráulicos de la propia región como un factor para su desarrollo autosostenido, lo que ha originado la sobre-explotación de acuíferos, cambios en el uso del agua y transferencia de recursos entre cuencas hidrológicas (Saavedra, 1991). Los problemas de contaminación del agua se manifiestan con carácter de gravedad en diferentes regiones del país, entre las que destacan las cuencas del Valle de México, la del Lerma, Tula, Atoyac Zahuapan y la Comarca Lagunera. Aunada al problema de la contaminación de aguas está la falta de abastecimiento de agua potable en diversas regiones del país. Por lo general, como afirma Vásconez (1991), los barrios populares ubicados en las zonas periféricas de las ciudades están fuera de la red de distribución y carecen no sólo de agua potable, sino también de otros servicios y equipamientos colectivos. 
El modelo de desarrollo urbano seguido por las ciudades del país en las últimas décadas ha causado graves daños a las diferentes cuencas, entre los que resaltan los originados en la del Valle de México, donde se observan los siguientes problemas relacionado con el agua: incremento de los volúmenes de las aguas drenadas, tanto residuales como pluviales, que agravan el círculo vicioso entre los requerimientos de agua para fines urbanos y las necesidades de obras para drenaje; y una peligrosa contaminación de las aguas residuales con detergentes no biodegradables y desechos industriales, lo cual dificulta, encarece y en algunos casos imposibilita su tratamiento, por lo que disminuye su potencial de aprovechamiento (Llerena, 1989).

Las aguas residuales generadas en la zona metropolitana de la ciudad de México (ZMCM) no sólo le han ocasionado problemas de contaminación, sino que los han transferido a otras regiones, entre las que cabe destacar la del Mezquital, cuyas aguas y campos se han visto gravemente contaminados por las aguas provenientes de la ciudad de México; sin embargo, los problemas de descarga de las aguas residuales en el Valle del Mezquital no pueden reducirse exclusivamente a los de contaminación, pues han generado un conjunto de problemas económicos, políticos y sociales que, desde el punto de vista de Sarmiento (1989), es importante considerar para descubrir la complejidad de los fenómenos que encierra el aprovechamiento de aguas residuales. En el caso del Mezquital, Sarmiento afirma que el problema de la contaminación por aguas negras ha pasado a un segundo lugar, ya que el abastecimiento de estas aguas se ha convertido en un problema de sobrevivencia, por lo que su uso resulta indispensable. Recientemente, y a raíz de la legislación sobre aguas residuales que está siendo puesta en práctica por el gobierno, se ha planteado como posibilidad dejar de verter las aguas negras en el Mezquital. Esto ha ocasionado fuertes protestas por parte de los agricultores de la región, que se verían seriamente dañados al dejar de disponer de estas aguas que se utilizan para el riego y que han incrementado sus ingresos económicos. Cabe destacar, según Sarmiento (1989), que el beneficio de las aguas negras no ha alcanzado a todos los campesinos, sino que ha sido acaparado por unos cuantos caciques. El problema de la falta de agua en esta región es tan agudo que las aguas negras son empleadas indistintamente para dar de beber a los animales y lavar ropa y enseres domésticos (Sarmiento, 1989). El Distrito de Desarrollo Rural 063 ubicado en el Mezquital es uno de los más grandes del país y el que recibe el mayor volumen de aguas negras, que se destinan al cultivo de maíz, sorgo, cebada, alfalfa, chile, jitomate, trigo, cártamo, calabaza, cebolla, ajo, haba, avena, nopal, tuna, aguacate, higo y nogal, cultivos que son vendidos preferentemente en la ciudad de 


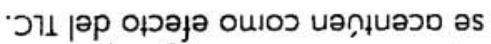

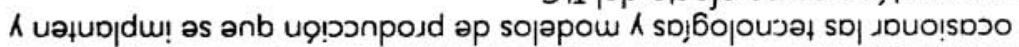

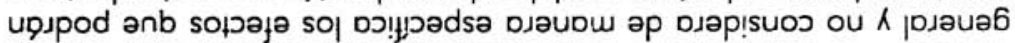

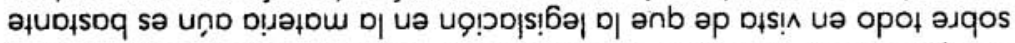

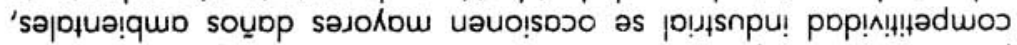

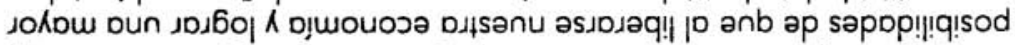

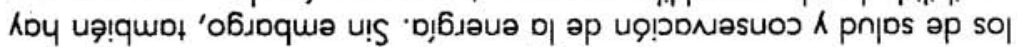

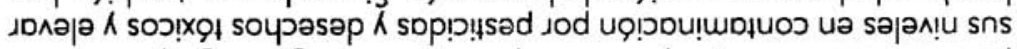
נְ.

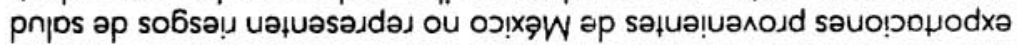

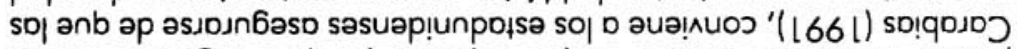

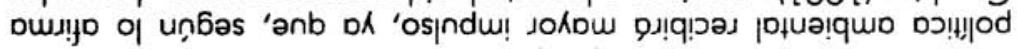

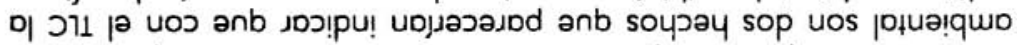

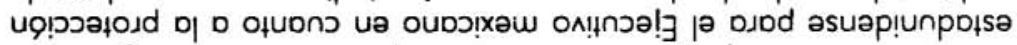

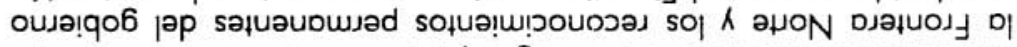

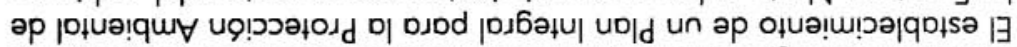
- (ว11) о!

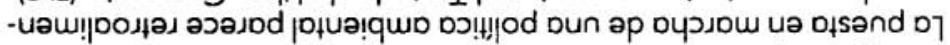

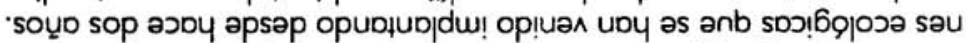
- o!

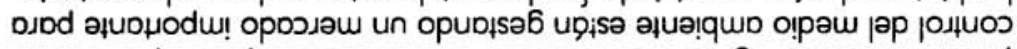

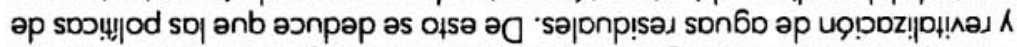

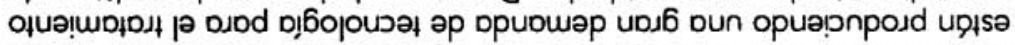

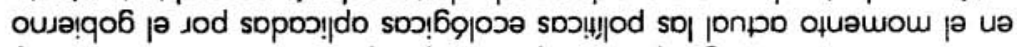

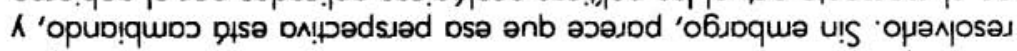

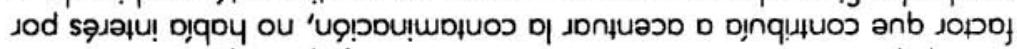

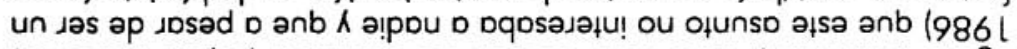

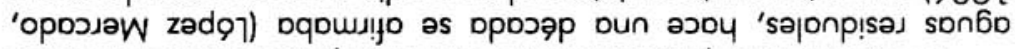

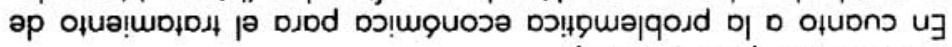

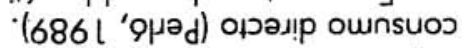

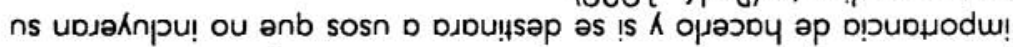

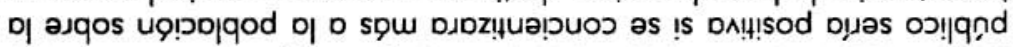

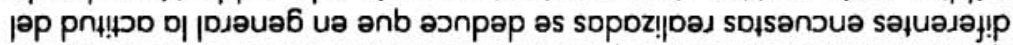
әр

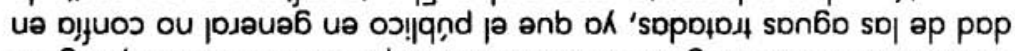

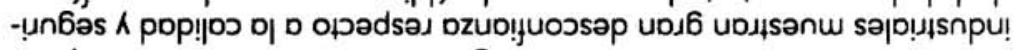

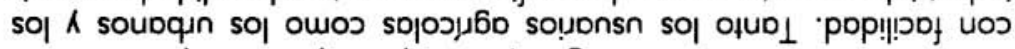

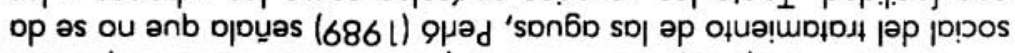

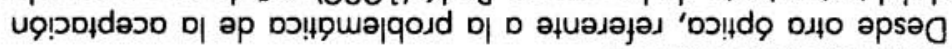

son!!|ก so| әp pop!n!!วกposd

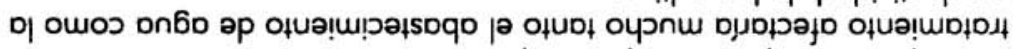

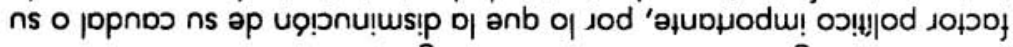

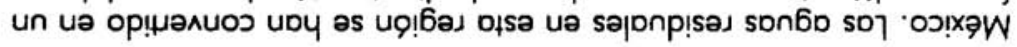


El problema que surge como resultado de una voluntad política orientada a aminorar los problemas de contaminación del agua está relacionado con la capacidad con que cuenta México para responder a esa demanda, lo que entraña apoyarse en una infraestructura tecnológica; es decir, żcon qué procesos biotecnológicos que se encuentren en etapa de demostración o de protctipos ya desarrollados cuenta el país como para que las empresas interesadas en controlar sus emisiones de aguas contaminadas puedan optar por comprar tecnologías nacionales? El apartado siguiente se referirá a los principales esfuerzos que se realizan en México y al problema que enfrentan los investigadores en biotecnología para poder responder a la demanda antes mencionada.

\section{CARACTERÍSTICAS DE LAS TECNOLOGÍAS PARA EL TRATAMIENTO BIOLÓGICO DE AGUAS RESIDUALES}

Los sistemas para el tratamiento de aguas residuales no son recientes y desde principios del siglo $X X$ se han ideado métodos y operaciones para acelerar los procesos naturales de autopurificación. Hay tres tipos de tratamiento: a) el primario, que sólo emplea operaciones físicas; b) el secundario, que utiliza procesos químicos y biológicos, y c) el terciario o avanzado, que se compone de procesos físicos, químicos y biológicos. La calidad del agua obtenida en cada caso es diferente y la índole de los contaminantes que son retirados varía (López Mercado, 1985). En general, por su eficiencia y por ser los más económicos y los que menor volumen de lodo residual producen, los sistemas de tratamiento biológico son los más utilizados.

Los procesos biologicos para el tratamiento de aguas residuales se diferencian por dos vías metabólicas: la aerobia, que requiere de oxígeno, y la anaerobia, que no lo necesita; aunque la más utilizada hasta ahora es la primera (Zúñiga, 1990). Sin embargo, los procesos anaerobios han empezado a desarrollarse más intensamente y según Zúniga son atractivos para los países en desarrollo debido a sus costos razonables.

Los sistemas de tratamiento biológico transforman el material orgánico (coloidal y disuelto en el agua) en material celular, que por encontrarse suspendido puede ser retirado con mayor facilidad; esto hace de ellos los métodos más versótiles ya que pueden emplearse en la reducción de sólidos suspendidos, sólidos disueltos, de nutrimientos y de microorganismos (Cañizares, R. O. y Casas-Campillo, C., 1991). Es decir, la biodegradación consiste en la actividad de un sistema biológico sobre alguna sustancia, cuya consecuencia es la modificación total o parcial de su estructura (López Mercado, 1985). 
En lo referente a los sistemas de tratamiento biológico se cuenta con dos tipos: los sistemas con microorganismos en crecimiento sobre una superficie, entre los que figuran los filtros de precolación, los discos biológicos rotatorios y los filtros anaerobios; y los sistemas con microorganismos de crecimiento en suspensión, entre los que se encuentran los de lodos activados, las lagunas de estabilización, las lagunas de oxidación, los digestores anaerobios y las lagunas aerobias de alta velocidad (Cañizares y Casas-Campillo, 1991).

Según López Mercado, los sistemas de sedimentación, aunados a lodos activados, son los que tienen un porcentaje de renovación de sólidos y bacterias más alto, al igual que los sistemas de tratamiento biológico ya mencionados (López Mercado, 1985). Uno de los problemas aún sin solución en el uso de tecnologías basadas en lodos activados es el de los lodos residuales que quedan después del tratamiento biológico de las aguas y que se producen en gran cantidad. En las plantas de tratamiento se procesa exclusivamente el agua, pero en muchos casos los lodos residuales se devuelven al agua. Esto significa que es preciso secar los lodos residuales, los cuales, según López Mercado (1986), podrían emplearse como mejoradores de los suelos. Este problema está siendo abordado por Noyola (1991) y colaboradores, quienes han formulado un proceso tecnológico que emplea los lodos residuales de los procesos aerobios y los convierte en inóculos para tratamiento de aguas residuales por vía anaerobia, con lo cual se integra un paquete tecnológico compuesto por el reactor y su inóculo.

Las lagunas de estabilización y los lodos activados son los sistemas que más se utilizan, y junto con los otros sistemas biológicos de tratamiento (aerobios y anaerobios) han dado cabida a la aplicación de la biotecnología en el diseño de dichas plantas. Cabe mencionar que en estos sistemas se incluye tanto tratamiento de aguas residuales primario como secundario. En cuanto al terciario, los procesos en México se encuentran en fase de experimentación y se desarrollan básicamente mediante el empleo de microalgas y de cianobacterias. Este último es un proceso interesante porque se trata de organismos que captan muy bien la luz solar y convierten la energía luminosa en biomasa de valor alimenticio (Cañizares y Casas-Campillo, 1991).

En el campo del desarrollo biotecnológico para el tratamiento de aguas residuales hay una amplia gama de ofertas tecnológicas, muchas de las cuales ya se emplean en otros países y otras se encuentran aún en proceso de experimentación en México. Sin embargo, cabe considerar, tal como lo afirma Romero Luna (1985), que los procesos biológicos de tratamiento de aguas residuales domésticas no son complejos y obedecen a algunas reglas que han probado su eficacia 
a través de los años, y que la atención técnica la acaparan más los aspectos constructivos y electromecónicos que el biológico. No obstante, afirma el autor, cuando se trata de diseñar y controlar sistemas de tratamiento de aguas residuales industriales se concede gran importancia al aspecto bioquímico y biológico; se requiere de investigación experimental basada en conceptos que se comprenden mejor cuando se tiene presente la manera de crecer que tienen los microorganismos. En el cuadro 1 se enlistan los sistemas de tratamiento de aguas residuales instalados en México hacia 1985.

En el plano nacional, desde hace varios años hay grupos de investigación de alto nivel que trabajan en estas tecnologías; sus trabajos en general se ubican en campos tales como la microbiología y la ingeniería ambiental. La SARH comenzó a investigar sobre el tratamiento de desechos de agua a principios de los años setenta y la SEDUE misma entró a dicho campo de investigación en 1982, lo que originó un problema político con la SARH; la SEDUE, además, no ha contado en realidad con un centro apropiado de investigación. En provincia hay varios centros de investigación que trabajan en este campo: en Guadalajara, Puebla, Monterrey y Baja California (López Mercado, 1986). En el Distrito Federal la investigación se concentra en la Escuela Nacional de Ciencias Biológicas (ENCB) del Instituto Politécnico Nacional, que trabaja con microorganismos puros que se inmovilizan para degradar los residuos contenidos en las aguas; la UAM-Iztapalapa, con diversas líneas de investigación en este campo, tanto por vía anaerobia como mediante el empleo de lirio acuático; el Instituto de Ingeniería, la Facultad de Ingeniería y la Facultad de Química de la UNAM, que han trabajado en diversos procesos para el tratamiento de aguas residuales de diversas industrias (azúcar, maíz, papel); el Instituto de Ingeniería en particular cuenta con una planta piloto de aguas residuales; y el Departamento de Biotecnología y Bioingeniería del Centro de Investigación y Estudios Avanzados (CINVESTAV), que ha trabajado en degradación de detergentes, aguas residuales de la industria azucarera y en optimización de sistemas de lodos activados (López Mercado, 1986; Durán de Bazúa, 1986; Monroy, 1986). En cuanto al tratamiento terciario de efluentes mediante la utilización de microalgas, varios centros de investigación realizan esfuerzos hacia este objetivo; entre ellos cabe mencionar al Departamento de Biotecnología de la UAM-Iztapalapa, el Deportamento de Biotecnología y Bioingeniería del CINVESTAV y el Instituto Mexicano de Tecnologías Apropiadas (IMETA). Hacia 1990 se venía elaborando un gran proyecto interinstitucional para tratamiento de aguas residuales en la Huasteca Potosina en el cual participaban la Facultad de Química y el Instituto de Ingeniería de la UNAM, Azúcar S. A., CINVESTAV, 
Universidad Autónoma de San Luis Potosí y el Instituto de Investigaciones Eléctricas.

CUADRO 1

SISTEMAS DE TRATAMIENTO DE AGUAS RESIDUALES INSTALADOS EN MEXICO, 1985

Lodos activados
Lagunas biologicas
Tanques Imhof
Sedimentadores primarios
Separadores API
Filtros rociadores
Zanjas de oxidación
Emisores submarinos

FUENTE: Vicente López Mercado, "Tratamiento biológico de aguas residuales", en Prospectiva de la biotecnología en México, compilado por R. Quintero, México: Fundación "Javier Barros Sierra"-Consejo Nacional de Ciencia y Tecnología, 1985.

Sin embargo, la estrategia tecnológica seguida en México para el tratamiento biológico de aguas residuales ha sido importar las innovaciones, con muy poca asimilación y adaptación por parte de los especialistas nacionales (Romero Luna, 1985). Esta estrategia parece extenderse en la actualidad y se puede ejemplificar con el caso de la empresa CELANESE, que opera con un sistema de tratamiento por lodos activados y que ha resuelto el problema de los lodos residuales mediante su descarga en una laguna inmensa en donde se almacenan; dichos lodos ya no contienen tóxicos. Esta empresa ha planteado adquirir una tecnología más moderna, para lo cual ha buscado alternativas en el exterior y está a punto de adquirir un nuevo equipo sin haberse interesado en explorar las ofertas o avances tecnológicos generados en el país ni la conveniencia de invertir en ellos para ponerlos a punto y resolver su demanda de tecnología (Galindo, 1991).

Actualmente hay dos posibilidades de satisfacer la demanda de plantas para el tratamiento biológico de aguas residuales, demanda que se ha acentuado como resultado de las medidas de control de la contaminación a las que se hizo referencia en el inciso anterior: la primera es crear tecnologías endógenas basadas en tecnologías existentes, en proceso de mejoramiento en cuanto a rentabiliad económica, eficiencia de los procesos y disposición de los residuos que generan; y la segunda está constituida por la importación directa de tecnologías ya probadas en otras economías. 
Diversos problemas técnicos tienen que resolverse para hacer que los desarrollos tecnológicos que se generan endógenamente se vuelvan procesos de interés comercial. El primero se refiere al residuo resultante del tratamiento por lodos activados. Como se ha mencionado, este remanente en ocasiones contamina de nuevo las aguas tratadas; evitar esto requiere de grandes depositos para almacenarlo, lo que también constituye un problema. En el Distrito Federal el tratamiento de aguas residuales se efectúa mediante este proceso de lodos activados y gas de cloro, que no ha resuelto el problema mencionado.

Otro problema por resolver es controlar la calidad de las aguas tratadas y los usos que deberán dárseles. Cabe mencionar aquí que uno de los intereses centrales en el tratamiento de aguas residuales es poder resolver la escasez de agua para consumo humano y para usos de tipo industrial y agrícola en el país. En este sentido, el tipo de tratamiento que aseguraría la calidad del agua para esos usos es el terciorio, que además produce una biomasa que podría ser empleada con fines alimentarios.

Finalmente, cabe mencionar que un porcentaje elevado de las plantas de tratamiento de aguas residuales municipales e industriales con las que se cuenta no operan adecuadamente. Hasta el momento no se cuenta con la información necesaria para definir las causas de esa situación; sin embargo, se hace necesario determinar si ello se debe a problemas técnicos o a simple negligencia en el manejo de las plantas.

\section{PERSPECTIVAS PARA UN DESARROLLO BIOTECNOLOGICO ENDÓGENO PARA EL TRATAMIENTO DE AGUAS RESIDUALES}

La importancia en el tratamiento de aguas residuales radica en que $33 \%$ de la población del país no cuenta con agua potable y cerca del $50 \%$ carece de un sistema de alcantarillado municipal. Es decir, se trata de un problema social representado por la falta de abastecimiento de agua a la población, que podría mejorarse mediante el tratamiento de las aguas residuales. Sin embargo, a pesar de que existen varios cientos de plantas municipales e industriales para tratar estas aguas, aproximadamente $30 \%$ de ellas opera con poca eficiencia y del total de aguas residuales sólo 15\% recibe algún tratamiento (Zúñiga, 1990).

En el plano de la política ambiental la posibilidad del tratamiento biológico de aguas residuales podría orientarse tanto a la instrumentación de una estrategia encaminada a resolver los problemas de contaminación como a la de una política ambiental preventiva, ambas definidas por Simonis (1989) como opuestas. En la determinación de una política preventiva influyen, según el autor citado, tres factores: la 
acumulación de periuicios causados al medio ambiente, la adquisición de conocimientos técnicos y una mayor toma de conciencia por parte del público.

Desde nuestro punto de vista, el tratamiento de aguas residuales podría formar parte de cualquiera de las dos orientaciones de política mencionadas, según la etapa en la que se aplique el proceso de tratamiento. Si éste se realiza una vez que las aguas han sido vertidas a los ríos o corrientes de agua limpia, entonces la orientación será correctiva; pero si, por el contrario, los sistemas de tratamiento son incorporados en las industrias mismas, en las unidades de producción agrícolas o en el plano municipal, antes de verter las aguas la política sería preventiva, ya que el proceso se aplicarla antes de haber originado el problema de contaminación.

Como se ha mencionado al inicio de este trabajo, México cuenta ya con un gran número de plantas de tratamiento de aguas residuales. En el Distrito Federal hay en la actualidad 10 plantas ubicadas en El Rosario, Coyoacán, Ciudad Universitaria, Tlatelolco, Acueducto Guadalupe, San Juan de Aragón, Ciudad Deportiva, Cerro de la Estrella, Chapultepec y Bosques de las Lomas. El agua se destina al riego de áreas verdes, llenado de canales en Xochimilco y de los lagos en Chapultepec y Aragón, así como a su utilización en la industria, principalmente en las delegaciones Iztapalapa y Azcapotzalco (Herrera Toledo, 1989). No obstante, es necesario realizar un balance del funcionamiento de estas plantas y evaluar las tecnologías empleadas, así como la calidad del agua que se genera después del tratamiento. Es importante resaltar que en lo referente al Distrito Federal y la ZMCM, los requerimientos de agua son enormes, fundamentalmente de agua potable y para usos domésticos; en este sentido es necesario operar tecnologías que, mediante sistemas biológicos, produzcan agua que pueda ser reutilizada domésticamente y para usos agrícolas, lo cual significa aplicar tratamientos terciarios.

En cuanto a desechos industriales, las propias empresas, presionadas por las reglamentaciones de las descargas de aguas residuales, están buscando las posibilidades más interesantes. Cabe mencionar que, entre otras estrategias, la SARH, mediante empresas descentralizadas, estó aplicando "Sistemas de recolección de aguas residuales" como los que ya operan en el Primer Distrito de Control de la Contaminación en la Zona del Conjunto Industrial del Valle de Cuernavaca (CIVAC) en el estado de Morelos (Salazar, 1991) y en el Valle de Lerma. El sistema implantado en Morelos capta las aguas residuales de 88 industrias, cinco fraccionamientos y tres poblados. Cada empresa aplica un pretratamiento mediante el cual se eliminan algunos compuestos químicos que no se degradan con el tratamiento 
biológico; se emplea el tratamiento biológico de lodos activados, el lodo desaguado se envía a relleno sanitario y la empresa paga una cuota al Distrito para el tratamiento de sus aguas, la cual se fija en relación con el volumen de aguas tratadas. La operación de estos distritos es un buen ejemplo de una política ambiental preventiva cuyo contenido tecnológico es el tratamiento biológico de las aguas que se descargan en esas zonas.

Uno de los aspectos que parece no estar del todo claro en el proceso que se está siguiendo para definir una política ambiental y reglamentar lo referente a las aguas residuales es si el objetivo que se persigue resulta social o económico. El tema de la contaminación ha representado en los últimos años una de las principales demandas de la población, y los requerimientos de agua potable por parte de las poblaciones urbana y rural siguen aún sin satisfacerse y se agravan cada vez más a consecuencia de la contaminación a que están siendo sometidas las cuencas hidrológicas, con las consiguientes repercusiones de todo esto en la salud humana. Sin embargo, todo parece indicar que la presión ejercida por tales demandas no es lo que ha hecho al gobierno decidir reglamentar el derrame de las aguas residuales.

Los orígenes de esta políica ambiental van mós allá del plano social, y desde nuestra perspectiva tienen que ver con condicionantes políticos y con una problemática económica. Los primeros se relacionan estrechamente con la política ambiental estadunidense y con las presiones que se ejercen para hacer mós eficiente el marco jurídico y las medidas de control. A esto habría que agregar que debido a que México no cuenta con una oferta tecnológica para satisfacer la demanda de plantas de tratamiento biológico, ésta se traduce en una demanda hacia el exterior y en una manera de canalizar la compra de tecnología e incluso la inversión extranjera; es decir, se ha gestado un nuevo mercado para esas tecnologías que no puede ser satisfecho por la oferta tecnológica nacional. Por lo que se refiere al plano económico, las medidas adoptadas representan un nuevo mecanismo del gobierno para captar recursos adicionales, en este caso provenientes de multas y pagos de derechos; es decir, en el fondo no se trata de atender una demanda social, sino de aprovechar la oportunidad que plantea el problema de la contaminación del agua, así como de fomentar la apertura de un nuevo mercado para las empresas trasnacionales del ramo.

El caso que hemos analizado en este trabajo es un ejemplo claro de que los avances tecnológicos importantes para la problemática social no cobrarón trascendencia y no recibirán los apoyos suficientes mientras no se genere una demanda tecnológica en el mercado, aunque exista una demanda social. En el momento en el que surge una 
demanda del mercado, combinada con politicas definidas en el campo especfifico de que se trate, y una voluntad decidida a hacer de esa política un negocio económico es cuando se produce la demanda tecnológica. En este proceso no se contempla la importancia social de los avances tecnológicos, ni se prevén los efectos que tendrán en la población. Ademós, puesto que la capacidad de generación de esas tecnologías no fue apoyada y fortalecida previendo el surgimiento de la demanda, la capacidad de respuesta, o en este caso de oferta tecnológica, resulta sumamente limitada y no puede responder a la demanda generada.

Los centros de investigación nacionales, tales como el Instituto de Ingenierla de la UNAM y otros centros en la capital se están enfrentando a un cambio notable, ya que las demandas de tecnología hacia esos centros son permanentes y provienen de diferentes sectores interesados en acatar la legislación e instalar sus plantas de tratamiento de aguas residuales. Los investigadores en biotecnología están conscientes de que la demanda se incrementará y de que en el país no se dispone de la capacidad para satisfacerla, ya que entraña no sólo producir equipo sino realizar experimentación para crear un equipo adecuado a las características de las aguas residuales que deberón ser tratadas, así como a los usos que se pretende darles.

Queda entonces por saber cuál es la capacidad real de respuesta de la base tecnológica con la que cuenta el país, cuól el interés del Estado por aprovechar esa capacidad y cuál el deseo por resolver el problema de contaminación de las aguas para contribuir así a propiciar mejores condiciones de vida para la población y un mejor abastecimiento de agua. Estas interrogantes forman parte del programa de investigación que sobre este tema se realizará en los próximos años.

\section{BIBLIOGRAFÍA}

Cañizares Villanueva, R. O., y Casas-Campillo, C. 1991. "El papel de las microalgas en el tratamiento terciario de aguas residuales". Cuademos sobre biotecnología, Departamento de Biotecnología y Bioingeniería CINVESTAV-IPN.

Carabias, J., y Provencio, E. 1991. "Medio ambiente y TLC". Cuadernos de Nexos, Nexos. Núm. 37, junio, pp. XM-XMII.

Comisión Nacional del Agua. "Por qué todos tenemos derecho a tener agua limpia". La Jomada, 17 de septiembre de 1991, p. 17.

Durán de Bazúa, C. 1986. México: Entrevista personal, Departamento de Alimentos, Facultad de Qú́mica, UNAM, 18 de octubre. 
Galindo, E. 1991. "Alternativas biotecnológicas en el control de la contaminación". . $v$ Congreso Nacional de Biotecnología y Bioingeniería, 8-12 de septiembre, Mérida, Yucatán.

Herrera Toledo, C. 1989. "Disposición de aguas residuales de la zona metropolitana de la Ciudad de México". Aguas residuales de la zona metropolitana de la Ciudad de México. Impactos y perspectivas. Compilado por G. Quadri de la Torre. México: Fundación F. Ebert-DDF.

López Mercado, V. 1985. "Tratamiento biológico de aguas residuales". Prospectiva de la biotecnología en México. Compilado por R. Quintero Ramírez. México: Fundación J. Barros Sierra-CO. NACYT.

1986. México: Entrevista personal, Departamento de biotecnología y bioingenierfa, CINVESTAV, 15 de diciembre.

Llerena Villalpando, F. A. 1989. "Aspectos generales de la Cuenca del Valle de México: evolución y perspectivas". Aguas residuales de la zona metropolitana de la Ciudad de México. Impactos y perspectivas. Compilado por G. Quadri de la Torre, pp. 7-54.

Monroy, O. 1986. México: Entrevista personal, Departamento de Biotecnología, UAM-Iztapalapa, 23 de octubre.

Noyola Robles, A. 1991. "Tratamiento anaerobio de aguas residuales: una experiencia de adaptación de tecnología en México". México: Instituto de Ingeniería, UNAM (inédito).

Perl6 Cohen, M. 1989. "Problemas sociopolíticos para la utilización de las aguas residuales". Aguas residuales de la zona metropolitana de la Ciudad de México. Impactos y perspectivas. Compilado por G. Quadri de la Torre. México: pp. 89-102.

Romero Luna, F. 1985. "La biotecnología en México: tratamiento biológico de aguas residuales". Perspectiva de la biotecnología en México. Compilado por R. Quintero Ramírez, pp. 395-412.

Saavedra Shimidzu, J. C. 1991. "El desarrollo de los ecosistemas hidráulicos para atender los centros de población en México". La modernización de las ciudades en México. Compilado por M. Perló Cohen. México: IIS-UNAM.

Salazar, C. 1991. "Alternativas biotecnológicas en control de la contaminación". IV Congreso Nacional de Biotecnología y Bioingenieríc. Mérida, Yucatán. 8-12 de septiembre.

Sarmiento Silva, S. 1989. "Aguas negras y procesos sociales en el Valle del Mezquital, Hgo." Aguas residuales de la zona metropolitana de la Ciudad de México. Impactos y perspectivas. Compilado por G. Quadri de la Torre, pp. 103-132.

SEDUE. 1990. Programa Nacional para la Protección del Medio Ambiente 1990-1994. México. 
Simonis, U. E. 1989. "La modernización ecológica de la sociedad industrial: tres elementos estratégicos". Revista Internacional de Ciencias Sociales, UNESCO. Núm. 121, septiembre.

Vásconez, M. 1990. "Sistema urbano, necesidades de la población y formas de abastecimiento de agua y saneamiento en los barrios populares de las ciudades de América Latina". La modernización de las ciudades en México. Compilado por M. Perló Cohen. México: Instituto de Investigaciones Sociales-UNAM, pp. 75-89.

Zúniga, J. 1990. Entrevista con el lng. Jesús Zúñiga de la Comisión Nacional del Agua. Gaceta UNAM, 17 de septiembre. 
.

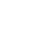




\title{
Consideraciones sobre la aplicación de la bioteenología vegetal en el sureste de México
}

\author{
AMARELLA EASTMOND
}

\section{INTRODUCCIÓN}

Este siglo ha sido testigo de transformaciones radicales en los sistemas alimentarios de todo el mundo. En los países avanzados los alimentos han cambiado de productos sencillos (casi directamente traídos del campo o con poco procesamiento industrial) a mercancías de alto valor agregado, diferenciadas en un rango amplio de calidades y gustos. Esto ha sido posible debido a la convergencia de varios fenómenos sociales, tales como la incorporación de la mujer al mercado de trabajo y los avances tecnológicos -entre ellos la biotecnología- que ha resultado en la creciente industrialización del proceso de producción de alimentos. Al mismo tiempo, las familias de dos ingresos han creado una demanda mucho más compleja, afluente y exigente en los últimos años y están dispuestas a pagar precios altos por ahorrar tiempo en la preparación de comida y obtener calidad y variedad de sabores.

En los países en vías de desarrollo la transformación de los sistemas alimentarios ha sido igualmente radical, pero en general causada por presiones y estímulos externos, no por fenómenos internos. Es decir, parte del éxito del norte ha sido la gradual incorporación del sur a un sistema alimentario mundial de grandes dimensiones (Goodman y Redclift, 1991) en el que han impuesto a todos no sólo sus gustos sino también sus métodos científicos de producción, sus procesos industriales y sus necesidades comerciales.

Bajo este esquema de avance tecnológico y competencia mundial, los países en vías de desarrollo no han tenido otra opción que la de seguir los patrones establecidos y participar en el mercado internacional 
de manera subordinada; primero, en el papel de proveedor de materias primas para la elaboración de productos y, segundo, como comprador de éstos una vez que han sido transformados y encarecidos por el valor agregado.

Mientras que los niveles de vida y las dietas del norte se han visto grandemente enriquecidos durante este siglo, los del sur soblo han mejorado (hasta cierto punto) para los sectores urbanos; mientras tanto, las poblaciones rurales han sufrido deterioros en sus niveles de vida y en sus sistemas tradicionales de producción de alimentos, los cuales tienden a desaparecer en algunos casos. Irónicamente, justo cuando muchos países del Tercer Mundo estaban llegando al "punto sin retorno" en el proceso de su integración al esquema mundial, han aparecido algunas evidencias de que el modelo agrícola del norte tiene graves limitaciones para sostenerse a largo plazo (National Research Council, 1989).

Al mismo tiempo, el norte empieza a reconocer que son precisamente los sistemas menos "eficientes", gradualmente erradicados por la modernización agrícola, los que mantienen uno de los factores clave para el futuro de la producción alimentaria mundial: el germoplasma, la base de todos los sistemas agrícolas existentes.

Este trabajo propone que es de gran importancia mantener alguno de estos sistemas como fuente de sustento para la poblacion rural y como fuente de recursos genéticos, y que la biotecnología vegetal, a pesar de las tendencias actuales contrarias, podría y debería contribuir a resolver este dilema.

La biotecnología vegetal (BV), grupo de técnicas celulares y moleculares que permite manipular en el laboratorio las células de las plantas y sus genes, surgió cuando el modelo de la Revolución Verde empezaba a agotarse. La característica de versatilidad y polivalencia (Goodman y cols., 1987) de la biotecnología la hace potencialmente aplicable casi a cualquier cultivo y a una gama muy amplia de condiciones ecológicas, sobre todo mediante el control de enfermedades y la resistencia a ambientes adversos, lo cual significa que las condiciones agricolas desfavorables de muchas partes del Tercer Mundo (antes soslayadas por la ciencia) también podrlan beneficiarse.

Los análisis de los efectos socioeconómicos de la biotecnología (Kloppenburg, 1989; Fowler y Mooney, 1990; Goodman y Redclift, 1991) subrayan cada vez más la influencia de las empresas trasnacionales en dirigir y fomentar el crecimiento de este campo según sus propios intereses y requerimientos de privatización, concentración e integración vertical que no parecen favorecer a los pequeños agricultores de pocos recursos del Tercer Mundo. Sin embargo, debido a las preocupaciones ya mencionadas que entraña sostener el modelo 
agrícola intensivo del occidente, también hay presiones y esfuerzos orientados a elevar la competitividad de la agricultura no intensiva de los países del Tercer Mundo (Bunders, 1990). Estos esfuerzos parten de la idea de que la conservación de muchos de los recursos genéticos existentes depende de la capacidad de los productores rurales del Tercer Mundo de seguir obteniendo suficientes ingresos de estos sistemas ineficientes para sobrevivir y que, por lo tanto, es necesario buscar una fórmula técnica y económica (Pearce y cols., 1989) que les permita hacerto, lo cual resuelve el doble dilema de empleo rural y conservación de sistemas agroecológicos. La aplicación de la biotecnología vegetal conjuntamente con una serie de estímulos económicos parece representar una opción viable, aunque de ninṇuna manera fácil.

Este trabajo intenta contribuir al tema especulando (en ausencia de casos concretos) acerca de la aplicación de la BV a algunos cultivos importantes en el sureste de México. Esta región tropical y subtropical de tierras marginales para la agricultura (que abarca los estados de Chiapas, Tabasco, Campeche, Quintana Roo y Yucatán), todavía muestra una utilización relativamente extensiva de la tierra con un nivel bajo de tecnificación e insumos.

El sureste es el centro de diversidad de sólo uno de los cultivos que se analizan en el trabajo (el henequén), lo que hace su conservación en la región de mayor significancia ecológica que la de los demás; sin embargo, todos los sistemas de producción de cultivos comerciales que se analizan (plátano, cítricos y coco) son todavía poco intensivos y coexisten geográficamente con sistemas tradicionales. De hecho muchas veces los mismos productores son quienes combinan su milpa (para obtener alimentos) con los cultivos comerciales (para obtener ingresos). Debe hacerse hincapié en que en el sureste aún es posible descubrir nuevas especies; de ahí la importancia especial de lograr un balance entre el grado de explotación comercial (que indudablemente eleva al bienestar de los agricultores individuales o empresas) y la conservación de la naturaleza.

En el análisis subsecuente la biotecnología no se plantea como una panacea para resolver los problemas ecológicos y sociales de la región, sino como recurso que contribuya a mejorar los cultivos bajo las condiciones prevalecientes.

Se analizan muy brevemente los problemas de cada cultivo y se plantea cómo la BV podría contribuir a su solución y el efecto socioeconómico que tendría. Se analizan también las oportunidades y dificultades que han enfrentado algunas investigaciones sobre estos cultivos. Sólo se proponen técnicas de cultivo in vitro, como la micropropagación y la limpieza de "material madre" que utilizan las metodologías más sencillas y baratas, que están disponibles en México en este momento 
y podrian ser fácilmente incorporadas; es decir, se trata de estrategias perfectamente viables desde el punto de vista técnico. Claro estó, la factibilidad económica tiene mucho que ver con las polfiticas agrícolas y de desarrollo rural. Aunque no se prevén aumentos considerables en las inversiones federales directas en el campo, sí se espera un incremento en coinversiones, mayor investigación agronómica y mayor participación del sector privado, pues el abandono del campo ha llegado a un punto peligroso para el país.

El análisis se concentra en los cultivos de coco, africos, agaves y plátano por ser importantes económica y socialmente en el sureste, por presentar problemas que podrían ser resueltos por las biotecnologías y porque hay cierta factibilidad económica de que, por lo menos en los casos de cítricos, plátanos y agaves, su aplicación sea inmediata.

\section{COCO}

La industria cocotera genera empleo para alrededor de 50 mil personas en todo el país, de las cuales la mayoría son pequeños productores, ejidatarios y jornaleros, aunque sólo una pequeña parte de la producción se genera en el sureste (Tabasco es el tercer estado productor de México). No se cuenta con números exactos sobre los productores ya que el cultivo de coco normalmente se combina con otras actividades como la pesca. Debido al bajo nivel de tecnología utilizada, la falta de aplicación de fertilizantes y riego y un manejo inadecuado de las palmas, los rendimientos son bajos (un promedio de dos toneladas de fruta fresca por hectárea o una tonelada de copra).

Ademós, los cocoteros en México estón amenazados por la enfermedad denominada "amarillamiento letal", que mata los árboles en unos cinco meses desde la aparición de los primeros síntomas (Robert y Zizumbo, 1990). La enfermedad es causada por un micoplasma que se desarrolla en el floema de los árboles infectados. El patógeno es transmitido de las palmas enfermas a las sanas por medio de un insecto (Myndus crudus) que se alimenta de la savia de las plantas.

No se dispone de ninguna cura para el amarillamiento letal; es posible retrasar su desarrollo mediante aplicaciones de antibióticos, pero los árboles están destinados a morir en cuanto se deja de aplicar la medicina. Hasta cierto punto puede detenerse la dispersión de la enfermedad aplicando rocío; con insecticidas, pero el insecto es cosmopolita y habita también en los pastizales, lo cual hace imposible rociar una zona lo bastante extensa para erradicarlo. En los últimos años la enfermedad ha avanzado desde la costa caribeña de México a una velocidad de $50 \mathrm{~km}$ por año y a la fecha ha llegado ya a Campeche. 
La única posibilidad real de control es sustituir gradualmente las variedades susceptibles por otras resistentes. Hay algunas provenientes del Pacífico que muestran mayor resistencia a la enfermedad, y se han producido algunos híbridos desarrollados en Jamaica (y más recientemente en Costa Rica) que parecen combinar tolerancia con productividad elevada; sin embargo, todos estos materiales tienen que ser propagados por semilla ya que no hay maneras de propagar vegetativamente las palmas.

A pesar de las enormes dificultades que se han enfrentado hasta la fecha para aplicar el cultivo de tejidos in vitro a las palmas de coco en Inglaterra, Francia y recientemente en México (Robert y cols., 1991), esta técnica ofrece la única posibilidad para lograr la propagación asexual de la especie (Blake, 1990); la técnica no sólo proporcionaría material libre de enfermedades sino que produciría suficientes plántulas con mayor rapidez una vez que se logre disponer de la metodología. Sin embargo, no se espera disponer de ella antes de cinco años.

Sin amarillamiento letal, el cultivo del cocotero puede servir como fuente secundaria de empleo (45 días por ha. por año) para los campesinos y ejidatarios de bajos ingresos de las zonas costeras que pueden combinarlo con otras actividades tales como la pesca y la producción de sal.

Hasta la fecha, la respuesta de la comunidad internacional ante el avance del amarillamiento letal a toda América Central ha sido ineficiente y no ha aportado apoyo económico para realizar las investigaciones necesarias y tomar las medidas adecuadas. Por un lado esto puede ser producto de una falta de interés directo en el cultivo y, por otro, de que varios países, principalmente Estados Unidos, están introduciendo un nuevo aceite de canola cuya composición va mós acorde con las tendencias dietéticas del momento y con el cual pretenden sustituir los aceites tropicales en la industria alimentaria.

A pesar de lo apremiante del problema en México, el cual aparenta una clara rentabilidad de inversión de fondos públicos, no ha sido posible hasta la fecha crear un programa nacional para controlar la enfermedad, y es casi nulo el apoyo económico para realizar las investigaciones necesarias que generen los materiales resistentes que necesitan los productores de copra.

\section{CITRICOS}

En Yucatán la aplicación de BV a los cítricos podría reducir el costo y los riesgos del control químico, tanto para los productores como para el medio ambiente, y aumentar el período de producción de naranjas 
maduras, actualmente limitado a seis meses. Su uso para producir material sano (por medio de una metodologla bien probada en España por el doctor Navarro y colaboradores (1985), del Instituto Valenciano de Investigaciones Agrarias, y adaptada en México) disminuirfa sustancialmente las pérdidas actuales (entre 30 y $50 \%$ ) generadas por plagas y enfermedades; ademós, no costaría mucho después de la inversión inicial en la infraestructura básica de viveros e invernaderos. De hecho la región cuenta ya con un laboratorio que podría producir los materiales parentales micropropagados. Si la aplicación de la BV se enfocara inicialmente a la producción de material libre de virus no desplazaría mano de obra en las operaciones intensivas de trabajo como deshierbar, podar y regar las parcelas pequeñas de naranjas. Además, cualquier pérdida sería compensada por el aumento en la demanda de mano de obra para la cosecha y el transporte debido al incremento en la producción total.

Los productores pequeños (con menos de tres ha) representan el 98\% de los 5246 productores agrícolas que cultivan cítricos en la región Puuc de Yucatán. $\mathrm{A}$ incrementar los rendimientos se aumentarían también los ingresos de los campesinos y probablemente se elevarfa la demanda de jornaleros, quienes podrían recibir mejores salarios. Esto puede predecirse con bastante certeza, ya que el mercado está asegurado por la planta de jugo concentrado que pertenece a la Unión de Ejidos Citrícolas.

Aunque los precios fluctúan mucho por vender el $90 \%$ del jugo concentrado a Estados Unidos, la juguera ha podido sobrevivir sin mayores dificultades desde 1980.

La lenta industrialización de la agricultura de la zona ha estimulado la economía local con muy favorables resultados hasta la fecha. Compradores de naranjas de todas partes de la República vienen al mercado de Oxcutzcab en ciertas épocas, cuando Yucatón es el único lugar que tiene fruta madura, lo que ayuda a elevar los precios. En total, la producción de naranjas proporciona empleo por lo menos para el $37 \%$ de la población económicamente activa de la región y, debido a los precios altos, hay mayor demanda de jomaleros, por lo cual los ingresos reales han crecido significativamente. También el número de empleos en el sector informal relacionado con la agricultura ha aumentado. De hecho el efecto multiplicador de la juguera ha producido una movilización económica y social hacia arriba de un grupo considerable de campesinos que ahora conforman una clase de campesinos empresariales que pueden ganar dos o tres veces el salario anual de un burócrata de la Sectretaría de Agricultura y Recursos Hidrólicos (Eastmond, 1991).

Estos cambios relativos en los ingresos y el valor cada vez mayor de la tierra (a pesar de ser ejidal) han causado un pequeño aumento 
maduras, actualmente limitado a seis meses. Su uso para producir material sano (por medio de una metodología bien probada en España por el doctor Navarro y colaboradores (1985), del Instituto Valenciano de Investigaciones Agrarias, y adaptada en México) disminuiŕa sustancialmente las pérdidas actuales (entre 30 y 50\%) generadas por plagas y enfermedades; además, no costaría mucho después de la inversión inicial en la infraestructura básica de viveros e invernaderos. De hecho la región cuenta ya con un laboratorio que podría producir los materiales parentales micropropagados. Si la aplicación de la BV se enfocara inicialmente a la producción de material libre de virus no desplazaría mano de obra en las operaciones intensivas de trabajo como deshierbar, podar y regar las parcelas pequeñas de naranjas. Además, cualquier pérdida sería compensada por el aumento en la demanda de mano de obra para la cosecha y el transporte debido al incremento en la producción total.

Los productores pequeños (con menos de tres ha) representan el $98 \%$ de los 5246 productores agrícolas que cultivan cítricos en la región Puuc de Yucatán. $\mathrm{Al}$ incrementar los rendimientos se aumentarían también los ingresos de los campesinos y probablemente se elevaría la demanda de jornaleros, quienes podrían recibir mejores salarios. Esto puede predecirse con bastante certeza, ya que el mercado estó asegurado por la planta de jugo concentrado que pertenece a la Unión de Ejidos Citrícolas.

Aunque los precios fluctúan mucho por vender el $90 \%$ del jugo concentrado a Estados Unidos, la juguera ha podido sobrevivir sin mayores dificultades desde 1980.

La lenta industrialización de la agricultura de la zona ha estimulado la economía local con muy favorables resultados hasta la fecha. Compradores de naranjas de todas partes de la República vienen al mercado de Oxcutzcab en ciertas épocas, cuando Yucatán es el único lugar que tiene fruta madura, lo que ayuda a elevar los precios. En total, la producción de naranjas proporciona empleo por lo menos para el $37 \%$ de la población económicamente activa de la región y, debido a los precios altos, hay mayor demanda de jornaleros, por lo cual los ingresos reales han crecido significativamente. También el número de empleos en el sector informal relacionado con la agricultura ha aumentado. De hecho el efecto multiplicador de la juguera ha producido una movilización económica y social hacia arriba de un grupo considerable de campesinos que ahora conforman una clase de campesinos empresariales que pueden ganar dos o tres veces el salario anual de un burócrata de la Sectretaría de Agricultura y Recursos Hidráulicos (Eastmond, 1991).

Estos cambios relativos en los ingresos y el valor cada vez mayor de la tierra (a pesar de ser ejidal) han causado un pequeño aumento 
en la diferenciación social y económica; sin embargo, el carócter ejidal de la tierra, la escala pequeña de la producción y la importancia del factor mano de obra en la producción (los costos de mano de obra comprenden el $80 \%$ de los costos totales de producción) se combinan para disminuir el efecto de concentración de los recursos y asegurar una distribución amplia de los beneficios del desarrollo económico de la región. Aunque la aplicación de la BV a la producción de naranjas podría disminuir un poco la proporción del factor de mano de obra, mientras la tierra siga siendo ejidal la distribución de los beneficios de la nueva tecnología sería bastante amplia y no afectaría de manera considerable la estructura social actual.

Instrumentar un programa de BV significaría construir un laboratorio sencillo e invernaderos comerciales que también crearían empleos de técnicos y trabajadores de campo. Se calcula que podrían venderse por lo menos 500 mil plantas por año (la cantidad que actualmente se comercializa). Los productores en la actualidad compran sus esquejes injertados en naranja agria a $\$ 2000$ por planta; pero no hay ninguna garantía respecto a la calidad del producto. Aunque es difícil estimar los costos de producción de material libre de virus, más de la mitad de los productores entrevistados señalaron que estarían dispuestos a comprar material de alta calidad producido biotecnológicamente, aunque costara más, siempre y cuando les dejara más ganancia. Al parecer la aplicación de la BV a los ć́tricos es sólo cuestión de tiempo y de que alguien tome la iniciativa de crear el mercado para el nuevo material, mercado que no se ha formado hasta la fecha debido a la falta de un problema agronómico lo suficientemente serio. Ante el Tratado de Libre Comercio y el riesgo de perder su mercado si no mejora calidad y competitividad, la actitud de los productores grandes con capacidad financiera está cambiando y en Nuevo León empiezan a considerar la instrumentación de proyectos de clonación con cítricos y manzanos.

\section{AGAVES}

En Yucatán el henequén, que se emplea para la producción de fibra, ha adolecido de una falta de mejoramiento genético, mientras que en Jalisco el agave tequilero (materia prima para producir tequila) ha sido sobre-explotado como resultado de la demanda cada vez mayor de tequila por parte del extranjero, lo cual deja una escasez de plantas para resembrar las plantaciones. En 1985 se calculo el déficit en no menos de 12 millones de plántulas para restablecer las plantaciones y mantener los niveles de producción. Esto ha conducido a adoptar estándares más bajos en la elaboración del licor, tales como cambios 
en las normas que permiten agregar hasta $49 \%$ de azúcar derivado de otras fuentes, entre ellas la caña de azúcar.

La mayor parte de las compañías tequileras obtiene las cabezas de Agave tequilana mediante contratos con los campesinos y pequeños productores que cultivan el agave en sus parcelas. La compañía proporciona gratis los hijuelos a sus productores y garantiza la compra de las cabezas maduras (a los ocho o nueve años) al precio establecido en el mercado.

Hace seis años, preocupada por la oferta futura de materia prima, una de las grandes compañías tequileras empezó a explorar la posibilidad de comprar tecnología estadunidense para micropropagar agaves. Sin embargo, por casualidad, en un simposio internacional sobre agaves en Estados Unidos los representantes de la compañía se encontraron con científicos mexicanos que ya habían creado sistemas de micropropagación en henequén. Se llegó a un acuerdo entre las dos partes en el cual el centro de investigación se comprometió (por una modesta suma) a adaptar la metodología para la micropropagación de $A$. tequilana, entrenar a los técnicos de la compañía y supervisar el diseño y la construcción del laboratorio para llevar a cabo el proceso en gran escala.

Aunque la tecnología fue acondicionada con éxito y aceptada (Robert, 1987), cambios radicales en la administración y las políticas de la compañía suspendieron su utilización poco después de terminado el contrato. Es probable que dos factores fueran determinantes en la decisión de la compañía de abandonar su programa de micropropagación: los insuficientes conocimientos acerca de los beneficios que pueden derivarse de esta técnica y los altos costos iniciales de producción de material micropropagado. Sin embargo, la compañía nunca entendió que el potencial de la biotecnología radicaba principalmente en reducir el tiempo requerido para el mejoramiento genético (aumentar los rendimientos) mediante la selección repetida y la multiplicación de los individuos élite y, sólo en segundo término como método para restablecer las plantaciones por medio de la multiplicación masiva de plantas madres. Una vez que se reconoce la contribución de la micropropagación a largo plazo, se justifica el costo más elevado del material producido de este modo. Se debe hacer hincapié también en que la compañía obtuvo la tecnología por una cantidad muy modesta en comparación con lo que hubiera tenido que pagar si la hubiera comprado de Estados Unidos, como se pretendía originalmente.

Este esfuerzo no se perdió del todo ya que otras compañías tequileras se han interesado en la tecnología y ahora una de ellas está colaborando con la misma institución de investigación para evaluar en el campo el material micropropagado de los individuos élites. Después 
de dos años los resultados son muy alentadores (Robert y cols., en prensa) y muestran incrementos en velocidad de desarrollo; la compañía planea aumentar la proporción de plantas micropropagadas en sus plantaciones y en las que contratan con los campesinos. De esta manera, cualquier beneficio de la nueva tecnología se extenderá a los campesinos y los pequeños productores que cultivan el agave. Al producir plantas de más alto rendimiento ganarón más con la misma cantidad de trabajo y superficie cosechada ya que el precio se fija por peso. Más aún, como la compañía proporciona los hijuelos gratis, la mejora tecnológica no les costará nada a ellos.

En cuanto al henequén, aunque orginalmente la metodología fue formulada para este cultivo, y podrían derivarse de ella grandes beneficios en su productividad, bojo las circunstancias actuales de la industria cordelera en Yucatán (en proceso de venta al sector privado) y con precios mundiales deprimidos es muy poco probable que sea empleada por los ejidatarios y productores pequeños; habrá que esperar su desarrollo en manos privadas. Este caso, mejor que cualquier otro, ilustra cómo la aplicación de una biotecnología depende no sólo de su potencial o de la necesidad que se tenga de ella, sino también de que haya quien pueda pagarla y quiera hacerlo.

\section{PLÁTANO}

Tabasco es uno de los estados más importantes en la producción de plátano. La mayoría de los productores sigue siendo relativamente pequeña (en Teapa, por ejemplo, las fincas varían de 15 a 300 has., todas privadas) y poco tecnificada, en comparación con los grandes productores de América Central como las compañías Standard Fruit, United Fruit Company y Del Monte quienes, desde hace cien años, han tenido acceso a los mejores suelos mundiales de aluvión para este cultivo. Además de esta ventaja natural, ahora no siembran más que plantas micropropagadas para lograr mayor control fitosanitario y la más alta calidad en fruta y rendimientos. Datos de Costa Rica muestran que las plantas micropropagadas producen $50 \%$ más que las plantas propagadas tradicionalmente (Corporación Bananera Nacional, 1991).

Aunque hasta hace poco en México no se había hecho ninguna investigación sistemática para la micropropagación de plátano, hay demanda de los productores más grandes por este producto, ya que no se cuenta con un sistema eficiente de comercialización de semilla y mucho menos de plantas completamente sanas, libres de nemátodos. Además, sienten la presión que ejercen las compañías multinacionales, 
las cuales imponen los criterios en el me:cado internacional. Por ello, algunos productores están experimentando con la posibilidad de usar micropropagación como la única metodología para obtener sus plantas y se han iniciado ya plantaciones para evaluar el potencial de estos materiales.

\section{CAPACIDAD CIENTÍFICA}

Este tema ha sido ampliamente discutido en muchas otras publicaciones (Robert y Loyola, 1985; CEPAL, 1988; Arroyo y cols., 1989) y aquí sólo se menciona muy brevemente con el propósito de poner de relieve dos aspectos: primero, que México tiene cierta capacidad para llevar a cabo el tipo de investigaciones planteadas en este trabajo y, segundo, señalar algunos de los problemas fundamentales que limitan en el país un desarrollo más amplio del campo.

En México la falta de recursos humanos calificados y de apoyo económico en cantidad suficiente es una limitante, pero no un impedimento total para el desarrollo de la biotecnología vegetal. En comparación con Estados Unidos, Europa y Japón, nuestra capacidad es reducida; sin embargo, disponemos de centros de investigación que pueden adaptar y desarrollar biotecnologías en las áreas de cultivo de tejidos, ingeniería genética y biosíntesis. Por otro lado, hay algunos programas de maestría y doctorado que pueden permitir incrementar paulatinamente la base de los recursos humanos. También se cuenta con sistemas de información, bibliotecas, bancos de datos, etcétera.

Las principales limitaciones se derivan de la falta de un programa nacional definido de biotecnología, pocos investigadores de alto nivel, desvinculación entre la investigación básica y la aplicada, escasez de recursos económicos $y$, hasta la fecha, poca participación del sector privado y escasa factibilidad económica de muchos de los proyectos.

Tal vez la principal dificultad en el señalamiento de prioridades sea la enorme cantidad de problemas que pueden ser considerados prioritarios para el país en comparación con el limitado número de científicos y de recursos para abordarlos. Por otro lado, parece también imposible definir prioridades en un ambiente tan rápidamente cambiante como el actual. En los últimos años la política nacional de desarrollo ha cambiado radicalmente para alinearse con los acontecimientos políticos mundiales y las tendencias de apertura comercial y liberación de las fuerzas del mercado. Esto necesariamente afecta la investigación, particularmente un campo como la BV cuyo objetivo es producir bienes y servicios. 


\section{VINCULACIÓN ENTRE INVESTIGACIÓN BÁSICA Y APLICADA}

Muchos científicos en México siguen pensando que la búsqueda de conocimiento debiera ser el único objetivo de la investigación científica, menosprecian a los que "se ensucian las manos" buscando soluciones a los problemas prácticos. Los bioquímicos y los biólogos moleculares tienden a considerar a los agrónomos como más cercanos a los agricultores que a los científicos, mientras que estos últimos acusan a los primeros de encerrarse en torres de marfil; hasto hace poco ambos grupos podían sobrevivir sin mucha interacción, pero las circunstancias han de cambiar si la biotecnología vegetal va a prosperar en México, ya que se trata de un campo de estudio eminentemente multidisciplinario que requiere investigación a todos niveles, desde el laboratorio hasta el campo. Aunque estamos de acuerdo en que la investigación a cualquier nivel antes que nada debe ser de calidad, al hablar de biotecnología pensamos en resultados que deben encontrar una aplicación en forma de productos comerciables.

Debido a la falta de capital privado de riesgo en México, la BV tuvo que iniciarse con fondos públicos; los resultados fueron los siguientes: 1) cantidad insuficiente de recursos totales, que además han disminuido en los últimos años debido a la crisis, y 2) una tendencia a llevar a cabo proyectos desligados del mercado. Estas condiciones están cambiando rápidamente, en gran medida por la inminente firma del Tratado de Libre Comercio y por la nueva relación con Estados Unidos, la cual promete facilitar un flujo considerable de dinero del Banco Mundial y otras agencias internacionales, que será canalizado a los centros de investigación mediante el gobierno federal, con el objeto de consolidar grupos de excelencia y financiar proyectos de investigación de alta calidad, lo cual obligará a las instituciones de investigación y a la industria privada a vincularse más en un esfuerzo común por mejorar su calidad, eficiencia y competitividad.

Las nuevas maneras de relacionarse son los contratos externos en los que se negocia el precio, de acuerdo con las fuerzas de un mercado que cada vez se vuelve más internacional. Es un ambiente bien establecido en el mundo industrial en el cual sólo sobreviven los mejores. México tiene mucho que perder ante la competencia de los países ricos; pero en lo que se refiere a algunos cultivos específicos de zonas tropicales (tales como agaves, cocoteros, etcétera), tiene ciertas ventajas de experiencia, clima, acceso al germoplasma y mano de obra barata, incluida la de los científicos altamente calificados. 


\section{BIOTECNOLOGIAS DEL EXTRANJERO}

Sería poco realista esperar que mucha de la investigación y su aplicación llevadas a cabo en los países industriales sea de utilidad directa para los retos agrícolas de México, y especialmente de la región sureste. En primer lugar porque los países industriales están preocupados por resolver sus propios problemas y elevar sus ganancias al móximo; en segundo, porque las características agrícolas del sureste lo hacen un mercado poco atractivo. Como declaró L. V. Mayer, asistente del Secretario de Economía de la Secretaría de Agricultura de Estados Unidos en una reunión de biotecnólogos: "Olvídense del Tercer Mundo, no pueden pagar nuestros productos." Por lo tanto, los resultados de la investigación realizada por los países industriales llegarán sobre todo a las naciones en vías de desarrollo a través de dos canales: I) incidentalmente, como producto secundario de la investigación dirigida hacia otros propósitos; y 2) mediante las compañías multinacionales que tienen intereses en la región y que aplican sus propios logros tecnológicos o compran los derechos de utilizar los de otros. Con los cambios en las leyes de inversión extranjera y la promoción de asociaciones entre capital privado y productores agrícolas, es posible que aumente el interés de las corporaciones multinacionales en el campo mexicano. Es interesante notar a este respecto la creación del International Service for the Acquisition of Agri-Biotech Applications (ISAAA), organización internacional no lucrativa para la transferencia de agrobiotecnologías de propiedad privada de los países industriales, en beneficio del Tercer Mundo (ISAAA, 1991). Con fondos de fundaciones privadas, comités de científicos expertos y redes de colaboradores en los países del Tercer Mundo, esta organización pretende asesorar y promover la compra, de parte de países en vías de desarrollo, de biotecnologías de propiedad privada de Estados Unidos y Europa. La organización argumenta que para alimentar a la poblacion mundial en el año 2040, cuando $90 \%$ de la humanidad viva en los países subdesarrollados, éstos necesitarán toda la tecnología avanzada disponible. Dado que el $75 \%$ de la inversión en investigación en biotecnología está en manos privadas, los países del Tercer Mundo requerirán, además, asesoría experta para poder escoger bien las tecnologías más apropiadas a sus necesidades.

Las repercusiones de estas tendencias parecen indicar que si México quiere aprovechar algunas de las ventajas de la BV y no depender totalmente del extranjero, tendrá que realizar por sí mismo buena parte de la investigación necesaria. Esto no resultará barato y tendrá que limitarse a unas cuantas áreas en donde realmente se tenga la capacidad de entregar productos útiles demandados por un merca- 
do. De otra manera, tendrá que aceptar los consejos de organizaciones como el ISAAA y estar dispuesto a pagar muy caro por lo que compre, sin poder verificar cuán adecuada será la tecnología para sus requerimientos.

\section{CONCLUSIONES GENERALES}

Aunque es muy riesgoso tratar de llegar a conclusiones, los ejemplos analizados sugieren que:

1) Sin una intervención más decidida de parte del gobierno y de la iniciativa privada mexicanos, la BV será empleada de modo reducido a corto plazo en el país y los beneficios estarán limitados a algunos cultivos de alto valor agregado y restringidos a los sectores con capacidad propia de financiamiento.

2) Por lo tanto, una reducción general de los precios de los alimentos no será una consecuencia inmediata.

3) Pese a ello, los ejemplos parecen indicar que la BV es una opción viable, con muchas cualidades atractivas, tanto para los productores grandes como para los pequeños, que merece mayor estudio y atención. (En ningún país industrial el gobierno ha tomado el riesgo de no participar en el desarrollo de este campo, pues se le considera un elemento fundamental para el desarrollo mundial económico y comercial.)

4) Los ejemplos mencionados también indican que, aunque en este momento puede parecer sólo como una opción adicional para los productores, en un futuro no muy lejano su aplicación será estrictamente necesaria para poder competir en los mercados internacionales. El dilema para el gobierno es decidir qué políticas adoptar, pues al no participar con mós recursos públicos y orientar las investigaciones, las aplicaciones no estarán dirigidas a los pequeños productores, a pesar de sus necesidades urgentes y la viabilidad de hacerlo en este momento, con lo cual se perderá la oportunidad de orientar la BV como un apoyo para el desarrollo rural del sector social.

5) Por lo contrario, en el caso de decidir aplicar algunas biotécnicas sencillas (mediante programas federales) a los cultivos comerciales que tienen suficiente mercado, pero que sufren 
de algún problema agronómico, puede esperarse un aumento general en las economías agrarias locales y en la demanda de mano de obra, lo que facilitaría la conservación de los recursos genéticos en los sistemas tradicionales de la zona. La pérdida de empleos por la mecanización facilitada por las nuevas tecnologías no parece ser una amenaza inmediata en el sureste; dadas las condiciones ecológicas adversas, la intensificación de la mecanización es probable sólo en la etapa de procesamiento de los alimentos, y serd en pequeña escala debido a la mano de obra relativamente barata y la falta de capital para llevar a cabo sustituciones a largo plazo. Un aspecto positivo sería crear unos cuantos empleos técnicos en los laboratorios biotecnológicos. La introducción futura de variedades que no requieren fertilizantes o protección de plaguicidas disminuiría ligeramente la demanda de trabajo; pero los beneficios para la salud humana y el ambiente compensarían esto con creces.

6) Finalmente, en México empieza a reconocerse la inevitabilidad de la aplicación mundial de la biotecnología y también se debate sobre las ventajas o desventajas que representaría el no emplearla. Por lo tanto, aun cuando se reconoce que el país no tiene la capacidad de aplicar muchas de las biotecnologías disponibles debido a que fueron creadas para condiciones económicas generales muy distintas (de altos salarios, altas inversiones por trabajador y altos niveles de ahorro que no existen en nuestro país), pensamos que es importante acelerar los esfuerzos nacionales ya iniciados para poder aplicar las metodologías que convengan a México y contribuir a detener el deterioro ecológico y social del campo.

\section{BIBLIOGRAFÍA}

Arroyo. G., et al. 1989. La biotecnología y el problema agroalimentario en México. México: UAM-Xochimilco y Plaza y Valdés.

Blake, J. 1990. "Plant tissue culture as an alternative technology in coconut propagation". La problemática del amarillamiento letal del cocotero en México. Compilado por M. L. Robert y V. D. Zizumbo. Mérida: Centro de Investigación Científica de Yucatón (CICY).

Bunders, J. F. G. Comp. 1990. Biotechnology for Small-scale Farmers in Developing Countries. Amsterdam: vu University Press. 
"Coffee and Biotechnology". Biotechnology and Development. Monitor. Núm. 4. Septiembre 1990, pp. 20-22.

Comisión Económica de las Naciones Unidas para América Latina (CEPAL). 1988. "Desarrollo biotecnológico en la producción alimentaria de México: orientaciones de política". Reporte preparado por G. Arroyo y M. Waissbluth (mimeo).

Corporación Bananera Nacional. 1991. Informe anual 1990. San José, Costa Rica.

Eastmond, A., y Robert, M. L. 1989. “Advanced Plant Biotechnology in Mexico: A Hope for the Neglected?" Ginebra: World Employment Programme Research, Working Paper núm. 200. International Labour Office.

Eastmond, A. 1991. "Modernización agrícola y movilización social hacia arriba en el sur de Yucatán". Nueva Antropología. Vol. Xl. Núm. 39, pp. 189-200.

Fowler, C., y Mooney, P. 1990. Shattering Food, Politics and the Loss of Genetic Diversity. Tucson: The University of Arizona Press.

Goodman, D. E.; Sori, B.; y Wilkinson, J. 1987. From Farming to Biotechnology: A Theory of Agro-industrial Development. Oxford: Basil Blackwell.

Goodman, D. E., y Redclift, M. 1991. Refashioning Nature. Londres: Routledge.

International Service for the Acquisition of Agri-Biotech Applications (ISAAA). 1991. Progress Report on the International Service for the Acquisition of Agri-Biotech Applications (ISAAA). Mimeo. 1991.

Navarro, L.; Ballester, J. E.; Juórez, J.; Piña, J. A.; Arregui, J. M.; y Bono, R. 1.985. "Development of a programme for disease freecitrus pathogens in propagative budwood in Spain". Proc. of the Int. Soc. of Citriculture 1, pp. 70-72.

Pearce, D.; Markandya, A.; y Barbier, E. B. 1989. Blueprint for a Green Economy. Londres: Earthscan Publications Ltd.

1990. Sustainable Development: Economics and Environment in the Third World. Londres: Hants, England.

Robert, M. L., y Hants, Edward Elgar, 1987. "Micropropagación de Agave tequilana weber". Reporte, no publicado, para Tequila Cuervo.

Robert, M. L., y Loyola-Vargas, V. M. Comps. El cultivo de tejidos vegetales en México. México: Centro de Investigación Cientifica de Yucatón (CICY)-CONACYT.

Robert, M. L., y Zizumbo, V. D. Comps. 1990. La problemática del amarrillamiento letal del cocotero en México. Mérida, Yucatón: Centro de Investigación Científica de Yucatón.

Robert, M. L., Loyola-Vargas, V. M., y Zizumbo, V. D. 1991. "Lethal Yellowing in Mexico". Buro Trop. Núm. 1, pp. 13-14. 


\title{
Efecto socioeconómico de la biotecnología en el cultivo de la papa: el caso de Cuba
}

\author{
LUIS LAGO CASTRO*
}

\section{INTRODUCCIÓN}

El cultivo de la papa (Solonum tuberosum L.) tiene su centro de origen en América del Sur, y se le conoció en Europa después de la conquista de América por España. Introducida y luego diseminada en el viejo continente, fue domesticada y seleccionada de acuerdo con los patrones de exigencia agroecológica de una Europa que durante dos siglos la vio como una curiosidad botónica hasta convertirla en un componente de gran importancia en la economía de muchos paises desarrollados.

\section{Se considera que}

... la papa es uno de los cultivos más eficientes en convertir los recursos naturales, el trabajo y el capital, en un alimento de alta calidad con una amplia aceptación. A la vez, su producción se expande mós rópidamente que cualquier otro cultivo en los países en desarrollo y, en algunas óreas donde era virtualmente desconocida por algunas generaciones anteriores, es ahora parte de la dieta de la población (Horton, 1981).

Rhoades (1982) ha expresado de manera contundente que "la producción anval de papa a precios de consumo (106 mil millones de dólares) es mayor que todo el valor del oro y la plata que se llevaron los españoles del Nuevo Mundo". La importancia del cultivo de la papa en la producción de alimentos radica en que:

1) Ocupa el cuarto lugar en lo referente a valor.

2) Se desarrolla en una gran variedad de sistemas agroecologicos.

- Jefe del laborotorio de cultivo de tejidos y transformación. Agrupación de plantas y fertilizantes. Centro de Ingeniería Genbtica y Biotecnología. La Habana, Cuba. 
3) Rinde mós por unidad de superficie que el trigo, el máz y el arroz.

4) Dentro de los cultivos considerados como raíces y tubérculos, tiene el ciclo vegetativo más corto (tres-cuatro meses).

5) Es de gran docilidad, lo cual permite la aplicación de las más variadas tecnologías.

Este cultivo ha generado un intenso comercio, como lo muestran los datos presentados por Horton (1988) cuando señala que en 1984 el volumen alcanzó casi los siete millones de toneladas; a los países en desarrollo correspondió importar 1.2 millones de toneladas de dicho cultivo (cuadro 1).

CUADRO 1

COMERCIO DE TUBÉRCULOS, 1984

(miles de tonoladas)

PAPA

\begin{tabular}{lcc}
\hline & Importaciones & Exportaciones \\
\hline Países en vías de desarrollo & 1241 & 786 \\
Países desarrollados & 6516 & 6909 \\
\hline
\end{tabular}

FUENTE: Horton, 1988.

Hoy el cultivo de la papa retorna a los lugares de su origen genético como producto netamente acabado, ya sea en forma de variedades con alto potencial de rendimiento $(t / h a) \circ$ de productos alimenticios. Resulta paradójico que América fuera la que brindara al mundo la diversidad genética para las actuales variedades y sin embargo no disfrute de ellas sino a condición de aumentar su dependencia economica y reforzar su atraso tecnológico. ¿̇En verdad es esto así?

Veamos algunos datos que reflejan la realidad de nuestros países:

a) América Latina vive el décimo año consecutivo de su peor crisis económica y social.

b) El nuevo continente alcanzó los 447 millones de habitantes en 1990.

c) Se estima que en 1989 entre 35 y $40 \%$ de la población en edad laboral se encontraba total o parcialmente desempleada.

d) En 1985 el número de desnutridos ascendía a 55 millones, que llegarán hasta 62 millones al finalizar el siglo. 
e) Casi dos siglos después de que la mayor parte de los países logró su independencia, el $15.3 \%$ de la población latinoamericana adulta sigue siendo analfabeta.

f) En 1990 la deuda alcanzaba 423 mil millones.

g) La inflación, que en 1982 fue de $56.1 \%$, alcanzó en 1990 el promedio casi increíble de 1500 por ciento.

h) En su conjunto, los recursos financieros necesarios para alcanzor la solución de las metas sociales ascenderían a unos $\mathbf{2 8 2}$ mil millones de dólares, cifra que equivale al $66 \%$ de la deuda extema acumulada al final de 1990 (Castro, 1991).

i) En 1987 la FAO hace una evaluación del pronóstico mundial de la alimentación y la agricultura hasta finales de siglo y señala que el $22 \%$ de la población de los paises subdesarrollados se encuentra en niveles de malnutrición (Brader, 1989).

i) Tenemos cuatro veces menos científicos y técnicos por habitantes que los países desarrollados.

Estas realidades vinculadas al sector agrícola y científico-técnico nos llevan a la conclusión de que cuando en un país las mayorías no tienen acceso a los medios de producción tecnológica, las limitaciones productivas de los cultivos no resultan sólo genéticas, sino fundamentalmente económicas y culturales.

La agricultura necesita a corto plazo nuevas alternativas y tecnologías de producción, nuevos enfoques y soluciones que permitan un uso racional de nuestras potencialidades. En tal sentido, es importante combinar la expectativa de los científicos agrícolas, los economistas y los sociólogos (quienes entienden los intereses de esas necesidades) con la de los biólogos modernos (quienes conocen nuevas vías para resolver viejos problemas).

Estos nuevos colaboradores son un elemento clave para integrar las nuevas tecnologías a los programas de investigación con que ya se cuenta en diferentes cultivos.

Todo ello debe tener una vía productiva, por lo que se ha señalado (Persley, 1989) que, en producción vegetal, el principal camino para aplicar nuevas tecnologías será mediante el desarrollo de semilla de nuevas variedades de plantas con nuevas características.

\section{AGRICULTURA MODERNA Y BIOTECNOLOGÍA}

"Aun en los países avanzados, los programas de mejoramiento de la papa pueden tomar de seis a siete años para crear una nueva variedad 
y dos décadas o más para alcanzar un efecto" (Sawyer, 1990). Cálculos realizados indican que un mejorador debe manipular alrededor de 100 mil posturas como resultado de un cruzamiento, para llegar (al cabo de seis a siete años) a una variedad, sin tener en cuenta aún su posible repercusión productiva.

Como manera de aliviar esas limitaciones, uno de los propósitos de la agricultura moderna es integrar la biotecnología a los programas de desarrollo agrícola. En dicho contexto, su aplicación ha expandido su gama desde la investigación básica hasta las tecnologías de ensayos de campo (Cohen, 1990), por lo cual influye cada vez más en la producción de semillas y en la solución de los problemas prócticos de dichas producciones.

Las investigaciones en manipulación genética de plantas, por otro lado, son llevadas a cabo fundamentalmente en países desarrollados, y sólo una cantidad reducida de países del Tercer Mundo (y dentro de ellos sólo algunas instituciones) tienen acceso a esas tecnologías de avanzada.

Dichas actividades incluyen el cultivo de tejidos y células (cultivo de anteras, variación somaclonal, cultivo de meristemos, multiplicación rápida y conservación de germoplasma in vitro, producción de plantas libres de patógenos), diagnóstico molecular (sondas de ácidos nucleicos, anticuerpos monoclonales, prueba de ELISA) y la ingeniería genética.

Como puede observarse, dentro de los métodos biotecnológicos se contempla toda una gama de alternativas: desde los técnicamente complejos, a menudo costosos, ejemplificados por las técnicas del ADN recombinante, hasta los más utilizados comúnmente y de fácil comprensión para cualquier productor como son laş técnicas de bajo costo, 0 sea el cultivo de células y tejidos.

\section{LA BIOTECNOLOGÍA EN LA AGRICULTURA CUBANA. EL CASO DEL CULTIVO DE LA PAPA}

La biotecnología de las plantas en su concepción más elemental (la micropropagación in vitro) surgió en la agricultura cubana a partir del modelo de cultivo de la papa (1977), como consecuencia lógica y necesaria de nuestra economía, al no disponer de material de siembra sin enfermedades para ser utilizado como semilla básica y así poder organizar el Esquema Nacional de Producción de Semillas de Alta Calidad.

Esta experiencia se fue expandiendo hacia otros cultivos como la caña y el plátano, y en la actualidad llega a niveles comerciales (los 
cuales aunque no basaban su producción en la importación de semillas sí requerían de grandes volúmenes de material de siembra).

Cuba es un país pequeño, que basaba su producción de papa en la importación total de su semilla y en su consumo posterior en la alimentación humana al no tener grandes capacidades de almacenamiento refrigerado. De la misma manera, al no ser centro de origen genético de dicho cultivo, debía utilizar variedades foráneas que en la mayor parte de los casos no respondían a las exigencias edafoclimatológicas del país.

Este cultivo se ve afectado por una cantidad considerable de agentes patológicos como hongos, bacterias y virus, unidos al ataque de insectos y nemátodos, que originan daños cuantiosos en la producción o pueden volver inservible la semilla.

Los primeros intentos de repetir la concepción tecnológica tradicional (europea y americana) de producción de semillas brindaron datos interesantes (cuadros 2 y 3 ) que influyeron en la búsqueda de otros métodos:

CUADRO 2

INFLUENCIA DE LAS ENFERMEDADES VRALES EN EL RENDUMIENTO (LAGO, 1987)

\begin{tabular}{llccc}
\hline \multicolumn{1}{c}{ Variedad } & Enfermedad & \multicolumn{2}{c}{ Rendimiento (t/ha) } & $\%$ \\
& & Sana & Enferma & Disminución \\
\hline Red La Soda & PLRV & 25257 & 10062 & 50 \\
Viking & PLRV & 13515 & 7144 & 47 \\
Cariboo & PLRV & 18268 & 12425 & 32 \\
Red La Soda & Mosaico & 25257 & 10062 & 66 \\
\hline
\end{tabular}

FUENTE: Lago, 1987.

CUADRO 3

AUMENTO DE LOS\% DE CONTAMINACION DE ENFERMEDADES

DESPUES DE LA IY II REPRODUCCIONES

\begin{tabular}{lcc}
\hline & \multicolumn{2}{c}{ Presencia de virus (\%) } \\
\hline \multicolumn{1}{c}{ Provincia } & $\begin{array}{c}\text { Treproducción } \\
\text { (PVX+PVY+PLRV) }\end{array}$ & $\begin{array}{c}\text { Mreproducción } \\
\text { (VX+PVY }+ \text { PLVV) }\end{array}$ \\
\hline Pinar del Rio & $0.35-5.40$ & $6.0-29.0$ \\
Habana & $0.35-5.40$ & $15.0-30.0$ \\
Villa Clara & $0.38-3.05$ & 44.0 \\
Matanzas & $0.60-2.80$ & 4.6 \\
\hline
\end{tabular}

NOTA: dichas producciones fueron realizadas sin eliminar las plantas enfermas.

FUENTE: Lago, 1987. 
Con posterioridad a todo un trabajo desarrollado de evaluación de las distintas alternativas, se llegó a las siguientes conclusiones:

1. Las enfermedades virales influyen significativamente en los rendimientos del cultivo.

2. La producción de semilla sin la realización de la "selección negativa" (extracción de plantas enfermas) es imposible al originarse una "degeneración de la semilla", lo cual limita el potencial productivo del material biológico.

3. "in condiciones tropicales como la nuestra, donde las poblaciones de insectos vectores de virus (afidos), no son disminuidas por las heladas, resulta imposible aplicar una concepción tradicional para la producción de semillas del cultivo, basada en reiteradas multiplicaciones en el campo hasta llegar a producir tubérculos destinados a la alimentación.

Tomando en consideración estos resultados que forman parte de un trabajo experimental de 10 años (Lago, 1976) encaminado a la adecuación de un esquema de producción de semillas acorde a nuestras limitafiones agroclimáticas del cultivo, los hábitos de consumo, su demanda y la experiencia productiva de los productores privados y estatales, en la década de los ochenta se inició la incorporación de la biotecnología, y como primer paso "la micropropagación in vitro" para responder a las exigencias productivas de una extensión de alrededor de 13 mil hectáreas y un rendimiento promedio que en la actualidad llega a 20 t/ha.

Según señala Persley (1989),

... en producción vegetal, las mayores aplicaciones de la biotecnología son a corto plazo; tal es el caso del mejoramiento de los métodos de diagnóstico de enfermedades. Sin embargo, a largo plazo la ingeniería genética contribuye a mejorar la resistencia de las plantas ante los insectos y las enfermedades (particularmente virus), tolerancia a herbicidas y mejoramiento de la calidad nutricional.

Las biotecnologías que pueden tener un efecto importante en el cultivo son: la del cultivo de tejido (figura 1) y la ingeniería genética (figura 2).

Al tomar en cuenta las características propias de nuestro país y los resultados obtenidos en investigación, se ha considerado que las repercusiones que tiene y tendrá durante los próximos 10 años la biotecnología en el cultivo de la papa abarcarán campos que actúen 


\section{Figura 1: Área mundial de papa (Coseche, mo/89)}

Desarrollado 66\%

11875

(1000 has)

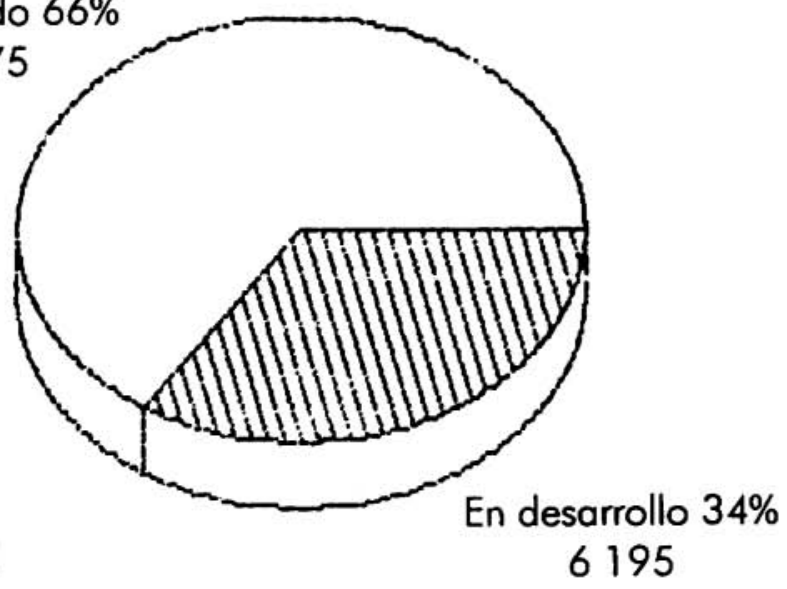

\section{Figura 2: Rendimiento papa (Reporte mo/89)}

( $\mathrm{Kg} / \mathrm{ha})$

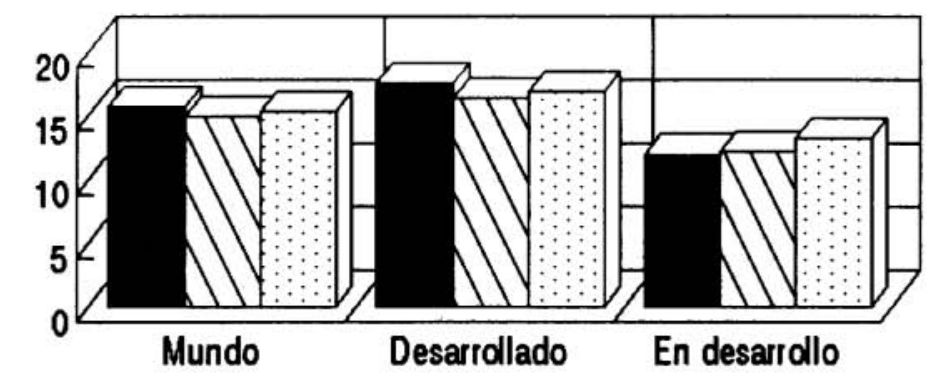

\begin{tabular}{|l|c|c|c|}
\hline 1987 & 15.669 & 17.54 & 11.962 \\
1988 & 14.923 & 16.384 & 12.125 \\
1989 & 15.316 & 16.916 & 13.245 \\
\hline
\end{tabular}

口1987 $\nabla_{1988}$ 国1989 
entre sí como son: 1) conservación de germoplasma; 2) producción de semilla de papa y 3) mejoramiento genético de variedades.

\section{EFECTO EN LA CONSERVACIÓN Y DISTRIBUCIÓN DE GERMOPLASMA}

Los intentos de crear variedades nacionales han sido limitados, en gran medida al no ser centro de origen genético del cultivo, aunque el intercambio genético de germoplasma hace que las especies solicitadas puedan ser entregadas a instituciones y organismos internacionales que de este modo pueden enriquecer el acervo genético nacional.

La pérdida de genotipos debida a desastres naturales o bien a la limitación para crear órganos reproductivos es un hecho común en las colecciones mantenidas in vivo. Tomando en consideración esos problemas, se han desarrollado en los últimos años algunas tecnologías de conservación a largo plazo como la cryopreservacion en nitrógeno líquido (Towill, 1984), por lo regular costosa, o el mantenimiento a corto plazo que produce bajas tasas de crecimiento de las plántulas implantadas in vitro (Espinosa, 1985). En ambos casos se obtiene un ahorro considerable en recursos financieros.

De esta manera, en nuestro Programa Nacional se ha venido aplicando la conservación in vitro a tasas de crecimiento muy bajas, y por la cual las transferencias se réalizan una vez por año; esto no sólo hace posible tener los genotipos deseados para fines genéticos, sino todos los clones "sin enfermedades" de las diferentes variedades utilizadas en la producción de semillas.

\section{EFECTOS EN LA PRODUCCIÓN DE SEMILLAS}

La producción de semillas se basa en la selección de individuos idénticos al deseado; multiplicados en un tiempo dado, incluso años, pueden satisfacer las necesidades alimentarias de la población.

Una semilla deja de serlo desde el punto de vista agrícola cuando se desvía de sus características propias, pierde su capacidad productiva o se ve afectada por plagas y enfermedades que la hacen inservible.

La perspectiva del valor de la semilla se ensombrece más aún cuando conocemos que durante su reproducción se infecta con diversas enfermedades que afectan considerablemente su capacidad productiva (véase el cuadro 2) y su valor de uso. De no aplicarse los métodos apropiados, lo anterior puede limitar su utilización continua; a esto hay que agregar los limitados recursos con que cuenta el pequeño agricultor para volver a adquirir semillas. 
En nuestro país dicho cultivo no se ha dirigido a las economías de subsistencia, sino a la aplicación de tecnologías, con un gasto considerable en el cǫmponente de semilla y de otros insumos.

Tradicionalmente la producción del cultivo, aun después de 1959 (cuando se produjo un cambio social), basó su estrategia en la importación de semilla para alimentar un esquema "artificial" de producción (véase la figura 3) -con los esperados riesgos de introducción de patógenos cuarentenados- que origina la entrada al país de más de 16 mil toneladas de semilla anvales; el resultado fue una estrategia que permitió reducir en $50 \%$ dichas importaciones. Sin embargo, el objetivo final, la sustitución total de las importaciones, aún no ha terminado por la falta de capacidad de almacenamiento refrigerado para toda la semilla requerida.

Habrá de tenerse en cuenta que mientras la producción de papa para el consumo se realiza tanto por parte del sector privado como del estatal, nuestra producción de semillas y su Servicio de Inspección y Certificación tienen un carácter estatal. Por lo anterior, y tomando en consideración las experiencias científicas referentes al saneamiento de variedades (Mellor, 1977) y la mulfiplicación acelerada in vitro (Westcott, 1982; Schilde, 1984), el Estado financió la organización de un Centro Especializado dedicado a la multiplicación (por dicha vía) de las variedades más utilizadas $y$, simultáneamente, a la investigación y producción del material original y básico necesario.

Para ello fue indispensable establecer:

1) Un sistema de eliminación de patógenos de las variedades de uso comercial.

2) La implantación de una tecnología de propagación que produce en la actualidad 250 mil plántulas in vitro para obtener 3.5 millones de tubérculos anualmente como primera etapa del Esquema de Producción de material de alta calidad.

3) La utilización de medios diagnósticos (antisueros) para virus, con el objetivo de vigilar durante las distintas etapas vegetativas los niveles de virus expresados en porcentajes existentes, tanto en clases de alta calidad como en las comerciales.

Consideramos que el efecto más importante será la producción de toda la semilla del país basada en el uso del cultivo de tejidos, además de la aplicación masiva de medios de diagnóstico (sondas, anticuerpos monoclonales, prueba de ELISA), los cuales permitirán producir el material de siembra con mayor calidad fitosanitaria. 


\section{Figura 3: Producción de papa (Reporte mo/89)}

(MT)

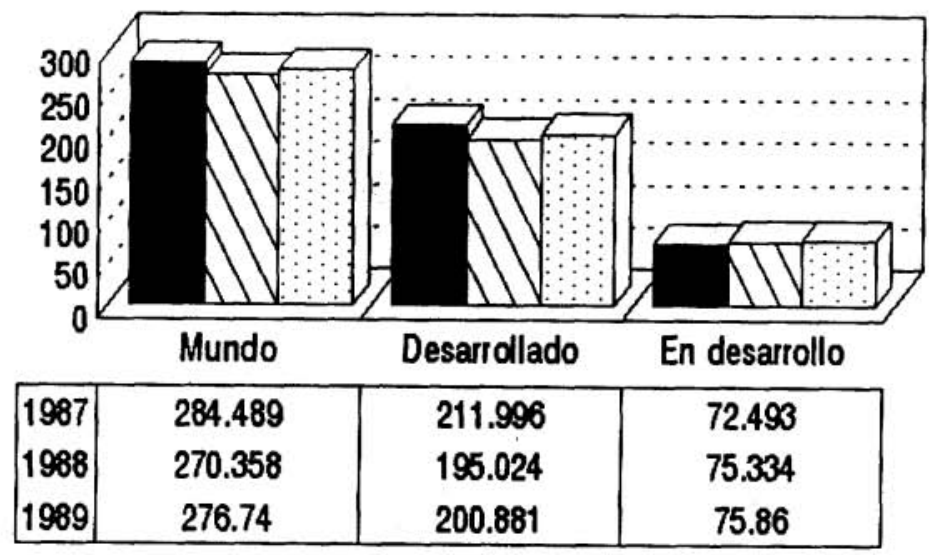

口 1987 \1988 回1989

\section{EFECTO EN EL MEJORAMIENTO GENÉTICO DE VARIEDADES}

En toda la historia del cultivo en el país no ha sido posible crear una sola variedad debido, entre otros factores, a la falta de recursos genéticos y cuadros cientificos para tales actividades.

$\mathrm{El}$ efecto que ha tenido el mejoramiento genético en Cuba ha sido la vertiente de prueba de variedades extranjeras que, finalmente, genera una mayor dependencia económica al tener que importar semilla desde el país que las envió a prueba.

Se ha dicho que mediante la biotecnología es mós fácil incorporar un nuevo carócter a una variedad de cultivo dada que crear una nueva, y que ello reduce, como es de suponer, el tiempo que se lleva crear una nueva variedad. De ahí la importancia del trabajo de ingeniería genética que nos permite (mediante técnicas de manipulación genética) incorporarle el carácter deseado y mantener en rasgos generales las características iniciales de la misma variedad.

El acceso a las técnicas del ADN recombinante y su ulterior uso en aspectos de nuestra agricultura sólo fue posible mediante un amplio proceso educacional que sacó del analfabetismo a grandes sectores de 
la población, generalizó la enseñanza y propició que la aparición de talentos y personal calificado fuera la regla y no la excepción.

Esta políica educacional y cientffica tiene como su purf́to culminante la creación del Centro de Ingeniería Genética y Biotecnología, que coloca a nuestra ciencia a los niveles del mundo desarrollado.

Hay antecedentes en el mundo que muestran que mediante ingeniería genética es posible lograr resistencia a virus de plantas; tal es el caso de la reportada por Powell-Abel y cols. en 1986, quienes observaron que las plantas de tabaco modificadas demoraban significativamente la expresión de los síntomas al ser inoculadas con el TMV. Actualmente esto ha sido demostrado en un grupo considerable de cultivos.

Más recientemente se ha reportado resistencia a virus de papa para los virus PVX y PVY (Lawson, 1990), PLRV (Kawchuk, 1990) y el PVS (Mackenzie, 1991), entre otros resultados notables. Sin embargo, la aplicación de estas técnicas de ingeniería genética ha sido factible en años recientes con el desarrollo de técnicas eficaces de cultivo de tejidos para la regeneración de tejidos transformados (Stiekema y cols., 1988; De Block, 1988).

En nuestro país las aplicaciones de la ingeniería genética en el cultivo de la papa van encaminadas en los momentos actuales a generar resistencia a las enfermedades virales (PVX, PVY, PLRV) o sus combinaciones $(P V X+P V)$, las cuales ya se encuentran en algunos casos en evaluación en nuestros invernaderos y en estudios de campo para 1993.

La incorporación de estas resistencias a variedades que normalmente no la tienen propiciará un mejor comportamiento productivo, así como la posibilidad de realizar una producción de semillas a más largo plazo (con el aumento del número de ciclos de reproducción en algunas categorías) y disminuir los niveles de aplicación de plaguicidas para el control de insectos.

Consideramos que el efecto más notable será poder reducir drásticamente los plazos para crear una nueva variedad, lo cual revolucionará los conceptos clásicos del mejoramiento y a la vez brindará al agricultor un nuevo producto a corto plazo.

\section{LIMITACIONES PARA LA TRANSFERENCIA DE TECNOLOGIAS HACIA LOS PAÍSES SUBDESARROLLADOS}

Por último queremos mencionar en este apartado algunas reflexiones en torno al acceso y desarrollo de la biotecnología en los países subdesarrollados.

La instrumentación de las tecnologías celulares y moleculares en los países subdesarrollados, independientemente del propósito que se 
persiga, tiene características muy particulares que deben tenerse en cuenta para la transferencia exitosa de cualquier tecnología. Ellas son:

1. Los especialistas tienen un conocimiento parcial o limitado de una tecnología dada.

2. El científico tiene muchas dificultades para aplicar correctamente en su país un conocimiento generado bajo otras condiciones.

3. La instrumentación de la tecnología en su país se ve limitada al no contar con suficientes medios para su puesta en marcha o no tener respaldo financiero. El abandono de ese esfuerzo es el caso más frecuente.

4. En innumerables casos la integración con el programa convencional de investigación agrícola no se produce debido a las barreras ficticias que contraponen entre sí lo convencional a lo moderno.

5. La coordinación con los requerimientos de bioseguridad es el imperativo que a menudo se nos impone como argumento más frecuente para ejemplificarnos que sólo debemos recibir el producto acabado.

La adquisición o adaptación de biotecnologías a objetivos locales requiere del desarrollo de una capacidad técnica en el país que permita seleccionarlas y usarlas satisfactoriamente. En la mayor parte de los casos, tales capacidades no han sido creadas, lo cual no está desvinculado de la política educacional y científica de un país determinado.

Ante los países subdesarrollados se presentan dos opciones: adquirir tecnologías o crearlas, con posibles repercusiones jurídicas por parte de sus creadores.

La adquisición de nuevas tecnologías para ser aplicadas en el mundo subdesarrollado no debe limitarse a conceptos que exaltan solamente el papel del sector privado o estatal sino, por el contrario, deben considerarse en el contexto de las particularidades de cada país, de acuerdo con sus recursos económicos y sus concepciones propias de desarrollo.

Por tal razón, consideramos que la biotecnología, en sus diferentes facetas, puede contribuir a preservar los valiosos recursos genéticos con que contamos y a mejorar los sistemas de diagnóstico de enfermedades, así como de las características de nuestras variedades; todo ello debe propiciar un aumento de producción que se reflejaró en el mejoramiento nutricional de nuestras poblaciones.

Como se ha señalado, un obstáculo para el desarrollo en nuestros países han sido las discusiones que se producen entre naciones 
desarrolladas y subdesarrolladas en materia de patentes y de propiedad intelectual en biotecnología vegetal, pues el sector privado ha incrementado su papel y por ende la comercialización de los productos derivados de ella. En este sentido, James (1989) ha señalado la posibilidad de que los productos biotecnológicos no sean protegidos en el Tercer Mundo, y apunta que esto debe evitarse si se les transfiere del sector privado para beneficio de los países subdesarrollados. Sin embargo, más allá de dicha aseveración, consideramos que deben buscarse fórmulas apropiadas que beneficien y no marginen las aspiraciones de muchos países a mejorar su acceso a nuevas alternativas o formas de producción.

\section{CONCLUSIÓN}

En general se ha considerado como positivo el efecto socioeconómico de la biotecnología en lo referente al incremento de la producción que genera o las facilidades que realmente ofrece para producir semillas sobre bases cientifficas. En nuestro país es una alternativa de desarrollo económico. Así pues, la biotecnología tendrá una profunda repercusión en las investigaciones agrícolas y en la producción.

Como resultado de su influencia, se gestan nuevos conceptos en la esfera productiva de la papa, aś como conceptos diferentes de producción de semilla y de creación de variedades; esto debe originar el tan anhelado sueño del trabajo en equipos multidisciplinarios.

El incremento del dominio del sector privado en las actividades de investigación puede elevar el costo del acceso de los países subdesarrollados a las tecnologías de avanzada, o simplemente no permititlo. De esta manera, corremos el riesgo de no llegar a tiempo a obtener los beneficios de esta revolución en la agricultura o no participar en ellos.

Las discusiones en forno a qué debe patentarse y cuál es el derecho de los países subdesarrollados a recibir los beneficios de la constante revolución científico-técnica auguran un futuro de tensión en un mundo que requiere una nueva óptica productiva y presenta el imperativo de los desposeídos de siempre.

La biotecnología agrícola ha llegado a la agricultura para formar parte de ella, y su introducción rápida o lenta en los procesos productivos dependerá de las características de cada país.

Basados en las realidades económicas de América Latina, consideramos que si sólo impera la Ley del Valor como palanca impulsora, es de esperar que la biotecnología pase a ser una alternativa malograda de desarrollo si no se utilizan armónicamente los recursos humanos y materiales de que se dispone en la región. 
En nuestro país dicho efecto se observa ya en un proceso de consolidación:

1) Su integración a los distintos componentes de la producción del cultivo (micropropagación in vitro, uso de métodos de diagnóstico).

2) Nuevas variedades adaptadas a nuestros problemas agronomicos específicos (resistencia al PVX, PVY, PLRV).

3) Un esquema de semilla completamente nacional que elimine los gastos por concepto de compra de semilla en el extranjero y su ulterior transportación.

4) Un aumento en la demanda de infraestructura de frigoríficos que satisfaga los volúmenes de semilla por almacenar.

5) Una autosuficiencia en materia de semilla que origina una competencia en las capacidades de almacenamiento para consumo y cultivo, lo cual debe poner fin a la creación de instalaciones para el procesamiento industrial de dicha semilla.

Así, el efecto más notable debe ser la formación de una cultura biotecnológica orientada al productor-consumidor que verb́ en ella una posibilidad de desarrollo económico para el país que sirva a la vez de modelo extrapolable a otros cultivos de importancia.

\section{Figura 4: Algunas vertientes del cultivo de tejidos en plantas}

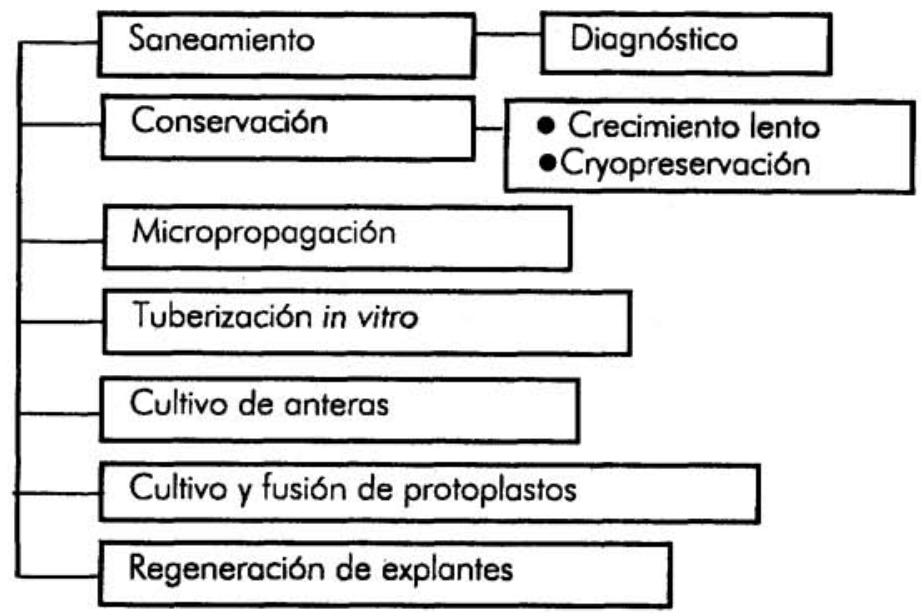




\section{Figura 5: Algunas tendencias de ingeniería genética en el cultivo de la papa}
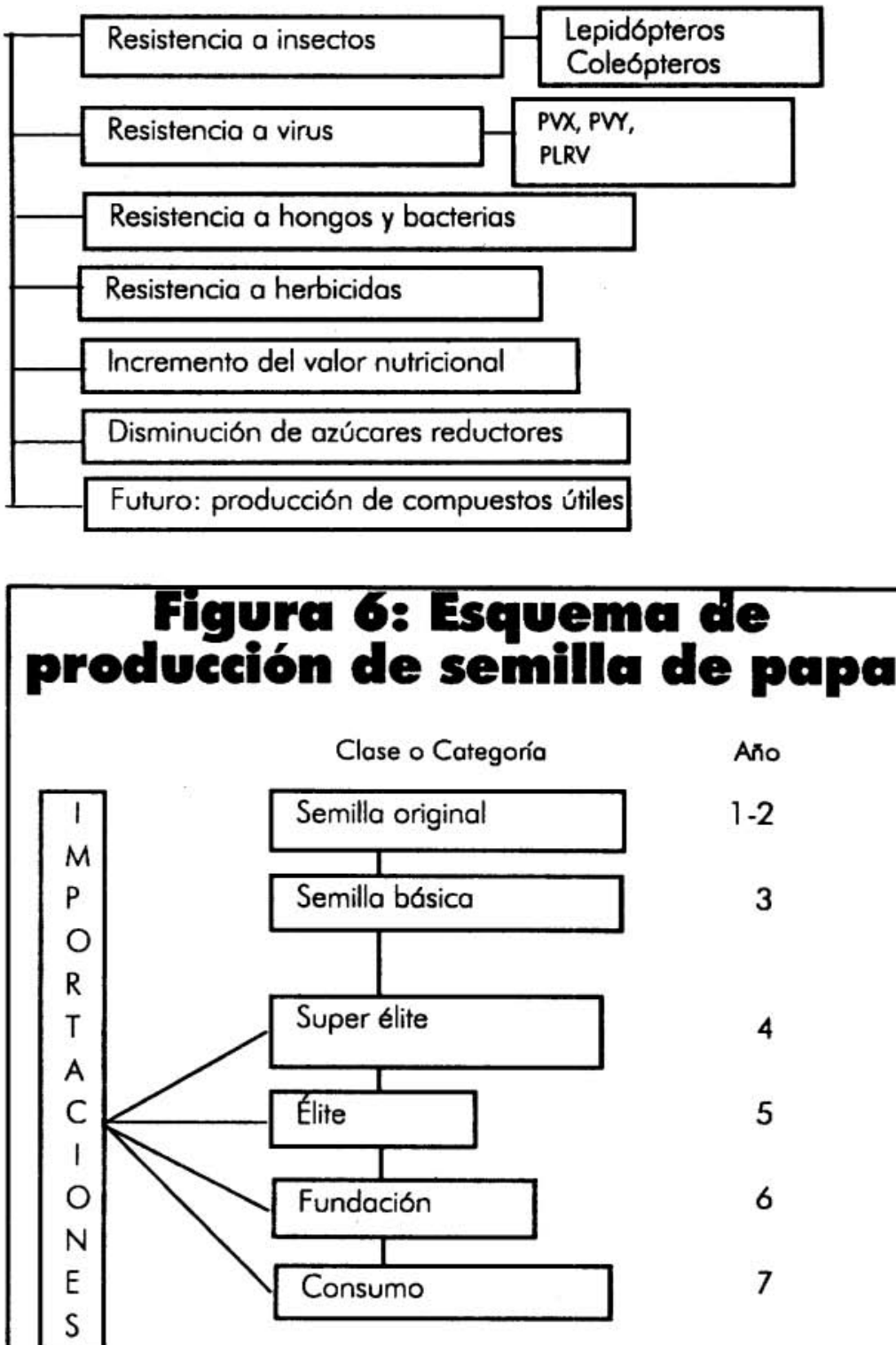

Anัo

1-2

3

4

5

6

7 


\section{BIBLIOGRAFÍA}

Braader, L. 1989. "Agricultural Development and Plant Biotechnologie". Simposio Plant Biotechnologies for Developing Countries. Luxemburgo: CTAFAO, 26-30 de junio.

Castro, F. 1991. "Mensaje a la Primera Cumbre Iberoamericana". Guadalajara, México.

Cohen, J. L. 1990. "International Donor Support for Agricultural Biotechnology". Food Policy, febrero, pp. 57-66.

De Block, M. 1988. "Genotype independent leaf discs transformation of potato (Solanum tuberosum) using Agrobacterium tumefeciens". Theor. Appl. Genet. 76: 767-774.

Espinosa, N.; Estrada, R.; Tovar, Pilar; Bryan, J.; Dodds, D. 1985. Cultivo de tejidos: micropropagación, conservación y exportación de germoplasma de papa. Documento de tecnología especializada 1. Centro Internacional de la Papa. 17 págs.

FAO. 1989. Anuario de producción. Vol. 43, 346 pp.

Horton, D. 1981. Potato CERES. Enero-febrero.

. 1988. Underground Crops. Long-term in Production of Roots and Tubers. Winrock International Institute for Agricultural Development.

James, C. 1989. "The Role of the Private Sector in Transferring Plant Biotechnology to the Third World". Simposio Plant Biotechnologies for Developing Countries. Luxemburgo: CTAFAO, 26-30 de junio. Lago, L. 1976. Una revolución en la concepción de la producción de semilla de papa. La Habana, Cuba: CIDA, Min. Agricultura.

. 1987. "El aislamiento en la producción de semillas". Memorias del Primer Taller de Degeneración de la Semilla de Papa. La Habana, Cuba: Programa Regional Cooperativo de Papa, 20-27 de marzo.

Mellor, F. C., Stace-Smith, R. 1977. Virus-free Pototoes by Tissue and Organ Culture. Compilado por Reinert J. Bajaj, Y.P. Heidelberg, Nueva York, pp. 617-640.

Persley, Gabrielle. 1989. "Agricultural Biotechnology Opportunities for International Development". Simposio Plant Biotechnologies for Developing Countries. Luxemburgo: CTAFAO, 26-30 de junio. Rhoades, R. E. 1982. "The Incredible Potato". National Geographic Magazine. Vol. 165. Núm. 5, mayo, pp. 668-684.

Sawyer, R. 1990. "Programming the Potato to Serve a Changing World". 2nd. Triennial Meeting of the African Potato Association. Reduit, Mauricio, 23-27 de julio.

Schilde, L. R., y Schmiediche, P. E. 1984. "El cultivo de tejido: su pasado, presente y futuro". Circular CIP. Vol. 12. Núm. 1, pp. 1-10. 
Stiekema, W. J.; Heidekamp, F.; Louwerse, J. D.; Verhoeven, H. A.; Dijkhuis, P. 1988. "Introduction of Foreign Genes into Potato Cultivars 'Bintie' and 'Desirre' Using Agrobacterium Tumefaciens Binary Vector". Plant Cell Report. 7:47-50.

Towill, Leigh E. 1984. "Survival at Ultra-Low Temperature Short Tips from Solanum Tuberosum Groups Andigeno, Phureja, Stenotomum, Tuberosum and Other Tuber-bearing Solanum Species". Cryo-Letters 5, pp. 319-326.

Westcott, R. 1982. "The Application of Tissue Culture Techniques to Seed Potato Production". Proc. 5 th. Int. Cong. Plant Tissue Culture \& Cell Culture. 


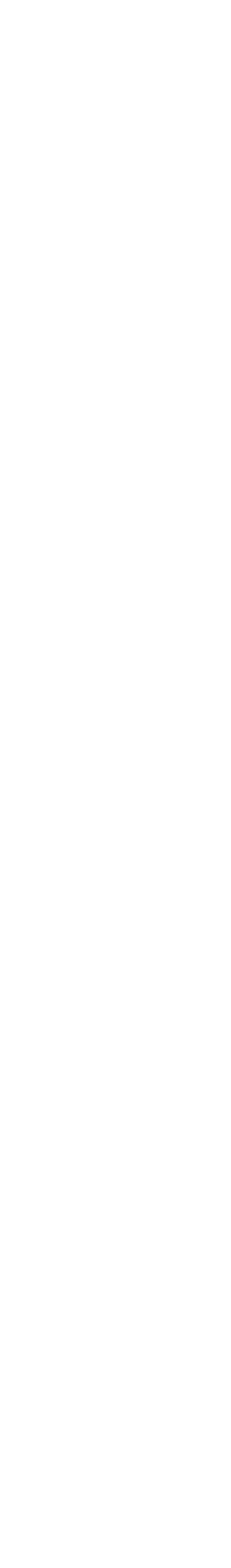




\title{
Aplicaciones de la bioteenología a la florieultura de México: efectos en el empleo
}

\author{
YOLANDA MASSIEU, MICHELLE CHAUVET, \\ YOLANDA CASTAÑEDA Y ROSA ELVIA BARAJAS
}

\section{INTRODUCCIÓN}

El presente trabajo analiza los efectos socioeconómicos de la biotecnología con base en un estudio de caso, la floricultura, y destaca dos aspectos prioritarios y delicados: el empleo y el mercado de trabajo.

El estudio de caso se enmarca en la situación de la agricultura en el proyecto económico neoliberal aplicado por los gobiernos recientes de México: de economía abierta, basada en las exportaciones para obtener divisas con el fin de financiar el crecimiento industrial. Esto conduce a que se pierda el estímulo para elaborar internamente los productos que se puedan adquirir en el exterior a un precio menor, como los granos básicos, cuyos costos de producción en el país son altos.

Simultáneamente a este fenómeno que se observa en la producción de alimentos, se fomenta el aumento de productos suntuarios de exportación, como flores, frutas y hortalizas. Las aplicaciones comerciales de la biotecnología vegetal ya se han generalizado en estas especies vegetales que, en el actual contexto de liberalización del comercio internacional, se perfilan como los productos más dinámicos y con un mercado exterior rentable.

Por esas razones consideramos pertinente realizar un análisis comparativo entre la floricultura tradicional, a cielo abierto, y el mercado interno —en Temixco, Morelos-, y la floricultura intensiva

* Equipo de Investigación "Biotecnología y Sociedad", Departamento de Sociología, Universidad Autónoma Metropolitana, Azcatpozalco. 
de invernadero para exportación auspiciada por el gobiemo de Morelos mediante su Instituto de Floricultura.

El estudio de caso se basa en datos recopilados en distintos períodos entre 1988 y 1991. Se expone un resumen de lo mós importante de esa información, relativa a la aplicación de la biotecnología en la producción intensiva de flores y sus efectos en el mercado de la fuerza laboral. En la última parte del trabajo enunciamos los avances de la sistematización en la información de campo.

\section{NEOLIBERALISMO, TRATADO DE LIBRE COMERCIO Y FLORICULTURA}

De los programas de ajuste aplicados en América Latina es común escuchar que el caso mexicano ha sido el más exitoso. Sobra decir que dichos programas son totalmente indiferentes a los "costos sociales" -el deterioro en el nivel de vida de la mayoría de la poblaciónnecesarios para aumentar la inversión y reactivar la economía.

Según el proyecto neoliberal, el libre mercado entraña la apertura total del comercio exterior, lo cual exige la derogación de toda clase de impuestos, cuotas y aranceles. Esta política se ha aplicado rigurosamente en las naciones subdesarrolladas y no ha encontrado una correspondencia en los países centrales, donde se siguen levantando fuertes barreras proteccionistas.

El actual gobierno de México prescribe la apertura de fronteras como una de las principales estrategias para revitalizar la economía; de esa manera espera obtener divisas y estimular la inversión extranjera.

Es en ese marco donde nos interesa analizar las repercusiones del Tratado de Libre Comercio (TLC) en la producción agropecuaria del país, particularmente en la floricultura.

Hay argumentos que ponen en tela de juicio los pronósticos referentes al TLC y consideran que la capacidad exportadora de México sigue siendo débil frente a sus necesidades de importación. Se estima que en 1991 el déficit de la balanza comercial se duplicó en relación con 1990: de 3.25 millones de dólares a 6.5 mil millones de dólares (Barranco, 1991). Por otra parte, resulta cuestionable buscar una mayor integración a la economía estadunidense, dado que ésta ha disminuido su importancia relativa en el ámbito internacional ante el terreno ganado por Japón y Alemania Federal. ${ }^{1}$

'Entre 1950 y 1973 la productividad por hora/hombre creció en EU a una tasa media anual del $2.4 \%$, mientras que en Alemania Federal y Japón esta tasa era de $6 \%$ y $7.6 \%$ respectivamente. Entre 1973 y 1984 esto cifra fue de $1.2 \%$ para EU y de 3 a $3.1 \%$ para las otras dos potencias (Fujii, 1990: 23). 
Un punto especialmente delicado del debate es la producción agropecuaria. De sobra conocida es la debilidad de México en la producción de ciertos bienes, en particular los granos básicos, ${ }^{2}$ frente a la alta productividad de la agricultura estadunidense, debida en buena parte a los generosos subsidios con que se le beneficia. Esta situación ahonda cada vez mós la vulnerabilidad alimentaria de nuestro país. No es casual que sean precisamente los precios de los alimentos básicos los que han experimentado incrementos mayores que la inflación; ello obedece a la dependencia cada vez mayor de las importaciones.

Los alimentos básicos han sido objeto de discusión en las negociaciones del TLC. En 1990, la Secretaría de Agricultura y Recursos Hidráulicos (SARH) anunció que sólo el maíz y el frijol quedarán exentos de una abierta competencia comercial, es decir, que contarán con protección arancelaria (La Jomada, 1990:24); pero el silencio oficial al respecto hace pensar que quizás el asunto no esté plenamente definido en la mesa de negociaciones.

Es paradb́jico que al tiempo que crecen las importaciones de alimentos básicos se otorguen estímulos a los productos que encuentran un mercado rentable en el exterior, como las tradicionales frutas y hortalizas y, más recientemente, las flores. Es decir, la producción agropecuaria mexicana se perfila como exportadora de productos de lujo e importadora de alimentos, lo que previsiblemente se agudizará con la puesta en práctica del TLC.

Los productos exportables registran los avances más significativos en la aplicación comercial de la biotecnología. Entre las flores, frutas y hortalizas encontramos que ya es una realidad la producción de material genético clonado y la reproducción por cultivo de tejidos. Es innegable el poder de las grandes corporaciones multinacionales en esa materia, dado que son las abastecedoras de las nuevas técnicas.

La biotecnología está estrechamente relacionada con un punto delicado del debate: la soberanía sobre los recursos fitogenéticos, dado que el conocimiento generado a partir de las manipulaciones genéticas del ADN permite apropiarse la materia viva y hace posible patentarla. En virtud de que los países subdesarrollados no cuentan con recursos suficientes para conservar este patrimonio, el libre flujo de éste como mercancía patentable aumentaría el poderío de las empresas interesadas en recolectar estos materiales con el objeto de obtener nuevas especies que puedan patentarse.

${ }^{2}$ La incosteabilidad de la producción interna de alimentos ha conducido a las crecientes importaciones: en 1990 compramos en el exterior 10 millones de toneladas de granos básicos, con un costo aproximado de 2400 millones de dólares (La Jornada, 1991). Dichas importaciones provinieron de Estados Unidos, que absorbe $75 \%$ (cifra de 1989) de nuestras exportaciones agropecuarias (Espinal, 1989), lo que pone de manifiesto la profunda dependencia de México con respecto a Estados Unidos. 
Consideramos que hay una contradicción entre el proyecto modernizador neoliberal mexicano y el trato que se da a la investigación científico-técnica (ICT). Ninguna modernización capitalista es viable sin un fuerte aparato generador de tecnologías propias, y en México los recursos destinados a la ICT son irrisorios. ${ }^{3}$

En este contexto presentamos un estudio de caso sobre la floricultura en el estado de Morelos, pues se trata de una rama productiva con un gran dinamismo exportador que incorpora la biotecnología en su proceso productivo y absorbe una considerable porción de fuerza de trabajo.

Dado que el estudio de caso se elaboró tomando en cuenta los efectos de las biotécnicas en el empleo y el mercado de trabajo, presentamos algunas consideraciones sobre este mercado en el medio rural en México.

\section{PROLETARIZACIÓN Y MERCADO DE TRABANO}

Economía campesina y proletarización

El punto central del debate, que se inició desde los años setenta, ha sido la modalidad del proceso de proletarización en la agricultura y la relación que éste guarda con la economía campesina (EC). En algunos estudios de lo años ochenta (Astorga, 1985; Carton, 1986) se afirma que los asalariados agrícolas siguen vinculados a la EC, lo cual contribuye a mantener el bajo nivel de sus salarios. Según un estudio de la $\mathrm{SARH}$, en 1988 el $78.3 \%$ de los jornaleros agrícolas mexicanos no ganaba ni la mitad del salario mínimo (La Jornada, 24 de julio de 1988:15).

Por otra paite, las funciones de la EC en relación con la modalidad de acumulación del capitalismo mexicano se han transformado: de ser una importante productora de alimentos y materias primas baratas que apoyó el crecimiento urbano-industrial hasta fines de los sesenta, ahora se perfila como expulsora de fuerza de trabajo sin posibilidades de encontrar empleo en la agricultura capitalista o en las ciudades, lo cual contribuye a aumentar la migración.

La proletarización no es un fenómeno unilineal y homogéneo, sino que comprende una amplia gama de grados y matices entre el productor independiente y el proletario despojado de todo medio de

3 En los años ochenta representaban apenas el $0.5 \%$ del PIB frente al $1 \%$ recomendado por la ONU (Casas, 1989) y, para 1990 el presupuesto gubernamental en este rubro era equivalente al costo de tres aviones de guerra de desecho de la Fuerza Aérea estadunidense (La Jornada, 22 de junio de 1990). 
producción. Esto no es exclusivo de México; se presenta, con variantes, en todo el Tercer Mundo.

Hay evidencia empírica de que el patrón de cultivos que se impuso en la agricultura empresarial mexicana en los años setenta tuvo fuertes repercusiones en el mercado de trabajo (Rubio, 1983:44). Así pues, el uso intensivo de capital -mediante la mecanización y agroquímicos como los herbicidas- desplaza mano de obra, en tanto que los campesinos pobres han sufrido un proceso de despojo de sus tierras, principalmente por acción de la ganadería extensiva que se expandió a un nivel sin precedente en el período 1950-1980. Estos cambios en el capital agropecuario han traído como consecuencia que la principal característica del mercado de trabajo rural sea una gran masa de campesinos desempleados o subempleados.

Ante el presente fenómeno de modernización y globalización económica, la empresa agrícola mexicana debe aplicar los avances recientes de la biotecnología si ha de conservar su competitividad, lo cual tiene repercusiones innegables en el mercado de trabajo rural, las que trataremos de identificar en el estudio de caso.

\section{MERCADO DE TRABAJO RURAL}

El mercado de trabajo rural en México se caracteriza por ser abundante, barato y desorganizado. Esto se agudizó con la mecanización y el cambio en el patrón de cultivos de la agricultura capitalista en los años setenta, y con la recesión y el desempleo generalizado en los ochenta.

Ante el actual proceso de modernización tecnológica y de apertura comercial en que se tiene que insertar la agricultura capitalista, los cultivos que se perfilan más dinámicos son los exportables, entre los que figuran los tradicionales - frutas y hortalizas - y, últimamente, las flores. Estas actividades no se mecanizan con facilidad y ya absorben, en el nivel comercial, nuevas biotécnicas. Ello repercute en el mercado de trabajo en virtud de que no necesariamente desplazan mano de obra, sino que, por el contrario, la absorben en gran cantidad.

En México el mercado de trabajo rural presenta una gran movilidad, como lo expresan las migraciones, a veces muy grandes, que tienen que realizar los jornaleros — provenientes de estados como Guerrero, Oaxaca, Tlaxcala, Querétaro y de algunas comunidades de Hidalgo- hacia las zonas de agricultura empresarial dinámica, como los distritos de riego de Sonora y Sinaloa, El Bajío y algunas partes de Tamaulipas.

La precarización y feminización son características recientes del mercado de trabajo rural mexicano. Se observa que una cantidad cada 
vez mayor de mujeres se está incorporando al trabajo agrícola asalariado, lo cual permite mantener aún más bajos los salarios e imprime características particulares a los procesos de organización. Este fenómeno se ha interpretado como resultado de la mayor oferta de trabajo rural ante las condiciones de miseria que vive la EC. Sin embargo, se ha rebatido esta versión con la tesis de que quizás existen mercados de trabajo agrícolos paralelos, ya que las mujeres no trabajan en las mismas ramas que los hombres. Las investigaciones realizadas a principios de los años ochenta sobre la participación de las mujeres en el trabajo asalariado en diferentes cultivos de exportación se orientaron a mostrar lo característico de la fuerza de trabajo femenina (Arizpe y Aranda, 1981; Roldán, 1981).

En general se ha tipificado al proletariado agrícola como un grupo social desheredado. Para las jomaleras agrícolas la "inferioridad" es resultado de su doble condición: mujer y trabajadora. Se habla así de una precarización y feminización del trabajo agrícola. También se ha presentado una mayor incorporación de mano de obra infantil, migrante e indígena; es decir, de los sectores que se encuentran en una situación de desvalorización social que pueden ser sujetos adecuados de una política laboral que busca flexibilizar el precio de la fuerza de trabajo mediante su descalificación.

La flexibilidad se presenta como un instrumento de modernización en escala mundial que significa la aplicación "de mecanismos que permiten todas las formas posibles de adaptación del uso de la fuerza de trabajo a las necesidades de los procesos" (Lara, 1990). Se aplica en particular a los sectores de la economía que requieren de altos niveles de calidad en el producto y plazos de entrega precisos y a veces discontinuos, como las flores de exportación.

Las mujeres son el sujeto social por excelencia para poner en próctica todas las formas de trabajo flexible, como el empleo a domicilio, la maquila y las ocupaciones de tiempo parcial.

Un informe del Buró Internacional del Trabajo calcula que en 1989 las mujeres representaban entre un tercio y la mitad de la fuerza de trabajo asalariada en el campo, $65 \%$ de las cuales se ocupaban de manera temporal en las plantaciones (Lara, 1990). En México, L. Arizpe (1989) estima que en 1985 habla un millón y medio de asalariadas agrícolas.

La fuerza de trabajo puede clasificarse según la tarea realizada: las labores que las mujeres y los niños pueden desempeñar a la perfección y las que requieren de hombres adultos. El consumo propiamente dicho de esta fuerza de trabajo se da en los campos, donde la duración de la jomada depende de las características geoclimáticas y de los requerimientos técnicos del cultivo. 
vez mayor de mujeres se está incorporando al trabajo agrícola asalariado, lo cual permite mantener aún mós bajos los salarios e imprime características particulares a los procesos de organización. Este fenómeno se ha interpretado como resultado de la mayor oferta de trabajo rural ante las condiciones de miseria que vive la EC. Sin embargo, se ha rebatido esta versión con la tesis de que quizós existen mercados de trabajo agrícolos paralelos, ya que las mujeres no trabajan en las mismas ramas que los hombres. Las investigaciones realizadas a principios de los años ochenta sobre la participación de las mujeres en el trabajo asalariado en diferentes cultivos de exportación se orientaron a mostrar lo característico de la fuerza de trabajo femenina (Arizpe y Aranda, 1981; Roldán, 1981).

En general se ha tipificado al proletariado agricola como un grupo social desheredado. Para las jornaleras agrícolas la "inferioridad" es resultado de su doble condición: mujer y trabajodora. Se habla así de una precarización y feminización del trabajo agrícola. También se ha presentado una mayor incorporación de mano de obra infantil, migrante e indígena; es decir, de los sectores que se encuentran en una situación de desvalorización social que pueden ser sujetos adecuados de una política laboral que busca flexibilizar el precio de la fuerza de trabajo mediante su descalificación.

La flexibilidad se presenta como un instrumento de modernización en escala mundial que significa la aplicación "de mecanismos que permiten todas las formas posibles de adaptación del uso de la fuerza de trabajo a las necesidades de los procesos" (Lara, 1990). Se aplica en particular a los sectores de la economía que requieren de altos niveles de calidad en el producto y plazos de entrega precisos y a veces discontinuos, como las flores de exportación.

Las mujeres son el sujeto social por excelencia para poner en práctica todas las formas de trabajo flexible, como el empleo a domicilio, la maquila y las ocupaciones de tiempo parcial.

Un informe del Buró Internacional del Trabajo calcula que en 1989 las mujeres representaban entre un tercio y la mitad de la fuerza de trabajo asalariada en el campo, $65 \%$ de las cuales se ocupaban de manera temporal en las plantaciones (Lara, 1990). En México, L. Arizpe (1989) estima que en 1985 había un millón y medio de asalariadas agrícolas.

La fuerza de trabajo puede clasificarse según la tarea realizada: las labores que las mujeres y los niños pueden desempeñar a la perfección y las que requieren de hombres adultos. El consumo propiamente dicho de esta fuerza de trabajo se da en los campos, donde la duración de la jomada depende de las características geoclimáticas y de los requerimientos técnicos del cultivo. 
El intento de relacionar las modalidades del mercado de trabajo rural con la tecnología dominante en el capital agrario se justifica sobre todo en estos momentos, cuando nos hallamos en el umbral de una nueva revolución tecnológica, representada en la agricultura por los avances de la biotecnología y la ingeniería genética.

En este sentido, cabe preguntarse si aplicar el progreso técnico en la producción desplaza inevitablemente fuerza de trabajo y qué importancia desempeña la elección de una $u$ otra técnica en un momento determinado. El punto central del debate en torno al desplazamiento de fuerza de trabajo que acarrean las nuevas tecnologías es (más que una discusión para elegir entre técnicas intensivas en capital o en mano de obra) determinar la mejor elección en el tiempo y el orden de prioridades sectoriales que debe seguirse en la incorporación del progreso técnico (CET y CIDE, 1985:17).

Si tomamos como punto de partida que la productividad del trabajo consiste, básicamente, en aumentar la cantidad de bienes producidos con menor costo en trabajo y capital, o que en cada bien producido aumente la cantidad de trabajo muerto en relación con el trabajo vivo, encontramos que resulta de especial importancia analizar las ramas agrícolas que se dinamizan y adoptan inicialmente los avances tecnológicos, lo cual determina su demanda de fuerza de trabajo. Esto cobra mayor influenciu si se considera que el ritmo y el modo que adopte la modernización tecnológica en la agricultura será determinante en su capacidad de absorber o expulsar fuerza de trabajo.

Consideramos que la floricultura es una de las ramas que han ganado dinamismo y se han expandido gracias a las actuales condiciones de desarrollo económico en el agro. Al mismo tiempo, la floricultura se caracteriza por absorber una considerable porción de fuerza de trabajo y por adoptar las biotécnicas recientes en su proceso productivo.

Otro aspecto que cabe remarcar es la tendencia de la agricultura mexicana a agudizar las diferencias entre los productores.

Los elementos hasta aqui vertidos contribuyen a enmarcar el problema del mercado de trabajo rural mexicano, que se va a transformar profundamente con la modernización biotecnológica (como ya ha sucedido en algunos productos).

\section{BIOTECNOLOGÍA Y FLORICULTURA}

A fin de situar nuestro estudio de caso, en seguida se exponen algunas de las principales potencialidades de aplicación de la biotecnología en la floricultura y, por tanto, en su mercado de trabajo. 
La aplicación de la biotecnología vegetal a las actividades agrícolas puede agruparse en cuatro secciones:

1) Micropropagación.

2) Mejoramiento genético.

3) Cultivos industriales de células vegetales.

4) Fijación biológica de nitrógeno.

La técnica que ya lleva una década de aplicarse rutinaria y comercialmente en especies ornamentales, frutícolas $y$ hortícolas es la micropropagación. ${ }^{4}$ Estas técnicas no pueden adoptarse de modo indiscriminado en todas las especies de plantas y no son importantes para las especies que se reproducen rápidamente por semillas.

Todas las técnicas de biotecnología de plantas comprenden operaciones realizadas en tubos de ensayo con partes de plantas (tejidos, órganos y protoplastos).

La micropropagación y propagación in vitro son las formas modernas de propagación vegetal y permiten la reproducción rápida y en gran escala de plantas genéticamente idénticas a partir de tejidos, órganos o células de "plantas madre" altamente productivas (clonación).

La micropropagación se justifica especialmente para plantas ornamentales y hortalizas, dado que su alto potencial comercial valora la necesidad de obtener plantas genéticamente idénticas, libres de virus. También tiene inportancia para conservar germoplasma de las especies caracterizadas por propagación vegetativa o con semillas recalcitrantes, así como por muestras superiores clonadas o especies de lento crecimiento, como las arbóreas.

En cuanto a las unidades e instituciones de investigación donde actualmente se realizan proyectos biotecnológicos relacionados con especies ornamentales, de un total de 31 unidades dedicadas a investigar en materia de micropropagación y preservación de germoplasma, 15 trabajan con especies ornamentales, de las cuales 10 se dedican a distintas especies de flores (Casas, 1989). Es importante señalar que la participación del capital privado en la investigación en cultivo de tejidos vegetales por micropropagación es notable.

En 1972 la compañía japonesa Matsumoto instalo el segundo laboratorio en este campo en el país (el primero se fundó en el Centro de Genética del Colegio de Posgraduados de Chapingo). También cabe hacer notar que los proyectos de investigación de productos

${ }^{4}$ La mayor parte de la información de este capf́tulo proviene del excelente trabajo de R. Casas, Biotechnology Research in Mexico: Relevance for the Agricultural and Food Sector, Universidad de Sussex, tesis de doctorado, 1989. 
hortícolas son muchos menos que los que se dedican a los ornamentales y a las frutas, y que los de forrajes, agave y forestales son escasos.

La mayor parte de la investigación en micropropagación se puede describir como aplicada, ya que su objetivo es encontrar las condiciones optimas para micropropagar plantas de determinadas especies; varia el medio de cultivo, la relación de hormonas del crecimiento y la luz. Es un trabajo que se podría calificar más adecuadamente como "artesanal", pues intenta descubrir las "recetas" para micropropagar las especies en estudio. En consecuencia, una porción considerable de este trabajo resulta repetitivo; los cientificos experimentan con las especies cuya reproducción in vitro ya ha sido reportada en las publicaciones internacionales. En algunos casos el objetivo es mejorar las técnicas reportadas para la micropropagación.

En general puede afirmarse que hay pocos estudios que intenten dar una base científica al trabajo de micropropagación; es decir, que pretendan entender los fundamentos y el control de los mecanismos que participan en la regeneración de plantas in vitro. Esto se manifiesta en la ausencia de vínculos entre los trabajos de micropropagación y los estudios básicos; aunque ambos se realicen en las mismas unidades de investigación, con frecuencia se efectúan independientemente.

Cabe señalar que algunos autores ${ }^{5}$ consideran lo anterior como una de las principales limitantes para formular un proyecto biotecnologico autónomo para América Latina. El cultivo de tejidos vegetales es una técnica que puede aplicarse sin conocer los fundamentos científicos de la biología molecular, y si no trabajan esa base, nuestros países corren el peligro de convertirse en simples "maquiladores de cultivo de tejidos vegetales" para el gran capital transnacional.

Debido a las limitaciones científicas, la micropropagación se ha orientado a especies ornamentales y frutales, así como a otros cultivos importantes desde el punto de vista comercial como café, agave y especies forestales, aunque cuantitativamente los esfuerzos invertidos en éstos son menores. Es de hacer notar la poca factibilidad de aplicar dicha técnica a cultivos básicos importantes para México, como el maíz y el frijol. Esto óbedece en buena medida a que la micropropagación presenta limitaciones técnicas en las plantas que se reproducen más fácilmente por semillas. Sin embargo, entre los biotecnólogos mexicanos hay opiniones encontradas al respecto. Mientras que unos sobreponen el aspecto técnico, para otros la causa del abandono de la investigación en los cultivos básicos es su baja rentabilidad frente al elevado valor de los omamentales, frutas y hortalizas.

${ }^{5}$ Al respecto, véase D. Goldstein, Biotecnología, universidad y política, México: Siglo $x \in$ Editores, 1989. 
En todo caso, la posibilidad que brinda la biotecnologra vegetal de mejorar los cultivos básicos se localiza en otras biotécnicas, tales como la fijación de nitrógeno (para las leguminosas como el frijol) o el mejoramiento genético.

Por tanto, puede afirmarse con certeza, en cuanto a la factibilidad económica de la biotecnología vegetal, que las únicas técnicas que han tenido éxito comercial hasta la fecha son las de cultivo de tejidos vegetales, las cuales han demostrado su rentabilidad sobre todo en especies ornamentales y frutales (en México hay algunas compañías pequeñas que producen material vegetativo para exportación). Esto se refleja en el rápido aumento del número de especies que pueden reproducirse por micropropagación: en 1968 se informó de 30 diferentes especies, en 1978 la cifra había crecido a 300 y en 1988 ya eran 3000 (Bancomext-INFOTEC, 1988). Tal crecimiento de las exportaciones a la luz del cuadro crítico de la agricultura mexicana antes descrito explica el gran dinamismo de dichas especies.

En este marco cobra mayor importancia el presente estudio de caso, el cual se centra en el análisis de la rosa. Su estudio, pese a ser una de las especies florales menos investigadas, se considera importante porque su cultivo se ha incrementado de manera considerable y hay proyectos de inversión transnacionales para producirla de manera intensiva y exportarla.

\section{ESTUDIO DE CASO: LA FLORICULTURA EN EL ESTADO DE MORELOS}

La floricultura mexicana y el mercado internacional

Puesto que el marco de nuestro estudio de caso sobre el dinamismo adquirido por la floricultura mexicana es el nuevo escenario de liberalización comercial y aplicación de la biotecnología, iniciamos la exposición con algunas consideraciones en torno al mercado internacional de la flor y la situación de México en él.

Un estudio realizado en 1988 por el Banco Mexicano de Comercio Exterior, el INFOTEC y la Secretaría de Comercio y Fomento Industrial señala que la exportación de flores de corte representa una de las mejores oportunidades para lograr una posición competitiva de México en el mercado internacional.

Colombia es actualmente el principal exportador de flores del mercado norteamericono. Esto lo logró porque inició sus ventas en los años setenta, cuando el mercado era aún muy joven y la reacción en contra de las importaciones era débil. Durante esos años los productores colombianos disfrutaron de enormes ganancias y alcanzaron 
márgenes de utilidades de hasta 100 por ciento, lo que les permitio ganar penetración mediante una agresiva política de precios.

Estimulados por el éxito de Colombia, otros países productores intentaron hacer lo mismo. La atención de los inversionistas se centró naturalmente en México, entre otras razones porque su clima es similar al colombiano y porque su cercanía a Estados Unidos significa una ventaja importante, ya que la transportación aérea refrigerada representa entre el $25 \%$ al $50 \%$ del costo total de la flor.

México inició proyectos de floricultura de exportación en 1975 y a principios de los años ochenta. En la misma época, Colombia consolidaba su posición: en 1976 alcanzó el $91 \%$ de las flores bósicas en Estados Unidos, a pesar de la competencia de 26 países; hacia 1985 su penetración era todavía mayor a $85 \%$, aunque 47 países productores más ingresaron al mercado estadunidense.

El dominio de Colombia en esa materia sólo es superado por Holanda, el mayor exportador mundial. Ningún otro país exporta a Estados Unidos más del $5 \%$ del monto de las ventas de ese país sudamericano. Además de haber resistido dos investigaciones antidumping y un plan temporal de inspección de drogas que redujeron drásticamente sus operaciones, ha logrado expandirse y diversificarse hacia flores de especialidad.

Los dos mercados principales para flores de tallo son la Comunidad Europea y Estados Unidos (cuadro 1).

\section{CUADRO 1}

CONSUMO TOTAL DE FLORES, 1986

(millones de dólares al menudeo)

\begin{tabular}{|lr|}
\hline CEE & 3678 \\
EUA & 2769 \\
Japón & $\mathrm{A}$ \\
Canadó & $\mathrm{B}$ \\
Austria & 209 \\
Suiza & 109 \\
Suecia & 130 \\
\hline
\end{tabular}

Nota: A: Las importaciones on 1983 fueron 17 millones.

B: Las importaciones en 1986 fueron 34 millones; $48 \%$ provenía de Estados Unidos.

Las ventas al menudeo son de 3 a 5 veces el valor de los compros a productores.

FUENTE: Bonco Nacional de Comercio Exterior y Secretaría de Comercio y Fomento Industrial, Sector agroindustrial. Flores de corte, México: Estudio elaborado para el gobierno de México por Booz-Allen \& Hamilton e INFOIEC, 1988, p. 46. 
Para México, sólo Estados Unidos representa una posibilidad importante como mercado de flores, aunque el grupo Visaflor, con financiamiento de Nacional Financiera, busca ingresar a los mercados japonés y europeo. El proyecto es ambicioso: se pretende tener una capacidad instalada para producir anualmente 53.1 millones de tallos (mdt) de rosas; 3.1 de claveles; 1.2 de gerberas; 2.2 de nerine; 3.5 de lilium y 0.8 de otras variedades. El monto total de las inversiones previstas es de 23.521 millones de dólares: 20.1 millones $(86 \%)$ serán inversión fija; 3.4 (14\%), inversión diferida y 100 mil dólares se destinarón al capital trabajo inicial. El proyecto se denomina "Cosmoflor" y en él participan las empresas filiales y asociadas del grupo Visaflor, las cuales están integradas horizontal y verticalmente. Entre ellas se pueden mencionar: Visaflor, Flores Selectas de México, Invernaderos Tecnificados (Invertec), Empacadora Mexicana de Flores, Florcalli, Multivía, Transamérica Floral Imports, Hulco Blumen y Flores de Oro (Presencia, 1990).

La Comunidad Económica Europea es el mercado más grande, pero también muy difícil de penetrar. Tres de los proveedores más importantes son miembros de ella: Holanda, Francia e ltalia. La industria de flores en los Países Bajos, que emplea 63 mil personas y en 1985 exportó un monto superior a los mil millones de dólares, cuenta con una protección arancelaria que va del 17 al 24 por ciento. Los miembros de la Comunidad tienen derecho a vetar importaciones si éstas causan disturbios en el mercado, lo cual significa que no se permite una cornpetencia agresiva de precios.

Mientras que tanto Israel como Colombia fletan aviones de carga completos a Europa, México depende de la carga aérea comercial. Aunque algunas exportaciones mexicanas llegan a Suecia y Holanda, en el corto plazo es poco probable que ese mercado sea importante para el país (Bancomext, 1988). Nuestra floricultura no tiene presencia en el mercado europeo; ningún floricultor mexicano ha logrado penetrar el mercado de flores de Aalsmeer, Holanda, el más grande del mundo (Excélsior, 1991).

Japón es sumamente proteccionista y, por tanto, difícil de penetrar: en 1983 sólo importó 17 millones de dóläres (cuadro 1). El Consejo Florista de Holanda mantiene una oficina en ese país asiático, pero ha tenido poco éxito. Las normas fitosanitarias son aún mós estrictas que en Holanda, donde a su vez son más estrictas que en Estados Unidos. Las importaciones se restringen para favorecer a la industria interna y la competencia existente para este pequeño mercado incluye a Tailandia, Taiwán, Singapur y Nueva Zelanda.

Estados Unidos es un mercado atractivo, pero está experimentando cambios que revertirán esta situación. La competencia se recrudece 
cada día más. Muchos de los productores se localizan en California y están más consolidados y fortalecidos que las pequeñas empresas dispersas que antes suministraban gran parte de las flores. Además, están protegidos con medidas proteccionistas antidumping frente a muchos países (en un producto tan perecedero como las flores es frecuente tener que vender a un precio menor que el costo). En el cuadro 2 se presentan los porcentajes del arancel antidumping que aplica Estados Unidos a distintas empresas mexicanas.

CUADRO 2

ANTIDUMPING A PRODUCTORES MEXICANOS, 1986

\begin{tabular}{|lc|}
\hline \multicolumn{1}{|c|}{ Empresa } & \% ad valorem \\
\hline Florex & 4.6 \\
Visaflor & 29.4 \\
Floremor & 0.0 \\
Tzictzic Toreto & 4.0 \\
Rancho Daisy & 29.4 \\
Rancho Alisitos & 17.3 \\
Rancho Misión El Descanso & 24.3 \\
Rancho Las Dos Palmas & 29.4 \\
Las Flores de México & 29.4 \\
Todos los demás & 18.2 \\
\hline
\end{tabular}

FUENTE: Bancomext, op. cit., p. 48.

Se estima que en 1986 el mercado norteamericano de flores frescas en tallo era de 525 a 600 millones de dólares, con posibilidades de aumentar 100 millones de dólares más hacia 1991 (Bancomext, 1988). En el cuadro 3 se observa el consumo en 1988 de las principales especies de flores en ese mercado. 


\section{CUADRO 3}

CONSUMO DEL MERCADO NORTEAMERICANO EN 1988

(miles de tallos o amarres)

\begin{tabular}{lrcc}
\hline \multicolumn{1}{c}{ Flor } & Importaciones & Producción EUA & Consumo Total \\
\hline Clovel S. & 718500 & 288170 & 1006670 \\
Clovel M. & 85445 & 114130 & 199575 \\
Crisant. S. & 40484 & 58732 & 99216 \\
Pompón & 411793 & 217608 & 629401 \\
Rosas & 173151 & 370313 & 543464 \\
\hline
\end{tabular}

FuENtE: Bancomext, op. cit.

México tiene un enorme mercado interno y una riqueza apreciable de germoplasma - no menos de 30 mil especies- (FIRA, 1989), pero históricamente los productores no han logrado una calidad de exportación. En los años setenta, un grupo de inversionistas se centraron en cumplir las normas internacionales de calidad y así explotar este mercado. En 1976 se construyeron algunos invernaderos para el mercado mexicano y en 1978 se estableció la Asociación de Productores; el esfuerzo de desartollo se dio durante la década de los ochenta, cuando se iniciaron tres grandes proyectos. En 1982 el grupo Visa inició una compleja operación en 11 hectáreas localizadas en el estado de Michoacán y se estableció un acuerdo de comercialización con CFX, un importador de Miami. Esta empresa enfrentó problemas y finalmente la adquirió la firma Florex, planta que sigue en operación y fue vendida a un grupo de trabajadores financiados en parte por el programa FIRA-Bancomext para exportación de flores.

El proyecto de mós éxito a la fecha en la floricultura mexicana se establecio entre 1971 y 1980, cuando Ricardo Delgado y Roberto San Román se unieron para producir rosas en una empresa conjunta que más tarde se separó en dos compañías: Rosemex y Visaflor. Ambas siguen funcionando y son rentables, al grado que Visaflor planeo iniciar en 1991 el proyecto de gran envergadura ya mencionado.

En estos años se creó Anapromex, asociación de productores que se formó con diez miembros fundadores. También se abrieron otras empresas, dos de las cuales aún manejan la mayor parte de las exportaciones mexicanas. Indirectamente, a través de ex empleados y arreglos de comercialización, su presencia se observa en muchos de los otros proyecros en vigor. Visaflor fue un factor determinante para el desarrollo inicial del proyecto en Morelos, que comprende nuestro estudio de caso. 
La industria mexicana ha experimentado una considerable expansión: Anapromex ha crecido hasta llegar a 50 miembros y las 25 hectóreas dedicadas a la exportación en 1981 aumentaron a 100 o más en 1988. En el programa FIRA-Bancomext se planteaba otorgar en 1988 de 8 a 10 millones de dólares en préstamos para incorporar a la actividad otras 48 hectáreas.

La producción de flores en México no ha permanecido estática. La superficie cosechada se incremento $3.49 \%$ entre 1981 y 1984 . En este sentido destaca la rosa, que casi triplicó su superficie cosechada: de 2 480 se elevó a 7220 hectáreas (SARH, 1981-1984). En estos años descendió la cantidad de flores exportadas, pero su valor se incrementó 178 por ciento (Anuarios estadísticos de comercio exterior, 19811984). Para 1988 (hay ciertas variaciones según la fuente consultada), de acuerdo con el trabajo de Bancomext-INFOTEC, había entre tres mil y seis mil hectáreas dedicadas a cultivar flores para el consumo interno, la mayor parte en áreas cercanas a la Ciudad de México: 784 en el Distrito Federal, 3896 en el Estado de México, 130 en Veracruz, 585 en Puebla, 520 en Morelos y 455 en Michoacán (Bancomext, 1988). En cuanto a la producción intensiva de exportación, hay cerca de 205 hectáreas de invernaderos, cuya distribución por entidad es la siguiente: el Estado de México, 65; Morelos, 35; Puebla, 25; Michoacán, 19; Querétaro, 12; el Distrito Federal, 10; Guanajuato, 10; Hidalgo, 8; Baja California, 7; Jalisco, 5; Oaxaca, 4; Aguascalientes, 4; Zacatecas, 3, y Veracruz, 2. En épocas de demanda baja en el mercado de Estados Unidos, del 30 al $40 \%$ de esta producción se destina al mercado nacional (FIRA, 1989), con consecuencias desventajosas para los productores tradicionales, como se demuestra en el estudio de caso.

En el cuadro 4 aparece el volumen, la superficie y el valor de la producción de rosas en 1991.

CUADRO 4

SUPERFICIE, PRODUCCIÓN Y RENDIMIENTO DE ROSA, 1991

\begin{tabular}{lccc}
\hline Estado & $\begin{array}{c}\text { Superficie } \\
\text { ha riego }\end{array}$ & $\begin{array}{c}\text { Producción } \\
\text { (ton) }\end{array}$ & $\begin{array}{c}\text { Rendimiento } \\
\text { miles gruesas, ho }\end{array}$ \\
\hline México & 18 & 50 & 2778 \\
Michoacán & 485 & 7772 & 16025 \\
Tamaulipas & 4 & N. D. & N. D. \\
Tot. Nal. & 507 & 7822 & 15428 \\
\hline
\end{tabular}

FUENTE: Secretaría de Agricultura y Recursos Hidraulicos, 1991. 
Los productores tradicionales suelen cultivar para el mercado nacional, que no exige una alta calidad, pues no alcanzan las normas de exportación por carecer de infraestructura e insumos. Este sistema adolece de un manejo y manera de cosechar inadecuados. Es marcado el contraste entre el empaque para el mercado interno y el de exportación. En el primer caso las flores se atan en racimos y se embarcan en camiones descubiertos. Las de exportación, en cambio, se cortan temprano por la mañana, se sumergen en agua, se refrigeran y se colocan en cajas con empaques muy especializados. Esto tiene repercusiones en el proceso de trabajo, pues genera toda una gama de actividades nuevas y especializadas durante la preparación del producto, además de las habituales de corte, cosecha y punto de apertura.

Las condiciones de embarque en el aeropuerto de la Ciudad de México son poco adecuadas; además, este producto presenta desventajas por el gran volumen y poco peso característico de las flores. Si tienen oportunidad, las aerolíneas fletan otras cargas más rentables en el último momento.

De lo anterior se desprende que un factor clave para la exportación exitosa de flores es el control total de los canales de comercialización. La mayor empresa de México en el ramo es Visaflor, claramente adelante del resto pues tiene 30 hectáreas de invernadero en producción. Opera con un complejo sistema de producción y un punto de distribución en Houston. Esto explica que cuente con capitales de riesgo mayores, como los que mencionamos en el proyecto Cosmoflor.

En 1988 había cerca de 70 nuevos floricultores, muchos de los cuales carecían de experiencia. Las entrevistas realizadas por el estudio de Bancomext-SECOFI-INFOTEC indican que, aunque es relativamente sencillo producir flores, resulta muy difícil alcanzar la calidad necesaria para acceder al mercado internacional y, aún más, obtener canales de comercialización y mercadeo en Estados Unidos.

Es conocido el dominio de las grandes corporaciones holandesas, francesas y estadunidenses sobre el material genético de la floricultura, lo cual tiene relación con las altas erogaciones en semillas importadas: entre 1981 y 1982, aunque el volumen de estas importaciones decreci6 $44 \%$, su valor aumento 720 por ciento (Anuarios estadísticos de comercio exterior, 1981-1982).

El estudio de Bancomext-INFOTEC señala como una debilidad de la floricultura de exportación mexicana su alta dependencia de las empresas transnacionales para obtener material genético. Los productores de rosa generalmente importan las plantas de proveedores importantes como Meillend (Francia) o Jackson y Perkins (Estados Unidos). La producción de rosales de alta calidad (planta madre) es por demás refinada y los productores mexicanos tienen dificultades para importar- 
las. En nuestro estudio de caso se confirma que estas compañías mantienen el control de los esquejes y las "plantas madre" mediante el dominio de biotécnicas para su obtención, de manera que dichas técnicas no se conocen ni se difunden entre los floricultores mexicanos. También los insumos necesarios, como fertilizantes y pesticidas especiales, se obtienen en el exterior, no sin dificultades.

La mayor parte de las flores de exportación en México se producen de manera intensiva, en invernaderos de plástico, unidades de refrigeración y cuartos de selección. Hay una incipiente industria de fabricación de invernaderos creada por productores que han construido suficientes y han aprendido las técnicas. El proyecto del Instituto de Floricultura de Morelos -en el que basamos nuestro estudio de caso- es el único que cuenta con una instalación centralizada de selección y almacenamiento. La transportación se hace mayoritariamente por vía aérea, que es lo más viable a la luz de la atomización de la demanda en el mercado norteamericano: es decir, los compradores no adquieren grandes volúmenes aunque los productores tengan capacidad para producirlos.

El estudio de Bancomext señala que, como la floricultura es una rama fuertemente competitiva, conviene contar con un comprador confiable, pues a menudo los compradores norteamericanos hacen falsas reclamaciones por deterioro del producto o retrasan pagos. Otra debilidad de los exportadores mexicanos, señala la misma fuente, es su falta de información, punto importante porque el mercado de la flor se caracteriza por súbitas y bruscas variaciones de precios.

Las flores cortadas se dividen en tres grupos: básicas (claveles, crisantemos y rosas), de especialidad y de relleno. Estados Unidos importa principalmente flores básicas.

\section{ESTUDIO DE CASO: LA FLORICULTURA EN MORELOS}

Nuestro estudio está comprendido en la participación social en el sector, la cual es una prioridad en la política oficial mediante instituciones como FIRA y Nacional Financiera, debido a su alto contenido de mano de obra y bajas extensiones de terreno. La producción para exportación en Morelos se inició con el Proyecto FIESTAMOR en 1986, que dos años después contaba con 10-15 hectáreas en producción.

Dado que el proyecto del Instituto de Floricultura del estado de Morelos representa la participación del llamado "sector social" en esta rama y que se planteo como un instrumento de generación de empleo para la mujer campesina, su estudio resulta fundamental en lo referente a la relación que esto guarda con la conformación de la economía campesina y el mercado de trabajo rural. 
El estudio de caso se elaboró como un análisis comparativo entre la floricultura tradicional a cielo abierto y la floricultura intensiva de invernadero. Particularmente, se recopiló información estadística y de campo sobre la producción de rosa en el estado de Morelos.

Para el estudio de la floricultura tradicional se realizaron encuestas a trabajadores asalariados y productores de rosa del ejido de Temixco. La floricultura intensiva queda comprendida en los cerca de 30 invernaderos distribuidos en 1986 por el gobierno de Morelos en el territorio de esa entidad.

En Morelos la producción de rosa ha tenido un crecimiento notable. De 1976 a 1980 la superficie cosechada casi se duplicó (de 175 a 346 hectáreas). En el período 1982-1987, la superficie creció $241 \%$ y la producción en gruesas, 46 por ciento. ${ }^{6}$

\section{FLORICULTURA TRADICIONAL}

De acuerdo con la información que arrojó la investigación de campo, en el ejido de Temixco - uno de los 16 que tiene el municipiohabía en 1988 cerca de 200 productores de rosa para el mercado interno, ninguno con más de dos hectáreas de riego. Con base en las entrevistas que realizamos a 20 de ellos, el proceso de producción se resume de la siguiente manera.

La rosa se produce por esqueje, al cual se le hace una labor de "injerto" que consiste en cortar los muñones que no florean cuando el rosal tiene 30 centímetros de altura; se realiza una sola vez al iniciar la plantación. Es la única tarea que requiere alguna capacitación y su costo es de 10 mil pesos por plantita (1988). Cada surco de hectárea tiene aproximadamente 400 plantas. Un rosal puede permanecer en producción hasta 30 o 40 años, pero su productividad disminuye con el tiempo, por lo que los productores suelen conservar sus rosales de 8 a 10 años.

El rosal es una plantación que no requiere mecanización, excepto para preparar el terreno al principio. Además, es una actividad que absorbe gran cantidad de mano de obra: por lo menos ocho jornadas por hectárea cada tercer día, cerca de 32 jornadas por hectárea cada semana, y 1664 jornadas por hectárea en un año, lo cual es alto para el promedio general de las actividades agropecuarias. ${ }^{7}$ Para las labores de la rosa se requiere fuerza de trabajo sin capacitación ni distinción de edad o sexo.

\footnotetext{
${ }^{6}$ Una gruesa contiene 144 rosas.

${ }^{7}$ El sorgo, sumamente mecanizable, absorbe 10 jornadas por hectárea en todo el ciclo de temporal.
} 
Por ser un producto suntuario, las variaciones de precios son muy marcadas: en 1988 la gruesa llegó a costar hasta 40 mil pesos en días festivos, cuandc el precio promedio era de $8 \mathrm{mil}$; sin embargo, el precio puede caer hasta mil pesos.

En el ejido de Temixco contar con transporte para comercializar el producto en la Central de Abasto de la Ciudad de México es un factor clave en la diferenciación social entre productores: los que poseen transporte propio pueden vender a precios más altos y obtener mayores excedentes.

En este proceso productivo destaca el uso abundante y cada vez mayor de insecticidas, lo cual eleva los costos y causa problemas de intoxicación entre los trabajadores. Este insumo representa ya una dificultad técnica y económica que quizá podría ser superada por el uso de biotécnicas, en el caso de que éstas sean accesibles.

Ninguno de los productores de la muestra de Temixco tiene acceso al mercado de exportación porque no posee el material genético que proporciona la calidad exigida en esos mercados ni la infraestructura de transporte necesaria.

\section{FLORICULTURA INTENSIVA DE EXPORTACIÓN}

Por otro lado, la participación del sector social en la industria de la flor para exportación en Morelos está controlada, desde 1986, por el Instituto de Floricultura. Se trata de una asociación entre el gobierno de la entidad y diversas compañías francesas, holandesas y estadunidenses, las cuales proporcionan la tecnología y el material genético a condición de que éste no lo reproduzcan los floricultores mexicanos. Este control del germoplasma es el que garantiza que las variedades aceptadas en el mercado internacional sean las producidas por estas compañías; de ahí la base del dominio de las empresas multinacionales sobre la floricultura mexicana de exportación.

Así, estas empresas son las únicas que pueden reproducir el material genético, producto del cultivo de tejidos y clonación. Es precisamente el monopolio tecnológico lo que les permite el dominio exclusivo de este material, por lo que la posibilidad de que la biotecnología se difunda entre los productores y trabajadores mexicanos es muy reducida.

Esta producción se realiza en invernaderos con un alto control de condiciones climáticas, como temperatura y humedad. El material clonado permite características de mayor rentabilidad, así como la posibilidad de homogeneizar la producción y aumentarla para las fechas festivas en las cuales el precio es superior. Permite también un 
mayor control de plagas y enfermedades, lo que significa un ahorro considerable en la cantidad de plaguicidas aplicados.

Características como éstas repercuten en el proceso de trabajo y en las particularidades de este mercado. El programa de producción de flor comprende principalmente cuatro variedades: clavel, miniclavel, gerbera y rosa, de las cuales esta última es la de mayor demanda. Ocasionalmente se exportan otras flores, como ave del paraíso y agapando, que alcazan altos precios en el mercado internacional.

Los invernaderos pertenecen formalmente a "sociedades" de mujeres, quienes en la práctica no tienen influencia en el proceso productivo ni en la contabilidad. Cada invernadero es supervisado por un técnico que dirige los trabajos y toma las decisiones, en tanto que el manejo de costos y utilidades corre a cargo del Instituto de Floricultura, de manera que a cada sociedad le llega mensualmente un estado de cuenta y reparto de utilidades, en caso de que las haya. Además, se contratan trabajadoras asalariadas eventuales, ambos tipos de trabajadoras reciben un salario mínimo (60 mil pesos semanales en 1991) por una jornada de las 8 de la mañana a las 3 de la tarde, de lunes a sábado.

La información de campo indica que las trabajadoras provienen mayoritariamente de la misma localidad o del mismo estado y que su edad promedio oscila entre 15 y 20 años o más de 35 . Ello podría indicar que entre los 20 y 30 años las mujeres difícilmente pueden trabajar como asalariadas, tal vez por encontrarse dedicadas a la crianza de sus hijos.

El acceso a esta fuente de trabajo lo obtuvieron originalmente las socias, quienes fueron seleccionadas por los promotores del programa. Se dio preferencia a las viudas y madres solteras; las asalariadas de reciente ingreso se enteraron por conocidos en la misma localidad. A estas mujeres no se les exigieron conocimientos técnicos especiales para obtener el trabajo, aunque se han capacitado sobre la marcha. La mayoría no considera que su labor tenga que ser exclusivamente femenina.

Cabe señalar que no cuentan con un contrato escrito ni están sindicalizadas. Tampoco tienen ninguna prestación social como servicios médicos, aguinaldo, vacaciones, etcétera. Las socias afirmaron que sólo reciben reparto de utilidades en las fechas de mayor venta y consideran que el técnico decide totalmente sobre su trabajo.

Sus actividades consisten en: limpiar y barrer las camas, así como podar y cortar los botones para favorecer los mejores tallos. Un aspecto importante para lograr calidad en la rosa es la longitud del tallo al momento de cortarla; esto constituye un punto de conflicto en la manera como se organiza el trabajo, dado que las utilidades se reparten 
en función de la cantidad - y no de la calidad — de los tallos cortados. Así, las trabajadoras procuran cortar el mayor número de ellos sin cuidar el largo adecuado.

El programa comprende 30 invernaderos con 13 hectáreas sembradas. Es importante hacer notar que antes de que estos terrenos se incorporaran a la producción de flor, algunos eran sembrados con caña de azúcar, maíz o frijol, ${ }^{8}$ lo cual demuestra que los cultivos ornamentales compiten con la producción de granos básicos; se prevé que esta situación se agudizará con la puesta en próctica del TLC, de tal suerte que se dará prioridad al desarrollo de cultivos comerciales de exportación en detrimento de granos básicos.

En estos invernaderos laboran 250 empleadas y 25 agrónomos, unas 300 personas en total. Cada invernadero manda diariamente su producción en camión refrigerado al centro de acopio del Instituto. Ahí se seleccionan los tallos, se empacan y se envían al mercado nacional o de exportación, según la calidad y la demanda; alrededor de $60 \%$ de las rosas se destinan a la exportación y el $40 \%$ restante al mercado interno. Por su calidad superior, estas últimas compiten con ventaja frente a las rosas de los floricultores tradicionales.

Se considera que un invernadero es altamente productivo cuando el $95 \%$ de su producción se destina al mercado de exportación; los poco productivos son los que envían a dicho mercado sólo 50 por ciento.

Cada tallo tiene un precio promedio de 500 pesos (15 centavos de dólar), pero las oscilaciones pueden ser muy pronunciadas. Por ejemplo, el 14 de febrero, en Estados Unidos se llega a vender en un dólar el tallo, pero se puede desplomar hasta a diez centavos de dólar. Otras flores, como el agapando y el ave del paraíso, llegan a elevarse a 1.25 dólares por tallo.

La determinación de la calidad (longitud y rectitud del tallo) y del punto de apertura es un proceso complejo que tiene repercusiones importantes en el precio del producto, en el cual influye también la capacitación y la habilidad de las trabajadoras.

El Instituto cuenta con dos distribuidoras: una en la Ciudad de México, desde donde las flores se reparten por vía aérea a las ciudades del país, y la otra en Denver, que se encarga de su distribución en Estados Unidos. El Instituto es su socio en $49 \%$, y a ella se envían en promedio 120 cajas a la semana, cada una con 14 paquetes de 25 rosas. Si son de muy buena calidad y la demanda se incrementa - sobre todo si se trata de fechas de precio alto-, cada envío representa un ingreso bruto de 21300 dólares. Pero

${ }^{8}$ Cuando la flor sustituyó a estos cultivos se preparó la tierra enriqueciéndola con material orgánico, tierra de hoja, cascarilla de arroz, tezontle o bagazo. 
cuando el precio cae, aunque la calidad de la flor sea la mejor, el ingreso se reduce a 4200 dólares.

Así pues, el mercado de exportación es muy variable: en la temporada en que los productores estadunidenses y del Estado de México logran alta productividad, el precio se abate y no resulta costeable exportar.

Con la finalidad de ampliar mercados - como el estadunidense, que tradicionalmente ha estado dominado por productores colombianos y del Estado de México- y abrir otros, se buscó mejorar la presentación del producto.

En el siguiente cuadro se resumen los efectos de la biotecnología, que se observan en las diferencias en materia de productividad y rentabilidad entre la floricultura a cielo abierto, que no utiliza estas técnicas, y la floricultura intensiva, que sí las incorpora.

CUADRO 5 ,

FIORICUITURA INTENSIVA Y TRADICIONAL, ESTADO DE MORELOS, 1988

\begin{tabular}{|c|c|c|}
\hline & Eiido Temixco & Invernadero \\
\hline & Floricultura tradicional & Floricultura intensiva \\
\hline Inversión & ha/sem: \$387 586 & $\begin{array}{l}\text { Inicio invernadero de } \\
4000 \mathrm{~m}: \$ 6000000^{*}\end{array}$ \\
\hline $\begin{array}{l}\text { Producción de } \\
\text { flores ha/sem }\end{array}$ & $\begin{array}{l}\text { a) Baja productividad } \\
3456 \text { rosas } \\
\text { b) Alta productividad } \\
10800 \text { rosas }\end{array}$ & $\begin{array}{l}\text { Productividad uniforme } \\
21000 \text { flores (rosa, } \\
\text { gerbera, clavel y miniclavel) }\end{array}$ \\
\hline $\begin{array}{l}\text { Producción de } \\
\text { flores/jornada }\end{array}$ & $\begin{array}{l}\text { a) } 144 \text { rosas } \\
\text { b) } 450 \text { rosas }\end{array}$ & $\begin{array}{l}\text { Productividad uniforme } \\
225 \text { flores }\end{array}$ \\
\hline $\begin{array}{l}\text { Ingresos totales } \\
\text { ha/sem }\end{array}$ & $\begin{array}{l}\text { a) } \$ 572414 \text { (buen } \\
\text { precio) } \\
\$ 195560 \text { (precio } \\
\text { prom.) } \\
\text { b) } \$ 2612414 \text { (buen } \\
\text { precio) } \\
\$ 212414 \text { (precio } \\
\text { prom.) }\end{array}$ & $\begin{array}{l}\$ 6000000 \text { (precio } \\
\text { promedio)** } \\
\$ 52500000 \text { (buen } \\
\text { precio)** }\end{array}$ \\
\hline $\begin{array}{l}\text { Precio unitario de } \\
\text { la rosa }\end{array}$ & $\begin{array}{l}\text { Buen precio } \$ 277.00 \\
\text { Precio promedio } \$ 55.50 \\
\text { Precio bajo } \$ 7.00\end{array}$ & $\begin{array}{l}\$ 0.15 \text { dólares (precio } \\
\text { promedio) } \\
\$ 1.00 \text { dólares (buen } \\
\text { precio) }\end{array}$ \\
\hline
\end{tabular}

Fuente: * Instituto de Estudios para el Desarrollo Rural Maya, A. C., "La producción intensiva de flores en el estado de Morelos", 1987.

** No fue posible, por falta de datos, incluir el costo de transporte oéreo y refrigerado. Investigc ción de campo, 1988. 


\section{CONCLUSIONES}

Hemos observado que el uso de tecnología de punta en los procesos agropecuarios de productos para exportación, como las flores, está en manos de corporaciones multinacionales que, mediante prácticas monopólicas, condicionan el acceso a esta tecnología y a los beneficios que puede generar. Esta situación se agudizará con el libre flujo de mercancías y capitales que plantea el Tratado de Libre Comercio.

En el caso de la floricultura, tal dominio se manifiesta en el control del material genético que no se puede reproducir internamente y cuya calidad es la aceptada en el mercado internacional.

El proceso de clasificación para el mercado externo es muy detallado y las diferentes calidades de las rosas se dan en rangos de manejo muy delicado para la conservación de la flor, como sucede con el punto de apertura. La complejidad en la clasificación de la calidad influye en el proceso de trabajo: resulta necesario poner atención en la longitud de los tallos, y no sólo en la cantidad de éstos, que es lo que se contabiliza para el reparto de utilidades de las trabajadoras.

En nuestro estudio de caso se observa una "feminización" del trabajo, que obedece al objetivo explícito original del programa de flor de exportación: dar empleo a las mujeres campesinas, sobre todo a las viudas y a las madres solteras. Sin embargo, los bajos salarios que reciben estas mujeres, aunado a que son muy jóvenes o ya maduras, con hijos que mantener (es decir, con extrema necesidad de trabajo), hacen pensar que se trata de una fuerza de trabajo flexible, maleable y que permite un manejo administrativo totalmente al margen de las decisiones de las supuestas "socias".

La condición jurídico-formal de "socias" en los invernaderos facilita una mayor explotación, ya que a cambio de un reparto de utilidades, cuyo monto es a criterio del empleador, éste se ahorra seguro social, aguinaldo, vacaciones, etcétera. Dichas trabajadoras se hallan en un estado de semiproletarización y el conjunto del programa es semejante a una empresa privada donde el capital productivo lo conforma una entidad gubernomental: "el Instituto de Floricultura" y el trabajo asalariado lo integran las "socias" de los invernaderos.

Son evidentes las ventajas en materia de productividad que se obtienen de la floricultura intensiva en relación con la tradicional. Ante ello, los floricultores tradicionales estón en una situación desventajosa, pues son desplazados por la floricultura intensiva que destina parte importante de su producción al mercado interno y cuya calidad es mayor. Además, la floricultura intensiva cubre el mercado nacional de lujo, inaccesible para los floricultores tradicionales. 
Algunas de estas ventajas se relacionan con el uso de la biotecnología en el proceso de producción: el material clonado permite una producción mayor y más homogénea en las fechas de mayor venta.

Se puede inferir que el control de la materia prima principal, el material genético, que ejercen las empresas multinacionales impide que los beneficios potenciales de la nueva biotecnología vegetal lleguen a todos los grupos sociales interesados. En este caso los productores tradicionales se ven directamente perjudicados.

En el aspecto del empleo, podemos decir que la floricultura absorbe mucha fuerza de trabajo, como todo cultivo de plantación cuya cosecha es manual. La floricultura tradicional, a cielo abierto, absorbe 1664 jornadas anuales, frente a 5947 en la intensiva. En comparación, un cultivo mecanizable como el sorgo absorbe sólo 10 jornadas en todo el ciclo de temporal.

El que estos empleos sean ocupados principalmente por mujeres, en condiciones que permiten su sobreexplotación, hace pensar que para el capital internacional, que controla el mercado del material genético y los insumos, es muy rentable invertir en los países subdesarrollados, poes aprovechan la fuerza de trabajo abundante, dócil y barata. Eso cobra especial importancia si consideramos que los productos agropecuarios que México está en condiciones de exportar con alguna ventaja - flores, frutas y hortalizas - requieren también de grandes cantidades de fuerza de trabajo. En este caso, son innegables los efectos de la biotecnología en el aumento del empleo y las características del proceso de trabajo, como sucede en la floricultura intensiva de exportación, por las nuevas condiciones de calidad que impone la posibilidad de usar material clonado.

Estas características asemejan a la floricultura de exportación a las "agromaquilas", donde el dominio de los insumos esenciales da a las empresas multinacionales ventajas innegables en el mercado internacional -sólo la flor de algunas casas comerciales ya citadas es aceptada en él-y les permite aprovechar, sin perder prerrogativas, las condiciones de fuerza de trabajo barata y accesible de los países subdesarrollados.

Se podría considerar que las agroexportaciones representan una opción de los países subdesarrollados para conseguir divisas, ventaja que resulta cuestionable a la luz de que los mercados internacionales tienen una capacidad restringida.

En el caso de la flor, el mercado se estima en 700 millones de dólares, por lo que se contrapone a varios países en la competencia por este espacio. 


\section{BIBLIOGRAFÍA}

Arizpe, L., y Aranda, J. 1981. Empleo agroindustrial y participación de las mujeres en el desarrollo rural: un estudio de las obreras del cultivo de exportación de la fresa en Zamora, Mich. México: Organización Internacional del Trabajo.

Arizpe y cols. 1989. "Los efectos de la crisis económica en las mujeres pobres". El ajuste invisible. Bogotá: UNICEF.

Astorga Lira, E. 1985. Mercado de trabajo rural en México. México: Ediciones Era, p. 14.

Bancomext, SECOFIN, INFOTEC. 1988. Sector agroindustrial. Flores de corte. México.

Barranco, A. 1991. "Polvora mojada". La Jornada, 24 de junio, p. 23.

Bartra, A. 1979. La explotación del trabajo campesino por el capital. México: Ed. Macehual.

Bruno, S. 1979. "The Industrial Reserve Army, Segmentation and the Italian Labour Market". Cambridge Joumal of Economics. Núm. 3, p. 131.

Carton De Grammont, H. 1986. "Los asalariados del campo: Źquiénes son?" Asalariados agrícolas y sindicalismo en el campo. México: Juan Pablos Editor-IIS/UNAM.

Casas, R. 1989. "El estado actual de la biotecnología en México". La biotecnología y el problema alimentario de México. Coordinado por G. Arroyo. México: Ed. UAM, Plaza y Valdés, p. 195.

Centro de Estudios Transnacionales (CET) y Centro de Investigación y Docencia Económica (CIDE). 1988. "Problemas de empleo: una agenda abierta para América Latina". Empleo, desempleo y mercados de trabajo, p. 17.

Colegio de México. 1991. Centro de Estudios Económicos. Proyecciones matemáticas basadas en:

. Sobarzo, H. "Análisis de los efectos de un Tratado de Libre Comercio entre México y América del Norte. Un enfoque de equilibrio general".

. Yúnez, A. "Hacia un Tratado de Libre Comercio en América del Norte, efectos en los sectores agropecuario y alimenticio de México".

. Cox, A., y Gulterne, R. "El comercio libre en América del Norte y sus implicaciones para Canadá".

. Brown, A., y Deardeff, A. "Tratado de Libre Comercio en América del Norte: análisis y evaluación".

Dirección General de Información. 1988. SARH-Morelos.

Espinal, M. 1989. "Negociaciones de México en el GATT y los principales problemas en el comercio agropecuario con Estados Unidos". 
Ciclo de Conferencias: "Comercialización y abasto de productos agropecuarios y pesqueros". Centro de Desarrollo Profesional para la Educación Agropecuaria, SEP.

Excélsior. 1991. "El mercado de flores más grande del mundo se ubica en Aalsmeer, Holanda, para importación y exportación". 4 de marzo, 3-B. Fideicomiso Instituto de Recursos para la Agricultura (FIRA). 1989. Boletín Informativo. Núm. 205. Vol. WW, 31 de mayo.

Fujii, G. 1990. "2́Libre comercio con una economía decadente?" La Jornada, 20 de octubre, p. 23.

Goldstein, D. 1989. Biotecnología, universidad y política. México: Siglo XX1 Editores.

Instituto de Estudios para el Desarrollo Rural Maya, A. C. 1987. La producción intensiva de flores en Morelos.

Instituto Nacional de Estadística, Geografía e Informática (INEGI) y Secretaría de Programación y Presupuesto (SPP). Anuarios estadísticos del comercio exterior de los Estados Unidos Mexicanos (1981, 1982, 1983, 1984, 1985).

La Jomada. 1990. "Dos mil 400 millones de dólares para importar granos básicos este año", 16 de agosto, p. 22.

. 1990. "El gasto en ciencia y tecnología, equivalente al costo de tres aviones", 22 de junio.

1990. "SARH: maíz y frijol, exentos de la competencia comercial abierta", 13 de septiembre, p. 24.

. 1991. "Veintidós productos básicos han subido más que la inflación en casi tres años", 9 de septiembre, pp. 1 y 25.

. 1991. "Para México, dramático el efecto del TLC en empleo", 8 de julio.

Lara, S. 1990. "Las obreras agrícolas: un sujeto social en movimiento".

Ponencia presentada en el Coloquio Nueva Antropología: Análisis y categorización de las clases y los sujetos sociales en el agro. México, septiembre.

Martínez, Marielle P. L., y Rendón, T. 1985. "Las unidades domésticas campesinas y sus estrategias de reproducción". El campesinado en México. México: El Colegio de México.

Mohan Rao, J. 1988. "Fragmented Rural Labour Markets". The Joumal of Peasant Studies. Vol. 15. Núm. 2. Enero de 1988, 240 pp.

Munslow, B., y Finch, H. Comps. 1984. Proletarianisation in the Third World. Londres: Croom Helm, p. 1.

Nacional Financiera. 1990. "Producción de flores para exportación". Presencia. Año 1. Núm. 4. Septiembre-octubre.

Roldán, M. I. 1981. Trabajo asalariado y condición de la mujer rural en un cultivo de exportación: el caso de las trabajadoras del tomate en Sinaloa. México: Organización Internacional del Trabajo. 
APLICACIONES DE LA BIOTECNOLOGÍA A LA FLORICULTURA

279

Rubio V., Blanca. 1983. “La nueva modalidad del desarrollo capitalista en la agricultura mexicana, 1965-1980". Revista Teoría y Política. Núm. 10, p. 44.

Secretaría de Agricultura y Recursos Hidráulicos. 1988. "Condiciones de vida y trabajo de los jornaleros agrícolas en México", citado en La Jomoda, 24 de julio de 1988, p. 15.

. 1991. Producción agropecuaria.

Agenda agropecuaria (1981, 1982, 1983, 1984, 1985). 


$$
\text { . }
$$




\title{
Avances y repercusiones de la bioteenología en la producción de café
}

\author{
IDOLINA VELAZQUEZ S.*
}

El presente trabajo se propone reseñar los principales efectos socioeconómicos de la biotecnología aplicada a la producción de café.

Aunada a la crisis internacional en el mercado del café ha aparecido una serie de avances tecnológicos basados en biotécnicas estrechamente relacionadas con su producción y procesamiento, cuyos resultados probables causarán desórdenes en el mercado mundial en un período no mayor de 10 años.

Las tendencias actuales del comercio internacional del café y el empleo de la biotecnología en el marco de los nuevos mercados oligopólicos transnacionales tendrán graves repercusiones tanto para el futuro de los cafeticultores en pequeña escala como para la economía del país. La red biotecnológica facilitaró un desplazamiento de la cafeticultura a gran escala, concentrada en la producción de cafés suaves tipo arábiga.

Los rasgos sobresalientes de la dinámica económica son los procesos de globalización y formación de bloques económicos. Estos procesos de reordenación económica se insertan dentro de los cambios tecnológicos y sus probables consecuencias. Dentro de este contexto de crisis cafetalera y de reordenamiento económico, se analizarán las transformaciones que se están realizando en la cafeticultura mediante la aplicación de la biotecnología. Y, por último, abordaré las posibles repercusiones, aún no claras, en lo económico y social, que tienen las innovaciones tecnológicas en el café.

* Profesora-investigadora. Área de Economía del Colegio de Historia de la Universidad Autónoma de Puebla (UAP). 


\section{ANTECEDENTES}

Las transformaciones políticas y sociales que han ocurrido en la esfera internacional, motivadas por una mayor democratización de la vida política y por acceder a los mercados mundiales, estón determinadas por los cambios en los procesos económicos que tienen como resultado muchos avances científicos y tecnológicos.

El desarrollo actual del capitalismo muestra un funcionamiento basado en un sistema económico internacional impulsado por grandes empresas transnacionales que actúan como sus principales agentes económicos. Esta dinámica ha llevado a que el control de los procesos productivos de las economías se supedite cada vez más a las decisiones del capitalismo transnacional, lo cual favorece las políticas económicas que tienen como objetivo el mercado mundial de mercancías. Dichas economías tratan de alcanzar una posición competitiva en el plano mundial y subordinan consideraciones internas.

El reordenamiento mundial de la economía ha pasado de ser un enfrentamiento norte-sur, este-oeste, organizado en una simple economía de mercado, y en su lugar han aparecido bloques regionales de países con áreas de influencia económica, política y social donde los "modos de organización" se han vuelto la regla más que la excepción (Chesnais, 1990:259).

Japón, Alemania y ahora Estados Unidos están surgiendo como las potencias que encabezan el desarrollo económico capitalista en el marco de ese contradictorio proceso de globalización y formación de bloques económicos. El nuevo sistema económico, cuyas fuerzas de mercado han traído consigo, por un lado, un carácter universal de su funcionamiento y, por el otro, el surgimiento de bloques económicos es, sin duda, jerarquizado y por lo tanto asimétrico en detrimento de los países menos desarrollados; el acceso al mercado mundial para los países exportadores de productos agrícolas está determinado por la inversión en infraestructura agrícola y el desarrollo de nuevas tecnologías, lo que genera mucha competitividad y por lo tanto pérdidas de mercado e ingresos.

Todos los países están inmersos en una competencia sin tregua para lograr insertarse en forma favorable dentro del comercio internacional o al menos para no ser desplazados hacia posiciones más bajas o periféricas, como sucede en los países en desarrollo, pero también podría suceder en los más desarrollados (Arroyo, 1991).

Las inversiones que deberían realizar los países en desarrollo para incrementar el avance científico y tecnológico hacia el logro de innovaciones tecnológicas que les diera mayor ventaja competitiva en el comercio mundial, se ven afectadas por las políticas neoliberales 
impuestas por el Fondo Monetario Internacional (FMI) y los bancos internacionales de desarrollo. Estas políticas económicas constituyen una serie de imposiciones a los países en vías de desarrollo con miras a lograr un campo apropiado para generar y captar rentas capitalistas merced a las rentas tecnológicas ${ }^{1}$ en beneficio de las empresas transnacionales que detentan las patentes en los nuevos campos de microelectrónica, biotecnología y nuevos materiales. La capacidad de estos países para dedicar una parte considerable de sus ingresos a la investigación ( \& D) tenderá a ensanchar la brecha tecnológica y acrecentará las desigualdades tanto en la economía mundial como en los países.

\section{LA BIOTECNOLOGÍA DENTRO DEL CAMBIO TECNOLOGGICO}

Diversas interpretaciones han surgido del pensamiento schumpeteriano para explicar los cambios económicos y sociales a raíz de la crisis económica y de la carencia de formulaciones teóricas que expliquen el nuevo orden económico internacional.

La explicación de las crisis cíclicas o ciclos económicos tiene como factor central la relación entre cambios e innovaciones tecnológicas y desarrollo económico (Schumpeter, 1939).

Según Schumpeter, la crisis actual impone como análisis dominante la interacción entre cambio técnico y movimiento de largo período como principio explicativo de la crisis económica. Este autor califica la crisis como un proceso de "destrucción creadora" y describe los grandes auges económicos de los llamados "ciclos largos" de Kondratieff como el despliegue de una revolución tecnológica y la absorción de sus efectos.

Bajo esta línea de pensamiento, investigadores como Dosi (1982), y Freeman y Pérez (1986), tratan de vincular los períodos de prosperidad al predominio de un paradigma "tecno-económico", y los de crisis a la transición del antiguo a un nuevo paradigma dominante. Define el paradigma como un modelo o patrón de solución de problemas tecnológicos que conducen a un cierto sentido común, donde los esfuerzos y la imaginación tecnológica de los ingenieros y sus organizaciones, con una buena administración, elevan la productividad y rentabilidad de cualquier industria. Reconoce la necesidad de articular los cambios tecnológicos con cambios institucionales y sociales: innovaciones en las condiciones generales, sociales, políticas y culturales, que condicionan la capacidad de innovación de un país. Esto debería

"Véase M. Chauvet, "Biotecnología y rentas tecnológicas", Revista Sociológica, núm. 16, UAM-AZC, 1991. 
favorecer la transformación total del aparato productivo, según los requerimientos del nuevo paradigma (Pérez, 1986).

La biotecnología aparece como un nuevo paradigma que se mueve a lo largo de "trayectorias tecnológicas", capaz de modificar procesos productivos y crear nuevos productos.

La escuela de Amsterdam, representada por Junne (1984), Ruivenkamp (1986) y Roobeek (1990), discrepa de los economistos antes mencionados. Considera que la biotecnología y los nuevos materiales (zulenio, hofnio, cerámicas avanzadas, polímeros, etcétera), junto con la microelectrónica, forman parte de las tecnologías "bósicas" o core technologies, las cuales pueden revolucionar la economía. Sin embargo, estas tecnologías de punta no determinan la dirección del desarrollo económico y social de cada país, sino que logran llegar a una nueva regulación del orden político y económico (Roobeek, 1990:98). Para los autores de esta escuela, el análisis que realizan Pérez y Freeman (1986) sobre el surgimiento de los paradigmas tecnológicos revolucionarios se establece sólo en el plano económico. Por eso señalan la necesidad de introducir al análisis las variables políticas y culturales.

Los logros de estos investigadores están vinculados a las concepciones de "tecnologías de base y red de tecnologías (technologies web) como conceptos clave del cambio tecnológico y las formas generales de organización del trabajo y de la producción desde la esfera socioinstitucional".

Bajo las condiciones teóricas señaladas del cambio tecnológico, la biotecnología constituye un nuevo paradigma tecno-económico que forma parte de las tecnologías básicas y es elemento importante de la red tecnológica. Se le considera como un núevo polo de desarrollo que permitirá realizar las ganancias de la productividad y abordar un nuevo régimen de crecimiento: requisitos para el tipo de competencia descrito por Schumpeter.

Como se ha dicho a menudo, la biotecnología no es una industria per se, sino un conjunto de tecnologías y enfoques científicos y técnicos que se relacionan con ellas y que abarcan tanto los modernos procesos de fragmentación y transformación dirigidos por enzimas, como las nuevas tecnologías que resultan del desarrollo de la ingeniería proteínica de ADN recombinante y de la fusión celular. En otras palabras, también abarca lo que algunos autores han llamado "biotecnología de segunda y tercera generación" (Chesnais, 1990).

En breve, la biotecnología dará origen a un comercio específico y tendrá efectos de desplazamiento. El efecto más notable ya empezó a sentirse en el comercio de productos agrícolas y está en marcha una serie de avances tecnológicos de aplicación directa dentro de este 
sector, como los productos tropicales de alto valor comercial: café, cacao, etcétera.

Así pues, la biotecnología es un instrumento para la producción y el comercio, pero también un campo de batalla en donde diferentes combatientes luchan, con estrategias diferentes, para dar una orientación precisa a las trayectorias de esa nueva rama de la ciencia.

\section{TENDENCIAS DEL COMERCIO INTERNACIONAL DEL CAFÉ}

El café es el segundo producto de mayor intercambio mundial después del petróleo, y su comercio es uno de los más organizados entre las materias primas. México y Costa de Marfil se disputan el cuarto y quinto lugar, después de Brasil, Colombia e Indonesia en orden de importancia en la producción mundial. Para éstos y el resto de los países productores, la exportación de café representa una parte importante de sus ingresos.

De octubre a diciembre de 1990, las ventas de todas las modalidades de café realizadas por los países miembros de la Organización Internacional del Café (OIC) tuvieron un valor cercano a 1.6 mil millones de dólares, de los cuales México capta alrededor de 525 millones al año.

El comportamiento del mercado internacional de café se ha caracterizado por constantes fluctuaciones en la oferta $(y$, por consiguiente, en los precios), baja elasticidad de la demanda y acumulación de existencia en los países cafeticultores. Actualmente hay una sobreoferta del grano; precios deprimidos tendientes a la baja desde la suspensión de las cuotas de explotación del 3 de julio de 1989, principalmente para cafés robusta; creciente baja del consumo en Estados Unidos, principal importador; por consiguiente, bajas tasas de rentabilidad. Durante 1991 la captación de ingresos se redujo en 2.5 mil millones de dólares (World Coffee Situation, 1990).

De acuerdo con los datos de la OIC, durante octubre-septiembre de 1990-1991 la producción se incrementó en 9951 millones de sacos de 60 kilogramos respecto al ciclo 1988-1989. Las exportaciones totales para el mismo período totalizaron cerca de 78406 millones de sacos, $11.9 \%$ mayor que el ciclo 1988-1989; mientras las importaciones para el ciclo 1990-1991 tuvieron un comportamiento negativo, se importaron 751 mil sacos menos que en el ciclo 1989-1990 (véanse cuadros 1 y 2).

En 1990 la OIC presentó los resultados de un estudio sobre el consumo en Estados Unidos, realizado en el invierno de 1989. Para esos años las tazas de café al día por persona fueron de 1.75, aunque el año anterior habían sido de 1.67 tazas. Desde 1962 Estados Unidos 
dejó de consumir café a los niveles acostumbrados. Durante ese año el promedio fue el más alto: 3.12 tazas (OIC, Winter, 1989).

Con este panorama, los miembros de la OIC ( 50 productores y 25 importadores) participan de un mercado cafetalero expuesto al vaivén de la oferta y la demanda. Las causas que determinaron la ruptura del sistema de cuotas reguladas por la OIC fueron varias: incapacidad para ponerse de acuerdo sobre la reducción de las ventas a los países no miembros, redistribución de cuotas de exportación para los productores de "otros suaves", entre ellos México, y mayor disponibilidad de cafés de calidad requerida por los países consumidores.

Bajo el concepto de "mercado libre", al que hoy en día está sujeto el mercado de café, se previó que los productores menos eficientes en el mediano plazo se verían forzados a abandonar la cafeticultura, y que sólo los más competitivos podrían permanecer en él, lo cual inyecta salud a la economía global del café.

CUADRO 1

OFERTA MUNDIAL DE CAFE DE LOS PAISES LIDERES

(octubre-septiembre de 1990-1991)

\begin{tabular}{|c|c|c|c|c|c|c|c|c|c|c|c|}
\hline \multirow[t]{2}{*}{ Países } & \multicolumn{3}{|c|}{$\begin{array}{c}\text { Producción } \\
\text { (Miles de sacos) }\end{array}$} & \multirow[t]{2}{*}{$\%$} & \multicolumn{4}{|c|}{$\begin{array}{l}\text { Exportaciones } \\
\text { (Miles de sacos) }\end{array}$} & \multirow[t]{2}{*}{$\%$} & \multicolumn{2}{|c|}{$\begin{array}{l}\text { Rendi. Pre } \\
\text { miento Prome }\end{array}$} \\
\hline & Aróbiga & $\begin{array}{c}\text { Ro- } \\
\text { busla }\end{array}$ & Totol & & Grono & Toslado & $\begin{array}{c}\text { Solu- } \\
\text { ble }\end{array}$ & Total & & & (Dls/ \\
\hline Brasil & 27300 & 5700 & 33000 & 32.40 & 17000 & 0 & 2200 & 19200 & 24.50 & 500 & 75 . \\
\hline Colombia & 13600 & 0 & 13600 & 13.40 & 12500 & 0 & 400 & 12900 & 16.40 & 800 & 0 91. \\
\hline Indonesia & 410 & 6090 & 6500 & 6.40 & 5700 & 0 & 0 & 5700 & 7.30 & 565 & 552. \\
\hline México & 4650 & 100 & 4750 & 4.70 & 2900 & 100 & 30 & 3030 & 3.90 & 594 & 480. \\
\hline $\begin{array}{l}\text { Costa de } \\
\text { Marfil }\end{array}$ & 0 & 3670 & 3650 & 3.60 & 3300 & 4 & 776 & 4080 & 5.20 & 181 & \\
\hline Subtotal & 45960 & 15650 & 61250 & 60.50 & 4) 400 & 104 & 3406 & 44910 & 57.30 & & \\
\hline Otros & & & 40170 & 39.50 & & & & 33496 & 42.70 & & \\
\hline Total & & & 101690 & 10000 & & & & 78406 & 100.00 & & \\
\hline
\end{tabular}

FUENTE: Organización Internacional del caf́́ (OIC), 1991. 
CUADRO 2

DEMANDA TOTAL DE CAFE DE LOS PRINCIPALES PAISES IMPORTADORES EN LA OIC (ciclo octubre-septiembre $1989-1990$ y 1990-1991)

\begin{tabular}{|c|c|c|c|c|c|c|c|}
\hline Paises & $\begin{array}{l}\text { Importa- } \\
\text { ción } \\
\text { (Miles de } \\
\text { sacos) }\end{array}$ & $\begin{array}{c}\% \\
1989-199\end{array}$ & $\begin{array}{c}\text { Consumo } \\
P / C \\
(K g / a \% 0)\end{array}$ & $\begin{array}{l}\text { Imporia- } \\
\text { cion } \\
\text { (Miles de } \\
\text { sacos) }\end{array}$ & $\begin{array}{c}\% \\
1990-199\end{array}$ & $\begin{array}{l}\text { Consumo } \\
P / C \\
(K g / 0 \% 0)\end{array}$ & $\begin{array}{c}\text { Precio } \\
\text { Promedio } \\
\text { de compro } \\
\text { (Dis/loo } \\
\text { Lb) }\end{array}$ \\
\hline $\begin{array}{l}\text { E. U.A. } \\
\text { Alemania } \\
\text { Francia } \\
\text { Japón } \\
\text { Italia } \\
\text { Holanda } \\
\text { Inglaterra }\end{array}$ & $\begin{array}{r}22 \\
12730 \\
6279 \\
5737 \\
4703 \\
3060 \\
2797\end{array}$ & $\begin{array}{r}29.00 \\
16.60 \\
8.20 \\
7.50 \\
6.10 \\
4.00 \\
3.60\end{array}$ & $\begin{array}{r}4.8 \\
7.3 \\
2.5 \\
5.7 \\
4.5 \\
2.3 \\
10.1\end{array}$ & $\begin{array}{r}21009 \\
14212 \\
6301 \\
5506 \\
5242 \\
3128 \\
2898\end{array}$ & $\begin{array}{r}27.70 \\
18.70 \\
8.30 \\
7.20 \\
6.90 \\
4.10 \\
3.80\end{array}$ & $\begin{array}{r}4.5 \\
8.1 \\
2.5 \\
5.5 \\
0.5 \\
2.4 \\
10.5\end{array}$ & $\begin{array}{l}70.8 \\
76.7 \\
71.2 \\
80.8 \\
81.1 \\
89.9 \\
81.04\end{array}$ \\
\hline Subtotal & 57518 & 75.00 & 5.4 & 58296 & 76.70 & 5.5 & 78.7 \\
\hline Otros & 19182 & 25.00 & 5.3 & 17653 & 23.20 & 4.9 & $\cdots$ \\
\hline Total & 76700 & 100.00 & 4.9 & 75949 & 100.00 & 4.8 & 78.7 \\
\hline
\end{tabular}

Elaborado con base en: Statistics on Coffee (OIC), 1991.

\section{CRISIS Y LIBERALIZACIÓN DEL MERCADO DEL CAFÉ}

Es evidente que la lucha por el mercado cafetero empieza a enfrentar a los productores en una competencia sin tregua. La competitividad dependerá de una oferta estable de cafés de calidad, del uso alterno de tecnologías que permitan mayor productividad y menor costo productivo; quien no lo logre, será desplazado de manera definitiva del mercado.

La crisis del mercado internacional del café, traducida en sobreofertas del producto, persistencia de stocks, precios a la baja, y desregulación mercantil, se desarrolla en medio de una economía mundial que ha vivido en los últimos años una crisis financiera y una caída relativa de las tasas de ganancia, fenómenos que generan recesión y presión inflacionaria endógena y exógena de las economías desarrolladas, lo cual es transmitido hacia los países pobres vía precio de los productos industrializados. Ello agudiza las dificultades que 
experimentan los países menos desarrollados en sus balanzas comerciales y de pago.

La manera de resolver la crisis del mercado cafetero se presenta, en el marco de la restructuración económica que tiene lugar en los países consumidores, como un proceso creciente de organización científico-tecnológica. Estos procesos de regulación tienen su fundamento en las innovaciones tecnológicas que generan nuevos productos mediante nuevos procesos productivos tendientes a modificar las modalidades de acumulación del capital.

La tendencia cada vez mayor de desplazamiento de los cafeticultores del comercio internacional del café, por las razones antes expuestas, y la aplicación de nuevas tecnologías en su producción y beneficio (como es el caso de la biotecnología), los nuevos materiales y el manejo computarizado para controlar la calidad y la comercialización, van a generar diversas repercusiones en los países tradicionalmente productores. De la cafeticultura dependen millones de personas relacionadas con su actividad (en México suman más de tres millones). Salvo Brasil, Colombia, Indonesia, Costa Rica y Kenia, donde hay plantaciones de gran magnitud, el café no es una producción en gran escala.

En la mayor parte de los países, el cultivo se encuentra en manos de pequeños productores con diferentes formas de tenencia de la tierra. En México hay aproximadamente 178 mil campesinos dedicados al cultivo del café, quienes constituyen el $91 \%$ del total de productores de dicho cultivo (Velázquez, 1991). Es claro que este sector de productores se verá mayormente afectado, y en el mediano plazo abandonará la actividad, sobre todo los que aún pueden defenderse mediante sus organizaciones para la producción y la comercialización; pero aquellos, los más, que mantienen carteras vencidas con los bancos agrícolas y otras instituciones de crédito, y que tienen menos de 5 has de cafetos, desaparecerán en el corto plazo. Lo anterior generará más desempleo en el campo, cuyos habitantes emigrarán a las ciudades grandes y medianas, cuando no puedan hacerlo hacia Estados Unidos, lo que hará más difícil la situación económica de México.

El desplazamiento que sufrirán los países cafeticultores en pequeña escala se extenderá para todos aquellos grandes productores que no logren sortear los embates tecnológicos, financieros y comerciales.

\section{CAFÉ Y BIOTECNOLOGÍA}

El 95\% de todo el café que se bebe proviene únicamente de dos especies: Coffea Arabiga y Coffea Canephora Robusta. Ambas provie- 
nen de África. El café Arabiga, originario de Etiopía, se cultiva en grandes altitudes. Esta especie representa el $73 \%$ del consumo mundial y más del $\mathbf{9 7 \%}$ de la producción de América Latina. Su alta calidad se debe a su delicado aroma y a su bajo contenido en cafeína (1-1.3\%). El café robusta crece a bajas altitudes; $80 \%$ de la producción es africana, originaria de Zaire. Su calidad es menor ya que casi no tiene aroma y contiene alto nivel de cafeína (2-3\%). La industria solubilizadora de café es la que lo demanda mayormente para mezclarlo con café arábiga en diferentes proporciones, que después aparece en el mercado bajo diversas marcas.

La variedad aróbiga es una especie de hermafrodita y autógama que se reproduce fielmente por semillas. El mejoramiento que se le ha hecho hasta ahora ha hecho posibles varios cultivares relativamente homogéneos (Caturra, Mundo Novo). La variedad robusta es una planta heterógama autoincompatible, y su mejoramiento comprende la vía generativa y la vegetativa. La primera conduce a poblaciones muy heterogéneas y la segunda produce clones cuya explotación sólo puede utilizarse en mezcla policlonal en razón de su incompatibilidad (Berthouly, 1989). La especie arábiga es muy susceptible a la roya; mientras que la robusta contiene genes que la hacen resistente a esta enfermedad.

Se cree que las plantas de café Arabiga cultivadas en América Latina provenían de cafetos, variedad típica, trasplantados de Java en el Jardín Botánico de Amsterdam. Aunque esta variedad tiene cerca de 200 años de adaptación, también es cierto que su difusión masiva trajo consigo una extrema uniformidad genética. La falta de variabilidad genética en las plantaciones las hace vulnerables al ataque de plagas y enfermedades tales como la roya, la broca y los nemátodos que han devastado los cultivos y elevado los costos de producción.

Cuando el cultivo del café cobra un alto valor comercial (ya sea en África, Asia o América Latina), se impulsa al productor a que aplique técnicas de mejoramiento genético para lograr mayores rendimientos y nuevas variedades más comerciales. Mediante la "cruza" de ambas especies se han obtenido variedades híbridas. En general todos los países productores emprendieron programas de fitomejoramiento del cafeto (véase el cuadro 3).

A través de sistemas tradicionales de selección e hibridación, el fitomejoramiento ha permitido la separación de plantas más eficientes en sus actividades metabólicas con resistencia a plagas y enfermedades, adaptabilidad a diferentes áreas ecológicas y fenotipo que facilite una elevada tecnología del cultivo. El cruzamiento se ha utilizado para obtener cafetos híbridos y de corta estatura. 
La hibridación interespecífica ha sido aplicada exitosamente en tres cultivos comerciales: arabusta, icatú y catimor, lo que ha permitido enfrentar en cierta manera los problemas que amenazan a la cafeticultura. Estas variedades han generado incrementos en más de $300 \%$ en cultivares de café Arabiga que por sí misma amplía la base genética.

Sin embargo, la resistencia genética y la obtención de variedades híbridas comerciales obtenidas por métodos convencionales son tardados; requieren por lo menos de 15 a 20 años y, en el caso de híbridas resistentes a la roya, de 30 a 40 años de investigación, experimentación, validación y distribución. En los últimos años los procesos biotecnológicos, como el cultivo de tejidos y la ingeniería genética, han abierto importantes perspectivas en la investigación y aplicaciones prácticas para resolver problemas agronómicos; asimismo, han liberado nuevos y mejores biotipos en menos tiempo, así como su propagación masiva con menores costos. Algunos adelantos ya han empezado a influir en la calidad, la productividad y los beneficios.

Hasta ahora la biotecnología contempla dos métodos: genética celular y biología molecular (véase el cuadro 3). La primera consiste fundamentalmente en emplear técnicas de cultivo de tejidos, llamado también método in vitro; y la segunda se basa en la ubicación, aislamiento y transformación de genes, a partir del mapeo genético (RFLPs) (Restriction Fragment Length Polimorfisms) para acelerar los procesos de la ingeniería genética.

\section{CULTIVOS DE TEJIDOS (GENÉTICA CELULAR)}

El cultivo de tejidos o método in vitro constituye una serie de técnicas mediante las cuales las plantas son alteradas genéticamente para mejorar el cultivo del cafeto y la calidad del grano de manera masiva y en períodos cortos.

La micropropagación tiene un uso muy valioso en especies perennes como el café, pues representa un método simple y rápido de estimar el valor comercial de las plantas seleccionadas en un huerto de clones. Los mejores clones podrán propagarse a gran escala para la producción de café. Esta técnica reduce considerablemente el tiempo para desarrollar variedades propagadas por semillas y preservar la heterogeneidad y plasticidad. Puede usarse en híbridos individuales a gran escala provenientes de ambas especies, como catimor, icatú y arabusta.

En 1985 PROMECAFE, con el apoyo del Institut de la Recherche du Café et du Cacao (IRCC) del Centre International en Recherche Agronomique pour le Developpement (CIRAD) y el Instituto Interamericano de Capacitación Agrícola (IICA) en San José de Costa Rica, 
lograron propagación vegetativa in vitro mediante microestacas. En buenas condiciones de cultivo las nuevas plantas permiten obtener en un año cerca de 20 mil plantas provenientes de un solo explante (Berthouly, 1985).

\section{CUADRO 3}

TECNICAS Y OUTPUTS EN CAFE

\begin{tabular}{|c|c|c|c|c|c|}
\hline $\begin{array}{l}\text { Cultivo de ca- } \\
\text { fé por Fitome- } \\
\text { joramiento }\end{array}$ & Outputs & $\begin{array}{c}\text { Cultivo de teji- } \\
\text { dos (genética } \\
\text { celular) }\end{array}$ & Outputs & $\begin{array}{l}\text { Ingeniería ge- } \\
\text { nética Biolo- } \\
\text { gía molecular }\end{array}$ & Outputs \\
\hline $\begin{array}{l}\text { Selecciones de } \\
\text { población } \\
\text { natural }\end{array}$ & $\begin{array}{l}\text { Altos } \\
\text { rendimientos en } \\
\text { los cultivadores }\end{array}$ & $\begin{array}{l}\text { Micropropaga- } \\
\text { ción }\end{array}$ & $\begin{array}{l}\text { Micropropoga- } \\
\text { ción }\end{array}$ & $\begin{array}{l}\text { Identificación } \\
\text { de genes }\end{array}$ & $\begin{array}{l}\text { Nuevos } \\
\text { productos }\end{array}$ \\
\hline Hibridación & $\begin{array}{l}\text { Resistencia a } \\
\text { enfermedades }\end{array}$ & $\begin{array}{l}\text { Rescate de } \\
\text { embriones } \\
\text { (Embriogénesis } \\
\text { somb́tica) }\end{array}$ & $\begin{array}{l}\text { Nuevos } \\
\text { variantes }\end{array}$ & $\begin{array}{l}\text { Aislamiento de } \\
\text { genes }\end{array}$ & $\begin{array}{l}\text { Interruptor } \\
\text { de genes }\end{array}$ \\
\hline $\begin{array}{l}\text { Evaluación de } \\
\text { progenie }\end{array}$ & $\begin{array}{l}\text { Resistencia a } \\
\text { insectos }\end{array}$ & $\begin{array}{l}\text { Variación } \\
\text { somaclonal }\end{array}$ & $\begin{array}{l}\text { Líneas de } \\
\text { homocigotos }\end{array}$ & & Mapeo RfIPs \\
\hline Cruzamiento & Poca estatura & $\begin{array}{l}\text { Ordenación } \\
\text { genética }\end{array}$ & $\begin{array}{l}\text { Líneas de } \\
\text { células mutantes }\end{array}$ & & \\
\hline \multirow[t]{4}{*}{$\begin{array}{l}\text { Cruzas } \\
\text { interespecificas }\end{array}$} & & $\begin{array}{l}\text { Suspensión } \\
\text { celular }\end{array}$ & $\begin{array}{l}\text { Hibridación } \\
\text { interespecífica }\end{array}$ & $\begin{array}{l}\text { Construcción } \\
\text { de Cassettes }\end{array}$ & \\
\hline & & $\begin{array}{l}\text { Fusión de } \\
\text { protoplastos }\end{array}$ & $\begin{array}{l}\text { Hibridación } \\
\text { distante, } \\
\text { transferencia de } \\
\text { "Organelle" }\end{array}$ & $\begin{array}{l}\text { Transforma- } \\
\text { ción/regenera- } \\
\text { ción }\end{array}$ & \\
\hline & & Haploides & $\begin{array}{l}\text { Transferencia } \\
\text { de genes }\end{array}$ & $\begin{array}{l}\text { Métodos de } \\
\text { transformación: }\end{array}$ & \\
\hline & & $\begin{array}{l}\text { Preservación de } \\
\text { germoplasma }\end{array}$ & & $\begin{array}{l}\text { 1. Transferencia } \\
\text { indirecta de } \\
\text { genes } \\
\text {-Agrobacterias } \\
\text { - Virus } \\
\text { 2. Trasferencia } \\
\text { directa de genes } \\
\text { - Peg Uptake } \\
\text { - Microinyec- } \\
\text { ción } \\
\text { - Electroporación } \\
\text { - Balistica }\end{array}$ & \\
\hline
\end{tabular}

Elaborado con base en la información obtenida en: M. R. Sondahl, "The potential impact o biotechnology in coffee", Ponencia presentada en el "Treizeme colloque scientifique international sur le café", ASIC, PAIAP, 1989. 
El agroservicio que realiza la compañía Nestlé en la cafeticultura de Filipinas, a fin de mejorar rendimientos, calidades y costos para los fabricantes de Nescafé, la hizo desarrollar variedades de Robusta que permiten altos rendimientos y buena calidad mediante la propagación de clones y semilleros. En 1987 anunció un récord de 38\% en su producción de alto rendimiento en cortes de clones de café Robusta; de 317587 en 1986 a 437240 en 1987.

En Singapur, Plantek International (empresa dedicada a la biotecnología y financiada por capitales de Japón y Estados Unidos) tuvo en 1985 su primer éxito en la producción de clones de una nueva variedad de café Arabiga resistente a la roya; actualmente está produciendo miles de ese nuevo híbrido, destinado a las grandes plantaciones en el sudeste asiático (RAFI, 1989).

Investigadores de la compañía Synthelabo (Francia) y de Native Plants Inc. (Estados Unidos) han reportado resultados considerables en Arabiga.

La Universidad Autónoma de Chapingo, en colaboración con el Instituto Mexicano del Café (INMECAFE) y la Secretaría de Agricultura y Recursos Hidráulicos (SARH) presentaron en 1987 avances en la investigación en resistencia a la roya mediante propagación clonal en progenies de catimor y café garnica (Madrigal y Bailón, 1987).

Embriogénesis somática. El café puede ser propagado por corte o brotes auxiliares (nudos y ramas ortotrópicas). Ambas técnicas son útiles para establecer huertos de clones pero no para programas de gran escala. La embriogénesis somática en biorreactores es la única técnica que puede rendir en número y precio competitivo por unidad de árbol clonado. El cultivo de tejidos de arábiga y robusta tiene un alto potencial embriogenético que ofrece la posibilidad de que sus embriones encapsulados en medios nutritivos germinen igual que semillas. Las investigaciones de laboratorio motivadas por esta razón y por su trascendencia en la economía han continuado profundizando la embriogénesis somática que algún día dará como resultado la producción de semillas artificiales de cafeto (IIRC, 1987).

Esta técnica ha sido investigada por: Stanitsky, 1970; Herman y Hass, 1975; Pierson y cols., 1982; Pena, 1984; Yasuda y cols., 1985; Márques y Márques, 1987, 1989; Schoepke y cols., 1987; MichauzFerriere y cols., 1987, 1989; Neuenschwander y Baumann, 1990).

El rescate de embriones de especie de café silvestre puede recuperar recursos y características genéticas tales como: resistencia a enfermedades, insectos, salinidad y hábitos agronómicos. En poco tiempo esta técnica, combinada con una eficiente micropropagación, podrá comercializarse. 
Sondahl y Sharp establecieron una metodología para la formación y proliferación de embriones basada en dos patrones: (LFSE) Low Frequency Somatic Embryo directa, y High Frequency Embryo Induction (HFEI) o embriogénesis somática inducida que produce un callo secundario y células indirectas. PROMECAFE ha realizado estudios con café Arabiga y Robusta bajo estas técnicas con el fin de producir plantas resistentes a nemátodos e injertarse posteriormente. Los embriones somáticos en café Canephora o Robusta parecen dar mejor resultado debido a su variabilidad genética. Los últimos datos obtenidos muestran que, a partir de un explante de $1 \mathrm{~cm}^{2}$, se producen de tres mil a cuatro mil embriones. Con esta técnica se han obtenido líneas híbridas de catimor (híbrido timor y caturra) resistentes a la roya (CATIE, 1989).

Neuenschwander y Baumann (1990) obtuvieron en el laboratorio una mejor sincronización de la formación embriosomática al emplear un medio líquido durante la fase de inducción, lo que permite obtener un número ilimitado de proembriones que constan aproximadamente de 8 a 30 células. Ahora puede hacerse una oferta a gran escala de embriones somáticos. Para este logro se utilizó una nueva metodología, descubierta por ellos: Self Controlled Somatic Embryogenesis (SCSE). En Francia, CIRAD ha aplicado la embriogénesis somática en pequeña escala con el objeto de bajar los contenidos de cafeína en la variedad Arabiga.

Variación somaclonal. Los efectos mutagénicos de las condiciones del cultivo de tejidos han empezado a discutirse, al igual que la carencia de resultados obligados en la proliferación de células variantes que se presenta en el explante, o la activación de elementos transpuestos durante la fase de callosidad. Las variantes somaclonales pueden ser simples genes mutantes y a la vez intercambio de una base, la cual se comporta como mutante clásica mandeliana o, más frecuentemente, la realineación de cromosomas que afecta los rasgos determinados poligenéticamente. La mayor parte de los mutantes aislados a lo largo muestran resistencia a lo tóxico o a componentes que inhiben el crecimiento. Como se ve, el café puede mutar en un grano bajo o libre de cafeína. Los contenidos de cafeína pueden ser determinados poligénicamente, y el potencial somaclonal del café puede ser reconocido cuando aparecen muchos mutantes morfológicos. En síntesis, esta técnica permite producir mutaciones en segmentos vegetales, con lo cual se obtiene material que puede servir de base para nuevos programas de mejoramiento. Sirve para identificar y luego explotar las características resultantes a partir de las mutaciones inducidas. 
La DNA Plant Technology, Inc. (Estados Unidos), bajo contrato general con General Foods, se ha concentrado en el uso de la variación somaclonal con el propósito de descubrir características nuevas y deseables para los programas de mejoramiento. Algunos clones desarrollados por los laboratorios de DNA Plant fueron plantados en Brasil y ya dieron su primera cosecha.

En la Universidad de Zurich, Suiza, el Institute of Plant Biology ha venido trabajando esta técnica en combinación con la embriogénesis somática. Se han analizado alli más de 65 plantas de café Arabiga regeneradas mediante embriogénesis somática y se ha descubierto que, a lo largo, los contenidos de cafeína pueden variar considerablemente, por lo que se ha trabajado con la potencia somaclonal del café y se ha logrado considerable baja en los contenidos cafeínicos de las plantas (Baumann y Neuenschwander, 1990).

Fusión de protoplastos. La fusión de protoplastos puede producir híbridos que no podrían lograrse mediante cultivo convencional. Esta técnica utiliza enzimas especiales para disolver las paredes de las células vegetales. Las células desprovistas de paredes se denominan protoplastos. Al fusionar dos células, su material genético también se une, con lo cual se forma una nueva célula híbrida. Si luego el protoplasto puede producirse hasta conformar una planta, el resultado es una planta transgénica. Schoepke y cols. reportaron en 1987 la afortunada regeneración de plántulas de café Robusta a partir de protoplastos aislados provenientes de suspensión celular, a su vez derivada de embriones somáticos (Universidad de Frankfurt, CATIE y PROMECAFE, 1989).

Desde 1986 en ESCA Genetics Corporation (San Carlos, Ca., Estados Unidos), se han regenerado plantas intactas de protoplastos de variedad Arabiga que han demostrado una expresión pasajera de clorafenicol acetiltransferasa en protoplastos y, en suma, han obtenido una transformación estable de la resistencia a la kaenamicina que ya ha regenerado embriones somáticos en germinación.

Haploides. En relación con otras cosechas (trigo, arroz), los haploides de especies de café no han sido investigadas intensivamente. En 1973, Sharp y cols. obtuvieron en Brasil tejidos haploides y diploides de anteras. En 1987 Ascanio y Arcia trabajaron exitosamente en Venezuela con cultivo de anteras. Los callos diploides provenientes de anteras con microesporas prematuras dieron crecimiento a embriones de diferente estado de desarrollo. Las microesporas derivadas de haploides pueden ser superiores a los embriones somáticos diploides. 


\section{INGENIERÍA GENÉTICA (BIOLOGÍA MOLECULAR)}

La identificación y el aislamiento de genes es todavía una de las grandes limitaciones de esta técnica. Otra barrera es la posibilidad de un adecuado sistema de células que permitan la transferencia eficiente de genes y su regeneración (transformación). "Programa molecular exitoso es aquel que requiere la combinación de un buen cossette expression system, una célula eficiente y sistemas de cultivo de tejidos." La transformación es la interfase entre biología molecular o ingeniería genética celular, del mismo modo que la regeneración es la transición entre el cultivo de tejidos y el fitomejoramiento.

La técnica del ADN recombinante abre la posibilidad de introducir nuevos y valiosos genes dentro del cafeto y alterar los genes existentes para mejorar sus propiedades. Mediante las tecnologías del ADN las plantas de café pueden ser "designadas" sin ninguna restricción de las variedades tradicionales de café.

ESCA Genetics ha reportado la posibilidad de alterar las características del café mediante la manipulación genética, al igual que DNA Plant Technology. Los objetivos de la investigación se dirigen a obtener cualidades agronómicas superiores y "atributos deseables", entre ellos contenidos reducidos de cafeína y posibilidad de extraer mayor cantidad de sólidos. Actualmente ESCA Genetics se encuentra en proceso de patentar estos avances. Pese a ello, algunos científicos consideran que los resultados prácticos de recombinar o transferir genes sólo se podrán ver en unos diez años más.

Es claro, sin embargo, que muchas características del café tales como su sabor, aroma, fijación de nitrógeno, etcétera, estón determinadas por muchísimos genes que actúan juntos, lo cual hace más complejas las pruebas esenciales para los progresos futuros (Biotech. and Dev. Mon., 1990).

\section{POSIBLES REPERCUSIONES EN EL CULTIVO DEL CAFE}

Las diferentes técnicas aplicadas para producir y procesar café desde el cultivo de tejidos o genética celular hasta la tecnología del ADN recombinante son fuente de repercusiones potenciales, aun en los laboratorios.

Algunos logros (principalmente en el cultivo de tejidos) aplicados a la producción del café aún no han podido ser cuantificados en lo referente a sus efectos en la economía. Se supone que los productores-exportadores que se han beneficiado de estos avances tecnológicos han iniciado una carrera competitiva en el mercado internacional del 
café que les permite mantener posiciones de privilegio y por consiguiente mayores ingresos. No obstante, son las grandes empresas transnacionales las que desde antes de 1985 han venido invirtiendo fuertes sumas de dinero en proyectos biotecnológicos en café con la finalidad de reducir los costos en el cultivo mediante una mayor eficiencia en fertilizantes, crear resistencia a plagas y enfermedades, lograr mayor productividad y calidad del producto as' como tolerancia a diversas condiciones del entorno y reducir la mano de obra utilizada. Estos componentes que determinan la estructura de los costos y su mayor rentabilidad se ubican en el cultivo del grano. Respecto a su procesamiento, los proyectos biotecnológicos se orientan a lograr las siguientes características: mayor uniformidad en la maduración y medida del grano, acortar el ciclo de maduración, aumentar el total de sólidos solubles y mejorar la textura del grano. Con esto se pretende beneficiar y reducir costos en su procesamiento. En lo tocante a incrementar la demanda y mejorar su calidad, se intenta reducir los niveles de cafeína y mejorar el sabor y el aroma.

Con todo lo anterior se pretende que los países consumidores disfruten de precios más estables y calidad superior en la bebida, con lo cual se podrá incrementar la demanda; el precio y la calidad se incluyen en una estrategia de largo plazo. Esto plantea para los productores-exportadores un reto fundamental de sobrevivencia en el mercado mundial, cada vez más competido. Ante estas circunstancias, México tendrá que elevar sus niveles de eficiencia y calidad en su cafeticultura si desea continuar en el mercado cafetero. Es evidente que los mejoramientos en la producción y procesamiento del café mediante biotecnologías avanzadas serán más factibles para los productores a gran escala, mientras que los pequeños agricultores y campesinos tendrán que depender de subsidios y financiamiento externo para crear nuevas variedades de cafetos y subsistir en ese mercado.

Por el carácter privado que tienen los avances biotecnológicos en el café, es natural que sus precios de adquisición sean prohibitivos para los cafeticultores menores o de baja escala. Por lo tanto, sólo los grandes productores podrán tener acceso a ellos.

\section{ALGUNAS CONSIDERACIONES PARA EL FUTURO}

Cuando sea posible obtener variedades de café con tolerancia al frío, la salinidad, y mantengan o mejoren su calidad y productividad, los productores agrícolas de países no cafeticultores podrán cultivarlas. Esto tenderá a incrementar aún más la oferta de café, con lo cual las 
áreas tropicales, zonas tradicionales de producción, se verán desplazadas, toda vez que dichos avances reducen costos de embarque y tiempo de traslado.

Mediante la fijación del nitrógeno al café será más fácil producir mucho más café en zonas menos fértiles, lo cual causará un mayor desplazamiento de los cafeticultores marginales, quienes no podrán adquirir el paquete tecnológico propiedad de las empresas.

La uniformidad en la maduración y en el tamaño del grano permitirá emplear maquinaria nueva que vendrá a reducir el uso de la mano de obra, siempre y cuando mantenga o incremente los niveles de calidad. Si la producción y cosecha de café se realiza en los países consumidores, la ventaja comparativa que tienen los productores al emplear mucha mano de obra barata tenderá a desaparecer.

Cuando aparezcan a la luz pública las nuevas plantas de café con bajo nivel de cafeína o sin ella, el mercado del café robusta, que contiene cafeína en grandes proporciones, perderá su demanda y sus precios se desplomarán. A su vez, cuando el mejoramiento en sabor y aroma sea un hecho, países como Colombia, México, El Salvador y otros productores de variedad arábiga tenderán a perder su posición en el mercado mundial y habrá tendencia al desplome de los precios, que actualmente son los más altos.

Las presiones que ejercen los grupos internacionales de ecologistas y la actual caracterización de la demanda, que persigue el consumo de bienes de calidad y valor nutricional, serán las barreras para que desaparezcan los cafés solubles con altos niveles de cafeína y sean sustituidos por las mezclas de robusta que éstos contienen en mayor proporción.

Un efecto de rebote se localiza en la micropropagación del cafeto ya que en los cultivos de gran escala (para los cuales resulta rentables) la aplicación del cultivo de tejidos tiene sus desventajas. Aún se desconoce el número de efectos que dicha aplicación causa por el carácter uniforme de la planta; lo cierto es que dichos cultivos son más susceptibles a plagas y enfermedades cuando empiezan a alterar la ecología del lugar. Sin embargo, la micropropagación masiva de plantas puede ser controlada para que la roya y otras plagas y hongos se exterminen más fácilmente.

El desarrollo de resistencia a herbicidas e insecticidas podrá reducir el empleo de mano de obra, mientras se incrementa la necesidad de agroquímicos. Los cafetos tolerantes al Round-up y otros herbicidas como Simacine y Diuron ya están desarrollados y listos para su uso. 


\section{CONCLUSIONES}

Es indudable que los pequeños productores tendrán que competir con los cafés biotecnológicos en lo que respecta a producción, procesamiento y comercialización. Para ello deberán centrar sus estrategias en reducir costos e incrementar la calidad y la productividad. Sin embargo, a pesar de todos los esfuerzos que estos productores realicen, será difícil que en su mayoría sobrevivan a los embates del mercado mundial, tanto por la reducción en los precios como por las nuevas condiciones que impondrón las biotecnologías.

Para comprender la problemática del sector cafetalero campesino es necesario ubicarlo como parte del proceso de ajuste modernizador; éste lo orilla a la autogestión sin resolver los problemas económicos de carteras vencidas, altas tasas de interés bancario e insuficiente ayuda técnica. Lo anterior está vinculado a formas de organización para la producción y comercialización incipientes o a vicios de funcionamiento. El sector cafetalero sólo cuenta con la exigua ayuda del PRONASOL y los recursos de FIDECAFE. Esto empobrecerá y deprimirá la cafeticultura campesina y favorecerá al agronegocio.

El atraso cientf́fico y tecnológico, las tendencias mostradas por las politicas de reordenación económica, la insuficiencia de recursos para crear biotecnologías apropiadas y las presiones ejercidas mediante las politicas financieras internacionales encauzadas a la reprivatización de la cafeticultura, amén de los efectos mós obvios que traerá consigo el Tratado de Libre Comercio (TLC) transnacionalizando dicha actividad, generarán importaciones de paquetes biotecnológicos en la desesperación de no quedarse atrós y tener que salir del comercio intemacional (Velázquez, 1991).

Las patentes biotecnológicas, como todos los business de high tech, están controlados en el marco de mercados oligopólicos transnacionales, razón por la cual la generación de alternativas biotecnológicas propias y la mejor utilización de las que ya se encuentran en proceso es un imperativo categórico. La respuesta de los productores frente a estas tendencias definirá en el mediano plazo tanto el nivel de costos y beneficios nacionales como la capacidad mínima de inserción del cafeticultor en el mercado internacional. Mientras, los países consumidores que detentan las patentes acrecentarán su dominación sobre los países en desarrollo.

\section{BIBLIOGRAFÍA}

Arroyo, G. 1991. "Teoría sobre el desarrollo industrial". Ponencia presentada en el II Seminario Nacional sobre la Agroindustria en 
México. Universidad Autónoma de Chapingo y Consejo Nacional de Ciencia y Tecnología. Chapingo, México.

Ascanio, C. E., y Arcia, M. A. 1987. "Haploides from another culture in coffea arabiga. I International Congress of Plant Tissue Culture Tropical Species". Bogotá, Colombia.

Baumann, T., y Neuenschwander, B. 1990. "Tissue Culture in Coffee Biotechnology". Documentation Analytique, Café, Cacao, Thé. París. Vol. Xxolv. Núm. 2.

Berthouly, M. 1985. "Micropropagación del cafe". Primer Seminario Internacional sobre Biotecnología en la Agroindustria Cafetalera. México: INMECAFE, ORSTOM Y UAM-I.

Biotechnology and Development Monitor. 1990. "Coffee and Biotechnology". Núm. 4. Amsterdam: Universidad de Amsterdam.

Centro Agronómico Tropical de Investigación y Enseñanza (CATIE). 1989. Informe Anual. Núm. 10. Turrialba, Costa Rica.

Chauvet, M. 1991. "Biotecnología y rentas tecnológicas". Revista Sociológica. Núm. 16. UAM-A.

Chesnais, F. 1990. "La biotecnología y la exportación de productos agrícolas de los países en desarrollo". Comercio Exterior. Vol. 40. Núm. 3.

Dosi, G. 1982. "Technical Paradigms and Technological Trajectories: A Suggested Interpretation of the Determinants and Directions of Technical Change". Research Policy. Vol. 11. Núm. 4.

Freeman, C., y Pérez C. 1986. "The difusion of technological innovation and changes of techno-economic paradigms". Ponencia presentada en Venecia. Mimeo.

Herman, E., y Hass, G. 1975. "Clonal Propagation of Coffee Arabiga L. from callus culture". HorstScience. Vol. 10. Saint Joseph.

Institut de Recherches du Café et du Cacao (IRCC). 1987. "Summary Report". Association Scientifique Internationale du Café (ASIC). Núm. 3.

Junne, G. 1984. "Nuevas tecnologías de punta: una amenaza para las exportaciones de los países en desarrollo". Seminario de Revolución Tecnológica y Empleo. México: PNUD, OIT, STPS.

Madrigal, R., y Bailón, R. 1987. "Aplicaciones de la biotecnología en cultivos agroindustriales: caso del café". La agroindustria en México. Vol. 2, Universidad Autónoma de Chapingo. Programa Integración Agricultura-Industria.

Márques, D., y Márques, Q. 1987. "Study on in vitro somatic embriogenesis of coffea arabica". International Congress of Plant Tissue Culture Tropical Species. Bogota, Colombia.

Organización Internacional del Café (OIC). 1989. Coffee Drink Study. OIC. 
Pena, M. 1983. "Somatic embryo induction and plant regeneration from Coffea Canephora and Coffea Arabica". Simposio sobre ferrugens do caffeiro. Oeiras, Brasil.

Pérez, C. 1984. "Las nuevas tecnologías: una visión de conjunto". La tercera revolución industrial, impactos intemacionales del actual viraje tecnológico. Buenos Aires: RIAL-Anuario.

Pierson y cols. 1982. "In vitro development of embryoids from punched leafdises of Coffea Canephora". Protoplasma. Viena. Vol. 115.

Roobeek, A. 1990. Beyond the Technology Race and Analysis of Technological Policy in Seven Industrial Countries. Amsterdam: Elsevier Science Publishers.

Ruivenkamp, G. 1986. "The Impact of Biotechnology on International Development: Competition between Sugar and New Sweeteners". New Technologies and Third World Development. Forschunginstitut der Friederich-Ebert-Stiffung, Alemania.

Rural Advancement Fund International (RAFI). 1989. "Café y biotecnología". Pittsboro, North Carolina.

Schoepke y cols. 1987. "Somatic Embryogenesis and Regeneration of Plantlets in Protoplast Culture from Somatic Embryos of Coffee (C. canephora P. ex. Fr.). Plant Cell, Tissue and Organ Culture. Dordrecht, Alemania. Vol. 8.

Schumpeter, J. 1939. Bussiness Cycles: A Theoretical and Statical Analysis of the Capitalist Process. Nueva York: McGraw-Hill.

Sonchal, M. R.; Spahlinger, D. A.; Sharp, W. R. 1979. "A Histological Study of High Frequency and Low Frequency Indication of Somatic Embryos in Cultured Leaf Explants of C. arabica". L. Zeitschrift fur Pflanzen physiologie. Sttutgart. Vol. 94.

Sonchal, M. R., y Loh, W. H. T. 1987. "Coffee biotechnology". Coffee. Compilado por R. J. Clarck y R. Macrae. Elsevier.

Stanistky, G. 1970. "Embryoid Formation in Callus Tissue of Coffee". Acto Botanica Neerlandica. Leiden. Vol. 19.

Velázquez, S. 1991. "Algunos impactos biotecnológicos sobre café: avances recientes". Revista Sociológica. Núm. 16, UAM-Azc.

Yasurda y cols. 1985. "Embryogenic Callus Induction from C. arabica Leaf Explants by Benzyladenine". Plant and Cell Physiology. Tokio. Vol. 26. 


\title{
Potencialidades de la biotecnología para Ia producción de tomate
}

\author{
ARGELIA LORENCE QUIÑONES
}

\author{
INTRODUCCIÓN
}

La biotecnología es el conjunto de técnicas que tienen por objeto la explotación industrial de los microorganismos, de las células animales, vegetales y sus componentes, o bien la explotación "por lo vivo" de materiales orgánicos; su objeto es aplicar en la industria los resultados de la investigación a una escala suficiente para producir nuevos materiales, utilizables en muchos sectores de la actividad industrial.

Hasta hace algunos años, para mejorar la utilización de las células vivas en investigación o en la industria los investigadores debían limitarse a seleccionar las mejores especies y las mejores variedades; gracias a la ingeniería genética hoy en día es posible producir a voluntad células adaptadas a los proyectos del hombre. Como dijera Haldane: «si no eres capaz de encontrar un microbio que produzca lo que quieras, créalon (Prentis, 1989).

En general la principal ventaja de aplicar la ingeniería genética es la posibilidad de transferir genes de un organismo a otro con el objeto de obtener microorganismos que puedan producir diferentes sustancias en mayor cantidad y menor tiempo, lo cual reduce costos. Entre estas sustancias se encuentran, además de las que los microorganismos producen naturalmente, algunas que les son ajenas.

Por ejemplo, hace poco tiempo sólo era posible obtener la hormona de crecimiento en seres humanos en pequeñas cantidades extrayéndola de la glándula pituitaria de cadáveres. Actualmente es posible obtener esta hormona mediante cultivos celulares recombinantes, am-

1 Este artículo está basado en A. Lorence, H. Rojas y S. Santillán, "Estudio de prefactibilidad de la producción y venta de semillas de tomate (Lycopersicon esculentum) resistente a lepidópteros". Trabajo de Curso. Departamento de Biotecnología, México: Universidad Autónoma Metropolitana-Iztapalapa, 1991. 
pliando su aplicación, ya que se incrementa su producción no sólo para satisfacer las necesidades existentes, sino también para darle nuevas aplicaciones como el tratamiento de quemaduras, fracturas y osteoporosis.

Otro ejemplo es el caso de la insulina, la cual se obtenía únicamente del páncreas de los vacunos o porcinos y actualmente, gracias a la ingeniería genética, es posible obtenerla a partir de bacterias a las cuales se les introdujo el gen codificador de la insulina.

Hasta 1980, las células humanas eran la única fuente de interferón humano, cuyo costo llegó a estimarse en $\mathbf{5 0}$ millones de dolares por gramo; en ese año, el gen para un tipo de interferón humano fue sometido a clonación e injertado en una bacteria; la producción mundial de interferón creció de manera fantástica y sus costos disminuyeron $90 \%$ (Prentis, 1989).

Sin embargo, la aplicación práctica de la biotecnología presenta algunos inconvenientes. Una desventaja de la ingeniería genética consiste en que, por ejemplo, al transferir genes de fijación de nitrógeno atmosférico a los cereales mediante un microorganismo, existe la posibilidad de que éste se propague en el suelo y favorezca a plantas distintas de los cereales cultivados, lo cual rompería el equilibrio biológico tanto en el seno de las asociaciones vegetales como en las biocenosis animales (Herrera, 1986).

Sin embargo, algunos biólogos consideran que no hay peligros potenciales causados por la ingeniería genética, ya que los microorganismos de genoma modificado apenas tienen posibilidad de sobrevivir fuera de las condiciones de laboratorio. Por el contrario, otros biólogos se inquietan ante las normas actuales de seguridad, así como por la ausencia de reglamentación frente a la futura bioindustria (Prentis, 1989).

Desde otro punto de vista, la principal desventaja de la ingeniería genética es que la investigación y la magnitud de la inversión en tiempo y dinero hace que solamente productos con un alto valor agregado puedan obtenerse por vía de procesos modificados mediante ingeniería genética, dejando fuera productos de menor valor agregado pero que satisfacen necesidades muy importantes, como los alimentos.

Las plagas están constituidas por organismos que interfieren en el valor de los productos de los cultivos a los que están relacionados. Dentro de los organismos plaga se consideran los insectos, nemátodos, virus, bacterias, hongos, malezas, roedores, moluscos, pájaros y otros de menor importancia. Se calcula que en el mundo hay alrededor de 10 mil especies de insectos plaga en cultivos, ganados, hombre y productos almacenados. Las malas hierbas son otro grupo importante de plagas; se estima que hay en el mundo alrededor de 30 mil especies de plantas consideradas como maleza, y de éstas, más de 
1800 causan pérdidas económicas a la agricultura. Las enfermedades de las plantas son consideradas plagas tambien y se calcula que hay 100 mil enfermedades causadas por 8 mil especies de hongos, 500 especies de nemátodos, 250 virus y 160 especies de bacterias (Sorensen, 1991).

Los métodos de control químico tradicionales para combatir plagas han causando grandes problemas, como el proceso de la resistencia insectil a los plaguicidas, la contaminación de los mantos acuiferos, el deterioro de los ecosistemas e intoxicaciones a humanos; la resistencia insectil es responsable de la "necesidad" de incrementar continuamente la cantidad de tóxico como acción inmediata para mantener bajo control a una población-plaga, la cual presenta cada vez mayor respuesta hacia la dosis de los productos usados; esto se vuelve un círculo vicioso que puede ocasionar el abandono del cultivo en una región agrícola debido al incremento "exponencial" de los costos del combate químico. ${ }^{2}$

La toma de conciencia ecológica, aunada a problemas económicos graves debido a pérdida de cosecha, han conducido a prestar mayor atención a las posibilidades que ofrecen el control biológico y el genético.

Para el control de insectos se prefiere el uso de productos de origen microbiano, ya que tienen elevada especificidad y biodegradabilidad. La bacteria Bacillus thuringiensis es el más claro ejemplo de control biológico de plagas. Este microorganismo produce un cristal proteico específicamente tóxico para larvas de lepidópteros, coleb́pteros, dípteros, nemátodos, platelmintos o protozoarios (Feitelson, 1992). La toxina no ha mostrado tener efecto sobre los mamíferos, ni sobre insectos benéficos (Basurto, 1990).

Con técnicas de ingeniería genética, la estrategia mós adecuada es la que introduce la información genética de la proteína tóxica al genoma de la planto, lo que hace a ésta producir su propio insecticida.

De la gran variedad de especies vegetales de interés agrícola con que cuenta el país destacan las hortalizas, ya que su cultivo es una de las pocas actividades agrícolas altamente tecnificadas; de alli que constantemente estén haciéndose innovaciones tecnológicas que redundan en una mayor productividad y calidad de los productos.

La actividad hortícola es el sector más sobresaliente de la agricultura mexicana, no sólo por ser autosuficiente, sino también porque representa una importante fuente generadora de empleo rural.

Los cultivos de hortalizas ocupan anualmente una superficie de $\mathbf{4 5 0}$ mil hectáreas, principalmente de riego, por lo que adquieren una gran

2 "La resistencio insectil la crea el hombre, no los plagas", Agro Síntesis, 1990, marzo, pp. 74-79. 
importancia socioeconómica; con sólo el $2.3 \%$ de la superficie total agrícola del país, aportan el $11 \%$ del volumen total de la producción agrícola, el $20 \%$ del valor de ésta, contribuyen con el $42 \%$ del valor total de la exportación de productos agrícolas y ocupan el $13 \%$ de la población económicamente activa en la agricultura. ${ }^{3}$ Las exportaciones de hortalizas ascienden a 700 millones de dólares. ${ }^{4}$

En el Programa Nacional de Modernización del Campo 1990. 1994 se hace notar la importancia económica de las hortalizas y se señalan diferentes medidas que se tomarán para aprovechar al móximo el potencial de este sector, como son: eliminación de las restricciones para la exportación, difusión de las normas internacionales de calidad y acciones que faciliten la promoción externa de los productos hortofrutícolas mexicanos, así como el establecimiento de canales de distribución en el extranjero.

Uno de los principales productos hortícolas es el tomate, ya que su cultivo tiene importancia no sólo como generador de divisas, sino también por la elevada derrama económica que genera, pues proporciona mano de obra a una gran masa de trabajadores estacionales del campo. Crea y fomenta también empleo en otras ramas de la actividad económica como son: la de transportes y empresas que se dedican a la compra-venta de insumos utilizados en las distintas etapas de la producción y comercialización de dicho fruto.

Algunas publicaciones indican que se producen cuantiosas pérdidas en el cultivo de tomate en México a causa de plagas de lepidópteros; en especial por causa del gusano alfiler (Keiferia lycopersicella) puede perderse en muchos casos el $80 \%$ del cultivo, y en otros el 100 por ciento. ${ }^{5}$

Otros hechos que hacen una opción atractiva la transformación genética del tomate son: se trata de un producto con valor suficiente para justificar la inversión; no tiene precio de garantía, es decir, estó sujeto a la ley de la oferta y la demanda; el tomate tiene un mercado maduro en Estados Unidos, situado alrededor de 420 mil toneladas y otras 30 mil destinadas anualmente a Canadá y algunos países europeos; ${ }^{6}$ se pronostica que el tomate seguirá siendo el "rey de la exportación" de las hortalizas mexicanas; el uso restringido de plagui-

3 "Panorama de la exportación de hortalizas y frutas frescas, su importancia, situación actual y problemática 1985-1986", Boletín Anual, Unión Nacional de Productores de Hortalizas (UNPH).

4 "Vale 700 millones de dólares la exportación de hortalizas", Hortalizas, frutas y flores, enero, 1991, pp. 9-12.

5 "Gusano alfiler: enemigo a vencer por los tomateros de Sinaloa", Síntesis Horticola, octubre, 1989, pp. 30-33.

6 "El tomate, rey de la exportación", Sintesis Hortícola, agosto, 1989, pp. 12-13. 
cidas y fungicidas que se tendrá si se aprueba la Ley de Protección al Ambiente de California o Big Green, según pronostican investigadores del Departamento de Agricultura, Estados Unidos hará una reducción en los rendimientos de las hortalizas de $50-60 \%$, lo cual disparará sus costos para el consumidor ${ }^{7}$ si los exportadores de tomate mexicanos cumplen con las tolerancias permitidas en plaguicidas, pueden aumentar de manera considerable sus volúmenes de exportación al mercado norteamericano; esto beneficiaría también a los productores de semilla.

Por todo lo anterior, el objetivo del presente trabajo consiste en exponer las bases científicas y técnico-industriales que entrañaría la posible creación de una empresa productora de semillas de tomate resistente a lepidópteros. Con el presente estudio también se pretende demostrar que la biotecnología, y en específico la ingeniería genética, puede ser un buen negocio en México, como ya lo es en otros países.

\section{PROCESO CIENTIFICO-TECNICO PARA OBTENER SEMILLAS RESISTENTES A LOS LEPIDÓPTEROS}

La obtención de la semilla de tomate resistente a lepidópteros puede dividirse en las siguientes etapas:

A.

a) Transformación genética de la planta

b) Micropropagación

c) Pruebas de campo y bioseguridad

B.

d) Invernadero

e) Planta industrial

En el presente trabajo se analiza la posibilidad de crear una empresa productora de dichas semillas; se parte del hecho de que en México hay grupos de investigación con experiencia en el fitomejoramiento de variedades vegetales, así como en la tecnología para su transformación genética.

Dicha empresa podría adquirir variedades híbridas de tomate que pueden transformar y contratar los servicios del grupo de investigación que tiene experiencia en el desarrollo de plantas transgénicas. De tal

7 "El Big Green de California beneficiará a México", Hortalizas, frutas y flores, enero, 1991 , pp. 25-32. 
cidas y fungicidas que se tendrá si se aprueba la Ley de Protección al Ambiente de California o Big Green, según pronostican investigadores del Departamento de Agricultura, Estados Unidos hará una reducción en los rendimientos de las hortalizas de $50-60 \%$, lo cual disparará sus costos para el consumidor ${ }^{7}$ si los exportadores de tomate mexicanos cumplen con las tolerancias permitidas en plaguicidas, pueden aumentar de manera considerable sus volúmenes de exportación al mercado norteamericano; esto beneficiaría también a los productores de semilla.

Por todo lo anterior, el objetivo del presente trabajo consiste en exponer las bases científicas y técnico-industriales que entrañaría la posible creación de una empresa productora de semillas de tomate resistente a lepidópteros. Con el presente estudio también se pretende demostrar que la biotecnología, y en específico la ingeniería genética, puede ser un buen negocio en México, como ya lo es en otros países.

\section{PROCESO CIENTIFICO-TECNICO PARA OBTENER SEMILLAS RESISTENTES A LOS LEPIDÓPTEROS}

La obtención de la semilla de tomate resistente a lepidópteros puede dividirse en las siguientes etapas:

A.

a) Transformación genética de la planta

b) Micropropagación

c) Pruebas de campo y bioseguridad

B.

d) Invernadero

e) Planta industrial

En el presente trabajo se analiza la posibilidad de crear una empresa productora de dichas semillas; se parte del hecho de que en México hay grupos de investigación con experiencia en el fitomejoramiento de variedades vegetales, así como en la tecnología para su transformación genética.

Dicha empresa podría adquirir variedades híbridas de tomate que pueden transformar y contratar los servicios del grupo de investigación que tiene experiencia en el desarrollo de plantas transgénicas. De tal

7 "El Big Green de California beneficiará a México", Hortalizas, frutas y flores, enero, 1991 , pp. 25-32. 
modo que los investigadores llevarían a cabo la etapa $A$, antes citada, y la empresa, la etapa B.

A continuación se hace un análisis de este hecho desde los puntos de vista técnico, tecnológico, financiero y de mercado.

En el campo experimental de Zacatepec, Morelos, del Instituto Nacional de Investigaciones Forestales y Agropecuarias (INIFAP) se cuenta con experiencia en el desarrollo de nuevas variedades híbridas de tomate; por ejemplo, el "híbrido 101" es una variedad que produce frutos de 150 gramos con un rendimiento de 50 a 60 toneladas por hectárea. El costo de productos como el anterior es de 250 millones de pesos por híbrido (Magallanes, 1991).

En el Centro de Investigación de Estudios Avanzados, unidad Irapuato (CINVESTAV-Irapuato) del Instituto Politécnico Nacional (IPN), hay un grupo de científicos con experiencia en la transformación genética de diferentes variedades vegetales, como por ejemplo tabaco, tomate, espárrago y chile. Los investigadores con estudios de posgrado que han trabajado en la transformación de diferentes variedades de tomate para hacer a éstas producir su propio insecticida son Regina Basurto, Beatriz Xoconostle y José Antonio Garzón Tiznado y los doctores Ariel Álvarez Morales y Luis Herrera Estrella.

Las variedades de tomate que han sido transformadas por el equipo de investigación antes citado son Hayslip, Floradade y UC-92B.

Estas variedades no han podido ser probadas en el campo ya que hasta el momento no hay una regulación acerca de la liberación al ambiente de organismos modificados genéticamente (OMG). La Ley de Sanidad Fitopecuaria de los Estados Unidos Mexicanos y su reglamento en materia de sanidad vegetal están en proceso de modificación (González, 1991).

Los parámetros con que deben medirse los OMG aún no se han establecido en México; sin embargo, se han realizado algunos esfuerzos al respecto. Por ejemplo, hay un banco de datos de bioseguridad del Consejo Nacional de Ciencia y Tecnología (CONACYT), y algunos investigadores como el doctor Alejandro Blanco han impulsado la idea de integrar un Comité Nacional de Bioseguridad, la cual al parecer no se ha consolidado aún.

Los miembros del Grupo de Estudio Interamericano de la Nueva Biotecnología en Salud y Agricultura participaron en una reunión realizada en Brasilia del 30 de mayo al $1^{\circ}$ de julio de 1990; en esta reunión elaboraron un documento que contiene un análisis del marco jurídico referente a la liberación de OMG que hay en otros países, entre ellos Estados Unidos y Canadá, y una serie de propuestas para controlar la liberación de OMG en América Latina. 


\section{DEFINICIÓN DEL PROCESO DE OBTENCIÓN DE SEMILLA DE TOMATE RESISTENTE A LEPIDÓPTEROS}

La transformación genética de la planta consiste en obtener el gen de Bacillus thuringiensis que codifica para la proteína tóxica e insertarto al genoma de la planta; para ello se emplea una bacteria que transfiere naturalmente información genética a las plantas que infecta, Agrobacterium tumefaciens.

Una vez que se ha obtenido una planta transformada, ésta debe ser propagada con el fin de obtener un gran número de copias idénticas de ella.

Las pruebas de campo y bioseguridad tienen como finalidad demostrar que el gen introducido se expresa en todas las plantas modificadas, y que la cantidad de toxina que cada planta produce es suficiente para combatir a la plaga, al mismo tiempo que no resulta tóxica para otros insectos benéficos, mamíferos y humanos.

El proceso de invernadero y planta industrial consta de las siguientes partes:

1. Siembra del tomate en invernadero. Las plantas se polinizan a mano una a una, por tratarse de variedades híbridas.

2. Recolección del fruto y lavado con una solución de fungicida.

3. Despulpado. Este proceso consiste en separar la pulpa y cáscara del tomate de las semillas. De esta separación se obtiene como subproducto la pulpa del tomate, la cual se planea procesar para obtención de jugo.

4. Las semillas son limpiadas de la capa muscilaginosa que las rodea; este proceso se hace usando pectinasas en medio ligeramente ácido.

5. Lavado de las semillas con agua corriente.

6. Secado con aire caliente.

7. Clasificación según peso y tamaño. A las semillas clasificadas se les agrega una dosis de fungicida para evitar el ataque de hongos al ser sembradas.

8. Envasado en latas de una libra cerradas al vacío.

9. Etiquetado

10. Venta.

\section{CÁlCULO DEL COSTO DE LA TRANSFORMACIÓN GENÉTICA DE UNA VARIEDAD DE TOMATE}

Para estimar la inversión que la empresa que se creara debiera hacer por concepto del costo de la transformación genética de cada variedad 
de tomate, consultamos a los investigadores que han llevado a cabo este proceso y encontramos que ese cálculo no estaba disponible. Con base en una lista de los insumos, infraestructura y capital de trabajo requeridos para este proceso, que nos fue proporcionada por los investigadores, hicimos un cálculo directo y encontramos que el costo unitario de transformación es de 251355 dólares.

Para calcular la inversión correspondiente a las pruebas de campo encontramos que en Estados Unidos la empresa Monsanto realizó pruebas de campo y bioseguridad para una variedad de tomate transgénico y reportó que el costo de éstas fue de $500 \mathrm{mil}$ dólares (Quintero, 1991). Este costo tan elevado pudo deberse a que, como se tenía poca experiencia para hacer este tipo de pruebas, se midieron todas las variables posibles. Los costos deben de haber disminuido ahora que sólo se cuantifican las variables más importantes.

El número de permisos para la liberación de OMG ha ido en aumento y en la actualidad ya son mós de 240 sólo en Estados Unidos (González, 1991).

La utilidad del dato obtenido acerca del costo unitario de transformación del tomate es que permite comparar los resultados con los obtenidos por otras instituciones de investigación nacionales e internacionales. En caso de que esta tecnología llegara a negociarse, a este costo debiera aumentarse un porcentaje ya que falta considerar el "saber hacer" (know how).

Para este análisis se considera que una manera adecuada de que la empresa que se creara pague a CINVESTAV-Irapuato por concepto de esta tecnología es del $8 \%$ de las ventas totales que dicha empresa pudiera tener.

\section{CARACTERISTICAS DEL MERCADO DE LA SEMILLA TRANSGÉNICA}

Para fines de nuestro estudio, los criterios aplicables para segmentar el mercado del producto son el geográfico, la concentración de la población y el nivel cultural.

La primera aproximación al mercado meta está constituida por todos aquellos productores de tomate del país, los cuales se encuentran distribuidos en 25 entidades federativas.

Son cuatro los estados que aportan el $78.5 \%$ del total de la exportación de hortalizas en México: Baja California, Michoacán, Sinaloa y Sonora.

Por ser las semillas de tomate modificadas genéticamente, un producto nuevo y fruto del avance de la biotecnología de plantas, dicho 
producto estaró destinado sólo a agricultores con una mentalidad abierta a los cambios tecnológicos de nuestro tiempo.

Es importante el análisis del nivel cultural, pero sobre todo de la actitud hacia la ingeniería genética por parte de los usuarios potenciales de una tecnología como ésta. En Estados Unidos se ha descubierto que no todos los agricultores responden de manera positiva hacia la ingeniería genética y se detectaron las características de los que sí lo hacen, a saber:

- Son más jóvenes que el promedio.

- Están mejor educados (licenciatura o posgrado).

- Son nuevos en agricultura.

- Generalmente tienen extensiones de tierra más grandes que el promedio.

- Tienen un mejor ingreso que el promedio.

- Son gerentes financieros de avanzada.

- Ven a la agricultura como un negocio, no como un modo de vida.

- Están altamente motivados y tienen voluntad de arriesgar.

- Están conectados a redes de comunicación que les proporcionan, entre otras cosas, datos sobre nuevos productos, procesos, mercado de productos agrícolas, etcétera y

- Tienden a ser líderes de opinión.

Un estudio llevado a cabo por el Centro de Biotecnología de Carolina del Norte en 1988-1989 reveló que la aprobación del público es diferente para las posibles aplicaciones de la ingeniería genética en la agricultura. Los resultados obtenidos son los siguientes:

USO

APROBACIÓN PÚBLICA (\%)

\begin{tabular}{ll}
\hline Más nutrientes alimenticios & 77 \\
Plantas resistentes a heladas & 58 \\
Plantas resistentes a insectos & 53 \\
Plantas resistentes a herbicidas & 41 \\
Productos cómicos y lácticos & $13^{*}$ \\
\hline
\end{tabular}

* FUENTE: Sorensen, 1991.

Los horticultores sinaloenses y baja californianos emplean sistemas de producción de alta técnica, realizan cultivos agrícolas de elevados rendimientos, alto empleo de agroquímicos y mecanización agrícola 
que se apoya en aspersiones aéreas. ${ }^{8}$ Están en continuo contacto con centros de investigación internacionales como la Universidad de Purdue con el objeto de aprovechar los avances cientificos logrados para diferentes tipos de hortalizas; los productores de tomate de Sinaloa actualmente financian proyectos de investigación a una universidad de Israel por valor de 500 mil dólares anuales (Quintero, 1991). Por lo anterior el mercado meta se reduce a los estados de Baja California y Sinaloa.

Los agricultores de Sinaloa están agrupados en 10 asociaciones; los productores de tomate se concentran en tres de ellas: las asociaciones de los ríos Fuerte Sur, Sinaloa Poniente y Culiocán.

En el caso de los productores de tomate de Baja California, las principales zonas productoras de esta entidad son: San Quintín, Meneadero, San Vicente, Valle de Mexicali y el Ejido Chapultepec.

La producción de estos posibles consumidores de semilla transgénica está casi en su totalidad enfocada al mercado de exportación, principalmente al de Estados Unidos. La oferta de tomate mexicano cumple una función complementaria en el comercio exterior, según lo muestra el análisis de esta población consumidora.

Por ser las semillas el insumo principal para la producción de tomate, los agricultores buscan semilla de muy alta calidad. Las características del tomate más deseadas por los productores son:

a) Vida de anaquel larga (tiempo de maduración prolongado).

b) Resistencia a tizón tardío (Phytophethora infestans).

c) Resistencia a lepidópteros, principalmente al gusano alfiler (Keiferia lycopersicella).

d) Alta productividad.

e) Resistencia al manejo, ya que puede perderse hasta el $40 \%$ de la cosecha por un mal manejo del fruto.

f) Para tomate de consumo fresco buscan tomates rojos, con buena presentación, firmeza y, sobre todo, buen sabor.

g) Para tomate de consumo industrial buscan acidez y alto contenido de sólidos (Quintero, 1991).

Según la superficie que cada productor siembra y el método utilizado para ello, es decir, por trasplante o bien por siembra directa, por cada hectórea y de acuerdo con la variedad de tomate sembrada, los productores utilizan de 1 a 2.5 libras de semilla.

Para plantear un escenario de la producción y venta de tomate en Sinaloa se recurrió a los datos siguientes: 40-46.

8 "La producción de hortalizas en México", Síntesis Hortícola, enero, 1990, pp. 


\begin{tabular}{ccc} 
TEMPORADA & SUP. SEMBRADA (hos) & TON. EXPORTADAS \\
\hline $1980-1981$ & 17287 & 215254 \\
$1981-1982$ & 15208 & 210983 \\
$1982-1983$ & 17302 & 251617 \\
$1983-1984$ & 18392 & 281365 \\
$1984-1985$ & 17905 & 300394 \\
$1985-1986$ & 16908 & 312451 \\
$1986-1987$ & 20659 & 328766 \\
$1987-1988$ & 27312 & n. d. \\
$1988-1989$ & 28400 & n. d. \\
$1989-1990$ & 34227 & 425024 \\
$1990-1991$ & n. d. & $\left({ }^{*}\right)$ \\
\hline
\end{tabular}

n. $d .=$ no disponible

La temporada (*) resultó ser la peor en 15 años, ya que la caja de 12 kilogramos de tomate de exportación se cotizó a 3.5 dólares, cuando el costo de producción fue de 5.5 (Crisantes, 1991).

La superficie sembrada de tomate en los Estados de Sinaloa y Baja California permanecerá constante los próximos cinco años; por lo tanto pueden hacerse las proyecciones siguientes:

\begin{tabular}{cc} 
TEMPORADA & EXPORTACIÓN (Ton) \\
\hline $1991-1992$ & 457050 \\
$1992-1993$ & 479600 \\
$1993-1994$ & 502150 \\
$1994-1995$ & 524700 \\
$1995-1996$ & 547250 \\
\hline
\end{tabular}

Para determinar la demanda actual de semilla de tomate tomamos como base de cólculo la máxima superficie sembrada en los estados de Sinaloa y Baja California (38 813 hectáreas) y los dos métodos de siembra diferentes (trasplante y directo); descubrimos que anualmente se requieren en promedio 72774.375 libras o 33.003 toneladas.

En la actualidad no se han puesto a la venta semillas de tomate resistente a lepidópteros, como las que este estudio plantea que podrían obtenerse; sin embargo, en Estados Unidos diferentes compañías han obtenido ya permisos para realizar pruebas de campo y bioseguridad para productos similares: Calgene Inc., DuPont Co., Monsanto Co., Sandoz C. P. Corp., Agrigenetics Co., Upiohn y Canners Seed. Se estima que para 1992 este tipo de productos estará disponible en el mercado (Quintero, 1991). 


\section{Mercado de abasto}

Las materias primas utilizadas en el proceso de obtención de semillas de tomate resistente a lepidópteros son relativamente pequeñas en volumen, lo mismo que la producción de la planta, pero su valor es alto.

Una de las materias primas más importantes en el proceso es el agua, por lo que la abundancia de este recurso determinó en gran medida la localización de la planta que se contempla como base de este proyecto.

El resto de las materias primas son sales nutritivas, ácido clorhídrico, polietilenglicol 8000 , pectinasas, fungicidas y envases.

Los estados de Sinaloa y Baja California se caracterizan por tener una agroindustria muy desarrollada, por lo que los insumos que requieren están disponibles durante todo el año.

Localización de la planta

Para la macrolocalización de la planta se seleccionaron los cuatro exportadores de tomate más importantes del país: Sinaloa, Baja California, Sonora y Michoacán.

Los criterios generales considerados fueron la cercanía al mercado de consumo, la cercanía a las fuentes de materia prima, disponibilidad y características de la mano de obra, facilidades de transporte, disponibilidad y costos de energía eléctrica y combustible, fuentes de suministro de agua, facilidades para la eliminación de desechos, disposiciones legales, fiscales y de política económica, servicios públicos diversos, condiciones climatológicas, actitud de la comunidad, disponibilidad de maquinaria y enseres agrícolas y disponibilidad de medios de comunicación. El estado que ofrece más ventajas para la ubicación de la planta es Sinaloa.

Los criterios considerados para determinar la microlocalización en cualquiera de los 13 parques industriales con que cuenta dicho estado fueron la disponibilidad de registro ante SECOFI, drenaje, telégrafo, naves industriales, vigilancia, zona de carga y descarga, agua, energía eléctrica, teléfonos, correo, ferrocarril, carretera, superficie disponible, costo por metro cuadrado, cercanía al mercado de consumo, mano de obra y tratamiento de efluentes.

El lugar más adecuado para la localización de la planta es el Parque Industrial y Comercial de Topolobampo.

Tamaño de la planta

Puesto que, de llevarse a cabo, este proyecto se desenvolvería en un mercado de tipo oligopólico y en uno o dos años más estarían 
disponibles productos similares al aquí planteado (provenientes de las compañías transnacionales antes citadas), decidimos finalmente tomar el $20 \%$ de la demanda total de Sinaloa y Baja California como el tamaño de planta: 6.615 toneladas de semilla de tomate por año, lo que equivale a procesar 3.5 toneladas de tomate diario.

Determinación del precio del producto

El costo de la semilla híbrida, los plaguicidas empleados para combatir a los lepidópteros y de la aplicación de éstos (PAQUETE TRADICIONAL) está en el siguiente rango:

$\begin{array}{lll}\text { Semilla } & \$ 1228888 / \mathrm{ha} & \text { Vista hib (Asgrow) } \\ & \$ 6969337 / \mathrm{ha} & \text { Sunny hib (Asgrow) } \\ \text { Plaguicidas } & \$ 39000 & \text { Thuricide (Sandoz) } \\ & \$ 139500 & \text { Cutlass (ISK) } \\ \text { Aplicación } & \$ 44000 & 1-50 \mathrm{~L} / \mathrm{ha} \\ & \$ 44000 & 1-25 \mathrm{~kg} / \mathrm{ha}\end{array}$

NotA: Datos obtenidos por cotización directa.

Los escenarios:

$11228888+39000+44000=1311888$ pesos $/$ ha II $6969337+139500+44000=7152837$ pesos $/$ ha Promedio: 4232362.5 pesos/ha

Cuando se emplea el paquete tradicional se obtienen en promedio 27 toneladas de tomate por hectárea.

De emplearse la semilla transgénica que pudiera generarse en México como se ha planteado en este estudio, se ahorraría el gasto en plaguicidas, y su aplicación y el rendimiento obtenido por el productor aumentaría 10\% (PAQUETE RENOVADO). Para cuantificar el valor de esta ganancia, consideramos el costo de 5.5 dólares por caja de 12 kilogramos de tomate de exportación (Crisantes, 1991).

$$
\begin{aligned}
& 27000 \mathrm{Kg} \quad 1 \text { caja } \quad 5.5 \mathrm{dls} . \quad 0.1=1237.5 \mathrm{dls} / \mathrm{ha} \text {, } \\
& \text { ha } 12 \mathrm{Kg} \text { caja }
\end{aligned}
$$

lo que equivale a 3.774 millones de pesos/ha.

El precio de la semilla del paquete renovado está en el rango siguiente: 


\section{I $1311888+3.774$ millones $=5085888$ pesos $/$ ha II $7152837+3.774$ millones $=10926837$ pesos $/$ ha Promedio: 8006362.5 pesos/ha}

La diferencia al usar estos dos paquetes diferentes es de 3774000 pesos.

Establecimos que el precio de la semilla transgénica sea el valor de la semillo del paquete tradicional más el $50 \%$ de la diferencia antes citada: 6120000 pesos/libra.

Esta estrategia de fijación de precio es similar a la que empleó Monsanto para determinar el precio de su hormona bovina del crecimiento.

Análisis financiero

El cálculo de la inversión fija se llevó a cabo mediante factores y se tomó como base de cólculo el costo total del equipo de proceso, el cual fue cotizado directamente con los principales productores y distribuidores en México.

Un proyecto como el presente, donde el producto está en la primera fase de su ciclo de vida, requiere de capital de riesgo.

La sociedad financiera que invierte capital de riesgo en proyectos de inversión en la industria es Promociones Industriales Banamex. Los principales requisitos que debe cumplir un proyecto para ser aprobado son: que no se trate de un negocio familiar; debe haberse realizado el estudio de mercado, localización de la planta e ingeniería básica y de detalle; el proyecto debe comprender una inversión de 4 a 20 millones de dólares y debe tener un TIR de 20 por ciento.

De ser aprobado un proyecto por el comité especializado, Promociones Industriales Banamex participa como inversionista con un porcentaje de acciones que va del 25 al 33 por ciento. A los cinco años de iniciado el proyecto, Banamex se retira y, debido a una claúsula que se firma con anterioridad, los demás socios quedan comprometidos a adquirir sus acciones (Vega, 1991).

El total de capital que requiere el proyecto planteado en este estudio es de 40299893044 pesos (13 213 millones de dólares). Consideramos entonces que una opción que pudiera considerarse es conseguir que Banamex participara con $33 \%$ de las acciones y el resto, otros inversionistas. Para comprar las acciones en el plazo establecido (cinco años), se plantea como posibilidad el pedir un crédito a NAFIN a las condiciones siguientes: 1 año de gracia, tasa de interés CETES más 6 puntos y 5-6 años de plazo.

De las tasas de flujos netos de efectivo pudo observarse que al tomar una tasa de interés de 3.72 veces el CETES (70\%), es decir, una 
tasa de interés mayor a la que ofrece la más productiva de las sociedades de renta variable ("Sección Financiera" de Excélsior), el VPN obtenido resulta de 18638104365.04 pesos y un PRI de un año y 9.5 meses.

Desde el punto de vista del inversionista, el TIR resulta de $104.55 \%$ con un PRI de 2.81 años; desde el punto de vista del proyecto, el TIR es de $773.45 \%$ y el PRI respectivo, de 3.44 años.

El volumen de producción mínimo a partir del cual se obtendrían utilidades (PUNTO DE EQUILIBRIO) es de 847.267 latas, las cuales equivalen al $5.815 \%$ de la producción total al $100 \%$ de uso de la capacidad instalada de la planta ( $2 \%$ del mercado total de Sinaloa y Baja California).

Los resultados obtenidos al analizar la sensibilidad a volumen de ventas, pago de regalías por concepto de transformación genética de las variedades de tomate, precio de venta y aumento de costo de la inversión fija de $100 \%$ son como sigue:

- La máxima disminución en el volumen de ventas que soporta el proyecto a una tasa de $70 \%$ es de $50 \%$, lo que equivale a atender el $10 \%$ del mercado total de semilla de Sinaloa y Baja California.

- El porcentaje máximo de regalías que el proyecto puede pagar por concepto de la transformación genética de seis variedades de tomate es de $29.5 \%$ de las ventas totales.

- Si la transformación genética no resultara efectiva (riesgo tecnológico del proyecto) la semilla tendría que venderse a un precio similar al del paquete tradicional (4 232362.5 pesos/lb). Aun a este precio de venta el proyecto resulta rentable.

- En el caso de que la estimación de la inversión fija no sea una buena aproximación (error 100\%), y que su costo se duplicara, el proyecto seguiría siendo rentable.

\section{CONCLUSIONES}

Al término del análisis de mercado, técnico, tecnológico y financiero, podemos concluir lo siguiente:

a) Hay una necesidad real por satisfacer: se requiere de procesos y productos que no deterioren el ambiente ni causen daño al hombre. La semilla resistente a lepidópteros cumple con estas características.

b) El régimen de mercado al que se enfrentaría el producto es de tipo oligopólico, donde dominan las grandes empresas transnacionales 
productoras de semillas y plaguicidas. De llevarse a cabo este proyecto, DuPont, Sandoz, lci, Monsanto, Calgene, Agrigenetics, Upjohn y Canners Seed constituyen la competencia futura.

c) La nueva ley de patentes permite el registro de variedades vegetales, por esta razón ya no puede transformarse genéticamente cualquier variedad sin antes tramitar el permiso o concesión correspondiente. Este factor afecta en gran medida al proyecto aquí planteado, ya que el costo de las variedades de tomate por transformar, parte de la inversión fija del proyecto, aumenta.

d) Un criterio fundamental en el mercado de los nuevos productos biotecnológicos, como es el caso de la semilla transgénica, es la actitud de los posibles consumidores. Son los productores de tomate de Sinaloa y Baja California quienes tienen una mentalidad abierta a los avances producidos por la investigación pues arriesgan continuamente millones de pesos en cada cultivo, y esto les permite ser los líderes en el plano nacional. Lo anterior confirma los resultados de estudios similares en otros países: la actitud de los agricultores es un factor clave para la adopción de las innovaciones tecnológicas.

e) El análisis de la población consumidora de Estados Unidos nos permitió identificar que el mercado interno de ese país no tiene déficit en lo que respecta a la producción de tomate, y que adquieren tomate mexicano para revenderlo a Canadá, Europa y Japón, aprovechando su poderoso y eficiente sistema comercializador.

f) Del análisis de la competencia podemos afirmar que para tener alguna oportunidad en el mercado de semillas de tomate deben transformarse por lo menos seis variedades para los diferentes tipos de uso: dos para uso en fresco, dos para uso industrial, un tipo cherry y uno de doble propósito.

g) Debido a este hecho, la inversión que se haŕa en subcontratar los senvicios de transformación genética de cada variedad resulta muy alta.

h) La fijación del precio, distribución, promoción del producto, servicios y garantías postventa son los factores más importantes que determinarían el éxito de este proyecto.

i) Para tener una mejor aproximación de la estimación de la oferta y la demanda, dados los datos disponibles, pensamos que deben hacerse encuestas a los productores de tomate de Sinaloa y Baja California.

i) De las partes técnica y tecnológica los riesgos más importantes serían: que la transformación genética no resultara efectiva y que no se obtuvieran los rendimientos esperados en el invernadero y la semilla ( $450 \mathrm{ton} / \mathrm{ha}$ y $5.25 \mathrm{~kg}$ semilla/ton fruto, respectivamente).

k) Del análisis financiero podemos concluir que el aquí planteado sería un proyecto muy atractivo; con las utilidades obtenidas sería 
posible adquirir variedades híbridas más caras para su transformación, o bien se podría adquirir un mayor número de variedades para tener productos más diversificados.

1) Este proyecto coincide con otros estudios de caso sobre la biotecnología agrícola en México, donde los productores que poseen tierras de riego, con alto grado de organización y amplia disponibilidad de recursos de todo tipo, están recibiendo y recibirán los beneficios de este tipo de tecnologías.

m) Podemos afirmar que la producción y venta de semillas de tomate resistente a lepidópteros sería un buen negocio.

Por último, este proyecto entrañaría muchos riesgos, por tanto requeriría de empresarios de gran capacidad, pues la inversión total calculada es de 13213079.69 dólares.

\section{BIBLIOGRAFÍA}

Arroyo G. Coord. 1989. "La biotecnología y el problema alimentario en México". México: Ed. Plaza y Valdés-UAM-X.

Basurto, R., Xoconostle, B., y Alvarez, M. 1990. "Programación genética de plantas e insecticidas". ICYT. Vol. 12. Núm. 166-167, pp. 66-72.

Crisantes, Enciso T. 1991. Comunicación personal, Culiacán, Sinaloa: CAADES, julio.

Feitelson, J.; Payne, J.; y Kim, L. 1992. "Bacillus thuringiensis: Insects and Beyond". Biotechnology, marzo. Vol. 10, pp. 271-275.

González Aguirre, R. 1991. Comunicación personal. México: UAM-I, julio.

Herrera, N. 1986. "Microorganismos al servicio de la agricultura". ICrT. Vol. 8. Núm. 119, pp. 35-46.

Magallanes González, V. 1991. Comunicación personal. México: INIFAP, julio.

Prentis, S. 1989. Biotecnología. Barcelona: Biblioteca Cientifica Salvat.

Quintero Ramírez, R. 1991. México. Comunicación personal. ONUDI, julio.

Secretaría de Agricultura y Recursos Hidraúlicos. 1990. "Programa nacional de modernización del campo 1990-1994". México.

Sorensen, A. 1991. "Will Farmers Accept Biotechnology?" Chemtech, American Chemical Society, junio, pp. 344-349.

Vega Ramos, E. 1991. Comunicación personal. México: Promociones Industriales Banamex, junio. 



\section{COMENTARIOS}




\title{
Oportunidades para la aplieación de la biołecnología
}

\author{
ALEJANDRO BLANCO
}

La presente década ha visto florecer de manera significativa el campo de la biotecnología debido a las características propias de las ciencias en punta, las cuales requieren para su desarrollo de una importante fundamentación en ciencia básica, así como de una agilidad muy grande para entender, asimilar e incorporar los nuevos conocimientos y hacer de ellos una herramienta adecuada que permita alcanzar día con día los nuevos niveles que la investigación va logrando. A estas características se debe en parte que en dicho campo la diferencia entre los países avanzados y los que se hallan en vías de desarrollo, como México, aumente con el tiempo. Aunque es realista aceptar dicha brecha científica y tecnológica, resulta de gran interés también analizarla con el fin de entender cuáles son las oportunidades y cómo debe estructurarse el crecimiento en este campo para nuestro país. Por ello, foros como el presente simposio representan una excelente oportunidad para analizar algunos de los temas importantes en la biotecnología, pues México cuenta con científicos capacitados y con una infraestructura que puede hacer posible su desarrollo.

Tal vez sea importante señalar desde el principio que aunque no se puede competir en todos los temas de la biotecnología en los que los países más avanzados han podido realizar muy importantes logros, sí es posible determinar los "nichos" de la biotecnología en donde por diferentes circunstancias contamos con un capital especial, sea éste la riqueza genética del país, el desarrollo temprano en un tema especifice, - la presencia de un pequeño pero significativo grupo de científicos con la capacidad intelectual y física para generar la infraestructura requerida para el desarrollo de ese campo. Estos nichos representan posibles oportunidades no sólo para actualizarnos en el campo, sino para poder estar a la vanguardia en su desarrollo.

Algunos organismos internacionales denominan este tipo de oportunidad (sobre todo en el caso de plantas), "cultivos huérfanos", ya que 
por no ser un cultivo de especial interés económico para el primer mundo, no se le da la debida atención.

Todo el esquema antes descrito se deriva del hecho de que la biotecnología ha tenido un gran desarrollo debido fundamentalmente a la gran inversión que se ha hecho por considerarla un buen negocio.

Hemos tenido la oportunidad de conocer cuól es el potencial actual en el campo de tratamiento de aguas. Podemos ver, al analizar los datos que se nos han presentado, que existe ya en México un número considerable de grupos trabajando sobre este tema. Resulta tal vez repetitivo, pero no por ello innecesario, remarcar la necesidad que hay en este campo de contar con un fuerte apoyo científico-tecnológico para poder pasar los conocimientos generados a su aplicación real y constituir así un acervo de tecnologías reales, es decir, de técnicas que, desarrolladas bajo un marco de conocimientos científicos, puedan aplicarse exitosamente a los problemas reales que afronta en este momento la industria, la agricultura y muchos otros usuarios. El número de científicos preparados en este campo es aún incipiente si se consideran las exigencias que plantean las nuevas disposiciones sobre contaminación, las cuales, si no se actúa de inmediato, afectarán a una gran parte de las plantas de producción instaladas. A ello debe sumarse la situación que se presenta como consecuencia del Tratado de Libre Comercio. Este nuevo factor hará la situación aún más diff́cil debido, entre otras cosas, a que se instalará mayor cantidad de industrias extranjeras, con procesos mós eficientes que los que maneja la mayor parte de industrias nacionales, las cuales durante mucho tiempo se han caracterizado por no modernizar sus procesos y sus equipos.

Por otro lado, al aplicarse más estrictamente la obligatoriedad de no exceder los niveles de contaminación permitidos, se presenta de improviso una amplia demanda de servicios, los cuales incluyen, entre otros, tratamientos de aguas y afluentes, contaminación atmosférica, etcétera. Representan un inmenso potencial de trabajo, el cual (de acuerdo con datos recientes en Estados Unidos) resulta uno de los mejores negocios de la aplicación de la biotecnología.

Sin embargo, según los datos que se nos han presentado, los distintos grupos existentes en el país no podrán ser competitivos para ofrecer soluciones reales ya transferibles a la industria o al productor que lo demanda. Por otro lado, habrá compañías extranjeras que estén en espera de ofrecer sus servicios, compañías que si bien cuentan con una gran experiencia en la solución de problemas de contaminación, no están en contacto con la índole de problemas que presenta nuestra industria.

Este es uno de esos "nichos tecnológicos" en los cuales nuestros grupos podrían contar con una gran oportunidad. 
Es importante afrontar pronto ese problema a fin de que nuestros tecnólogos puedan contar con la capacidad necesaria para aprovechar ese gran mercado de demandas que necesariamente surgirá, con un carácter ascendente, en el número y complejidad de los problemas. Para ello se requiere completar los análisis con que ya se cuenta, planificar de manera adecuada y contar con los fondos necesarios para reforzar a los grupos potencialmente importantes del país. Complementario a lo anterior será el poder contar con asesoría calificada para la adquisición de tecnologías adecuadas, ya que no por el hecho de ser grupos o compañías extranjeras la tecnología que ofrezcan serb́ necesariamente la apropiada.

En relación con el estudio sobre la aplicación de la biotecnología a la industria de producción de leche, representa un típico ejemplo de una tecnología que no plantea una solución real a un problema sino que, por el contrario, generará una nueva problemática, ya que Estados Unidos tiene sobreproducción de leche. Dicha tecnología, tendiente a incrementar la producción de leche, puede ser rechazada o al menos no favorecida para esa sociedad. Sin embargo, al analizar el caso de México en este campo, se trata de un país altamente deficitario y dependiente en cuanto a producción lechera. El problema fue muy bien escogido y ampliamente analizado al mostrarnos que ese tipo de tecnología sería de gran ayuda para nuestra deficiente industria de lácteos.

El problema es, por otra parte, más profundo. En el caso del tratamiento de aguas fue posible identificar a varios grupos con un buen nivel de preparación. Por el contrario, en el caso de la biotecnología aplicada a animales, en México la investigación resulta muy escasa en lo referente a inserción de genes foráneos para producir un mayor crecimiento del animal o una sobreproducción de hormonas que dé origen a un mayor volumen de leche. Hay dos grupos, uno de ellos de reciente creación y el otro ya con alguna experiencia valiosa, pero con un número totalmente insuficiente de científicos de alto nivel.

Los avances son significativos no sólo en la producción de leche sino también en otros derivados lácteos como el queso, el yogur, la crema, etcétera. En estos campos la industria de países avanzados ha tenido importantes logros. Nuestra industria, sin embargo, no ha incorporado todavía una tecnología moderna; por el contrario, con el tiempo su calidad ha venido decreciendo. La pregunta entonces sería: bajo estas condiciones y las que se avecinan con el TLC, ¿qué puede esperarse para nuestra industria de lácteos?

Otro de los temas analizados en este apartado fue el relacionado con el papel que la biotecnología puede tener en la industria del petróleo. Si tomamos en cuenta que ésta representa para nuestro país 
la fuente más importante de divisas, los señalamientos presentados nos ofrecen un panorama no sólo de grandes oportunidades, sino también de la gran necesidad de incursionar en este novedoso esquema para combinar, de manera muy eficiente, el campo de la biotecnología con el de la producción y modificación de diferentes productos derivados de la petroquímica.

Este campo se torna aún más interesante si consideramos los notables avances logrados recientemente en el campo de la tecnología de enzimas. Antes se consideraba que las enzimas eran catalizadores biológicos que se desarrollaban a temperatura menor a 40 grados centígrados y a presión normal, además de que la naturaleza proteica de las enzimas parecía impedir que esas condiciones pudieran cambiarse. Por tal motivo, hasta hace poco tiempo los procesos catalizados por enzimas siempre se realizaron tan cercanos a las condiciones de los seres vivos como era posible. En la última década han surgido importantes evidencias de que esa manera de entender la enzimología provenía de un análisis totalmente antropocéntrico y muy limitado.

Algunas evidencias nos muestran que existen distintas enzimas que actúan perfectamente no sólo en medios orgónicos (como el de los hidrocarburos derivados del petróleo) sino que en ocasiones incrementan su actividad catalítica y pueden llegar incluso a cambiar su especificidad, lo cual genera importantes y nuevas posibilidades para los productos de donde esas reacciones catalizadas se obtienen. También se ha demostrado que la variable de la temperatura puede ser manejada en el campo de las enzimas. Se han reportado que algunas resisten temperaturas mayores a los 80 grados centígrados, o bien que otras son activas por debajo de los cero grados centígrados.

Todos estos nuevos esquemas son generadores de nuevas e importantes posibilidades para explotar mejor no sólo nuestra industria del petróleo, sino el amplio campo de la biotecnología enzimática. En los últimos cuatro años, sobre todo, ha habido un importante avance en el diseño de nuevas enzimas: ya no su descubrimiento sino el diseño mismo de enzimas con nuevas capacidades de catálisis.

Una vez más se antoja interminable el proceso de generación de nuevos paradigmas que necesitamos comprender primero y después aprender a adaptar rápidamente para poder participar de este hermoso, pero muy demandante, campo de constantes innovaciones.

Deseo terminar con un comentario acerca de la importancia que tienen estos foros en los cuales se reúnen científicos de la economía y la sociología con biotecnólogos. Los enfoques son muy diferentes, pero resulta sorprendente la gran complementariedad que existe. Estoy seguro de que el campo de la biotecnología requiere del concurso de todas las disciplinas cuyos campos se ven afectados por el surgimiento 
de estas nuevas alternativas, las cuales pueden, en un momento dado, generar cambios cuya adaptación no es ni espontánea ni sencilla.

Es necesario subrayar el hecho de que la generación de conocimientos es la base del desarrollo. Sin embargo, con la producción de los conocimientos, que generalmente se traduce en la publicación de artículos originales en las revistas cientificas de mayor circulación, sólo se genera un libre flujo de conocimientos. Cuando los conocimientos generados resultan trascendentes, son aprovechados por las grandes compañías del mundo desarrollado. Resulta por lo tanto indispensable encontrar esquemas que permitan primero analizar, como en este simposio, la realidad nacional y de ahí trazar rutas críticas con pasos específicos para producir resultados biotecnológicos aplicados nacionalmente. Puede venderse también a las grandes compañías pero siempre y cuando sea al país y a los grupos nacionales, ya se trate de industrias, científicos, etcétera, quienes se vean favorecidos en ese esquema.

Estoy seguro de que los enfoques multidisciplinarios en foros como éste harán más eficiente la creación de un esquema de biotecnología realista y eficiente. 


\title{
La bioteenología agrícola
}

\author{
HÉCTOR LOZOYA SALDAÑA
}

\section{INTRODUCCIÓN}

Por sus raíces etimológicas, la biotecnología es cualquier técnica que aplicamos a los seres vivos, y la agricultura, por mós rudimentaria que sea, constituye uno de los más claros ejemplos, independientemente de su rentabilidad, significado y propósito. La agricultura altera la naturaleza para nuestro beneficio, lo cual trae aparejadas otras complicaciones también de carácter biológico, en cuyas soluciones empezamos a trabajar con seres vivos $u$ otras opciones naturales. Los biofertilizantes reducirán a futuro los riesgos de aumento de la salinidad de los suelos que ahora enfrentamos por la excesiva fertilización química, y los cultivares resistentes de la fitogenética tradicional y de la ingeniería genética requerirán de menos agua y agroquímicos.

Las biotecnologías recientes aplicadas en plantas no resuelven los problemas del campo por sí solas; de la misma manera en que las semillas mejoradas producto de la revolución verde tampoco aumentan la producción si no van acompañadas de todo el paquete tecnológico diseñado para ellas. Bajo situaciones de carencias, la agricultura tradicional empírica y los materiales criollos de siembra superan a los mejorados, como es el caso de los maíces de temporal escaso y los de tierras altas del centro del país.

Habrá otras ocasiones en las que pensamos que la biotecnología representa el primer eslabón en la cadena que resolverá otros problemas agrícolas, pero la realidad demuestra que no es asi, o que hay otras posibilidades. Por ejemplo, a diez años de la aparición en México de la tan temida roya del cafeto y con un rezago considerable en el ataque del problema por parte de los biotecnólogos, se ha aprendido a convivir con el patógeno sin detrimento en la calidad y cantidad de cosecha que se esperaba. Esto se logró con modificaciones sencillas de las prácticas culturales, como aplicación de fertilizantes y fungicidas, y eliminación parcial o total de la sombra. 
micropropagación y la verificación de sanidad del material producido. Todo esto dirigido a mejorar la calidad fitosanitaria del material de siembra y sustituir o eliminar importaciones. Al mismo tiempo, mediante la ingeniería genética se busca dotar de resistencia a virosis a las variedades con que se cuenta.

Por otra parte, en México se atacan problemas particulares que son de dimensiones menores en Cuba, como la resistencia al tizón tardío, al nemátodo dorado y a la bacteriosis por pseudomonas. En Cuba, mientras tanto, se plantea la posibilidad de refinar los métodos de diagnóstico viral con hibridaciones moleculares y antisueros monoclonales, que desde nuestro particular punto de vista resultan muy costosos, requieren de personal altamente calificado, serían muy específicos y no pueden procesarse tantas muestras tan rápida y directamente como con la serología enzimática normal (ELISA) de sueros policlonales. En Cuba otro aspecto importante, no tanto para nosotros, es la variación somaclonal dirigida a obtener materiales genéticos con mayor adaptación a sus condiciones climáticas.

\section{LA TÉCNICA Y SU COMERCIALIZACIÓN}

La biotecnología agrícola, cuando supera la etapa de investigación y pasa a la producción, negocio, ganancias, etcétera, debe ajustarse a las leyes no escritas de la economía de mercado. La agricultura es una de las empresas con más riesgos, pues se trabaja con entes biológicos que responderán al medio ambiente natural o proporcionado, muchas veces impredecible. El producto es perecedero en mayor o menor grado, y la oferta y demanda determinarán de qué color serán los números al final de las operaciones.

Saber crecer es una lección que debemos aprender al aplicar la biotecnología vegetal a la producción. De otra manera corremos el riesgo de desprestigiar al gremio, como ya ha sucedido.

Pueden presentarse varias situaciones:

a) Inversionistas metidos a biotecnólogos y a agricultores, que otorgan recursos suficientes a técnicos con conocimientos, pero sin tradición en el negocio, en donde la empresa nace "crecida". La falta de ganancias a corto plazo les ha hecho desistir de la aventura en poco tiempo.

b) Biotecnólogos y especialistas relacionados que se arriesgan a invertir sobre la base de sus conocimientos, pero sin el apoyo de la experiencia empresarial; también sucumben pronto. 
c) Organismos paraestatales dispuestos a financiar sistemas de producción que incluyan propuestas (y empleos) de y para biotecnólogos. Lo más probable es que la permanencia de estos sistemas dependa de la duración del período del gobierno en turno, porque a veces obedece más a intereses políticos, de imagen, o de períodos particulares, que a propósitos comerciales. Los ejemplos no abundan, pero entre ellos estón: INMECAFE, Impulsora Guerrerense del Cocotero, Comisión Nacional del Maguey, Comisión Nacional de Fruticultura, Comisión Nacional de Zonas Avidas. Todos incluyeron alguna vez el cultivo de tejidos entre sus proyectos.

d) Grandes empresas agrícolas, de viverismo, de ornamentales, agroquímicos o producción de semillas botánicas o de propagación vegetativa que, con modestas inversiones iniciales de su departamento de desarrollo, a la larga logran colocarse a la vanguardia en su ramo (en México: Tatamil, Viveros "El Morro", Rancho "Providencia", ViviToluca, Gota de Vida, Rancho "La Joya").

Su éxito se basa en el respaldo que la experiencia, las instalaciones, los contactos políticos y comerciales y la organización en general con que cuentan desde el principio. Antes de hacer biotecnología ya hacían negocio con las plantas o con su ramo específico en el comercio. No al revés.

En parte se han adecuado los sistemas norteamericanos que practican el cultivo de tejidos sólo en cierta época del año, y desplazan a los empleados a las diversas unidades de producción según la temporada o la demanda. Se puede prescindir parcialmente de la micropropagación o reprogramarla durante ciertas épocas para mejorar la eficiencia, salir antes al mercado, ahorrar tiempo o hacer más ciclos de incrementos al año.

En estas empresas las nuevas tecnologías son complementos que se adoptaron después de varios años de trabajar con métodos tradicionales de propagación de plantas o de importaciones cíclicas de material inicial. El negocio muy bien pudiera seguir siéndolo sin el laboratorio ahí instalado, sólo que éste ha aportado ventajas prácticas y económicas que hacen conveniente su inclusión en el engranaje productivo.

Entre otras razones que convencen a estas empresas para establecer la micropropagación está la generación de muchos individuos en poco espacio, obtención de poblaciones más o menos uniformes, producción todo el año o específicamente en épocas programadas o durante períodos en los que el clima no lo permitiría, métodos tradicionales, aumento en la calidad fisiológica y sanitaria de los vitroplantas, y eliminación de barreras cuarentenarias en el transporte internacional. 
Debemos mencionar que a pesar de lo anterior, además de lo barato de la mano de obra mexicana, algunas de las empresas transnacionales de viverismo y propagación no han querido instalar laboratorios en México, más que nada por la falta de mercado para el producto; o, dicho de otra manera, la demanda se satisface de inmediato, y al presentarse la saturación o al haber más oferta que demanda se abatirían los precios en detrimento de la empresa. Se ha estudiado la posibilidad de que una vez instaladas en el país pudieran abastecer de planta a Centro y Sudamérica, pero aún así los números no resultan convincentes.

\section{BIOTECNOLOGÍA VEGETAL Y EMPLEOS EN FLORICULTURA}

El eje neovolcánico tiene características positivas sobre otras regiones del país y del mundo en lo referente a la producción agrícola; gran diversidad de climas y suelos con nichos ecológicos únicos, con consecuente diversidad de especies vegetales nativas; proximidad física entre regiones, lo cual facilita y abarata el transporte de las cosechas, tanto para mercado intemo como para exportación; y abundancia de mano de obra. Un aspecto que podría considerarse desfavorable sería la topografía accidentada, que limitaría a la agricultura extensiva en muchas zonas.

La producción florícola ha tomado ventaja de las bondades; desde Jalisco hasta Veracruz, se considera toda esta zona como de gran potencial para la horticultura omamental y, casualmente, es en esta línea donde la biotecnología ha visto sus mayores aplicaciones prácticas. En párrafos anteriores mencionamos tas razones principales por las que se tienen laboratorios en viveros y explotaciones afines, y en otro trabajo de esta mesa se describe la situación al respecto en México a finales de la década pasada.

Ahora bien, aunque es cierto que la posible privatización del ejido, el Tratado de Libre Comercio con Norteamérica y la ubicación del campo mexicano en el contexto capitalista eficiente desalentarán la producción en baja escala, también lo es el cambio de siembras de productos básicos hacia otros cultivos más redituables como los florícolas "de subsistencia", que cuentan con la tierra, el clima, la proximidad a los mercados y su mano de obra. Además, las nuevas tecnologías no necesariamente van a desplazarlos de su fuente de ingresos, pues ellas también pueden ser accesibles, como lo demuestran los programas del FIRA en Tezoyuca, Mor., y en su zona de influencia.

No es necesario ser el gran cientffico para establecer, practicar y explotar a la micropropagación y a la selección clonal empírica en 
ornamentales. Reconocemos la carencia de bases cientificas en muchos pero también debemos aceptar que las experiencias de varios países demuestran la factibilidad de la ejecución de cultivo de tejidos por parte de personas de salario mínimo.

El mejor respaldo a la posición anterior lo encontramos en Estados Unidos, con uno de los iniciadores de estas técnicas, el doctor Toshio Murashige. En incontables ocasiones manifestó su inquietud de impartir los entrenamientos de verano también en español, pues normalmente se hacían en inglés. Esta necesidad de los cursos bilingües surgió del hecho de que en los viveros de follajes comprendidos entre los condados de San Diego y Ventura, a más de $200 \mathrm{~km}$ de distancia entre ambas ciudades en el Estado de California, los trabajadores encargados de las rutinas de elaboración de medios de cultivo siembran in vitro; el trasplante in vivo lo realizan mexicanos, que (sin entender las bases científicas de lo que hacen) desempeñan su trabajo a satisfacción.

Lo descrito hasta aquíse refiere al efecto directo de los laboratorios de cultivo de tejidos vegetales sobre el empleo ahí mismo, según la preparación del empleado. Los efectos indirectos aparecen cuando el producto, generalmente vitroplantas, deja de ser el objeto por obtenerse para convertirse en el instrumento de la producción. Es decir, las plantas micropropagadas son el punto de partida de una explotación en ornamentales mediante métodos tradicionales, ya sea de flor cortada, de plantas completas, esquejes, planta en bolsa o maceta, follajes, etcétera, en donde el laboratorio ya no tiene nada que ver.

La influencia de las nuevas técnicas en la floricultura del estado de Morelos podría ilustrar dicho efecto indirecto. Para esto habrá que hacer algunas precisiones. Agruparemos a los sistemas productivos en tres estereotipos:

a) Empresas privadas con capital.

b) Pequeños productores independientes.

c) Sociedades de producción rural controladas por el Instituto para el Fomento de la Floricultura, del gobierno del estado.

\section{a) Las grandes empresas}

Entre las grandes empresas con recursos están Pelfi, en Tetecalita; Plantec, en Puente de lxtla; Viveros del Morro, al Sur; y Viveros Yautepec, en el municipio del mismo nombre. Tomemos únicamente, y de manera superficial, el primer ejemplo.

Pelfi, de reciente creación, tiene capital alemán y mexicano, y se dedica principalmente a la producción de esqueje de geranio para exportación. Esta empresa recibe anualmente de Alemania un millón 
de propágulos obtenidos de plantas micropropagadas, y exporta treinta millones en un período comprendido de octubre a abril. Con unas 20 hectóreas, dan empleo por lo menos a 200 personas, quienes se ven beneficiadas indirectamente por la biotecnología vegetal de vanguardia.

Cabe aclarar que, de las empresas mencionados, sólo Viveros el Morro tiene sus propios laboratorios. No obstante, en todas se manejan propágulos de tipo fundación.

\section{b) Pequeños productores independientes}

Los productores intermedios, independientes, con o sin capital, difícilmente controlan superficies florícolas superiores a los $5000 \mathrm{~m}$ (media ha) de cielo abierto, aunque tengan más terreno. Limitóndonos al cultivo del rosal, señalaremos sólo uno de los más productivos: Hidroproductos, ubicado entre Tepoztlón y Yautepec. Trabaja aproximadamente $3000 \mathrm{~m}$ (un tercio de ha), y tanto ellos como el resto en este grupo también tienen acceso a cultivares de aceptación internacional que pueden ser micropropagados; $y$, nuevamente, tanto los pequeños empresarios como sus trabajadores son recipientes indirectos del beneficio de la biotecnología.

\section{c) Sociedades Cooperativas}

Las sociedades de producción controladas por el Instituto para el Fomento a la Floricultura del gobierno del Estado son producto de una evolución de programas oficiales para fomentar el empleo y el arraigo de personas de escasos recursos. Las buenas intenciones de la idea original no han sido aparejadas con los resultados en su manejo pues el burocratismo no le ha permitido operar con fluidez.

Es pertinente precisar conceptos e ideas al respecto.

El Instituto no controla toda la exportación de flor cortada en el Estado, sólo la que se produce en sus unidades, sociedades o cooperativas.

Es cierto que las Sociedades están formadas en su mayoría por mujeres, como también es cierto que sí participan directamente en el proceso productivo, pues son ellas quienes realizan todas las labores culturales de la explotación. Las instalaciones ni les costaron ni les pertenecen, pero su amortización se completará en un lapso de no menos de cinco años, después del cual ellas podrán decidir sobre la totalidad del negocio, razón por la que de momento son asalariadas.

Podría suponer que las condiciones del trabajo permiten la "sobreexplotación femenina altamente rentable para el capital internacional", pero ni el burocratismo ni las mujeres mismas lo han permitido. 
Hablando de las Cooperativas del Estado en general, las protagonistas distan mucho de ser dóciles. El más claro ejemplo está en la Cooperativa de Amilcingo, o Tulio Montaño, al oriente de Cuautla, donde las socias desde el principio se "adueñaron" de las instalaciones, se constituyeron en un organismo independiente y no rinden cuentas al Instituto que se supone debe controlarlas. Para evitar problemas políticos mayúsculos, el gobiemo ha tolerado la situación.

Un último comentario respecto a la distribución de la flor del Instituto. La producción que se va a la ciudad de México difícilmente se distribuye en el país por vía aérea, y la filial estadunidense, "Two Eagles", distribuye desde Dallas, Texas, y no desde Denver, Colorado. Siempre por vía aérea, pues la producción no es tanta como para llenar un trailer.

Una vez aclarados los puntos anteriores vemos que, ante esta panorámica, muchas personas se han beneficiado de la biotecnología por vías oficiales al proporcionárseles medios en los que se trabajan especies de plantas propagables mediante cultivo de tejidos, como crisantemo, clavel, gerbera, rosal y gipsofila (nube). No disfrutan de estos beneficios quienes trabajan ave del paraíso, nardos y estatice, ente otros cultivos.

\section{CONSIDERACIONES FINALES}

El avance más grande que el hombre ha logrado es el paso de la colecto a la cosecha; la agricultura, la domesticación. Empíricamente empezó a seleccionar granos y a investigar lo que necesitaban para crecer y reproducirse, hasta que logró modificar su ambiente y llegó a la Revolución Verde. Esto se llevó 10 mil años. En lo que va del presente siglo, gracias al mejoramiento genético, la maquinaria agrícola y la optimización de los paquetes tecnológicos, muchos cultivos de grano han triplicado sus rendimientos. Esto es la biotecnología.

Las "nuevas" biotecnologías que surgieron recientemente en plantas fueron el cultivo de células, tejidos y órganos, y la modificación de una pequeña parte del genomio (información genética); al individuo generado se le llamó "planta transformada" o "transgénica".

En hortalizas se han creado plantas en las que sólo el gen transformado se ha reflejado en la resistencia a herbicidas, virosis o insectos, o de más tolerancia al manejo postcosecha. En floricultura se busca mejorar la eficiencia productiva, variabilidad atractiva, mejor arquitectura de las plantas y mayor longevidad de la flor o del producto vendible (planta completa, follaje, esqueje, etcétera). En frutales también se buscan resistencias a herbicidas, enfermedades, insectos, 
mayor adaptación y resistencia al manejo y transporte. En granos se trabaja en el mayor contenido alimenticio, y en forestales se busca la mejor y más rápida producción de biomasa, ya sea para combustión, papel, construcción (como ornamental o como parte del ecosistema).

No debemos estar ajenos a estos cambios que nos afecton a todos. La instrumentación de los adelantos científicos irb́ en función del efecto económico, político, social y biológico que pudiera tener, y es nuestra responsabilidad buscar el equilibrio o la conciliación. Todos necesitamos comer pero no todos somos agricultores. Por lo tanto no busquemos una agricultura de subsistencia, "ecológica", que conserve las tradiciones como objetivo prioritario. Tampoco se debe satanizar a la producción capitalista, eficientista, corporativista, que tienda a "descampesinizar" al individuo.

En el mundo actual hay tres factores que rigen al éxito y subsistencia de las empresas y, por consiguiente, a la humanidad: el ingenio, el trabajo, y el capital. Sabemos que no debe haber explotación del hombre por el hombre; pero si lo más importante es el ser humano como individuo, y éste supuestamente va a vivir "mejor" como parte de una corporación que como campesino, dejemos que las nuevas biotecnologías y los nuevos órdenes económico-sociales del mundo sigan su curso hacia esas tendencias. 


\section{POLÍtICA BIOTECNOLÓGICA: ELEMENTOS PARA SU DEFINICIÓN}




\title{
La bioteenología en Chile y las experiencias de su aplicación
}

\author{
GONZALO ARROYO
}

\section{ANTECEDENTES}

El desarrollo de la biotecnología se encuentra todavía en una etapa relativamente incipiente en Chile, sobre todo en lo que respecta a sus aplicaciones industriales. Sin embargo, es evidente que podrí llegar a tener gran aplicación en diversos sectores de la producción de ese país. Los logros que se obtengan en el campo de la biotecnología deberían tener miras a futuro en un aumento y diversificación de las exportaciones llamadas no tradicionales, ligadas a la explotación de recursos naturales renovables.

Esto resulta de gran importancia puesto que en la última década Chile y, por supuesto, otros países latinoamericanos, han entrado decididamente en un crecimiento económico basado en un modelo de desarrollo abierto y exportador. El desarrollo biotecnológico podría contribuir a continuar produciendo de manera competitiva (en términos de calidad de los antiguos y nuevos productos para los mercados internacionales) mediante un proceso de modernización productiva. Podría además mantener, y en ciertos casos restablecer, el equilibrio de los ecosistemas explotados productivamente mediante el uso de biotécnicas compatibles con el clima, la biomasa disponible y las condiciones económicas y sociales existentes en el país.

En este trabajo se expondrá de modo resumido el resultado de dos investigaciones realizadas en Chile. La primera se llevó a cabo entre diciembre de 1990 y junio de 1991. Su objetivo era hacer un diagnóstico del estado actual de la investigación biotecnológica en ese país. Para lograrlo se efectuó una encuesta del total de unidades de investigación o laboratorios que operaban en universidades, centros públicos y privados y también en empresas que realizaban actividades de Investigación y Desarrollo (I \& D) en el campo de la biotecnología utilizable en la explotación y transformación de recursos naturales renovables. 
La segunda investigación, aún en curso, corresponde a un estudio comparativo organizado por el Instituto Interamericano de Cooperación Agraria (IICA) sobre los factores de éxito y fracaso de empresas biotecnológicas de diversos países de América Latina. En esta oportunidad me limitaré a hacer algunos comentarios sobre los estudios de caso realizados en Chile.

Finalmente, se harán algunas reflexiones sobre cómo podría un país como Chile considerar a futuro el desarrollo de la biotecnología. Es decir, cuáles deberían ser las políticas tecnológicas y las modalidades de transferencia tecnológica que permitirían a este país, y a otros similares de América Latina, enfrentar exitosamente el desafío de la competencia dentro de un sistema económico intemacional transnacionalizado e interdependiente.

\section{UNA INVESTIGACIÓN SOBRE LA BIOTECNOLOGÍA EN CHILE}

Esta investigación fue realizada por SUR profesionales para la Corporación de Fomento de la Producción, entre diciembre de 1990 y junio de 1991, y tuvo como objetivo hacer un diagnóstico del estado actual de la investigación biotecnológica en el país. Para lograrlo se efectuó una encuesta del total de unidades de investigación o laboratorios en universidades, centros públicos y privados y en empresas que realizaban actividades de I \& D en el campo de la biotecnología utilizable en la explotación de recursos naturales renovables.

Sobre este tema no había hasta ahora muchos antecedentes empíricos. Sólo pueden mencionarse algunos estudios de la CORFO' que trataban el tema de manera más bien general y abarcando el conjunto de sectores de aplicación de la biotecnología. Una investigación más reciente de FAO Regional ${ }^{2}$ presenta un diagnóstico mós completo, pues se hizo un catastro y evaluación de laboratorios, pero limitado sólo al campo de la biotecnología vegetal. Finalmente, en el país han aparecido también algunos libros generales sobre la biotecnología como el publicado por el INTA, ${ }^{3}$ pero que no contienen un diagnóstico sobre el estado actual de la investigación biotecnológica en el país.

'Entre otros están los siguientes: CORFO, Impacto de la biotecnología en el desarrollo nacional, Gerencia de Desarrollo (AMI 83/8), Santiago, 1983, 3 vols.; Fondo de Desarrollo Productivo, Investigación de la biolecnología para su aplicación en el país, Santiago: Gerencia de Desarrollo, CORFO (AA-87/7a), abril de 1987.

2 FAO, Catálogo regional de laboratorios de biolecnología vegetal. Encuesta Regional 1989-1990, Santiago de Chile: Oficina Regional de la FAO para América Latina y el Caribe, 1990.

${ }^{3}$ Fernando Monckeberg, La revolución de la bio-ingeniería, Santiago: Publicaciones Técnicas Mediterróneo, 1988, p. 187. 


\section{OBJETIVOS DE LA INVESTIGACIÓN}

El universo cubierto por la investigación comprendió el total de universidades, centros de investigación públicos y privados y empresas que realizan actividades de Investigación y Desarrollo (I\&D) en las siguientes áreas aplicadas de biotecnología: producción agropecuaria, forestal y acuícola y las industrias de transformación y proveedoras de insumos, ligadas a dichas óreas.

¿Por qué estas áreas aplicadas de la biotecnología y no otras, más aún si se sabe que en Chile el desarrollo de la biotecnología se ha orientado más bien a la industria farmacéutica y a la minería? El principal criterio utilizado fue escoger como objetivo de la investigación los sectores económicos centrados en la explotación y procesamiento de recursos naturales renovables que hayan registrado un crecimiento económico dinámico, basado sobre todo en las exportaciones no tradicionales. Las empresas, en estos sectores seleccionados, ciertamente lo han logrado, pese a la áspera competencia a que sus productos están sometidos en los mercados internacionales. Por ejemplo, entre 1984 y 1989 se han quintuplicado los embarques hortofrutícolas y el valor de éstos ha ascendido ya a más de 700 millones de dólares, lo que es considerable para un país pequeño como Chile.

Sin embargo, se puede esperar la entrada de nuevos exportadores provenientes de otros países del Cono Sur y también del hemisferio sur, que competirán con los productos chilenos en temporada de invierno en los países industrializados del norte. Esto plantea grandes desafíos tecnológicos para los productores nacionales, pues deberán aumentar su competitividad si pretenden conservar su presencia en los mercados internacionales ya penetrados $y$, por lo tanto, deben continuar por el proceso de modernización tecnológica que ya iniciaron. Por lo demós, estos mercados se caracterizan por una demanda cambiante en función de volúmenes transados y del tipo de productos ofrecidos; por lo tanto, cada vez exigen más en cuanto a la calidad del bien exportado. En consecuencia, se requiere no sólo de continuar con la transformación tecnológica en la producción de materias primas de origen agropecuario, forestal y acuícola, sino también tecnificar la producción acuo-agrosilvo-industrial, es decir, las industrias procesadoras de materias primas y proveedoras de insumos para esos sectores.

Es indudable que actualmente en Chile (como en el resto de América Latina) hay cierto despilfarro de productos, y especialmente de subproductos, provenientes de esos sectores. Precisamente, las aplicaciones potenciales de la biotecnología en la producción primaria y agroindustrial son enormes. Por lo demós, el progreso de la biotecnología en esas áreas de aplicación contribuye también a la consolida- 
ción del modelo de desarrollo abierto y exportador actualmente adoptado en el país.

La evaluación del estado de avance de la biotecnología en Chile permite formular políticas mós precisas de desarrollo biotecnológico para los sectores agropecuario, forestal y acuícola, así como para la industria de transformación y proveedora de los insumos de los sectores productivos señalados. Ése fue el objetivo final de esta investigación.

\section{METODOLOGÍA Y ETAPAS DE LA INVESTIGACIÓN}

La primera etapa de la investigación se centró inicialmente en la recolección de materiales escritos y de información con el fin de obtener un doble resultado. Primeramente, realizar una revisión bibliográfica de los datos empíricos sobre el tema específico de la investigación. Es decir, recabar la mayor información posible sobre los laboratorios o unidades de investigación que hay actualmente en el país en universidades y centros de investigación públicos y privados, para luego establecer la metodología de la investigación. ${ }^{4}$ Posteriormente diseñar la encuesta que habrá de realizarse entre los laboratorios detectados.

El problema metodológico principal que se planteó fue determinar con precisión cuáles campos de investigación podrían ser definidos concretamente como "biotecnológicos" con el fin de elaborar la ficha del cuestionario. Huelga señalar que hay muchas definiciones de biotecnología. En sentido amplio, es el conjunto de técnicas y conocimientos que permiten la utilización de seres vivos o partes de ellos con fines productivos. ${ }^{5}$ Estas técnicas dan un salto cualitativo con los grandes descubrimientos de la biología molecular realizados por Watson y Crick en 1953 acerca de la estructura de la doble hélice y operación de la molécula ADN (ácido desoxirribonucleico) cuyas porciones son los genes, en los cuales está inscrito el patrimonio de los seres vivos. En 1977 se crea la primera industria de ingeniería genética

4 En la primera etopa se logrb́ lo siguiente: a) juntar unos 500 libros, revistas y documentos especializados, que se clasificaron en informática mediante el mbtodo ISIS; b) hacer un primer catastro de los laboratorios que hay en instituciones universitarios, centros de investigación, empresas comerciales públicas y privadas con departamento de 1 \& $\mathrm{D}$ sobre las áreas biotecnolb́gicas seleccionadas. El número de unidades de investigación o laborotorios identificados se acercó a 60 en este primer cotólogo.

5 Esto sucedia desde la antigüedad, cuando se fabricaban quesos y bebidas fermentadas. En ol siglo pasado Pasteur incursionó en la identificoción de microorganismos y logrb probar que no existía la "fermentación espontánea". Más tarde Mendel identificó algunas leyes de la herencia genttica y Fleming descubrib la penicilina en los años treinta. Sin duda fueron precursores de la biotecnologla de "cuarta generación" inougurada con el descubrimiento del ADN o código genético de los seres vivos. 
(Genetech) y ya en 1983 aparece en el mercado el primer producto: la insulina humana.

Desde entonces hasta ahora se han multiplicado las investigaciones, y la lista de utilizaciones de la técnica del ADN recombinante (ADNr) ha ido creciendo. Ya que puede alterar las formas de la vida vegetal, animal y también humana, se la considera como el breakthrough mayor de la biología de este siglo. Actualmente los productos resultantes de la aplicación de esta nueva tecnología (calificada como una de las tres "tecnologías de punta", junto a la microelectrónica y a los nuevos materiales) comienzan a entrar significativamente en el mercado sobre todo los productos provenientes de la industria química y farmacéutica, así como en el sector alimentario y agroindustrial, en la agricultura y la minería.

Conviene con todo precisar qué se entiende en este trabajo por biotecnología. Para fines de la encuesta se definió entonces como biotecnología las líneas de investigación presentadas en el siguiente listado:

PRODUCCIÓN VEGETAL ( FORESTAL)

- ingeniería genética

— cultivo de células y tejidos

- conservación/intercambio in vitro de germoplasma

- producción de metabolitos in vitro

- diagnóstico de patógenos

- mecanismos de defensa de las plantas

- proteínas y enzimas de las plantas

PRODUCCIÓN PECUARIA

- inseminación artificial

- almacenamiento de semen

- sincronización del "celo"

- recuperación de embriones

- trasplante de embriones

- fertilización in vitro

- banco de embriones

- superovulación

- selección de sexo

- clonación

- fusión celular

- ADN recombinante 
PRODUCCIÓN ACUÍCOLA

— transformación genética (animal y vegetal)

- mapeo de genes (animal y vegetal)

- cultivo de células y tejidos (animal y vegetal)

- embriogénesis somática (vegetal)

- embriogénesis y desarrollo (animal)

- organogénesis (vegetal)

- conservación/intercambio in vitro de germoplasma

- cultivo (vegetal)

- cultivo (onimal)

- producción de individuos selectos (animal y vegetal)

- mecanismos de defensa (animal y vegetal)

- proteínas y enzimas de los organismos hidrobiológicos

- tratamiento de espacios hídricos

INDUSTRIA DE TRANSFORMACIÓN, AGROINDUSTRIA Y SERVICIOS

- ingeniería genética

- inmovilización

- catálisis enzimática

- downstream processing

- cultivo de células animales

- cultivo de células vegetales

- kits de diagnóstico

- biotransformaciones

- producción de metabolitos

- alimentos fermentados

- medio ambiente

- biodeterioro y biodegradación

- biorreactores

- formulación de productos

- digestión anaerobia

- compostaje

Conviene con todo señalar que en toda clasificación hay siempre algo de arbitrario o más bien convencional, según los fines buscados por la investigación. Por ejemplo, el cultivo de tejidos o de ápices en el área vegetal, o la inseminación artificial entre las técnicas pecuarias, se consideran aquí como parte de las técnicas biotecnologicas. Bien podrían haberse descartado del cuestionario, pues en verdad estas técnicas pueden aplicarse sin ninguna manipulación genética. Este último elemento define stricto sensu a la "nueva biotecnología". Sin 
embargo, se estimó que había dos razones para incluirlas: porque son un punto de partida que puede conducir a la utilización de la ingeniería genética para potenciarlas; y porque en general se incluyen entre las biotécnicas y así las consideran los investigadores. De este modo se construyó el cuestionario que se inspiró en el realizado por la FAO regional. 6

La segunda etapa de la investigación se llevó a cabo entre los meses de enero a mayo del presente año. El trabajo de terreno se topó con varias dificultades y demoró más de lo previsto. El número de laboratorios y unidades de investigación entrevistados resultó más elevado de lo que se esperaba: se obtuvieron respuestas de 72 unidades de investigación desde la IV hasta la X Región, varias de las cuales fueron detectadas en el curso de la.encuesta. ${ }^{7}$ De ese total se eliminaron tres por considerar que no trabajaban en el campo biotecnológico, según los parámetros definidos en la encuesta. ${ }^{8}$ Otros tres laboratorios se negaron o no respondieron a tiempo el cuestionario, lo que arroja un resultado final de 69 unidades de investigación. En la mayor parte de los casos hubo que realizar por lo menos de dos o tres visitas por empresa para lograr un buen resultado. Finalmente, conviene señalar que, en general, la recepción a los encuestadores fue muy positiva, tanto en universidades, empresas públicas y privadas como en centros de investigación y de formación técnica.

En la tercera etapa se realizó el análisis técnico de las encuestas proporcionadas por cada unidad de investigación; esto permitió confeccionar el catálogo de laboratorios o unidades de investigación y realizar el anólisis estadístico y cualitativo de los datos con el fin de llegar a conclusiones evaluativas de la investigación biotecnológica en las áreas seleccionadas.

${ }^{6}$ La ficha está diseñada para dar información sobre cinco áreas de análisis, a saber: A. Información sobre el laboratorio; B. Evaluación del laboratorio; C. Investigación; D. Equipamiento del laboratorio; E. Evaluación del laboratorio. Es necesario agradecer aquí, por las facilidades otorgadas, al doctor Juan Izquierdo de FAO, quien nos permitió usar como paradigma la encuesta contenida en el BIOCAT Regional sobre biotecnología vegetal. Sin embargo, se le agregaron nuevos campos de aplicación (pecuario, forestal, acuícola - industrias de transformación y varias preguntas adicionales en las cinco áreas que componen la ficha).

7 Se entiende por "laboratorio" una unidad de investigación con equipos de trabajo (a veces identificados formalmente o que integran unidades académicas más amplias) encargados de proyectos dentro de áreas específicas de la biotecnología. De este modo puede haber varios "laboratorios", en el sentido explicado, en unidades académicas y aun en empresas con actividades de I\& $D$.

${ }^{8}$ Se trata de laboratoriós pertenecientes al Instituto Profesional de Osorno, sede Puerto Montt; a la Escuela de Veterinaria, Facultad de Ciencias Agrarias y Forestales, Universidad de Chile; a la empresa Papeles Bio-Bio. El rechazo de estas respuestas no entraña en ningún caso un juicio negativo respecto al trabajo realizado on esas instituciones. 
embargo, se estimó que había dos razones para incluirlas: porque son un punto de partida que puede conducir a la utilización de la ingeniería genética para potenciarlas; y porque en general se incluyen entre las biotécnicas y así las consideran los investigadores. De este modo se construyó el cuestionario que se inspiró en el realizado por la FAO regional. 6

La segunda etapa de la investigación se llevó a cabo entre los meses de enero a mayo del presente año. El trabajo de terreno se topó con varias dificultades y demoró más de lo previsto. El número de laboratorios y unidades de investigación entrevistados resultó más elevado de lo que se esperaba: se obtuvieron respuestas de 72 unidades de investigación desde la IV hasta la X Región, varias de las cuales fueron detectadas en el curso de la.encuesta. ${ }^{7}$ De ese total se eliminaron tres por considerar que no trabajaban en el campo biotecnológico, según los parámetros definidos en la encuesta. ${ }^{8}$ Otros tres laboratorios se negaron o no respondieron a tiempo el cuestionario, lo que arroja un resultado final de 69 unidades de investigación. En la mayor parte de los casos hubo que realizar por lo menos de dos o tres visitas por empresa para lograr un buen resultado. Finalmente, conviene señalar que, en general, la recepción a los encuestadores fue muy positiva, tanto en universidades, empresas públicas y privadas como en centros de investigación y de formación técnica.

En la tercera etapa se realizó el análisis técnico de las encuestas proporcionadas por cada unidad de investigación; esto permitió confeccionar el catálogo de laboratorios o unidades de investigación y realizar el análisis estadístico y cualitativo de los datos con el fin de llegar a conclusiones evaluativas de la investigación biotecnológica en las áreas seleccionadas.

${ }^{6}$ La ficha está diseñada para dar información sobre cinco áreas de análisis, a saber: A. Información sobre el laboratorio; B. Evaluación del laboratorio; C. Investigación; D. Equipamiento del laboratorio; E. Evaluación del laboratorio. Es necesario agradecer aquí, por las facilidades otorgadas, al doctor Juan Izquierdo de FAO, quien nos permitió usar como paradigma la encuesta contenida en el BIOCAT Regional sobre biotecnología vegetal. Sin embargo, se le agregaron nuevos campos de aplicación (pecuario, forestal, acuícola e industrias de transformación y varias preguntas adicionales en las cinco áreas que componen la ficha).

7 Se entiende por "laboratorio" una unidad de investigación con equipos de trabajo (a veces identificados formalmente o que integran unidades académicas más amplias) encorgados de proyectos dentro de áreas específicas de la biotecnología. De este modo puede haber varios "laboratorios", en el sentido explicado, en unidades académicas y aun en empresas con actividades de 18. D.

${ }^{8}$ Se trata de laboratorios pertenecientes al Instituto Profesional de Osorno, sede Puerto Montt; a la Escuela de Veterinaria, Facultad de Ciencias Agrarias y Forestales, Universidad de Chile; a la empresa Papeles Bio-Bio. El rechazo de estas respuestas no entraña en ningún caso un juicio negativo respecto al trabajo realizado en esas instituciones. 
Para realizar el diagnóstico de cada unidad de investigación y de su conjunto, cuyo número llego a 66 , se eligib un enfoque o perspectiva de análisis que permitiera situar cada unidad de investigación dentro del conjunto de laboratorios del país. De este modo se pudo llegar a algunas conclusiones sobre el estado actual de la biotecnologla, sus fuerzas y debilidades y las perspectivas que se abren.

\section{DIAGNÓSTICO DE LAS UNIDADES DE INVESTIGACIÓN}

Como ya se dijo, el total de unidades de investigación o laboratorios censados llegó a 66. A continuación se presentarón los antecedentes generales sobre cada uno de ellos, su forma de financiamiento, su personal, sus líneas de investigación y su equipamiento.

\section{ANTECEDENTES GENERALES DE LOS LABORATORIOS}

Las 66 unidades pueden clasificarse, según su pertenencia institucional, de la siguiente manera:

\begin{tabular}{|lr|}
\hline Universidades & 54 \\
Institutos profesionales & 2 \\
Organismos públicos & 2 \\
Empresas privadas & 8 \\
\hline
\end{tabular}

Del total de unidades de investigación universitarias, 12 pertenecen a la Universidad de Chile, 11 a la Universidad Católica de Chile, 6 a la Universidad Austral, 5 a la Universidad Católica de Valparaíso, 4 a la Universidad de Santiago de Chile y 3 a la Universidad de la Frontera. Las universidades con sólo un laboratorio son las siguientes: Universidad de la Serena, Universidad Federico Santa María y Universidad de Talca. El Instituto Profesional de Osorno cuenta también con dos unidades de investigación. Las dos instituciones públicas con investigación biotecnológica son el Instituto de Investigaciones Agropecuarias (INIA) y el Instituto Tecnológico de Chile (INTEC).

En lo que se refiere a su localización geogrófica, se encuentran desde la Región IN hasta la X: 


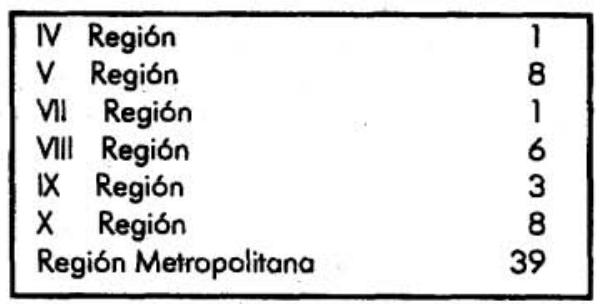

Resulta evidente que la mayor parte de las Unidades de investigación está concentrada en la Región Metropolitana; se distribuyen de la siguiente manera: 29 en universidades, 2 en instituciones públicas (INIA • INTEC) y 8 son de empresas privadas (Alimentos Golondrina, Bios-Chile, Biotécnica de Chile, Dos Alamos, Lefersa Alimentos, Probical y Veterquímica).

La encuesta arroja también resultados sobre los recursos humanos en cada laboratorio, en investigadores y el personal técnico de los laboratorios. En el formulario de los recursos humanos fueron clasificados según dos puntos de vista: a) grado académico (lng., M. Sc., Doct.) y b) cargo (jefe, asociado, asistente, ayudante, auxiliar, etcétera).

El resultado de la encuesta muestra que en los 66 taboratorios encuestados trabajan 390 personas, de las cuales 139 han realizado estudios de posgrado (103 Doct. y $36 \mathrm{M}$. Sc.) y hay además 24 ingenieros. El resto está conformado por otros profesionales (biologos, bioquímicos, microbiólogos, etcétera). En los laboratorios trabajan además 108 personas como personal auxiliar, de servicios, etcétera. Llama la atención el alto número de doctores y posgraduados, lo cual, como se verá más adelante, es un rasgo positivo y de futuro.

La encuesta proporcionó además información sobre el equipamiento relacionado con la biología molecular, con la microbiología y el cultivo de células, con el apoyo analítico a los experimentos en curso y con las plantas piloto existentes. Cada una de estas categorías incluye varios equipos específicos, los cuales fueron censados por la encuesta.

En general se puede decir que sólo un bajo número de laboratorios cuenta con el equipamiento necesario para llevar a cabo sus investigaciones. ${ }^{9} \mathrm{~A}$ contrario, para la mayor parte de ellos los equipos constituyen una limitante en sus trabajos de investigación, ya sea por no contar con ellos o bien porque los que tienen están caducos.

Por ejemplo, sólo poquísimas de las unidades cuentan con los medios instrumentales para realizar experimentos en biología molecular. Asimismo, se detectaron poquísimas plantas pilotos (U. Católica, $U$. Valparaíso, USACH, Inst. Profesional de Osorno, U. Concepción, U. de

${ }^{9}$ Conviene recordar que los laboratorios tienen líneas de investigación diferentes, como se verá más adelante. Esto complica el análisis de los resultados de la encuesta, pues no todas requieren los cuatro tipos de equipos arriba señalados. 
la Serena, Veterquímica ...) lo que indica que, en general, la investigación está todavía en una etapa de laboratorio. Es casi innecesario repetir que, para pasar del descubrimiento científico a la innovación tecnologica (es decir, a la producción comercial) se comienza el escalamiento industrial pasando primero por plantas piloto. Si no existen en los laboratorios esto indica el grado aún bajo de desarrollo de la biotecnología aplicada a la industria. En conclusión, hay carencia de equipos en los laboratorios, y con los que se cuenta son antiguos y no disponen de un mantenimiento apropiado. Se da también el caso de unidades de investigación con equipamiento modemo, pero pueden carecer de ciertos complementos que resultan de elevado costo. Por otra parte, la encuesta muestra también que las empresas privadas en general tienen un mejor equipamiento para las áreas en las cuales trabajan.

El financiamiento principal de los laboratorios proviene de tres fuentes: de la institución a la cual pertenecen, de proyectos financiados por organismos nacionales e internacionales y de operaciones comerciales. Estas últimas constituyen más bien financiamientos adicionales, como por ejemplo la venta, por parte de algunas universidades, de servicios de investigación a empresas privadas. No ocurre así en las empresas privadas, como se veró más adelante. Desgraciadamente, una proporción muy alta de las encuestas no contenía respuestas sobre los montos de financiamiento, y por lo tanto no se puede presentar aquí la cifra global de capital destinada a I \& $D$ en esta área de desarrollo.

En el siguiente cuadro se da una visión general de las distintas formas de financiamiento en las diferentes instituciones y empresas.

\begin{tabular}{|lcrc|}
\hline \multicolumn{1}{|c|}{ FINANCIAMIENTO } & \multicolumn{3}{c|}{ RESPONDEN } \\
\hline & SI & NO & NR \\
\hline Proyectos nacionales & 58 & 6 & 2 \\
Proyectos internacionales & 37 & 26 & 3 \\
Propia institución & 58 & 6 & 2 \\
Producción comercial & 14 & 48 & 4 \\
\hline
\end{tabular}

La dotación de recursos para las unidades de investigación pertenecientes a las universidades proviene casi totalmente de proyectos nacionales presentados a CONICYT, al Fondo Productivo de CORFO y a la Fundación Andes. Los fondos proporcionados por proyectos internacionales sirven también para financiar la investigación en laboratorios universitarios. Por su lado, las mismas universidades proporcionan financiamiento, aunque escaso, a sus laboratorios, el cual está destinado principalmente a cancelar sueldos de profesores contratados en 
forma permanente así como de estudiantes de pregrado y posgrado que cumplen con ayudantías, y al pago de gastos fijos en servicios. De este modo, una parte significativa de los investigadores y técnicos que no son catedráticos están sólo bajo contrato financiado por proyectos con duración limitada. Esto crea por lo tanto una situación de inestabilidad que no favorece a la investigación.

Las dos instituciones públicas (INIA, INTEC) censadas con unidades de investigación se financian en gran medida con proyectos nacionales y proyectos internacionales. Es decir, se encuentran en una situación similar a las universidades. En las empresas privadas encuestadas hay actividades de I \& D para su propio desarrollo tecnológico. Otras empresas producen bienes comerciales (Bios-Chile, Probical y Veterquímica), y generan ingresos provenientes de redes de comercialización (Neterquímica). Esto no impide que puedan procurarse fondos para investigación de FONDICYT y otros préstamos relativamente blandos como por ejemplo del Fondo Productivo de CORFO que, con todo, requieren del apoyo de empresas ${ }^{10}$ y desde este año de FONTEC y FONDEF. Es el caso de Leferso y Dos Álamos. En cuanto a contratos de laboratorios universitarios con el sector privado, resultan poco importantes, como lo demuestra su escaso número.

\section{LÍNEAS DE INVESTIGACIÓN PRIORITARIAS}

Para determinar las líneas y prioridades de la investigación la encuesta dividió en cuatro óreas la investigación desarrollada por los laboratorios censados: la biotecnología utilizable en los sectores agrícola, pecuario, forestal, acuírola (cultivo de algas, moluscos y piscicultura de agua salada y dulce); $y$, finalmente, en la producción industrial (industrias de transformación e insumos ligados a la agricultura, la ganadería y la producción acuícola). La encuesta reveló que la mayor parte de los laboratorios encuestados están trabajando con varias líneas de investigación que corresponden a los ya mencionados sectores productivos.

En algunos casos se da una combinación de estas líneas de investigación. Como lo muestra el cuadro siguiente, sólo 37 de las 66 unidades de investigación se dedican a investigar en una sola área productiva, es decir un poco más de la mitad. Hay algunos laboratorios que no sólo cubren tres o cuatro áreas productivas, sino además realizan proyectos para la salud humana, la minería y otros proyectos de investigación básica.

10 Desde este oño el FONDEP remplaza al Fondo Productivo de CORFO y se crea además el FONDEF, dependiente de CONICYT. 


\begin{tabular}{lc} 
LABORATORIOS CON: & Labs. \\
\hline 1 Línea de investigación & 37 \\
2 Líneas de investigación & 20 \\
3 Líneas de investigación & 4 \\
No responden & 1 \\
\hline
\end{tabular}

Conviene, en fin, señalar que la investigación para el sector industrial, una de las líneas más frecuentes, estó casi siempre ligada a lo agropecuario, lo forestal y lo acuícola.

\begin{tabular}{lc} 
LINEAS DE INVESTIGACIÓN & No. Labs. \\
\hline Sector agrícola & 37 \\
Sector pecuario & 1 \\
Sector forestal & 3 \\
Sector acuícola & 11 \\
Sector industrial & 5 \\
Otros * & 4 \\
\hline
\end{tabular}

* Otros: investigación básica, medica, minería.

\section{ACTIVIDAD PRINCIPAL DE LAS UNIDADES DE INVESTIGACIÓN}

La encuesta da resultados sobre la orientación o dedicación del laboratorio en cuanto a su actividad, es decir, investigación, docencia, investigación-docencia, investigación aplicada, producción comercial, transferencia de tecnología, etcétera. Si consideramos que la mayor parte de los laboratorios que trabajan con biotecnología se encuentran en universidades, la actividad principal de éstos (38) se dirige principalmente a investigación/docencia, o bien sólo a la investigación.

En investigación aplicada encontramos sólo cuatro laboratorios y el mismo número para los que investigan para la producción comercial. Esto indica que el esfuerzo actual no está directamente orientado a mejorar la producción mediante nuevas biotecnologías. Por el contrario, se realiza mucha investigación que no desemboca en innovaciones comerciales por predominar la docencia y, ademós, por carencias de medios económicos para su desarrollo.

\begin{tabular}{lc} 
ACTIVIDAD PRINCIPAL & Núm. LABS. \\
\hline Investigación/docencia & 38 \\
Investigación & 13 \\
Docencia & 1 \\
Investigación aplicada & 5 \\
Inv./transferencia tecnológica & 4 \\
Producción comercial & 4 \\
Control de calidad & 1 \\
\hline
\end{tabular}




\section{PROYECTOS DE INVESTIGACION EN CURSO}

Los datos proporcionados por la encuesta permitieron censar el total de los proyectos que actualmente llevan a cabo los laboratorios. Su número asciende a 255 . De éstos, 65 corresponden al área acuícola $(25 \%), 61$ a la industrial $(23 \%), 51$ a la vegetal $(20 \%), 28$ a la forestal (10\%) y sólo 14 a la pecuaria (5\%). Al examinar las especies más utilizadas en las unidades de investigación, se encontro, como era de esperar, una gran diversidad: virus y otros microorganismos como bacterias, hongos, levaduras, enzimas, especies vegetales de muy diverso tipo y animales como los vacunos, peces, etcétera.

La encuesta también inquirió sobre las óreas de investigación hacia futuro. En casi todos los laboratorios la respuesta fue más bien conservadora pues coincidía con las actuales líneas de investigación.

Las preguntas sobre capacitación del personal demostraron que tanto su oferta como su demanda están relacionadas con los intereses y prioridades de los laboratorios. Entre las áreas de capacitación mencionadas, sobre todo como demanda, están la ingeniería genética, inmovilización de enzimas, kits de diagnóstico y otras relacionadas con el medio ambiente.

La encuesta permitió identificar también las principales carencias percibidas por los mismos laboratorios. La pregunta abierta del cuestionario les pedía señalar, en orden de importancia, hasta tres carencias. Respecto a la más importante las respuestas se muestran en el siguiente cuadro.

Contrariamente a lo que podría esperarse, el cuadro revela que el problema se sitúa más bien en el ámbito de las infraestructuras, en la falta de equipos y en menor grado en la falta de financiamiento y de capacitación del personal. Sin embargo, la falta de financiamiento influye fuertemente en las dos principales carencias declaradas por los equipos de investigación.

\begin{tabular}{lc} 
PRINCIPAL CARENCIA & Núm. LABS. \\
\hline Infraestructura física & \\
(insuficiente o limitada) & 26 \\
Equipamiento técnico & 19 \\
(falta o caduco) & 10 \\
Financiamiento reducido & 8 \\
Capacitación personal & 2 \\
Contratación personal & \\
\hline
\end{tabular}

Por último, hay un cierto grado de cooperación técnica horizontal, es decir, entre laboratorios. Aunque $34.8 \%$ de ellos no practica con 
otros ninguna clase de cooperación, $60 \%$ tiene algunos vínculos de intercambio. Respecto a las principales demandas de capacitación del personal, éstas se relacionan obviamente con las líneas de investigación prioritarias para cada laboratorio.

\section{DEBILIDADES Y FORTALEZAS DE LA BIOTECNOLOGÍA EN CHILE}

Un primer análisis de los datos de la encuesta permite obtener algunos elementos de diagnóstico. " Los resultados confirman la hipótesis de que el desarrollo de la biotecnología, al menos en los sectores productivos seleccionados, es aún incipiente. Sin embargo, esta conclusión necesita ser matizada. Sin duda resulta incipiente si comparamos la situación de Chile con la de los países líderes en el desarrollo de nuevas tecnologías como son Estados Unidos, la CEE y Japón.

En efecto, la principal debilidad radica en que la investigación biotecnológica actual está centrada en la fase de laboratorio y orientada más bien a la docencia. Por ejemplo, los datos señalan que 38 de las 66 unidades de investigación están en función de la docencia, o al menos relacionadas con ella. Sólo hay cuatro dedicadas a la investigación para la producción comercial, también cuatro relacionadas con la transferencia tecnológica y cinco que realizan investigación aplicada. ${ }^{12}$ Es decir, que en la mayor parte de los casos las empresas no se interesan en hacer contratos con las universidades y centros de investigación; se trata por lo tanto de una investigación más bien académica que no está desembocando en innovaciones productivas con capacidad de competencia en el mercado. Esto exigiría pasar por una fase intermedia de experiencias en plantas piloto para llegar por último a la producción industrial. Como se vio anteriormente, hay poquísimas plantas piloto, lo que confirma lo ya señalado.

En lo que respecta a las empresas con departamento de I \& $D$, la encuesta señala que sólo ocho los tienen. Huelga repetir que las empresas en los sectores estudiados requieren nuevas tecnologías para competir exitosamente en los mercados nacionales y mós aún en los internacionales. Se podría plantear la hipótesis de que recurren preferentemente a la adquisición de tecnologías importadas con el fin de elevar la productividad y realizar su competitividad. Sin embargo, aun

1 Un diagnóstico más acabado se presentará en un libro cuya publicación está prevista para los meses siguientes. La proposición de políticas para el desarrollo biotecnológico debe ser resultado de una nueva investigación que se espera realizar en SUR Profesionales.

${ }^{12}$ Según algunos, los financiamientos destinados a la investigación revelarían un "culto al proyecto" y no tanto al avance productivo. 
en ese caso se requiere tener capacidad suficiente para asimilar la tecnología comprada en el exterior. De ahí la importancia de lograr un desarrollo tecnológico nacional, aunque fuere sólo para poder importar tecnologías adecuadas a nuestros recursos naturales que aseguren por lo demás la conservación de los equilibrios ecológicos. Se aprovecharían así juiciosamente nuestras escasas disponibilidades financieras.

La afirmación de que el desarrollo tecnológico es aún incipiente queda aún más reforzada por lo que es obvio: los limitados recursos destinados a actividades de I\&D, la precariedad de los salarios destinados a los científicos y técnicos, la falta de seguridad en su empleo y la infraestructura y equipamientos insuficientes. Al respecto se hizo una evaluación global de los laboratorios en función de los datos proporcionados por las encuestas. Se tuvo en cuenta el equipamiento existente en función de las líneas de investigación de los proyectos de cada unidad. Se calificaron en tres categorías: sobresaliente, bueno y con deficiencias. Los resultados son los siguientes:

\begin{tabular}{|ll|}
\hline Unidades sobresalientes & 19 \\
Unidades aceptables & 35 \\
Unidades deficientes & 12 \\
\hline
\end{tabular}

Pese al desarrollo deficiente de la biotecnología en Chile, no pueden dejarse de recalcar algunos elementos positivos que dan pie a un cierto optimismo respecto al futuro.

El primero es la existencia de un número no tan pequeño de laboratorios: cerca de 70 en las áreas estudiadas. Este resultado más bien inesperado de la encuesta señala que el primer paso en el desarrollo de la biotecnología ya está dado. El segundo se refiere a los recursos humanos actualmente existentes. Del personal total, 39\% (390 personas) ha realizado estudios de posgrado. En efecto, se cuenta con 103 doctorados y 36 maestrías en ciencias, lo que es considerable, al menos al comparar con otros países en desarrollo de la región. Trabajan además otros profesionales: ingenieros, biólogos, bioquímicos, etcétera, en un número que, además de los que han realizado estudios de posgrado, alcanza 282 personas.

Un tercer elemento positivo es el clima o ambiente económico relativamente favorable al desarrollo futuro de la biotecnología. En efecto, el modelo actual de desarrollo, abierto al exterior, hace hincapié en una modernización productiva; esto dado el grado de competencia en los mercados internacionales. Aparentemente surge una nueva clase empresarial y a la vez un movimiento sindical que pone más interés en la búsqueda de la concertación con el empresario. Ambos comien- 
zan a darse cuenta que su suerte está unida al éxito de la empresa y que ésta debe modernizarse para afrontar la competencia.

Un cuarto elemento es la abundancia de biomasa en el país, lo cual debería estimular a aprovechar las grandes oportunidades productivas aún desaprovechadas y, al mismo tiempo, lograr un mayor equilibrio del medio ambiente que asegure una sustentabilidad de los sistemas ecológicos del país.

Este clima favorable al desarrollo biotecnológico requiere además de políticas estatales que lo fomenten decididamente en la concertación con los agentes económicos. Dichas políticas deberían fijar estrategias en que se dé prioridad a las áreas de mayor futuro en función de la disponibilidad nacional en lo referente a recursos naturales, humanos $y$ financieros.

\section{EMPRESAS BIOTECNOLOGICAS: DOS ESTUDIOS DE CASO}

Los datos presentados en la sección anterior pueden ser complementados por dos estudios de caso realizados en los meses de julio y agosto de este año dentro del marco de un proyecto de investigación realizado por IICA en varios países de América Latina. ${ }^{13} \mathrm{Se}$ trata de análisis de dos empresas, ambas de reciente inicio, que adolecen de las limitaciones propias de un país con un mercado interno relativamente pequeño, escasez de capital de riesgo, y un desarrollo de la investigación biotecnológica aún incipiente en sus aplicaciones industriales como se demostró en la investigación anteriormente expuesta.

\section{BIOS-CHILE, una empresa en pleno crecimiento}

BIOS-CHILE se fundó en el año 1986, después de un período de dos años de preparación. Fue resultado de la iniciativa de tres profesionales químico-farmacéuticos de la Universidad de Chile que fueron compañeros de curso. Uno de ellos era especialista en farmacéutica; el segundo trabajaba como investigador en la misma universidad, pero se trasladó posteriormente a Estados Unidos donde fundó una empresa de biotecnología; el tercero se desempeñaba entonces como académico de la $U$. de Chile. Posteriormente fueron reclutados otros cientifi$\cos y$ un gerente administrativo.

13 Este proyecto dirigido por el doctor Walter Jaffe, del HCA, se encuentra actualmente en curso. Es un estudio comparativo de empresas biotecnológicas en Argentina, Brasil, Colombia, Costa Rica, Chilo, Mb́xico, Uruguay y Venezuela. Su objetivo es analizar los logros de las empresas, sus factores de bxito y fracaso, su nivel de 1 \& D, etcétera. 


\subsection{Las estrategias iniciales}

La empresa inicialmente era muy pequeña. Su estrategia consistió bósicamente en estar inmediatamente presente en el mercado mediante la venta de productos biotecnológicos, aunque no fueran de producción propia. Es decir, se puso en marcha con un pequeño laboratorio bien montado con dos o tres proyectos y simultáneamente se comercializaron productos de terceros, con el fin de explorar el mercado y además darse a conocer mientras la empresa no fuera capaz de desarrollar sus propios productos. La venta de productos del órea de diagnóstico humano se realizó con el apoyo de dos o tres vendedores en el mercado.

En los dos primeros años se logró consolidar la empresa en el sentido de estar presente en el mercado y, por otro lado, se buscaron recursos de organismos oficiales para desarrollar los proyectos de investigación. Por lo tanto, la empresa pudo financiarse en parte con el aporte inicial de los socios y en parte con proyectos de investigación, ganados en competencia ante la Comisión Nacional de Investigación Científica y Tecnológica (CONICYT) y, más específicamente, de FONDECYT. También intentó obtener recursos del Fondo de Desarrollo Productivo de la Corporación de Fomento de la Producción (CORFO) que financiaba proyectos de investigación básica.

Sin embargo, estos esfuerzos realizados en 1987 fracasaron en dos oportunidades. La primera vez se presentó un proyecto básico para desarrollar la vacuna contra la hepatitis $B$; este proyecto fue aprobado en un principio por CORFO. Luego se presento una segunda investigación al Instituto Tecnológico INTEC, dependiente también de CORFO, que supuestamente ofrecía hasta $50 \%$ del proyecto bajo forma de capital de riesgo; pero en ambos casos los proyectos no se llevaron a cabo debido al fondo de garantía muy elevado (alrededor de 150\%) solicitado por el organismo público. Esto no resultaba ctractivo para la empresa pues dicha condición era equivalente a la de los bancos privados.

\subsection{Financiamiento mediante aportes de capital de otras empresas}

Hacia 1990 entró en contacto, de manera casi casual, con Laboratorio Chile, S. A., empresa farmacéutica estatal de larga trayectoria. En ese momento ésta evaluaba la posibilidad de incursionar en el área de la BT. Posteriormente, las conversaciones más a fondo culminaron con la incorporación del Laboratorio Chile en Bios-Chile mediante la adquisición de un paquete accionario y la formación de 
una nueva empresa. ${ }^{14}$ De ese modo obtuvo capital para proseguir el desarrollo de la empresa. Aunque esto presentaba algunas limitantes para los primeros socios, el acuerdo de desarrollo conjunto era favorable pues permitía un cierto grado de libertad para realizar proyectos conjuntos de investigación mediante el capital aportado por Laboratorio Chile. ${ }^{15}$

Recientemente se formó una nueva sociedad -la cual está aún en trámite-con una de las mayores empresas biotecnológicas norteamericanas: la Chiron Corporation. ${ }^{16}$ El aporte de capital que hace Chiron a Bios-Chile equivale a 19 por ciento. Esto significó emitir nuevas acciones. La independencia de Bios-Chile aparentemente no se pierde tampoco en este caso. A Chiron no le interesa intervenir en el manejo de la empresa, sino más bien invertir en ella, pues tiene plena confianza en las personas que están a cargo. La vinculación se hace mediante el científico, a la vez ejecutivo de Chiron y director de la empresa chilena.

\section{EXTENSIÓN HACIA EL MERCADO INTERNACIONAL}

Recientemente, Bios-Chile IGSA montó una empresa subsidiaria de distribución y venta de reactivos para laboratorios de investigación en Estados Unidos. Su sede está en San Francisco, California, y se llama Austral Biologicals. Los productos comercializados no son refinados y de alta rentabilidad. Sin embargo, cubren un nicho de mercado interesante para productos de Bios-Chile que no tienen demanda nacional, ni tampoco en países de América Latina y que en Estados Unidos no son fabricados. Austral Biologicals vende y distribuye una variedad de anticuerpos monoclonales y productos desarrollodos por

${ }^{14}$ Bios-Chile Ingeniería Genética, S. A. En esta nueva sociedad, Laboratorio Chile participa con $25 \%$ del capital.

${ }^{15}$ En la estrategia del consejo de la empresa hay dos aspectos importantes. EI primero es que a Bios-Chile le interesaba seguir manejando la empresa y no ser absorbido por Laboratorio Chile, ya que no habría tenido ningún sentido vender parte de la empresa. El segundo es que Laboratorios Chile tiene sólo dos directores de siete y, de este modo, que el manejo de la empresa sigue estando mayoritariamente en manos de los socios fundadores de la empresa. La nueva empresa es una sociedad anónima cerrada que tiene que hacer público el balance anual a través de Laboratorio Chile, pues ésta es una empresa pública.

16 Con ésta había una vinculación muy sólida ya que uno de los científicos fundadores había trabajado en dicha empresa cuando se trasladó a Estados Unidos y no dejó de ser socio de Bios-Chile. Chiron Corporation aisló virus de hepatitis $\mathrm{B}$ y produce la primera vacuna; también fue la primera en aislar y hacer una prueba para el virus de hepatitis C. Desarrolla hoy vacunas para el virus del SIDA. Chiron tiene vinculaciones con otras empresas grandes como CIBA en la parte de biodiagnóstico; CIBA, además, acaba de adquirir dos empresas biotecnológicas: CETUS, y SAU, empresa italiana. 
Bios-Chile. La interacción con Chiron ha permitido tener una cartera de productos biotecnológicos (algunos muy refinados) que tienen demanda en Estados Unidos. ${ }^{17}$

En suma, la situación actual es de crecimiento acelerado ya que los ingresos aumentan en los últimos años con una tasa de 100 por ciento. Se dispone de oficinas de gerencia y administración por un lado y de laboratorios en lugar aparte. ${ }^{18}$ Por último, Bios-Chile ha realizado grandes esfuerzos por establecer contactos con empresas de biotecnología de Chile y de América Latina. De hecho está participando en la formación de una Asociación Latinoamericana y Chilena de Empresas de BT, la cual estaría próxima a funcionar.

Su objetivo es convertirse en una empresa del área biofarmacéutica, en todo sentido integrada y abierta a todo tipo de interacciones con otras empresas. Pretende desarrollar una biotecnología propia y a la vez vender productos fabricados por la empresa, adquirir licencias de tecnología desarrollada por terceros y vender tecnología propia a terceros. Se trata en realidad de una empresa abierta a todas las posibilidades del mercado. Comienza con la distribución comercial de productos para rápidamente tratar de remplazar éstos por biotécnicas desarrolladas por Bios-Chile.

Quizás el éxito de la empresa se debe a que partió con planes más bien modestos que iban de acuerdo con la disponibilidad de capital que ha ido creciendo mediante la incorporación de nuevos socios nacionales y extranjeros. Los planes a futuro fueron formulados de acuerdo con las potencialidades existentes, por lo que ha ido pasando etapas y ha crecido de manera regular.

\section{UNA EMPRESA QUE ENFRENTA PROBLEMAS EN SU DESARROLLO}

La creación de biotecnología en Chile comienza a gestarse como proyecto en el año de 1987. La idea fue de dos personas: un empresario de gran experiencia en otros campos y un científico que venía llegando de Israel, donde había obtenido un doctorado en

17 Precisamente hay productos desarrollados por Chiron que no se venden directamente en el mercado y sobre los cuales Austral Biologicals tiene los derechos de distribución. Esta nueva empresa distribuidora funciona con tres o cuatro personas y vende a través de avisos en revistas especializadas y mediante correo directo a investigadores y laboratorios especializados.

18 Por otra parte, Bios-Chile acaba de adquirir una propiedad en Santiago de $3000 \mathrm{~m}^{2}$ con $1600 \mathrm{mt}$ construidos de galpones. Dado que por ahora no se va a ocupar en su totalidad la infraestructura adquirida, parte de la compra se financiarta arrendando la mitad de la propiedad a los antiguos propietarios (Laboratorios Merck) y el resto se estó remodelando para los laboratorios y oficinas de gerencia y administración. 
bioquímica. En 1988 se compra un terreno en Padre Hurtado, en las afueras de Santiago; se comienza la construcción de los edificios del laboratorio, al mismo tiempo que se importan los equipos necesarios. La inversión inicial fue de un millón de dólares financiado en parte con un crédito blando de CORFo (Fondo Productivo) y créditos de bancos particulares, en este caso el Banco de Concepción.

\section{LA ESTRATEGIA INICIAL}

La idea inicial fue remplazar importaciones para el área médica por productos factibles de elaborar en Chile; es decir, los de un grado de dificultad menor, sobre todo en lo que se refiere a diagnóstico clínico. Se planificaron cuatro líneas principales de trabajo: diagnóstico clínico; control de calidad de alimentos y bebidas; producción de enzimas de uso agroindustrial, y hormonas y otros productos para elevar el rendimiento animal. Se adquirieron equipos de alta tecnología para garantizar la calidad de los productos y hacerlos competitivos en los mercados internacionales.

\section{LOS PROBLEMAS DE LA NUEVA EMPRESA}

En 1990, cuando se inauguró la empresa, ésta tenía un personal compuesto de bioquímicos, químicos, microbiólogos, tecnólogos en alimentos, técnicos médicos. Hoy cuenta con 25 empleados, de los cuales 14 son profesionales y dos tienen doctorado en bioquímica. Después de año y medio de funcionar, la empresa ha logrado colocar en el mercado de manera relativamente estable los siguientes productos: kits de diagnóstico humano; kits de diagnóstico para bacterias e implantes hormonales para animales.

Sin embargo, la gestion ha sido difícil por diversas causas, sobre todo en lo que se refiere a llegar al mercado: a) hay una cierta preferencia por productos médicos importados en desmedro de los nacionales, a menudo de costo mucho más bajo. Esta situación exige un sistema de marketing mediante demostraciones a los clientes en sus propios laboratorios; b) el primer sistema de distribución entró en crisis en agosto de 1990. Se había firmado un contrato de distribución exclusiva con una tercera empresa. Ésta no cumplió el contrato, lo que produjo una situación muy difícil para la empresa frente a los clientes. Quedó prácticamente paralizada y tuvo que empezar casi de cero en febrero de 1991; c) lo anterior determinó que el ejercicio anual de 1990 arrojara cifras rojas y que la empresa rematara parte del equipo. 
Actualmente se está superando la situación mediante un sistema de distribución en el mercado nacional a cargo de la empresa misma. Mientras tanto, se está comenzando a exportar a Unuguay, sobre la base de un contrato por el cual la Ciba-Geigy de Unuguay distribuye los productos chilenos. También se exportan a empresas lecheras argentinas (Serenísima y Sanco) kits de diagnóstico de bacterias. Finalmente, empezó a producir productos, no estrictamente biotecnológicos, como agua destilada mediante un proceso que da una pureza de 99 por ciento.

La empresa está constituida como sociedad anónima y debe efectuar ejercicios anuales. Las ventas mensuales están en alrededor de seis millones (algo menos de 18 mil dólares), lo cual es bajo. Según la empresa, uno de los factores que hace subir los costos de producción es la materia prima importada y cara; algo semejante sucede con los envases plásticos; a partir de febrero ha repuntado en lo que corresponde a la industria; la sección de investigación clínica experimenta algunas dificultades, pero tiene buenas expectativas ya que los productos son de buena calidad.

\section{ALGUNAS REFLEXIONES SOBRE ESTRATEGIAS DE DESARROLLO TECNOLOGICO}

Los estudios que hemos presentado nos muestran el caso de un país que dentro de América Latina no parece ser excepción. En verdad, el rezago biotecnológico en que se encuentra en relación con los países industrializados (sobre todo aquellos líderes en el campo como son Estados Unidos y la CEE) se manifiesta en los siguientes elementos:

- investigación biotecnológica incipiente y predominantemente dirigida a la docencia y no a la producción;

- escaso número de empresas biotecnológicas;

- insuficientes recursos financieros para la investigación cientifica y tecnológica en los centros universitarios;

- falta de seguridad y de buenas condiciones de trabajo y remuneraciones del personal científico y técnico aun en el caso de que éste cuente con una buena formación;

- insuficiente I\& D en el caso de las empresas en los sectores estudiados: en la mayor parte de los casos prefieren comprar tecnología en el mercado internacional o asociarse con empresas extranjeras antes que desarrollarla conjuntamente con los centros científicos.

Sin embargo, Chile, como otros países de América Latina, ha optado por una estrategia de desarrollo abierto a la competencia 
extranjera con el objeto de lograr una mejor inserción de sus exportaciones en el mercado mundial. Resulta indudable que sus posibilidades de penetrar ese mercado están relacionadas con un mayor desarrollo tecnológico que no sólo permita aumentar la productividad y rebajar los costos de producción, sino además mejorar la calidad de los productos de exportación, adaptándose a las demandas cambiantes y exigentes de ese mercado. La pregunta que surge entonces es ¿́cómo cerrar la brecha entre el rezago tecnológico hoy existente y las urgentes necesidades de modernización tecnológica? Más concretamente, ¿̇cómo lograr una transferencia de competitividad internacional y que se logre en un período suficientemente rápido?

La estrategia tradicional de los gobiernos de la región ha consistido más bien en fomentar la investigación científica y tecnológica a través de las universidades y centros paraestatales. Esta estrategia contenía un modelo de desarrollo tecnológico implícito, el cual apuntaba a la autosuficiencia y la autonomía nacional, lo que en buena medida se aplica en un período de desarrollo de la industria nacional, protegido contra la competencia extranjera, modelo que se agotó hacia comienzos de los años setenta, cuando la economía se globaliza mundialmente.

No se puede negar que la estrategia de desarrollo autónomo tuvo algunos frutos pues la investigación creció en los centros académicos fomentada por los Consejos de Ciencia y Tecnología y por cierto apoyo financiero. Es decir, felizmente no se parte de cero; pero, en definitiva, el rezago aumentó sobre todo en lo que respecta a las nuevas tecnologías, como lo demuestra la encuesta sobre la investigación biotecnológica en Chile. Por lo demás, el sector productivo moderno finalmente tuvo que adquirir tecnología del mercado externo —a veces no fácilmente adaptable a las condiciones propias de la producción nacional-o asociarse con las empresas extranjeras no sólo por falta de capitales sino también para poder adquirir una tecnología y un know how competitivos para exportar a los mercados internacionales.

Sin embargo, en los últimos diez años pueden observarse en América Latina algunas estrategias innovadoras de transferencia de tecnología, que se presentan en el cuadro adjunto.

La primera es la experiencia del Centro de Ingeniería Genética y Biotecnología en Cuba y que en los últimos años ha logrado producir y exportar anticuerpos monoclonales, vacunas y otros productos biotecnológicos. Iniciativa del Estado revolucionario, este Centro, dotado de equipos e instrumentos importados de todo el mundo reúne un grupo de científicos de primer nivel que además colaboran en la formación de estudiantes universitarios que hacen prácticas en sus amplios laboratorios. Este centro es de carácter público y el Estado ha concentrado en él considerables recursos. 
La segunda experiencia innovadora es la del Centro para la Innovación Tecnológica de la UNAM que entra en su sexto año de funcionamiento. Probablemente la universidad estimó que la investigación académica estaba poco relacionada con la producción y que por lo tanto tenía poco efecto en la modernización de la industria. Este Centro no tiene investigación tecnológica como tal, sino que se limita a coordinar la que se realiza en facultades y centros de investigación de la universidad, incentivar a los investigadores y facilitar el contacto con empresarios. Desde su creación ha habido un número considerable de patentes adquiridas por empresarios y los resultados parecen prometedores.

Otra estrategia innovadora es la desarrollada por la Fundación BIORIO que reúne instituciones académicas (Universidad Federal de Río de Janeiro, UFR Fundacao Oswaldo Cruz), dependencias del Gobierno Federal (Ministerio de Ciencia y Tecnología, CHPq, etcétera) y de organismos empresariales. Esta fundación de derecho privado y sin fines de lucro pone a disposición de empresas interesadas terrenos del parque industrial (dentro del campus de la UFRI); coordina proyectos de I \& D de las empresas con los laboratorios de la misma Universidad y de la Fundación $\mathrm{O}$. Cruz; ofrece facilidades como laboratorios de cultivo de tejidos, banco de células humanas y animales y otros que aumentarán en el futuro.

La última estrategia innovadora es la desarrollada por la Fundación Chile, creada en 1976 con aportes iguales de 25 millones de dólares de la empresa ITT y del gobierno chileno. Es el caso raro de una asociación entre un gobierno y una empresa transnacional que se produjo como manera de poner fin al litigio entre ambas partes a raíz de que la filial chilena de ITT había sido expropiada en tiempos de la Unidad Popular. Al contrario de las experiencias anteriores, la Fundación Chile no pretende hacer investigación y sólo cuenta con laboratorios de diagnóstico y servicios de control de calidad.

Su objetivo es transferir y asimilar adecuadamente al país la mejor tecnología posible, adquiritla en el mundo para aplicarla en el desarrollo de empresas en cuatro áreas de prioridad con base en estudios de marketing: agroindustria, industria forestal, piscicultura y pesca y comercialización, a las cuales se ha agregado más recientemente la microelectrónica. Cuenta hoy en día con más de una decena de empresas, a veces asociadas con empresarios locales en las áreas mencionadas, las cuales son vendidas cuando se han afianzado con base en una nueva tecnología. Es el caso de una empresa de cultivo de salmones, actividad inexistente en Chile hasta que la Fundación trajo tecnología noruega y canadiense, que al tener éxito hizo que otras empresas comenzaran a producir lo mismo. Sin duda el efecto de demostración logrado por estas empresas ha sido decisivo para el desarrollo 
de varios nuevos rubros de exportación: uvas, manzanas y otras frutas adaptados a los mercados del norte, kivi traído de Nueva Zelanda, beries, semillas, aparte de la introducción del salmón, el turbot, truchas, etcétera.

El secreto del éxito de la Fundación parece residir en el excelente nivel de sus funcionarios, sus contactos intemacionales con medios científicos y empresariales, su orientación al mercado como criterio para emprender nuevas experiencias productivas, la reducción del riesgo de innovar para los gerentes de las nuevas empresas y la creación de un medio empresarial abierto a la innovación logrado mediante el efecto de demostración de las empresas y de seminarios de alto nivel dirigidos a los productores de las áreas mencionadas.

\begin{tabular}{|c|c|c|c|}
\hline ESTRATEGUAS & $\begin{array}{l}\text { En lo referente a } \\
\text { Investigación }\end{array}$ & $\begin{array}{l}\text { Participación } \\
\text { del Estado }\end{array}$ & $\begin{array}{l}\text { Participación empresas } \\
\text { nacionales } \\
\text { y transnocionales }\end{array}$ \\
\hline Tradicionales & $\begin{array}{l}\text { Centrada en la Univer- } \\
\text { sidad (y organismos } \\
\text { públicos), orientados a } \\
\text { la docencia y academia } \\
\text { y no a la producción. }\end{array}$ & $\begin{array}{l}\text { Apoyo a laboratorios y } \\
\text { financiamiento por } \\
\text { parte de Consejos de } \\
\text { Ciencia y Tecnologia } \\
\text { estatales. }\end{array}$ & $\begin{array}{l}\text { Nulo a empresas } \\
\text { nocionales sin I\& D que si } \\
\text { se modernizan compran } \\
\text { tecnologia traniera. }\end{array}$ \\
\hline $\begin{array}{l}\text { Innovadora I (Cuba) } \\
\text { Centro de Ingeniería } \\
\text { Genctica y Biotecnolo- } \\
\text { gla }\end{array}$ & $\begin{array}{l}\text { Orientada a la investiga- } \\
\text { ción de punta para pro- } \\
\text { ductos do exportacion. } \\
\text { Formación de cientificos } \\
\text { mediante prácticas de } \\
\text { estudiantes en el centro. }\end{array}$ & $\begin{array}{l}\text { Creado y financiado } \\
\text { inicialmente por } \\
\text { Estado, es una empresa } \\
\text { que hoy percibe ingresos } \\
\text { por exportaciones de } \\
\text { productos, sobre todo } \\
\text { farmactuticos. }\end{array}$ & 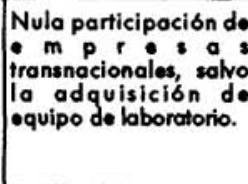 \\
\hline $\begin{array}{l}\text { Innovadora II (Mbxico) } \\
\text { Centro para la Innova- } \\
\text { cion Tocnologica, } \\
\text { UNAM }\end{array}$ & $\begin{array}{l}\text { Sin investigación pro- } \\
\text { piamente tal, busca } \\
\text { poner en contacto } \\
\text { cientificos con empresas } \\
\text { para transferir a tstas la } \\
\text { tecnología desarrollada } \\
\text { en la Universidad. }\end{array}$ & $\begin{array}{l}\text { Investigación financia- } \\
\text { da con fondos propios } \\
\text { de la Universidad Públi- } \\
\text { ca, con apoyo de ogen- } \\
\text { cias estatales y funda- } \\
\text { ciones, y con contratos } \\
\text { con empresas. }\end{array}$ & $\begin{array}{l}\text { Participación de empre- } \\
\text { sas, sobre todo naciona- } \\
\text { les, mediante contratos } \\
\text { de investigación y la } \\
\text { adquisicibn do patentes } \\
\text { registrodas por cientifi- } \\
\text { cos de la UNAM }\end{array}$ \\
\hline $\begin{array}{l}\text { Innovadora III (Brasil) } \\
\text { Funda ción BlO-RIO, } \\
\text { Universidad Federal de } \\
\text { Rio do Janeiro y Fund. } \\
\text { O. Cruz }\end{array}$ & $\begin{array}{l}\text { Busca integrar ciencia } \\
\text { industria mediante } \\
\text { colaboración mutua } \\
\text { entre el sector de } \\
\text { investigaciones y } \\
\text { sector productivo } \\
\text { ofreciendo facilidades } \\
\text { de un parque industrial } \\
\text { en la UFR. }\end{array}$ & $\begin{array}{l}\text { Fundacion de derecho } \\
\text { privado sin fines do } \\
\text { lucro cuyos socios } \\
\text { cientficos son la UFR y la } \\
\text { Fund. O. Cruz con } \\
\text { socios estatales (Ministe- } \\
\text { rios, OMPa.) y empre- } \\
\text { sarioles. }\end{array}$ & $\begin{array}{l}\text { Participación activa de } \\
\text { empresas pequeKas y } \\
\text { medianas que prestan } \\
\text { servicios administrativos } \\
\text { y de ot ro tipo } \\
\text { especializados en el órea } \\
\text { de la biotecnología } \\
\text { (laboratorios). }\end{array}$ \\
\hline $\begin{array}{l}\text { Innovadora N (Chilo) } \\
\text { Fundación Chilo }\end{array}$ & $\begin{array}{l}\text { Difunde tecnologías do } \\
\text { punta adquiridas on ol } \\
\text { extranjero mediante ol } \\
\text { ofocto de demostración } \\
\text { de empresas comercia- } \\
\text { les que las utilizan, } \\
\text { creadas por la funda- } \\
\text { ción. }\end{array}$ & $\begin{array}{l}\text { Fundación de derecho } \\
\text { privado resultante do } \\
\text { una negociación ontre } \\
\text { la } 17 \pi \text { y el Gobierno do } \\
\text { Chile, con una imversión } \\
\text { inicial de } 25 \text { millones } \\
\text { de dolares de cada } \\
\text { socio. }\end{array}$ & $\begin{array}{l}\text { Auticulación entre una } \\
\text { empresa internacionaly } \\
\text { il Estado, que so logra } \\
\text { en condiciones historicas } \\
\text { excepcionales. }\end{array}$ \\
\hline
\end{tabular}




\title{
Las políticas de promoción de Ia ciencia y la teenología: el cerso de la biotecnología
}

\author{
RAÚl CONDE,* ROSA LUZ GONZÁLEZ** \\ Y JUVENCIO WING***
}

\section{INTRODUCCIÓN}

El estudio de las fuentes y de los mecanismos de aceleración del cambio tecnológico (definido como la unidad de tres fases ampliamente conceptualizadas como invención-innovación-difusión) continúa presentando carácter de urgente. Cualquiera que sea el estadio de desarrollo económico, y por tanto tecnológico, de una formación social, la solución a los problemas de cómo acceder al avance cientffico-tecnológico, asimilarlo y renovarto es una exigencia permanente en tanto exista la voluntad efectiva por enfrentar tanto la aparición de nuevos desafíos que plantea el crecimiento económico mismo, como por la índole misma de la ciencia y la técnica. Cabe aqú recordar una afirmación recogida de un texto clásico sobre el tema:

En nuestros países es común pensar, por el hecho de ser espectadores y no protagonistas, que estamos viviendo el momento culminante de la revolución científico-tecnológica. Ello no es cierto, como bien lo prueban los estudios prospectivos que demuestran que son previsibles transformaciones científicas mucho más profundas que las experimentadas hasta el presente. Por lo tanto debemos adquirir conciencia de que estamos en medio de un proceso y no en su término final, de lo cual resulta que aún tenemos posibilidades de participación. La investigación científico-tecnológica jamás se detiene $y$, es preciso recordarlo, jamás se podrá detener (Śbato, 1975, p. 144).

- Profesor titular del Departamento de Economía de la Universidad Autónoma Metropolitana-Iztapalapa.

** Investigadora del Centro para la Innovación Tecnológica, UNuM.

*** Profesor de las Facultades de Economía y de Ciencias Polticas y Sociales, UNuM. 
Por otra parte, a través del discurso de la modemidad — que para el final del siglo pretende sustituir a las llamadas ideologías políticas hasta hace poco dominantes-, el avance cientifico-tecnológico se nos propone como condición impostergable para la sobrevivencia de la sociedad. Nada más natural, entonces, que cada quien busque conocer cómo se manejan las cosas comunes y corrientes movido por este afán que podemos calificar de "cientificista", pero que no deja de ser signo de una nueva cultura, evidencia de gestación de nuevos grupos sociales: los promotores y portadores del desarrollo científico. Esta es la razón por la que quizás el estudio de los efectos sociales de la biotecnología llama la atención, sobre todo si los avances de esa disciplina parecen representar a veces una amenaza y otras una promesa de bienestar sin precedente.

En esta circunstancia, los países de menor desarrollo relativo mal harían en alejarse de la corriente general de búsqueda de información y formación adecuada de profesionales, así como del establecimiento de contactos con quienes detentan los avances en el extranjero.

La primera medida de alenta debe consistir en estar informados.

La segunda, en mantener en actividad al personal que ha logrado calificarse en las nuevas disciplinas. Esto entraña vigilar la pervivencia del ambiente adecuado de su trabajo, con los medios materiales, satisfacciones materiales y espirituales, incentivos, pruebas de su utilidad práctica e intercambios con el exterior que son necesarios para evitar que el personal se aparte de la especialidad para la que se preparó.

La tercera medida consiste en insistir, aun contra las señales inmediatas provenientes del mercado, en la organización de empresas productoras tanto de servicios como de bienes a fin de aprovechar los conocimientos acumulados.

En nuestro país la actitud frente a la biotecnología no ha sido de rechazo; por el contrario, constituye uno de los vectores principales que orienta el desarrollo científico nacional. La información (optimista y pesimista) ha entrado sin negros augurios sobre nuevas dependencias, desastres económicos o de carácter ecológico. Se reconocen también los límites del desarrollo biotecnológico mexicano. Un diagnóstico ampliamente compartido de la situación de este campo en México podría ser el siguiente:

La industria biotecnológica nacional se caracteriza por la magnitud reducida de sus operaciones, por su dependencia tecnológica casi total, por la participación del Estodo en algunas áreas competitivas, y en lo que se refiere a la infraestructura de investigación y desarrollo, por contar con una fuerte tradición en biotecnología moderna y una buena posición para el desarrollo de la nueva biotecnología (Quintero, 1991:194). 
Pensamos que la arraigada tradición y la buena posición a la que se refiere la afirmación anterior reposan, sobre todo, en el personal capacitado en esta área. Sin embargo, en estos últimos años es la conservación y el aprovechamiento de ese personal donde puede observarse una política tambaleante, rasgo igualmente compartido por las otros dominios de la ciencia y la tecnología en México.

A esto quiere referirse este trabajo, pues la ausencia o fracaso de las medidas de aprovechamiento de los recursos humanos calificados puede dar al traste con lo que se ha logrado mediante los programas de formación de personal, los cuales, sin duda, representan uno de los mayores esfuerzos que en el campo de la promoción de la ciencia y la tecnología se han realizado en México. Por ello se impone un tratamiento adecuado, integral de la formación de personal en el que se reconozca que, para ser efectiva, ésta no puede disociarse del mantenimiento del personal calificado en actividades de investigación, lo cual exige armar un plan de aprovechamiento con los científicos disponibles en cualquier tipo de institución.

El presente trabajo pretende rescatar aquellos aspectos de índole económica y social que suelen ser pasados por alto muy a menudo al formular las políticas de fomento de la investigación en ciencia y tecnología. En particular, desde luego, nos referiremos a los elementos que deben tomarse en cuenta para el tratamiento satisfactorio del problema del aprovechamiento de los recursos materiales e intelectuales en biotecnología.

\section{EL CONTEXTO DEL CAMBIO TECNOLÓGICO}

Durante las dos últimas décadas, en el análisis del cambio social en general y de las transformaciones de la acumulación de capital en particular, se ha venido imponiendo un enfoque que pone de relieve las relaciones entre ciencia y tecnología y la conformación de nuevas estructuras productivas que constituirían las bases de un nuevo estadio de crecimiento y desarrollo económicos.

La crisis económica que se desató a principios de los años setenta se caracteriza dentro de este enfoque comó un proceso de restructuración tecnológico-productivo de gran envergadura, más que como una ruptura fundamental de los procesos de acumulación y sistemas de relaciones institucionales vigentes. Se pensaba que los efectos negativos de tal modernización, en particular el desempleo, serían superados una vez que la mutación tecnológica, concepło que también gana terreno en el análisis de la crisis, fuese un hecho asimilado por la planta productiva. 
El vector del cambio social era la gran transformación tecnológica que se producía en esos momentos: las nuevas tecnologías se presentaban como promesas claras y de grandes alcances para lograr una nueva etapa de crecimiento económico sin precedentes.

Los notables avances de la microelectrónica y su pareja, la informática, han tenido como producto inmediato la automatización de numerosos procesos productivos que sin duda han generado saltos cualitativos en la productividad en los lugares donde han sido aplicados de manera intensiva a través de máquinas herramientas de control numérico, robots industriales y los diversos sistemas computer aid design/computer aid manufacturing. Los nuevos materiales se presentan como nuevas posibilidades de utilizar minerales antes soslayados y de optimizar la utilización de otros a fin de lograr un uso más racional de los actuales recursos. Los mismos objetivos racionalizadores inspiran las investigaciones sobre otras fuentes de energía como la solar, la eólica o la originada en la biomasa. La biotecnología es otro vector fundamental del cambio tecnológico cuyos alcances aparecen sumamente prometedores y ricos en consecuencias; su aplicación a muchos campos como la agricultura, la ganadería, la farmacéutica y la química, a la misma generación de energía y a los esfuerzos de preservación del medio ambiente la convierten en eslabón clave de la transformación productiva en curso.

Basados en esta explosión de invención-innovación que ha caracterizado a este último tercio del siglo XX, difícilmente cobría albergar pesimismos sociales. Las expectativas de transformación virtuosa de los actuales sistemas económicos y la aparición en el horizonte cercano de soluciones a problemas de escasez alimentaria, energética, de remedios a la morbilidad planetaria, de oportunidades de empleo y generación de satisfactores materiales en la abundancia exigida por una población cuyas necesidades no han cesado de volverse cada más complejas, dependen de las posibilidades tecnológicas.

Si la idea de modernización tiene algún sentido claro y contundente, habría que encontrarlo en la identificación que se hace entre modernidad; desarrollo científico-tecnológico y elevación de la productividad global, vista esta última como el triunfo sobre la escasez y como expresión de la racionalidad económica.

Los resultados económicos de la década de los ochenta (en la que se esperaba que todas esas promesas se materializarian) parecieron, sin embargo, desmentir la capacidad de los incuestionables alcances científico-tecnológicos para llevar a cabo la transformación productiva que habría permitido superar definitivamente las tendencias de lento crecimiento, desempleo, deterioro de los recursos naturales y del medio ambiente en general predominantes en las principales economías modernas. 
Esta contradicción flagrante entre las potencialidades físicas de la revolución científico-tecnológica y la incopacidad de los sistemas actualmente constituidos para encauzarlas en un sentido progresivo constituve, a nuestro juicio, el principal problema que enfrento octualmente el desorrolo económico (Ominami, 1986:18).

Fueron estos resultados los que condujeron a cuestionar una idea que se aceptaba en los estudios sobre el crecimiento y desarrollo economicos: la relación causal que va del cambio técnico a la transformación económico-social. Hoy día, la reflexión económico-sociológica sobre el cambio técnico conduye (sin negar los alcances potenciales cientfficos y técnicos de las nuevas tecnologías) en la necesidad de invertir la relación causal tradicional: es la transformación de la matriz de relaciones economicas e institucionales de una formación social —algunos de cuyos elementos discutiremos más adelante-, lo que puede permitir que la ciencia y la tecnología prosperen y sus efectos sobre la productividad global de la economía puedan materializarse.

\section{"PRODUCTIVISMO" Y DESARROLLO DE LA CIENCIA Y LA TECNOLOGÍA}

Una de las consecuencias del enfoque tradicional del análisis de las relaciones entre cambio técnico y transformación productiva consiste en atender fundamentalmente la relación entre innovación y los niveles de producción que podrían obtenerse: deformación profesional de los economistas impuesta al resto de los científicos sociales. Dicha relación obliga a introducir en la formulación de políticas y estrategias de desarrollo tecnológico criterios sumamente restrictivos, proyección de una racionalidad administrativa y económica propias de la administración presupuestal de una unidad empresarial. Con ello se olvidan en la práctica, por más que se reivindiquen en el discurso, las múltiples determinaciones sociales del fenómeno tecnológico:

De ahí que el proceso que media entre la aparición de una determinada innovación tecnológica y su integración plena a un sistema social de producción esté sujeto a múlfiples determinaciones. Este proceso de adaptación del nivel micro al universo macro-social es tanto más complejo cuanto que, como ocurre actualmente, el viraje tecnológico no se circunscribe a áreas específicas sino que aborca al conjunto del sistema técnico y de la organización social (Ominami, 1986:21).

La misma reflexión puede hacerse a propósito del proceso de gestación de la innovación misma y no sólo a su inserción en el sistema 
productivo, aunque no fuera más que por el hecho de que el fracaso de esa inserción puede comprometer la posibilidad de continuar con las investigaciones futuras.

Si aceptamos la inversión de la relación causal antes propuesta, la reconceptualización del papel que desempeña la ciencia y la tecnología en la transformación de una economía deberá subordinar la relación técnica-producción a la búsqueda de una relación que de suyo y de entrada incluya la dimensión global del fenómeno tecnológico. Esta propuesta no intenta pecar de un "sociologismo" a ultranza, sino señalar la necesidad de rescatar la complejidad del fenómeno tecnológico al formular las políticas científico-tecnológicas.

\section{Azar y desperdicio}

La carencia de una teoría aceptada del cambio técnico ha obligado, cuando se ha recurrido a ella como base de la formulación de políticas de promoción de la ciencia y la tecnología, a sustituirla subrepticiamente por reglas generales derivadas de prácticas administrativas de corte eminentemente empresarial, las que, a su vez ly éste es el problema), terminan por sustentarse en criterios de rentabilidad económica inmediata. Al final, tanto las prócticas como los criterios se reducen las más de las veces a la relación entre un presupuesto y el producto generado por su aplicación. La formulación de las políticas de ciencia y tecnología al privilegiar la relación directa entre cienciatecnología, tomada ésta como insumo, y un determinado nivel de producción (o bien por una relación que es sólo una variante de aquélla: costos de la innovación en relación con las ganancias esperadas por aumento de la productividad directamente imputable a dicha innovación) propiciará políicas que inevitablemente dejarán de considerar el carácter azaroso o, si se prefiere, complejo de la tarea científica. El criterio de rentabilidad inmediata limita, empobrece, el horizonte posible de procesos de invención e innovación que podrían tener lugar bajo condiciones más flexibles y generosas de financiamiento de la ciencia y la tecnología.

También, al no cumplirse los resultados de rentabilidad esperados, el enfoque "productivista" considerará los desperdicios que producen inevitablemente las actividades que conducen a los desarrollos científicos-tecnológicos como índices definitivos de ineficiencia, incapacidad y fracaso de la labor cientíica; pero con ello se pierde de vista la dimensión global de esta labor y el hecho de que se trata de una tarea de largo plazo, por lo menos en lo que concierne a la ciencia básica, y que, en conjunto, cualquiera que sean los resultados inmediatos de ella (desde luego siempre obtenidos mediante el seguimiento de los 
métodos que la comunidad respectiva acepta como científicos) representan futuras posibilidades de experimentación y desarrollo, así como la creación de una experiencia científica y, en ocasiones, de infraestructura física que corresponderá al conjunto social aprovechar por caminos que no es posible prefijar antes de que aparezcan esos "desperdicios creadores". Al extenderse al terreno de la misma investigación básica, el enfoque productivista olvida la índole multifacética del proceso de adquisición por parte de la sociedad de una amplia base científica que es, al mismo tiempo, la condición primera para cualquier salto tecnológico-productivo.

El contenido del concepto de productividad significativo para el científico social es el de la productividad global de una formación social en su conjunto; lo que interesa son los mecanismos de la modernización general de la economía y de los comportamientos de los agentes económicos encaminados a reproducir las bases de esa transformación productiva en una escala cada vez mayor.

Desarrollo de la ciencia ... y de los científicos

Si pretendemos rescatar el carácter social del fenómeno tecnológico, y a partir de él explicar los determinantes y fuerzas que obran a favor de su desenvolvimiento como vector de transformación de la sociedad, no debemos olvidar una de las enseñanzas básicas de la economía y la sociología: los grupos sociales y las relaciones que se establecen entre ellos (su clasificación posterior en grupos de presión, clases sociales, etcétera, es otro problema teórico que sale de la presente discusión) constituyen la matriz donde se generan y emiten las fuerzas del cambio.

En este sentido, lo notable en la promoción de la ciencia y la tecnología es que su avance se sustenta mediante el desarrollo y fortalecimiento de un grupo social que es el portador y beneficiario inmediato de la modernidad: los científicos, los técnicos y los intelectuales. Lo primero que debe considerarse en las políticas científicotecnológicas no es cuánto contribuirán al mejoramiento de la producción, sino cómo pueden consolidar y fortalecer, ampliándolo, al grupo responsable, animador y portador de los cambios científico-tecnológicos.

No pensamos que esta posición signifique una suerte de antiproductivismo; más bien se trata de profundizar en una consideración que está presente en los muchos estudios realizados hasta el momento sobre los caminos seguidos por experiencias nacionales de desarrollo científico-tecnológico calificadas como "exitosas": el papel decisivo de las características sociales, $\mathrm{o}$, si se quiere, el contexto social y económico 
en que se encuentran inmersos los portadores y ejecutores de los proyectos de ciencia y tecnología. Como veremos en la última sección de este trabajo, en el caso de la biotecnología este elemento ha cobrado gran importancia.

Los esfuerzos en ciencia y tecnología venden esperanzas o bien un conjunto de cosas a las que la cultura del progreso les atribuye importancia; algunas de esas esperanzas llegan a materializarse por caminos muchas veces insospechados; resulta sumamente arriesgado determinar de antemano lo que la ciencia modificará de la producción, en qué sentido y en cuánto tiempo, pero lo que seguramente transformará es el estatus social y político del portador del esfuerzo cientfficotecnológico. Mediante los efectos esperados de la actividad científica, la valoración de la sociedad se vuelca a favor de estos portadores. Su proliferación, situación indisociable de un movimiento por elevar su posición económica y moral en la escala social, tiene un efecto de arrastre para la sociedad en su conjunto.

\section{La prioridad no debe significar exclusividad}

Si aceptamos lo anterior, deberemos reconocer también que el conjunto de criterios de evaluación de lo que debe favorecerse o eliminarse deberó construirse de tal manera que pueda relativizarse el peso que tradicionalmente suele atribuirse a los criterios estrechamente "economicistas", y que han conducido a una idea de prioridad fundada en la relación directa que se supone debe guardar tal innovación con tal incremento de producción.

Dicho criterio, que se presenta casi como universal pero que tan sólo define un tipo de prioridad, la mayor parte de las veces presenta un carácter excluyente. Este criterio de dictaminación, al final de cuentas, es cuestionado permanentemente en el terreno del quehacer cotidiano del investigador. La comunidad que realiza esta actividad sabe bien que el desarrollo científico no puede regirse por criterios de aplicabilidad y rentabilidad inmediatas. Finalmente, en estas condiciones, la idea de prioridad pierde todo sentido claro, unívoco.

Dentro de ciertos límites aceptados por la comunidad científica y la ideología del momento, la idea de lo prioritario se transforma casi inevitablemente, y como recurso para poner fin a discusiones interminables, en una propuesta del tipo de: hay que apoyar lo urgente y después lo necesario, sin dejar de apoyar todo lo demás. Propuesta que representa un gran recipiente que cada quien llenara según la correlación de fuerzas políticas y las ideologías que animen a esas fuerzas en la localidad. 
De cualquier modo, esta posición conciliadora comprende un aspecto positivo: se evita la tendencia a la exclusión que puede conducir a una excesiva concentración de recursos a favor de un conjunto reducido de proyectos. Bajo el argumento de racionalizar recursos escasos se escondería una ineficiencia mayor: monopolizar los medios que deberían estar disponibles para ampliar los esfuerzos cientificos.

Creemos, entonces, que deben prevalecer orientaciones de politica científica-tecnológica que eviten las posibilidades de que se inhiba la diversificación del desarrollo cientifico; es la diversidad la que conforma la base real de apoyo y la que permite estructurar la integración de programas de investigación de amplia cobertura y largo plazo y que, al mismo tiempo, produzcan resultados de corto plazo. Desde luego, la diversidad es una de las condiciones que posibilitan la renovación de las líneas de investigación que se consolidarán en nuevos proyectos en el futuro.

En la biotecnología, debido al carácter aún experimental de muchos de sus logros y a la falta de verificación práctica en la industria y en la agricultura de los alcances ciertamente extraordinarios que se le atribuyen, la discusión de lo prioritario se vuelve un problema todavía más complejo, pero que al mismo tiempo presenta un carácter predominantemente académico: evaluación de ventajas y desventajas de potencialidades. Las diferencias entre ecoagricultura y biotecnología ilustran esta polémica. Para muchos se trata de vías opuestas (Trujillo, 1990); para otros son actividades complementarias según los objetivos de desairollo productivo y social que se persigan (Barkin y Suárez, 1990); y para algunos más se trata de una cuestión de definiciones (R. Casas, 1991). Sin embargo, lo importante de esta discusión, y de acuerdo con el orden de cosas que hemos venido planteando, es, en todo caso, profundizar y rescatar el conocimiento de distintas posibilidades de hacer las cosas.

Desde un punto de vista estrictamente administrativo, establecer las prioridades para el empresario se resuelve en una regla: financiar lo que aparece como más cercano e inmediato de producir resultados satisfactorios, para poder financiar con ellos, quizá, los proyectos de más largo plazo. Tendríamos aquí una nueva fuente de incompatibilidad entre las preocupaciones del científico y las exigencias del mercado. Establecer los medios para superar estas diferencias en la concepción de lo prioritario probablemente sea una de las aportaciones más útiles de una política de ciencia y tecnología.

Las torres de marfil

Los científicos sociales han justificado su participación en los análisis de la ciencia y la tecnología sobre la base de la hipótesis de que el 
cambio técnico no se genera independientemente de un determinado contexto social; pero nos parece que no se ha insistido lo suficiente en una consecuencia de esta hipótesis: el éxito de un proyecto cientificotecnológico (medido por su cabal desarrollo e incorporación plena a la producción) no depende tanto de sus bondades intrínsecas como de la capacidad de recepción de la contraparte a la que se pretende dirigir ese proyecto. La incomprensión de este hecho ha impedido muchas veces que no se evalúen de manera correcta las verdaderas razones del fracaso o pérdida de dinamismo de proyectos y procesos de desarrollo científico-tecnológico que recibieron apoyos y fueron planeados en sí mismos de manera adecuada.

La toma de conciencia de esta situación, sin embargo, en lugar de llevar a la constitución de una visión integral de la ciencia y del aparato social y productivo, a menudo condujo al otro extremo, es decir, a sostener la idea de que sólo eran válidas (y por lo tanto merecedoras de apoyo) la ciencia y la tecnología consagradas inmediata y directamente a resolver los problemas prácticos del país. Todo aquel científico que saliera de esta orientación representaba una actitud elitista, aislacionista; se le acusaba de encerrarse en su "torre de marfil".

Con ello caíamos nuevamente, por otra vía, en el problema del desfase entre la preocupación del científico que gira alrededor de los avances propios de su disciplina, y las exigencias de un cierto medio económico y social en que se desenvuelve. El portador de las innovaciones por lo regular se ha formado en el extranjero, y su actividad se moldea en una búsqueda constante por alcanzar y ampliar las fronteras de su conocimiento. Es inevitable que de diversos modos se vea glejado de la realidad que lo rodea; que trabaje de tal modo que se haga acreedor a la acusación de estar en una "torre de marfil".

Esta situación se ve propiciada, además, por las maneras de evaluar de las instituciones que financian la actividad científica; ellas premian, sobre todo, el esfuerzo científico que mantiene en la punta a la ciencia nacional, y esto siempre siguiendo criterios y parámetros internacionales. $Y$ no podríamos encontrar nada fundamentalmente criticable en esto, de no ser por los excesos que se suelen cometer y la ausencia, en ocosiones, de un equilibrio entre los exigencias internacionales y las necesidades nacionales.

Sin embargo, esta falta de equilibrio en el que sin duda se ha incurrido no debe hacernos olvidar que es el atraso general de un medio social el que determina la creación de islas de modernidad científica, las cuales resultan inevitables en un país en vías de desarrollo. La política de ciencia y tecnología, si tiene éxito en promover la excelencia científica, es la principal constructora de "torres de marfil" y un índice de su eficiencia. Y qué bueno que así sea; siempre ha sido así. EI 
problema, entonces, no es eliminar esas islas, suprimiendo la investigación de punta, sino crear las condiciones para una mayor receptividad de la sociedad que la capacite para aceptar los proyectos de transformación implícitos en el trabajo del científico. Tenemos aquí otro campo muy rico para las propuestas de los científicos sociales.

Las anteriores consideraciones nos hacen adherirnos a una crítica que suele hacerse a los programas de planeación de la ciencia y la tecnología y que señala su carb́cter predominantemente "cientificista" y "ofertista". Es decir, se trata de una planeación que se dirige sólo al fomento de la capacidad científica y pasa por alto la "demanda". "Por ello las políticas parecen diseñadas en el vacío, ajenas a cualquier influencia del contexto social, económico y político" (Ávalos, 1990:170).

La relación entre la ciencia y la industria: la biotecnología y el mercado

La mayoría de los autores que se han ocupado del desarrollo y difusión de la nueva biotecnología reconoce la importancia que tiene en este proceso una relación eficaz y estrecha entre las universidades (donde se está generando gran parte del conocimiento de las nuevas tecnologías y la industria).

En el caso de México la relación universidad-industria no ha sido eficaz, en parte porque no ha habido otras condiciones que han tenido gran importancia en el florecimiento de la nueva biotecnología en los países de mayor desarrollo, y las cuales representan de muchos modos el contenido del modelo de relaciones socioeconómicas que favorecería una eficaz relación universidad-industria.

En Estados Unidos el desarrollo y difusión de la nueva biotecnología ha sido rápido e intenso; algunas de las condiciones identificadas como importantes para el florecimiento empresarial en este campo son:

- Centros universitarios de investigación en ciencias de la vida, de gran calidad y en gran cantidad (vale la pena subrayar esto último);

- Un clima favorable de inversión;

- Mercado de capital de riesgo de gran dinamismo;

- Una cultura que incentive la actividad empresarial;

- Calidad y costo de vida atractivos en los lugares donde se encuentran los centros de investigación.

Lo anterior, aunado a una eficaz relación universidad-industria, ha generado una gran actividad empresarial en Estados Unidos desde mediados de los años setenta. De tal suerte que en la actualidad se 
cuenta aproximadamente con 1100 empresas, de las cuales alrededor de 700 han nacido como empresas pequeñas, en donde el grupo empresarial innovador ha tenido entre sus integrantes a un investigador (generalmente a un científico universitario). Hay que señalar que las pequeñas empresas, por to regular individuales, surgen y al poco tiempo desaparecen. Algunas de ellas han sido abiertas exclusivamente para que negocios grandes absorban al personal científico que gracias a la pequeña empresa han podido exhibirse. Pocas perviven explotando sus innovaciones patentadas (Burril, 1990).

En Estados Unidos, aunque la biotecnología, como otras disciplinas, fue fomentada en sus inicios por el gobiemo, a partir de cierta fecha se ha convertido en campo de dominio casi exclusivo del capital privado, y las grandes compañías luchan por obtener las innovaciones y la protección de las patentes; a veces con su propio personal, otras con el ajeno.

\section{EI CASO MEXICANO}

En México la difusión de la tecnología biológica ha sido lenta y restringida. El proceso se inició en 198 ) (cinco años después que en Estados Unidos) y el número de empresas que se ha ormado en nueva biotecnología suma apenas diez. Esta cantidad, comparada con las 1100 empresas especializadas en biotecnologia que hay en Estados Unidos indica el escaso dinamismo, siempre relativo desde luego, de este sector. $Y$ es precisamente en esta sección donde abordaremos, en algunos de sus aspectos fundamentales, el análisis de las razones de esta deficiencia relativa, con hincapié en las relaciones universidad-industria, puesto que son ellas las que constituyen uno de los aspectos privilegiados del modelo de desarrollo tecnológico que se busca impulsar en México.

Dado el reducido número de empresas de la nueva biotecnología en el país, se tomaron como base de la información casos específicos que permitieron caracterizar algunos aspectos de la relación universidad-industria y la gerencia de la empresa, en particular la gerencia tecnológica. Los casos revisados permitieron llegar a la siguiente clasificación:

Empresa A: sector-rama: químico/especialidades químicas; actividades de la empresa: investigación y desarrollo; tipo de innovación: proceso/incremental.

Empresa B: sector-rama: químico/especialidades químicas; actividades de la empresa: investigación y desarrollo y produc- 
ción-comercialización; tipo de innovación: proceso/incremental.

Empresa C: sector-rama: agroindustrial/alimentos balanceados; actividades de la empresa: producción-comercialización; tipos de innovación: producto/incremental.

Empresa D: sector-rama: agroindustrial/micropropagación; actividades de la empresa: producción-comercialización; tipos de innovación: proceso/incremental.

Empresa E: sector-rama: agroindustrial/micropropagación; actividades de la empresa: producción-comercialización; tipos de innovación: proceso/incremental.

El período analizado abarca diez años, a lo largo de los cuales todas las empresas analizadas han tenido relaciones con universidades y centros de investigación. Salvo en la empresa A, la cual no está operando actualmente, la relación no ha sido fundamental y continua. Es importante resaltar que esta empresa se formó para avanzar en el trayecto laboratorio-producción, ya que hace diez años la infraestructura y organización para desarrollo en las universidades no era muy proclive a la innovación.

La empresa $B$ presenta una capacidad de innovación y tendencia a correr riesgos que está fuera de lo común, si se toma en cuenta la situación de la mayor parte del empresariado nacional. Sin embargo, esta empresa no ha tenido una relación fuerte con las universidades, pues en sus primeros acercamientos (también hace casi diez años) hubo puntos de desacuerdo con respecto a la propiedad de los resultados y a los tiempos; es decir, "el sentido de la urgencia" del empresariado no coincidía con el de las universidades, lo cual conducía a cancelar los contratos con ellas para continuar con los desarrollos en sus propias instalaciones.

Una decisión de este tipo, es necesario subrayarlo, sólo está al alcance de las empresas que cuentan con capacidad técnica para desarrollo y adaptación de tecnología disponible para emplearla en una empresa.

En el caso de la empresa $C$, la relación con la universidad fue fundamental en el arranque, ya que se trataba de una tecnología desarrollada originalmente en ella. Posteriormente se han mantenido relaciones más bien de tipo informal.

Las empresas D y E no han tenido una relación formal con la universidad, pero se han basado en investigaciones universitarias "del dominio público" (tesis de maestría y licenciatura). Muy recientemente la empresa $D$ inició una relación formal con un centro de investigación universitario especializado. 
De las cinco empresas analizadas, la que se acerca más al modelo norteamericano es la empresa A: tecnología universitaria; empresario emprendedor-universitario; actividades de investigación fundamentalmente; intensa relación con la universidad, etcétera; pero a diferencia de las empresas norteamericanas pequeñas, la cantidad de recursos que esta empresa consumía en actividades de I \& D era 25 veces menor a la de sus similares estadunidenses.

Presupuestos tan limitados, que por lo regular son de los que dispone la empresa mexicana, difícilmente darán lugar a nuevos desarrollos $y$, en caso de que se estuviera planteando una idea novedosa, la escasez de recursos asignados a su desarrollo haría que ésta pronto perdiera oportunidad. $Y$ como ya mencionamos, esta empresa, la primera de la nueva biotecnología que se estableció en el país, no está actualmente en operación.

En lo que se refiere a la empresa $B$, la cual realiza actividades de $1 \& D$ y ha demostrado una gran capacidad de innovación en el medio mexicano, la cantidad y la calificación de recursos humanos en I \& D permiten equipararla a una empresa estadunidense pequeña. Aun así sus actividades de producción y comercialización no incluyen productos nuevos, y las de I \& D han estado orientadas a apoyar sus procesos productivos actuales. Hasta muy recientemente ha comenzado a considerar la venta de sus logros tecnológicos como posible fuente de ingresos adicionales.

La empresa $C$ realiza actividades de I\&D de manera muy rudimentaria y más como un sesgo hacia la investigación por parte del empresario en cuestión que como una necesidad de la empresa y, por supuesto, sin cargo a ella.

Las empresas $D$ y $E$ prácticamente no realizan actividades de I \& D. Ambas empresas tienen amplios antecedentes en actividades de "puesta a punto" de sus tecnologías, y su origen se encuentra en la restructuración de la primera empresa en micropropagación que se estableció en el país. Recientemente comenzaron a estudiar la posibilidad de establecer una alianza estratégica entre ellas. De darse lo anterior, consideran que estarían en posibilidades de hacer I \& $D$ de manera formal y sistemática.

En síntesis, y sin mucho riesgo de violentar los datos sobre la comparación entre lo que sucede con el modelo norteamericano y el mexicano, podríamos afirmar que el hecho de que sólo se tengan diez nuevas empresas biotecnológicas (micro, pequeñas y medianas) pone de manifiesto la escasa propensión del empresariado nacional a correr riesgos, su falta de espíritu emprendedor, de visión a largo plazo, de información técnica y de mercado y de la capacidad para interpretarla. 
Por otra parte, el hecho de que cuatro de las cinco empresas analizadas no hayan tenido una relación formal y sistemática con las universidades, a pesar de que los empresarios mantenían actitudes positivas con respecto a ellas en general, y en especial con respecto a la I \& D realizada en sus recintos, pone de manifiesto que no había en las universidades mexicanas condiciones adecuadas para establecer esa relación. Son varias las razones de ello; exploremos algunas.

\section{Relación universidad-industria}

Es importante resaltar que la industria biotecnológica nacional, incluida la nueva industria, no produce bienes servicios nuevos. Todos los productos son conocidos, y la tecnología que se aplica en su producción generalmente se encuentra en el exterior, de donde por lo regular se ha adquirido.

En productos y procesos conocidos, las universidades o no se sienten atraídas o la falta de experiencia y rotación del personal de apoyo (tesistas y estudiantes), hace que los tiempos sean largos y las tecnologías extemporáneas. En productos nuevos, la experiencia es limitada y los tiempos han sido más largos que en el exterior (debido a la insuficiencia de recursos humanos, técnicos y económicos).

Por otro lado, las universidades generan "paquetes tecnológicos" incompletos; entre otras razones porque no es su función generarlos completos y ese tipo de conocimiento tecnológico, al igual que toda tecnología inmadura, requiere de capacidad técnica por parte del empresario para completar y adaptar e introducir por vez primera un desarrollo. Sin embargo, esa capacidad no ha sido demostrada por el empresario nacional, no sólo en el caso de la biotecnología, sino en el de todas las demás áreas.

Aunado a todo lo anterior, el capital de riesgo, fundamental para el desarrollo de la nueva biotecnología estadunidense, no apareció en nuestro país sino hasta épocas muy recientes; aunque en general se trata de un capital de "menor riesgo" que en otros terrenos. Primero que todo, este capital estaría apoyando avances de menor potencial de ganancia pero de menor riesgo ya que se considera elegibles a empresas con ventas de casi dos millones de dólares al año. Es decir, dicho capital no está preparado para apoyar ideas prometedoras que ofrezcan resultados a mediano y largo plazo. Por supuesto, no entra (ni ha entrado) en sus cálculos apoyar a investigadores emprendedores cuyas actividades en los primeros años se limita básicamente a crear tecnología, por lo que todo, en consecuencia, es pérdida, hasta que se realiza la primera vento. 
Por último, otra característica de la situación mexicana y que contrasta radicalmente con lo sucedido en el modelo estadunidense, es la larga crisis en la que quedó inmerso el país y cuyas secuelas todavía hoy imponen fuertes restricciones sobre el desarrollo cientifico y tecnologico nacional. Este hecho significo, durante la época en que no se tenía un mayor control sobre la inflación y la paridad cambiaria, dificultades notables para obtener el financiamiento en los montos requeridos y en el momento en que se necesitaba. Finalmente, cuando el financiamiento llegaba a otorgarse, la inflación y las devaluaciones hacían que no alcanzara a cubrir lo que se pretendía desarrollar.

El contexto económico desfavorable, sin embargo, sólo agudizaba el problema de fondo: las deficiencias de la relación empresa-universidad, las cuales, a su vez, se explican en buena parte por las diferentes visiones del empresario y del investigador:

- empresario: productos conocidos sin riesgo técnico, aunque presenten menor potencial comercial.

- investigador: productos nuevos (o que el investigador considera que son nuevos), aunque carezca de una idea clara de su potencial comercial.

Una política nacional en ciencia y tecnología deberfa, entonces, procurar incentivar de algún modo al empresario a que corra riesgos, o facilitarle esos compromisos.

En este terreno, los apoyos estatales a la pequeña empresa se vuelven fundamentales si consideramos los montos requeridos de inversión para el éxito relativo de algún proyecto. Un proyecto de I \& D de cinco personas dedicadas tiempo completo solamente por concepto de sueldos y salarios requiere de 60 mil dolares anvales (considerando sueldos universitarios), si se suponen 40 mil dólares por año de operación y de una inversión mínima de 25 mil dólares anuales para reposición de infraestructura, se totalizarían 125 mil dólares al año. Si se considera que las ramas más dinámicas invierten el $10 \%$ de sus ventas anuales en I \& $D$, se estaría hablando de una empresa que debería contar con ventas de 1250000 dólares por año, y ésa ya no es una empresa pequeña para las características del mercado mexicano. De ahí la afirmación de que la pequeña y mediana empresa se encuentren desplazadas de estos mercados, a menos que la política nacional plantee algún modo de participación estatal en esos desarrollos, o servicios centralizados; por ejemplo: la unificación de varias empresas para financiar un proyecto tecnológico de interés común.

Vemos entonces que buena parte de los problemas que enfrenta el fomento de la biotecnología en páses de menor desarrollo como 
México podrían resumirse en: a) cómo enfrentan el problema del financiamiento por parte de empresas pequeñas y medianas, base del modelo de desarrollo de la biotecnología mexicana; b) cómo enfrentar un mercado dominado por los intereses a largo plazo de las grandes empresas multinacionales y que se expresan, entre otras cosas, en la imposición de orientaciones tecnológicas que no son necesariamente compatibles con el entorno económico nacional.

Dentro de las posibles respuestas a esta problemática surge una inevitable: la recomendación de que el financiamiento público deba ser el apoyo privilegiado de los proyectos biotecnológicos. $Y$ en lo que respecta al sector privado, deberón estimularse iniciativas que conformen una nueva cultura empresarial que propicie un tipo de inversión cuya dinámica no dependa de obtener una elevada rentabilidad inmediata, y que, por tanto, sea capaz de resistir los plazos largos de maduración y los riesgos de inversión implícitos en los proyectos sobre nuevas tecnologías. Es claro que dentro de esta nueva cultura empresarial desempeñarán un papel fundamental los conocimientos y capacitación que se ponga al alcance de los inversionistas que les permitan adentrarse y experimentar por las numerosas vías gerenciales, comerciales y de gestión tecnológica existentes, sobre todo en el campo de la biotecnología, para competir eficazmente.

Desde luego, la intervención del Estado deberá propiciar, en particular, una investigación de los campos de aplicación hasta ahora inatendidos, particularmente los que constituyen todavía las franjas de marginación social, las zonas de la pequeña empresa o los de la peculiaridad regional, campos en donde la biotecnología parece tener especiales aptitudes para formular soluciones más eficaces.

Las conclusiones de esta sección nos señalan implícitamente, en el nivel de los comportamientos microeconómicos, un conjunto de elementos de carácter global, macroeconómico, que traban no sólo la consolidación y conclusión feliz de iniciativas científico-tecnológicas una vez que éstas ya han aparecido, sino que incluso anulan la posibilidad del mero surgimiento de iniciativas. Las mejores intenciones del programa mejor estructurado de promoción científico-tecnológica se desvirtúan ante la acción corrosiva de obstáculos a los que hemos denominado "sociopolíticos", según el estudio de un biotecnólogo reconocido que rescata, en un reciente trabajo (Niniegra, 1991), la importancia de estos obstáculos. Sirva esto, además, como defensa de probables acusaciones de parcialidades economicistas y sociológicas de nuestra parte: cada vez es más clara la conciencia que los científicos de las llamadas ciencias "duras" tienen acerca de los determinantes globales sobre la ciencia y la tecnología que provienen del patrón de desarrollo económico dominante. 


\section{Modelos de desarrollo económico y su contenido tecnológico}

Dichos determinantes tienen que ver con los procesos de evaluación-selección de tecnologías que al final conforman los programas de promoción científico-tecnológica de un país. Estos procesos contemplan limitantes de tres órdenes: naturales, esto es, las leyes físicas, químicas y biológicas que determinan la factibilidad científica de un proyecto; técnico-económicas, es decir, las condiciones propicias o no de disponibilidad de insumos, financiamiento y mercado para un producto, $y$, finalmente, ligadas a estas últimas, las de orden sociopolítico. Dentro de éstas podemos englobar un conjunto de prácticas discriminatorias de muy diverso origen social e institucional que hacen que un conjunto de proyectos se presente como carente de viabilidad dada una estructura específica de poder económico y político imperantes. Los factores sociopolíticos, en palabras de nuestro autor antes citado,

Son los que limitan la posibilidad de asumir una decisión en función de los intereses sociales y políticos dominantes. Depende de las relaciones sociales, de los intereses de los grandes grupos comerciales, de la aceptación comercial de los productos, de la penetración en el mercado por las empresas vendedoras y del apoyo político y financiero otorgado a cada proyecto. Finalmente es lo que acaba por definir la selección en muy pocas alternativas viables para el desarrollo de nuevos productos (Viniegra, 1991:220).

Alternativas viables que en países en vías de desarrollo se expresarán en la pobreza del programa científico-tecnológico que logra sobrevivir en un momento dado y cuyas limitaciones mantienen en el atraso y dependencia tecnológicas a una nación.

En este punto resulta inevitable ser explícito; el argumento: la acción de los oligopolios internacionales presenta un papel determinante en la imposición de orientaciones de desarrollo tecnológico e inhibición de propuestas contrarias a sus intereses. Por otro lado, cuando se habla de competir en los mismos mercados de estas grandes empresas, no se subraya lo suficiente los muchos apoyos que ellas reciben de sus gobiernos mediante diversas agencias e institutos públicos y privados de investigación. No suele mencionarse o dar el valor que le corresponde al hecho de que la estrategia adoptada para enfrentar la competencia en el mercado mundial por parte de esas grandes corporaciones (además de ser coordinada por los Estados de esas potencias) busca sustentarse en la independencia en la disposición 
de insumos claves y en un desarrollo tecnológico recreado y controlado fundamentalmente por fuerzas económicas nacionales. La contrapartida de esta estrategia de soberanía tecnológica la encontramos en la exigencia de la ampliación y profundización del mercado interno como el principal medio de fortalecimiento de la posición negociadora de los países más industrializados. A pesar de la posición globalista que propone que las nuevas fuentes del crecimiento económico se encuentran en el mercado mundial, los países más industrializados son los más celosos protectores de su mercado interno. Todos esos factores generales y los particulares que de ellos se derivan conforman el marco socioeconómico al que debe enfrentarse el desenvolvimiento de la generación de alternativas científicas y tecnológicas en nuestros países.

\section{LA ESTRATEGIA: DIVERSIDAD Y FLEXIBILIDAD}

Ante una situación en la que empresas gigantescas están a la cabeza de la expansión hacia otros países, absorbiendo adelantos personales de todos lados, con la fuerza de la organización no sólo de la propia estructura de la corporación, sino del medio donde provienen, bien vale la pena considerar la reorganización de nuestros recursos para hacer frente a estrategias de expansión y de inversión que no tienen por qué preguntar sobre nuestros intereses.

En las páginas anteriores hemos indagado sobre algunos elementos que deben ser considerados en las respuestas que se formulen sobre cuáles pueden ser los caminos y medios que articulen eficazmente el laboratorio universitario con la unidad productiva. Del mismo modo, hemos buscado rescatar los aspectos del ámbito socioeconómico que debieran privilegiarse en la conformación y evaluación de las políticas de planeación del desarrollo tecnológico, aspectos que precisamente una visión estrechamente economicista se ha encargado de ocultar. Hemos intentado, en este sentido, rescatar los elementos que deberían defenderse en un proyecto nacional de creación de las condiciones para lograr una capacidad de innovación tecnológica nacional, cuyos resultados puedan incorporarse efectivamente de manera generalizada a la planta productiva nacional, proporcionándole la competitividad internacional que requiere su sobrevivencia. En este punto son dos las conclusiones a las que podemos llegar: flexibilidad y diversidad.

La teoría económica no carece de análisis que en principio deberían permitir descartar tal o cual vía de desarrollo tecnológico. La mayor parte de ellos pone en primer plano una optimización de los recursos que se traduce en centralización de decisiones, rentabilidad inmediata de las inversiones, justificación de los proyectos por su efecto directo 
en los incrementos de los volúmenes de producción y mayor participación de las empresas en los mercados, y de la economía nacional en el ámbito mundial. Las políticas de promoción cientffica y tecnológica se asumen así en una rigidez de criterios avalada por la fuerza de los argumentos estrictamente económicos.

Sin embargo, en el momento de buscar la comprobación empírica de tales estrategias, el comportamiento de las empresas y de la historia misma de los avances tecnológico-productivos invalidan las generalizaciones de optimización de recursos; es decir, al final, la generalización presenta su lado más negativo: la simplificación.

No creemos que estaríamos ejerciendo un excesivo reduccionismo interpretativo si dijéramos que en la búsqueda por determinar las relaciones entre la ciencia y la tecnología y el crecimiento económico, la rica bibliografía al respecto producida en las dos últimas décadas ha destacado un hecho: las dificultades para establecer caminos probados y únicos para crear capacidades científico-tecnológicas que a su vez sean la base de un desarrollo productivo sostenido. Los estudios de caso de empresas demuestran la diversidad de estrategias que, según el contexto económico y social, pueden tener éxito. Cuando el análisis ha abarcado a la nación, las conclusiones a este respecto son similares.

Vale la pena citar dos conclusiones de un experto en el tema, $\mathrm{N}$. Rosemberg, una de ellas citada por otro reconocido analista de los problemas de gestión tecnológica en América Latina, J. Mercovitch:

En su estudio sobre la riqueza de Occidente, Rosemberg y Birdzell concluyen que el éxito tecnológico allí alcanzado se debe principalmente:

1) a la descentralización de la selección de los proyectos innovadores, que favoreció la distribución de la decisión en innumerables firmas, las cuales, en busca de recompensas ofrecidas por nuevas franjas de mercado, ponían en jaque a las empresas tradicionales que no reaccionaban ante los cambios.

2) a las empresas innovadoras que, al adoptar las nuevas tecnologías, obtuvieron las recompensas ofrecidas por el mercado cuando las innovaciones introducidas tuvieron éxito.

3) a la organización de la investigación, constituida jerárquicamente flexible. La investigación, por haber sido financiada por numerosas entidades, dificultó la adopción de directrices ideológicas ńgidas (Mercovitch, 1989:164).

Los autores observan que el desarrollo económico produce crecimiento económico, pero que el desarrollo del saber científico y tecnológico sólo se transformó en crecimiento económico continuo porque 
hubo un consenso social favorable a la ciencia. Este consenso favoreció el uso de las innovaciones y fue paralelo a la existencia de un grado significativo de libertad política y religiosa, libertades que permiten crear formas de organización adecuadas a las nuevas tareas que exige todo proceso de crecimiento.

En otro trabajo Rosemberg afirma que

las exactas disposiciones institucionales que contribuirán al éxito siempre serán difíciles de especificar a priori. Quisiera indicar que esto sucede así, sobre todo porque el éxito o fracaso depende siempre del medio en que está inmersa una institución determinada, es decir, del complejo de otras instituciones así como de valores y tradiciones muy compartidos que afectan de manera crítica su funcionamiento ... El tipo de instituciones que funcionarán con éxito en un medio determinado es algo sobre lo que no se puede generalizar con facilidad a priori. Sin duda esto está confirmado por nuestra historia y experiencia reciente, que indica que una amplia diversidad de tácticas de organización han demostrado ser útiles (Rosemberg, 1979:189).

Hemos deseado terminar este conjunto de reflexiones y señalamientos sobre los elementos que deben considerarse en una política de promoción de la ciencia y la tecnología con otra deformación profesional de la práctica académica: apelar a la autoridad reconocida internacional. De cualquier modo, creemos que lo señalado se aplica en particular a la biotecnología, cuyas repercusiones sobre una amplisima gama de actividades productivas de hecho la convierten en el vector principal de los desarrollos científicos y productivos de las próximas décadas. Si el científico social pretende establecer el puente entre el trabajo del ingeniero y el medio macroeconómico y macrosocial en donde las invenciones e innovaciones tendrán su sanción definitiva, deberá volver sus ojos al análisis de las condiciones sociales en que tal o cual estrategia o institución específica puede alcanzar sus objetivos, independientemente de las bondades técnicas o administrativas inherentes a los proyectos o programas de planeación.

\section{BIBLIOGRAFÍA}

Ávalos, I., y Antonorsi, M. 1990. La planificacion de ilusiones. Caracas: Ed. Ateneo.

Barkin, David, y Suárez, B. 1990. "El impacto de la biotecnología en la agricultura mexicana". Biotecnología para el progreso de México. México: Centro de Ecodesarrollo. 
Burrill, G. Steven. 1990. "Changing Environment in Biotechnology". Compilado por Arthur Young. High Technology Group.

Casas, Rosalba. 1991. "Las capacidades de investigación biotecnologica y su relevancia para el sector agroalimentario. Tendencias durante la década de 1980". Documento presentado en el seminario permanente interinstitucional sobre efectos socioeconómicos de la biotecnología, UNAM-UAM, julio.

Freeman, Chr. 1989. "The nature of innovation and the evolution of the productive system". International Seminar on Science Technology and Economic Growth. París: OCDE.

Mercovitch, Jacques. 1989. "Tecnología y competitividad". PROTEC 91. México: CIT-UNAM, 1991.

Ominami, Carlos. 1986. "Tercera revolución industrial y opciones de desarrollo". La tercera revolución industrial; impactos internacionales del actual viraje tecnológico. Buenos Aires: Editorial GEL.

Quintero R., Rodolfo. 1991. "Biotecnología". México ante las nuevas tecnologías. Compilado por L. Corona. México: CIIH-UNAM-Porrúa.

Rosemberg, Nathan. 1979. Tecnología y economía. Barcelona: Ed. Gustavo Gili.

Sabato, Jorge, y Botana, Natalio. 1975. "La ciencia y la tecnología en el desarrollo futuro de América Latina". El pensamiento latinoamericano en la problemática ciencio-tecnología-desarroIlo-dependencia. Compilado por J. Sábato. Buenos Aires: Paidós.

Trujillo, Javier. 1990. "Biotecnología o agroecología: selección de paradigma tecnológico para el desarrollo campesino en México". ¿̇Biotecnología para el progreso de México? Compilado por Blanca Suárez. México: Centro de Ecodesarrollo.

Viniegra González, G. 1991. "Objetivos para la biotecnología en Mexico". México ante las nuevas tecnologías. Compilado por $\mathrm{L}$. Corona. México: CIIH.UNAM-Porrúa. 


\title{
Importancia de la reflexión prospectiva en el desarrollo bioteenológico'
}

\author{
JOSÉ LUIS SOLLEIRO,* ROSA LUZ GONZÁLEZ* \\ Y SILVIA ALMANZA**
}

\section{INTRODUCCIÓN}

Después de la microelectrónica, se ha reconocido a la biotecnología como la segunda revolución científica y tecnológica de la última mitad de este siglo. Quienes califican el carácter de la biotecnología como revolucionario se basan en su amplia gama de aplicaciones, que abarca múltiples áreas de la actividad productiva, relacionada con muchas necesidades humanas (Solleiro y Arriaga, 1990).

En México el potencial de las nuevas biotecnologías ha sido ampliamente reconocido y se ha impulsado la creación de infraestructura y recursos humanos para su desarrollo. Sin embargo, hasta hoy México carece de una estrategia propia de desarrollo biotecnológico, razón por la que los esfuerzos de investigación han estado dispersos y alejados de la realidad del mercado. De hecho una gran parte de los procesos generados en los centros de investigación se detiene por su poca rentabilidad o porque simplemente no es posible demostrar su factibilidad económica (Casas, 1987).

Ante esta circunstancia, los autores del presente trabajo, desde hace poco más de un año, hemos realizado una serie de actividades que nos han permitido estructurar y poner en marcha el proyecto de

' Los autores desean hacer patente su gratitud al Programa de Apoyo a Programas de Investigación e Innovación Docente de la UNAM, así como al Centro Internacional de Investigaciones para el Desarrollo de Canadá (IDRC) por el apoyo financiero otorgado al Proyecto. El Programa Universitario de Alimentos de la UNAM aportó los fondos para la concepción inicial del proyecto.

- Centro para la Innovación Tecnológica, UNaM.

** Instituto de Fisiología Celular, UNAM. 
investigación "Determinación de Prioridades de Investigación y Desarrollo de Mecanismos de Fomento en Biotecnología" (proyecto "Prospectiva en Biotecnología"). Su intención es aportar elementos metodológicos que refuercen la capacidad de instituciones y de grupos para identificar, jerarquizar y aplicar criterios que impartan racionalidad al proceso de asignación de recursos, de modo que la investigación y el desarrollo (I\&D) en biotecnología realmente llegue a realizar objetivos económicos y sociales, tomando en cuenta además su inserción en entornos cambiantes.

La herramienta clave para lograr este objetivo es la incorporación de técnicas de prospectiva de la investigación. En el presente trabajo se analiza el valor y la importancia de estas técnicas para la planificación de la I \& D.

\section{LA NECESIDAD DE HACER PROSPECTIVA EN LA INVESTIGACIÓN}

El reciente interés por la prospectiva proviene en buena medida del reconocimiento, dentro del gobierno, de que la planeación a largo plazo de la investigación es inevitable en una era de creciente competencia en los mercados globales.

En efecto, una de las principales preocupaciones gubernamentales en el mundo de hoy es la estructuración de políticas que permitan aumentar la capacidad competitiva de sus países en el plano internacional.

Desde la Segunda Guerra Mundial, la índole y las características de los bienes comerciales están sufriendo un cambio radical, debido en gran parte a las iniciativas tomadas en el lado de la oferta por parte de gobiernos y empresarios que han estado privilegiando cada vez más la función innovadora.

De esta manera, las ventajas comparativas y las bases de los recursos se van desasociando de los factores geográficos tradicionales para ser moldeados por factores de innovación predeterminados por el hombre, de tal modo que la competitividad de un país se va haciendo cada vez mós dependiente de la capacidad de innovación, lo cual nos remite directamente a la actividad de la I \& $D$, a recursos humanos calificados y a gastos de inversión de capital.

Así pues, varias naciones europeas han reconocido que deben responder al reto de la competitividad manejando la investigación como un recurso estratégico. Por eso dichos países necesitan un sistema oportuno de alerta sobre los desarrollos más promisorios en ciencia y tecnología hacia los cuales canalizarán fondos con el fin de asegurar la prosperidad y el progreso social durante las próximas décadas 
(Elzinga, 1986). Sin embargo, no basta tener conciencia sobre las oportunidades de investigación. Se requiere información sobre tres grupos de factores (Martin e Irvine, 1989):

i) Tendencias esperadas en las necesidades socioeconómicas, así como en las demandas para la investigación.

ii) Fortalezas y debilidades intemas en 1 \& $D$ y ubicación relativa a nivel internacional a lo largo de los diferentes campos científicos y tecnológicos considerados estratégicos.

iii) La capacidad doméstica para explotar comercialmente, o de cualquier otra manera, los resultados de las investigaciones promisorias.

Por otro lado, los mecanismos tradicionales para establecer políticas de investigación, basadas en la opinión de colegas (peer review) están estructurados de acuerdo con líneas unidisciplinarias, que no corresponden a la necesidad de enfoques sistémicos para la toma de decisiones, que son los que se requieren para campos eminentemente multidisciplinarios como la biotecnología.

La prospectiva aporta un mecanismo sistemático para abordar la complejidad y la interdependencia propias de la planeación a largo plazo de la investigación, lo cual facilita establecer políticas en los casos en que la integración de actividades en diversos campos resulte vital.

Finalmente, es importante destacar el carácter de la prospectiva como "ciencia de la acción" (Álvarez, 1991), en el sentido de que la corriente moderna de aplicación de esta herramienta de análisis abandona la característica puramente exploratoria para buscar una racionalidad de anticipación y normativa del futuro.

Este carácter preventivo exige reconocer que las elecciones hechas ahora pueden conformar o crear el futuro, y que no tiene mucho sentido realizar simples predicciones determinísticas en esferas donde los procesos políticos y sociales ejercen una influencia decisivn.

De esta manera, en nuestro proyecto buscamos apegarnos a la definición de prospectiva formulada por Coates (1985):

Un proceso mediante el cual se llega a una comprensión más completo de las fuerzas que conforman el futuro a largo plazo que deben tomarse en cuenta en la formulación de políticas, en la planeación y en la toma de decisiones ... La Prospectiva incluye los medios cuantitativos y cualitativos para monitorear indicios e indicadores de tendencias evolutivas y desarrollos, y encuentra el mejor terreno de aplicación cuando se le vincula directamente al análisis de las implicaciones de política. La Prospectiva 
nos prepara para tender las necesidades y oportunidades del futuro. La Prospectiva en el gobiemo no puede definir políticas, pero puede ayudar para que las políticas sean más apropiadas, más flexibles y más sólidas en su implantación, dado que los tiempos y circunstancias cambian. La Prospectiva, por eso, estó íntimamente ligada a la planeación. No es planeación, sólo un paso de la planeación.

\section{LA EXPERIENCIA MEXICANA EN PROSPECTIVA DE LA BIOTECNOLOGIAA}

Los antecedentes del proyecto

En México se han realizado muchos esfuerzos por impulsar el desarrollo y difusión de la biotecnología moderna. En lo que se refiere a prospectiva y formulación de políticas de desarrollo, en su mayor parte han sido resultados de iniciativas de origen universitario y con carácter más bien exploratorio (individuos y grupos); aunque ha habido también actividades promovidas por el gobierno, como se puede apreciar en el cuadro 1. Sin embargo, ni los esfuerzos directos gubernamentales, ni los no gubernamentales, han cristalizado en una política explícita e integral para la biotecnología mexicana, que articule y potencie las acciones que se han tomado en torno a ella.

El proyecto "La Alimentación del Futuro", realizado en la UNAM en 1981 y 1982, ha sido uno de los intentos más ambiciosos realizados en el país para moldear el futuro de la investigación en este campo; pero no cristalizó en acciones concretas. "México 2010" es otro ambicioso estudio prospectivo que está siendo realizado por la "Fundación Javier Barros Sierra" desde hace cinco años y que servirá de base para determinar los escenarios más probables de lo que se podrá hacer si éstos se presentan.

Un estudio muy reciente realizado para la Secretaría de Relaciones Exteriores (Blanco, 1991) detecta prioridades de I \& D en biotecnología en el país con propósitos de cooperación internacional; los resultados están siendo actualmente revisados por el Instituto de Biotecnología de la UNAM (IB). El estudio se basó en un análisis sobre la inserción de la biotecnología en las cadenas productivas.

En el plano internacional, la determinación de prioridades en I \& D - la detección de oportunidades en el campo de la biotecnología constituyen un quehacer cotidiano, una realidad a nivel macro y empresarial; pero no se ha reportado mucho sobre los aspectos metodológicos. 
CUADRO 1

LOS ESFUERZOS GUBERNAMENTALES EN PROSPECTNA DE LA BIOTECNOLOGÍA EN MÉXICO

\begin{tabular}{|c|c|c|c|c|c|}
\hline Año & \begin{tabular}{|c|}
$\begin{array}{c}\text { Dependen- } \\
\text { cia }\end{array}$ \\
\end{tabular} & $\begin{array}{l}\text { Tipo de } \\
\text { esfuerzo }\end{array}$ & Características & $\begin{array}{c}\text { Aciertos y } \\
\text { limitaciones }\end{array}$ & $\begin{array}{c}\text { Proyecto } \\
\text { dominante }\end{array}$ \\
\hline 1981.1982 & \begin{tabular}{|l|} 
Secretaría \\
de \\
Programación \\
y \\
Presupuesto \\
(spp) \\
Dirección \\
General de \\
Análisis de \\
Ramas \\
Económicas.
\end{tabular} & $\begin{array}{l}\text { Realización de } \\
\text { un estudio del } \\
\text { análisis técnico: } \\
\text { "Análisis y } \\
\text { Expectativas de } \\
\text { la Biotecnología } \\
\text { en México". }\end{array}$ & $\begin{array}{l}\text { Realizado por } \\
\text { una empresa } \\
\text { consultora } \\
\text { privada. } \\
\text { Un año de } \\
\text { duración. } \\
\text { Participación de } \\
\text { ocho expertos } \\
\text { técnicos de alto } \\
\text { nivel y un grupo } \\
\text { bósico de } \\
\text { trabajo, } \\
\text { orientado a } \\
\text { biotecnología } \\
\text { industrial (uso } \\
\text { de microorga- } \\
\text { nismos, sus } \\
\text { partes o } \\
\text { componentes). } \\
\text { Participación } \\
\text { del Programa } \\
\text { Universitario de } \\
\text { Alimentos (PUAl- } \\
\text { UnAM) en el } \\
\text { desarrollo final } \\
\text { del estudio. }\end{array}$ & $\begin{array}{l}\text { Se utilizó un } \\
\text { marco } \\
\text { conceptual } \\
\text { que explica } \\
\text { el fenómeno } \\
\text { de } \\
\text { desarrollo y } \\
\text { difusión de } \\
\text { una nueva } \\
\text { tecnología } \\
\text { en modo } \\
\text { ocertado. } \\
\text { La } \\
\text { biotecnología } \\
\text { se clasificó y } \\
\text { se } \\
\text { establecieron } \\
\text { categorías } \\
\text { de análisis. } \\
\text { Recursos } \\
\text { económicos } \\
\text { limitados } \\
\text { para su } \\
\text { realización. } \\
\text { Dominio de } \\
\text { la } \\
\text { perspectiva } \\
\text { técnica. } \\
\text { El estudio } \\
\text { tuvo una } \\
\text { circulación } \\
\text { muy limitoda } \\
\text { y no logró } \\
\text { trascender } \\
\text { en un plan } \\
\text { de acción } \\
\text { en biotecno- } \\
\text { logía. }\end{array}$ & $\begin{array}{l}\text { Nacional: } \\
\text { esquemas } \\
\text { proteccionistas a la } \\
\text { industria en donde } \\
\text { la necesidad de } \\
\text { innovar no es tan } \\
\text { clara. } \\
\text { La biotecnología } \\
\text { más importante en } \\
\text { volumen y valor era } \\
\text { la de primera } \\
\text { generación, en la } \\
\text { cual las } \\
\text { oportunidades eran } \\
\text { menos } \\
\text { espectaculares. } \\
\text { La biotecnología } \\
\text { de segunda } \\
\text { generación } \\
\text { dominada por } \\
\text { inversión extranjera. } \\
\text { Percepción } \\
\text { incipiente de las } \\
\text { potencialidades } \\
\text { ofrecidas por la } \\
\text { biotecnología. } \\
\text { Marco institucional } \\
\text { universitario poco } \\
\text { propicio para } \\
\text { interactuar con la } \\
\text { industria; reducido } \\
\text { número de } \\
\text { investigadores con } \\
\text { poca experiencia } \\
\text { en investigación. } \\
\text { Institucional: virajes } \\
\text { en la politica } \\
\text { gubernamental. }\end{array}$ \\
\hline 1982 & $\begin{array}{l}\text { Secretaría } \\
\text { de } \\
\text { Patrimonio y } \\
\text { Fomento } \\
\text { Industrial } \\
\text { (SEPAfIN), } \\
\text { Dirección } \\
\text { de } \\
\text { Inversiones } \\
\text { Extranjeras. }\end{array}$ & $\begin{array}{l}\text { Institucionali- } \\
\text { zación de un } \\
\text { mecanismo de } \\
\text { evaluación y } \\
\text { prospección de } \\
\text { tecnología: } \\
\text { "Sistema } \\
\text { Nacional de } \\
\text { Prospectiva } \\
\text { Tecnológica". }\end{array}$ & $\begin{array}{l}\text { Foro de análisis } \\
\text { sobre las } \\
\text { potencialidades y } \\
\text { amenazas de la } \\
\text { biotecnología. } \\
\text { Participación } \\
\text { Interinstitucional. } \\
\text { Enfoque } \\
\text { multidisciplinario. }\end{array}$ & $\begin{array}{l}\text { Efímero, no } \\
\text { logró } \\
\text { trascender ol } \\
\text { cambio } \\
\text { sexenal. } \\
\text { Sin ligas } \\
\text { claras hacia } \\
\text { el poder } \\
\text { legislativo. }\end{array}$ & Igual al anterior. \\
\hline
\end{tabular}


(continúa CUADRO 1)

\begin{tabular}{|c|c|c|c|c|c|}
\hline Año & \begin{tabular}{|c|}
$\begin{array}{c}\text { Dependen- } \\
\text { cia }\end{array}$ \\
\end{tabular} & $\begin{array}{l}\text { Tipo de } \\
\text { esfuerzo }\end{array}$ & Características & $\begin{array}{c}\text { Aciertos y } \\
\text { limitaciones }\end{array}$ & $\begin{array}{c}\text { Proyecto } \\
\text { dominante }\end{array}$ \\
\hline 1984.1985 & $\begin{array}{l}\text { Consejo } \\
\text { Nacional de } \\
\text { Ciencia y } \\
\text { Tecnología. } \\
\text { Dirección } \\
\text { Adjunta de } \\
\text { Desarrollo } \\
\text { Tecnologico. }\end{array}$ & $\begin{array}{l}\text { Realización de } \\
\text { un estudio de } \\
\text { evaluación y } \\
\text { prospección de } \\
\text { tecnología } \\
\text { Technology } \\
\text { Assessment). }\end{array}$ & $\begin{array}{l}\text { La } \\
\text { responsabilidad } \\
\text { y recursos } \\
\text { fueron } \\
\text { asignados a un } \\
\text { experto en } \\
\text { biotecnología } \\
\text { (sin rolación } \\
\text { laboral con el } \\
\text { conacnT), el } \\
\text { cual } \\
\text { subcontrató } \\
\text { instituciones y } \\
\text { personas con } \\
\text { experiencia en } \\
\text { prospectiva } \\
\text { tecnológica: } \\
\text { Fundación } \\
\text { Barros Sierra, } \\
\text { Centro de } \\
\text { Investigación en } \\
\text { Química } \\
\text { Aplicada, un } \\
\text { gran número de } \\
\text { expertos, } \\
\text { etcétera. }\end{array}$ & $\begin{array}{l}\text { Esfuerzo } \\
\text { integral y } \\
\text { participativo. } \\
\text { So } \\
\text { realizaron } \\
\text { talleros y } \\
\text { estudios } \\
\text { nacionales y } \\
\text { regionales. } \\
\text { Estudios } \\
\text { focales para } \\
\text { areas } \\
\text { cientifico- } \\
\text { tecnologicas } \\
\text { importantes } \\
\text { para la } \\
\text { biotecnología } \\
\text { y en las que } \\
\text { se trabaja } \\
\text { activamente } \\
\text { on el pais. } \\
\text { Dificultades } \\
\text { para } \\
\text { integrar el } \\
\text { reporte final } \\
\text { (frecuentes } \\
\text { en este tipo } \\
\text { de estudios). } \\
\end{array}$ & $\begin{array}{l}\text { Nacional: crisis } \\
\text { económica y social } \\
\text { coda vez más } \\
\text { grave. Proceso } \\
\text { inflacionario } \\
\text { acelerado; } \\
\text { devaluaciones } \\
\text { frecuentes de la } \\
\text { moneda; control } \\
\text { de cambios. } \\
\text { Inicio de la } \\
\text { apertura comercial. } \\
\text { Predominio de la } \\
\text { mentalidad de } \\
\text { corto plazo on la } \\
\text { industria poco } \\
\text { propicia para i \& D. } \\
\text { Escaso inteŕss en } \\
\text { tecnología } \\
\text { endógena. } \\
\text { Desarticulación } \\
\text { universidad-sec- } \\
\text { tor productivo. }\end{array}$ \\
\hline & & & $\begin{array}{l}11 / 2 \text { años de } \\
\text { duración; } \\
\text { participación de } \\
\text { cerca de } 250 \\
\text { individuos } \\
\text { relacionados } \\
\text { con el } \\
\text { desarrollo y } \\
\text { difusión de la } \\
\text { tecnología. } \\
\text { Orientado a } \\
\text { biotecnología } \\
\text { industrial y } \\
\text { agrícola } \\
\text { (microorganis- } \\
\text { mos, células ve- } \\
\text { getales, células } \\
\text { animales, sus } \\
\text { partes, } \\
\text { agregados o } \\
\text { componentes). }\end{array}$ & $\begin{array}{l}\text { Reticencia } \\
\text { de los } \\
\text { expertos } \\
\text { nacionales } \\
\text { para hablar } \\
\text { del futuro. } \\
\text { Número } \\
\text { insuficiente } \\
\text { de expertos } \\
\text { en las areas } \\
\text { de estudio. } \\
\text { Los } \\
\text { resultados y } \\
\text { recomenda- } \\
\text { ciones no } \\
\text { lograron } \\
\text { cristalizar en } \\
\text { una política } \\
\text { nacional pa- } \\
\text { ra biotecno- } \\
\text { logía. }\end{array}$ & $\begin{array}{l}\text { Institucional: } \\
\text { Retroalimentación } \\
\text { constante de los } \\
\text { resultados del } \\
\text { estudio e } \\
\text { instrumentación, } \\
\text { en la medida de lo } \\
\text { posible (crisis), de } \\
\text { algunas } \\
\text { recomendaciones: } \\
\text { becas especiales, } \\
\text { apoyo a proyectos } \\
\text { de I \& D así como } \\
\text { de infraestructura, } \\
\text { etcétera. }\end{array}$ \\
\hline
\end{tabular}


Algunas orientaciones interesantes pueden desprenderse de los análisis presentados en al taller sobre "Asignación de Recursos para Investigación Agrícola" organizado por el International Development Research Center of Canadá (IDRC) en Singapur en 1981. La experiencia del caso colombiano advierte sobre las dificultades de instrumentar la primera etapa:

La identificación de prioridades socioeconómicas, la generación de una imagen consensual involucra decisiones de política respecto a los criterios a ser usados y a los aspectos bósicos de política económica; la experiencia colombiana reporta una gran lentitud en esta etapa del proceso ( $F$. Chaparro y cols., 1981).

Un aspecto muy interesante y muy aplicable a la dinámica de la biotecnología es la señalada por Manahan respecto a la necesidad de incluir análisis de sensibilidad al determinar prioridades; esta metodología es utilizada en el Instituto Batelle de Estados Unidos. Lo anterior reafirma la necesidad de abordar los aspectos metodológicos de la identificación de prioridades.

Como respuesta a esta necesidad, el Centro para la Innovación Tecnológica de la UNAM (CIT) ha trabajado desde 1985 la línea de investigación de la planeación de la investigación y el desarrollo. En este sentido, se formuló parcialmente una metodología para determinar prioridades en ciencia y tecnología (Waissbluth y De Gortari, 1990), que fue aplicada para el caso de la Cooperación Técnica Internacional de México bajo contrato con la Secretaría de Relaciones Exteriores y, posteriormente, para el desarrollo tecnológico agroindustrial de México, con el apoyo de la FAO y la Secretaría de Agricultura y Recursos Hidráulicos.

Los resultados de estas experiencias fueron prometedores, pero la concepción global de la metodología quedó inconclusa.

Lo anterior fue una de las consideraciones que de partida motivaron al $\mathrm{CIT}$ a apoyar la realización del proyecto de prospectiva en biotecnología. La otra consideración fue que los recursos para I \& D son muy escasos en un país como México, y en las condiciones de competencia mundial que vivimos hoy en día es prócticamente indispensable asignar estos recursos a las áreas que en verdad representen una oportunidad de desarrollo empresarial, económico y social.

Las tareas de esta índole enfrentan algunos retos: determinar prioridades y formular líneas de política en un campo de carácter multidisciplinario y de aplicación multisectorial como la biotecnología no pueden realizarse sin la participación de un gran número de personas e instituciones participantes en el desarrollo y difusión. 
Por otro lado, la acelerada marcha de la ciencia y la tecnología mundial y el entorno social, económico y político tan cambiante, nos ha enseñado que para países con recursos limitados como el nuestro no basta con determinar prioridades en I \& D, debemos poder realizar un control sistemático de los avances en la materia y de los cambios en el entorno, y actualizar de manera permanente nuestra "cartera de prioriaiades".

Una tarea de esta envergadura tendría poca repercusión si no tiene como base un análisis sobre la factibilidad de desarrollar las oportunidades seleccionadas, de "implementar la cartera"; ${ }^{2}$ este análisis debe estar basado en los recursos y la organización existentes y las posibilidades de modificarlos.

A nuestro juicio, el principal reto es determinar los lineamientos de política que hagan posible articular la acelerada marcha del desarrollo científico y tecnológico, con las necesidades y prioridades del desarrollo social, económico y ambiental.

Algunos retos de menor envergadura pero muy interesantes son los relacionados con la realización del proyecto, a saber:

- ¿Cómo establecer las unidades de análisisł ¿Por áreas técnicas, por sectores de aplicación? ¿Seguimos hablando de generaciones de tecnología?

- ¿Cuán predecible es la investigación? żEs suficiente la incorporación de análisis de riesgo y de sensibilidad?

- ¿Cómo incorporar las perspectivas de las diferentes disciplinas?

- ¿Qué herramientas y metodologías utilizar? ¿Tenemos un número suficiente de expertos en el país, de tal suerte que sus estimaciones resulten confiables?

- ¿Cómo identificar a los actores del proceso? ¿Cómo hacerlos participar y mantener su interés?

- ¿Cómo avanzar en el proceso de instrumentación de los resultados del proyecto? ¿Cómo sintetizar los resultados y presentarlos de manera atractiva para los tomadores de decisiones?

Como puede observarse, aún hay muchas interrogantes abiertas. En las próximas notas sólo apuntaremos algunos aspectos generales de la metodología.

${ }^{2}$ Se refiere a la instrumentación de las alternativas seleccionadas. 


\section{ALGUNAS NOTAS METODOLÓGICAS}

En principio hemos adoptado la estructura del proceso de prospectiva enfocado a determinar prioridades sugerido como modelo general por Martin e Irvine (1989). Esta estructura se ilustra en la figura 1.

Como puede observarse, en este modelo se presentan tres fases principales -preprospectiva, prospectiva y posprospectiva-, cada una de las cuales comprende muchos elementos interrelacionados.

Es justo apuntar que el modelo puede ser aplicado iterativamente a diferentes niveles, antes de la definición de las prioridades. Por otro lado, el proceso no concluye con la presentación de un reporte a la institución que ordenó el estudio; y resulta útil realizar análisis prospectivos continuos, por ejemplo con el fin de definir un programa continuo de investigación o de identificar mecanismos de seguimiento.

Otro punto clave para el éxito del proceso de prospectiva es dotarlo de una estructura organizacional y administrativa adecuada. La figura 2 muestra la usada más a menudo. En ella destaca la existencia de un grupo de trabajo constituido por expertos que se encargan de obtener y analizar la información requerida para todo el proceso, así como la que resulta de los talleres de discusión. Este grupo es apoyado por una secretaría, que apoya también al comité de vigilancia, y que se responsabilizará de las encuestas, la organización de los talleres de discusión, reuniones y otras actividades informales de consulta necesarias para garantizar un proceso realmente de participación. También se muestra en la figura la existencia de comités de "afinación o retoque" (light touch), que aportan orientación informal sobre aspectos críticos, lo cual ayuda a establecer redes con los principales actores en la industria, el gobierno y la comunidad de investigación.

Finalmente, es indispensable señalar que el enfoque metodológico aplicado a cada caso deberá tomar en cuenta los siguientes factores:

1) La función administrativa y la ubicación de la organización encargada del estudio dentro del sistema de I \& D.

2) La amplitud de las actividades de investigación que se pretende cubrir.

3) Los objetivos y la función que se espera de la prospectiva.

4) La índole de la investigación bajo análisis y sus características estructurales.

5) El balance relativo que se establece entre tres factores intrínsecos de tensión: impulso científico vs. demanda de mercados; impulso de la base vs. impulso de la dirección (bottom-up vs. top-down), responsabilidad e interés de los que participan 
FIGURA 1. ELEMENTOS Y ETAPAS EN LA PREVISIÓN ORIENTADA A LA DETERMINACIÓN DE PRIORIDADES (ENTRE ELLAS INSTRUMENTACION)

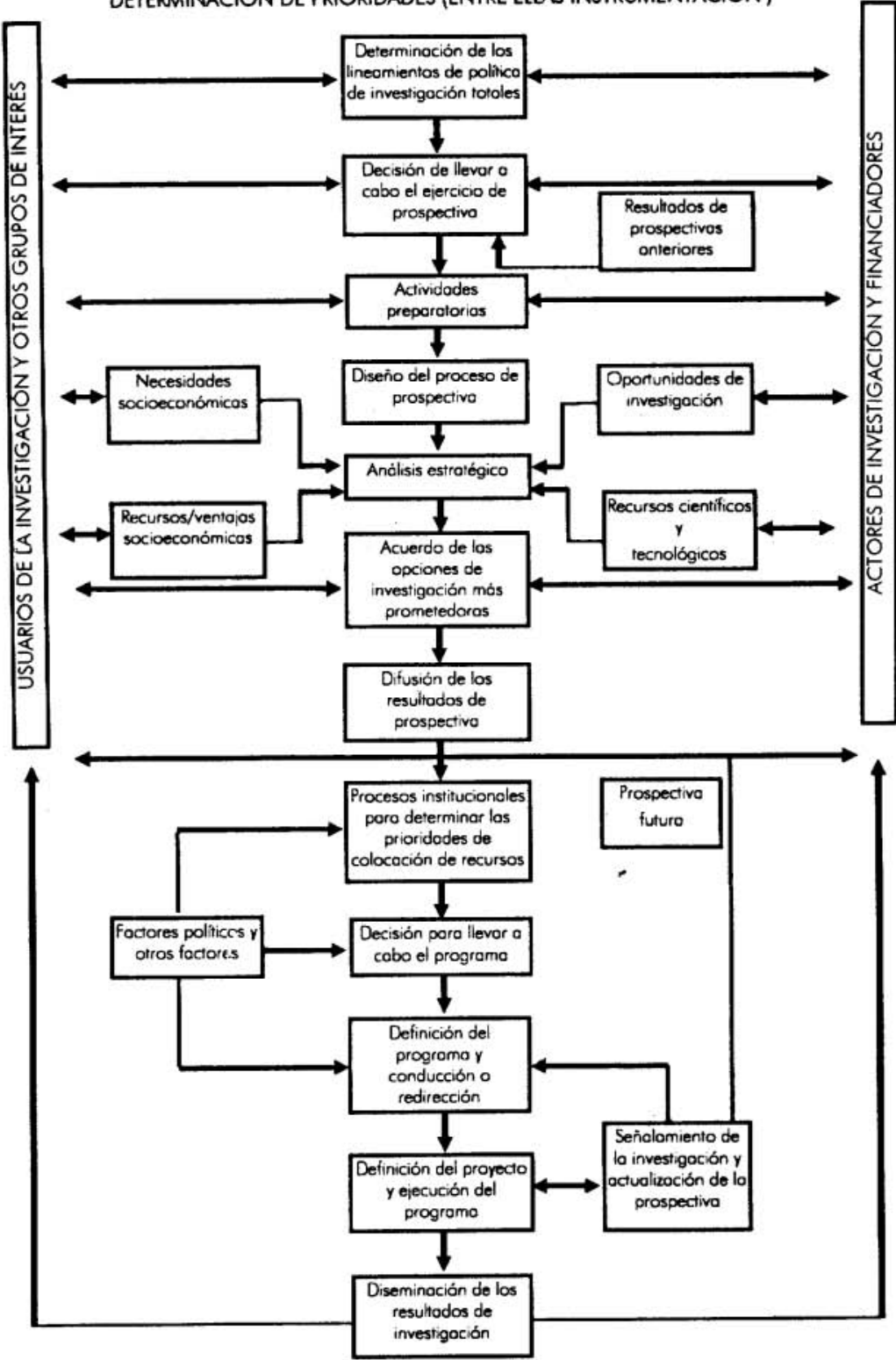

FUENTE: Martin e Irvine (1989). 
FIGURA 2

ORGANIZACION ADMINISTRATIVA DEL PROCESO DE PROSPECTNA

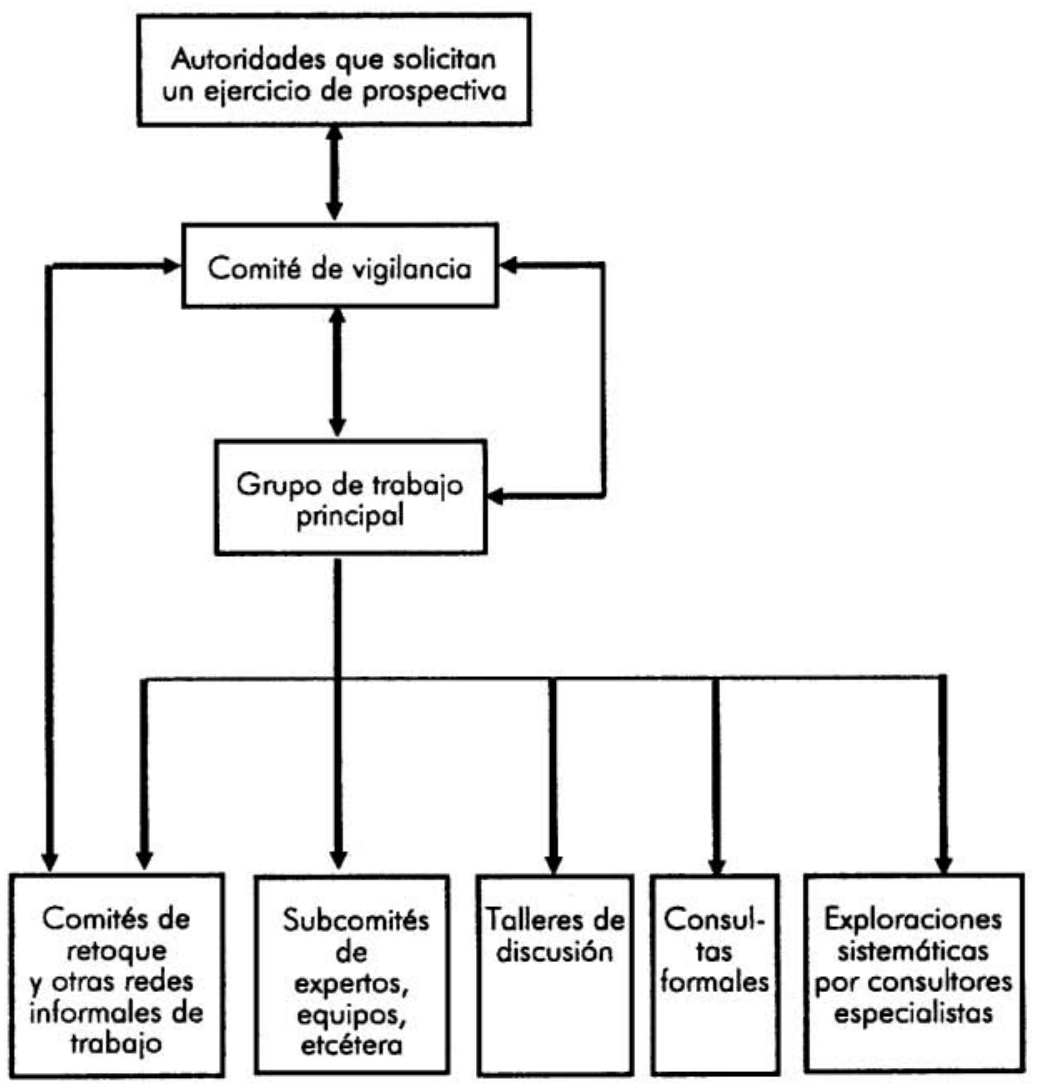

FUENTE: Martin e Irvine, 1989. 
directamente en la investigación vs. intereses de terceras partes.

6) Horizonte temporal del análisis.

7) Enfoque y técnicas usadas.

\section{METODOLOGÍA PROPUESTA}

Como se ha mencionado anteriormente, la metodología y las herramientas que habrán de seleccionarse deben considerar que la determinación de prioridades de I \& D en biotecnología es un problema complejo que requiere de consideraciones de tipo técnico y económico, así como políticas y sociales, así como de una conciliación entre lo que se puede hacer y lo que se desea. Se trata de un proceso dinámico que exige de retroalimentación constante pues constituye un problema que engloba muchas disciplinas y sectores de aplicación.

El estudio que estamos realizando cubre el entorno tecnológico internacional, así como las fuerzas y debilidades de la investigación biotecnológica en el país y aporta elementos sobre el proceso de implantación de la biotecnología en los sectores agroindustriales y de salud.

A partir de este diagnóstico se plantearán escenarios sobre futuros posibles que contemplen diferentes posibilidades de acción estatal, del sector académico de organismos internacionales.

La evaluación de los escenarios se hará mediante técnicas tipo "Delphi" a grupos de expertos. La práctica aconseja hacer un esfuerzo económico y de organización para que la aplicación de estas técnicas se realice a través de pequeños encuentros estructurados, y no mediante correo o algún recurso electrónico porque el número de respuestas por estos medios disminuye sensiblemente en cada vuelta del cuestionario. Cabe resaltar que las respuestas obtenidas en el equipo de expertos tienen mayor confiabilidad si éste se integra al menos por 11 personas (Martin, 1983). Además se busca en el proyecto contribuir a la integración de un "colegio invisible", ${ }^{3}$ lo cual se facilita con el trabajo de grupo. Para integrar este grupo se cuenta ya con la participación y asesoría de personalidades como el

${ }^{3}$ El término se aplica a un grupo de colaboradores en un campo de investigación unidos por medio de sus directores de trabajo, que se comunican unos con otros y se transmiten información sobre nuevos descubrimientos informalmente, antes de la publicación del resultado de la investigación (Heartsill, 1988). Se puede aplicar también al conjunto de agentes e instituciones que intervienen en una problemática y que como resultado de un proceso de identificación e integración de un dominio lya sea núcleo central o red) tienen capacidad de emprender acciones prospectivas en función del dominio (Carvajal, 1985). 
presidente de la Asociación de Empresas de Biotecnología, el director del Centro de Investigación Científica de Yucatán y, desde luego, los expertos de la propia UNAM, entre otros.

Asimismo, se consideró importante organizar una reunión metodológica sobre prioridades. Esta reunión fue la primera que organizamos, y sus resultados han sido sumamente importantes para la selección de la herramiento de prospectivas que aplicaremos para el resto del estudio. En dicha reunión se discutió sobre los aciertos en ejercicios de prospectivas realizados anteriormente en nuestro país con el propósito de determinar prioridades en investigación y desarrollo, así como sobre el potencial de los instrumentos reportados en publicaciones recientes que han sido adquiridas en el marco del proyecto.

La reunión ha contribuido a definir la metodología que habrá de emplearse, así como sus posibilidades de instrumentación; además, aportó elementos respecto a la manera de retroalimentar el proceso de determinación de prioridades. Al respecto se considera importante realizar periódicamente análisis de sensibilidad e incertidumbre.

Una vez que hayamos definido y afinado la metodología en varias "rondas" institucionales (IB), sería deseable realizar su conversión a un juego interactivo por computadora, ${ }^{4}$ que permita su aplicación expedita en programas de capacitación y ejercicios reales.

La aplicación de la metodología de determinación de prioridades se realizará en cuatro fases, a saber:

Primera fase: aplicar la metodología de planeación para el caso de la biotecnología agrícola y agroindustrial.

Segunda fase: a partir de los resultados obtenidos en la fase anterior, realizar los ajustes necesarios a la metodología.

Tercera fase: probar nuevamente la metodología mejorada al caso de la biotecnología con aplicaciones en la salud.

Cuarta fase: realizar ajustes finales y "empaquetamiento" de la metodología para que pueda ser aplicada en otros sectores e incluso en otros países.

Al mismo tiempo se realizará un estudio internacional de los mecanismos o instrumentos de fomento y regulación al desarrollo y difusión de la biotecnología. De especial importancia resultará conocer con mayor detalle y profundidad las características y criterios de

${ }^{4}$ Se refiere a la conversión de la metodología a un programa de computadora de modalidad interactiva; es decir, un sistema de intercambio de mensajes y de información entre el operador de un dispositivo terminal y el computador. Cada intercambio produce una respuesta del otro, similar a la conversación entre dos personos (Heartsill, 1988). 
evaluación del capital de riesgo, tanto en Europa como en Norteamérica, así como el conocimiento a fondo de políticas biotecnológicas exitosas en otros países como Japón, Canadá, Holanda, etcétera, sobre todo el análisis de aspectos de bioseguridad.

Más tarde, mediante el trabajo de expertos se analizará la viabilidad de aplicación en México de los mecanismos de fomento y regulación que han sido importantes en la biotecnología internacional. Lo anterior, teniendo como base un análisis profundo de las características, requerimientos y proceso histórico que está viviendo la biotecnología en México.

El proyecto de prospectiva en biotecnología tendrá una duración de casi dos años. A lo largo de este tiempo el equipo básico de trabajo del proyecto organizará una serie de actividades (talleres y reuniones de trabajo) con la participación activa de grupos reducidos de especialistos distintos ( 10 a 15 participantes por taller); los resultados de estas actividades se irán articulando según se muestra en el diagrama de flujo (figura 3). La reunión de todos los grupos se dará al final del proyecto en un seminario de difusión de los resultados (con unos 100 participantes).

Los talleres pretenden propiciar una discusión sobre las tendencias y posibilidades reales de la biotecnología dentro de un contexto económico y social como el mexicano. En otras palabras, pretendemos no solamente conocer lo que se espera de la biotecnología, de acuerdo con lo que se reporta en la bibliografía y con los hallazgos de las grandes empresas multinacionales; sino que, tomando en cuenta las fortalezas y debilidades del país, poder realmente identificar escenarios futuros alternativos, que puedan ser comentados y discutidos por expertos desde una perspectiva multidisciplinaria. De hecho, como puede observarse en el diagrama de flujo del proyecto, un primer taller explorará las tendencias. Sus resultados nos servirán para elaborar un documento de trabajo para la discusión que deberá tener lugar en el segundo taller, donde se evaluarán los escenarios alternativos.

Un proyecto con estas características requiere de un medio de comunicación ligero, como un sello distintivo que mantenga informados a los participantes acerca del avance global del proyecto y contribuya así a ubicar su participación a lo largo de él, a mantener y estimular su interés y a reforzar el compromiso de participación. Un boletín con los resultados de reuniones específicas y las perspectivas de algunos de los participantes será de gran utilidad para este proposito.

\section{ALGUNAS REFLEXIONES FINALES}

Los problemas que enfrenta el país en su desarrollo: rezago en la generación de empleo, gran asimetría en la distribución del ingreso, 
FIGURA 3

DLAGRAMA DE FLUJO DEL PROYECTO

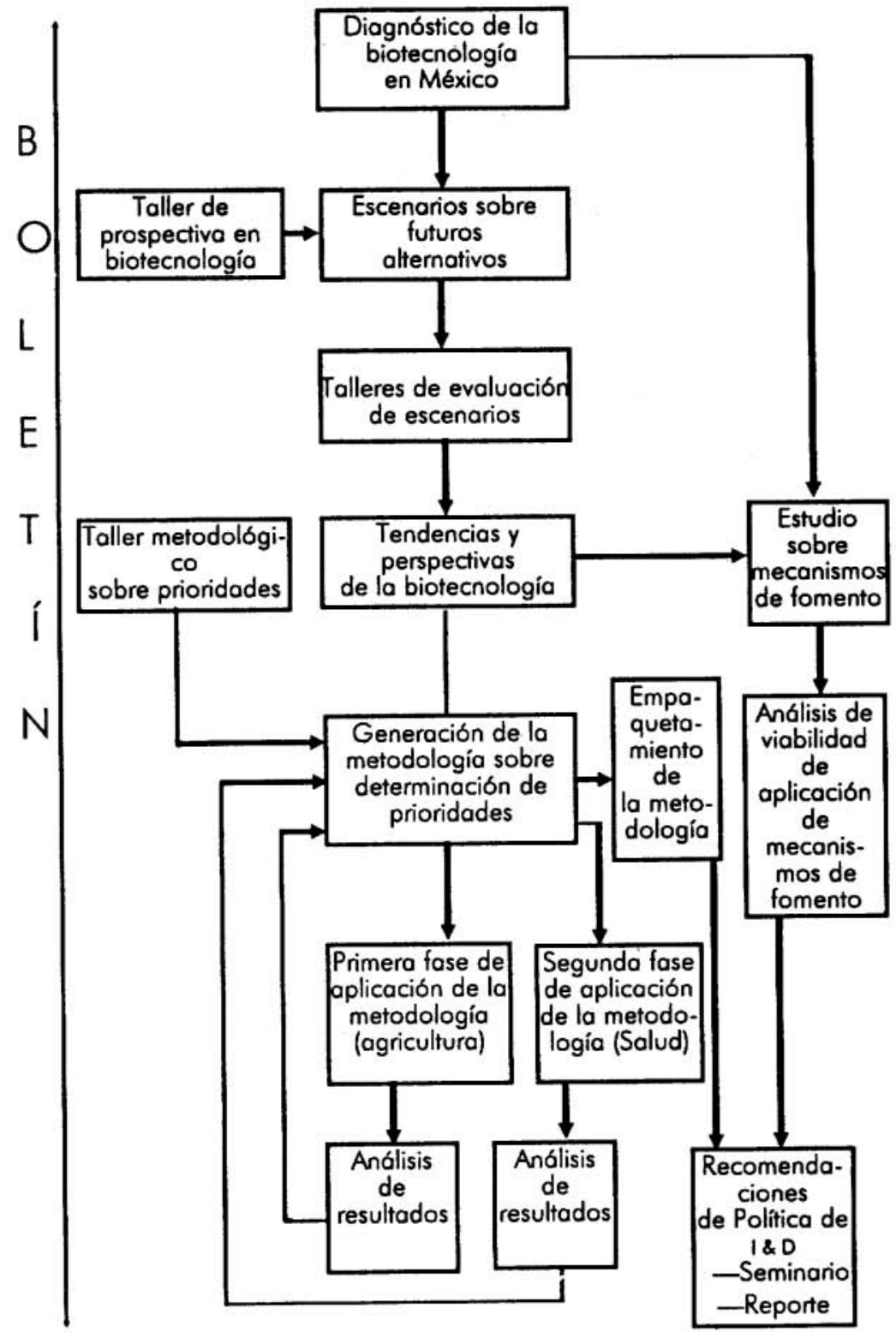


contaminación elevada en zonas urbanas y agrícolas, etcétera, aunodos a las fuertes presiones resultado de su inserción en los procesos mundiales de globalización, hacen necesario romper la inercia que ha padecido el sistema de innovación tecnológica en el país, e imprimile una dinámica nueva y diferente a sectores que deben y pueden ser clave para el desarrollo nacional.

El proyecto "Determinación de prioridades de I\&D y de mecanismos de fomento en biotecnología" trasciende las perspectivas de generación de una metodología de jerarquización y de formulación de lineamientos de política en la materia. El proyecto aspira a ser el punto de partida en la generación de una imagen común que oriente cada vez más las acciones de los agentes del cambio técnico en biotecnología; que los concientice de sus interrelaciones sin que esto signifique pérdida de autonomía y que les aporte elementos que apoyen su adaptación a la realidad cambiante tanto del sistema científico y tecnológico como del económico y social.

Una tarea de gran magnitud, relacionada con la complejidad propia de cualquier análisis prospectivo, exige la participación de muchos especialistas de diversas disciplinas. Por ello, este trabajo constituye una invitación a los colegas a participar en esta área de reflexión que consideramos fundamental para el futuro establecimiento de políticas que tengan mayor probabilidad de transformar el campo de la tecnología que a todos nos interesa.

\section{BIBLIOGRAFIA}

Alonso, C. A. 1990. "México 2010: Design, features and progress report". Futures. Vol. 2. Núm. 9, mayo.

Álvarez, M. J. M. 1991. "Elementos generales de prospectiva". Ponencia presentada en el Seminario sobre Prospectiva de la Educación Superior, México: CIDSE-UNAM.

Barbieri, E. 1989. "The future of future studies". Futures. Vol. 21. Núm. 2, abril.

Blanco, A. 1991. Reporte final de la preparación del Programa Nacional de Cooperación Intemacional en Biotecnología. SRE (MEX/89009).

Carvajal, R. 1985. La alimentación del futuro. Tomo I. México: PUAL, UNAM.

Casas, R. 1987. "La biotecnología agrícola y agroindustrial en México: estado actual y perspectivas". Memorias del Primer Seminario Nacional sobre Agroindustria en México. México: Universidad Autónoma de Chapingo. 
Chaparro, F. y cols. 1982. "Prioridades de investigación de recursos en agricultura: el caso colombiano". Asignación de recursos para la investigación agrícola. Actividades del taller efectuado en Singapur, 8-10 de junio de 1981.

Coates, J. F. 1985. "Foresight in Federal Government Policy Making" Future Research Quarterly. Vol. 1, pp. 29-53.

Elzinga, A. 1986. "Foresighting Canada's Emerging Science and Technologies", en Brochie.

Heartsill, Y. 1988. "Glosario Ala" de bibliotecologia y ciencias de la información. Madrid: Ed. Díaz de Santos.

Hodara, Joseph. 1984. Los estudios del futuro. Problemas y métodos. México: Instituto de Banca y Finanzas, A. C.

Manahan, M. P. 1989. "Technology acquisition and research priorization". Int. J. Technology Management. Vol. 4. Núm. 1.

Martin, B. R., e Irvine, J. 1989. Research Foresight Priority Setting in Science. Londres: Printer Publishers.

Martin, J. P. 1983. Technological Forecasting for Decision Making. North-Holland: Elsevier Science Publishing Co.

Miklos, T., y Tello, M. E. 1991. Planeación prospectiva. Una estrategia para el diseño del futuro. México: Ed. Limusa.

Quintero, R. Comp. 1985. Prospectiva de la biotecnología en México. México: Fundación Barros Sierra/CONACYT.

Secretaría de Programación y Presupuesto. Análisis y expectativas de la biotecnología en México.

Smits, R., y Leyten, J. 1988. "Key issues in the institutionalization of technology assessment". Futures. Vol. 20. Núm. 1, noviembre.

Solleiro, J. L., y Arriaga, E. 1990. "Patentes en biotecnología: amenazas y opciones para América Latina". Comercio Exterior. Vol. 40. Núm. 12, diciembre.

Waissbluth, M., y De Gortari, A. 1990. "A methodology for science and technology planning based upon economic escenarios and delphi techniques: the case of Mexican agroindustry". Technological Forecasting and Social Change, 37/2. 
comentarios 


\title{
Puntos críticos en el establecimiento de políticas científicas: el caso de la bioteenología
}

\author{
MIGUEL ÁNGEL CAMPOS*
}

En este trabajo comentaré algunos aspectos que me parecen críticos en el establecimiento de políticas de desarrollo científico y tecnológico, para lo cual retomaré algunos planteamientos hechos por Arias, ${ }^{* *}$ Conde, González, y Wing, y Solleiro, González y Almanza.

\section{EL CARÁCTER DISCURSIVO DE LA POLÍTICA NACIONAL EN MATERIA DE CIENCIA Y TECNOLOGÍA}

Antes de comentar directamente sobre el trabajo de estos autores, considero necesario contextualizar la política científica nacional: establecer políicas en materia de ciencia y tecnología es un ejercicio que se está convirtiendo en costumbres de cada gobierno federal desde hace varias décadas. ' Sin embargo, siempre ha habido una distancia considerable entre el discurso que presentan las políticas de los diversos planes nacionales e indicativos a este respecto y la implantación de acciones directamente derivadas de ellas. La diferencia ha sido tan grande que el efecto neto en la vinculación entre la investigación tecnológica y el aparato productivo es prácticamente nulo. Por otra parte, esta diferencia ha terminado por generar una situación crítica para la supervivencia de la comunidad científica, que se pierde poco a

* Instituto de Investigaciones en Matemáticas Aplicadas y en Sistemas, UNAM.

** Se comenta la ponencia de este autor en razón de su pertinencia temática, ya que por causas de fuerza mayor no participó en el evento. de 1970.

${ }^{1}$ En particular véanse los planes nacionales para la ciencia y la tecnología a partir 
poco debido a la fuga de cerebros, pese a los esfuerzos de formación de recursos humanos en la década de los setenta.

La brecha entre el discurso y la acción parece sustentarse en un esfuerzo legitimador del aparato gubernamental como símbolo de cobertura multisectorial; pero el efecto neto en beneficio de la comunidad cientffica, y para los sectores donde se desea que lleguen estas políticas, es poco sustancial. Se trata de un punto crítico, de carácter estructural, que condiciona el desarrollo cientffico-tecnológico de nuestro país.

\section{LA REVOLUCIÓN CIENTIFICO-TECNOLÓGICA}

En este contexto histórico-social de nuestro país nos encontramos con una nueva situación internacional que parece estar tomándonos por sorpresa: resulta que estamos en medio de una revolución tecnológica. Tanto es así que modifica los patrones de vinculación de la actividad y los productos cientfficos con la actividad productiva. ${ }^{2}$ La biotecnología es precisamente una de las áreas de esta nueva revolución científicotecnológica. A este respecto, Arias señala acertadamente en su trabajo que:

el peso asignado a los cambios tecnológicos, ... y sobre todo a la biotecnología ... serb́a aun mayor en el futuro, ya que la productividad y los ventajas comparativas para la producción agrícola dependerán cada vez mós del nivel tecnológico y menos de los recursos naturales dados cada vez. $^{3}$

Con ello, el autor da cuenta de una de las tendencios que están tomando los nuevos patrones de producción. Si en el caso particular de la biotecnología se trata efectivamente de un hecho económico,

2 David, Corona y Guadarrama han trabajado ampliamente el concepto de revolución tecnológica e industrial. E. David, "Industrial research in America: challenge of a new synthesis", Science, 209, 4452, julio, 1980, pp. 133-139; L. Corona, "Perspectivas de la politica científico-tecnológica en México: el rol do los universidades", Problemas del Desarrollo. Revista Latinoamericana de Economía, XV, núm. 57, 1974, feb.-abr., pp. 9.28; "Revolución científico-t6cnica en el contexto mundial", ponencia presentada en el Simposio "México ante las Nuevas Tecnologías", enero de 1989, mecanoescrito, 18 pp.; y R. Guadarrama, La tercera revolución científico-tecnológica de la humanidad, Estudios Politicos, 7, ene.-mar. de 1989, pp. 4-12.

3 S. Arias, "Campos y perspectivas de la biotecnología. Una estrategia para su introducción en el istmo centroamericano". Ponencia presentada en el Simposio Nacional "Efectos Socioeconómicos de la Biotecnología", unaM y UaM, MÉxico, 1991, nov. 25.27, mecanoescrito, $46 \mathrm{pp}$. 
entonces es necesario conocer mejor los componentes de los cambios tecnológicos del caso y entenderlos como insumos y como procesos. Es decir, entenderlos por una parte como factor no material cuya indole estó basada en la información o, en otras palabras, concebir el conocimiento científico como parte fundamental de los llamados paquetes tecnolbgicos; ${ }^{4}$ por otra parte, es necesario entender los componentes de los cambios tecnológicos como procesos sociales, cuyas dimensiones polificas, culturales y organizacionales pueden tomar modalidades coyunturales muy específicas.

\section{LA ÍNDOLE DE LAS POLITICAS}

De acuerdo con los elementos anteriores, aunque la propuesta que presenta Arias es una descripción muy interesante de las posibilidades de organización para conseguir ciertos objetivos deseables, me pregunto si resulta realista y factible, además de generalizable. Se antoja poco realista y parcialmente factible. Aunque la propuesta se plantee para una región centroamericana, tendrían que discutirse sus posibilidades de generalización, en particular por su orientación especializadora, y sugerirse actividades especfficas para centros de investigación específicos. Sin duda el autor no tiene la intención de que su propuesta se tome a la letra y se generalice indiscriminadamente, por lo que habra que analizarse con mucho detalle para visualizar su aporte al desarrollo de la investigación en biotecnología en otras regiones, en otras condiciones. Esta situación nos ilustra una característica fundamental de toda política: que es coyuntural y localizada, aspectos ambos definidos por parámetros históricos y geopolíticos.

Una politica definida como coyuntural y localizada no deja de ser estructural, ya que interpreta, en la mayor parte de las veces de manera implícita, las relaciones entre ciencia y el sistema de producción. Este problema es el que abordan Conde y sus colegas precisamente. No puedo menos que convenir con estos autores cuando afirman que: "... resulta sumamente arriesgado determinar a priori lo que la ciencia modificarb́ de la producción y en qué sentido". 5

4 Waissbluth y Gutierrez formulan una definición muy detallada que da idea de "paquete tecnológico"; englobo aspectos materiales y no materiales de la tecnología potencial en el aparato productivo. M. Waissbluth - I. Gutibrrez, "Elementos para una estrategia de un desarrollo cientffico y tecnológico", Ciencia y Desarrollo, año Vill, núm. 45, jul.-ago., 1982, pp. 88.103.

${ }^{5}$ R. Conde, R. González y J. Wing, "Las polfiticas de promoción de la ciencia y la tecnología: el caso de la biotecnología", ponencia presentada en el Simposio Nacional "Efectos Socioeconb́micos de la Biotecnología", unuM y un, M6xico, 1991, nov. 25-27, mecanoescrito, 25 pp. 
El riesgo consiste en que, como se afirma en teoŕa social, todo desarrollo institucional (como lo es la planeación y el establecimiento de políticas), genera efectos no esperados, a veces no deseados. Este proceso generador de efectos diversos no necesariamente significa que la ciencia tiene un efecto transformador en lo que se refiere al "estatus social y político del portador del esfuerzo cientf́fico-tecnológico". "De hecho, debido a que la política cientifica, primordialmente discursiva, no ha podido establecer las condiciones concretas para articular la investigación y el aparato productivo. El esfuerzo cientifico-tecnologico ha quedado prácticamente encerrado en la academia, y su portador no posee un estatus social y político sustantivo en la sociedad mexicana. ${ }^{7}$

Por otra parte, el "efecto de arrastre para la sociedad en su conjunto" también ha sido sumamente limitado ya que, como plantean Casar y Ros, hay una muy débil irradiación tecnológica en el aparato industrial del México moderno. El bajo nivel de desarrollo de la industria de bienes de capital, que según Chudnovski ${ }^{9}$ constituye un factor fundamental de desarrollo tecnológico, es una de las razones por las cuales no existe tal efecto de arrastre. El desarrollo de alto contenido científico-tecnológico en las aplicaciones industriales de la biotecnología en nuestro país es todavía incipiente y muy específico. ${ }^{10}$

La existencia concreta de la articulación entre la investigación científico-tecnológica con el aparato productivo puede estudiarse, como sugieren Conde y sus colegas, a partir de la siguiente hipótesis: "... el éxito de un proyecto no depende tanto de sus bondades intrínsecas, como de la capacidad de recepción de la contraparte a la que se pretende dirigir este proyecto". 11

${ }^{6}$ Op. cit., p. 9.

7 En las obras de Campos se analizan las condiciones históricas que han generado este divorcio entre investigación y estructura social, en particular desde el punto de vista sociocultural: M. A. Campos, "Problemática sociocultural de la ciencia", Sociología, año 5, 1992, mayo-agosto, 16, pp. 11.12; "Una aproximación teórica al analisis de la investigación cientffica y tecnológica", Polifica cientifica - innovación tecnológica en México. Retos para la Universidad, compilado por M. A. Campos y S. R. Medina, Mbxico: unuM (en prensa).

$8 \mathrm{~J}$. I. Casar y J. Ros, Problemas estructurales de la industrialización en MÉxico, Auticulación tecnológica y productiva, compilado por M. Pérez Lizaur, A. Castaño y J. A. Esteva, M6́xico: UNaM, 1986, pp. 31-60.

9 A. Chudnovsky, "Problemas tecnológicos en la industria de bienes de capital en Amórica Latina", Problemas del Desarrollo. Revista Latinoamericana de Economía, XV, núm. 57, feb.-abr. de 1984, pp. 9-28.

${ }^{10}$ R. Casas, "Perspectivas del desarrollo biotecnológico agroalimentario en México para la década de los noventa", Prospectiva social y revolución cientifica-fecnológica, compilado por M. A. Campos y R. Varela, Mbxico: uAM (en prensa).

11 Conde y cols., op. cit.; p. 11. 
Es decir, si se analiza la investigación desde el punto de vista de los resultados, se requiere discutir el problema del usuario. Este es uno de los puntos clave del problema de la vinculación investigación-producción. Como he planteado en otras oportunidades, 12 hay diferencias en la lógica constitutiva del discurso, del diálogo y la acción entre investigador y usuario. Estas diferencias pueden plantearse en términos culturales, ${ }^{13}$ y así es precisamente como lo hacen Conde y sus colegas cuando plantean el problema del "desfase entre la preocupación del científico y las exigencias de cierto medio". ${ }^{14} \mathrm{El}$ "medio" al que se refieren los autores puede interpretarse a trovés de los actores del caso: el investigador, el usuario y los mediadgres entre ellos; es decir, agentes que definen e implantan políticas mediante diversos mecanismos.

\section{LOS ACTORES}

La mediación encarna en los agentes conductores de la actividad científica como actividad institucional. Es el plano de acción de los gestores, o como los llama Díaz, ${ }^{15}$ los traductores de la tecnología. Es el plano de las políicas, de los programas, de los planes. No puedo menos que estar de acuerdo con Solleiro y sus colegas en lo que se refiere a traspasar las fronteras disciplinarias al establecer seriamente políticas de investigación en un proceso que comprenda a estos diferentes actores.

Por otra parte, me parece que el ejercicio de establecimiento de políticas en general, y por tanto de políticas particulares, como en el caso de la biotecnología, necesita verse y hacerse como un ejercicio continuo de búsqueda, como un ejercicio de creación. En este sentido la propuesta metodológica de Solleiro ${ }^{16}$ y sus colegas debe alimentar el ejercicio sistémico de elaboración de políticas. En su caso, habrá que esperar resultados y esperar también que los que toman decisiones conozcan tales resultados y los tomen en cuento. Esto último no ocurre muy a menudo; es decir, que los investigadores logren que sus

${ }^{12}$ M. A. Campos, "Una aproximación ..."

${ }^{13}$ M. A. Campos, "Problemática sociocultural ..."

${ }^{14}$ Conde y cols., op. cit., p. 12.

15 R. Díaz, "Recursos para el desarrollo tecnológico. El caso de la comunidad emergente de gestores de tecnología", Politica cientifica e innovación tecnológica en México. Retos para la Universidad, compilado por M. A. Campos y S. R. Medina, México: UNAM (en prensa).

16 J. L. Solleiro, R. L. Gonź́lez y S. Almanza, "La importancia de la prospectiva en el desarrollo biotecnológico", ponencia presentada en el Simposio Nacional "Efectos Socioeconómicos de la Biotecnología", unaM y uaM, Mb́xico, nov. de 1991, pp. 25-27, mecanoescrito, 28 pp. 
resultados y propuestas lleguen a los niveles de toma de decisiones. Dicha situación constituye un punto crítico en donde se da la desarticulación del llamado sistema de ciencia y tecnología.

A partir del supuesto de que la actividad científico-tecnológica es una necesidad económica, social y cultural de la sociedad, y de que el gobierno, representante de ésta, es una instancia social que tiene que establecer condiciones para satisfacer tal necesidad, se justifica la existencia de una polfitica nacional en materia de ciencia y tecnología. Así pues, los cuatro puntos críticos mencionados anteriormente deben estar considerados en el proceso de establecimiento de polfiticas a este respecto.

En la figura anexa se muestran algunas relaciones posibles para ese efecto, y se presta atención a los puntos críticos mencionados:

- el núcleo de este mecanismo lo ocupan los criterios de polfitica, es decir, los enunciados discursivos que fundamentan y justifican el contenido y la orientación de las acciones gubernamentales, abriendo la participación a los sectores que toman parte en la actividad cientifico-tecnológica; todo ello con el propósito de articular el discurso a la acción;

- los actores, en particular los mediadores, en los cuales se basa la gestión; sólo con la participación de todos los actores participantes es posible generar instancias concretas y realistas de vinculación entre investigadores y el aparato productivo;

- esas instancias constituyen el punto de partida del que se derivan el contenido de la revolución cientffico-tecnológica y las necesidades específicas a corto, mediano y largo plazo.

Mediante las diversas maneras de relación que se proponen, se plantea el establecimiento de mecanismos concretos que puedan servir como base de los múltiples procesos que deben estar presentes en el funcionamiento del sistema de ciencia y tecnología: flujo de información, juego de oferta y demanda, generación de insumos materiales, inversión, y reproducción de la comunidad científica, entre otros. En este contexto, la biotecnología tiene un papel muy importante en el desarrollo de entidades sociales de producción social (centros de investigación y de docencia en el campo). Así, los trabajos de los colegas, que he comentado, pueden analizarse de acuerdo con estas categorías con el propósito de entender mejor el proceso de generación de políticas científico-tecnológicas y de llegar a planteamientos mejor definidos y deseables.

Deseo agradecer a Miguel Ángel Rossano su colaboración en el diseño y producción de la figura que acompaña este trabajo. 
FIGURA 1

RELACIONES FUNDAMENTALES EN EL PROCESO DE ESTABLECIMIENTO DE POLIITICAS DE DESARROLIO CIENTÍFICO

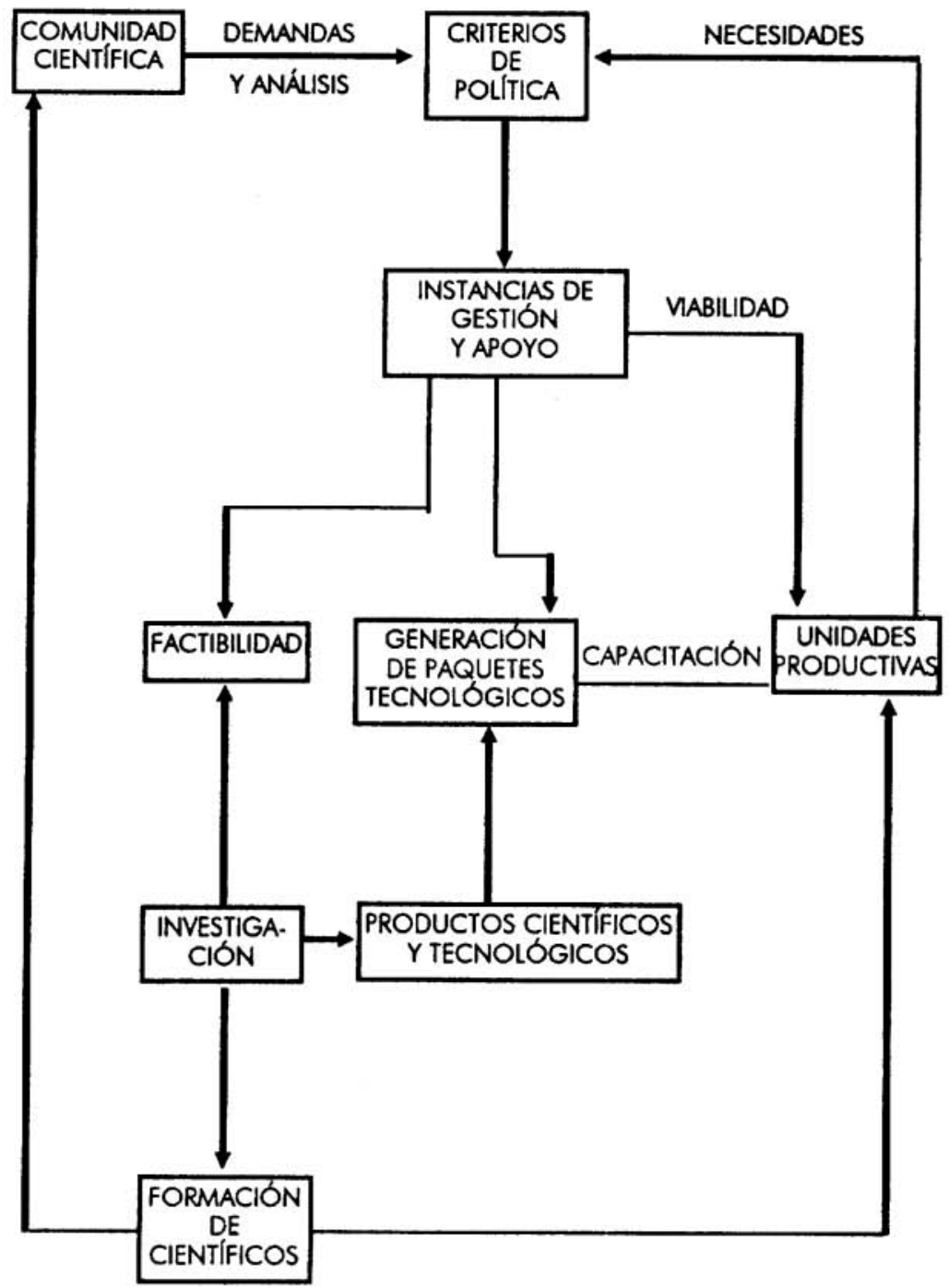




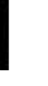

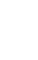
.

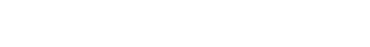

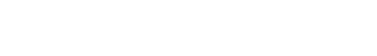

.

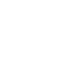

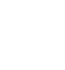

,

.

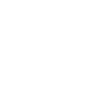

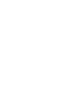

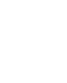

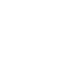

,

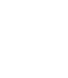

.
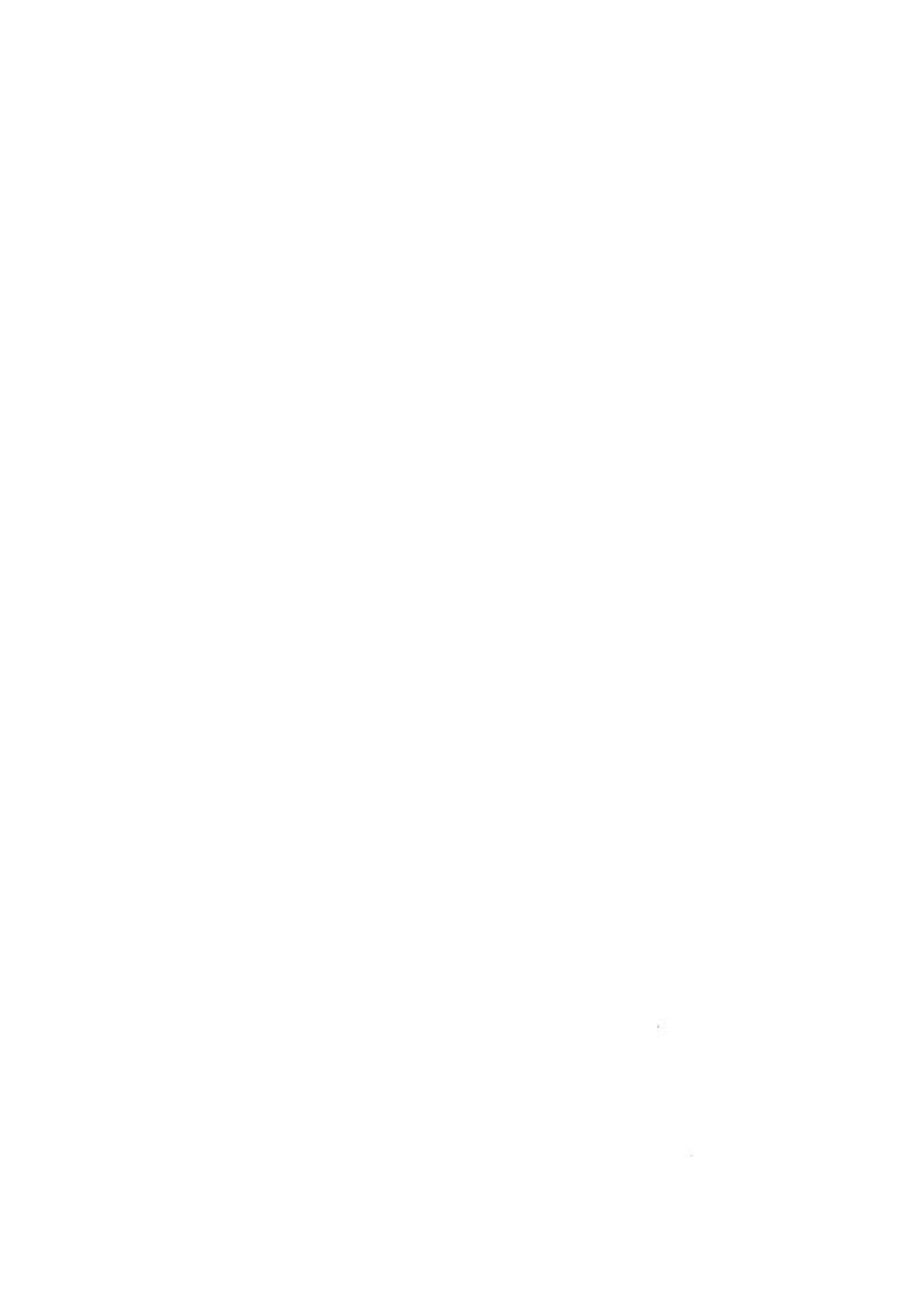


\title{
Prospectiva y planeación para la biotecnología
}

\author{
LEONEL CORONA*
}

Tres ponencias elaboradas por especialistas en planeación abordan preguntas clave para el desarrollo científico y tecnológico de la biotecnología. ${ }^{1}$

¿Es posible planear la tecnología y la ciencia para desarrollar la biotecnología? Si ello es posible, ¿́cómo?, ¿́para qué? y ¿̇para quién?

Los preguntas pueden tener dos tipos de respuesta según el punto de vista: el del científico o el del empresario. Aquél proyecta el qué hacer sobre la base del contenido y eventualmente agregara justificantes de las bondades económicas y sociales de las posibles aplicaciones.

El empresario o sus representantes, generalmente economistas o administradores de la asignación de recursos, evaluarán los resultados y sus costos, pues para los bancos la incertidumbre de los resultados puede ser tal que no se le acepte dentro de los marcos financieros actuales. Pero supongamos por ahora que hay mecanismos que consideran el "capital de riesgo" precisamente para inversiones intensivas en tecnología, como es el caso de la nueva biotecnología. $\mathbf{A}$ respecto se afirma que el copital de riesgo estuvo ausente en México hasta épocas muy recientes. ${ }^{2}$

En principio se llegaría a un diálogo de sordos que dificulta poner en práctica políticas de vinculación, pues

* División de Estudios de Posgrado, Facultad de Economía, UnaM.

1 Comentarios a las ponencias: J. L. Solleiro, R. L. Gonzallez y S. Almanza, "Importancia de la reflexión prospectiva en el desarrollo biotecnológico"; R. Conde, R. L. Gonzólez y J. Wing, "Las políticas de promoción de la ciencia, la tecnología: el caso de la biotecnología"; S. Arias, "Campos y perspectivas de la biotecnología: una estrategia para su introducción en el istmo centroamericano".

2 De "diez nuevas empresas biotecnológicas", una tuvo relaciones formales con la universidad. Raúl Conde Hernández, Rosa Luz González, Juvencio Wing, "Las politicas de promoción de la ciencia y la tecnología: el caso de la biotecnología", ponencia, p. 19. 
la ineficiencia de la relación empresa-universidad radica en parte en las diferentes visiones del empresario y del investigador; sus objetivos grosso modo son, para el empresario: productos conocidos sin riesgo técnico, ounque presenten menor potencial comercial, y para el investigador: productos nuevos (o que el investigador considera que son nuevos), aunque carezca de una idea clara de su potencial comercial. ${ }^{3}$

La incompatibilidad de las visiones parece resolverse cuando se trata de las nuevas tecnologías, pues como se basan en una mayor interrelación de la ciencia y la tecnología, surgen investigadores que investigan para innovar, es decir, se trata del investigador-emprendedor, como lo llaman Conde y cols.

En México se han alcanzado logros tecnológicos en las universidades, en especial biotecnológicos, entre los que cabe mencionar la penicilina y la insulina, ${ }^{4}$ que muestran la ausencia de mecanismos para su aplicación productiva pese al esfuerzo empresarial de los científicos.

Por tanto, aunque resulta fundamental encontrar los puntos y maneras de interacción entre la universidad y la industria, el problema es más crítico ante la ausencia de una infraestructura para la vinculación así como para la innovación y la difusión tecnológica.

El proyecto de investigación planteado por el Centro de Innovación Tecnológica de la UNAM (en Solleiro y cols.) $)^{5}$ puede ayudar con esta amplia perspectiva a planear la investigación y el desarrollo biotecnológico, lo que entraña considerar objetivos y recursos. Antes conviene saber para qué se requiere planear la ciencia. Solleiro y colaboradores simplemente anotan que "es inevitable en una era de creciente competencio en los mercados globales" (p. 2).

Sin embargo, el cómo se consideran los objetivos determina el camino mismo de la evaluación. Por un lado, el enfoque neoliberal predominante establece que el mercado proporciona los indicadores suficientes para su validación. En esta línea se ubica la propuesta de Solleiro y cols. cuando señalan que México "carece de una estrategia propia de desarrollo biotecnológico" ya que "los esfuerzos de investigación han estado dispersos y alejados de la realidad del mercado". 6

Por otro lado, la opción con objetivos sociales explícitos la presenta Salvador Arias, quien propone una estrategia para emplear la biotec-

3 Op. cit., p. 20.

4 R. L. Gonzólez, Antibióticos semisintéticos, insulina humana, coordinado por L. Corona, México: Universidad en la Política Científico-Tecnológica en México, GEFE-SEP. 1982.

5 José Luis Solleiro, Rosa Luz González, Silvia Almanza, "La importancia de la reflexión prospectiva en el desarrollo biotecnológico", ponencia.

${ }^{6} \mathrm{lbid}$. 
nología con el fin de alcanzar la autosuficiencia alimentaria, en su caso para la región del Istmo Centroamericano.

Ambas propuestas requieren ser revisadas. Primero, respecto a las innovaciones es necesario tomar en cuenta el mercado en el largo plazo; y respecto a las estrategias sociales se hace indispensable hacer participar a los actores, lo que lleva a sobrepasar los planteamientos meramente académicos. Se pretende entonces integrar el mercado en una visión de largo plazo como instrumento para los objetivos sociales, y no a la inversa. Así pues, la biotecnología se aplica para exportar, por ejemplo flores, en vez de dirigirse a la salud o a la producción de bienes básicos.

Las tres ponencias comentadas coinciden, aunque con distintas perspectivas, en la necesidad de establecer un Alerta sobre los nuevos conocimientos. Sin embargo es importante distinguir la Alerta tecnologica de la Alerta científica, y su necesaria interrelación en el caso de la biotecnología pues la industria se hace científica y la ciencia se convierte en industrial.

Ambas alertas dependen, primero, de la capacidad interna de los grupos de investigación biotecnológica para absorber y responder al conocimiento. científico y tecnológico. Por lo que desde este punto de vista se puede aceptar la propuesta de Conde y cols. de "consolidar y expandir" los grupos científicos comp fin en sí mismo.

En segundo lugar, la Alerto depende también de las necesidades productivas, pues éstas se acoplan en las actividades intensivas de conocimientos con un proceso de cambio y caducidades tecnológicas aceleradas. En este sentido, las políticas tecnológicas nacionales no pueden independizarse de las regionales y globales, en las que las empresas trasnacionales desempeñan el papel central.

La internacionalización productiva alcanza a las actividades científicas y tecnológicas, pues surgen acuerdos internacionales de cooperación entre empresas (ACI) con vistas al intercambio de información y en ocasiones de personal; en otros casos a invertir capital de riesgo (joint ventures) en pequeñas empresas especializadas de alta tecnología y contratar trabajos de investigación realizados por los laboratorios, cada vez más de origen extranjero. También se observa un incremento de diversos senvicios internacionales de información científica y tecnológica (L. Corona, 1991b, que refiere a R. Brainard y Ch. Leedman, 1988). ${ }^{7}$

Sin embargo, en este proceso las universidades y los centros de investigación de excelencia participan cada vez más en investigaciones por cuenta de empresas extranjeras y enseñanza en cooperación

7 L. Corona, coord., México ante las nuevas tecnologías, México: CllH-UnuM, Ed. Porrúa, 1991. 
internacional. Los $\mathrm{ACl}$ de las empresas incluyen la realización de inversiones en centros de investigación relacionados con ciudades científicas, generalmente situados en las universidades. Por tanto, la política científica y tecnológica estó ante la encrucijada de continuar con una visión volcada hacia dentro, con la mayor parte de los presupuestos destinada a las actividades en sus propios países, ante nuevos fenómenos de internacionalización donde la cooperación internacional constituye uno de los aspectos fundamentales del desarrollo científico y tecnológico.

\section{En resumen:}

La prospectiva es una herramienta que puede ayudar a rebasar la mudez o los diálogos de sordos entre empresas y universidades; sin embargo, tiene sus límites en el manejo de la incertidumbre y la participación.

Una prospectiva en la biotecnología para alertar (en el sentido de anticiparse a los cambios respecto tanto a las potencialidades como a los retos de la nueva biotecnología) encuentra su límite en la capacidad para controlar acontecimientos con incertidumbre. La Universidad puede aportar metodologías en este aspecto.

Una actitud mós activa llevaría a encontrar mecanismos de participación de quienes tienen a su cargo tomar decisiones, lo cual entraña incorporar en el ejercicio prospectivo a actores de la industria, finanzas, universidad y gobierno. Si la Universidad promueve un ejercicio con estas características, los límites se ubican en los mecanismos participativos, pues toman parte intereses y opiniones diversas y opuestas.

Desde el punto de vista de las orientaciones se sugiere considerar los siguientes aspectos para realizar una prospectiva biotecnologica:

1. El problema de la vinculación universidad-industria no se restringe a ambos actores, pues los elementos básicos están en los mecanismos, que los rebasan. Entre ellos está la disponibilidad de capital de riesgo, y las formas de su obtención. ${ }^{8}$ La creación de parques científicos, entre otros. ${ }^{9}$

${ }^{8}$ En Estados Unidos se han incrementado las coinversiones de las grandes empresas establecidas con las dedicadas a la biotecnología (EDE). Por tanto, la competitividad dependerá de la habilidad de estas empresas para sobrevivir, pues la biotecnología es intensiva en capital. En este caso se refiere a la nueva tecnología.

${ }^{9}$ La creación de parques o incubadoras de empresas cientfficas fue explosivo en los años ochenta on varios países industrializados; sin embargo, resulta un fenómeno reciente en México, pues no es sino hasta 1991 que la UNAM se propone crear uno (Gaceta UNAM, noviembre de 1991). 
2. La política nacional de la biotecnología es por principio de cuentas una política ligada a procesos intemacionalizados, lo cual entraña considerar la cooperación internacional, pues constituye uno de los aspectos fundamentales del desarrollo científico y tecnológico.

3. La gestión en biotecnología significa adecuar una política que integre la biotecnología tradicional y la nueva tecnología. ${ }^{10} \mathrm{En}$ esto los centros de investigación pueden coadyuvar mediante sus interrelaciones y explotar sus posibilidades. Las relaciones de la biotecnología con otras nuevas tecnologías, en particular con la informática (mecanismos de control de procesos), resultan clave para su propio desarrollo.

4. El desarrollo científico y tecnológico no garantiza en sí mismo el crecimiento económico, la competitividad o el bienestar social, pues el éxito de la estrategia científica y tecnológica depende de una política integradora de los componentes industriales, científicos, tecnológicos y sociales, y educativos, en un proceso social nacional, regional y global.

${ }^{10}$ En efecto, es necesario distinguir la nueva biotecnología de la biotecnología tradicional. Una definición que las abarca señala que se trata de las técnicas que utilizan organismos vivos para producir bienes y servicios mediante el mejoramiento de plantas - animales, o desarrollar microorganismos para usos especfficos. La nueva tecnología se refiere solamente al uso industrial de la ingeniería genética (que incluye el ADN recombinante), la fusión celular y nuevos bioprocesos. Office of Technology Assesment (OTA), 1991, pp. 5 y 45. 


\title{
La importancia socioeconómica de la biołecnología*
}

\author{
ARTURO BONILLA SÁNCHEZ**
}

Me parece muy atinado comenzar a partir de lo señalado por el doctor Rodolfo Quintero cuando afirmó que los biotecnólogos no deben adoptar una actitud meramente receptiva ante lo que ocurre en el campo de la biotecnología, sobre todo porque influyen muchos elementos ajenos a ella. Ante tal situación, él recomienda adoptar una actitud defensiva.

En efecto, en mi calidad de economista considero necesario sugerirles adoptar una actitud defensiva o de resistencia en el campo de la biotecnología, como creo que se debiera hacer en otros aspectos de las ciencias que están en la punta de la investigación científica y que repercuten poderosamente en el curso de los acontecimientos econbmicos y sociales del mundo. Es más, tan convencido estoy de la importancia de la biotecnología que, si yo tuviera poder político, le daría prioridad a la investigación científica en este campo; pero, ¿́por qué creen ustedes que me inclinaría por hacerlo? A continuación intentaré dar la respuesta, a riesgo de equivocarme. Pienso que el mundo en su conjunto está siendo víctima de una guerra económicr internacional en la que estamos destruyéndonos unos a otros mediante la competencia que se lleva a efecto en el mercado mundial.

Ahora se dice que todos los países deben exportar más para conquistar los mercados de otros países que tengan menor capacidad de competencia. Eso afirma el neoliberalismo, concepción económica predominante en el hemisferio occidental desde antes de la caída de buena parte de los países que se consideraban a sí mismos como

* Comentario corregido y aumentado, impartido en el Serninario "Efectos Socioeconómicos de la Biotecnología". Ciudod Universitaria, noviembre de 1991.

** Investigador Titular del Instituto de Investigaciones Económicas de la UNaM, marzo de 1992. 
socialistas, pero que, con su caída, favorecieron y fortalecieron aún más esa concepción. Es muy lamentable que al desestructurarse el Consejo de Ayuda Mutua Económica que abarcaba a un buen número de países hasta hace poco socialistas, ahora entren en la competencia mundial para exportar a los países occidentales los productos que antes solían comerciar entre sí. Ello fomentará mós la competencia feroz.

Por ello, para México y otros países del Tercer Mundo las cosas se complicarán más, pues también entran en la competencia internacional estos otros países ex socialistos en búsqueda de exportaciones; pero no sólo eso. También Cuba o China, que son socialistas, estón buscando afanosamente mecanismos que les permitan fomentar sus exportaciones.

Con la escasa capacidad de penetración comercial que tienen los países débiles del Tercer Mundo, entre ellos México, aunque no esté entre los más pobres y débiles, las condiciones se vuelven cada vez más difíciles de superar.

De la crisis actual, dicen los neoliberales, saldremos adelante sólo mediante una mayor competencia; cuanto más compitamos, mejor, declaran. Según esta concepción - con la que no estoy de acuerdosólo deben subsistir los más eficientes, los más fuertes, los que tengan mayores conocimientos y más recursos financieros para fomentarlos y canalizarlos vía la tecnología a la producción comercial, y muy especialmente a las exportaciones.

Si México o América Latina no están preparados para competir contra las grandes potencias, que tienen muchos científicos, mucho capital y cuentan además con poderosas redes comerciales que les dan mayor capacidad de penetración mercantil, entonces podemos decir que ni México ni América Latina podrán salir airosos de la guerra económica mundial.

Dada la escasa capacidad científica, financiera y comercial con la que cuenta el país y en general el Tercer Mundo, y frente a la competencia desatada entre los países poderosos del mundo, retomo las palabras del doctor Rodolfo Quintero para sugerir que se adopten medidas de caracter defensivo mediante la creación de medios o el fortalecimiento de los existentes; desarrollar la ciencia y la tecnología a fin de resistir la gran ofensiva comercial, no tanto para aspirar a ganar en esa feroz guerra económica internacional, sino para evitar ser barridos ya no sólo como competidores, sino hasta como seres humanos.

Aquí es donde entra la impontancia y la jerarquía que debe dórsele a la investigación en biotecnología, puesto que se trata no sólo de una rama de punta que está al alcance de los modestos y escasos recursos que tiene este país, sino sobre todo que tiene que ver con los grandes 
cambios que están ocurriendo y que, como se ha dicho aquí, seguirán presentándose cada vez de manera más espectacular en el futuro.

La biotecnología debe servirnos -entre otros aspectos- como uno de los medios más importantes para garantizar la alimentación de la inmensa mayoría de la población del país. Seguramente ustedes están informados de una tendencia peligrosa para nuestra subsistencia que aquí quisiera hoy destacar: desde mediados de los sesenta, México y en general todo el Tercer Mundo han perdido capacidad productiva para obtener los montos necesarios de productos alimenticios para sostener a su población.

Si para las grandes potencias del mundo lo importante es desarrollar la biotecnología para destruirse, para competir más eficazmente unas contra las otras, para nosotros, desarrollar la biotecnología significa evitar morirnos de hambre. Así de elemental y sencillo, pero decisivo.

Quienes están hoy día al frente de la responsabilidad de gobernar, están convencidos de la necesidad de competir en el plano internacional, subestimando profundamente las desventajas estructurales que para tal fin tenemos como país. Esa misma convicción de que el mercado es la vía mediante la cual progresará el país, se presenta en las políticas que se siguen para estimular el desarrollo científico.

En efecto, se oye y se percibe cada vez más en los ambientes universitarios que sólo lo que tiene eficacia en el desarrollo de la ciencia es a lo que debe dársele prioridad. Ese modo de pensar, fuertemente influido en nuestros medios por el neoliberalismo, sostiene que sólo el tipo de investigación que genere dinero es el que tiene sentido impulsar. Eso es lo que vale, y se nos trata de convencer que el desarrollo de la ciencia por la ciencia misma carece de sentido y de realidad, por lo cual se impulsa sólo la que sea redituable; así, el mercado será la vara para medir el trabajo científico. Y se llega en casos extremos al colmo de considerar que si hay otros campos de la investigación y de la cultura que no sean redituables, no vale la pena apoyarlos.

Así, se subestima profundamente lo que recordaba el colega economista Juvencio Wing en el sentido de que el desarrollo de la investigación científica está sujeto y condicionado por el desenvolvimienta de sus propias leyes, en donde el papel que desempeña el azar en la lobtención de resultados es un fenómeno sumamente frecuente. De eśte modo, no es fácil compatibilizar el desarrollo científico con el de las necesidades del mercado. Con este criterio mercantilista todas las investigaciones de alto riesgo y de largo plazo están condenadas a desaparecer. Sin embargo, no hay que olvidar que en el desarrollo de las ciencias está implícita o explícita una serie de factores que influyen e impulsan su mayor o menor desarrollo, 
entre los que hoy esłá presente la exacerbación de la competencia entre pueblos, estados e individuos.

Desde luego, insisto en que alimentar la idea de que mediante la competencia contra otros saldremos adelante de la crisis me parece un error de proporciones históricas, pues si seguimos así iremos todos al desastre.

En efecto, los dirigentes de las principales potencias del mundo se preocupan, sobre todo, por no perder poder, de ellos o de sus respectivos países, y por eso impulsan la guerra económica entre naciones; incluso con la derrota de Iraq a manos de Estados Unidos, George Bush decidió mejorar la calidad mortífera de las armas, algunas muy nuevas y que por primera vez se usaban.

En esa lógica, sin embargo, el mundo avanza hacia el desastre; considérense como ejemplos los siguientes:

- La enfermedad del SIDA sigue proliferando sin que hasta ahora nadie pueda impedirlo.

- Con fuerza resurgió el cólera, enfermedad que se suponía erradicada o por lo menos controlada.

- El hambre y la desnutrición siguen aumentando en vastas regiones de los países débiles del Tercer Mundo, sobre todo en los más pobres, como los del Sahel africano.

- El consumo y la producción de drogas se incrementa sin que poder alguno lo detenga, lo cual vuelve multimillonarios a los narcotraficantes de la noche a la mañana.*

- Los efectos destructivos sobre la naturaleza siguen su terrible y devastador curso, en lo que debe llamarse "escocido": desertificación, desforestación, contaminación de suelos, aguas y aire.

- Mientras todo esto avanza, sigue dedicándose lo mejor del ingenio humano y vastas cantidades de dinero para producir armas más eficaces para matar a la gente. Conviene recordar lo que se dijo en Ixtapa, Zihuatanejo, en 1986, en la reunión de los presidentes de varios países latinoamericanos que conforman el Grupo de los Ocho, en el sentido de que, de cada 100 científicos, 60 están dedicados a los medios de destrucción y sólo 40 se dedican a fines pacíficos.

De este modo, pareciera entonces que nos enfrentamos a una crisis, de grandes-pvastas proporciones nunca dntes cortempladas, tal vez la hayor de la civilización moderna.

* Éste es un excelente negocio en donde los gobiernos de los países en donde se localizan las matrices se hacen desentendidos. Cabe preguntarse: źcómo es posible que se "laven" 500 mil millones de dólares anuales sin que los grandes bancos lo perciban? 
Por lo dicho creo que una verdadera solución a la crisis contemporánea que nos afecta sólo puede alcanzarse mediante la colaboración entre todos los seres humanos al margen de su nacionalidad, color, posición ideológica o geográfica. De esto estoy ahora convencido. Casi suena a música celestial, pero el mundo se mueve al margen de los deseos de cualquiera de nosotros, y aunque no nos guste la no solución que da el mercado, éste seguirá imponiendo su ley, la cual seguirá manifestándose en todos los aspectos de la vida social y, por lo mismo, se expresará en el ámbito de la educación, en especial la superior, y en el de toda la investigación.

Si a largo plazo y desde una perspectiva internacional el panorama que se vislumbra no es alentador, quisiera hacer unos comentarios de corto plazo referidos a México.

Como ya se sabe, nuestro país puede quedar incorporado al Tratado Trilateral de Libre Comercio con Estados Unidos y Canada. Ello significaría que México abriera totalmente sus fronteras para que las mercancías, sobre todo las elaboradas en Estados Unidos, pudieran entrar en México a competir con los productos mexicanos.

Como lo he dicho en otros foros, la creación del TLC entre los países de Norteamérica no es más que una expresión de la guerra económica mundial, en la que cada superpotencia trata de crear una verdadera fortaleza económica para amortiguar el asedio de la competencia de las otras potencias: Alemania al frente de la Comunidad Económica Europea, y Japón a la cabeza de los países de la Cuenca del Pacífico.

Las autoridades gubernamentales de México consideran que este Tratado será un estímulo importante, aunque no único, en los intentos de modernizar la planta productiva: se sabe que $95 \%$ de las instalaciones de dicha planta han caducado ya.

Ante una competencia abierta y feroz, el país corre el peligro de que una buena parte de la planta productiva nacioral sea eliminada por la competencia de los productos provenientes de EUA, generalmente elaborados en condiciones de mayor productividad y con instalaciones de nivel tecnológico más avanzado que el existente en México. Cabe entonces la posibilidad de que el país pueda modernizar su planta productiva con base en capital y tecnología extranjeros; pero, y aquí está el gran "pero", que se haga una vez que haya sido arruinada la planta productiva del país.

De cumplirse esta lógica de razonamiento, ya deberían prenderse los focos rojos, de verdadera alarma, pues no sería poco lo que se perdería. Ya desde hace años debió dársele un impulso muy fuerte a la educación superior y a la investigación científica mexicana, así como a la tecnológica, para que el país pudiera enfrentar en condiciones 
menos desfavorables la desigual competencia a la que podría quedar sujeto con el TLC.

Sin embargo, las cosas no marchan, desafortunadamente, en esa dirección. Como se recordará, los presupuestos de las universidades públicas que están en condiciones de hacer investigación se han reducido en térrninos reales. Aunado a ello han bajado los salarios de los académicos y se han reducido las facilidades con que se debe contar para la investigación, con el agravante de que hay poca vinculación entre las fábricas y las universidades, tal y como lo han recordado aquí Juvencio Wing y José L. Solleiro.

En los medios de comunicación se habla de que México tendrá a su alcance el mercado más poderoso del mundo, como lo es el de Estados Unidos; pero no hay que olvidar que ellos cuentan con una gigantesca masa de científicos y tecnólogos, 850 mil aproximadamente, para mantenerse en la punta de la competencia. Incluso lo que fue la Unión Soviética, que atraviesa profunda crisis, a mediados de los ochenta tenía 1 millón 500 mil científicos y tecnólogos. Compárense esas cifras con las muy modestas de México, que cuenta con alrededor de unos 5 mil científicos, según unos cálculos y 16 mil según otras estimaciones.

Frente a este panorama tan difícil, nosotros no podemos ni debemos quedarnos con los brazos cruzados. En esto los especialistas de la biotecnología pueden contribuir a elevar la capacidad de resistencia de nuestro país, no sólo en esa inmensa tarea de coadyuvar a romper con esa siniestra tendencia de pérdida de capacidad productiva para alimentar a los nacionales, sino que también pueden y deben desempeñar un papel de gran trascendencia en la lucha por evitar el desastre ecológico en México. No dudo que conforme se eleve la conciencia pública sobre la destrucción que estamos haciendo de la naturaleza se podrá ejercer una gran presión política a efecto de que se canalicen cada vez más recursos financieros hacia la investigación en biotecnología, la cual puede ayudar inmensamente a evitar, o por lo menos a disminuir, el cotidiano atentado que realizamos en contra del medio ambiente.

Si las dos tareas arriba indicadas son de largo plazo y requieren de un esfuerzo sostenido y vigoroso también a corto plazo, la biotecnología puede ayudar desde su campo a resistir la tremenda competencia que nos hará Estados Unidos. 


\section{La biotecnologia y}

sus repercusiones

\section{socioeconómicas y políticas}

\section{Coordinadoras:}

Rosalba Casas

Michelle Chauvet

Dinah Rodríguez.

\section{Autores:}

Gilberto Aboites Manrique

Silvia Almanza

Gonzalo Arroyo

Rosa E. Barajas

Rosalba Casas

Yolanda Castañeda

Raúl Conde

Michelle Chauvet

Amarella Eastmond

Rosa Luz González

Luis Kato Maldonado

Martin Kenney
Jack Kloppenburg Jr.

Luis Lago Castro

Argelia Lorence

Yolanda Massieu Trigo

Gerardo Otero

Leonardo Héctor Rioja Peregrina

Dinah Rodríguez Chaurnet

José Luis Solleiro

Blanca Suárez

Idolina Velázquez S.

Juvencio Wing 
La presenfe obra es el resulfado de un esfuerzo por avanzar de manera organizada en el análisis socioeconómico y político de la biołecnología. En las discusiones sostenidas durante el simposio que precedió a la publicación de este libro resalfaron las repercusiones políticas de la biotecnología y sus relaciones con el Trafado de Libre Comercio. Se evilaron Ias generalizaciones imperantes en forno a los efectos socioeconómicos de esta disciplina y se abordó el estudio de caso de los avances biofecnológicos y sus efectos en diferenłes ámbifos. Desde esfa perspectiva, se analizaron las consecuencias potenciales y deseables de la biotecnología, las repercusiones ya presentes derivadas de la comercialización de productos biołecnológicos, así como la influencia en el plano nacional de las bioteenologías transferidas del exterior.

Hoy en día, los asombrosos avances de la biotecnología planfean dilemas que rebasan el ámbiło científico y se inscriben en el terreno de una ética de la creación humana que en el fuluro deberá responder a retos cada vez más complejos. Es éste el marco de reflexión social donde los trabajos contenidos aquí abordan los diversos aspectos de dicho campo de investigación con el objeto de definir sus limitaciones, deferminar los efectos reales de su aplicación en la sociedad y, finalmente, proponer orientaciones de política. Todo ello cobra particular frascendencia a la luz de los acuerdos y debałes de la reciente reunión en Brasil, la Cumbre de la Tierra. 